Prepared in cooperation with

Whatcom County Plannitig Department

\title{
Hydrogeology, Ground-Water Quality, and Sources of Nitrate in Lowland Glacial Aquifers of Whatcom County, Washington, and British Columbia, Canada
}

Water-Resources Investigations Report 98-4195

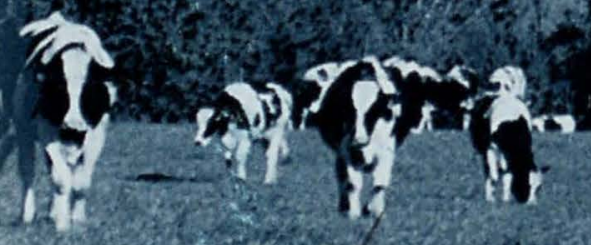


Cover - Photo of Whatcom County, Washington, by Stephen E. Cox, U.S. Geological Survey, Tacoma, Washington 


\section{Hydrogeology, Ground-Water Quality, and Sources of Nitrate in Lowland Glacial Aquifers of Whatcom County, Washington, and British Columbia, Canada}

By Stephen E. Cox and Sue C. Kahle

U.S. GEOLOGICAL SURVEY

Water-Resources Investigations Report 98-4195

Prepared in cooperation with the

WHATCOM COUNTY PLANNING DEPARTMENT

U.S. GEOLOGICAL SURVEY
RESTON, VA
OCT 191999
SR
LIBRARY 


\title{
U.S. DEPARTMENT OF THE INTERIOR \\ BRUCE BABBITT, Secretary
}

\author{
U.S. GEOLOGICAL SURVEY
}

Charles G. Groat, Director

The use of firm, trade, and brand names in this report is for identification purposes

only and does not constitute endorsement by the U.S. Geological Survey.

For additional information write to:

District Chief

U.S. Geological Survey

1201 Pacific Avenue - Suite 600

Tacoma, Washington 98402
Copies of this report can be purchased from:

U.S. Geological Survey

Information Services

Box 25286

Federal Center

Denver, CO 80225 


\section{CONTENTS}

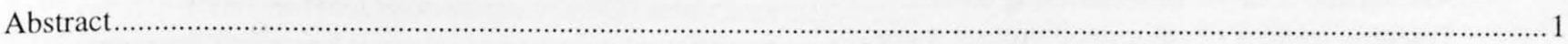

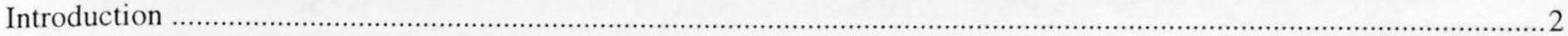

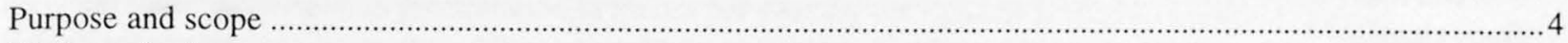

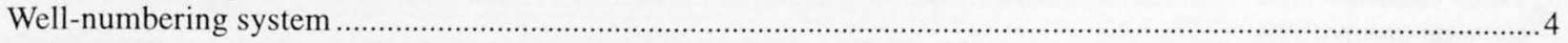

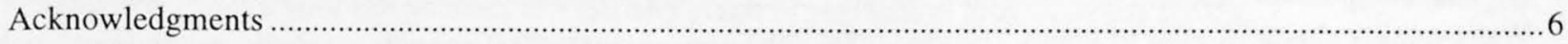

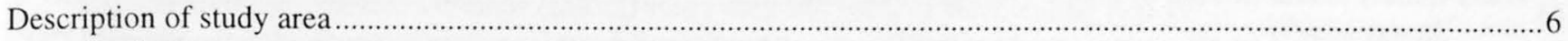

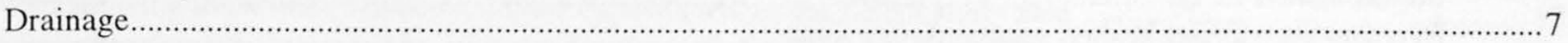

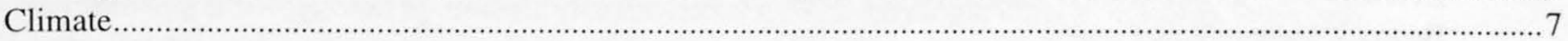

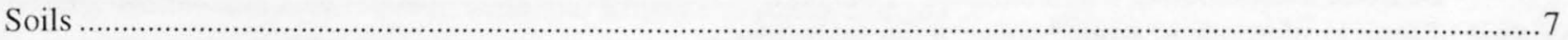

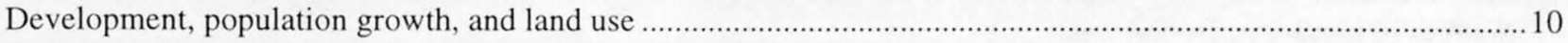

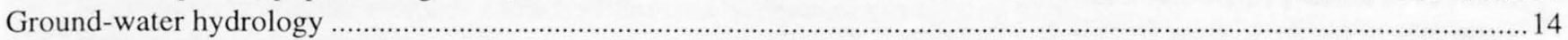

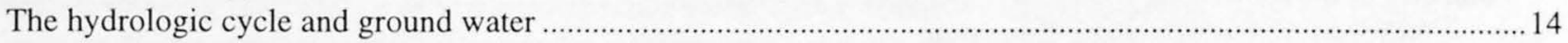

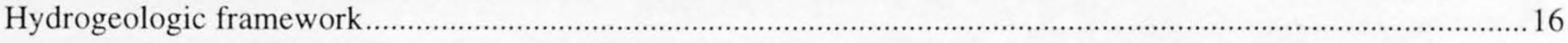

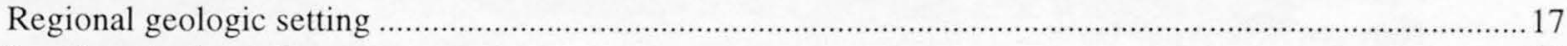

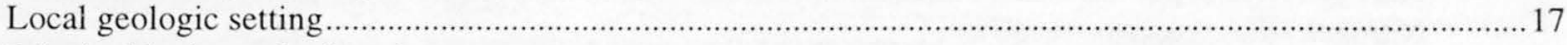

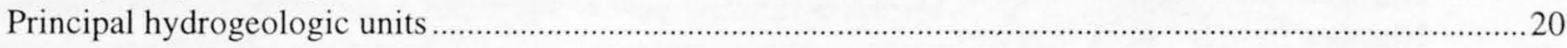

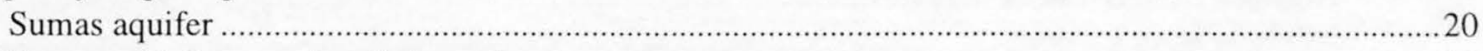

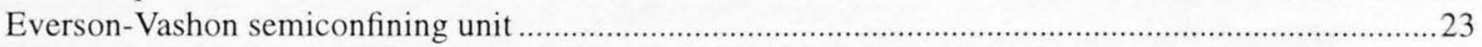

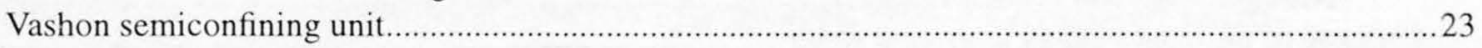

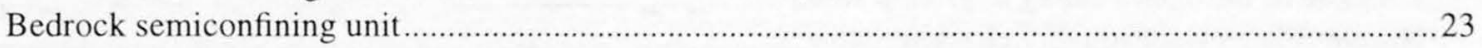

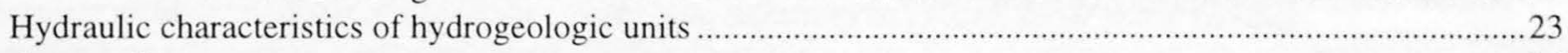

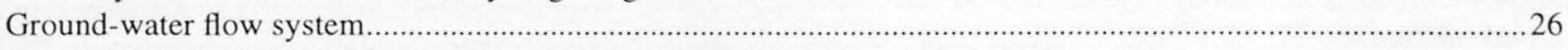

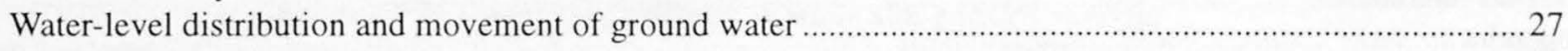

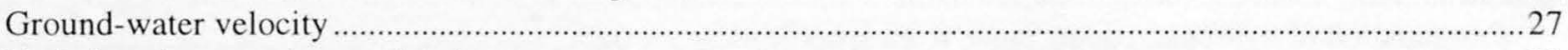

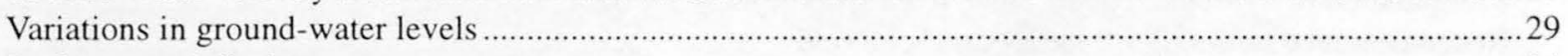

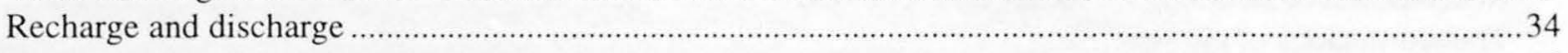

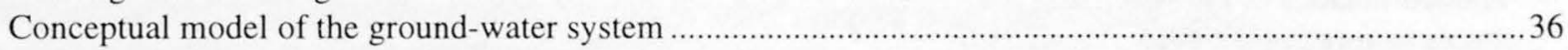

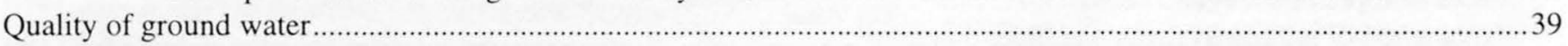

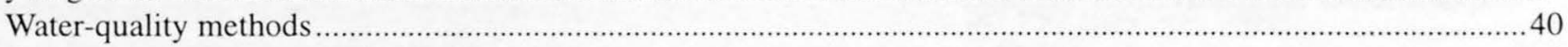

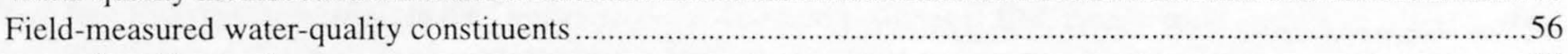

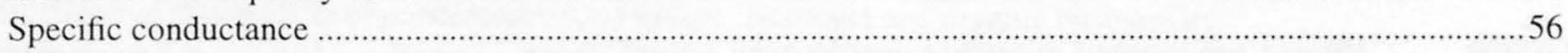

$\mathrm{pH}$

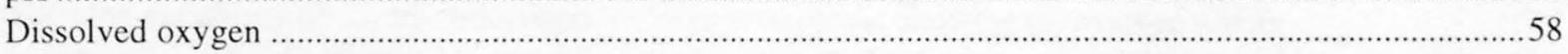

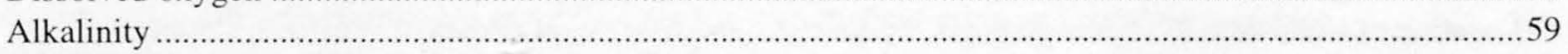

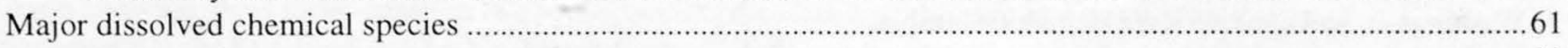

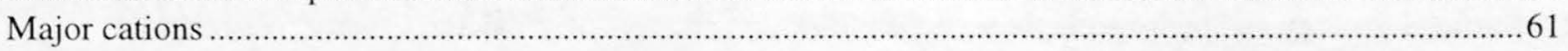

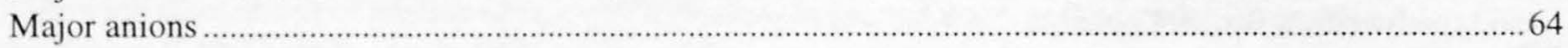

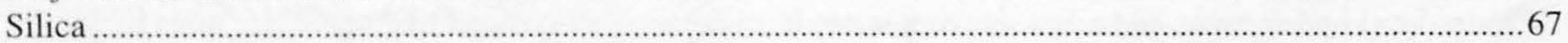

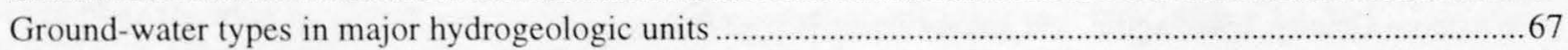

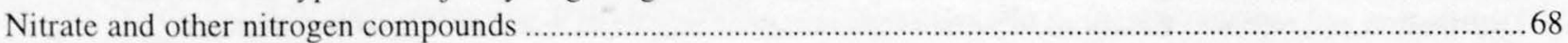

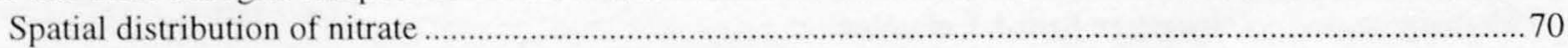

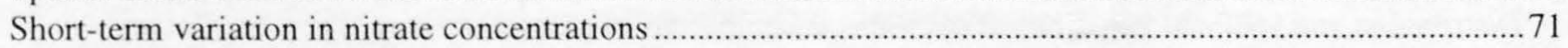

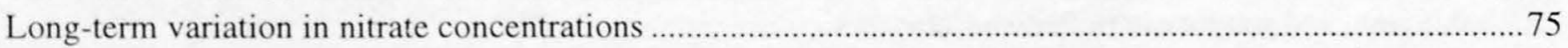

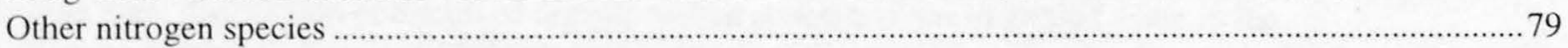

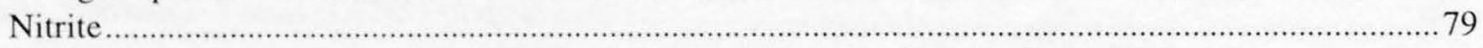

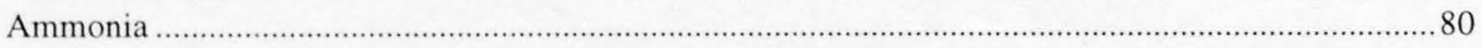

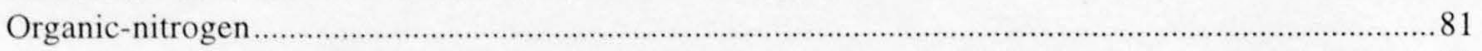

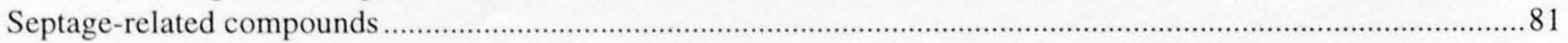


Boron.

Dissolved organic carbon.

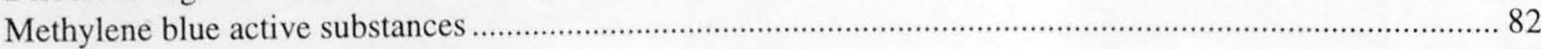

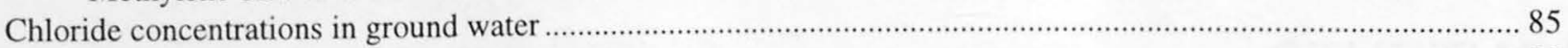

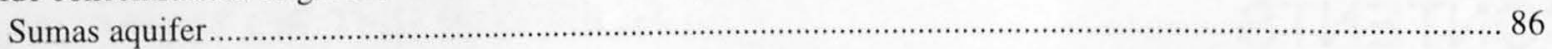

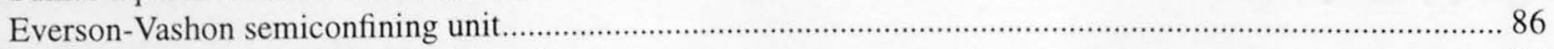

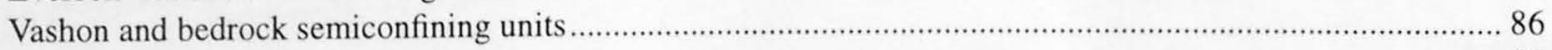

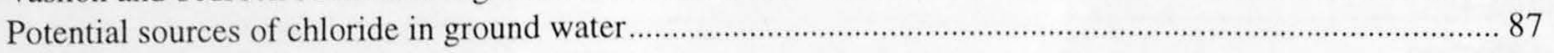

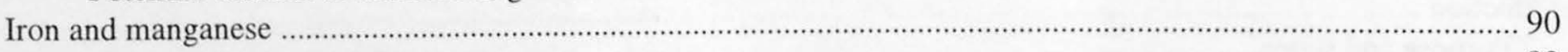

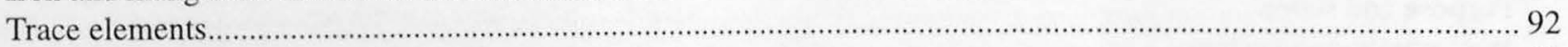

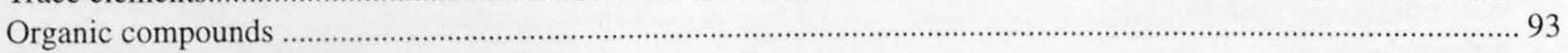

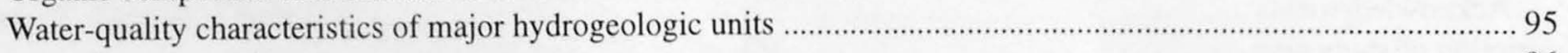

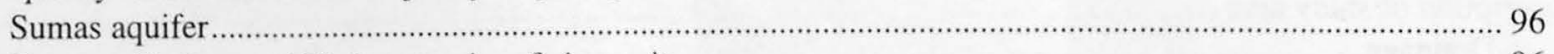

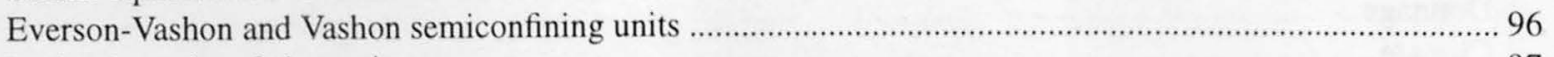

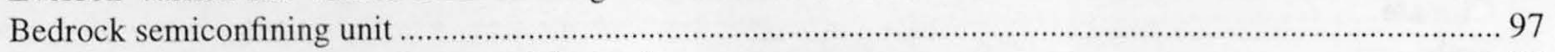

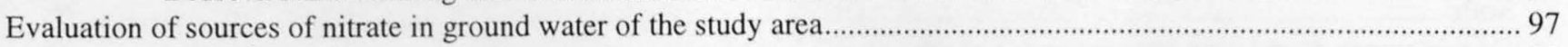

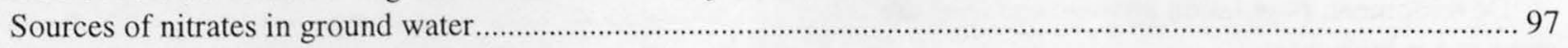

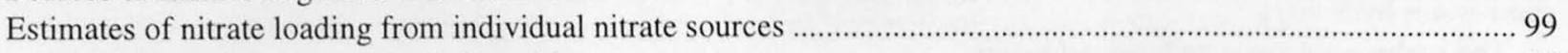

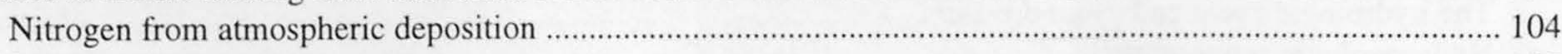

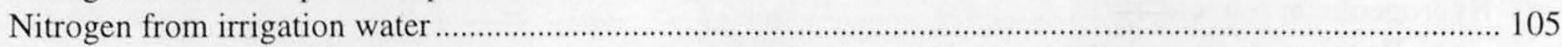

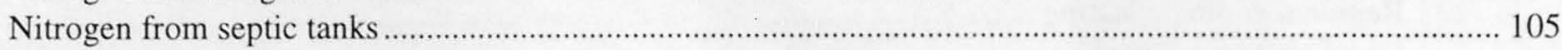

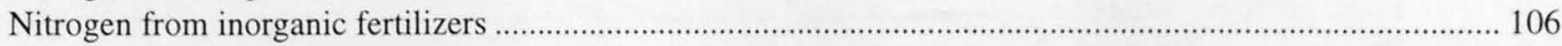

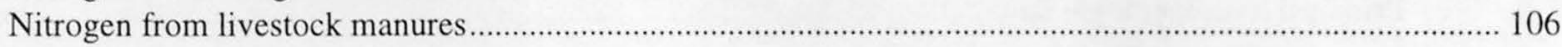

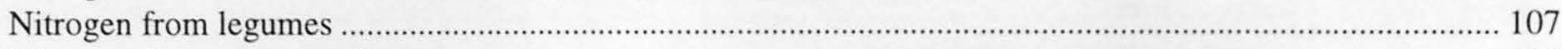

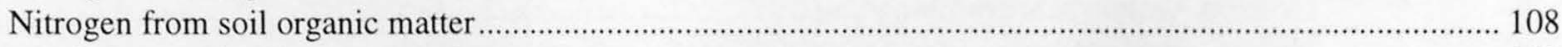

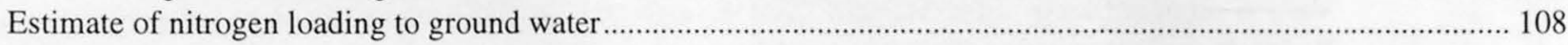

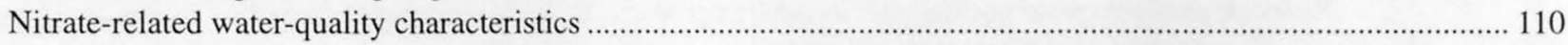

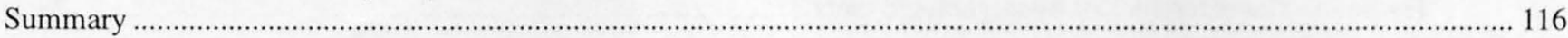

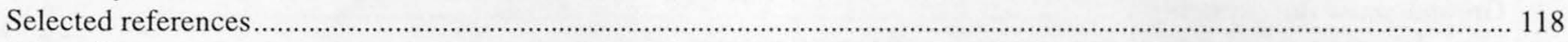

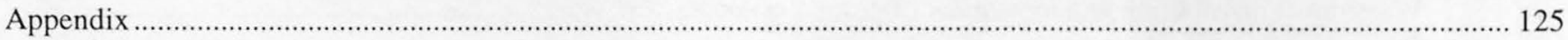

Computation of hydraulic conductance from specific capacity data ….............................................................. 126

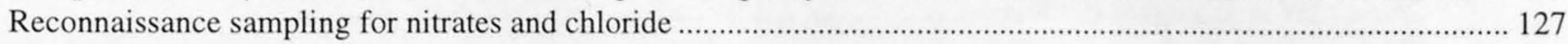

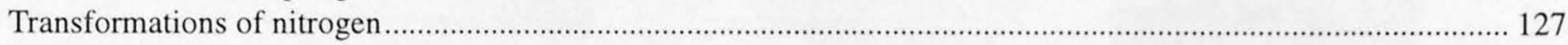

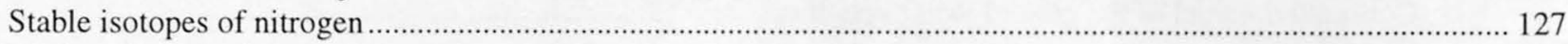

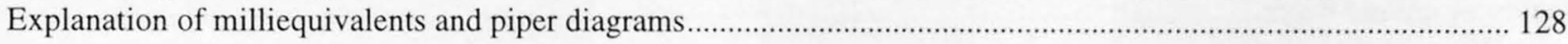

\section{PLATES (Plates are located in pocket, inside back cover)}

1. Location of wells used to collect geologic, hydrologic, and water-quality data in Whatcom County, Washington, and southwestern British Columbia.

2. Surficial geology and hydrogeologic sections in lowland aquifers of Whatcom County, Washington, and southwestern British Columbia.

3. Water-level hydrographs and maps showing water-level contours in surficial hydrogeologic units in Whatcom County, Washington, and southwestern British Columbia.

4. Distribution and seasonal variations of nitrate concentrations in ground water in Whatcom County, Washington, and southwestern British Columbia.

5. Distribution and seasonal variations of chloride concentrations in ground water in Whatcom County, Washington, and southwestern British Columbia. 
1. Map showing location of the Lynden-Everson-Nooksack-Sumas (LENS) study area in Whatcom

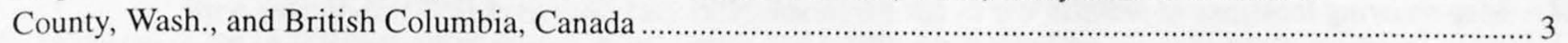

2. Diagram showing well- and spring-numbering systems used in Washington and British Columbia ..................... 5

3. Map showing surface drainage features and extent of peat and artificially drained soils in parts of the Lynden-Everson-Nooksack-Sumas (LENS) study area ..... 8

4. Bar graph showing (a) observed and mean monthly precipitation at Clearbrook, Wash. Weather Station, and map showing (b) annual precipitation in inches per year for the Lynden-Everson-Nooksack-Sumas (LENS) study area...

5. Map showing major land use patterns in 1992 and graph of population growth trends for the Lynden-Everson-Nooksack-Sumas (LENS) study area and parts of surrounding regions .................................... 13

6. Map showing thickness of unconsolidated deposits within the LENS study area ............................................... 18

7. Chart showing lithologic and hydrologic characteristics of hydrogeologic units in northern Whatcom County, Wash., and southwestern mainland British Columbia, Canada ............................................................ 21

8. Map showing extent, approximate thickness, and hydrologic condition of the Sumas aquifer .............................. 22

9. Map showing altitude of upper surface of Everson-Vashon semiconfining unit................................................. 24

10. Graphs showing concurrence of low ground-water levels and cumulative precipitation deficits of the LyndenEverson-Nooksack-Sumas (LENS) study area, Whatcom County, Wash., and British Columbia, Canada .............. 32

11. Map showing estimated rates of ground-water recharge of the LENS study area, Whatcom County, Washington, and British Columbia, Canada .......

12. Diagram showing the conceptual model of the ground-water flow system of the Lynden-EversonNooksack-Sumas (LENS) study area...

13. Boxplots showing distribution and median values of specific conductance, $\mathrm{pH}$, and concentration of alkalinity and dissolved oxygen in ground water from four hydrogeologic units of the Lynden-Everson-

Nooksack-Sumas (LENS) study area.....

14. Map showing areal distribution of dissolved oxygen concentrations in ground water in the Lynden-

Everson-Nooksack-Sumas (LENS) study area .....

15. Stiff diagrams showing distribution of major ion chemistry in wells along hydrogeologic sections $A-A^{\prime}$ and $I-I^{\prime}$.......

16. Boxplots showing distribution of concentrations of cations in milligrams per liter in ground water

from four hydrogeologic units in the Lynden-Everson-Nooksack-Sumas (LENS) study area.

17. Piper diagrams showing the percentage of major ions in water samples from four hydrogeologic units in the Lynden-Everson-Nooksack-Sumas (LENS) study area

18. Boxplots showing distribution of concentrations of anions in milligrams per liter in ground water from four hydrogeologic units in the Lynden-Everson-Nooksack-Sumas (LENS) study area.....

19. Boxplots showing distribution of concentrations of nitrate, ammonia and organic nitrogen by hydrogeologic unit in the Lynden-Everson-Nooksack-Sumas (LENS) study area.....

20. Graphs showing variability of nitrate concentrations in Sumas aquifer showing (a) average nitrate concentration and coefficient of variance and (b) average nitrate concentration and standard deviation.

21. Graph showing short-term variation in concentrations of nitrate and chloride in a water table piezometer in the Lynden-Everson-Nooksack-Sumas (LENS) study area

22. Boxplot showing comparison of median nitrate concentrations in ground water in the Lynden-EversonNooksack-Sumas (LENS) study area in 1972 and in 1990

23. Time-series plots showing long-term variability of nitrate concentrations at (a) well 092G.009.1.2.3-39, (b) well 39N/03E-10L01, (c) Sumas City wells and spring, (d) piezometer site A, (e) peizometer site $\mathrm{B}$, and (f) piezometer site $\mathrm{C}$

24. Map showing areal distribution of dissolved boron concentrations in ground water in the LyndenEverson-Nooksack-Sumas (LENS) study area

25. Map showing areal distribution of dissolved organic carbon concentrations in ground water in the Lynden-Everson-Nooksack-Sumas (LENS) study area ..... 
26. Plots of (a) bromide and chloride concentrations in ground water from aquifers in the Lynden-

Everson-Nooksack-Sumas (LENS) study area and in seawater; and (b) normal probability of

dissolved bromide concentrations in ground water from aquifers in the LENS study area......

27. Map showing locations of wells in the Lynden-Everson-Nooksack-Sumas (LENS) study area with

concentrations of chloride greater than 250 milligrams per liter or described as "salty water"

by well driller

28. Map showing areal distribution of iron concentration in ground water in the Lynden-Everson-

Nooksack-Sumas (LENS) study area

29. Map showing locations of wells sampled for pesticides and volatile organic compounds in the

Lynden-Everson-Nooksack-Sumas (LENS) study area

30. Simplified diagram showing biologically mediated nitrogen transformations in soils, showing

major processes of nitrogen addition and removal from soils in parts of the LENS study area.....

\section{TABLES}

1. Physical and hydrologic properties of major soils in the Lynden-Everson-Nooksack-Sumas study area, Whatcom County, Wash., and British Columbia, Canada.....

2. Summary of horizontal hydraulic conductivity values calculated from specific-capacity data, by hydrogeologic unit.

3. Calculated estimates of ground-water velocity in the Sumas aquifer and the Everson-Vashon semiconfining unit using selected values of hydraulic conductivity, hydraulic gradient, and porosity

4. Summary of seasonal water-level fluctuations in wells with 3 or more years of monthly observations

5. Monthly distribution of average precipitation, estimated potential evapotranspiration, and ground-water recharge at two weather stations within the Lynden-Everson-NooksackSumas study area, Whatcom County, Wash., and British Columbia, Canada

6. Median values and concentrations of water-quality constituents in ground waters from four hydrogeologic units

7. Statistical summary of values and concentrations of water-quality constituents in the Sumas aquifer

8. Statistical summary of values and concentrations of water-quality constituents in the

Everson-Vashon semiconfining unit

9. Statistical summary of values and concentrations of water-quality constituents in the

Vashon semiconfining unit.

10. Statistical summary of values and concentrations of water-quality constituents in the bedrock

semiconfining unit

11. Temporal variability of nitrate concentrations in ground waters with multiple observations.........

12. Nitrate concentrations in water samples obtained from the same well 3 years apart

13. Summary of concentrations of trace elements in ground water from four hydrogeologic units

14. Summary of total recoverable concentrations, analytical reporting limits, and health advisory

levels for pesticides and volatile organic compounds included in the analysis of selected

ground-water samples

15. Compilation of detection of organic pesticide compounds in ground waters of the study area from selected studies conducted between 1985-1993

16. Average concentration of major ions and yearly depositional rates at three locations in western Washington

17. Estimates of annual amounts of nitrogen applied and deposited in the Whatcom County portion of the Lynden-Everson-Nooksack-Sumas study area, Whatcom County, Wash., and British Columbia, Canada. 
18. Estimate of annual amount of nitrogen loading to soils and nitrate entering the ground-water system in the Whatcom County portion of the study area.

19. Characteristic ranges of selected water-quality constituents in ground waters containing nitrate

from different sources and concentrations observed in wells in the Sumas aquifer

20. Concentration of selected water-quality constituents and land use information

\section{APPENDIX TABLES}

1. Well, water-level, hydrogeologic, and reconnaissance water-quality data

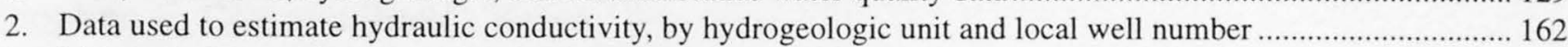

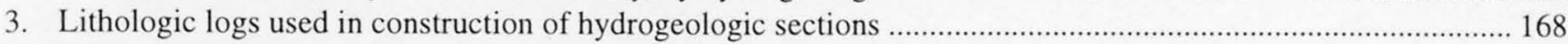

4. Values of common constituents, concentrations of major ions, iron, and manganese ........................................ 224

5. Concentration of trace elements in well water samples from portions of the Lynden-Everson-

Nooksack-Sumas study area, Whatcom County, Wash., and British Columbia, Canada.

6. Total recoverable concentrations of pesticides in selected well water samples from portions of the Lynden-Everson-Nooksack-Sumas study area, Whatcom County, Wash., and British

Columbia, Canada......

7. Concentrations of volatile organic compounds in well water samples from portions of the Lynden-Everson-Nooksack-Sumas study area, Whatcom County, Wash., and British

Columbia, Canada...

8. Concentrations of selected nitrogen species in ground water of the Lynden-Everson-Nooksack-

Sumas study area, Whatcom County, Wash., and British Columbia, Canada

\section{CONVERSION FACTORS AND VERTICAL DATUM}

\begin{tabular}{rcl}
\hline Multiply & By & To obtain \\
\hline foot $(\mathrm{ft})$ & 0.3048 & meter \\
mile $(\mathrm{mi})$ & 1.609 & kilometer \\
acre & 4,047 & square meter \\
acre & 2.47 & hectare \\
square mile $\left(\mathrm{mi}^{2}\right)$ & 2.590 & square kilometer \\
gallon $(\mathrm{gal})$ & 3.785 & liter \\
acre-foot $($ acre-ft) & 1,234 & cubic meter \\
foot per day \\
gallon per day per square foot $\left./ \mathrm{ft}^{2}\right)$ & 0.1339 & \\
pound per acre $(\mathrm{lb} / \mathrm{acre})$ & 1.12 & kilogram per hectare \\
degree Fahrenheit $\left({ }^{\circ} \mathrm{F}\right)$ & ${ }^{\circ} \mathrm{C}=5 / 9 \times\left({ }^{\circ} \mathrm{F}-32\right)$ & degree Celsius
\end{tabular}

Sea level: In this report "sea level" refers to the National Geodetic Vertical Datum of 1929 (NGVD of 1929)--a geodetic datum derived from a general adjustment of the first-order level nets of both the United States and Canada, formerly called Sea Level Datum of 1929. 



\title{
Hydrogeology, Ground-Water Quality, and Sources of Nitrate in Lowland Glacial Aquifers of Whatcom County, Washington, and British Columbia, Canada
}

\author{
By Stephen E. Cox and Sue C. Kahle
}

\section{ABSTRACT}

Ground water is an important source of domestic, municipal, and irrigation water supply throughout the Fraser-Whatcom Lowland, particularly for the 225-square mile agricultural area surrounding the Whatcom County communities of Lynden, Everson, Nooksack, and Sumas and the British Columbia communities of Abbotsford and Aldergrove. Population growth and developing ground-water-quality problems have increased the demand for additional sources of ground water. The U.S. Geological Survey, in cooperation with the Whatcom County Planning Department, collected water-level, lithologic, and water-quality data from 608 wells during 1990-92 to complete a regional appraisal of the ground-water system.

The study area is underlain largely by glacial sediments that vary from zero to more than 1,500 feet thick and overlie Tertiary bedrock. Ten hydrogeologic sections were constructed and used to delineate four principal hydrogeologic units: the Sumas aquifer and the Everson-Vashon, Vashon, and bedrock semiconfining units. The Sumas aquifer can supply large quantities of ground water to wells and is the major aquifer in the study area, whereas the semiconfining units supply limited quantities of ground water to some wells.

Precipitation ranges from 32 to more than 60 inches across the study area and is the primary source of ground-water recharge, which ranges from 11 to 45 inches per year. Most recharge occurs from October to March.
The chemical quality of most ground-water samples was generally good; however, nitrate concentrations exceeded the maximum contaminant level of 10 milligrams per liter (mg/L), established by the Environmental Protection Agency and Health Canada, in 15 percent of all wells sampled. For iron and manganese, concentrations exceeded drinking water guidelines based on esthetic consideration in 20 and 50 percent, respectively, of wells sampled for those constituents.

In the Sumas aquifer, nitrate concentrations ranged from less than 0.1 to greater than $40 \mathrm{mg} / \mathrm{L}$ as nitrogen, with a median concentration of $3.8 \mathrm{mg} / \mathrm{L}$; in the other hydrogeologic units the median concentration was less than $0.1 \mathrm{mg} / \mathrm{L}$. Nitrate concentrations in the Sumas aquifer exceeded the primary drinking water standard of $10 \mathrm{mg} / \mathrm{L}$ in more than 21 percent of the wells sampled, and in the other hydrogeologic units, in less than 2 percent of the wells sampled. The primary sources of nitrate in the shallow ground water includes the storage and application of barnyard manures, the application of nitrogen fertilizers to crops, and the use of domestic septic systems.

Nitrate concentrations in the Sumas aquifer showed significant short-term (seasonal) variation; long-term trends were difficult to discern, but concentrations appeared to be increasing in some areas. Nitrate concentrations in almost all wells in the Everson-Vashon, Vashon, and bedrock semiconfining units remained relatively unchanged over time.

Chloride concentrations ranged from 0.3 to 2,800 $\mathrm{mg} / \mathrm{L}$, and median chloride concentrations in the Sumas aquifer, Everson-Vashon, Vashon, 
and bedrock semiconfining units were $9,8,187$, and $37 \mathrm{mg} / \mathrm{L}$, respectively. In the Sumas aquifer, more than 70 percent of wells sampled had concentrations larger than background chloride concentrations of $4 \mathrm{mg} / \mathrm{L}$, suggesting that ground water in most of the aquifer has been affected by land-use activities. Large chloride concentrations found in many wells tapping the fine-grained glacial deposits are most likely associated with remnant seawater that was incorporated into these fine-grained deposits 13,000 to 20,000 years ago and has not been completely flushed by meteoric water. The widespread occurrence of remnant seawater in the deeper hydrogeologic units indicates that there is little chance of locating large, sustainable sources of fresh water within these units.

Ground-water samples from 24 wells open to the Sumas aquifer were analyzed for selected volatile organic compounds, triazine herbicides, and carbamate insecticides. One or more synthetic organic compounds were found in samples from four wells. Concurrent and subsequent sampling by other agencies also detected synthetic organic compounds.

Potential sources of nitrate in the ground water of the study area include dairy and poultry farming; fertilizers applied to croplands, lawns and gardens; residential septic systems; irrigation with ground water containing nitrates; land disposal of municipal biosolid wastes; and naturally occurring soil nitrogen, peat materials, and precipitation. About 75 percent of the area is used for agricultural activities, and evaluation of nitrate loading to ground water from these activities indicates that land application of manure, manure storage, and the use of fertilizers contribute the greatest quantities of nitrate. Residential sources contribute about 6 to 7 percent of total nitrogen input to ground water, but because this often occurs near areas where domestic wells are located, the impact of residential nitrate sources on concentrations of nitrates in some well water may be large. Even though agricultural sources contribute much larger quantities of nitrate to ground water than do residential sources, on a per-acre basis the rate of nitrate entering ground water from agricultural sources is about 1.5 to 3 times larger than for residential sources.

\section{INTRODUCTION}

The Nooksack River floodplain and the upper Sumas River Valley region of Whatcom County and British Columbia are located on glacial sediments of the Fraser-Whatcom Lowlands, much of which has been developed extensively as a major farming region. This study covers approximately 225 square miles of the southeastern portion of the Fraser-Whatcom Lowlands and is locally referred to as the LENS study, which refers to the Whatcom County communities of Lynden, Everson, Nooksack, and Sumas (fig. 1). Shallow ground water within these glacial sediments currently supplies much of the domestic, irrigation, and municipal water for the area. Early studies of the ground water within the LENS area (Newcomb and others, 1949; Washington State Division of Water Resources, 1960) considered the supply of shallow ground water to be ample and its quality "good." However, increasing numbers of water-quality problems were identified between 1973 and 1988 (Obbert, 1973; Black and Veatch, 1986; Liebscher and others, 1992; and Kwong, 1986). The study by Obbert (1973) and recent Whatcom County Health Department drinking water records show large concentrations of nitrate and iron commonly are found in ground water throughout the area. A trend of increasing nitrate concentration is also apparent in several wells where historical data are available. Areas of salty and corrosive water have been identified. Ethylene dibromide (EDB), a pesticide once commonly used in berry farming, also has been found in ground water at several locations. More recently, concerns have been raised regarding the extent and availability of ground water within the LENS area.

Declining water-quality conditions and an increasing population have resulted in an increased demand for supplies of potable ground water. Attempts to find additional sources of potable ground water have been hampered in part by inadequate knowledge of the hydrologic conditions of the area. Previous hydrologic investigations of this area have been limited in either scope or areal extent. Because of the need for a current, comprehensive hydrologic assessment of the area, the U.S. Geological Survey (USGS), in cooperation with 


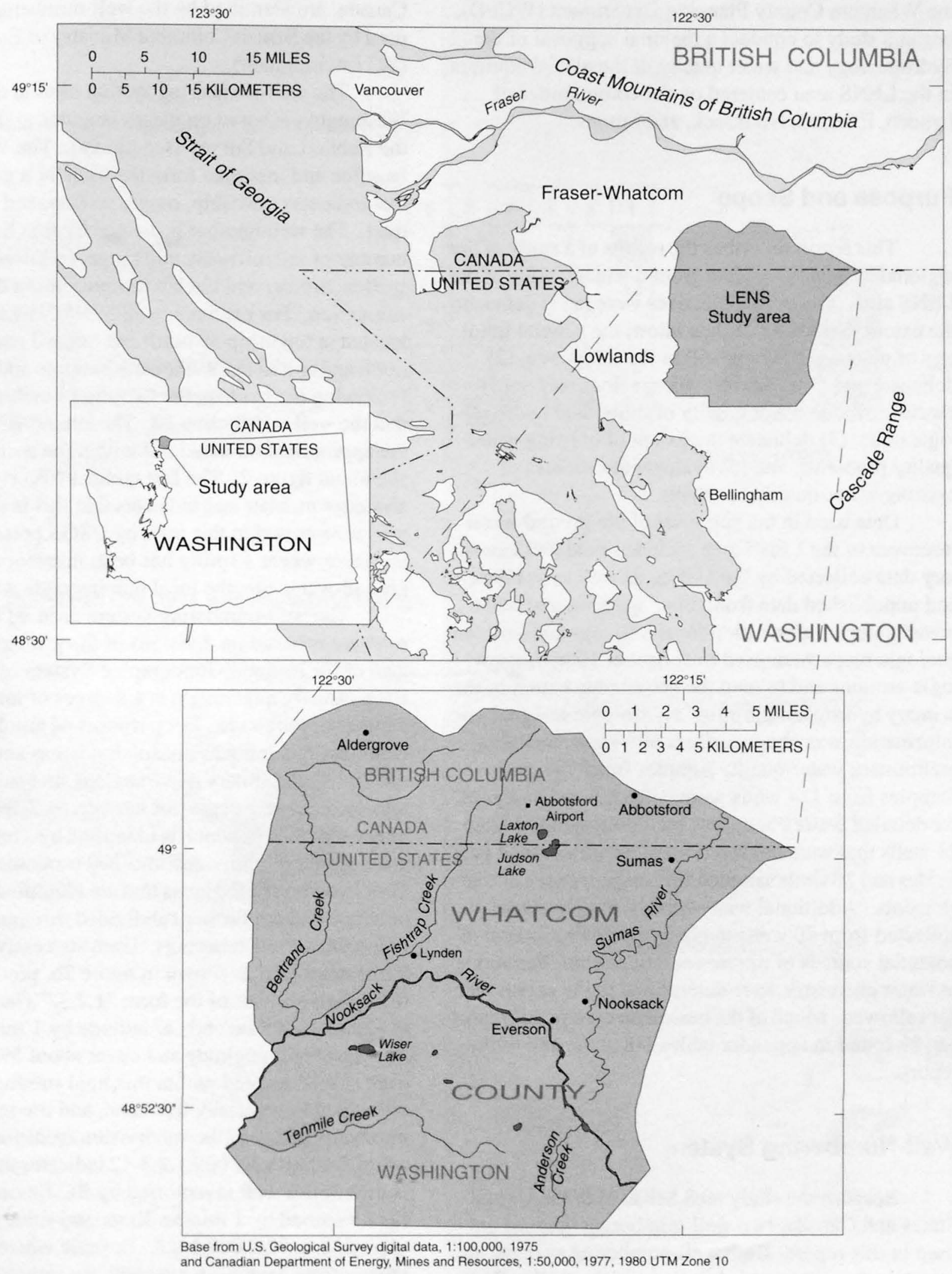

Figure 1. Location of the Lynden-Everson-Nooksack-Sumas (LENS) study area in Whatcom County, Washington, and British Columbia, Canada. 
the Whatcom County Planning Department (WCPD), began a study to conduct a regional appraisal of the hydrogeology and water quality of the glacial aquifers in the LENS area centered on the communities of Lynden, Everson, Nooksack, and Sumas.

\section{Purpose and Scope}

This report describes the results of a study of the regional hydrogeology and ground-water quality of the LENS area. The study objectives were to (1) define, to the extent that available data allow, the general lithology of glacial sediments within the study area; (2) delineate and characterize hydrogeologic units; (3) characterize the water quality of individual hydrogeologic units; (4) delineate the extent of existing waterquality problems; and (5) evaluate the sources of existing water-quality problems.

Data used in the appraisal of the ground-water resources of the LENS area included field and laboratory data collected by the USGS, as well as published and unpublished data from other agencies and other investigators. Information from well logs and surficial geologic maps were used to construct 10 hydrogeologic sections and to map the geographic extent of the primary hydrogeologic units. Hydrologic and geologic information was obtained from 608 wells, including preliminary water-quality samples from 356 wells. Samples from 124 wells were collected and analyzed for detailed water chemistry, including samples from 24 wells that were analyzed for concentrations of pesticides and 20 wells sampled for concentrations of trace elements. Additional water-quality samples were collected from 70 wells to aid in the determination of potential sources of nitrate contamination. Variations in water chemistry were determined to the extent that data allowed. Much of the basic data used in this report can be found in appendix tables 1-8 at the end of the report.

\section{Well-Numbering System}

Because the study area lies in both the United States and Canada, two well-numbering systems are used in this report. Both well-numbering systems are based on the geographic locations of the wells. Wells located within Whatcom County, Wash., are identified by the well-numbering system used in the State of Washington. Wells located within British Columbia,
Canada, are identified by the well-numbering system used by the British Columbia Ministry of Environment (BC Environment).

The well-numbering system used in the State of Washington is based on the rectangular grid system of the Public Land Survey (see fig. 2a). The Willamette baseline and meridian form the basis of a grid system that indicates township, range, section, and 40-acre tract. The well number is created by first listing the number of the township and range, followed by the section number and the letter representing the 40 -acre subsection. For example, well 39N/03E-12R02 is located in township 39 north and range 3 east, which is north and east of the Willamette baseline and meridian. Following the hyphen, the two-digit number indicates that the well is in section 12. The letter ("R") indicates the appropriate 40 -acre tract within the section, as shown on figure 2. The last number (02) is the sequence number and indicates that this is the second well inventoried in this tract by USGS personnel. In instances where a spring has been inventoried as a ground-water site, the local number ends with an "S".

The well-numbering system used by BC Environment is based on divisions of the primary quadrangles of the National Topographic System of Canada. Each primary quadrangle is 4 degrees of latitude by 8 degrees of longitude. For purposes of numbering wells, the quadrangles are subdivided as shown in figure $2 \mathrm{~b}$. Each primary quadrangle is first subdivided into 16 areas of 1 degree of latitude by 2 degrees of longitude, each of which is identified by a letter. These areas then are subdivided into 100 6-minute by 12-minute numbered areas that are identified by 3 -digit numbers and are further subdivided through a process of 3 successive quarterings. Each successive quartering is numbered as shown in figure $2 b$, producing a three-digit number of the form "1.2.3." The final subdivisions are 45 seconds of latitude by 1 minute and 30 seconds of longitude and cover about 590 acres each. Wells located within this final subdivision are numbered sequentially from one, and the sequential number is added to the subdivision identifier. For example, well 92G.008.1.2.3-12 indicates that this well is the twelfth well inventoried by BC Environment in the 45 second by 1 minute 30 second subdivision identified as $92 \mathrm{G} .008 .1 .2 .3$. In wells where nested piezometers have been installed, the individual piezometer cannot be distinguished by the well local number. In those cases the depth of the bottom of the screened-interval has been added to the end of the local 
(a) State of Washington well-numbering system

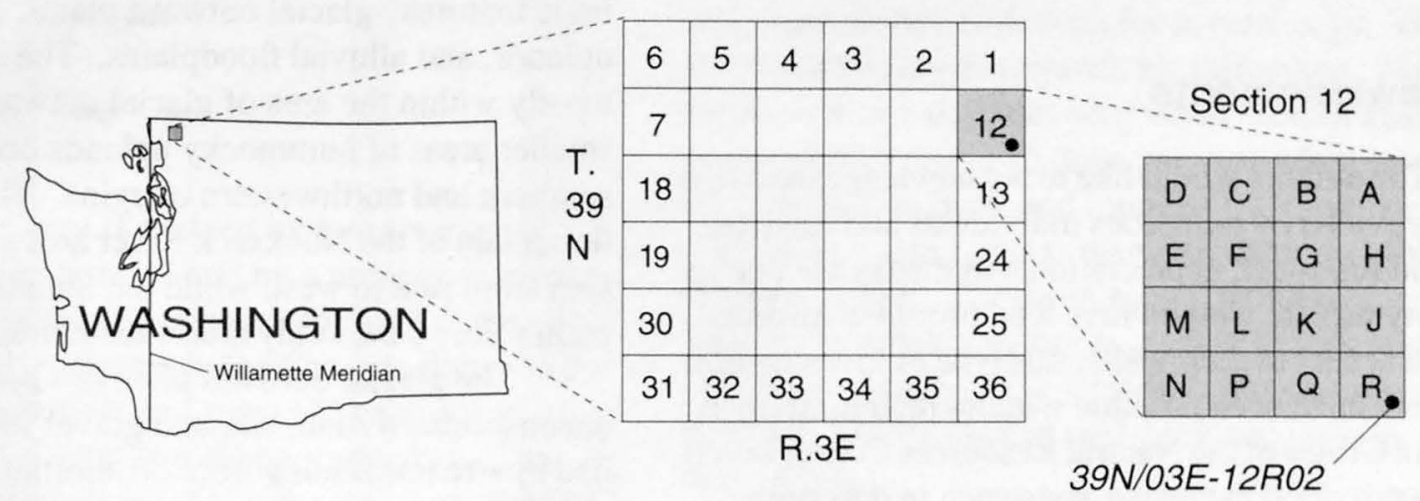

(b) British Columbia well-numbering system

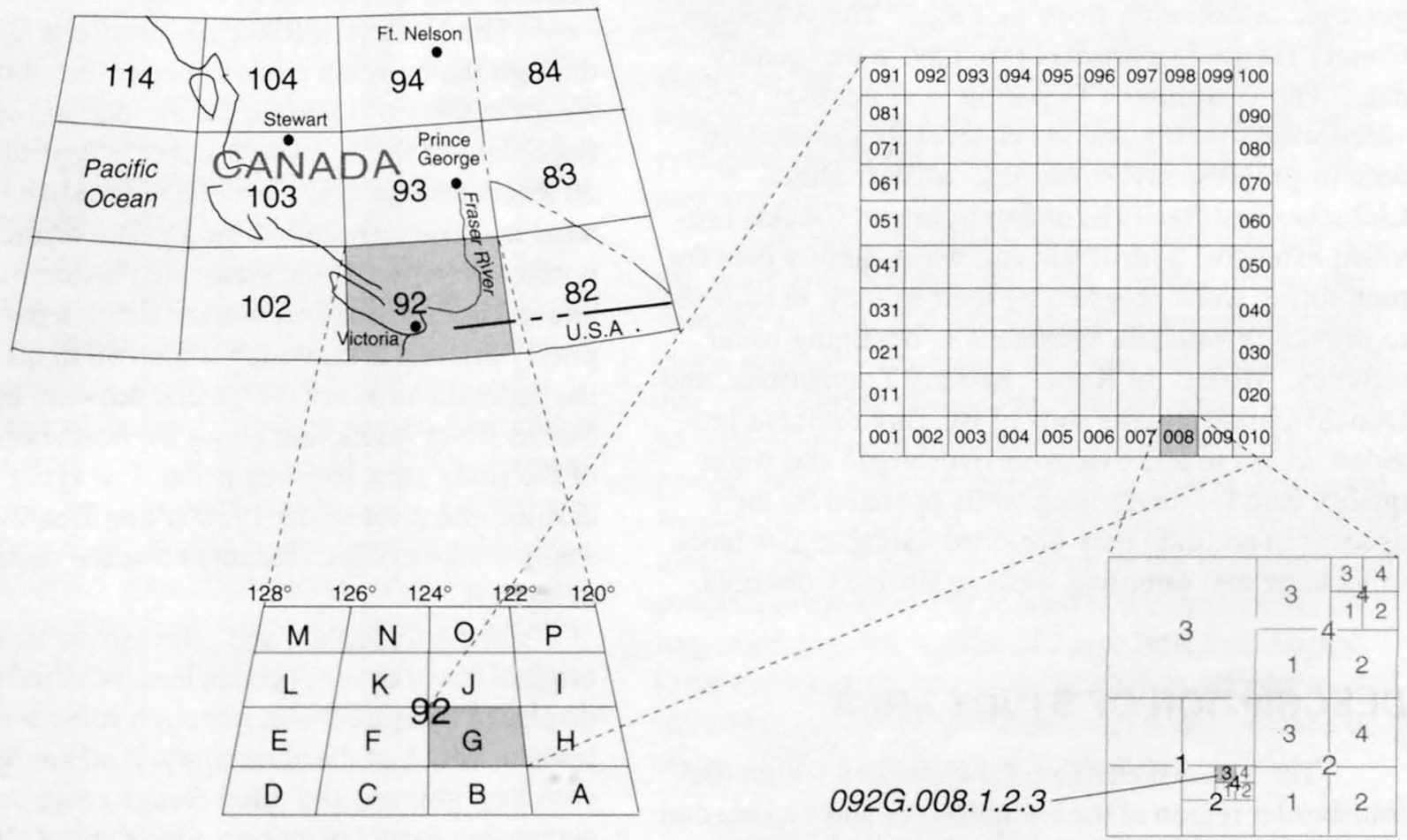

Figure 2. Well- and spring-numbering systems used in (a) Washington and (b) British Columbia. 
number as in well 092G.009.1.1.1-12(25). Wells that did not have BC Environment assigned sequence numbers were designated as $\mathrm{XX}$ or in cases where the well in question was a monitoring well installed by Environment Canada (EC), the EC monitoring well number was used, as in 092G.008.1.1.4-ABB1.

\section{Acknowledgments}

The authors would like to acknowledge the assistance provided by numerous individuals and agencies. First and foremost, appreciation and thanks are due to the many private well owners who provided information and access to their wells; this type of investigation would not have been possible without their assistance. Mr. John Gillies of the Natural Resources Conservation Service provided extensive assistance in describing agricultural practices within the area and in evaluating agricultural sources of nitrate in ground water. Similar assistance was also provided by Craig McConnel, Washington State University Extension Service. Dr. Charles Flora provided access to 11 years of weekly water-quality data. Hayes Drilling Company provided geologic information from well logs. The Whatcom County Health Department provided water-quality data. The Washington Department of Ecology provided water-quality and water-level data associated with in-progress investigations. Misters Hugh Liebscher and Basil Hii of Environment Canada provided extensive hydrologic and water-quality data for monitoring wells operated by their agency, in addition to providing valuable assistance in obtaining water samples. Misters Al Kohut, Rodney Zimmerman, and Donald Childs and the staff of BC Environment provided access to and extensive hydrologic and waterquality data for monitoring wells operated by their agency; in addition they provided valuable assistance in locating and sampling wells in British Columbia.

\section{DESCRIPTION OF STUDY AREA}

The Fraser-Whatcom Lowland lies within the transborder region of the United States and Canada and encompasses about $1,000 \mathrm{mi}^{2}$ (square miles). This region is bounded by the Coast Mountains of British Columbia, the Cascade Range, and the Strait of Georgia (see fig. 1). The LENS study area is limited to about $225 \mathrm{mi}^{2}$ in the southeastern part of the Fraser
Lowland near the Cascade foothills. Seventy-six percent of the study area is in Whatcom County, and the remaining area is in British Columbia.

The land surface of the study area is dominated by glacial features and can be characterized by three landforms that correspond to the major surficial geologic features: glacial outwash plains, hummocky uplands, and alluvial floodplains. The study area falls mostly within the area of glacial outwash plains, with smaller areas of hummocky uplands occurring on the southern and northwestern margins. The alluvial floodplain of the Nooksack River arcs across the study area from east to west, while the Sumas River floodplain follows the study area's eastern border.

The glacial outwash plain is a broad expanse of unconsolidated sand, silt, and gravel sediments deposited by streams issuing from the terminus of advancing and retreating continental glaciers. The surface of the outwash plain has limited relief except in places where it has been incised by streams, rivers, or glacial meltwater. Local depressions formed by glacial kettles are common, and because of the shallowness of the water table in this area, many of these kettles now contain lakes, ponds, or marshy peat bogs.

The Nooksack River has eroded and cut down through the outwash plain to bisect the study area. Near the town of Lynden, the altitude of the present floodplain of the Nooksack River is typically 40 to 60 feet below the altitude of the outwash plain, creating what is commonly called the Lynden terrace. The northeastern part of the study area is dominated by the alluvial floodplain of the Sumas River, a flat, low lying, poorly drained area, which is also 40 to 60 feet below the general altitude of the glacial outwash plain. In the Sumas River floodplain along the northeastern margin of the study area, the area is flat, low lying and poorly drained and prior to the 1920's, this area was part of a shallow lake in which recent lacustrine sediments were deposited.

In the floodplain and outwash areas, most of the original forest cover of cedar, hemlock, and fir has been displaced by agriculture, although some forested areas remain. Much of the agricultural land has been planted with hay, grasses, and other forage crops suitable for supporting dairy operations. One third of all the dairies in Washington State are located within the study area. In addition to pasture lands, berry production makes up a significant part of agricultural lands within the study area. 
The hummocky upland areas occur above the level of accumulation of the glacial outwash sediments that make up the outwash plain. These areas are characterized by undulating topography, fine-grained soils, and generally poor drainage. During heavy winter rains, water tends to accumulate within the many depressions of these areas.

\section{Drainage}

The study area is drained by two rivers--the Nooksack and the Sumas--and by a number of creeks and drainage ditches that empty into these rivers. The Nooksack River originates in the Cascade Range to the east of the project area, and most ( 72 percent) of its drainage area lies upstream of the study area. The Nooksack River traverses the study area for a distance of 25 miles, with an average gradient of 10 feet per mile above and 4 feet per mile below the town of Everson. During floods, the Nooksack River often overflows its banks near the town of Everson, where part of the overbank flow then enters the Sumas River drainage to the Fraser River in British Columbia. Tributaries to the Nooksack River include Bertrand, Fishtrap, Tenmile, and Anderson Creeks. The Sumas River flows northward, draining the eastern part of the study area and the adjacent Cascade Range foothills before leaving the study area and discharging to the Fraser River 10 miles northeast of Abbotsford.

Because much of the study area initially was poorly drained, numerous surface drainage ditches and subsurface tile drains have been built to remove excess surface and shallow ground water, allowing greater agricultural use of the land. Surface-water features and the extent of artificially drained soils (U.S. Department of Agriculture, Soil Conservation Service, 1992b) are shown in figure 3. Soils within the Canadian part of the study area, which is generally found at higher altitudes, typically are undrained (Bernard Zebarth, Agriculture Canada, oral commun., 1993).

\section{Climate}

The climate of the Fraser-Whatcom Lowlands is strongly influenced by maritime air from the Pacific Ocean, which has a moist moderating effect (Phillips, 1966). The Cascade Range and Rocky Mountains typically shield the region from cold air masses moving southward from Canada. The region generally experiences warm, dry summers and mild, rainy winters. Winter weather consists of a steady progression of low-pressure systems entering from the Pacific Ocean, bringing cloudy and rainy conditions; however, occasional high-pressure systems over the continental interior introduce strong, cold northeasterly winds to the area. Rainfall intensity is usually light to moderate, and rains can be continuous for several days. Thunderstorms and heavy downpours are infrequent. Typically, there are 4 to 5 days per year when rainfall amounts exceed 1 inch, 20 to 25 days per year when rainfall exceeds half an inch, and roughly 150 days per year with measurable (greater than 0.01 inch) rainfall (Phillips, 1966). The mean annual temperature is $49^{\circ} \mathrm{F}$, with the warmest weather occurring in July and the coldest in January. The frost-free growing season generally begins around mid-May and ends in mid-October.

Precipitation within the Fraser-Whatcom Lowlands is quite variable. Within the study area annual precipitation ranges from about 32 inches per year near the southwestern corner of the study area, to over 60 inches per year near Abbotsford, in the northeast. Isohyetal lines (contours of equal rainfall depth) generated from rainfall data provided from United States and Canadian weather service agencies are shown in figure 4. The influence of both the Coast Mountains and the Cascade Range is apparent, as precipitation increases near these mountains to the east and north.

Although the annual precipitation that falls on the study area is relatively large, rainfall during the summer is light, and irrigation of some agricultural crops is usually necessary because soil-moisture deficits occur during part of the summer growing season. Most precipitation falls during the October-April period, while evapotranspiration is largest during the June-to-August period. At the Bellingham weather station, located 20 miles southwest of the study area, pan evaporation is typically at least twice the rate of precipitation during the months of June, July, and August. Over the course of the growing season, recommended irrigation requirements range from 6 to 17 inches of water (U.S. Department of Agriculture, 1985).

\section{Soils}

The physical characteristics of soil affect the quantity and quality of water recharging shallow aquifers. The soils within the study area were derived largely from the underlying glacial and alluvial 


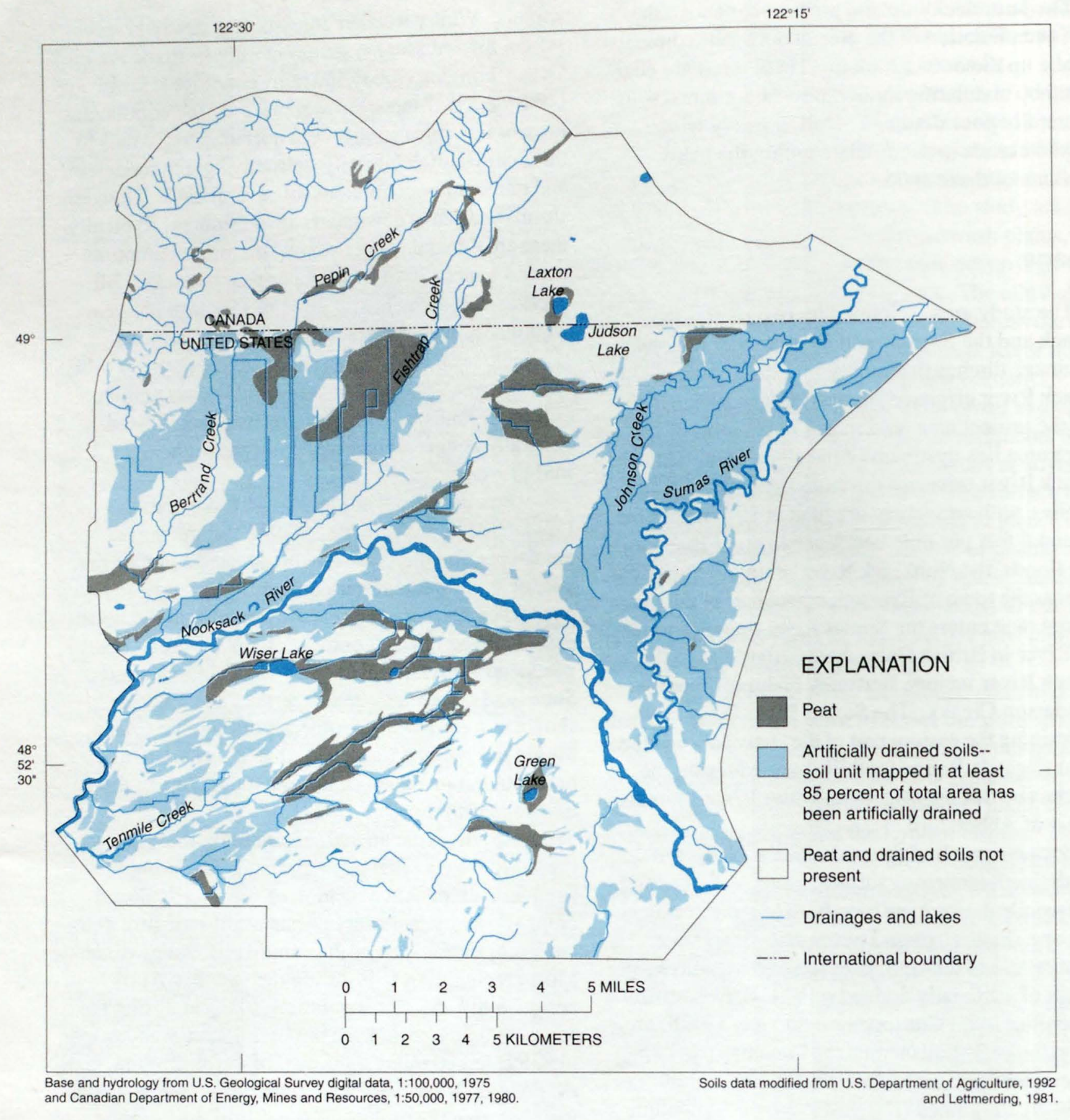

Figure 3. Surface drainage features and extent of peat and artificially drained soils in parts of the Lynden-EversonNooksack-Sumas (LENS) study area. 
(a)
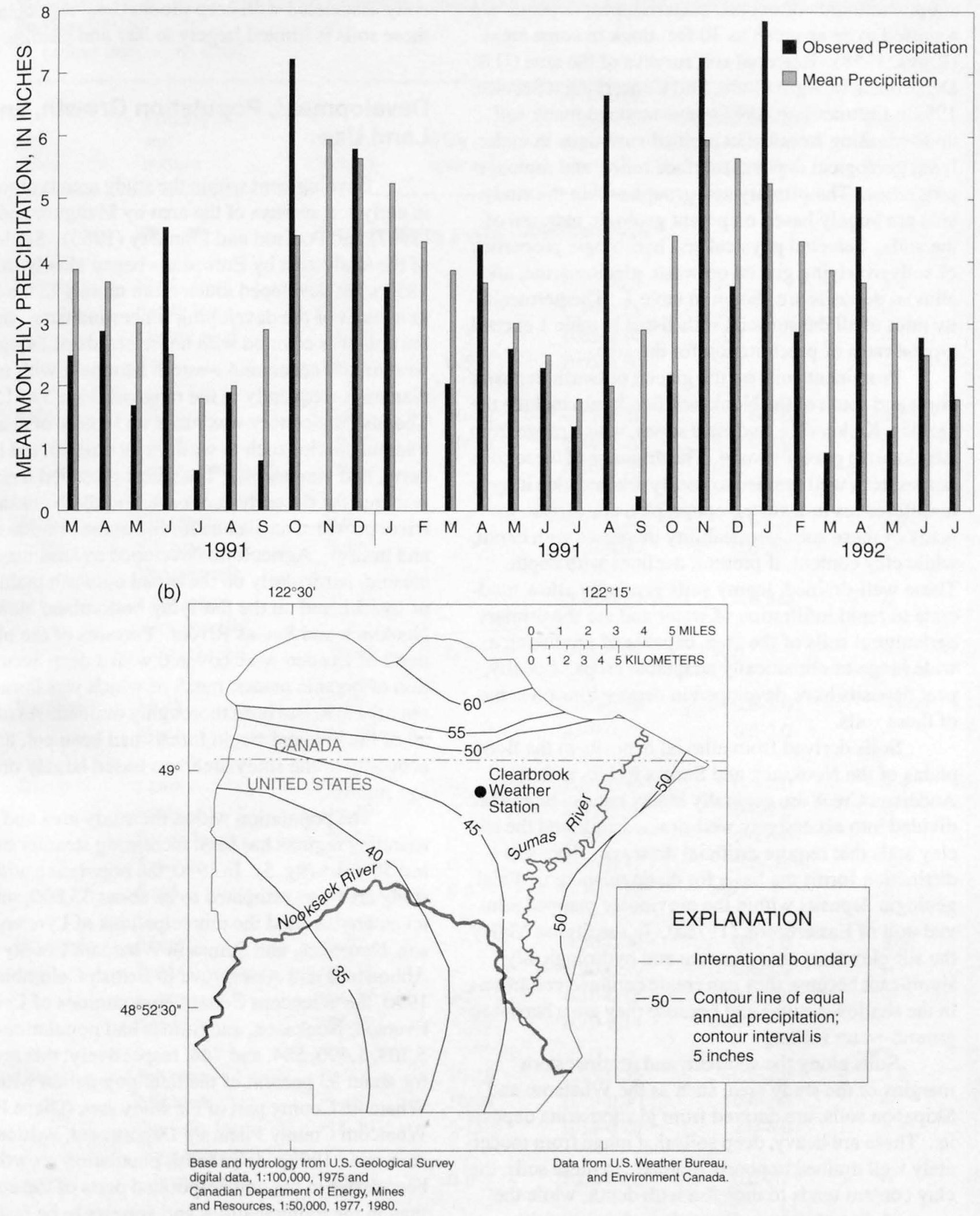

Figure 4. (a) Observed and mean monthly precipitation at the Clearbrook, Washington Weather Station, and (b) annual precipitation in inches per year for the Lynden-Everson-Nooksack-Sumas (LENS) study area. 
deposits. In some areas, soils have accumulated substantial amounts of organic material; peat deposits are reported to be as much as 30 feet thick in some areas (Riggs, 1958). Regional soil surveys of the area (U.S. Department of Agriculture, Soil Conservation Service, 1992b; Luttmerding, 1981) have mapped many soil units resulting from the combined variations in underlying geological deposits, surface relief, and drainage properties. The primary soil groups within the study area are largely based on parent geologic material of the soils. Selected physical and hydrologic properties of soils overlying glacial outwash, glaciomarine, and alluvial deposits are shown in table 1 . The permeability rates of all the surficial soils listed in table 1 exceed typical rates of precipitation for the area.

Prominent soils on the glacial outwash deposits north and south of the Nooksack floodplain include the Lynden, Kickerville, and Hale series, which range from silty loam to gravelly loam. The drainage of these soils ranges from well drained to poorly drained, due largely to differences in texture, topography, and slope. In many of these soils permeability increases with depth, while clay content, if present, declines with depth. These well-drained, loamy soils generally allow moderate to rapid infiltration of water and are the primary agricultural soils of the area, capable of producing a wide range of climatically adaptable crops. Locally, peat deposits have developed in depressions on some of these soils.

Soils derived from alluvial deposits in the floodplains of the Nooksack and Sumas Rivers and of Anderson Creek are generally loamy but can be further divided into excessively well-drained soils and the siltclay soils that require artificial drainage. This soil distinction forms the basis for distinguishing surficial geologic deposits within the previously mapped alluvial unit of Easterbrook (1976a). In the Sumas Valley the silt-clay soils are extensive and hydrologically significant because they can create confined conditions in the shallow aquifer and because they are a barrier to ground-water recharge.

Soils along the southern and northwestern margins of the study area, such as the Whatcom and Skipapoa soils, are derived from glaciomarine deposits. These are heavy, deep soils that range from moderately well drained to poorly drained. In these soils, the clay content tends to increase with depth; while the permeability of these soils tends to decrease with depth. The hummocky, undulating land surface results in variable drainage and increases the cost and difficulty associated with crop production. Agriculture on these soils is limited largely to hay and pasture.

\section{Development, Population Growth, and Land Use}

Development within the study area is chronicled in early soil surveys of the area by Mangum and Hurst (1907) and Poulson and Flannery (1953). Settlement of the study area by Europeans began slowly in the 1850 's but developed much more rapidly in the 1880's as a result of the developing timber industry. Initially the area was covered with dense stands of Douglas fir, western red cedar, and western hemlock, with tree diameters frequently in the range of from 5 to 15 feet. The lush understory was made up largely of shadetolerant species such as western swordfern, red huckleberry, and vine maple. The forest provided a rich resource for the early economy, and the Nooksack River provided an avenue for the transportation of logs and lumber. Agriculture developed as land was cleared, particularly on the broad outwash plain north of Lynden and on the flat-lying bottomland along the Nooksack and Sumas Rivers. Portions of the plain north of Lynden were covered with a deep accumulation of organic matter, much of which was burned off once the area had been thoroughly drained. As of 1950 , all of the lowland virgin forests had been cut, and the economy of the study area was based largely on agriculture.

The population within the study area and surrounding regions has been increasing steadily over the last 50 years (fig. 5). In 1990, the population within the study area was estimated to be about 35,000 , much of it centered around the municipalities of Lynden, Everson, Nooksack, and Sumas in Whatcom County and of Abbotsford and Aldergrove in British Columbia. In 1990, the Whatcom County communities of Lynden, Everson, Nooksack, and Sumas had populations of $5,709,1,490,584$, and 744 , respectively; this accounts for about 33 percent of the total population within the Whatcom County part of the study area (Diane Harper, Whatcom County Planning Department, written commun., 1992). In general, population growth has been faster in the unincorporated parts of the county than in the municipalities and appears to be fastest in British Columbia. 
Table 1. Physical and hydrologic properties of major soils in the Lynden-Everson-Nooksack-Sumas study area, Whatcom County, Wash., and British Columbia, Canada (U.S. Department of Agriculture Soil Conservation Service, 1992b)

[>, greater than; --, no data]

\begin{tabular}{llllll}
\hline & Primary & & Available \\
water & & $\begin{array}{l}\text { Permeability } \\
\text { capacity } \\
\text { Soil }\end{array}$ & $\begin{array}{l}\text { Soil } \\
\text { texches) }\end{array}$ & $\begin{array}{l}\text { Organic } \\
\text { rate (inches } \\
\text { per hour) }\end{array}$ & $\begin{array}{l}\text { Oratter } \\
\text { (percent) }\end{array}$ \\
\hline
\end{tabular}

Soils overlying glacial outwash deposits

\begin{tabular}{|c|c|c|c|c|c|c|}
\hline \multirow[t]{4}{*}{ Lynden } & Sandy loam & $0-8$ & -- & $0.15-0.25$ & $2-6$ & $3-9$ \\
\hline & Sandy loam & $8-18$ & -- & $0.10-0.15$ & $2-6$ & -- \\
\hline & Loamy sand & $18-30$ & $0-5$ & $0.05-0.10$ & $>20$ & -- \\
\hline & Sand & $30-60$ & $0-5$ & $0.05-0.10$ & $>20$ & -- \\
\hline \multirow[t]{3}{*}{ Hale } & Silt loam & $0-10$ & $10-18$ & $0.19-0.21$ & $0.6-2.0$ & $1-4$ \\
\hline & Loam & $10-26$ & $10-18$ & $0.16-0.20$ & $0.6-2.0$ & -- \\
\hline & Loamy fine sand & $26-60$ & $0-5$ & $0.16-0.20$ & $>20$ & -- \\
\hline \multirow{5}{*}{$\begin{array}{l}\text { Kicker- } \\
\text { ville }\end{array}$} & Silt loam & $0-9$ & -- & $0.25-0.35$ & $0.6-2.0$ & $3-9$ \\
\hline & Silt loam & $9-22$ & -- & $0.20-0.30$ & $0.6-2.0$ & -- \\
\hline & $\begin{array}{l}\text { Very gravelly } \\
\text { silt loam }\end{array}$ & $22-32$ & -- & $0.15-0.20$ & $0.6-2.0$ & -- \\
\hline & Very gravelly & & & & & \\
\hline & loamy sand & $32-60$ & $0-5$ & $0.03-0.08$ & $>20$ & -- \\
\hline \multirow{2}{*}{ Pangborn } & Muck & $0-15$ & -- & $0.40-0.50$ & $0.6-2.0$ & $40-90$ \\
\hline & Muck & $15-60$ & -- & $0.40-0.50$ & $0.6-2.0$ & -- \\
\hline \multirow[t]{5}{*}{ Tromp } & Loam & $0-11$ & -- & $0.20-0.30$ & $0.6-2.0$ & $3-9$ \\
\hline & Loam & $11-20$ & -- & $0.15-0.20$ & $0.6-2.0$ & -- \\
\hline & Sandy loam & $20-26$ & -- & $0.10-0.15$ & $2.0-6.0$ & -- \\
\hline & Sand & $26-46$ & $0-5$ & $0.10-0.15$ & $6.0-20$ & -- \\
\hline & Sand & $46-60$ & $0-5$ & $0.10-0.15$ & $>20$ & -- \\
\hline \multirow[t]{4}{*}{ Edmonds } & Loam & $0-11$ & -- & $0.30-0.40$ & $0.6-2.0$ & $3-9$ \\
\hline & Loam & $11-18$ & -- & $0.20-0.30$ & $0.6-2.0$ & -- \\
\hline & Loamy sand & $18-37$ & $0-5$ & $0.10-0.15$ & $6.0-20$ & -- \\
\hline & Sand & $37-60$ & -- & $0.10-0.14$ & $>20$ & -- \\
\hline \multirow[t]{5}{*}{ Clipper } & Silt loam & $0-9$ & $10-18$ & $0.25-0.35$ & $0.6-2.0$ & $2-9$ \\
\hline & Silt loam & $9-18$ & $10-18$ & $0.20-0.30$ & $0.6-2.0$ & -- \\
\hline & Gravelly loam & $18-30$ & $5-15$ & $0.15-0.20$ & $2.0-6.0$ & -- \\
\hline & Very gravelly & & & & & \\
\hline & loamy sand & $30-60$ & $0-5$ & $0.05-0.10$ & $6.0-20$ & -- \\
\hline
\end{tabular}


Table 1. Physical and hydrologic properties of major soils in the Lynden-Everson-Nooksack-Sumas study area, Whatcom County, Wash., and British Columbia, Canada (U.S. Department of Agriculture Soil Conservation Service, 1992b)--Continued

\begin{tabular}{|c|c|c|c|c|c|c|}
\hline $\begin{array}{l}\text { Soil } \\
\text { series }\end{array}$ & $\begin{array}{l}\text { Primary } \\
\text { soil } \\
\text { texture }\end{array}$ & $\begin{array}{l}\text { Depth } \\
\text { (inches) }\end{array}$ & $\begin{array}{l}\text { Clay } \\
\text { (percent) }\end{array}$ & $\begin{array}{l}\text { Available } \\
\text { water } \\
\text { capacity } \\
\text { (inches) }\end{array}$ & $\begin{array}{l}\text { Permeability } \\
\text { rate (inches } \\
\text { per hour) }\end{array}$ & $\begin{array}{l}\text { Organic } \\
\text { matter } \\
\text { (percent) }\end{array}$ \\
\hline
\end{tabular}

Soils overlying alluvial deposits

\begin{tabular}{|c|c|c|c|c|c|c|}
\hline \multirow[t]{2}{*}{ Briscot } & Silt loam & $0-9$ & $5-12$ & $0.19-0.24$ & $0.6-2.0$ & $3-9$ \\
\hline & $\begin{array}{l}\text { Stratified } \\
\text { silt loam }\end{array}$ & $9-60$ & $5-12$ & $0.13-0.20$ & $0.6-2.0$ & -- \\
\hline \multirow[t]{2}{*}{ Puget } & Silt loam & $0-9$ & $18-27$ & $0.19-0.21$ & $0.6-2.0$ & $3-9$ \\
\hline & Silty clay loam & $9-60$ & $18-35$ & $0.19-0.21$ & $0.2-0.6$ & -- \\
\hline \multirow[t]{2}{*}{ Oridia } & Silt loam & $0-10$ & $8-18$ & $0.19-0.21$ & $0.6-2.0$ & $2-6$ \\
\hline & Silt loam & $10-60$ & $8-18$ & $0.19-0.21$ & $0.6-2.0$ & -- \\
\hline \multirow{3}{*}{$\begin{array}{l}\text { Mt Vernon } \\
\text { Fine }\end{array}$} & & & & $013-015$ & $06-20$ & $3-9$ \\
\hline & $\begin{array}{l}\text { Sandy loam } \\
\text { Very fine }\end{array}$ & $0-7$ & -- & $0.13-0.13$ & $0.0=2.0$ & ליד \\
\hline & sandy loam & $7-60$ & - & $0.13-0.15$ & $0.6-2.0$ & -- \\
\hline \multirow[t]{3}{*}{ Sumas } & Silt loam & $0-8$ & $18-27$ & $0.19-0.21$ & $0.6-2.0$ & $3-9$ \\
\hline & Silt loam & $8-28$ & $18-35$ & $0.18-0.20$ & $0.2-0.6$ & -- \\
\hline & Loamy sand & $26-60$ & $0-5$ & $0.05-0.09$ & $6.0-20$ & -- \\
\hline
\end{tabular}

Soils overlying fine-grained glaciomarine deposits

\begin{tabular}{lllllll} 
Whatcom & Silt loam & $0-9$ & -- & $0.30-0.40$ & $0.6-2.0$ & $3-9$ \\
& Silt loam & $9-16$ & -- & $0.20-0.35$ & $0.6-2.0$ & -- \\
& Loam & $16-26$ & $18-35$ & $0.15-0.20$ & $0.2-0.6$ & -- \\
& Loam & $26-20$ & $18-35$ & $0.13-0.20$ & $0.06-0.2$ & -- \\
\multirow{2}{*}{ Skipapoa } & & & & & \\
& Silt loam & $0-8$ & -- & $0.30-0.40$ & $0.6-2.0$ & $3-9$ \\
& Silt loam & $8-20$ & -- & $0.20-0.30$ & $0.6-2.0$ & -- \\
& Silty clay & $20-60$ & $35-60$ & $0.15-0.20$ & $<0.06$ & -- \\
\hline
\end{tabular}




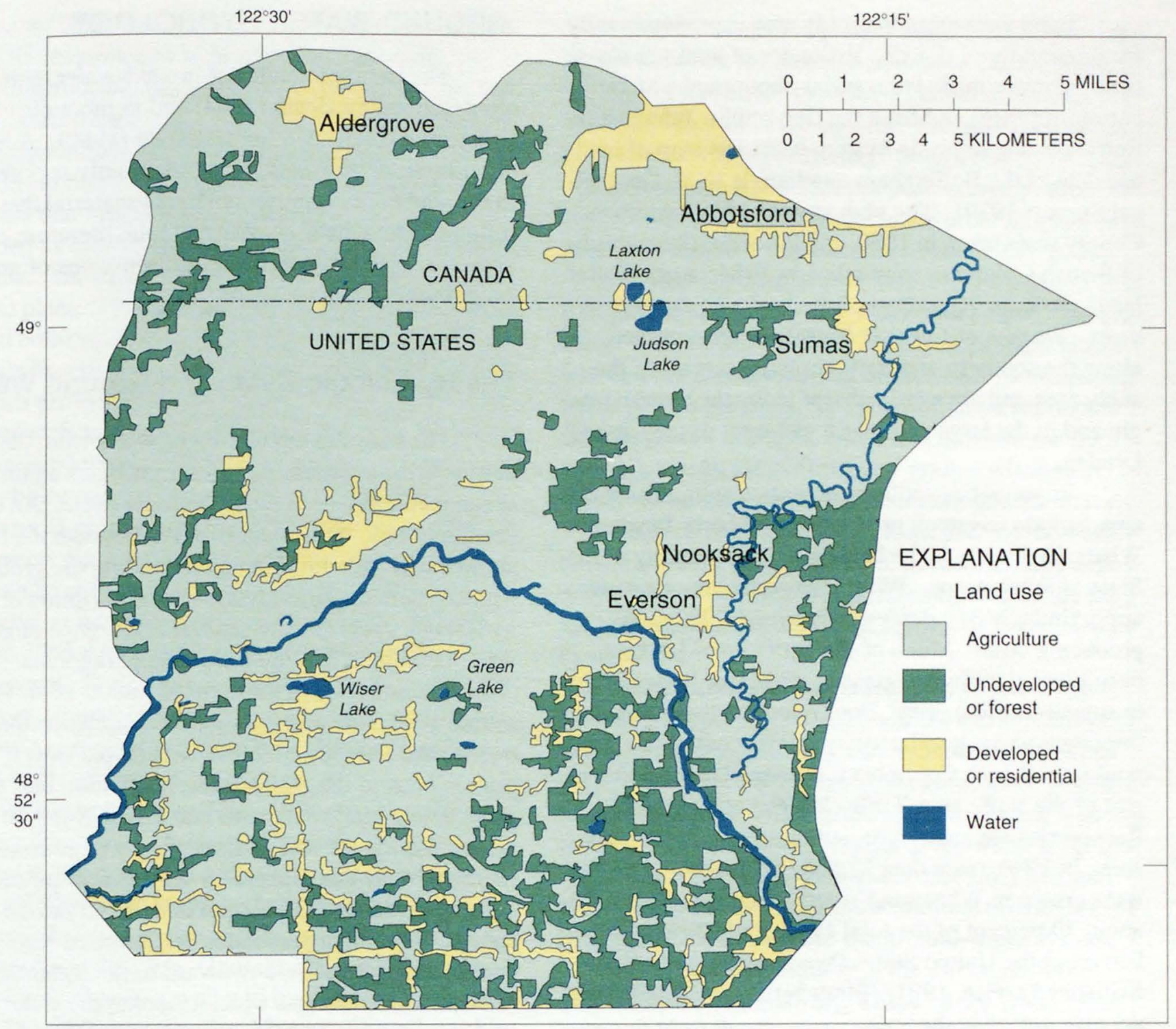

Base and hydrology from U.S. Geological Survey digital data, $1: 100,000,1975$ and

Canadian Department of Energy, Mines and Resources, 1:50,000, 1977, 1980.

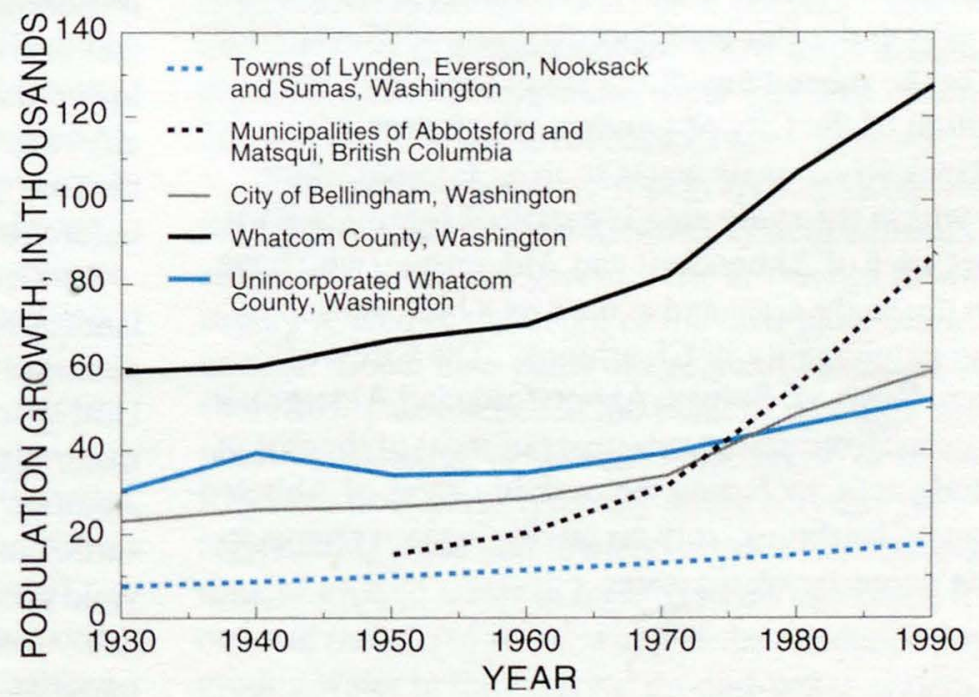

Figure 5. Major land use patterns in 1992 and population growth trends for the Lynden-Everson-Nooksack-Sumas (LENS) study area and parts of surrounding regions. 
Land use within the study area is predominantly rural-agricultural (fig. 5). Estimates of land-use classifications were made from aerial photographs of the entire study area and from the Geographic Information Retrieval and Analysis System (GIRAS) map of landuse data of the Bellingham quadrangle (U.S. Geological Survey, 1979). The photographs of Whatcom County were taken in 1990, and the aerial photographs of British Columbia were taken in 1984. Agricultural lands made up 75 percent of the land area in those years. Patches of forest or brushland are common along the southern and northwestern margins of the study area, but are nearly absent along the eastern margin and in the large area north and west of the City of Lynden.

Important agricultural activities within the study area include livestock production and berry farming. Whatcom County is the leading dairying county in the State of Washington. Within the study area there are approximately 310 dairies with over 46,000 milkproducing cows. Much of the agricultural land has been planted with hay, grasses, and other forage crops to support these dairies. Poultry production is also an important agricultural activity; 60 percent of the poultry in British Columbia is produced in the northern part of the study area (Liebscher and others, 1992). Raspberries are a major agricultural crop in the study area. In 1990, more than 13,500,000 pounds of berries were grown in Whatcom County, which accounted for about 30 percent of the total 1990 production of raspberries in the United States (Washington Agricultural Statistics Service, 1991). Strawberries and blueberries are also grown in the area.

Ground water is the primary source of water for most of the inhabitants of the study area, with the exception of the City of Lynden, which uses the Nooksack River as its water source. Ground water from within the study area is exported for use in parts of the Cities of Abbotsford and Aldergrove, which are not in the study area, and is used as a back-up supply for the municipality of Clearbrook. The Cities of Lynden, Everson, Sumas, Abbotsford, and Aldergrove have centralized sewer systems, but most of the rest of the study area, including the outlying areas of Abbotsford and Clearbrook, rely on on-site septic systems to handle domestic waste water.

\section{GROUND-WATER HYDROLOGY}

The basic principles of ground-water hydrology are described by Heath (1983) and in more detail by Freeze and Cherry (1979) and Todd (1980). A brief description of how these principles apply specifically to the study area is presented in the material that follows. The reader is referred to the literature cited above for more comprehensive discussions of groundwater hydrology.

\section{The Hydrologic Cycle and Ground Water}

The constant circulation of water from the oceans to the atmosphere, to land, and back again to the ocean is referred to as the hydrologic cycle. An understanding of the movement of water beneath the land surface will be helpful in understanding the groundwater system of the study area. A description of the hydrologic cycle and the general occurrence of ground water is presented in the following paragraphs.

Precipitation in the form of rain or snow is the source of all fresh ground water. Precipitation that falls on the land surface can follow several pathways: evaporation back to the atmosphere, infiltration into the ground, or runoff to streams and lakes. Some of the water entering the soil is drawn up by plant roots and returned to the atmosphere by way of transpiration; some water can also be evaporated directly to the atmosphere. Water that percolates below the root zone and continues to percolate downward to the water table is referred to as recharge; when it reaches the water table, it becomes ground water. Gravity is the driving force that moves ground water from higher altitudes toward lower altitudes, insuring that ground water will eventually return to the ocean. Some ground water returns to the land surface as seepage to springs, lakes, or streams before reaching the ocean.

Ground water can often be found beneath the land surface in the pore spaces or openings of porous geologic materials, like sediments and fractured rock. However, only a small fraction of saturated geologic materials can yield ground water in usable quantities. Aquifers are defined as geologic deposits that contain sufficient saturated permeable material and which can yield ground water to wells or springs in usable quantities. Confining units, on the other hand, are geologic materials that, because of their low permeability, generally do not yield water in usable quantities and that also restrict the movement of ground water into and out 
of adjacent aquifers. Semiconfining units are deposits that have properties of both aquifers and confining units; in particular, small supplies of ground water can be extracted from semiconfining units, but in much smaller quantities than from aquifer deposits.

From this standpoint, all saturated geologic materials that underlie the Earth's surface can be classified as either aquifers, confining, or semiconfining units. The distinction, however, will vary from place to place. The variations arise from interpretation of what constitutes a usable quantity of water and from the scale or size of area under consideration. Geologic materials are not homogeneous, and highly permeable aquifers such as the ones throughout much of the study area contain localized areas of fine-grained, lowpermeability materials that yield much smaller quantities of ground water than the unit as a whole. The reverse situation is also fairly common; confining units can have lenses of coarse-grained material that yield smaller quantities of ground water for limited periods. The term semiconfining unit is used herein to describe a geologic deposit which has bulk hydrologic properties typical of a confining unit but which also contains a sufficient number of localized occurrences of usable ground-water supplies.

Within aquifers, ground water occurs under two different conditions. In unconfined or water-table conditions, the aquifer is only partially saturated with water, and the upper surface of the saturated zone (the water table) is free to rise and fall with changes in recharge and discharge. Under these conditions the level of water within a well will be close to the level of the water table in the aquifer. Most of the wells within the study area are completed in the unconfined aquifer.

Confined conditions occur when the aquifer is completely filled with water and is bounded above and below by confining units. Because the aquifer is completely filled, the upper surface of the saturated zone cannot rise and fall in response to changes in recharge and discharge. This situation results in the development of hydrostatic pressure within the aquifer that causes water levels in wells completed in this unit to rise above the top of the aquifer. A well that is screened in such a system is called an artesian well. If the pressure is sufficient to raise the water above land surface, the well flows and is called a flowing artesian well. Confined ground water is defined by a pressure (potentiometric) surface analogous to the water-table surface, and, like the water table, this potentiometric surface fluctuates in response to changing recharge and discharge conditions.
The movement of ground water within an aquifer is dependent on the size and hydraulic conductivity of the aquifer and on the pressure gradient between different locations within the aquifer. The general rate of movement (velocity) can range from a few feet per second to less than a few feet per year, although groundwater velocities typically are on the order of a few feet to several hundred feet per year (Todd, 1980, p. 82).

Hydraulic conductivity refers to the capacity of a porous material to transmit water under a potential gradient. This characteristic is largely dependent on the size and interconnectedness of the voids (pore spaces) in the porous medium. In unconsolidated sediments such as glacial deposits, water will move in the pore spaces between the sedimentary grains, whereas in consolidated material such as bedrock ground water will move through fractures, joints, and solution channels. Hydraulic conductivity in unconsolidated deposits generally increases with increasing size of the pore spaces and with the degree of sorting of the sedimentary particles.

A pressure gradient is required to move water through the pore spaces of an aquifer and is referred to as the hydraulic gradient. The hydraulic gradient is derived from the difference in the altitudes of pressure heads at different points in the aquifer. A head is determined by measuring the altitude of the water level in a well. Water-level maps show contour lines of equal pressure head and as such show the areal distribution of pressure heads throughout the ground-water system. The flow of ground water is in the direction of the greatest hydraulic gradient, which on the water-level map will be in the direction that is perpendicular to the contour lines of pressure head. Flow lines that depict the idealized path of ground water can thus be drawn from maps of water-level contours.

In areas of irregular topography, ground-water flow paths within a ground-water system can vary in scale from local to regional. The difference is primarily related to the depth of the flow path within the aquifer. Local flow paths are generally shallow, with short flow paths between the point of recharge and point of discharge to springs, bogs, lakes, or streams. Regional flow paths typically occur between the regional highland and lowland areas. The residence time of ground water in local systems can be on the order of months to years, whereas the residence time of ground water in the regional ground-water system can be from tens to thousands of years. 
Within the study area, ground water is found in both unconsolidated sediment and consolidated bedrock. In the loose, unconsolidated sediment, water moves through the numerous pore spaces between the individual particles. In dense, consolidated bedrock, water can only move through interconnected joints, fractures, and solution channels, which are generally much less numerous and less productive than the interstitial pore spaces of unconsolidated sediments. In general, water production in wells from bedrock units is much lower than in wells completed in sand and gravel aquifers, unless the bedrock well encounters large joints or fractures.

\section{Hydrogeologic Framework}

Many studies have contributed to our current understanding of the hydrogeologic framework of the study area. Previous geologic investigations or mapping of Pleistocene deposits include those by Armstrong (1960, 1976, 1977, and 1981), Armstrong and Hicock (1976), Armstrong and others (1965), Cameron (1989), and Easterbrook (1963, 1966a, 1966b, 1969, 1971, 1973, and 1976a). Studies of Eocene sedimentary bedrock include those of Daly (1912) and S.Y. Johnson (1984a, 1984b, and 1991). Discussion of hydrogeologic conditions in the area is included in Newcomb and others (1949), Washington State Division of Water Resources (1960), Halstead (1986), Kohut (1987), Creahan and Kelsey (1988), Johanson (1988), Lindsay (1988), Kohut and others (1989), and Kahle (1990).

Most of the hydrogeologic data used in this study to describe and delineate the ground-water system came from 608 wells (shown on plate 1) inventoried during the initial phase of the project. The wellinventory process included locating the well in the field and establishing its location on aerial photographs; determining the latitude, longitude, and land-surface altitude from topographic maps; where possible, measuring the water level in the well and collecting a reconnaissance water sample; verifying general well construction details listed on drillers' logs, such as casing diameter and material; and tabulating lithologic and hydraulic information provided on drillers' logs. These data were then coded and entered into the USGS National Water Information System (NWIS) data base. Basic data on well location and construction, water level, and reconnaissance water quality of the inventoried wells are tabulated in appendix table 1 .
The selection of wells to be inventoried was based on several criteria. The primary consideration was to obtain adequate areal representation of the shal. low surficial aquifer and more general representation of the deeper hydrogeologic units. In general, only wells having Washington State or British Columbia water-well drillers' reports were selected; however, in instances where well selection was limited, wells without official drillers' reports were also inventoried. Exploration wells drilled for coal, gas, or geotechnical purposes also were used to obtain lithologic information. In many instances, only one or two wells in a given section ( 1 square mile) were available to inventory. In instances where several wells were available and of similar construction, field personnel were given the discretion to choose wells that were more readily accessible.

The physical extent of the major hydrogeologic units was determined from a map of surficial geology and the 10 lithologic sections constructed for this study (plate 2). The surficial geologic map is based on exist ing geologic maps of western Whatcom County (Easterbrook, 1976a); New Westminster, British Columbia (Armstrong and Hicock, 1976); and Mission, British Columbia (Armstrong, 1976) and existing soils maps of Whatcom County (U.S. Department of Agriculture, Soil Conservation Service, 1992b) and southwestern British Columbia (Luttmerding, 1981). For the purpose of this study, several of the geologic units recognized by Armstrong (1976) were combined to form a single surficial geologic unit (plate 2). The Holocene alluvium mapped by Easterbrook (1976a) was divided into fine-grained and coarse-grained units based on soils maps (U.S. Department of Agriculture, Soil Conservation Service, 1992) and well records.

Ten hydrogeologic sections (see plate 2 ), oriented in a north-south and east-west grid, were constructed from surficial geologic maps, drillers' lithologic descriptions, soils maps, and descriptions of lithologic materials examined at outcrops. In the Canadian part of the study area, existing fence diagrams of the subsurface stratigraphy (Halstead, 1986) also were used in the construction of the hydrogeologic sections. Where sufficient data existed, primarily for the shallow deposits, hydrogeologic units were correlated from well to well. Correlating deeper hydrogeologic units was much more difficult because of fewer available logs and generally less-precise drilling records.

Although adequate drilling records exist for wells in shallow unconsolidated deposits in the study area, 
records for wells exceeding 100 feet in depth are rare. Most of the logs available for deep wells were recorded during coal exploration, where the emphasis of drilling was to determine the location of coal-bearing strata within the Tertiary bedrock; changes in lithology of the overlying unconsolidated material, therefore, were often poorly documented. The location of the bedrock surface depicted in the hydrogeologic sections was taken from the deep drilling information mentioned previously and from a depth-to-bedrock map compiled by Jones (1996). In areas where lithologic descriptions were lacking for deposits below the numerous shallow wells and above the bedrock surface, the deposits were identified as undifferentiated deposits (see plate 2).

\section{Regional Geologic Setting}

The Fraser-Whatcom Lowlands represent the landward extension of a geological depression known as the Georgia Basin. The Georgia Basin is a large, elongate sedimentary trough that developed in response to tectonic activity beginning in Late Mesozoic time (England, 1991). This tectonic activity resulted in basin development (the Georgia Basin) in some areas and mountain building (the Coast and Cascade Ranges) in other areas. As the Coast and Cascade Ranges were uplifted, they underwent rapid weathering and erosion. This in turn resulted in enormous quantities of sediment being deposited in the Georgia Basin in fluvial, deltaic, and marine environments. Significant quantities of plant and other organic matter were deposited along with the sediment.

Post-depositional geologic activity resulted in the lithification and consolidation of the sediments into sandstone, mudstone, and conglomerate and the transformation of organic debris into hydrocarbon deposits, including coal. Locally the sedimentary formations have been described as the Huntingdon Formation (Daly, 1912) and the Chuckanut Formation (McLellan, 1927), both of which are Eocene in age. Post-depositional deformation resulted in folding and faulting of the sedimentary rock units, producing an irregular bedrock surface topography. Pleistocene glaciers subsequently eroded and smoothed this bedrock surface prior to depositing unconsolidated glacial sediments of variable thickness across the study area and much of the Puget Sound Lowlands. It is these overlying glacial sediments that comprise the principal aquifers of the study area.

\section{Local Geologic Setting}

Geophysical surveys and test drilling for coal and gas indicate that bedrock is beneath 1,000 to 2,000 feet of Pleistocene deposits throughout much of the Fraser-Whatcom Lowlands. The thickness of the overlying unconsolidated sediments in the study area, which equals the depth to bedrock, is shown in figure 6. In general, the thickness of unconsolidated sediment ranges from 0 to more than 1,500 feet, which is much thinner than most of the Fraser-Whatcom Lowlands (Jones, 1996). Sedimentary bedrock formations are exposed at land surface in the southeastern part of the study area.

Bedrock units described in the study area are of the sedimentary Chuckanut and Huntingdon Formations (Johnson, 1984a, 1984b, and 1991). The Chuckanut Formation is composed primarily of sandstone, mudstone, and conglomerate with local coal seams. The unit was originally deposited in a nonmarine environment as a thick sequence of alluvial strata. Easterbrook (1973) concluded that the deeper Huntingdon is lithologically similar to the Chuckanut Formation and that the only differences between them are (1) an erosional unconformity that separates them in geologic time and (2) a greater amount of postdepositional deformation in the Chuckanut Formation than in the Huntingdon. Together, these formations approach a combined thickness of 20,000 feet and represent one of the thickest nonmarine sedimentary sequences in North America (Johnson, 1991). Within the LENS study area, the Huntingdon Formation is exposed at land surface and is a relatively thin unit.

Most of the bedrock in the study area was covered by thick accumulation of unconsolidated glacial sediments, deposited as a result of repeated advances and retreats of continental glaciers during the Pleistccene Epoch. Little is known about the oldest and deepest of these deposits in the study area because they are not exposed at land surface and descriptive drilling information is scarce. Deposits of the last major glaciation are, however, either exposed at land surface or have been penetrated extensively during drilling. The deposits of this final glaciation, known as the Fraser Glaciation, comprise most of the hydrogeologic units identified during this study.

The Fraser Glaciation began approximately 18,000 years ago and lasted about 10,000 years (Easterbrook, 1963, 1969). Three phases of this glaciation, from oldest to youngest, are the Vashon Stade, the 


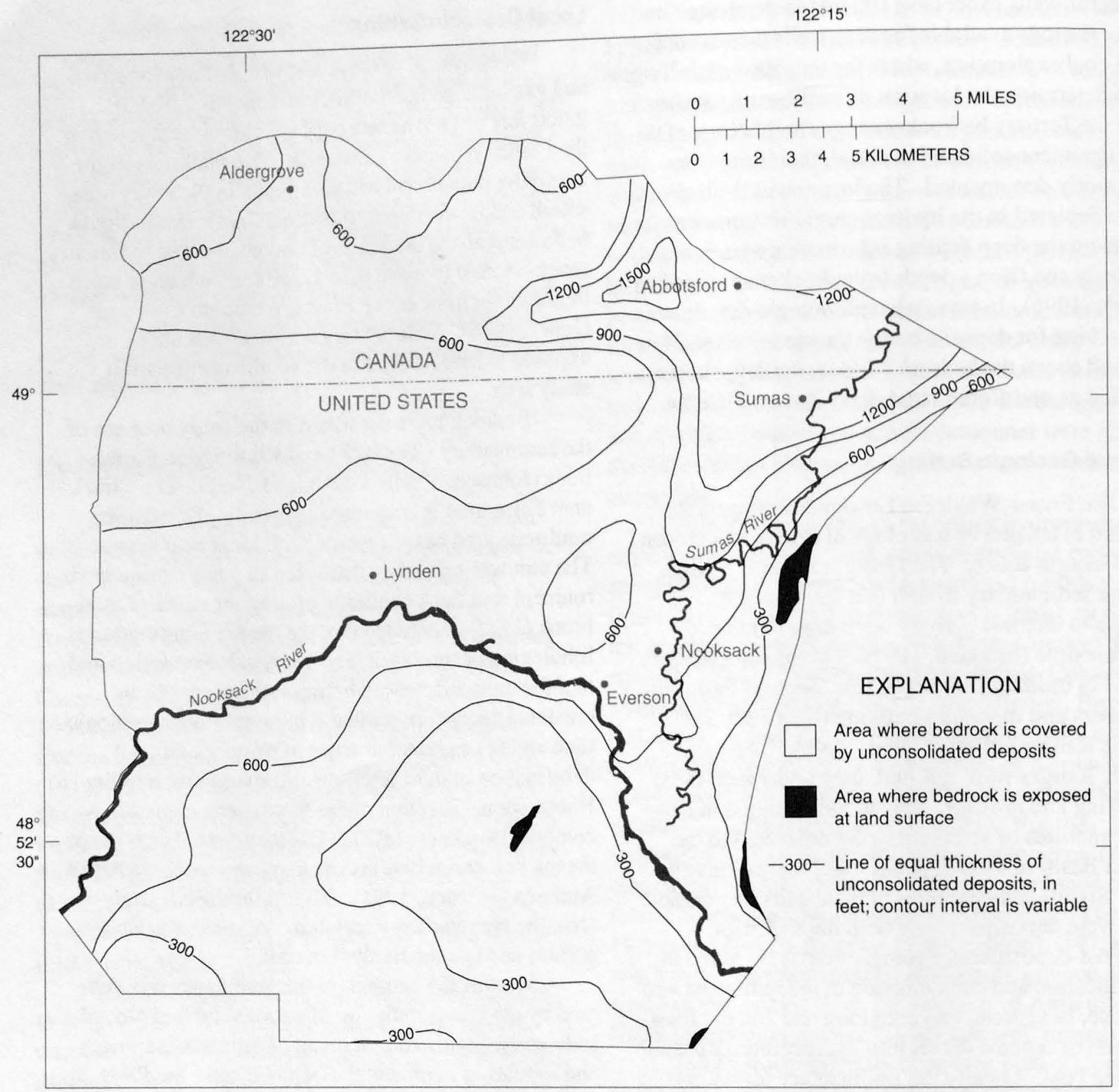

Base and hydrology from U.S. Geological Survey digital data, 1:100,000, 1975

Geology modified from Jones, 1996 and Canadian Department of Energy, Mines and Resources, $1: 50,000,1977,1980$

Figure 6. Thickness of unconsolidated deposits within the LENS study area. 
Everson Interstade, and the Sumas Stade. Glacial deposits from each of these phases are present in the study area.

During the Vashon Stade, from 18,000 to 13,500 years ago, two sedimentary units were deposited locally. The oldest, the Esperance Sand Member, is a cross-bedded outwash of sand and gravel that was deposited from meltwater streams emanating from the advancing Vashon Glacier. Vashon till, the younger of the two units, is a compact and poorly sorted mixture of cobbles, pebbles, and sand in a matrix of silt and clay, deposited beneath the ice of the advancing Vashon Glacier (Easterbrook, 1963, 1969). Within the study area, these deposits have limited surficial exposure, but likely occur extensively at depth below the younger Everson and Sumas deposits. Within the LENS study area, Vashon Drift (Qvd) occurs at land surface only along the flanks of Sumas Mountain, in the eastern part of the study area (plate 2).

Overlying the Vashon Stade deposits are deposits of the Everson Interstade that occurred from 13,500 to 11,000 years ago. As the Vashon Glacier retreated from its terminus in southern Puget Sound, it thinned, allowing seawater to reenter the basin and float the glacial ice. Everson interglacial deposits (Qed) represent debris that fell from the floating and melting glacial ice and was deposited in marine water. In the study area, deposits of the Everson Interstade are typically represented by glaciomarine drift, an unsorted mixture of pebbly silt and clay with some coarse-grained lenses deposited in seawater (Easterbrook, 1963, 1969).

Everson-age deposits are exposed at land surface in the northwestern hummocky uplands area and in the rolling and hummocky hills in the south-central part of the study area. Everson-age deposits also are found within an outwash plain near the center of the study area, where they are characterized by parallel ridges and swales (plate 2). In the southern part of the study area, a relatively thick body of stratified sand with some clay and gravel occurs within the Everson glaciomarine drift. According to Easterbrook (1973), this interlayer, called the Deming Sand, was deposited during the Everson Interstade on floodplains and beaches when sea level dropped relative to the land. The lateral extent of the Deming Sand is generally not well known, but it has been identified locally at the Cedarville landfill, located in the northwest quarter of section 28, township 39 North-Range 3 East (Golder Associates, 1989; Harding Lawson Associates, 1990).
Following deposition of the Everson glaciomarine drift, glacial ice readvanced a short distance southward into northern Washington and deposited the Sumas Drift (Easterbrook, 1963, 1966a, 1966b, 1969, 1971, 1976a; Armstrong, 1977, and 1981; Armstrong and others, 1965). The Sumas Stade, occurred from 11,000 to 10,000 years ago. During that time, the main glacial terminus was just north of the present-day international boundary, with a lobe extending southward into Whatcom County into the Sumas River Valley. Sumas outwash (Qso) was deposited on top of Everson glaciomarine drift by meltwater streams carrying sand and gravel southward and southwestward. The resulting outwash plain extends from north of the international border southward to Lynden and continues towards the mouth of the Nooksack River (plate 2). The outwash grades from gravel and cobble near the border to sand with occasional clay lenses near Lynden.

A discontinuous morainal ridge, composed of ice-contact deposits (Qsi), marks the maximum extent of the Sumas lobe (plate 2). The deposits are a poorly sorted mixture of till and outwash with varying proportions of boulders, cobbles, pebbles, silt, and clay. Icemarginal ponding resulted in localized deposits of lacustrine silt and clay within the Qsi. Just west of Sumas, Wash., ice-contact deposits are located on top of Sumas-age advance outwash sand and gravel. This sequence is similar to that found in the FraserWhatcom Lowland north of the international boundary, where moraine and ice-marginal debris overlie advance outwash or glaciomarine drift (Armstrong and others, 1965; Armstrong, 1981).

During the last 10,000 years (Holocene Epoch), the Nooksack River has incised a wide channel through Sumas Stade deposits, forming the nearly flat alluvial floodplain of the present Nooksack River Valley. Within the study area, Nooksack River alluvium grades from gravel in the upstream reaches near Cedarville to sand and silt in the downstream reaches near Lynden. Other fluvial deposits in the study area include alluvium of the Sumas River and of Bertrand, Johnson, and Fishtrap Creeks. At the same time that the modern Nooksack River was incising through Sumas Stade deposits, peat $(\mathrm{Qp})$, composed of plant remains, was accumulating in former outwash channels and other low-lying depressions in the Sumas outwash. Peatfilled depressions in the study area are numerous and include Pangborn Bog and the basins of Wiser and L'Axton Lakes (plate 2). 
Also during the late Holocene, a shallow lake occupied much of the Sumas Valley floor, eventually covering it with a relatively thin lacustrine silt and clay deposit (Armstrong, 1976; Cameron, 1989). The area most recently occupied by the lake is the northeastern, or Canadian, part of the Sumas Valley floor. Historical records show that the lake, known as Lake Sumas, existed just north of the border in British Columbia as late as the 1920's, at which time it was drained for land reclamation (Luttmerding, 1981). Sand and gravel found beneath the fine-grained lacustrine deposits are thought to be alluvium deposited by a northward-flowing Nooksack River, or a greatly enlarged Sumas River, following deglaciation of the area (Cameron, 1989).

For the purposes of this study, the Holocene sedimentary deposits were subdivided into two geologic units--coarse-grained alluvium (Qsc), which includes sand, gravel, and cobbles, and fine-grained alluvium (Qsf), which includes clay and silt. Peat, although Holocene in age, was mapped as a separate geologic unit because it is composed largely of organic material. The coarse-grained deposits dominate much of the Nooksack River channel, but fine-grained deposits become more prominent in downstream reaches. Fine-grained deposits also dominate most of the Sumas Valley floor (plate 2).

\section{Principal Hydrogeologic Units}

In this study, hydrogeologic units were distinguished primarily by their water-bearing characteristics and the geographic extent of the geologic deposit(s) comprising them. Two principal types of hydrogeologic units, aquifers and semiconfining units, were recognized. It is especially important to keep in mind the heterogeneity of the unconsolidated sediments in the study area; the general occurrence and movement of ground water can be influenced locally by small-scale variations in lithology.

Four principal hydrogeologic units were delineated in the study area. They are, in order of increasing geologic age (1) the Sumas aquifer; (2) the EversonVashon semiconfining unit; (3) the Vashon semiconfining unit; and (4) the bedrock semiconfining unit. The lithologic and hydrologic characteristics of these units are summarized in figure 7.

\section{Sumas aquifer}

The Sumas aquifer is the most productive and widely used aquifer in the study area; 419 (69 percent) of the inventoried wells are completed within this unit. The aquifer is composed largely of Sumas stratified sand and gravel outwash (Qso) and the coarse-grained alluvium of the Nooksack and Sumas Rivers (Qsc), but also includes some locally important fine-grained deposits such as ice-contact deposits (Qsi), lacustrine silt and clay (Qsf), and peat (Qp). The Sumas aquifer is commonly referred to as the Abbotsford aquifer in British Columbia. The Sumas outwash (Qso), which is the predominate geologic unit that makes up the Sumas aquifer, extends west and south of the study area. On a regional basis, the Sumas aquifer is included with the Fraser aquifer of Vaccaro and others (John Vaccaro, USGS, written commun., 1993), which includes reces. sional outwash of the Fraser Glaciation throughout the Puget Sound Lowlands.

Although ground water in most of the Sumas aquifer is unconfined, it becomes confined in places in the Sumas River Valley where it is overlain by recent lacustrine silt and clay and along the margins of the Sumas Valley where it is overlain by fine-grained icecontact deposits (see fig. 8 and plate 2). Several wells in the valley flow as a result of artesian conditions that develop during the wet winter months. The northwest. ern margin of the Sumas Valley is a transition zone in the aquifer--with unconfined conditions in the outwash plain on the west and confined conditions in the Sumas Valley floor on the east. In addition, clay lenses within the otherwise coarse-grained outwash can perch or confine ground water locally.

The thickness of the Sumas aquifer is shown on the hydrogeologic sections (plate 2) and on the Sumas aquifer-thickness map (fig. 8). All surficial coarsegrained materials shown on the sections are included in the Sumas aquifer, although lenses of clay and of peat can be found locally within the unit. The Sumas aquifer is present in most of the study area except in the northwestern and south-central highlands, along the eastern margin of the study area, and in the area northwest of Everson. As shown in figure 8, the unit is commonly about 40 to 80 feet thick, but can be more than 200 feet thick in the northeastern part of the study area where the unit includes ice-contact deposits. The unit is thinnest along the Nooksack River channel south of Lynden, where the river has eroded away all but about 15 feet of the sand and gravel outwash. 


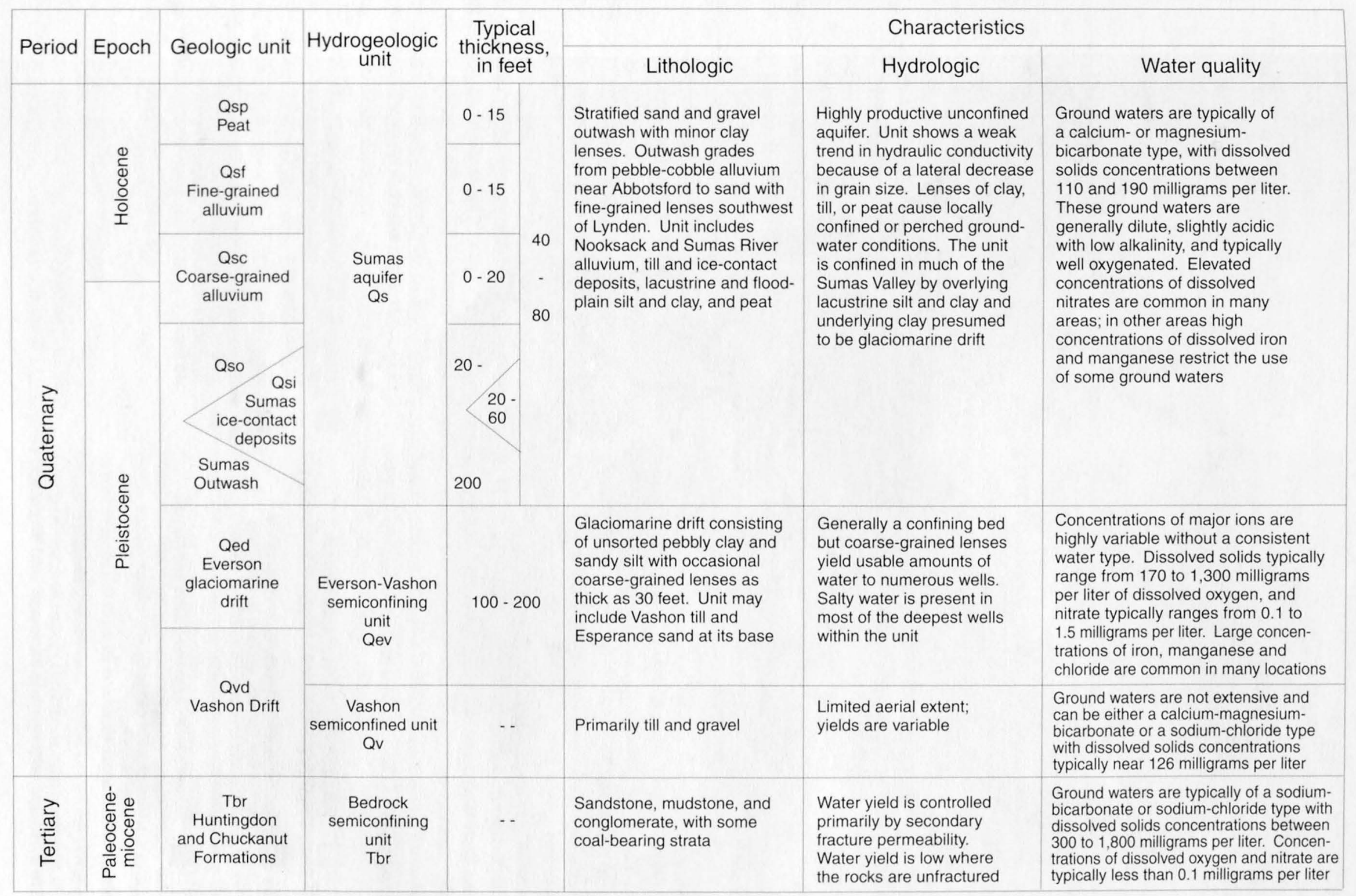

Figure 7. Lithologic and hydrologic characteristics of hydrogeologic units in northern Whatcom County, Washington, and southwestern mainland British Columbia, Canada. 


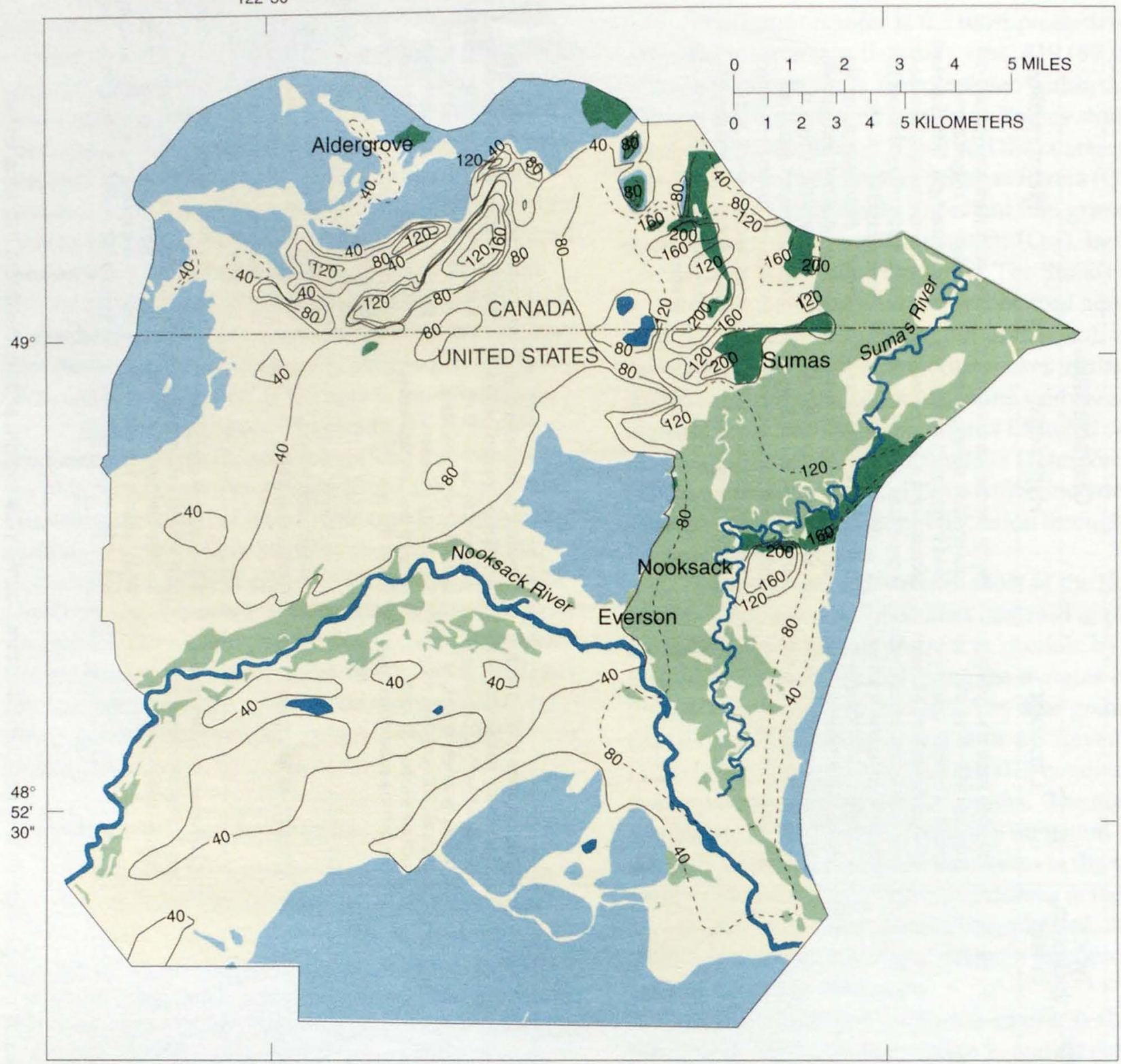

Base and hydrology from U.S. Geological Survey digital data, 1:100,000, 1975 and Canadian Department of Energy, Mines and Resources, 1:50,000, 1977, 1980.

Sumas aquifer: predominantly outwash sands and gravels; generally unconfined

Sumas aquifer: predominantly outwash sands and gravels; overlain by lacustrine silts or the fine-grained alluvial deposits, generally confined

Sumas aquifer: intermixed sand and gravels with fine-grained ice contact deposits; shallow wells generally unconfined, deeper wells confined
Sumas aquifer not present: contact with Sumas aquifer represents zero thickness of Sumas aquifer

\section{Water}

80-- Line of equal thickness of Sumas aquifer; dashed where inferred; contour interval is 40 feet

Figure 8. Extent, approximate thickness, and hydrologic condition of the Sumas aquifer. 


\section{Everson-Vashon semiconfining unit}

The Everson-Vashon semiconfining unit is composed of (1) thick accumulations of Everson-age glaciomarine drift, consisting of unsorted pebbly clay and sandy silt with local coarse-grained lenses, and (2) discontinuous deposits of sand or till. The till, encountered at considerable depth, may be of Vashon age; some of the coarse-grained material encountered deep in the Everson-Vashon unit may be Vashon-age Esperance Sand rather than coarse-grained lenses within the glaciomarine drift. Distinguishing between the two types of coarse-grained deposits, however, was often not possible because of their similar lithologies, discontinuous nature, and a paucity of deep-drilling information. Till, which was recorded on several drillers' logs as being directly beneath the glaciomarine drift, is probably of Vashon age. This till was included with the Everson-Vashon unit because of its hydrologic similarities with the fine-grained glaciomarine drift.

Although the bulk of this unit is composed of fine-grained material, numerous wells within the unit are completed in lenses of coarse-grained materials. Such is the case in the northwestern and south-central highlands where domestic and some public-supply wells are completed in the unit. The productive zones of the Everson-Vashon unit in the south-central part of the study area are believed to be the Deming Sand--a relatively thick (30 feet) interlayer within the glaciomarine drift. The other productive zones are probably small lenses within the glaciomarine drift or, if at considerable depth, the Esperance Sand. One hundred and eleven (18 percent) of the inventoried wells are completed in the Everson-Vashon unit.

The glaciomarine drift of the Everson-Vashon semiconfining unit underlies nearly all of the Sumas aquifer and is found at land surface along the northwestern and south-central margins of the study area and near the center of the study area northwest of the town of Everson. As shown in figure 9, the top of the unit ranges from more than 400 feet above sea level to approximately 120 feet below sea level. The thickness of the Everson-Vashon semiconfining unit is largely unknown because few wells penetrate it entirely. According to available drilling records, a typical thickness of the unit is 100 to 200 feet.

\section{Vashon semiconfining unit}

Within the study area, the Vashon semiconfining unit consists of a small band of poorly sorted Vashon drift and gravel that is exposed along the eastern part of the study area. The Vashon-age deposits in this particular area were recognized as a separate hydrogeologic unit because of their surficial exposure and substantial thickness. As previously discussed, most of the Vashon-age deposits in the study area were included with the Everson unit because, at depth, the Vashon deposits were generally indistinguishable from the Everson deposits in the lithologic descriptions recorded on well drilling reports. Additionally, the Vashon-age deposits included with the EversonVashon semiconfining unit were typically encountered well below present-day sea level, whereas the deposits of the Vashon semiconfining unit crop out at altitudes often greater than 200 feet above present-day sea level. The Vashon semiconfining unit yields variable quantities and qualities of water. All of the 11 inventoried wells completed in this unit encountered confined conditions. The thickness of this unit is mostly unknown, but probably does not exceed 200 feet.

\section{Bedrock semiconfining unit}

The bedrock semiconfining unit consists of sandstone, mudstone, conglomerate, and coal of the Huntingdon and Chuckanut Formations. Although this hydrogeologic unit is not highly productive, it yields usable quantities of water locally. Water yield is controlled chiefly by secondary fracture permeability and, as such, is unpredictable. Most of the 24 inventoried wells that are completed in this unit are located in the southeastern part of the study area where bedrock is shallow. Data are insufficient to determine whether the water occurs under unconfined or confined conditions. Where the bedrock is exposed at or near land surface, the ground water is likely to occur under unconfined conditions; where the bedrock is covered by a significant thickness of glaciomarine drift or till, the ground water is likely to be confined.

\section{Hydraulic Characteristics of Hydrogeologic Units}

An estimate of the magnitude and range of horizontal or lateral hydraulic conductivity of each hydrogeologic unit is helpful in understanding the movement and availability of ground water. Hydraulic conductivity is a measure of a hydrogeologic unit's ability to transmit water and is defined as the volume of water that will move in a unit of time under a unit of hydraulic gradient through a unit cross-sectional area. The unit used to report hydraulic conductivity is feet 


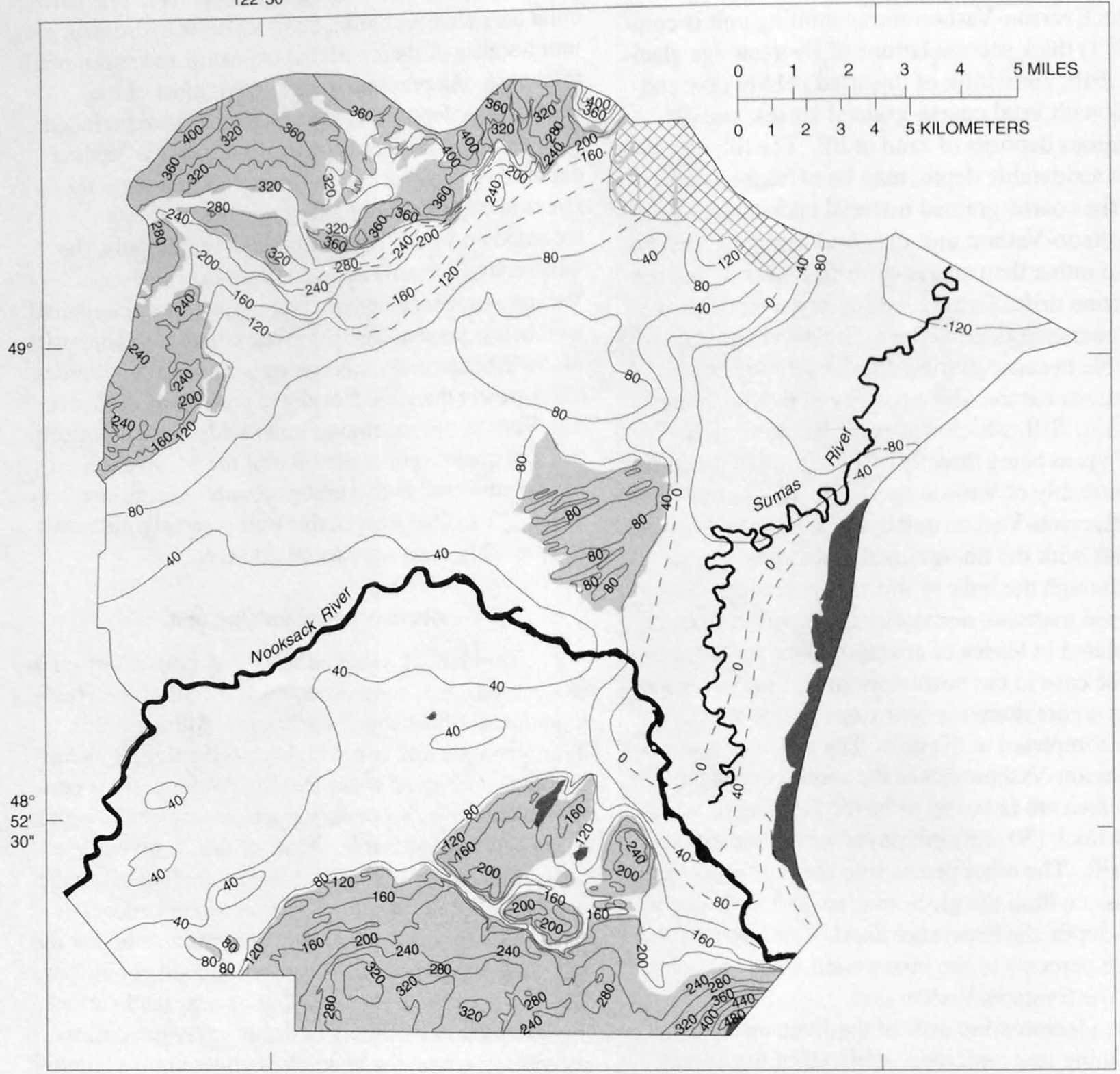

Base and hydrology from U.S. Geological Survey digital data, 1:100,000, 1975 and Canadian Department of Energy, Mines and Resources, 1:50,000, 1977, 1980.

Hydrology by S.E. Cox and S.C. Kahle, 1994

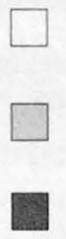

Everson-Vashon semiconfining unit beneath Sumas aquifer

Everson-Vashon semiconfining unit exposed at surface

Insufficient data to contour
Everson-Vashon semiconfining unit not present

-40- - Line of equal altitude, dashed where inferred; contour interval is 40 feet

Figure 9. Altitude of upper surface of Everson-Vashon semiconfining unit. 
per day, which is the same as the units of velocity; however, values of hydraulic conductivity are equivalent to velocity only under the specialized conditions when the values of hydraulic gradient and porosity are equal to 1. For unconsolidated materials, hydraulic conductivity depends in large part on the size, shape, and arrangement of the sedimentary particles and the intervening pore spaces. Because these characteristics are highly variable within the glacial deposits of the study area, hydraulic conductivity values also can be expected to be highly variable.

Estimations of the horizontal hydraulic conductivity for each hydrogeologic unit were made using data from those wells that had the most complete and reliable set of specific-capacity information including discharge rate, drawdown, long-term aquifer test data, well-construction data, and a geologic log. Of the 608 wells inventoried, 218 had such information. The procedures used to calculate hydraulic conductivity are presented in the Appendix section at the end of this report. Hydraulic conductivity data were statistically summarized so that medians and ranges within and between hydrogeologic units could be determined. A summary of hydraulic conductivity data by hydrogeologic unit is presented in table 2. Individual values of hydraulic conductivity and the data from which they were calculated can be found in appendix table 2 .

Hydraulic conductivity values calculated for the 170 wells completed in the Sumas aquifer covered three orders of magnitude, ranging from 6.8 to 7,800 feet per day and having a median value of
270 feet per day. Except for the extremes, the hydraulic conductivity data were log normally distributed. The range and median values of hydraulic conductivity observed throughout the entire extent of the Sumas aquifer for this study, (171 square miles) were similar to the range and median observed by Erickson (1991) for eight wells located within a subset of this study area of only several square miles west of Lynden; and also similar to the range reported for outwash and alluvial deposits of other studies within the Puget Sound Lowland, (Turney and others, 1995; John Vaccaro, USGS written commun., 1994). However, the median hydraulic conductivity calculated for the Sumas aquifer is generally larger than has been reported for similar outwash deposits within the Puget Sound Lowland and near the upper extreme of the range reported by Stephenson and others (1988) for glacial deposits of North America. This tends to indicate that the Sumas aquifer has a larger capacity to transmit water than is typical of similar glacial outwash deposits in the Puget Sound Lowland.

When hydraulic conductivity data for the Sumas aquifer were plotted to determine if an areal pattern of lower or higher values existed, no discernible pattern was found, and in some localities closely spaced wells displayed calculated hydraulic conductivity values that were vastly different. Because of the large spatial variability in the plotted data, a map of hydraulic conductivity values was deemed to be of limited usefulness and therefore was not included in this report. The plotted data did show several possible geographic trends,

Table 2. Summary of horizontal hydraulic conductivity values calculated from specific-capacity data, by hydrogeologic unit

\begin{tabular}{|c|c|c|c|c|c|c|}
\hline \multirow{2}{*}{$\begin{array}{l}\text { Hydro- } \\
\text { geologic } \\
\text { unit }\end{array}$} & \multirow[b]{2}{*}{$\begin{array}{l}\text { Number } \\
\text { of wells }\end{array}$} & \multicolumn{5}{|c|}{ Hydraulic conductivity (feet per day) } \\
\hline & & Minimum & $\begin{array}{c}25 \text { th } \\
\text { percentile }\end{array}$ & Median & $\begin{array}{c}\text { 75th } \\
\text { percentile }\end{array}$ & Maximum \\
\hline Sumas aquifer & 170 & 6.8 & 74 & 270 & 610 & 7,800 \\
\hline $\begin{array}{l}\text { Everson-Vashon } \\
\text { semiconfining unit }\end{array}$ & 32 & 3 & 19 & 81 & 160 & 570 \\
\hline Vashon semiconfining unit & 4 & 2.4 & 7.2 & 52 & 950 & 1,800 \\
\hline Bedrock semiconfining unit & 12 & 0.01 & 0.02 & 0.55 & 4.6 & 77 \\
\hline
\end{tabular}


with higher values near the international boundary and lower values toward the southwestern part of the study area. This trend is consistent with the observation of decreasing grain size in the Sumas outwash plain, as discussed earlier. In support of this theory, high hydraulic conductivity values were absent on the southern margins of the Sumas outwash plain south of the Nooksack River. Another apparent area of generally larger values of hydraulic conductivity is a band along the alluvial valleys occupied by the Sumas River and the upper reaches of the Nooksack River. This band of large hydraulic conductivity probably represents a buried river channel deposit, which would be characterized by well-sorted, coarse-grained material and may represent deposits of the ancestral Nooksack River.

In the Everson-Vashon semiconfining unit, the median hydraulic conductivity of 81 feet per day is larger than would be expected for a unit that is, for the most part, a fine-grained confining bed (Stephenson and others, 1988), but the median is similar to values calculated by similar methods for fine-grained units in other parts of the Puget Sound Lowland (John Vaccaro, USGS, written commun., 1994). The large hydraulic conductivity calculated for these fine-grained deposits is likely due to a bias in sampling that results from using wells that are screened in lenses of coarsegrained material that is not representative of the unit as a whole. It is reasonable to expect that successful wells were completed in the more productive parts of the unit and that any wells completed in less permeable zones either were subsequently abandoned or may not have produced enough water for an aquifer test to be practical.

Slug tests of the Everson-Vashon glaciomarine drift conducted by Sweet-Edwards (1984) resulted in estimates of horizontal hydraulic conductivity of 0.0014 and 0.027 feet per day, which are several orders of magnitude smaller than even the smallest hydraulic conductivity value generated from specific capacity data. Because the slug tests were conducted on two observation wells installed in the Everson glaciomarine drift to evaluate the potential for ground-water transport away from a landfill area, the results may be more representative of the hydraulic conductivity of the less productive parts of the Everson-Vashon semiconfining unit than estimates made from successful water producing wells. Four laboratory measurements of vertical hydraulic conductivity determined for core samples of clayey silt material from the same area were one to two orders of magnitude smaller than for slug-test values of horizontal hydraulic conductivity (Golder Associates, 1989) and (Harding Lawson Associates, 1990); these results coincide with the general trend in sedimentary materials in which vertical hydraulic conductivities are typically significantly smaller than horizontal hydraulic conductivities.

The lowest median hydraulic conductivity ( 0.55 feet per day) was found in the bedrock semicon. fining unit. Because ground water in bedrock occurs primarily in fractures, the low value of hydraulic conductivity observed in this unit indicated that the bedrock semiconfining unit generally does not contain sufficient open fractures and joints to transmit large quantities of water.

The high bias in the estimate of hydraulic conductivity probably occurs in varying degrees within all of the hydrogeologic units, depending largely upon the heterogeneity of the lithologic material making up each unit. As such, all of the median hydraulic conductivity values may be somewhat high; however, the bias in the estimate of hydraulic conductivity for the EversonVashon is probably largest because that unit displays the greatest variation in lithologic composition. An examination of the minimum hydraulic conductivities for the hydrogeologic units shows that there are indeed poorly producing wells in each unit. Also, the range of hydraulic conductivities is at least three orders of mag. nitude for most units, indicating a substantial degree of heterogeneity.

\section{Ground-Water Flow System}

The ground-water flow system includes the movement of water within and between individual hydrogeologic units and the movement of water into and out of the ground-water system. Typically, precip itation is the source of most ground water, and the general movement of ground water is from areas of recharge, generally found in the uplands, to areas of discharge, typically found at lower altitudes along river and stream channels. The ground-water flow path can range in scale from local flow paths that are generally short and shallow to regional flow paths that cover great distances and travel deep within the ground-water system. The movement of ground water is controlled by the topography, the geometry of the hydrogeologic framework, and the areal distribution and rate of ground-water recharge and discharge. 
Information on the ground-water flow system was derived primarily from water-level data taken from wells throughout the study area. These data were used to construct a contour map depicting the altitude of ground-water levels in 1990 (plate 3). Seasonal variations in ground-water levels were determined from monthly water-level measurements in 29 wells within the study area from October 1990 to October 1991. Historic water-level information from the U.S. Geological Survey, BC Environment, and EC was also used to quantify seasonal variations in ground-water levels.

\section{Water-Level Distribution and Movement of Ground Water}

Water-level data, mostly from the Sumas aquifer and partly from the Everson-Vashon semiconfining unit, were combined so that a water-level map could be drawn for most of the study area (plate 3 ). The waterlevel map was constructed from water-level altitudes measured in 450 wells at the time of well inventory, plus additional water-level information contained in Johanson (1988) and Kohut (1987). Information on stream elevations determined from topographic maps was also used to construct the map. The inventory water levels, which were collected over a 6-month period, were adjusted to account for seasonal variation. Water levels measured in wells within the EversonVashon semiconfining unit in the upland margins were included in the construction of this map because the Sumas aquifer is absent in these areas and the EversonVashon water levels are considered analogous to the water table of the Sumas aquifer in the central parts of the study area. Ground water within the EversonVashon semiconfining unit most probably flows laterally from the uplands into the Sumas aquifer at lower altitudes.

The water-level contours for the Sumas aquifer shown on plate 3 reflect regional water-table (unconfined) conditions everywhere except parts of the lower (northern) Sumas Valley and in the area northwest of the town of Sumas. In these areas ice contact deposits and the fine-grained alluvium--lacustrine silt and clay-that overlies much of the valley floor have created confined conditions, resulting in numerous wells being under artesian and even flowing conditions.

The general direction of ground-water flow can be inferred from the contours on plate 3 , which show the configuration of water levels throughout the study area. The horizontal movement of ground water is perpendicular to the water-level contours, from areas of higher head to areas of lower head. The general pattern of ground-water flow in the study area is toward the Nooksack and Sumas Rivers, which are the primary areas of ground-water discharge. Smaller scale flow patterns can be seen near creeks that also act as groundwater discharge areas. On a local scale, which is not apparent on plate 3 , ground water can flow toward drainage ditches and buried tile drains. This type of flow, however, occurs on a relatively small scale as compared to the regional ground-water flow systems.

The hydraulic gradient is the difference in waterlevel altitude between two locations and is an expression of the driving force that enables the movement of ground water. Lateral hydraulic gradients within the Sumas aquifer, as determined from the water-level contours shown on plate 3 , are typically about 15 feet per mile (equivalent to 0.0028 ) across much of the outwash plane north of Lynden but range from about 5 to 100 feet per mile. In the Everson-Vashon semiconfining unit, lateral hydraulic gradients are often about 35 feet per mile (equivalent to 0.0066 ) but range from 10 to 100 feet per mile. The lower hydraulic conductivity of the Everson-Vashon semiconfining unit requires larger hydraulic gradients to move similar quantities of ground water. Topography plays a large role in producing variations in hydraulic gradient and is the primary cause of the variations observed within each unit. Hydraulic gradients are generally small in areas of low relief and large in areas of high relief.

\section{Ground-Water Velocity}

The average rate at which ground water moves through porous geologic material, referred to as average interstitial velocity, is important, particularly in areas where water-quality problems may occur. Calculated estimates of lateral ground-water velocities within the Sumas aquifer range from 0.2 to 29 feet per day, depending on the data used; however, a best estimate of the horizontal velocities of much of the aquifer is that they are on the order of 2.5 feet per day. Similar rates may occur in the Everson-Vashon semiconfining unit, where smaller values of hydraulic conductivity are compensated for by larger hydraulic gradients. The estimated horizontal velocities are based on the hydraulic conductivity and hydraulic gradient data described above and the literature values for the effective porosity of the geologic material making up the aquifer and semiconfining unit. 
The equation representing average ground-water velocity is derived from Darcy's Law and the velocity equation and was amended to account for the effective porosity of the geologic material. It takes the form of

$$
(v)=K(d h / d l) / n_{e},
$$

where

$v=$ average interstitial ground-water velocity;

$K=$ horizontal hydraulic conductivity;

$(d h / d l)=$ hydraulic gradient, or the change in waterlevel head divided by the intervening distance; and

$n_{e}=$ effective porosity, or the ratio of the volume of pore spaces to total volume.
Because data in the previous sections have shown that values of hydraulic conductivity and hydraulic gradients vary throughout the ground-water system, average ground-water velocities also vary. Consequently, several values of each parameter were used to illustrate the range of ground-water velocities in the Sumas aquifer and the Everson-Vashon semicon. fining unit shown in table 3 . Hydraulic conductivity values for the Sumas aquifer and the coarse-grained lenses of the Everson-Vashon semiconfining unit were taken from the 25th, 50th, and 75th percentile values of the calculated values in table 2 ; values for the finegrained material in the unit were taken from measurements reported by Sweet-Edwards/EMCON (1989). Values of the hydraulic gradient were determined from the spacing of water-level contours on plate 3.

Table 3. Calculated estimates of ground-water velocity in the Sumas aquifer and the Everson-Vashon semiconfining unit using selected values of hydraulic conductivity, hydraulic gradient, and porosity

\begin{tabular}{|c|c|c|c|c|}
\hline \multirow[b]{2}{*}{$\begin{array}{l}\text { Hydraulic } \\
\text { conductivity } \\
\text { (feet per day) }\end{array}$} & \multirow[b]{2}{*}{$\begin{array}{l}\text { Hydraulic } \\
\text { gradient } \\
\text { (feet per mile) }\end{array}$} & \multicolumn{3}{|c|}{ Velocity (feet per day) } \\
\hline & & $\begin{array}{l}\text { porosity } \\
\left(\mathrm{n}_{\mathrm{e}}\right)\end{array}$ & $\begin{array}{l}\text { porosity } \\
\left(n_{e}\right)\end{array}$ & $\begin{array}{l}\text { porosity } \\
\left(\mathrm{n}_{\mathrm{e}}\right)\end{array}$ \\
\hline \multicolumn{2}{|l|}{ Sumas Aquifer } & $\left(\mathrm{n}_{\mathrm{e}}=0.25\right)$ & $\left(\mathrm{n}_{\mathrm{e}}=0.38\right)$ & $\left(\mathrm{n}_{\mathrm{e}}=0.50\right)$ \\
\hline 74 & $\begin{array}{r}5 \\
15 \\
75\end{array}$ & $\begin{array}{l}0.28 \\
0.84 \\
4.2\end{array}$ & $\begin{array}{l}0.18 \\
0.55 \\
2.8\end{array}$ & $\begin{array}{l}0.14 \\
0.42 \\
2.1\end{array}$ \\
\hline 270 & $\begin{array}{r}5 \\
15 \\
75\end{array}$ & $\begin{array}{l}1.0 \\
3.1 \\
15\end{array}$ & $\begin{array}{l}0.67 \\
2.0 \\
10\end{array}$ & $\begin{array}{l}0.51 \\
1.5 \\
7.7\end{array}$ \\
\hline 610 & $\begin{array}{r}5 \\
15 \\
75\end{array}$ & $\begin{array}{l}2.3 \\
6.9 \\
35\end{array}$ & $\begin{array}{l}1.5 \\
4.6 \\
23\end{array}$ & $\begin{array}{r}1.2 \\
3.5 \\
17\end{array}$ \\
\hline \multicolumn{2}{|c|}{ Everson-Vashon (coarse-grained material) } & $\left(\mathrm{n}_{\mathrm{e}}=0.35\right)$ & $\left(\mathrm{n}_{\mathrm{e}}=0.42\right)$ & $\left(\mathrm{n}_{\mathrm{e}}=0.50\right)$ \\
\hline 19 & $\begin{array}{r}15 \\
35 \\
125\end{array}$ & $\begin{array}{l}0.15 \\
0.36 \\
1.3\end{array}$ & $\begin{array}{l}0.13 \\
0.30 \\
1.1\end{array}$ & $\begin{array}{l}0.11 \\
0.25 \\
0.90\end{array}$ \\
\hline 87 & $\begin{array}{r}15 \\
35 \\
125\end{array}$ & $\begin{array}{l}0.71 \\
1.6 \\
5.9\end{array}$ & $\begin{array}{l}0.59 \\
1.4 \\
4.9\end{array}$ & $\begin{array}{l}0.49 \\
1.2 \\
4.1\end{array}$ \\
\hline \multicolumn{2}{|c|}{ Everson-Vashon (fine-grained material) } & $\left(\mathrm{n}_{\mathrm{e}}=0.35\right)$ & $\left(\mathrm{n}_{\mathrm{e}}=0.42\right)$ & $\left(\mathrm{n}_{\mathrm{e}}=0.50\right)$ \\
\hline 0.0014 & $\begin{array}{r}15 \\
35 \\
125\end{array}$ & $\begin{array}{l}0.00001 \\
0.00003 \\
0.00009\end{array}$ & $\begin{array}{l}0.00001 \\
0.00002 \\
0.00008\end{array}$ & $\begin{array}{l}0.00001 \\
0.00002 \\
0.00007\end{array}$ \\
\hline 0.027 & $\begin{array}{r}15 \\
35 \\
125\end{array}$ & $\begin{array}{l}0.00022 \\
0.00051 \\
0.00180\end{array}$ & $\begin{array}{l}0.00018 \\
0.00043 \\
0.00150\end{array}$ & $\begin{array}{l}0.00015 \\
0.00036 \\
0.00130\end{array}$ \\
\hline
\end{tabular}


These estimates included a value that was typical for much of the area and also values from areas of both high and low hydraulic gradient. Values of porosity used in the calculations of average ground-water velocity were taken from the ranges reported by Freeze and Cherry (1979) for sandy material of 0.25 to 0.50 ; for silty material 0.35 to 0.50 , along with the average of the values of porosity in sandy and silty glaciofluvial deposits reported by Morris and Johnson (1967), which were 0.38 and 0.42 , respectively.

In the Sumas aquifer, calculated average ground-water velocities ranged from 0.14 to 35 feet per day, and the general value based on the median or typical values of the variables controlling groundwater velocity resulted in an average velocity of about 2 feet per day. An independent estimate of groundwater velocity based on the arrival time of chloride in piezometers down gradient of a newly installed dairy lagoon resulted in an estimated average ground-water velocity of 1 to 2 feet per day Erickson (1992). The regional hydraulic gradient in the area of Erikson's chloride study, roughly 3 miles north of Lynden, is about 15 feet per mile; thus, the two estimates are in good agreement. If 2 feet per day is used as a reasonable estimate of average ground-water velocity, then ground water could be expected to travel on the order of 700 feet per year, and the average travel time along regional flow paths of 5 to 10 miles would be on the order of 20 and 40 years, respectively.

Estimates of average ground-water velocity in the Everson-Vashon semiconfining unit were based on hydraulic conductivity values of both the coarsegrained material encountered by water wells installed in this unit and the hydraulic conductivity of finegrained material encountered in some observation wells. In the coarse-grained Everson-Vashon material, hydraulic conductivities are lower, while hydraulic gradients are larger than in the Sumas aquifer. As a result, average velocities of ground water in this material were roughly half as large as estimates for the Sumas aquifer. However, in the fine-grained material of the Everson-Vashon semiconfining unit, the much smaller hydraulic conductivities resulted in groundwater velocities on the order of 0.0001 to 0.002 feet per day. The hydraulic gradient in the fine-grained material may be somewhat larger than measured in the coarse-grained material, which was used in both estimates in the Everson-Vashon material; but physical constraints of the ground-water system would limit the range to something less than a factor of two, which would only increase the velocity by the same factor. Consequently, average ground-water velocities in the fine-grained Everson-Vashon material are much slower than in either the coarse-grain Everson-Vashon material or the Sumas aquifer, and hence distances traveled by ground water in the fine-grained material during a year's time would be much less, on the order of a fraction of a foot.

\section{Variations in Ground-Water Levels}

Water levels in the Sumas aquifer typically show yearly oscillations of about 6 feet. The yearly rise and fall in ground-water levels coincide with the seasonal patterns in monthly precipitation amounts. Water levels in wells completed in shallow aquifers such as the Sumas aquifer typically respond more quickly to precipitation and experience larger fluctuations than wells completed in stratigraphically lower hydrogeologic units. Comparison of current and historic waterlevel data did not show definite signs of long-term change except in the area between the towns of Sumas and Abbotsford, where water levels appear to be declining. Information on the long-term trend in waterlevel variations was obtained from historical waterlevel records and the comparison of 1990 water-level contours to maps depicting water-level conditions in 1949 and 1960 (plate 3). Long-term water-level data were not available for the semiconfining units.

Analysis of the seasonal variation in groundwater levels included the monthly measurement of water levels in 29 wells and the analysis of historical monthly water-level data for 16 wells having periods of record longer than 3 years. Seasonal variations observed from measurements made during 1990-1991 in the Sumas aquifer typically ranged from 4 to 8 feet, while variation observed from historic data (table 4) ranged from 3 to 8 feet. The maximum seasonal fluctuation observed was on the order of 16 feet. Ground-water levels were typically lowest between October and December and highest between February and April. The period of rapidly rising water levels coincides with the period of heaviest precipitation. Most of the Sumas wells that showed water-level fluctuations between 7 to 8 feet were located in the outwash plain between Lynden and Abbotsford. This area of the Sumas aquifer receives the greatest amount of precipitation, and, thus, it is probable that the larger range in water-level fluctuations represents greater 
$\omega$ Table 4. Summary of seasonal water-level fluctuations in wells with 3 or more years of monthly observations

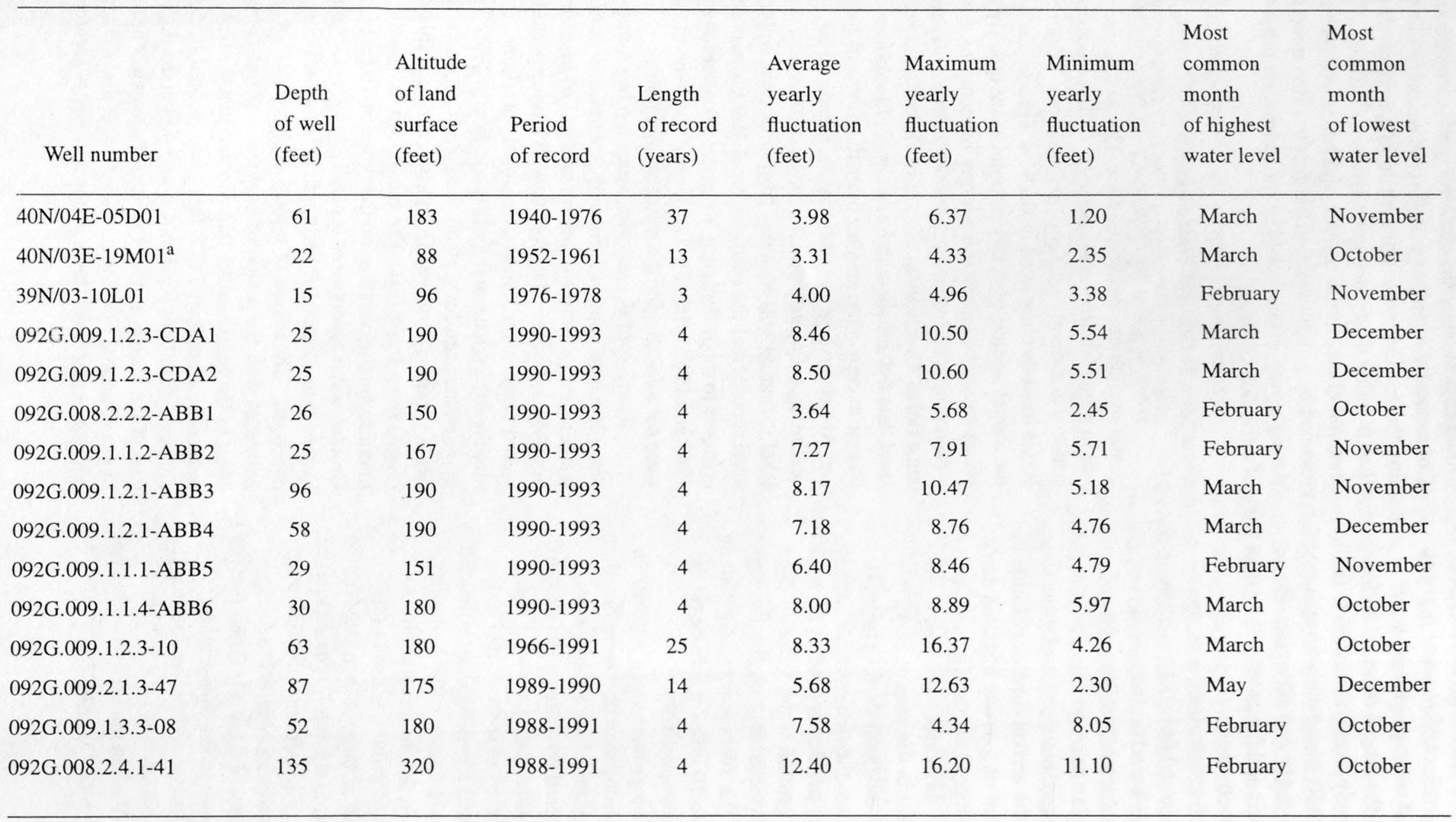

${ }^{\text {a }}$ Measured intermittently until 1971, well destroyed, not listed in Appendix Table 2. 
recharge in that area. Smaller seasonal fluctuations, typically from 1 to 5 feet, were more often observed in the semiconfining units.

Typically, water levels in wells completed in shallow water table aquifers, such as most of the Sumas aquifer, respond more quickly to precipitation and show larger fluctuations than do deeper wells that are completed in confined or semiconfined aquifers. The smaller range of water-level fluctuations found in the these units is probably related more to the fact that wells in these units are generally deeper, typically over 100 feet, than wells in the Sumas aquifer, which are typically less than 50 feet deep. Water-level fluctuations were about 4.5 feet in two Everson-Vashon wells approximately 60 feet deep and were only 1 to 2 feet in two other Everson-Vashon wells about 150 feet deep. However, in contrast, the second largest seasonal fluctuation (13.3 feet) was observed in the one shallow well in the Everson-Vashon semiconfining unit (39N/03E-36B03). The large fluctuations in this well could be the result of focused recharge, a characteristic of fine-grained deposits that have uneven, hummocky surfaces, such as the Everson-Vashon semiconfining unit. Water tends to pond in depressions in the uneven surface, thereby concentrating recharge into these areas. This concentration could result in large waterlevel variations in shallow wells in these areas.

Fluctuations of water levels in wells within the study area are caused largely by variation in monthly precipitation amounts. The direct relation between variations in precipitation and fluctuating groundwater levels can be seen in figure 10, which compares monthly precipitation recorded at the Clearbrook weather station to monthly ground-water levels in well 40N/04E-05D01. The well and the weather station are about a mile apart. Between 1945 and 1976, waterlevel altitude in this well fluctuated seasonally from 126 to 136 feet above sea level. The mean seasonal water-level fluctuation during this period was 3.9 feet per year. During this same period, annual precipitation at the Clearbrook weather station ranged from 32.0 to 65.6 inches per year, with an annual mean of 47.5 and a monthly mean of 3.96 inches. The difference between measured monthly precipitation and the 31-year average monthly precipitation (3.96 inches) is the monthly precipitation departure from the mean. Because precipitation is the major factor in determining recharge to the shallow aquifer, the cumulative precipitation departure then is a summation of the antecedent recharge conditions for the area surrounding the weather station.
The trend in ground-water levels in well 40N/04E-05D01 follows the trend of the line depicting the cumulative precipitation departure, particularly during the periods of below average precipitation. Years in which the total precipitation were substantially less than the mean annual precipitation occurred during 1949, 1952, 1958, 1963, 1970, 1973, and 1975; water levels in well 40N/04E-05D01 were noticeably lower during the months following these low-precipitation periods for all years except 1963 for which waterlevel data are incomplete (figure 10). Corresponding periods of high water tables following periods of precipitation excess are not as noticeable, probably because higher ground-water levels lead to higher natural discharge rates, thereby preventing large rises of the water table.

Information on long-term variation in groundwater levels was gathered from three sources: comparison of water levels measured prior to 1960 with water levels measured in the same wells in 1990, comparison of water-level contours prepared in 1949 and 1960 with those prepared for 1990, and monitoring data from observation wells. Most wells used in this study were constructed after 1970; pre-1960 water-level data were available for 26 wells where water levels were measured in 1990. Comparison of the 1990 measurements to pre-1960 measurements ranged from 4 feet lower to 11 feet higher. Most 1990 water levels were within 2 feet of the pre-1960 water level, the median waterlevel change being about 1 foot higher in 1990. In general, the observed differences could easily be attributed to seasonal variations, and thus these data are inconclusive with respect to determination of long-term water-level changes.

Water-level contours from previous studies by Newcomb and others (1949) and the Washington State Division of Water Resources (1960) are similar to those generated for this study from data collected in 1990. The source of the water-level data used by Newcomb and others (1949) was measured water levels obtained from several hundred wells during the summer of 1947 and 1948. The source of the water-level data used by the Washington State Department of Conservation (1960) is believed to be largely data collected by Newcomb and others (1949) plus additional data collected between 1948 and 1960. The area where the three water-level contour maps overlap is restricted to the central part of the study area surrounding the town of Lynden. To show the comparison of the three waterlevel maps, selected water-level contours $(50,60,100$, 

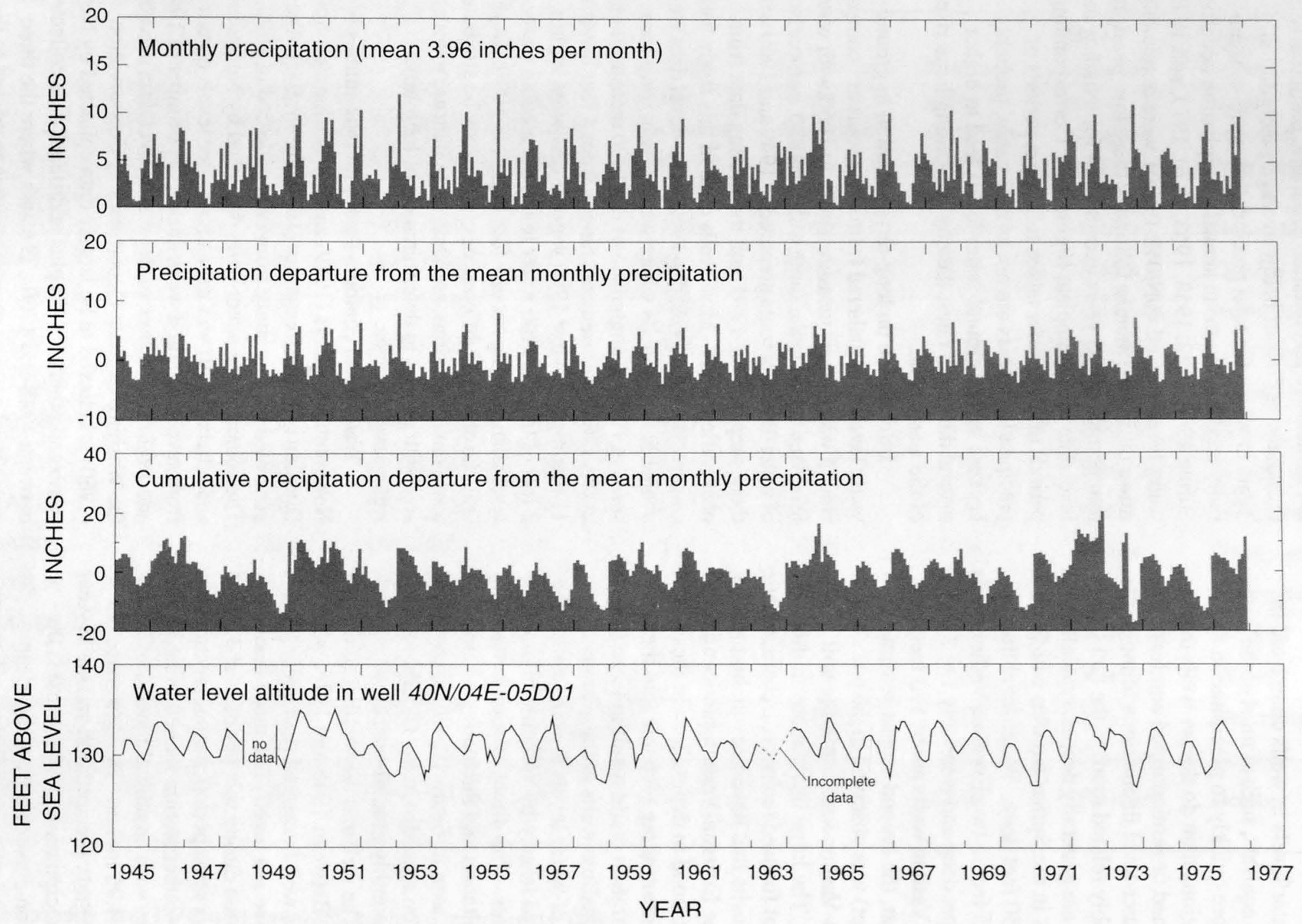

Figure 10. Concurrence of low ground-water levels and cumulative precipitation deficits of the Lynden-Everson-NooksackSumas (LENS) study area, Whatcom County, Wash., and British Columbia, Canada. 
120 , and 140 feet above sea level) are shown on plate 3 . The locations of 100-, 120-, and 140-foot contours were similar in many respects for all three data sets, particularly in the area north of the town of Lynden. For contours below 100 feet elevation, the 1990 water levels tended to be higher than both the 1960 and the 1949 water levels. Some differences in the placement of the three sets of water-level contours is to be expected because the individual sets of contours were drawn from water-level data which differed both in the number and spacing of water-level data points. Considering the potential differences in the data sets, the differences in water-level contours appear neither large enough nor consistent enough to indicate that water levels have changed substantially in the intervening time between the collection of data for each map.

Water levels in long-term observation wells appear to be declining in some areas. The two longterm observation wells within the Whatcom County portion of the study area (see table 4 and fig. 10) do not show patterns of long-term water-level change that are outside the range of seasonal variations; however, measurements of both observation wells were discontinued in the 1970s. Several long-term observation wells currently operated by BC Environment in the area northwest of the town of Sumas have provided current information on the long-term trend in water levels in that area. Kohut (1987), in his analysis of the groundwater supply capability of the Abbotsford aquifer (equivalent to the outwash of the Sumas aquifer within British Columbia), noted declining water levels in several of these observation wells. The water-level decline was most notable in wells near the eastern margin of the outwash plane where the Fraser Valley Trout Hatchery and the towns of Sumas and Abbotsford have large ground-water production facilities along the eastern bluff of the Sumas outwash deposit. Kohut's (1987) analysis of water-level and precipitation records showed high correlation of precipitation and groundwater levels from the early 1960 s until 1976 to 1979 , a period of below-average precipitation. During this period of below-average precipitation, water-level declines in observation wells exceeded the range expected from declining precipitation, particularly in wells located near the heavy pumpage along the eastern flank of the outwash deposits. The declining water levels were noticeable beginning in about 1977, which coincided with the beginning of the operation of the Fraser Valley Trout Hatchery. Further, Kohut noted in a water budget analysis of the Abbotsford aquifer for
1985 that ground-water withdrawal by the hatchery and the District of Abbotsford accounted for over 70 percent of all ground-water withdrawal from the Abbotsford aquifer, or about 20 percent of the total recharge to the Abbotsford aquifer. His budget did not include pumpage for the City of Sumas, which would increase the figures for the amount of ground-water withdrawal from that area. Together, this information suggests that the long-term trend of declining water levels observed in observation wells near the Sumas-Abbotsford pumping center is real and related to the pumpage of ground water.

The extent to which the declining ground-water levels extend away from the pumpage area is uncertain; however, water-level declines that are most likely related to pumpage along the eastern flank of the upland can be seen in BC Environment's observation well 2 (092G.009.1.2.3-10), located about 3 miles west of the pumping center. Average water levels declined in this well about 10 feet during the late 1970s, when below-average precipitation and increased pumpage began. In the mid 1980s when annual precipitation was again at or above average levels and the trout hatchery was continuing to pump large quantities of ground water, average water levels in the observation well rose about 5 feet, which was about 5 feet below the prestress level. Ground-water pumpage from that area has remained at or above the levels of the late 1970s.

Human activities that alter rates of ground-water recharge or discharge can also lead to long-term changes in water levels. Several activities noted within the study area that may lead to such changes include development and urbanization and the installation of shallow drainage systems. Development and urbanization generally include the building of roads, parking lots, buildings, and other impervious surfaces that can substantially reduce the amount of water that can infiltrate the soil surface and recharge the aquifer below. Developed areas make up only about 1 percent of the total study area (Lindsey, 1988). Thus for the study area as a whole, development that has occurred up until the early 1990 s is not expected to substantially change regional water levels; however, in those areas where development is concentrated, particularly near the town of Lynden and the City of Abbotsford, the reduced recharge may be sufficient to decrease local ground-water levels. 
Lower ground-water levels in parts of the study area may have been caused by the installation of shallow surficial drainage systems, which occur throughout much of the Whatcom County portion of the study area (fig. 3). Shallow subsurface drains are installed to reduce muddy or swampy conditions that inhibit the use of land. Drains change the timing of ground-water discharge, and when they are placed in areas that are not year-round ground-water discharge zones, the early discharge of ground water from the system will effectively reduce the amount of ground-water storage in the aquifer. This reduction will be most noticeable in the fall when ground-water levels are naturally lowest. This reduction in ground-water storage by early discharge will cause seasonally low ground-water levels to be even lower than they would be naturally. In turn, the low ground-water levels can also reduce base-flow to streams or in some areas eliminate streamflow altogether. The extent to which drainage features have affected the ground-water system of the study area is beyond the scope of this report; however, the anecdotal reports of reduced flow in small streams in the study area may in part be the result of drainage features.

\section{Recharge and Discharge}

Ground water in the form of recharge and discharge is constantly being added or removed from hydrogeologic units that make up the ground-water system. Quantitative estimates of recharge and discharge throughout the study area, essentially a water budget of the ground-water system, are beyond the scope of this study. Nevertheless, a review of existing information on recharge rates and characterization of the factors that control recharge and discharge processes in the study area should provide insight on how these processes affect ground-water supplies.

Recharge to the ground-water system is due largely to the infiltration of precipitation. Smaller quantities of recharge are derived from losing reaches of streams and other waterways, irrigation of croplands and lawns, and leachate from septic systems and manure storage lagoons. Recharge occurs to some degree throughout the study area, with the possible exceptions of areas of perennial ground-water discharge and impervious surfaces such as asphalt and concrete. The principal hydrologic factors that control recharge are (1) precipitation, which varies in both space and time; (2) surficial geology and topography, which is spatially variable; and (3) evapotranspiration, which is both spatially and temporally variable. Thus the rate of recharge will also vary in both space and time. In extreme situations, some areas can, at differen times of the year, either recharge or discharge water from the ground-water system.

Most precipitation falling on the study area has adequate opportunity to infiltrate the soil. Rainfall intensity is typically light to moderate. Rainfall intensity for durations longer than 1 hour typically occurs at rates of less than 0.5 inch per hour, although occasiona short-term cloud bursts may be higher (Miller and others, 1973). The permeability of most soils overly. ing the Sumas aquifer (table 1 ) is typically from 0.6 to 2.0 inches per hour or greater (U.S. Department of Agriculture, Soil Conservation Service, 1992b), allowing most precipitation falling on these areas ample opportunity to infiltrate the soil.

The rate of ground-water recharge varies seasonally, depending on the amount of precipitation and evapotranspiration. Generally, moisture that is not lost from the soil because of evapotranspiration will continue to slowly percolate through the unsaturated zone and become ground water. However, during the summer growing season, evapotranspiration returns substantial amounts of moisture back to the atmosphere. Because the hydraulic conductivity of soils is reduced exponentially at water contents below saturation (Campbell, 1985), little if any recharge is expected unless there is sufficient moisture to saturate most of the soil profile. Monthly soil water budgets for the Clearbrook and Abbotsford weather stations in table 5 (from Washington State Division of Water Resources, 1960, and Kohut, 1987) indicate that evapotranspiration typically exceeds precipitation between May and September and that the precipitation exceeds evapotranspiration from October to April. Consequently, most of the recharge is expected during October to April; additionally, this is the period during which water levels rise rapidly in shallow wells, also indicating recharge is occurring.

Estimates of recharge rates have been computed for portions or all of the study area during previous or concurrent studies. Halstead (1959) estimated 14.4 inches of recharge per year for a 20 -square-mile area of the Sumas aquifer near the Abbotsford Airport. Kohut (1987) reported a recharge estimate of 24.4 inches per year based on the analysis of natural discharge of springs in the 6-square-mile area of the Sumas aquifer northwest of the town of Sumas. Kohut (1987) further calculated estimates of recharge for the 
Table 5. Monthly distribution of average precipitation, estimated potential evapotranspiration, and ground-water recharge at two weather stations within the Lynden-Everson-Nooksack-Sumas study area, Whatcom County, Wash., and British Columbia, Canada

[Data from Washington State Division of Water Resources, 1960, and Kohut, 1987]

\begin{tabular}{|c|c|c|c|c|c|c|}
\hline \multirow[b]{2}{*}{ Month } & \multicolumn{3}{|c|}{$\begin{array}{l}\text { Clearbrook Weather Station, } \\
\text { Whatcom County }\end{array}$} & \multicolumn{3}{|c|}{$\begin{array}{l}\text { Abbotsford Weather Station, } \\
\text { Abbotsford Airport, British Columbia }\end{array}$} \\
\hline & $\begin{array}{l}\text { Average } \\
\text { precipi- } \\
\text { tation, } \\
\text { (inches) }\end{array}$ & $\begin{array}{l}\text { Potential } \\
\text { evapotrans- } \\
\text { piration } \\
\text { (inches) }^{1}\end{array}$ & $\begin{array}{l}\text { Average } \\
\text { ground- } \\
\text { water } \\
\text { recharge } \\
\text { (inches) }^{1}\end{array}$ & $\begin{array}{c}\text { Average } \\
\text { precipi- } \\
\text { tation, } \\
\text { (inches) }\end{array}$ & $\begin{array}{l}\text { Potential } \\
\text { evapotrans- } \\
\text { piration } \\
\text { (inches) }^{2}\end{array}$ & $\begin{array}{l}\text { Average } \\
\text { ground- } \\
\text { water } \\
\text { recharge } \\
\text { (inches) }\end{array}$ \\
\hline January & 5.6 & 0.2 & 5.4 & 8.2 & 0.2 & 8.0 \\
\hline February & 4.6 & 0.5 & 4.1 & 6.3 & 0.6 & 5.6 \\
\hline March & 4.1 & 1.2 & 3.9 & 5.5 & 1.1 & 4.4 \\
\hline April & 3.2 & 2.1 & 1 & 4.0 & 1.9 & 2.1 \\
\hline May & 2.6 & 3.2 & 0 & 3.1 & 3.0 & 0.1 \\
\hline June & 2.6 & 3.6 & 0 & 2.5 & 3.8 & 0 \\
\hline July & 1.5 & 4.5 & 0 & 1.6 & 4.5 & 0 \\
\hline August & 1.7 & 4.1 & 0 & 2.2 & 4.1 & 0 \\
\hline September & 2.8 & 2.9 & 0 & 3.5 & 3.0 & 0.5 \\
\hline October & 5.2 & 1.7 & 3.5 & 6.0 & 1.7 & 4.3 \\
\hline November & 5.6 & 0.9 & 4.7 & 7.6 & 0.8 & 6.8 \\
\hline December & 6.6 & 0.4 & 6.2 & 9.0 & 0.4 & 8.6 \\
\hline Total annual & 46.1 & 25.4 & 27.8 & 59.5 & 25.2 & 40.4 \\
\hline
\end{tabular}

${ }^{1}$ Estimated by the Washington Department of Natural Resources, 1960.

${ }^{2}$ Estimated by Kohut, 1987.

area studied by Halstead (1959) using the water balance method of analysis by Thornthwaite and Mather (1957) and an analysis of long-term water-level records in two wells. The water balance analysis, based on 30 years of meteorological data from Abbotsford Airport weather station and a soil-moisture capacity of 100 milliliters per meter, resulted in an estimate of recharge of 37.5 inches per year. The recharge estimates were based on analysis of 10 years of water-level records from well 092G.009.2.1.3-47 using specific storage values of $0.1,0.2$, and 0.3 , which resulted in recharge estimates of 10.7, 22, and 32 inches per year, respectively. Well 092G.009.1.2.3-47 also is reported to penetrate only sand and gravel that is expected to have a specific storage value in the range of from 0.1 to 0.3 , which would result in recharge estimates in this area ranging from 32 to 48 inches per year. Well 092G.009.1.2.3-10, which is located near the area of ice-contact deposits, is reported to have encountered silty material in addition to sand and gravel. The estimate of recharge for this well based on the analysis of water levels and specific storage values of 0.1 and 0.2 is in the range of from 11 to 32 inches per year. Similar duration and specific storage values were used for water levels from well 092G.009.1.2.3-10, which resulted in recharge estimates of 16,32 , and 48 inches, respectively. The specific storage for gravelly sand deposits typically is between 0.2 and 0.3 , whereas deposits with more intermixed fines would generally be 0.2 or less (A. I. Johnson, 1967).

Estimates of long-term average recharge for the Puget Sound region are part of the on-going Regional Aquifer Systems Analysis (RASA) of the glacial aquifers in that area (John Vaccaro, USGS, written commun., 1994). The RASA analysis has found that spatial variations in precipitation and underlying geology could explain most of the known local variations in regional recharge rates. Local variations aside, the 
RASA analysis has found that, in general, recharge in areas underlain by fine-grained deposits constitutes about 36 percent of annual precipitation, while recharge in areas underlain by coarse-grained deposits constitutes about 63 percent of annual precipitation.

The regional estimates of Vaccaro, based primarily on precipitation amount and underlying geology, compare favorably with the point estimates reported by Kohut (1987) that are based on site-specific data.

Kohut's estimate of 37.5 inches per year is based on the water budget analysis of meteorological data from the Abbotsford Airport, located in an area where the regional estimate of recharge is between 31 and 40 inches per year. Regional estimates of recharge in the area surrounding well 092G.009.1.2.3-10 vary from 16 to 30 inches per year. The estimate reported by Kohut (1987) of 24 inches per year, based on spring discharge data from the base of the bluff along the Sumas Valley, also includes this area where the regional estimates vary from 16 to 30 inches per year.

The portion of Vaccaro's recharge map that depicts the distribution of recharge within the study area is shown in figure 11 along with the point estimates from Kohut (1987). As shown, estimated mean annual recharge within the study area varies from 11 to 50 inches per year, reflecting in large part the large range in precipitation across the study area. In the area where the Sumas aquifer is extensive, estimated recharge rates are generally in the range of from 21 to 30 inches per year, while recharge in areas of the Everson-Vashon unit is estimated to be from 11 to 20 inches per year.

Local hydrologic features, which were not included in Vaccaro's regional estimates but will affect the local recharge rates, are peat deposits and artificially drained soils. Peat deposits are generally present in low-lying areas where ground water discharges to streams. Recharge may not occur or will be substantially reduced in these areas. Artificially drained soils are present in some areas where extensive networks of surface and buried drains maintain the water table below the root zone during the growing season by removing ground water from the ground-water system, primarily during the winter and spring periods, which effectively reduces the amount of yearly recharge in that area. Most of the areas artificially drained by either surface drainage ditches or buried tile drains are also shown on figure 3. Flow in these drainage systems occurs primarily during the winter and early spring and stops once the water table has declined below the level of the drain. The drained soil areas are no longer discharge areas when the water table drops below the level of the drainage feature. The magnitude of the effect of these features on the regional recharge estimate is not known.

In addition to artificial drainage, typical ground. water discharge occurs as spring flow, transpiration by plants, evaporation, withdrawals from wells, and seepage to rivers, lakes, and streams. Natural ground-water discharge areas are generally immediately adjacent to receiving surface-water bodies. The area of groundwater discharge is generally much smaller than the area of recharge.

\section{Conceptual Model of the Ground-Water System}

Based on the foregoing description of the ground-water flow system, a simplified conceptual model of the study area's ground-water system is shown in figure 12 . The study area can be characterized as a broad expanse of glacial deposits filling a topographic depression bounded by uplands on all sides, except where the channels of the Nooksack and Sumas Rivers drain the area. Because the area is generally low lying, within a few hundred feet of sea level, deep wells often draw ground water from altitudes below sea level.

The ground-water system within the study area comprises a sequence of glacial deposits that overlie bedrock. The bedrock is composed of fractured consolidated continental sediments and constitutes a low-yielding aquifer. Overlying the bedrock is the predominately fine-grained, low-permeability glaciomarine drift and older undifferentiated deposits that underlie virtually all of the study area. The glaciomarine drift is generally a confining unit except where lenses of more permeable sands produce sufficient water for low-yielding wells. Overlying the glaciomarine drift are glacial outwash sediments that compose the most extensively used aquifer in the study area. In the uplands along the study area boundaries, outwash is largely absent, and the glaciomarine drift is the important source of ground water.

Some precipitation falling on the area infiltrates past the plant root zone and becomes recharge to the ground-water system. Ground water in such upland areas as the Cascade Range and boundary uplands moves vertically downward and laterally to discharge points. Most ground water enters the shallow Sumas aquifer, then travels laterally. Lesser amounts of 


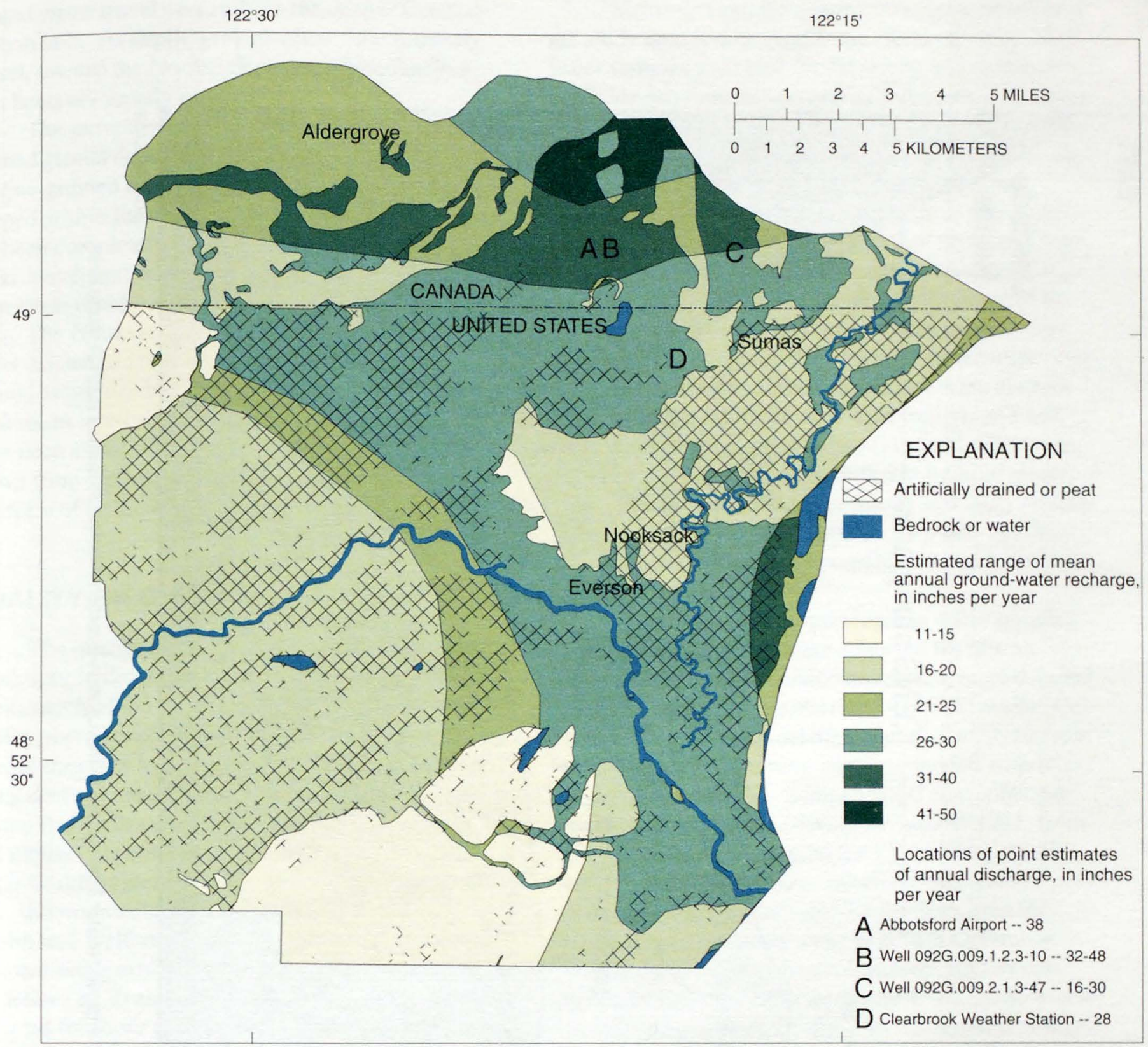

Base and hydrology from U.S. Geological Survey digital data, 1:100,000, 1975 and Canadian Department of Energy, Mines and Resources, 1:50,000, 1977, 1980

Soils data modified from U.S. Department of Agriculture, 1992 and Lettmerding, 1981

Figure 11. Estimated rates of ground-water recharge of the LENS study area, Whatcom County, Washington, and British Columbia, Canada (from Vaccaro and others, 1996, and Kohut, 1989). 


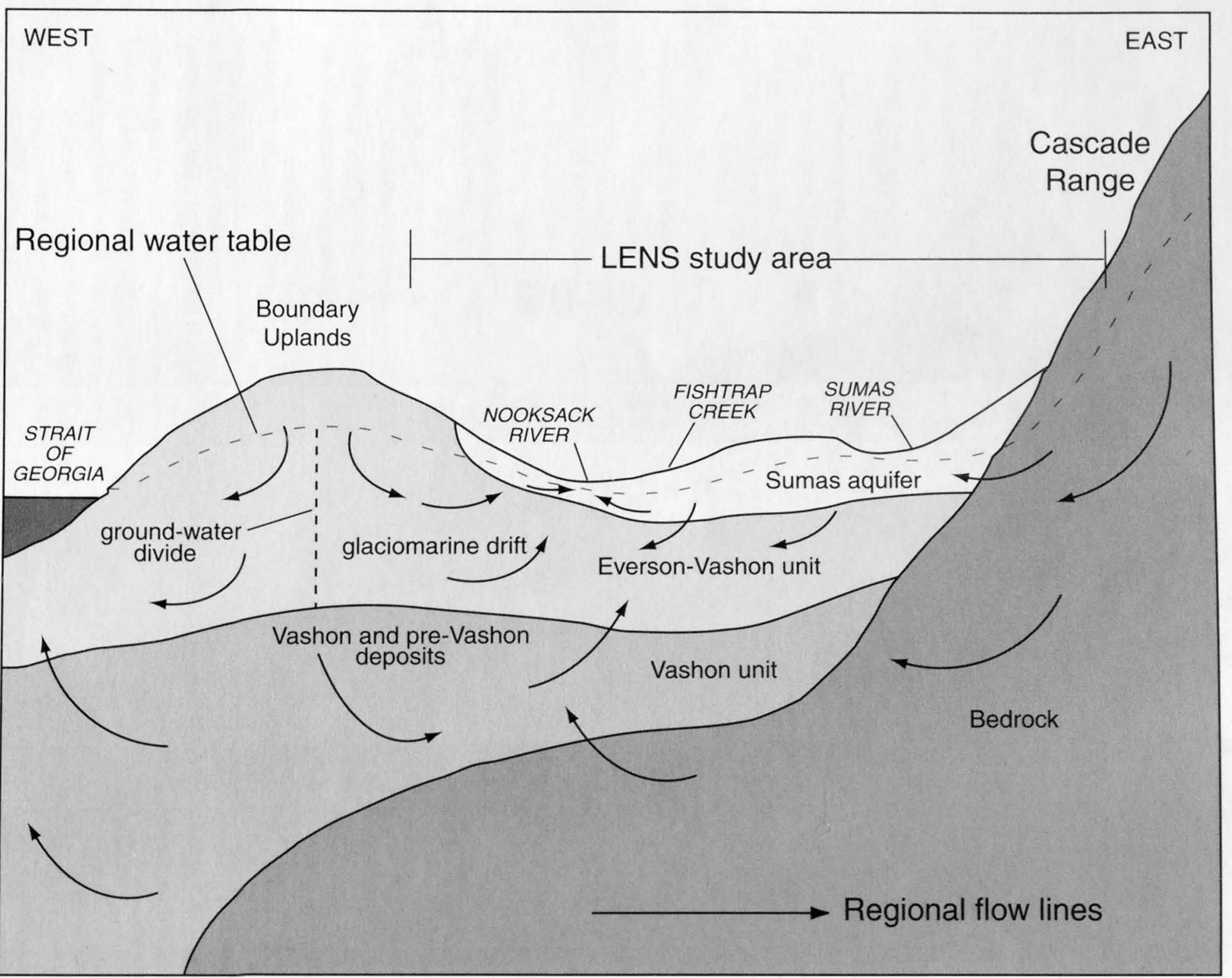

NOT TO SCALE

Figure 12. Conceptual model of the ground-water flow system of the Lynden-Everson-Nooksack-Sumas (LENS) study area. 
ground water travel vertically to the deeper EversonVashon unit. At depth, ground-water flow is mostly lateral, toward the Nooksack River, where the flow then becomes mostly upward.

The movement of ground water within the finegrained glacial deposits is slow. In several areas within the fine-grained deposits, connate seawater that was trapped within these sediments during deposition has not been completely flushed. By comparison, groundwater movement within the coarse-grained glacial outwash is rapid.

The Nooksack River is the regional groundwater discharge zone within the study area. Local ground-water discharge also occurs, generally along streams, in low-lying boggy areas, and in areas that have been artificially drained. Ground water withdrawn from wells for domestic and irrigation purposes is a form of artificial discharge.

\section{QUALITY OF GROUND WATER}

The quality of the ground water in the study area's four hydrogeologic units varies substantially. While much of the ground water sampled was of good quality, there are several areas where substantial waterquality concerns have resulted in some ground water being deemed unsuitable for specific uses. The concentration of nitrate in 15 percent of all wells sampled had nitrate concentrations larger than the drinking water health guideline of $10 \mathrm{mg} / \mathrm{L}$ established by the U.S. Environmental Protection Agency (USEPA) and Health and Welfare Canada (HC). Concentrations of iron and manganese exceeded drinking water aesthetic guidelines in 20 and 50 percent, respectively, of wells sampled for those constituents. Some water-quality problems within the study area are of natural origin; others are directly related to present and historic land-use practices.

The term water quality refers to the chemical and biological characteristics of water, the primary gage of which is the analysis of the chemicals and minerals dissolved in water. Water-quality assessment also depends on the uses for which the water is intended-human consumption, agricultural irrigation, industrial and commercial processes, and so forth. In this study, water quality is mainly compared to human-health and aesthetic-based standards established by the USEPA and $\mathrm{HC}$ for drinking water.
In this section, the quality of the ground water in the study area is described from chemical analyses of water samples collected for this study and readily available data from other studies. Summary data tables of the chemical analyses are included in the text, while complete data tables are located at the end of the report. Chemical concentrations and characteristics are discussed and related to geographic areas and hydrogeologic units where possible. Before this study was conducted, there already were public concerns about possible contamination of ground-water supplies by nitrate, chloride, iron, and organic compounds; thus, the frequency of occurrence, the areal distribution, and the possible sources of these constituents are discussed in more detail. Maps of areal distributions and box plots show patterns in concentrations and differences between ground water from different hydrogeologic units. Temporal variations of nitrate and other constituents are described using time series plots. A subsequent chapter will address potential sources of nitrate in ground water.

Data used in this report include water samples from 368 wells, which were analyzed for nitrate, chloride, and specific conductance; later, more detailed chemical analyses were obtained from 125 wells. Collection of samples for detailed chemical analysis from wells in British Columbia was coordinated with BC Environment and EC. Samples were also collected monthly, from August 1990 to November 1991, from 25 wells and were analyzed for total nitrate, chloride, and specific conductance. EC also collected and analyzed monthly water-quality samples from its network of observation wells in British Columbia.

Additional data from concurrent studies conducted by Ecology, BC Environment, and EC have also been included where appropriate. During this study, Ecology was conducting investigations of chemical inputs to ground water from manure storage lagoons (Erickson, 1991 and 1992 and Garland and Erickson, 1994). Water-quality data from those studies were incorporated into this report where appropriate. In 1987 BC Environment established three nested piezometer sites south of the Abbotsford Airport for the purpose of long-term, semiannual monitoring of nitrates at various depths in the Abbotsford aquifer, which is the upland portion of the Sumas aquifer north of the border between the United States and Canada. Selected results from BC Environment's monitoring are reported in several sections of this report to demonstrate vertical variations in water quality; however, it 
should be noted that these wells were installed in an area of known nitrate contamination and that some of the variations in chemistry may be due to the nitrate contamination. EC also provided data from its ongoing study of pesticide and nitrates in the Canadian portion of the Sumas aquifer (Liebscher and others, 1992).

It should also be noted that for many constituents, some concentrations may be reported as "less than" $(<)$ a given value, where the value given is the reporting limit of the analytical method. For example, the concentrations of many organic compounds are reported as $<0.2 \mu \mathrm{g} / \mathrm{L}$ (microgram per liter) where the reporting limit is $0.2 \mu \mathrm{g} / \mathrm{L}$. The correct interpretation of such concentrations is that the constituent was not detected at or above that particular concentration. The constituent could be present at a lower concentration, such as $0.1 \mu \mathrm{g} / \mathrm{L}$, or it may not be present at all, but that determination is beyond the capabilities of the analytical method used.

Data that describe the quality of the ground water are statistically summarized in the text, and complete data tables are given in the Appendix section at the end of the report. Table 6 compares median values for each of the common constituents by hydrogeologic unit. Tables 7-10 show variability of common constituents within each hydrogeologic unit by listing minimum, median, and maximum values, along with 25 thand 75 th-percentile values. Data on the variability of nitrate concentrations in ground water are presented in tables 11 and 12. Statistical summaries of the concentrations of trace elements and synthetic organic compounds are presented in tables 13-15. Relative cumulative frequency and boxplot diagrams show the distribution of sample concentrations. The distribution of nitrate and chloride concentrations in ground water within the Sumas aquifer and Everson-Vashon unit was analyzed and divided into four concentration groups and plotted on plates 4 and 5, along with relative cumulative frequency diagrams.

\section{Water-Quality Methods}

The sampled wells were selected to provide broad areal coverage and to be representative of all hydrogeologic units. The number of wells selected for sampling within each hydrogeologic unit was approximately proportional to the total number of wells inventoried in each unit. Wells from which samples were analyzed for concentrations of pesticides and volatile organic compounds were selected largely on the basis of the predominant land use in the vicinity of the well the susceptibility of the hydrogeologic unit to contan ination, and previous water-quality analysis.

During the initial well inventory, water-quality samples were collected from pumping or recently pumped wells. These samples were intended to max. mize the areal extent of preliminary water-quality information, and, hence, they are referred to as reconnaissance water-quality samples. The constituents analyzed in the reconnaissance water-quality samples were nitrate, chloride, and specific conductance.

These constituents are generally considered to be stable in solution, and the concentrations are not expected to alter substantially within the well or pumping system of wells that are routinely used. Unfiltered samples were collected after limited flushing ( 2 to 5 minutes) of the well and pumping system. See the Appendix sec. tion at the end of this report for additional details on reconnaissance water-quality sampling.

Nitrate samples were preserved with mercuric chloride and stored on ice prior to analysis by the USGS National Water Quality Laboratory (NWQL) in Arvada, Colo., while chloride samples were analyzed by the Bureau of Reclamation Laboratory (BR) in Boise, Idaho. Specific conductance was analyzed in the USGS Field Laboratory at the district office in Tacoma, Washington. A total of 368 reconnaissance samples were collected. The data from these samples formed the basis for mapping the areal distribution of nitrate and chloride within the study area and were used to guide the selection of sampling sites at which more detailed chemical analyses would be completed. 
Table 6. Median values and concentrations of water-quality constituents in ground waters from four hydrogeologic units

[The number of samples from each hydrogeologic unit is variable; deg $\mathrm{C}$, degrees Celsius; $\mu \mathrm{S} / \mathrm{cm}$, microsiemens per centimeter at $25^{\circ} \mathrm{Celsius} ; \mathrm{mg} / \mathrm{L}$, milligrams per liter; $\mu \mathrm{g} / \mathrm{L}$, micrograms per liter

\section{Hydrogeologic units ${ }^{1}$}

\begin{tabular}{|c|c|c|c|c|}
\hline Water-quality constituent & $\begin{array}{l}\text { Sumas } \\
\text { aquifer }\end{array}$ & $\begin{array}{l}\text { Everson- } \\
\text { Vashon } \\
\text { semicon- } \\
\text { fining unit }\end{array}$ & $\begin{array}{l}\text { Vashon } \\
\text { semicon- } \\
\text { fining unit }\end{array}$ & $\begin{array}{l}\text { Bedrock } \\
\text { semicon- } \\
\text { fining unit }\end{array}$ \\
\hline Temperature (deg C) & 10 & 10.8 & 9.6 & 11.5 \\
\hline Specific conductance, field $(\mu \mathrm{S} / \mathrm{cm})$ & 233 & 309 & 844 & 710 \\
\hline Specific conductance, lab $(\mu \mathrm{S} / \mathrm{cm})$ & 231 & 480 & 1,190 & 1,380 \\
\hline $\mathrm{pH}$, field (standard units) & 6.5 & 8.0 & 8.3 & 8.4 \\
\hline $\mathrm{pH}$, lab (standard units) & 6.7 & 8.1 & 7.8 & 8.3 \\
\hline Dissolved oxygen (mg/L) & 4.0 & 0.2 & 0.4 & 0.1 \\
\hline Hardness, total (mg/L as $\left.\mathrm{CaCO}_{3}\right)$ & 86 & 68 & 130 & 26 \\
\hline Calcium, dissolved (mg/L) & 22 & 16 & 35 & 9.9 \\
\hline Magnesium, dissolved (mg/L) & 6.4 & 7.0 & 12 & 0.7 \\
\hline Sodium, dissolved (mg/L) & 6.0 & 98 & 190 & 220 \\
\hline Sodium (percent) & 13 & 77 & 48 & 95 \\
\hline Sodium adsorption ratio & 0.3 & 5 & 6 & 24 \\
\hline Potassium, dissolved (mg/L) & 1.4 & 3.8 & 2.2 & 1.2 \\
\hline Alkalinity $\left(\mathrm{mg} / \mathrm{L}\right.$ as $\left.\mathrm{CaCO}_{3}\right)$ & 45 & 190 & 75 & 230 \\
\hline Sulfate, dissolved (mg/L) & 15 & 2.7 & 5.0 & 1.3 \\
\hline Chloride, dissolved (mg/L) & 8.8 & 7.7 & 182 & 37 \\
\hline Fluoride, dissolved (mg/L) & $<0.1$ & 0.3 & 0.2 & 0.4 \\
\hline Silica, dissolved (mg/L) & 19 & 19 & 17 & 9.9 \\
\hline Total dissolved solids (mg/L) & 147 & 252 & 132 & 567 \\
\hline Iron, dissolved $(\mu \mathrm{g} / \mathrm{L})$ & 26 & 80 & 54 & 48 \\
\hline Manganese, dissolved $(\mu \mathrm{g} / \mathrm{L})$ & 8 & 17 & 20 & 13 \\
\hline Ammonia as nitrogen, dissolved ( $\mathrm{mg} / \mathrm{L}$ ) & 0.02 & 0.15 & 0.03 & 0.30 \\
\hline Ammonia as nitrogen, total (mg/L) & 0.01 & 0.31 & 0.16 & 0.14 \\
\hline Nitrite as nitrogen, dissolved & $<0.01$ & $<0.01$ & $<0.01$ & $<0.01$ \\
\hline Nitrite as nitrogen, total & $<0.01$ & $<0.01$ & $<0.01$ & $<0.01$ \\
\hline Ammonia plus organic nitrogen, dissolved (mg/L) & 0.30 & 0.40 & 0.40 & 0.70 \\
\hline Ammonia plus organic nitrogen, total (mg/L) & 0.20 & 0.40 & 0.42 & 0.50 \\
\hline Nitrate plus nitrite as nitrogen, total (mg/L) & 3.8 & 0.10 & $<0.10$ & $<0.10$ \\
\hline Nitrate plus nitrite as nitrogen, dissolved (mg/L) & 3.7 & $<0.05$ & $<0.10$ & $<0.05$ \\
\hline Phosphate, ortho as phosphorus, dissolved (mg/L) & $<0.01$ & 0.26 & 0.02 & $<0.01$ \\
\hline Phosphate, ortho as phosphorus, total (mg/L) & $<0.01$ & 0.73 & 0.09 & 0.03 \\
\hline Dissolved organic carbon (mg/L) & 0.7 & 0.6 & 1.7 & 1.2 \\
\hline Boron, dissolved ( $\mu \mathrm{g} / \mathrm{L})$ & 20 & 120 & 30 & 60 \\
\hline Bromide, dissolved (mg/L) & 0.03 & 0.03 & $<0.01$ & 1.1 \\
\hline
\end{tabular}

1 The number of samples for each constituent from each hydrogeologic unit are shown in tables 7 to 10 . 
Table 7. Statistical summary of values and concentrations of water-quality constituents in the Sumas aquifer

[deg C, degrees Celsius; $\mu \mathrm{S} / \mathrm{cm}$, microsiemens per centimeter at $25^{\circ} \mathrm{Celsius;} \mathrm{mg} / \mathrm{L}$, milligrams per liter; $\mu \mathrm{g} / \mathrm{L}$, micrograms per liter; $<$, less than]

\begin{tabular}{|c|c|c|c|c|c|c|c|}
\hline Constituent name & $\begin{array}{l}\text { Number of } \\
\text { samples }\end{array}$ & Mean & Median & Minimum & Maximum & $\begin{array}{c}25 \text { th } \\
\text { percentile }\end{array}$ & $\begin{array}{c}75 \text { th } \\
\text { percentile }\end{array}$ \\
\hline Temperature (deg C) & 79 & 10 & 10 & 8.0 & 14 & 10 & 11 \\
\hline Specific conductance, field $(\mu S / \mathrm{cm})$ & 224 & 246 & 233 & 50 & 1,770 & 161 & 289 \\
\hline Specific conductance, lab $(\mu \mathrm{S} / \mathrm{cm})$ & 101 & 264 & 231 & 72 & 1,220 & 168 & 294 \\
\hline $\mathrm{pH}$, field (standard units) & 78 & 6.7 & 6.5 & 5.6 & 12 & 6.2 & 6.9 \\
\hline $\mathrm{pH}$, lab (standard units) & 97 & 6.8 & 6.7 & 5.8 & 8.7 & 6.4 & 7.1 \\
\hline Dissolved oxygen $(\mathrm{mg} / \mathrm{L})$ & 74 & 6.8 & 4.2 & 0 & 12.6 & 1.6 & 7.1 \\
\hline Hardness, total, (mg/L as $\mathrm{CaCO}_{3}$ ) & 97 & 98 & 86 & 27 & 400 & 59 & 120 \\
\hline Calcium, dissolved (mg/L) & 97 & 24 & 22 & 6.5 & 94 & 14 & 31 \\
\hline Magnesium, dissolved (mg/L) & 97 & 9.1 & 6.4 & 1.8 & 51 & 4.7 & 9.4 \\
\hline Sodium, dissolved (mg/L) & 97 & 8.9 & 6.0 & 3.1 & 61 & 4.7 & 8.7 \\
\hline Sodium (percent) & 97 & 16 & 13 & 6 & 42 & 11 & 19 \\
\hline Sodium adsorption ratio & 97 & 0.4 & 0.3 & 0.1 & 3 & 0.2 & 0.4 \\
\hline Potassium, dissolved (mg/L) & 97 & 4.2 & 1.4 & 0.5 & 110 & 0.9 & 2.6 \\
\hline Alkalinity $\left(\mathrm{mg} / \mathrm{L}\right.$ as $\left.\mathrm{CaCO}_{3}\right)$ & 97 & 64 & 45 & 10 & 560 & 26 & 70 \\
\hline Sulfate, dissolved (mg/L) & 100 & 18 & 15 & 0.1 & 120 & 7.3 & 24 \\
\hline Chloride, dissolved (mg/L) & 331 & 13 & 8.8 & 0.3 & 210 & 5.6 & 13 \\
\hline Fluoride, dissolved $(\mathrm{mg} / \mathrm{L})$ & 100 & $<0.1$ & $<0.1$ & $<0.1$ & 0.4 & $<0.1$ & 0.1 \\
\hline Silica, dissolved $(\mathrm{mg} / \mathrm{L})$ & 97 & 22 & 19 & 8.7 & 53 & 16 & 24 \\
\hline Total dissolved solids (mg/L) & 93 & 169 & 147 & 53 & 760 & 109 & 190 \\
\hline Iron, dissolved $(\mu \mathrm{g} / \mathrm{L})$ & 117 & 2,100 & 26 & $<3$ & 36,000 & 6 & 140 \\
\hline Manganese, dissolved $(\mu \mathrm{g} / \mathrm{L})$ & 97 & 160 & 8 & $<1$ & 3,500 & 2 & 110 \\
\hline (per milliliter) & 22 & 6.7 & 7.05 & 1.5 & 12 & 4.0 & 9.0 \\
\hline Ammonia as nitrogen, dissolved $(\mathrm{mg} / \mathrm{L})$ & 97 & 1.1 & 0.02 & $<0.01$ & 63 & $<0.01$ & 0.06 \\
\hline Ammonia as nitrogen, total (mg/L) & 65 & 1.3 & 0.01 & $<0.01$ & 46 & $<0.01$ & 0.03 \\
\hline Nitrite as nitrogen, dissolved (mg/L) & 97 & 0.02 & $<0.01$ & $<0.01$ & 0.37 & $<0.01$ & 0.01 \\
\hline Nitrite as nitrogen, total $(\mathrm{mg} / \mathrm{L})$ & 65 & 0.02 & $<0.01$ & $<0.01$ & 0.34 & $<0.01$ & 0.01 \\
\hline $\begin{array}{l}\text { Ammonia plus organic as nitrogen, } \\
\text { dissolved }(\mathrm{mg} / \mathrm{L})\end{array}$ & 96 & 1.5 & 0.30 & $<0.2$ & 63 & 0.20 & 0.60 \\
\hline $\begin{array}{l}\text { Ammonia plus organic as nitrogen, } \\
\text { total }(\mathrm{mg} / \mathrm{L})\end{array}$ & 39 & 2.6 & 0.20 & $<0.20$ & 50 & 0.20 & 0.51 \\
\hline $\begin{array}{l}\text { Nitrate plus nitrite as nitrogen, } \\
\text { total (mg/L) }\end{array}$ & 230 & 5.6 & 3.8 & $<0.05$ & 43 & 0.60 & 8.8 \\
\hline $\begin{array}{l}\text { Nitrate plus nitrite as nitrogen, } \\
\text { dissolved }(\mathrm{mg} / \mathrm{L})\end{array}$ & 108 & 6.0 & 3.7 & $<0.05$ & 43 & 0.44 & 9.8 \\
\hline $\begin{array}{l}\text { Phosphate, ortho as phosphorus, } \\
\text { dissolved (mg/L) }\end{array}$ & 81 & $<0.10$ & $<0.01$ & $<0.01$ & 3.3 & $<0.01$ & 0.01 \\
\hline $\begin{array}{l}\text { Phosphate, ortho as phosphorus, } \\
\text { total (mg/L) }\end{array}$ & 65 & $<0.01$ & $<0.01$ & $<0.01$ & 0.14 & $<0.01$ & 0.01 \\
\hline Dissolved organic carbon (mg/L) & 71 & 2.0 & 0.7 & 0.2 & 39 & 0.5 & 1.2 \\
\hline $\begin{array}{l}\text { Methylene blue active substances, } \\
\text { MBAS (mg/L) }\end{array}$ & 56 & $<0.02$ & $<0.02$ & $<0.02$ & 0.09 & $<0.02$ & $<0.02$ \\
\hline Boron, dissolved $(\mu \mathrm{g} / \mathrm{L})$ & 59 & 20 & 20 & 10 & 120 & 10 & 30 \\
\hline Bromide, dissolved (mg/L) & 33 & 0.15 & 0.03 & 0.01 & 3.1 & 0.01 & 0.04 \\
\hline
\end{tabular}


Table 8. Statistical summary of values and concentrations of water-quality constituents in the Everson-Vashon semiconfining unit

[deg C, degrees Celsius; $\mu \mathrm{S} / \mathrm{cm}$, microsiemens per centimeter at $25^{\circ} \mathrm{Celsius;} \mathrm{mg} / \mathrm{L}$, milligrams per liter; $\mu \mathrm{g} / \mathrm{L}$, micrograms per liter; $<$, less than]

\begin{tabular}{|c|c|c|c|c|c|c|c|}
\hline Constituent name & $\begin{array}{l}\text { Number of } \\
\text { samples }\end{array}$ & Mean & Median & Minimum & Maximum & $\begin{array}{c}25 \text { th } \\
\text { percentile }\end{array}$ & $\begin{array}{c}\text { 75th } \\
\text { percentile }\end{array}$ \\
\hline Temperature $(\operatorname{deg} C)$ & 28 & 12 & 10.8 & 9.0 & 17 & 10.5 & 12 \\
\hline Specific conductance, field $(\mu \mathrm{S} / \mathrm{cm})$ & 83 & 618 & 336 & 99 & 10,100 & 244 & 548 \\
\hline Specific conductance, lab $(\mu \mathrm{S} / \mathrm{cm})$ & 20 & 1,200 & 480 & 198 & 9,950 & 296 & 1,070 \\
\hline $\mathrm{pH}$, field (standard units) & 27 & 7.7 & 8 & 0.3 & 8.9 & 7.1 & 8.5 \\
\hline $\mathrm{pH}$, lab (standard units) & 19 & 8.0 & 8.1 & 6.6 & 8.8 & 7.7 & 8.6 \\
\hline Dissolved oxygen $(\mathrm{mg} / \mathrm{L})$ & 19 & 1.3 & 0.2 & 0 & 6.4 & 0.1 & 1.5 \\
\hline Hardness, total (mg/L as $\left.\mathrm{CaCO}_{3}\right)$ & 19 & 130 & 68 & 10 & 1,000 & 28 & 120 \\
\hline Calcium, dissolved (mg/L) & 19 & 23 & 16 & 2.0 & 140 & 4.0 & 27 \\
\hline Magnesium, dissolved (mg/L) & 19 & 17 & 7.0 & 0.9 & 160 & 4.3 & 12 \\
\hline Sodium, dissolved (mg/L) & 19 & 220 & 98 & 4.7 & 1,800 & 33 & 230 \\
\hline Sodium (percent) & 19 & 64 & 77 & 11 & 97 & 35 & 89 \\
\hline Sodium adsorption ratio & 19 & 10 & 5 & 0.2 & 31 & 1 & 14 \\
\hline Potassium, dissolved (mg/L) & 19 & 6.8 & 3.8 & 1.0 & 44 & 2.9 & 5.9 \\
\hline Alkalinity $\left(\mathrm{mg} / \mathrm{L}\right.$ as $\mathrm{CaCO}_{3}$ ) & 19 & 210 & 190 & 47 & 440 & 130 & 300 \\
\hline Sulfate, dissolved (mg/L) & 22 & 44 & 2.7 & 0.1 & 620 & 0.2 & 11 \\
\hline Chloride, dissolved (mg/L) & 87 & 98 & 7.9 & 0.8 & 2,800 & 4.8 & 30 \\
\hline Fluoride, dissolved (mg/L) & 22 & 0.4 & 0.3 & $<0.1$ & 1.1 & 0.2 & 0.5 \\
\hline Silica, dissolved (mg/L) & 19 & 20 & 19 & 13 & 31 & 16 & 23 \\
\hline Total dissolved solids (mg/L) & 14 & 905 & 252 & 136 & 5,630 & 173 & 1,280 \\
\hline Iron, dissolved $(\mu \mathrm{g} / \mathrm{L})$ & 25 & 190 & 80 & $<3$ & 960 & 30 & 260 \\
\hline Manganese, dissolved $(\mu \mathrm{g} / \mathrm{L})$ & 19 & 87 & 17 & $<1$ & 360 & 6 & 140 \\
\hline Ammonia as nitrogen, dissolved (mg/L) & 22 & 0.28 & 0.15 & 0.01 & 1.2 & 0.01 & 0.47 \\
\hline Ammonia as nitrogen, total (mg/L) & 7 & 0.34 & 0.31 & 0.02 & 0.76 & 0.28 & 0.41 \\
\hline Nitrite as nitrogen, dissolved (mg/L) & 22 & $<0.01$ & $<0.01$ & $<0.01$ & 0.01 & $<0.01$ & $<0.01$ \\
\hline Nitrite as nitrogen, total (mg/L) & 7 & $<0.01$ & $<0.01$ & $<0.01$ & 0.01 & 0.01 & 0.01 \\
\hline $\begin{array}{l}\text { Ammonia plus organic nitrogen, } \\
\text { dissolved }(\mathrm{mg} / \mathrm{L})\end{array}$ & 21 & 0.32 & 0.40 & $<0.01$ & 1.2 & $<0.01$ & 0.40 \\
\hline $\begin{array}{l}\text { Ammonia plus organic nitrogen, } \\
\text { total }(\mathrm{mg} / \mathrm{L})\end{array}$ & 7 & 0.45 & 0.40 & 0.20 & 0.93 & 0.20 & 0.50 \\
\hline $\begin{array}{l}\text { Nitrate plus nitrite as nitrogen, } \\
\text { total }(\mathrm{mg} / \mathrm{L})\end{array}$ & 81 & 0.68 & 0.10 & $<0.05$ & 10 & 0.10 & 0.25 \\
\hline $\begin{array}{l}\text { Nitrate plus nitrite as nitrogen, } \\
\text { dissolved }(\mathrm{mg} / \mathrm{L})\end{array}$ & 21 & 13 & $<0.05$ & $<0.05$ & 9.9 & $<0.05$ & 1.4 \\
\hline Phosphate as phosphorus, dissolved (mg/L) & 22 & 0.46 & 0.26 & 0.01 & 2.3 & 0.01 & 0.81 \\
\hline Phosphate as phosphorus, total $(\mathrm{mg} / \mathrm{L})$ & 7 & 0.72 & 0.73 & 0.01 & 1.8 & 0.14 & 1.2 \\
\hline Dissolved organic carbon $(\mathrm{mg} / \mathrm{L})$ & 12 & 1.4 & 0.65 & 0.3 & 6.8 & 0.4 & 2.0 \\
\hline Methylene blue active substances (mg/L) & 7 & $<0.02$ & $<0.02$ & $<0.02$ & 0.03 & $<0.02$ & $<0.02$ \\
\hline Boron, dissolved $(\mu \mathrm{g} / \mathrm{L})$ & 15 & 230 & 120 & $<10$ & 890 & 30 & 360 \\
\hline Bromide, dissolved (mg/L) & 10 & 0.38 & 0.03 & 0.01 & 1.90 & 0.02 & 0.49 \\
\hline
\end{tabular}


Table 9. Statistical summary of values and concentrations of water-quality constituents in the Vashon semiconfining unit [deg C, degrees Celsius; $\mu \mathrm{S} / \mathrm{cm}$, microsiemens per centimeter at $25^{\circ} \mathrm{Celsius;} \mathrm{mg} / \mathrm{L}$, milligrams per liter; $\mu \mathrm{g} / \mathrm{L}$, micrograms per liter]

\begin{tabular}{|c|c|c|c|c|c|c|c|}
\hline Constituent name & $\begin{array}{l}\text { Number of } \\
\text { samples }\end{array}$ & Mean & Median & Minimum & Maximum & $\begin{array}{c}25 \text { th } \\
\text { percentile }\end{array}$ & $\begin{array}{c}\text { 75th } \\
\text { percentile }\end{array}$ \\
\hline Temperature (deg C) & 3 & 9.5 & 9.5 & 8.0 & 10.5 & 8.0 & 10.5 \\
\hline Specific conductance, field $(\mu \mathrm{S} / \mathrm{cm})$ & 8 & 651 & 844 & 210 & 2,290 & 320 & 1,850 \\
\hline Specific conductance, lab ( $\mu S / \mathrm{cm})$ & 4 & 1,220 & 1,190 & 208 & 2,290 & 210 & 2,260 \\
\hline $\mathrm{pH}$, field (standard units) & 3 & 7.8 & 8.3 & 6.5 & 8.6 & 6.5 & 8.6 \\
\hline $\mathrm{pH}$, lab (standard units) & 4 & 7.7 & 7.8 & 6.9 & 8.3 & 7.0 & 8.3 \\
\hline Dissolved oxygen (mg/L) & 3 & 2.4 & 0.4 & 0.1 & 6.8 & 0.1 & 6.8 \\
\hline Hardness, total ( $\mathrm{mg} / \mathrm{L}$ as $\mathrm{CaCO}_{3}$ ) & 4 & 130 & 130 & 90 & 170 & 92 & 170 \\
\hline Calcium, dissolved (mg/L) & 4 & 32 & 35 & 13 & 46 & 17 & 45 \\
\hline Magnesium, dissolved (mg/L) & 4 & 12 & 12 & 7.0 & 16 & 7.8 & 16 \\
\hline Sodium, dissolved $(\mathrm{mg} / \mathrm{L})$ & 4 & 190 & 190 & 3.4 & 400 & 4.1 & 390 \\
\hline Sodium (percent) & 4 & 47 & 48 & 7 & 84 & 8 & 84 \\
\hline Sodium adsorption ratio & 4 & 7 & 6 & 0.2 & 14 & 0.2 & 14 \\
\hline Potassium, dissolved (mg/L) & 4 & 2.6 & 2.2 & 1.2 & 4.7 & 1.2 & 4.3 \\
\hline Alkalinity $\left(\mathrm{mg} / \mathrm{L}\right.$ as $\left.\mathrm{CaCO}_{3}\right)$ & 4 & 76 & 75 & 57 & 95 & 60 & 92 \\
\hline Sulfate, dissolved (mg/L) & 4 & 7.8 & 5.0 & $<0.1$ & 21 & 0.3 & 18 \\
\hline Chloride, dissolved (mg/L) & 8 & 270 & 182 & 1.7 & 750 & 13 & 580 \\
\hline Fluoride, dissolved (mg/L) & 4 & 0.2 & 0.2 & $<0.1$ & 0.4 & 0.1 & 0.4 \\
\hline Silica, dissolved (mg/L) & 4 & 18 & 17 & 15 & 21 & 15 & 20 \\
\hline Total dissolved solids (mg/L) & 2 & 132 & 132 & 127 & 137 & 127 & 137 \\
\hline Iron, dissolved $(\mu \mathrm{g} / \mathrm{L})$ & 4 & 80 & 50 & 10 & 190 & 20 & 160 \\
\hline Manganese, dissolved $(\mu \mathrm{g} / \mathrm{L})$ & 4 & 33 & 20 & $<1$ & 90 & 6 & 72 \\
\hline Ammonia as nitrogen, dissolved (mg/L) & 3 & 0.10 & 0.03 & $<0.01$ & 0.25 & $<0.01$ & 0.25 \\
\hline Ammonia as nitrogen, total (mg/L) & 1 & 0.16 & 0.16 & 0.16 & 0.16 & 0.16 & 0.16 \\
\hline Nitrite as nitrogen, dissolved (mg/L) & 3 & $<0.01$ & $<0.01$ & $<0.01$ & 0.01 & $<0.01$ & 0.01 \\
\hline Nitrite as nitrogen, total (mg/L) & 1 & $<0.01$ & $<0.01$ & $<0.01$ & $<0.01$ & $<0.01$ & $<0.01$ \\
\hline $\begin{array}{l}\text { Ammonia plus organic nitrogen, } \\
\text { dissolved }(\mathrm{mg} / \mathrm{L})\end{array}$ & 3 & 0.33 & 0.40 & 0.20 & 0.40 & 0.20 & 0.40 \\
\hline $\begin{array}{l}\text { Ammonia plus organic nitrogen, } \\
\text { total }(\mathrm{mg} / \mathrm{L})\end{array}$ & 1 & 0.42 & 0.42 & 0.42 & 0.42 & 0.42 & 0.42 \\
\hline $\begin{array}{l}\text { Nitrate plus nitrite as nitrogen, } \\
\text { total (mg/L) }\end{array}$ & 8 & 0.86 & $<0.10$ & 0.08 & 6.2 & $<0.10$ & 0.10 \\
\hline $\begin{array}{l}\text { Nitrate plus nitrite as nitrogen, } \\
\text { dissolved (mg/L) }\end{array}$ & 4 & 1.3 & $<0.10$ & $<0.05$ & 5.0 & $<0.10$ & 3.8 \\
\hline $\begin{array}{l}\text { Phosphate, ortho as phosphorus, dissolved } \\
\text { (mg/L) }\end{array}$ & 3 & 0.02 & 0.02 & $<0.01$ & 0.03 & 0.01 & 0.03 \\
\hline Phosphate, ortho as phosphorus, total (mg/L) & ) 1 & 0.09 & 0.09 & 0.09 & 0.09 & 0.09 & 0.09 \\
\hline Dissolved organic carbon $(\mathrm{mg} / \mathrm{L})$ & 1 & 1.7 & 1.7 & 1.7 & 1.7 & 1.7 & 1.7 \\
\hline Methylene blue active substances (mg/L) & 1 & $<0.02$ & $<0.02$ & $<0.02$ & $<0.02$ & $<0.02$ & $<0.02$ \\
\hline Boron, dissolved $(\mu \mathrm{g} / \mathrm{L})$ & 1 & 30 & 30 & 30 & 30 & 30 & 30 \\
\hline Bromide, dissolved $(\mathrm{mg} / \mathrm{L})$ & 1 & $<0.01$ & $<0.01$ & $<0.01$ & $<0.01$ & $<0.01$ & $<0.01$ \\
\hline
\end{tabular}


Table 10. Statistical summary of values and concentrations of water-quality constituents in the bedrock semiconfining unit

[deg $\mathrm{C}$, degrees Celsius; $\mu \mathrm{S} / \mathrm{cm}$, microsiemens per centimeter at $25^{\circ} \mathrm{Celsius;} \mathrm{mg} / \mathrm{L}$, milligrams per liter; $\mu \mathrm{g} / \mathrm{L}$, micrograms per liter; $<$, less than]

\begin{tabular}{|c|c|c|c|c|c|c|c|}
\hline Constituent name & $\begin{array}{l}\text { Number of } \\
\text { samples }\end{array}$ & Mean & Median & Minimum & Maximum & $\begin{array}{c}25 \text { th } \\
\text { percentile }\end{array}$ & $\begin{array}{c}75 \text { th } \\
\text { percentile }\end{array}$ \\
\hline Temperature (deg C) & 8 & 12 & 11.5 & 10 & 14 & 10.5 & 13 \\
\hline Specific conductance, field $(\mu \mathrm{S} / \mathrm{cm})$ & 14 & 937 & 710 & 88 & 4,020 & 250 & 1,060 \\
\hline Specific conductance, lab $(\mu \mathrm{S} / \mathrm{cm})$ & 6 & 1,730 & 1,380 & 360 & 4,200 & 746 & 2,720 \\
\hline $\mathrm{pH}$, field (standard units) & 7 & 8.4 & 8.4 & 7.7 & 9.2 & 7.8 & 9.1 \\
\hline $\mathrm{pH}$, lab (standard units) & 5 & 8.2 & 8.3 & 7.6 & 8.6 & 7.9 & 8.4 \\
\hline Dissolved oxygen $(\mathrm{mg} / \mathrm{L})$ & 7 & 0.1 & 0.1 & $<0.1$ & 0.3 & $<0.1$ & 0.2 \\
\hline Hardness, total (mg/L as $\left.\mathrm{CaCO}_{3}\right)$ & 5 & 56 & 26 & 13 & 200 & 13 & 110 \\
\hline Calcium, dissolved $(\mathrm{mg} / \mathrm{L})$ & 5 & 18 & 9.9 & 4.0 & 61 & 4.3 & 36 \\
\hline Magnesium, dissolved (mg/L) & 5 & 2.4 & 0.7 & 0.2 & 9.7 & 0.4 & 5.3 \\
\hline Sodium, dissolved (mg/L) & 5 & 330 & 220 & 67 & 760 & 140 & 570 \\
\hline Sodium (percent) & 5 & 92 & 95 & 82 & 98 & 86 & 97 \\
\hline Sodium adsorption ratio & 5 & 24 & 24 & 5 & 46 & 12 & 35 \\
\hline Potassium, dissolved (mg/L) & 5 & 2.0 & 1.2 & 0.8 & 5.3 & 0.8 & 3.4 \\
\hline Alkalinity $\left(\mathrm{mg} / \mathrm{L}\right.$ as $\left.\mathrm{CaCO}_{3}\right)$ & 5 & 310 & 230 & 150 & 600 & 160 & 490 \\
\hline Sulfate, dissolved (mg/L) & 5 & 14 & 1.3 & $<0.1$ & 79 & 0.3 & 23 \\
\hline Chloride, dissolved (mg/L) & 14 & 210 & 37 & 1.4 & 1,200 & 15 & 210 \\
\hline Fluoride, dissolved (mg/L) & 5 & 0.4 & 0.4 & 0.3 & 0.5 & 0.3 & 0.5 \\
\hline Silica, dissolved (mg/L) & 5 & 10 & 9.9 & 7.6 & 13 & 8.4 & 12 \\
\hline Total dissolved solids (mg/L) & 4 & 907 & 567 & 208 & 2,290 & 294 & 1,860 \\
\hline Iron, dissolved $(\mu \mathrm{g} / \mathrm{L})$ & 5 & 350 & 50 & $<3$ & 1,500 & 10 & 840 \\
\hline Manganese, dissolved $(\mu \mathrm{g} / \mathrm{L})$ & 5 & 48 & 13 & 6 & 110 & 8 & 100 \\
\hline Ammonia as nitrogen, dissolved (mg/L) & 5 & 0.63 & 0.30 & $<0.01$ & 2.0 & 0.02 & 0.8 \\
\hline Ammonia as nitrogen, total (mg/L) & 3 & 0.16 & 0.14 & 0.13 & 0.20 & 0.13 & 0.20 \\
\hline Nitrite as nitrogen, dissolved (mg/L) & 5 & $<0.01$ & $<0.01$ & $<0.01$ & $<0.01$ & $<0.01$ & $<0.01$ \\
\hline Nitrite as nitrogen, total (mg/L) & 3 & $<0.01$ & $<0.01$ & $<0.01$ & 0.01 & $<0.01$ & $<0.01$ \\
\hline $\begin{array}{l}\text { Ammonia plus organic nitrogen, } \\
\text { dissolved }(\mathrm{mg} / \mathrm{L})\end{array}$ & 5 & 0.94 & 0.70 & $<0.20$ & 2.4 & 0.30 & 1.7 \\
\hline $\begin{array}{l}\text { Ammonia plus organic nitrogen, } \\
\text { total }(\mathrm{mg} / \mathrm{L})\end{array}$ & 3 & 0.53 & 0.50 & $<0.20$ & 0.90 & 0.20 & 0.90 \\
\hline $\begin{array}{l}\text { Nitrate plus nitrite as nitrogen, } \\
\text { total }(\mathrm{mg} / \mathrm{L})\end{array}$ & 14 & 0.18 & $<0.10$ & $<0.05$ & 1.6 & $<0.10$ & 0.18 \\
\hline $\begin{array}{l}\text { Nitrate plus nitrite as nitrogen, } \\
\text { dissolved }(\mathrm{mg} / \mathrm{L})\end{array}$ & 5 & 0.07 & $<0.05$ & $<0.05$ & 0.16 & $<0.05$ & 0.10 \\
\hline $\begin{array}{l}\text { Phosphate, ortho as phosphorus, dissolved } \\
\text { (mg/L) }\end{array}$ & 5 & 0.02 & 0.01 & $<0.01$ & 0.04 & $<0.01$ & 0.04 \\
\hline Phosphate, ortho as phosphorus, total (mg/L) & 3 & 0.07 & 0.03 & $<0.01$ & 0.18 & $<0.01$ & 0.18 \\
\hline Dissolved organic carbon $(\mathrm{mg} / \mathrm{L})$ & 2 & 1.2 & 1.2 & 1.0 & 1.4 & 1.0 & 1.4 \\
\hline Boron, dissolved $(\mu \mathrm{g} / \mathrm{L})$ & 4 & 120 & 60 & 60 & 310 & 60 & 30 \\
\hline Bromide, dissolved (mg/L) & 3 & 1.4 & 1.1 & 0.4 & 2.6 & 0.4 & 0.01 \\
\hline
\end{tabular}


के Table 11. Temporal variability of nitrate concentrations in ground waters with multiple observations

[G, USGS; F, Flora, written communications; S, City of Sumas; C, Environment Canada; B, British Columbia Ministry of Environment; W, Washington State Department of Ecology; SUMS, Sumas aquifer; EVRS, Everson-Vashon unit; VSHN, Vashon unit; --, no data; <, less than]

\begin{tabular}{|c|c|c|c|c|c|c|c|c|c|c|c|}
\hline \multirow{2}{*}{$\begin{array}{l}\text { Well } \\
\text { number }\end{array}$} & \multirow{2}{*}{$\begin{array}{l}\text { Hydro- } \\
\text { geologic } \\
\text { unit }\end{array}$} & \multirow{2}{*}{$\begin{array}{l}\text { Depth } \\
\text { (feet) }\end{array}$} & \multirow{2}{*}{$\begin{array}{l}\text { Period } \\
\text { of record }\end{array}$} & \multirow{2}{*}{$\begin{array}{l}\text { Number } \\
\text { of } \\
\text { obser- } \\
\text { vations }\end{array}$} & \multirow{2}{*}{$\begin{array}{l}\text { Data } \\
\text { source }\end{array}$} & \multicolumn{4}{|c|}{ Nitrate concentrations, in milligrams per liter } & \multirow{2}{*}{$\begin{array}{l}\text { Standard } \\
\text { deviation }\end{array}$} & \multirow{2}{*}{$\begin{array}{l}\text { Coeffi- } \\
\text { cient of } \\
\text { variation } \\
\text { (percent) }\end{array}$} \\
\hline & & & & & & Range & Minimum & Maximum & Average & & \\
\hline $39 \mathrm{~N} / 02 \mathrm{E}-01 \mathrm{P} 02$ & SUMS & 34 & $8 / 90-10 / 91$ & 12 & $\mathrm{U}$ & 2.9 & 5.3 & 14 & 8.5 & 2.3 & 26 \\
\hline $39 \mathrm{~N} / 02 \mathrm{E}-10 \mathrm{~F} 01$ & SUMS & 20 & $8 / 90-10 / 91$ & 14 & $\mathrm{U}$ & 13 & 1.6 & 15 & 7.7 & 4.0 & 52 \\
\hline $39 \mathrm{~N} / 02 \mathrm{E}-27 \mathrm{~F} 03$ & SUMS & 44 & $10 / 90-10 / 91$ & 14 & $\mathrm{U}$ & 12 & 1.6 & 14 & 12 & 2.8 & 25 \\
\hline $39 \mathrm{~N} / 03 \mathrm{E}-01 \mathrm{C} 01$ & SUMS & 49 & 10/90-10/91 & 12 & $\mathrm{U}$ & 0.1 & 0.26 & 0.37 & 0.30 & 0.03 & 9.7 \\
\hline 39N/03E-10L01 & SUMS & 35 & $81-86$ & 237 & $\mathrm{~F}$ & 8.9 & 0.27 & 9.2 & 2.8 & 1.4 & 51 \\
\hline $39 \mathrm{~N} / 03 \mathrm{E}-10 \mathrm{~L} 01$ & SUMS & 35 & 10/90-10/91 & 11 & $\mathrm{U}$ & 2.7 & 0.14 & 2.8 & 1.4 & 0.98 & 70 \\
\hline 39N/03E-19N01 & EVRS & 62 & 10/90-10/91 & 10 & $\mathrm{U}$ & 0.3 & 1.1 & 1.4 & 1.3 & 0.12 & 9.9 \\
\hline 39N/03E-26P02 & EVRS & 155 & 10/90-10/91 & 11 & $\mathrm{U}$ & 0 & $<0.1$ & $<0.1$ & -- & -- & -- \\
\hline 39N/04E-03P01 & VSHN & 117 & 3/90-9/91 & 12 & $\mathrm{U}$ & 0 & $<0.1$ & $<0.1$ & -- & -- & -- \\
\hline $40 \mathrm{~N} / 02 \mathrm{E}-03 \mathrm{C} 01$ & EVRS & 100 & $11 / 90-9 / 91$ & 10 & $\mathrm{U}$ & 0 & $<0.1$ & $<0.1$ & -- & -- & -- \\
\hline $40 \mathrm{~N} / 02 \mathrm{E}-27 \mathrm{~B} 01$ & SUMS & 41 & $7 / 90-9 / 91$ & 13 & $\mathrm{U}$ & 5.7 & 6.3 & 12 & 8.2 & 2.7 & 33 \\
\hline 40N/03E-03B01 & SUMS & 29 & $7 / 90-12 / 91$ & 15 & $\mathrm{U}$ & 5.2 & 5.8 & 11 & 7.54 & 2.52 & 33 \\
\hline 40N/03E-5M05 & SUMS & 12 & $2 / 90-4 / 93$ & 18 & W & 96 & 2.5 & 99 & 34 & 33 & 96 \\
\hline $40 \mathrm{~N} / 03 \mathrm{E}-5 \mathrm{~N} 01$ & SUMS & 18 & $1 / 90-5 / 92$ & 7 & W & 4.4 & 0.2 & 4.6 & 1.7 & 1.6 & 92 \\
\hline $40 \mathrm{~N} / 03 \mathrm{E}-5 \mathrm{~N} 02$ & SUMS & 24 & $1 / 90-8 / 92$ & 11 & W & 1.6 & 0.8 & 2.4 & 1.2 & 0.71 & 59 \\
\hline $40 \mathrm{~N} / 03 \mathrm{E}-16 \mathrm{H} 02$ & SUMS & 29 & $7 / 90-9 / 91$ & 13 & $\mathrm{U}$ & 12 & 2.7 & 15 & 10 & 4.0 & 40 \\
\hline 40N/03E-32M01 & SUMS & 26 & $8 / 90-9 / 91$ & 15 & $\mathrm{U}$ & 4.1 & 8.9 & 13 & 11 & 1.0 & 9.1 \\
\hline 40N/03E-20F01 & SUMS & 18 & $11 / 90-12 / 91$ & 12 & $\mathrm{U}$ & 1.4 & $<0.1$ & 1.5 & 0.54 & 0.51 & 95 \\
\hline 41N/03E-32Q1 & SUMS & 25 & 6/90-7/91 & 5 & W & 26 & 16 & 43 & 24 & 13 & 54 \\
\hline 41N/04E-31J02 & SUMS & 80 & $10 / 90-9 / 91$ & 13 & $\mathrm{U}$ & 11.1 & 2.9 & 14 & 11 & 3.0 & 28 \\
\hline $41 \mathrm{~N} / 04 \mathrm{E}-33 \mathrm{H} 01$ & SUMS & 58 & $12 / 88-11 / 91$ & 34 & S & 3.3 & 1.7 & 5 & 2.2 & 0.5 & 22 \\
\hline 41N/04E-33H01S & SUMS & - & $12 / 88-11 / 91$ & 33 & S & 3.5 & 3.9 & 7.4 & 5.4 & 0.65 & 12 \\
\hline 41N/04E-33H02 & SUMS & 58 & $12 / 88-11 / 91$ & 35 & S & 3.8 & 4 & 7.8 & 5.5 & 0.8 & 15 \\
\hline $41 \mathrm{~N} / 04 \mathrm{E}-33 \mathrm{H} 03$ & SUMS & 58 & $12 / 88-11 / 91$ & 35 & S & 3.6 & 4.6 & 8.2 & 6.1 & 0.7 & 13 \\
\hline
\end{tabular}


Table 11. Temporal variability of nitrate concentrations in ground waters with multiple observations--Continued

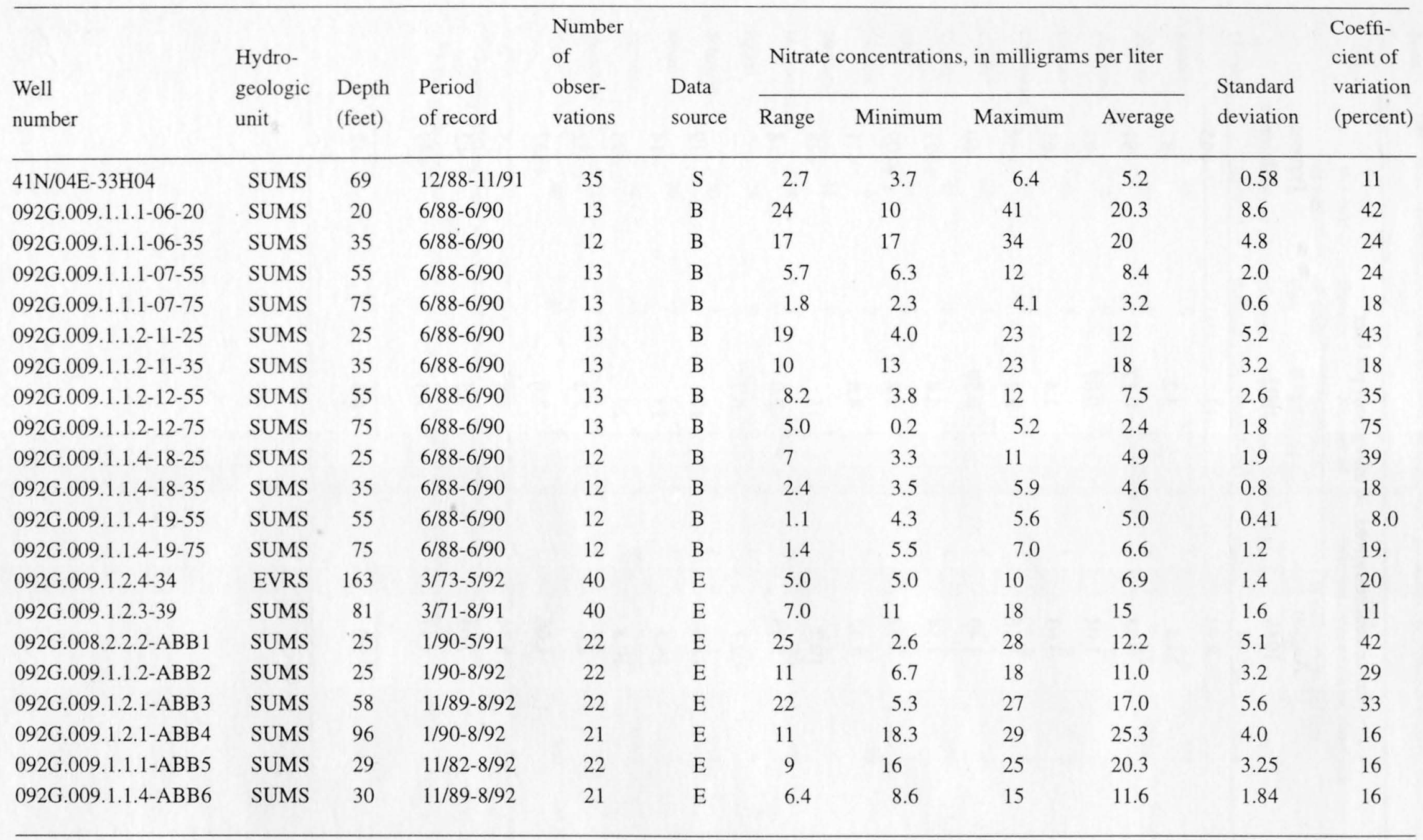


Table 12. Nitrate concentrations in water samples obtained from the same well 3 years apart [--, undefined; <, less than]

Nitrate concentrations, in milligrams per liter

\begin{tabular}{|c|c|c|c|}
\hline \multirow[b]{2}{*}{ Local number } & \multirow[b]{2}{*}{$\begin{array}{c}\text { August } \\
1988\end{array}$} & \multirow[b]{2}{*}{$\begin{array}{c}\text { August } \\
1991\end{array}$} & \multirow[b]{2}{*}{$\begin{array}{l}\text { Percent } \\
\text { difference }\end{array}$} \\
\hline & & & \\
\hline $40 \mathrm{~N} / 02 \mathrm{E}-14 \mathrm{P} 02$ & 8.94 & 13 & +45 \\
\hline 40N/02E-15A01 & 24.4 & 3.2 & -87 \\
\hline $40 \mathrm{~N} / 02 \mathrm{E}-15 \mathrm{C} 01$ & 0.28 & 0.12 & -57 \\
\hline $40 \mathrm{~N} / 02 \mathrm{E}-15 \mathrm{H} 01$ & 1.04 & 0.07 & -93 \\
\hline $40 \mathrm{~N} / 02 \mathrm{E}-15 \mathrm{P} 01$ & 3.63 & 1.4 & -61 \\
\hline 40N/02E-15R02 & 5.16 & 8.2 & +59 \\
\hline 40N/02E-21D01 & 1.49 & 0.59 & -60 \\
\hline $40 \mathrm{~N} / 02 \mathrm{E}-21 \mathrm{~J} 05$ & 1.14 & 4.8 & +321 \\
\hline 40N/02E-21N01 & 3.92 & 8.2 & +109 \\
\hline $40 \mathrm{~N} / 02 \mathrm{E}-22 \mathrm{E} 02$ & 4.32 & 4.8 & +11 \\
\hline $40 \mathrm{~N} / 02 \mathrm{E}-22 \mathrm{~N} 02$ & 10.2 & 13 & +28 \\
\hline $40 \mathrm{~N} / 02 \mathrm{E}-22 \mathrm{~N} 07$ & 5.43 & 5.0 & -8 \\
\hline 40N/02E-23A03 & $<0.1$ & 6.7 & -- \\
\hline 40N/02E-23B02 & 13.6 & 11 & -19 \\
\hline 40N/02E-23D04 & 15.2 & 13 & -14 \\
\hline 40N/02E-23P01 & 10.3 & 20 & +93 \\
\hline $40 \mathrm{~N} / 02 \mathrm{E}-26 \mathrm{C} 03$ & 4.6 & 2.2 & -52 \\
\hline 40N/02E-26D02 & 1.66 & 5.6 & +237 \\
\hline $40 \mathrm{~N} / 02 \mathrm{E}-27 \mathrm{C} 01$ & 8.24 & 7.8 & -5 \\
\hline 40N/02E-27D02 & 7.03 & 7.2 & +2 \\
\hline 40N/02E-28G01 & 4.97 & 7.4 & +49 \\
\hline Median & 5.0 & 6.7 & +2 \\
\hline
\end{tabular}


Table 13. Summary of concentrations of trace elements in ground water from four hydrogeologic units $[--$, no U.S. Environmental Protection Agency (USEPA) drinking water guideline; $\mathrm{HC}=$ Health Canada; $<=$ less than]

\begin{tabular}{|c|c|c|c|c|c|c|c|c|c|}
\hline \multirow{3}{*}{$\begin{array}{l}\text { Element } \\
\text { Arsenic }\end{array}$} & \multirow{3}{*}{$\begin{array}{l}\text { Number } \\
\text { of wells } \\
\text { with } \\
\text { analysis } \\
\text { reported }\end{array}$} & \multirow{3}{*}{$\begin{array}{l}\text { Number } \\
\text { of wells } \\
\text { with } \\
\text { elements } \\
\text { detected } \\
6\end{array}$} & \multirow{3}{*}{$\begin{array}{l}\text { Number of } \\
\text { wells with } \\
\text { elements not } \\
\text { detected } \\
\text { in analysis } \\
42\end{array}$} & \multicolumn{3}{|c|}{$\begin{array}{l}\text { Detected concentrations, dissolved, } \\
\text { in micrograms per liter }\end{array}$} & \multirow{2}{*}{\multicolumn{2}{|c|}{$\begin{array}{l}\text { USEPA } \\
\text { and }(\mathrm{HC}) \\
\text { drinking } \\
\text { water } \\
\text { reference* } \\
(\mu \mathrm{g} / \mathrm{L})\end{array}$}} & \multirow{2}{*}{$\begin{array}{l}\text { Number } \\
\text { of wells } \\
\text { exceeding } \\
\text { standard }\end{array}$} \\
\hline & & & & \multirow{2}{*}{$\begin{array}{c}\begin{array}{l}\text { Mini- } \\
\text { mum }\end{array} \\
1\end{array}$} & \multirow{2}{*}{$\begin{array}{c}\text { Median } \\
1.5\end{array}$} & \multirow{2}{*}{$\begin{array}{c}\begin{array}{l}\text { Maxi- } \\
\text { mum }\end{array} \\
* * 6\end{array}$} & & & \\
\hline & & & & & & & 50 & $(50)$ & 0 \\
\hline Barium & 43 & 40 & 3 & 3 & 12 & 1,100 & 2,000 & $(1,000)$ & 0 \\
\hline Beryllium & 18 & 0 & 18 & - & -- & -- & 4 & & 0 \\
\hline Cadmium & 46 & 2 & 44 & 1 & 2 & 3 & 5 & (5) & 0 \\
\hline Chromium & 46 & 1 & 45 & 2 & 2 & 2 & 100 & $(50)$ & 0 \\
\hline Cobalt* & 28 & 1 & 27 & 3 & 3 & 3 & - & & 0 \\
\hline Copper & 46 & 35 & 11 & 1 & 6 & 190 & $1,300 \mathrm{~b}$ & $(1,000)$ & 0 \\
\hline Lead & 44 & 2 & 34 & 1 & 1 & 1 & $15 b$ & (10) & 0 \\
\hline Lithium & 6 & 2 & 4 & 4 & 11 & 18 & - & & 0 \\
\hline Mercury & 18 & 0 & 18 & - & - & -- & 2 & (1) & 0 \\
\hline Molybdenum* & 28 & 3 & 25 & 10 & 20 & 40 & - & & 0 \\
\hline Nickel & 28 & 0 & 19 & - & - & -. & 100 & (10) & 0 \\
\hline Selenium & 30 & 1 & 29 & 1 & 1 & 1 & 50 & & 0 \\
\hline Silver & 36 & 9 & 27 & 1 & 1 & 2 & $100 \mathrm{a}$ & & 0 \\
\hline Strontium & 18 & 18 & 0 & 49 & 102 & 1,700 & - & & 0 \\
\hline Vanadium & 28 & 3 & 25 & 3 & 5 & 6 & - & & 0 \\
\hline Zinc* & 46 & 43 & 3 & 6 & 30 & 240 & $5,000 \mathrm{a}$ & $(5,000)$ & 0 \\
\hline
\end{tabular}

* Primary drinking water standard, unless noted, $\mathrm{a}=$ secondary standard, $\mathrm{b}=$ action level.

** Two wells reported non-detects at $250 \mu \mathrm{g} / \mathrm{L}$, not included in concentration range. 
Table 14. Summary of total recoverable concentrations, analytical reporting limits, and health advisory levels for pesticides and volatile organic compounds included in the analysis of selected ground-water samples

$[\mu \mathrm{g} / \mathrm{L}$, micrograms per liter; <, less than; --, no data; THM, trihalomethane; n.d., not detected]

\begin{tabular}{|c|c|c|c|c|c|c|}
\hline $\begin{array}{l}\text { Common } \\
\text { name }\end{array}$ & $\begin{array}{l}\text { Trade } \\
\text { name(s) }\end{array}$ & $\begin{array}{l}\text { Minimum } \\
\text { analytical } \\
\text { reporting } \\
\text { level } \\
(\mu \mathrm{g} / \mathrm{L})\end{array}$ & $\begin{array}{l}\text { Health } \\
\text { advisory } \\
\text { level } \\
(\mu \mathrm{g} / \mathrm{L})\end{array}$ & $\begin{array}{l}\text { Number } \\
\text { of wells } \\
\text { sampled }\end{array}$ & $\begin{array}{l}\text { Number of } \\
\text { analyses } \\
\text { greater than } \\
\text { or equal to } \\
\text { reporting } \\
\text { level }\end{array}$ & $\begin{array}{l}\text { Largest } \\
\text { detected } \\
\text { concen- } \\
\text { tration } \\
(\mu \mathrm{g} / \mathrm{L})\end{array}$ \\
\hline
\end{tabular}

Triazines and other nitrogen containing herbicides

$\begin{array}{lllrlll}\text { Alachlor } & \text { Lasso } & 0.1 & 60 & 24 & 0 & \text { n.d. } \\ \text { Ametryn } & \text { Evik/Ametrex } & 0.1 & -- & 24 & 0 & \text { n.d. } \\ \text { Atrazine } & \text { AAtrex } & 0.1 & 3 & 24 & 1 & 0.1 \\ \text { Cyanazine } & \text { Bladex } & 0.1 & 10 & 24 & 0 & \text { n.d. } \\ \text { Metolachlor } & \text { Dual } & 0.1 & 100 & 24 & 0 & \text { n.d. } \\ \text { Metribuzin } & \text { Lexone/Sencor } & 0.1 & 200 & 24 & 0 & \text { n.d. } \\ \text { Prometon } & \text { Pramitol } & 0.1 & 100 & 24 & 0 & \text { n.d. } \\ \text { Prometryn } & & 0.1 & & 24 & 0 & \text { n.d. } \\ \text { Propazine } & \text { Milogard } & 0.1 & 10 & 24 & 0 & \text { n.d. } \\ \text { Simazine } & \text { Princep/Simadex } & 0.1 & 1 & 24 & 0 & \text { n.d. } \\ \text { Simetryn } & \text { Simetryne } & 0.1 & -- & 24 & 0 & \text { n.d. } \\ \text { Trifluralin } & \text { Treflan } & 0.1 & 5 & 24 & 0 & \text { n.d. }\end{array}$

Carbamate insecticides and metabolites

\begin{tabular}{|c|c|c|c|c|c|c|}
\hline Aldicarb & Temik & 0.05 & 10 & 24 & 0 & n.d. \\
\hline $\begin{array}{l}\text { Aldicarb } \\
\text { sulfone }\end{array}$ & Standak & 0.05 & $10-40$ & 24 & 0 & n.d. \\
\hline $\begin{array}{l}\text { Aldicarb } \\
\text { sulfoxide }\end{array}$ & metabolite * & 0.05 & 10 & 24 & 0 & n.d. \\
\hline Carbaryl & Sevin & 0.05 & 700 & 24 & 0 & n.d. \\
\hline Carbofuran & Furadan & 0.05 & 40 & 24 & 0 & n.d. \\
\hline $\begin{array}{l}\text { 3-Hydroxy } \\
\text { carbofuran }\end{array}$ & metabolite * & 0.05 & -- & 24 & 0 & n.d. \\
\hline Methomyl & Lannate/Nudrin & 0.05 & 200 & 24 & 0 & n.d. \\
\hline 1-Naphthol & & 0.05 & & 24 & 0 & n.d. \\
\hline Oxamyl & Vydate & 0.05 & 200 & 24 & 1 & 0.05 \\
\hline Propham & Chem-Hoe & 0.05 & 100 & 24 & 0 & n.d. \\
\hline
\end{tabular}

Volatile organic compounds

$\begin{array}{llrlll}\text { Chloromethane } & <0.2 & - & 24 & 0 & \text { n.d. } \\ \text { Dichloromethane } & <0.2 & 5 & 24 & 0 & \text { n.d. } \\ \text { Trichloromethane } & <0.2 & -- & 24 & 0 & \text { n.d. } \\ \text { Tetrachloromethane } & <0.2 & -- & 24 & 0 & \text { n.d. } \\ \text { Bromomethane } & <0.2 & -- & 24 & 0 & \text { n.d. } \\ \text { Dibromomethane } & <0.2 & -- & 24 & 0 & \text { n.d. } \\ \text { Tribromomethane } & <0.2 & 1(\mathrm{THM}) & 24 & 0 & \text { n.d. } \\ \text { Bromodichloromethane } & <0.2 & 1(\mathrm{THM}) & 24 & 0 & \text { n.d. } \\ \text { Dibromochloromethane } & <0.2 & 1(\mathrm{THM}) & 24 & 0 & \text { n.d. }\end{array}$


Table 14. Summary of total recoverable concentrations, analytical reporting limits, and health advisory levels for pesticides and volatile organic compounds included in the analysis of selected ground-water samples--Continued

\begin{tabular}{|c|c|c|c|c|c|c|}
\hline $\begin{array}{l}\text { Common } \\
\text { name }\end{array}$ & $\begin{array}{l}\text { Trade } \\
\text { name(s) }\end{array}$ & $\begin{array}{l}\text { Minimum } \\
\text { analytical } \\
\text { reporting } \\
\text { level } \\
(\mu \mathrm{g} / \mathrm{L})\end{array}$ & $\begin{array}{l}\text { Health } \\
\text { advisory } \\
\text { level } \\
(\mu \mathrm{g} / \mathrm{L})\end{array}$ & $\begin{array}{l}\text { Number } \\
\text { of wells } \\
\text { sampled }\end{array}$ & $\begin{array}{l}\text { Number of } \\
\text { analyses } \\
\text { greater than } \\
\text { or equal to } \\
\text { reporting } \\
\text { level }\end{array}$ & $\begin{array}{l}\text { Largest } \\
\text { detected } \\
\text { concen- } \\
\text { tration } \\
(\mu \mathrm{g} / \mathrm{L})\end{array}$ \\
\hline \multicolumn{7}{|c|}{ Volatile organic compounds--Continued } \\
\hline \multicolumn{2}{|c|}{ Trichlorofluoromethane } & $<0.2$ & -- & 24 & 0 & n.d. \\
\hline \multicolumn{2}{|c|}{ Dichlorodifluoromethane } & $<0.2$ & -- & 24 & 0 & n.d. \\
\hline \multicolumn{2}{|c|}{ Chloroethane } & $<0.2$ & -- & 24 & 0 & n.d. \\
\hline \multicolumn{2}{|c|}{ 1,1-dichloroethane } & $<0.2$ & -- & 24 & 0 & n.d. \\
\hline \multicolumn{2}{|c|}{ 1,2-dichloroethane } & $<0.2$ & 5 & 24 & 0 & n.d. \\
\hline \multicolumn{2}{|c|}{$1,1,1$-trichloroethane } & $<0.2$ & 200 & 24 & 0 & n.d. \\
\hline \multicolumn{2}{|c|}{ 1,1,2-trichloroethane } & $<0.2$ & 5 & 24 & 0 & n.d. \\
\hline \multicolumn{2}{|c|}{ 1,1,1,2-tetrachloroethane } & $<0.2$ & -- & 24 & 0 & n.d. \\
\hline & $<0.2$ & -- & 24 & 0 & n.d. \\
\hline \multicolumn{2}{|c|}{$\begin{array}{l}1,1,2,2 \text {-tetrachloroethane } \\
\text { 1,2-dibromoethane }\end{array}$} & $<0.2$ & 0.05 & 24 & 1 & 0.3 \\
\hline \multicolumn{2}{|c|}{ Chloroethene, vinyl chloride } & $<0.2$ & 2 & 24 & 0 & n.d. \\
\hline \multicolumn{2}{|c|}{ 1,1-dichloroethene } & $<0.2$ & 7 & 24 & 0 & n.d. \\
\hline \multicolumn{2}{|c|}{ Cis 1,2-dichloroethene } & $<0.2$ & 70 & 24 & 0 & n.d. \\
\hline \multicolumn{2}{|c|}{ Trans 1,2-dichloroethene } & $<0.2$ & 100 & 24 & 0 & n.d. \\
\hline \multicolumn{2}{|c|}{ Trichloroethene } & $<0.2$ & ? & 24 & 0 & n.d. \\
\hline \multicolumn{2}{|c|}{ Tetrachloroethene } & $<0.2$ & - & 24 & 0 & n.d. \\
\hline \multicolumn{2}{|c|}{ 1,2-dichloropropane } & $<0.2$ & 5 & 24 & 2 & 5.6 \\
\hline \multicolumn{2}{|c|}{ 1,3-dichloropropane } & $<0.2$ & -- & 24 & 1 & 0.2 \\
\hline \multicolumn{2}{|c|}{ 2,2-dichloropropane } & $<0.2$ & -- & 24 & 0 & n.d. \\
\hline \multicolumn{2}{|c|}{ 1,2,3-trichloropropane } & $<0.2$ & -- & 24 & 1 & 1.4 \\
\hline \multicolumn{2}{|c|}{ 1,2-dibromo-3-chloropane } & $<0.2$ & 0.2 & 24 & 0 & n.d. \\
\hline \multicolumn{2}{|c|}{ 1,1-dichloropropene } & $<0.2$ & -- & 24 & 0 & n.d. \\
\hline \multicolumn{2}{|c|}{ Cis 1,3-dichloropropene } & $<0.2$ & -- & 24 & 0 & n.d. \\
\hline \multicolumn{2}{|c|}{ Trans 1,3-dichloropropene } & $<0.2$ & -- & 24 & 0 & n.d. \\
\hline \multicolumn{2}{|c|}{ Benzene } & $<0.2$ & 5 & 24 & 0 & n.d. \\
\hline \multicolumn{2}{|c|}{ Chlorobenzene } & $<0.2$ & -- & 24 & 0 & n.d. \\
\hline 1,2-dichlo & & $<0.2$ & 0.600 & 24 & 0 & n.d. \\
\hline 1,3-dichlo & & $<0.2$ & 0.600 & 24 & 0 & n.d. \\
\hline 1,4-dichlo & & $<0.2$ & 75 & 24 & 0 & n.d. \\
\hline Bromober & & $<0.2$ & -- & 24 & 0 & n.d. \\
\hline Toluene & & $<0.2$ & 1,000 & 24 & 0 & n.d. \\
\hline Chlorotol & & $<0.2$ & - & 24 & 0 & n.d. \\
\hline p-chloroto & & $<0.2$ & -- & 24 & 0 & n.d. \\
\hline Dimethyll & & $<0.2$ & - & 24 & 0 & n.d. \\
\hline Ethylbenz & & $<0.2$ & -- & 24 & 0 & n.d. \\
\hline Ethenylbe & & $<0.2$ & - & 24 & 0 & n.d. \\
\hline
\end{tabular}

* metabolite of parent compound 
I T Table 15. Compilation of detection of organic pesticide compounds in ground waters of the study area from selected studies conducted between $1985-1993$

[ppb, parts per billion; mg/L, milligrams per liter; $\mu \mathrm{g} / \mathrm{L}$, micrograms per liter; DSHS, Department of Social and Health Services; USGS, U.S. Geological Survey; USEPA, U.S. Environmental Protection Agency; EC, Environment Canada; CDN, Canadian; RU, restricted use only by licensed and certified applicators; GU, non-restricted, available for commercial and public use; --, not applicable; n.d., not detected; n.g., no guideline]

\begin{tabular}{|c|c|c|c|c|c|c|c|c|c|c|c|}
\hline \multirow[b]{2}{*}{ Compound } & \multirow{2}{*}{$\begin{array}{l}\text { General } \\
\text { use of } \\
\text { compound }\end{array}$} & \multicolumn{2}{|c|}{$\begin{array}{l}\text { Usage restric- } \\
\text { tion or date } \\
\text { of cancellation } \\
\text { or non-renewal } \\
\text { of registration }\end{array}$} & \multirow{2}{*}{$\begin{array}{l}\text { Source of } \\
\text { information }\end{array}$} & \multirow{2}{*}{$\begin{array}{l}\text { Number } \\
\text { of wells } \\
\text { sampled }\end{array}$} & \multirow{2}{*}{$\begin{array}{l}\text { Number } \\
\text { of } \\
\text { wells } \\
\text { with } \\
\text { detectable } \\
\text { concen- } \\
\text { tration }\end{array}$} & \multirow{2}{*}{$\begin{array}{l}\text { Range of } \\
\text { detected } \\
\text { concentra- } \\
\text { tion (ppb } \\
\text { or } \mu \mathrm{g} / \mathrm{L})\end{array}$} & \multirow{2}{*}{$\begin{array}{l}\text { USEPA } \\
\text { maximum } \\
\text { contami- } \\
\text { nant level } \\
\text { or health ad- } \\
\text { visory level } \\
(\mu \mathrm{g} / \mathrm{L})^{\mathrm{c}}\end{array}$} & \multirow{2}{*}{$\begin{array}{l}\text { Health } \\
\text { Canada } \\
\text { maximum } \\
\text { acceptable } \\
\text { concentration } \\
\text { or health } \\
\text { advisory level } \\
(\mu \mathrm{g} / \mathrm{L})^{\mathrm{d}}\end{array}$} & \multirow{2}{*}{$\begin{array}{l}\text { Number of } \\
\text { wells with } \\
\text { detected } \\
\text { concentration } \\
\text { above USEPA } \\
\text { health advi- } \\
\text { sory level }\end{array}$} & \multirow{2}{*}{$\begin{array}{l}\text { Number of wells } \\
\text { with detected } \\
\text { concentration } \\
\text { above Canadian } \\
\text { health advisory level }\end{array}$} \\
\hline & & US & CDN & & & & & & & & \\
\hline $\begin{array}{l}\text { Etheleyne } \\
\text { dibromide } \\
\text { (EDB) }\end{array}$ & Soil fumigant & $1983^{\mathrm{a}}$ & 1984 & $\begin{array}{l}\text { DSHS } 1985^{\mathrm{g}} \\
\text { Black and Veatch } 1986 \\
\text { Sweet-Edwards/EMCON } 19 \\
\text { Erickson and Norton } 1990 \\
\text { USGS 1991-1992 } \\
\text { Hulsman June } 1993^{\mathrm{f}}\end{array}$ & $\begin{array}{r}35 \\
24 \\
98926 \\
27 \\
24 \\
25\end{array}$ & $\begin{array}{l}5 \\
8 \\
6 \\
3 \\
1 \\
7\end{array}$ & $\begin{array}{c}0.28-4.3 \\
0.05-2.3 \\
0.03-1.64 \\
0.02-2.95 \\
0.3 \\
0.03-2.9\end{array}$ & $\begin{array}{l}0.05 \\
0.05 \\
0.05 \\
0.05 \\
0.05 \\
0.05\end{array}$ & $\begin{array}{l}\text { n.g. } \\
\text { n.g. } \\
\text { n.g. } \\
\text { n.g. } \\
\text { n.g. } \\
\text { n.g. }\end{array}$ & $\begin{array}{l}4 \\
8 \\
6 \\
2 \\
1 \\
6\end{array}$ & $\begin{array}{l}-. \\
-. \\
- \\
- \\
.- \\
.-\end{array}$ \\
\hline $\begin{array}{l}\text { 1,2 Dichloro- } \\
\text { propane } \\
(1,2 \mathrm{DCP})\end{array}$ & Soil fumigant & 1988 & 1985 & $\begin{array}{l}\text { Erickson and Norton } 1990 \\
\text { Liebscher and others } 1992 \\
\text { USGS } 1991-1992 \\
\text { Hulsman } 1993^{\mathrm{f}}\end{array}$ & $\begin{array}{r}27 \\
107 \\
24 \\
25\end{array}$ & $\begin{array}{r}9 \\
27 \\
2 \\
4\end{array}$ & $\begin{array}{c}0.3-24 \\
<0.1-5.5 \\
1.6-5.6 \\
1.0-9.3\end{array}$ & $\begin{array}{l}5 \\
5 \\
5 \\
5\end{array}$ & $\begin{array}{l}\text { n.g. } \\
\text { n.g. } \\
\text { n.g. } \\
\text { n.g. }\end{array}$ & $\begin{array}{l}5 \\
1 \\
1 \\
2\end{array}$ & $\begin{array}{l}- \\
-- \\
-- \\
-\end{array}$ \\
\hline $\begin{array}{l}\text { 1,3-Dichloro- } \\
\text { propene }\end{array}$ & $\begin{array}{l}\text { Soil fungicide } \\
\text { and nematacide }\end{array}$ & RU & GU & $\begin{array}{l}\text { Liebscher and others } 1992 \\
\text { USGS 1991-92 } \\
\text { Hulsman } 1993^{f}\end{array}$ & $\begin{array}{l}39 \\
24 \\
26\end{array}$ & $\begin{array}{l}1 \\
1 \\
0\end{array}$ & $\begin{array}{l}3.5 \\
0.2 \\
\text { n.d. }\end{array}$ & $\begin{array}{l}\text { n.g. } \\
\text { n.g. } \\
\text { n.g. }\end{array}$ & $\begin{array}{l}\text { n.g. } \\
\text { n.g. } \\
\text { n.g. }\end{array}$ & -- & -- \\
\hline $\begin{array}{l}\text { Dibromo- } \\
\text { chloro propane }\end{array}$ & Soil fumigant & RU & 1978 & $\begin{array}{l}\text { Erickson and Norton } 1990 \\
\text { USGS 1991-1992 } \\
\text { Hulsman } 1993^{f}\end{array}$ & $\begin{array}{l}27 \\
24 \\
25\end{array}$ & $\begin{array}{l}1 \\
0 \\
1\end{array}$ & $\begin{array}{l}0.36 \\
\text { n.d. } \\
0.2\end{array}$ & $\begin{array}{l}0.2 \\
0.2 \\
0.2\end{array}$ & $\begin{array}{l}\text { n.g. } \\
\text { n.g. } \\
\text { n.g. }\end{array}$ & $\begin{array}{l}1 \\
\text { n.d. } \\
0\end{array}$ & -. \\
\hline Carbofuran & $\begin{array}{l}\text { Insecticide and } \\
\text { nematacide }\end{array}$ & RU & $\mathrm{RU}^{*}$ & $\begin{array}{l}\text { Erickson and Norton } 1990 \\
\text { Liebscher and others } 1992 \\
\text { USGS 1991-1992 } \\
\text { Hulsman } 1993^{\mathrm{f}}\end{array}$ & $\begin{array}{l}27 \\
39 \\
24 \\
26\end{array}$ & $\begin{array}{l}1 \\
8 \\
0 \\
2\end{array}$ & $\begin{array}{c}2.4 \\
0.1-12 \\
\text { n.d. } \\
0.01-0.03\end{array}$ & $\begin{array}{l}40 \\
40 \\
40 \\
40\end{array}$ & $\begin{array}{l}90 \\
90 \\
90 \\
90\end{array}$ & $\begin{array}{l}0 \\
0 \\
\text { n.d. } \\
0\end{array}$ & $\begin{array}{l}0 \\
0 \\
\text { n.d. } \\
0\end{array}$ \\
\hline Prometon & Soil sterilant & $\begin{array}{l}\text { RU } \\
\text { and }\end{array}$ & $\mathrm{RC}$ & $\begin{array}{l}\text { Erickson and Norton } 1990 \\
\text { USGS 1991-1992 } \\
\text { Hulsman } 1993^{\mathrm{f}}\end{array}$ & $\begin{array}{l}27 \\
24 \\
26\end{array}$ & $\begin{array}{l}2 \\
0 \\
0\end{array}$ & $\begin{array}{l}0.5-0.9 \\
\text { n.d. } \\
\text { n.d. }\end{array}$ & $\begin{array}{l}100 \\
100 \\
100\end{array}$ & $\begin{array}{l}\text { n.g. } \\
\text { n.g. } \\
\text { n.g. }\end{array}$ & $\begin{array}{l}0 \\
\text { n.d. } \\
\text { n.d. }\end{array}$ & $\begin{array}{l}- \\
- \\
\text { n.d. }\end{array}$ \\
\hline
\end{tabular}


Table 15. Compilation of detection of organic pesticide compounds in ground waters of the study area from selected studies conducted between 1985-1993--Continued

\begin{tabular}{|c|c|c|c|c|c|c|c|c|c|c|c|}
\hline \multirow[b]{2}{*}{ Compound } & \multirow{2}{*}{$\begin{array}{l}\text { General } \\
\text { use of } \\
\text { compound }\end{array}$} & \multicolumn{2}{|c|}{$\begin{array}{l}\text { Usage restric- } \\
\text { tion or date } \\
\text { of cancellation } \\
\text { or non-renewal } \\
\text { of registration }\end{array}$} & \multirow{2}{*}{$\begin{array}{l}\text { Source of } \\
\text { information }\end{array}$} & \multirow{2}{*}{$\begin{array}{l}\text { Number } \\
\text { of wells } \\
\text { sampled }\end{array}$} & \multirow{2}{*}{$\begin{array}{l}\text { Number } \\
\text { of } \\
\text { wells } \\
\text { with } \\
\text { detectable } \\
\text { concen- } \\
\text { tration }\end{array}$} & \multirow{2}{*}{$\begin{array}{l}\text { Range of } \\
\text { detected } \\
\text { concentra- } \\
\text { tion }(\mathrm{ppb} \\
\text { or } \mu \mathrm{g} / \mathrm{L} \text { ) }\end{array}$} & \multirow{2}{*}{$\begin{array}{l}\text { USEPA } \\
\text { maximum } \\
\text { contami- } \\
\text { nant level } \\
\text { or health ad- } \\
\text { visory level } \\
(\mu \mathrm{g} / \mathrm{L})^{c}\end{array}$} & \multirow{2}{*}{$\begin{array}{l}\text { Health } \\
\text { Canada } \\
\text { maximum } \\
\text { acceptable } \\
\text { concentration } \\
\text { or health } \\
\text { advisory level } \\
(\mu \mathrm{g} / \mathrm{L})^{\mathrm{d}}\end{array}$} & \multirow{2}{*}{$\begin{array}{l}\text { Number of } \\
\text { wells with } \\
\text { detected } \\
\text { concentration } \\
\text { above USEPA } \\
\text { health advi- } \\
\text { sory level }\end{array}$} & \multirow{2}{*}{$\begin{array}{l}\text { Number of wells } \\
\text { with detected } \\
\text { concentration } \\
\text { above Canadian } \\
\text { health advisory leve }\end{array}$} \\
\hline & & US & $\mathrm{CDN}$ & & & & & & & & \\
\hline Dinoseb & $\begin{array}{l}\text { Wide spectrum } \\
\text { herbicide }\end{array}$ & $1986^{t}$ & $\mathrm{RU}$ & $\begin{array}{l}\text { Erickson and Norton } 1990 \\
\text { Liebscher and others } 1992 \\
\text { Hulsman } 1993^{\mathrm{f}}\end{array}$ & $\begin{array}{l}27 \\
39 \\
26\end{array}$ & $\begin{array}{l}0 \\
9 \\
2\end{array}$ & $\begin{array}{c}\text { n.d. } \\
0.1-1.95 \\
0.15-1.2\end{array}$ & $\begin{array}{l}7 \\
7 \\
7\end{array}$ & $\begin{array}{l}10 \\
10 \\
10\end{array}$ & $\begin{array}{l}\text { n.d. } \\
0 \\
0\end{array}$ & $\begin{array}{l}-- \\
0 \\
0\end{array}$ \\
\hline Simizine & $\begin{array}{l}\text { General } \\
\text { herbicide }\end{array}$ & $\mathrm{RU}$ & $\mathrm{GU}$ & $\begin{array}{l}\text { Erickson and Norton } 1990 \\
\text { Liebscher and others } 1992 \\
\text { USGS 1991-1992 } \\
\text { Hulsman } 1993^{\mathrm{f}}\end{array}$ & $\begin{array}{l}27 \\
39 \\
24 \\
26\end{array}$ & $\begin{array}{l}0 \\
7 \\
0 \\
1\end{array}$ & $\begin{array}{l}\text { n.d. } \\
0.1-1.25 \\
\text { n.d. } \\
0.2\end{array}$ & $\begin{array}{l}4 \\
4 \\
4 \\
4\end{array}$ & $\begin{array}{l}10 \\
10 \\
10 \\
10\end{array}$ & $\begin{array}{l}\text { n.d. } \\
1 \\
\text { n.d. } \\
0\end{array}$ & $\begin{array}{l}-. \\
0 \\
-- \\
0\end{array}$ \\
\hline Alachlor & $\begin{array}{l}\text { Preemergent } \\
\text { weed control } \\
\text { in corn, soy } \\
\text { beans }\end{array}$ & $\mathrm{RU}$ & 1985 & $\begin{array}{l}\text { Erickson and Norton } 1990 \\
\text { Liebscher and others } 1992 \\
\text { USGS } \\
\text { Hulsman } 1993^{\mathrm{f}}\end{array}$ & $\begin{array}{l}27 \\
39 \\
24 \\
26\end{array}$ & $\begin{array}{l}0 \\
1 \\
0 \\
0\end{array}$ & $\begin{array}{l}\text { n.d. } \\
0.1 \\
\text { n.d. } \\
\text { n.d. }\end{array}$ & $\begin{array}{l}2 \\
2 \\
2 \\
2\end{array}$ & $\begin{array}{l}5 \\
5 \\
5 \\
5\end{array}$ & $\begin{array}{l}\text { n.d. } \\
0 \\
\text { n.d. } \\
\text { n.d. }\end{array}$ & $\begin{array}{l}-- \\
0 \\
-- \\
--\end{array}$ \\
\hline Atrazine & $\begin{array}{l}\text { Broadleaf weed } \\
\text { and grass } \\
\text { control }\end{array}$ & $\mathrm{RU}$ & $\mathrm{GU}$ & $\begin{array}{l}\text { Erickson and Norton } 1990 \\
\text { Liebscher and others } 1992 \\
\text { USGS 1991-1992 } \\
\text { Hulsman } 1993^{\mathrm{f}}\end{array}$ & $\begin{array}{l}27 \\
39 \\
24 \\
26\end{array}$ & $\begin{array}{r}0 \\
11 \\
1 \\
4\end{array}$ & $\begin{array}{c}\text { n.d. } \\
0.1-4 \\
0.1 \\
0.02-0.32\end{array}$ & $\begin{array}{l}3 \\
3 \\
3 \\
3\end{array}$ & $\begin{array}{l}5+ \\
5+ \\
5+ \\
5+\end{array}$ & $\begin{array}{l}\text { n.d. } \\
1 \\
0 \\
0\end{array}$ & $\begin{array}{l}- \\
0 \\
0 \\
0\end{array}$ \\
\hline Dimethoate & $\begin{array}{l}\text { Systemic } \\
\text { insecticide }\end{array}$ & GU & $\mathrm{RU}$ & $\begin{array}{l}\text { Erickson and Norton } 1990 \\
\text { Liebscher and others } 1992 \\
\text { Hulsman } 1993^{f}\end{array}$ & $\begin{array}{l}27 \\
39 \\
26\end{array}$ & $\begin{array}{l}0 \\
3 \\
0\end{array}$ & $\begin{array}{l}\text { n.d. } \\
0.05-0.24 \\
\text { n.d. }\end{array}$ & $\begin{array}{l}\text { n.g. } \\
\text { n.g. } \\
\text { n.g. }\end{array}$ & $\begin{array}{l}20 \\
20 \\
20\end{array}$ & $\begin{array}{c}-- \\
0 \\
--\end{array}$ & $\begin{array}{l}\text { n.d. } \\
0 \\
\text { n.d. }\end{array}$ \\
\hline Diazinon & Insecticide & $\begin{array}{l}\mathrm{GU} \\
\mathrm{RU}\end{array}$ & $\begin{array}{l}\mathrm{GU} \\
\mathrm{RU}\end{array}$ & $\begin{array}{l}\text { Erickson and Norton } 1990 \\
\text { Liebscher and others } 1992 \\
\text { Hulsman } 1993^{\mathrm{f}}\end{array}$ & $\begin{array}{l}27 \\
39 \\
26\end{array}$ & $\begin{array}{l}0 \\
7 \\
0\end{array}$ & $\begin{array}{l}\text { n.d. } \\
0.05-2 \\
\text { n.d. }\end{array}$ & $\begin{array}{l}0.6 \\
0.6 \\
0.6\end{array}$ & $\begin{array}{l}20 \\
20 \\
20\end{array}$ & $\begin{array}{l}\text { n.d. } \\
2 \\
\text { n.d. }\end{array}$ & $\begin{array}{l}\text { n.d. } \\
0 \\
\text { n.d. }\end{array}$ \\
\hline
\end{tabular}


on Table 15. Compilation of detection of organic pesticide compounds in ground waters of the study area from selected studies conducted between 1985-1993--Continued

\begin{tabular}{|c|c|c|c|c|c|c|c|c|c|c|c|}
\hline \multirow[b]{2}{*}{ Compound } & \multirow{2}{*}{$\begin{array}{l}\text { General } \\
\text { use of } \\
\text { compound }\end{array}$} & \multicolumn{2}{|c|}{$\begin{array}{l}\text { Usage restric- } \\
\text { tion or date } \\
\text { of cancellation } \\
\text { or non-renewal } \\
\text { of registration }\end{array}$} & \multirow{2}{*}{$\begin{array}{l}\text { Source of } \\
\text { information }\end{array}$} & \multirow{2}{*}{$\begin{array}{l}\text { Number } \\
\text { of wells } \\
\text { sampled }\end{array}$} & \multirow{2}{*}{$\begin{array}{l}\text { Number } \\
\text { of } \\
\text { wells } \\
\text { with } \\
\text { detectable } \\
\text { concen- } \\
\text { tration }\end{array}$} & \multirow{2}{*}{$\begin{array}{l}\text { Range of } \\
\text { detected } \\
\text { concentra- } \\
\text { tion }(\mathrm{ppb} \\
\text { or } \mu \mathrm{g} / \mathrm{L})\end{array}$} & \multirow{2}{*}{$\begin{array}{l}\text { USEPA } \\
\text { maximum } \\
\text { contami- } \\
\text { nant level } \\
\text { or health ad- } \\
\text { visory level } \\
(\mu \mathrm{g} / \mathrm{L})^{\mathrm{c}}\end{array}$} & \multirow{2}{*}{$\begin{array}{l}\text { Health } \\
\text { Canada } \\
\text { maximum } \\
\text { acceptable } \\
\text { concentration } \\
\text { or health } \\
\text { advisory level } \\
(\mu \mathrm{g} / \mathrm{L})^{\mathrm{d}}\end{array}$} & \multirow{2}{*}{$\begin{array}{l}\text { Number of } \\
\text { wells with } \\
\text { detected } \\
\text { concentration } \\
\text { above USEPA } \\
\text { health advi- } \\
\text { sory level }\end{array}$} & \multirow{2}{*}{$\begin{array}{l}\text { Number of wells } \\
\text { with detected } \\
\text { concentration } \\
\text { above Canadian } \\
\text { health advisory leve }\end{array}$} \\
\hline & & US & $\mathrm{CDN}$ & & & & & & & & \\
\hline \multirow[t]{3}{*}{ Chlordane } & Insecticide & 1988 & 1990 & Erickson and Norton 1990 & 27 & 0 & n.d. & 2 & 7 & n.d. & n.d. \\
\hline & & & & Liebscher and others 1992 & 39 & 1 & 0.03 & 2 & 7 & 0 & 0 \\
\hline & & & & Hulsman $1993^{\mathrm{f}}$ & 26 & 0 & n.d. & 2 & 7 & n.d. & n.d. \\
\hline \multirow[t]{4}{*}{ Endosulfan } & Insecticide & GU & $\mathrm{GU}$ & Erickson and Norton 1990 & 27 & 0 & n.d. & 0.13 & n.g. & n.d. & -. \\
\hline & & and & & Liebscher and others 1992 & 39 & 3 & $0.02-0.13$ & 0.13 & n.g. & 1 & -- \\
\hline & & RU & & USGS 1991-1992 & 24 & 0 & n.d. & 0.13 & n.g. & n.d. & -- \\
\hline & & & & Hulsman $1993^{\mathrm{f}}$ & 26 & 0 & n.d. & 0.13 & n.g. & n.d. & - \\
\hline \multirow[t]{2}{*}{ DDT } & Insecticide & 1972 & 1985 & Liebscher and others 1992 & 39 & 1 & 0.01 & $0.1^{\mathrm{e}}$ & 30 & 0 & 0 \\
\hline & & & & Hulsman $1993^{\mathrm{f}}$ & 26 & 0 & n.d. & 0.1 & 30 & n.d. & n.d. \\
\hline \multirow[t]{3}{*}{ Oxamyl } & Insecticide and & RU & $\mathrm{RC}$ & Erickson and Norton 1990 & 27 & 0 & n.d. & 200 & n.g. & n.d. & - \\
\hline & & & & Hulsman $1993^{\mathrm{f}}$ & 26 & 0 & n.d. & 200 & n.g. & n.d. & - \\
\hline & & & & USGS 1991-1992 & 24 & 1 & 0.05 & 200 & n.g. & 0 & - \\
\hline
\end{tabular}

* USEPA 1992 maximum contaminant levels, unless noted with an a for lifetime exposure level

t Exemption: existing stocks of Dinoseb could be used on caneberries in non-coastal counties of Oregon and Washington through 1989.

${ }^{\text {a }}$ Exemption: existing stocks for beehive supers and honeycombs.

c U.S. Environmental Protection Agency (1993).

${ }^{d}$ Health Canada (1993).

e Risk specific dose for lifetime exposure of 150 pound person, Nowell and Resek (1994).

${ }^{f}$ Stephen Hulsman, Washington State Department of Health, written commun., 1994.

g DSHS 1985 data reported in Sweet-Edwards/EMCON, 1989. 
Samples for detailed water-quality analysis were analyzed for two or more of six suites of water-quality constituents. The six suites and the number of sampling sites for each suite are listed below. The detailed-level sampling took place during August 1990, April and May 1991, and October 1991.

Suites of water-quality constituents and number of sites sampled within the LENS study area.

\begin{tabular}{lr}
\hline Suite & Sites \\
\hline Field-measured water-quality & \\
$\quad$ constituents & 115 \\
Major ions & 125 \\
Nutrients only & 75 \\
Nutrient and septage-related compounds & 111 \\
Trace elements & 23 \\
Pesticides and volatile & \\
$\quad$ organic compounds & 24 \\
& \\
\hline
\end{tabular}

Field-measured water-quality constituents were collected at 115 of the 125 detailed chemistry sampling sites; these included temperature, specific conductance, $\mathrm{pH}$, and dissolved oxygen. The major-ion suite included calcium, magnesium, potassium, sodium, chloride, sulfate, alkalinity, silica, nitrate, iron, and manganese. The nutrient suite included nitrate, nitrite, organic nitrogen, ammonia, and orthophosphate. The septage-related compounds included boron, dissolved organic carbon (DOC), bromide, and methylene blue active substances (MBAS, or detergents). Trace elements included barium, beryllium, cadmium, chromium, cobalt, copper, lead, molybdenum, nickel, silver, strontium, vanadium, and zinc. The pesticide and volatile organic compounds included 12 triazines and other nitrogen-containing herbicides, 10 carbamate insecticides or metabolites, and 43 volatile organic compounds such as ethylene dibromide (EDB), 1,2dichloropropane (DCP), and trichloroethene (TCE).

The sampling and analytical methods used for the detailed water-quality samples collected for this study follow standard guidelines of the USGS. These procedures are described in Techniques of WaterResources Investigations (TWRI) reports (Britton and Greeson, 1988; Wood, 1981; Friedman and Erdmann, 1982; Fishman and Friedman, 1989; and Wershaw and others, 1987). After collection, samples were immediately preserved and stored according to standard USGS procedures (Pritt and Jones, 1989). All sampling equipment was cleaned and rinsed as appropriate before subsequent samples were collected. Samples requiring laboratory analysis were sent to the NWQL by first-class mail on the next work day. Analytical procedures used at the NWQL are described by Fishman and Friedman (1989) and Wershaw and others (1987).

Water samples were collected largely from the existing water-distribution systems of wells equipped with electric pumps. Considerable effort was made to obtain each sample from a tap close to the wellhead and before the water entered a pressure tank; however, water samples from about 40 percent of the wells sampled had passed through a pressure tank. In some wells, particularly observation wells, which did not have pumps installed, centrifugal, peristaltic, or submersible pumps were temporarily installed to obtain water-quality samples. All samples were collected prior to any water treatment, such as chlorination or softening. Water from the routinely used well system was allowed to run for a period of time deemed sufficient to flush water lines and the pressure tank. The water flow was directed from the tap to a closedsystem flow chamber equipped to monitor temperature, specific conductance, $\mathrm{pH}$, and dissolved oxygen continuously. Sample bottles were filled after the flushing period and only after the constituents monitored in the flow chamber were stable for a period of at least 5 minutes.

As part of the quality-assurance program for this study, field instruments for the measurement of specific conductance and $\mathrm{pH}$ were calibrated with known standards at the beginning of each work day. The dissolved-oxygen meters were calibrated daily using the water-saturated air technique. Five percent of the samples to be analyzed by the NWQL and the BR laboratory were collected in duplicate on a random basis. Reference samples for most inorganic constituents were submitted as blind samples by the NWQL into the sample stream; reference samples also were submitted from the field for chloride and MBAS. As a result of laboratory problems encountered in analyzing the MBAS samples, the resulting data were corrected for analytical bias. At the laboratory, appropriate standards were spiked into each sample for organic analysis to determine the percentage of constituent recovered. As a further quality-assurance measure, selected water samples were split between NWQL and laboratories used by BC Environment and EC. 
The resulting analytical data from the NWQL initially were reviewed by laboratory staff and then released to the local USGS district office in Tacoma, Wash., where the data were reviewed further by district personnel who are more familiar with the hydrologic environment from which the samples were collected. All of the laboratory data were judged to be of good quality for the intended use.

\section{Field-Measured Water-Quality Constituents}

Determinations of $\mathrm{pH}$, specific conductance, alkalinity, and dissolved-oxygen concentration were made in the field using methods outlined by Wood (1981). Dissolved-oxygen concentrations were also determined by meter; however, concentrations below $1 \mathrm{mg} / \mathrm{L}$ were verified using either a Winkler titration (American Public Health Association, 1989) or Rhodazine-D colorimetric method (White and others, 1990). The dissolved-oxygen meter was not used at wells where water had a strong hydrogen sulfide (rotten egg) smell. The distribution and median concentration of these constituents in ground water from the four hydrogeologic units of the study area are shown in figure 13.

\section{Specific Conductance}

Specific conductance is a general indicator of the amount of dissolved minerals in water. Dissolved minerals that possess electrical charge in water allow the water to conduct electrical current, and as the concentration of these dissolved minerals increases, so does the electrical conductance. Thus, electrical conductance is a good indication of the amount of dissolved material in water. Because electrical conductance will vary with temperature, measurements of electrical conductance are reported at a standard temperature of $25^{\circ} \mathrm{C}$, which is referred to as specific conductance. The unit of measurement for specific conductance is microsiemens per centimeter $(\mu \mathrm{S} / \mathrm{cm})$, which is equivalent to the older unit of micromhos per centimeter.

The values in microsiemens per centimeter $(\mu \mathrm{S} / \mathrm{cm})$ of the 351 samples analyzed for specific conductance ranged from 50 to 10,100 , and had a median of 258; those data are tabulated in appendix table 1.

For comparison, median values of specific conductance observed in the 12 Puget Sound counties in 1983 ranged from 113 to $950 \mu \mathrm{S} / \mathrm{cm}$ (Turney, 1986).
Median values of specific conductance, in $\mu \mathrm{S} / \mathrm{cm}$, within the four hydrogeologic units were 233 in the Sumas aquifer, 336 in the Everson-Vashon unit, 844 in the Vashon unit, and 710 in the bedrock unit (table 6). The data indicate a general trend of increased dissolved material in hydrogeologic units that are stratigraphically deeper and that generally have deeper median well depths and smaller hydraulic conductivities, as shown below.

Median values of specific conductance, well depth, and hydraulic conductivity for four principal hydrogeologic units in the LENS study area

\begin{tabular}{lccc}
\hline $\begin{array}{l}\text { Hydro- } \\
\text { geologic } \\
\text { unit }\end{array}$ & $\begin{array}{l}\text { Specific } \\
\text { conduc- } \\
\text { tance } \\
(\mu \mathrm{S} / \mathrm{cm})\end{array}$ & $\begin{array}{l}\text { Well } \\
\text { depth } \\
(\text { feet })\end{array}$ & $\begin{array}{l}\text { Hydraulic } \\
\text { conductivity } \\
\text { (feet per } \\
\text { day) }\end{array}$ \\
\hline $\begin{array}{l}\text { Sumas aquifer } \\
\text { Everson-Vashon }\end{array}$ & 233 & 33 & 270 \\
$\quad$ unit & 336 & 129 & 81 \\
$\begin{array}{l}\text { Vashon unit } \\
\text { Bedrock unit }\end{array}$ & 844 & 55 & 52 \\
& 710 & 130 & 0.55 \\
\hline
\end{tabular}

The larger specific conductance values, and hence the larger quantity of dissolved minerals, found in the deeper hydrogeologic units are most likely the result of longer residence times of ground water on generally deeper flow paths through less permeable geologic materials. The resulting longer residence times provide greater opportunity for ground water to dissolve minerals from the surrounding porous material.

\section{$\mathrm{pH}$}

$\mathrm{pH}$ is an indicator of the acidity or basicity of a substance and is actually a measure of the concentration (or activity) of hydrogen ions in solution. In water, $\mathrm{pH}$ is measured on a scale from 0 to 14 . A pH of 7.0 is considered neutral and is the $\mathrm{pH}$ of pure water at $25^{\circ} \mathrm{C}$; smaller values are acidic and larger values are basic. The $\mathrm{pH}$ scale is the negative logarithm of the hydrogen ion concentration; therefore, a $\mathrm{pH}$ of 6.0 indicates that a water is 10 times as acidic as water with a $\mathrm{pH}$ of 7.0 . 

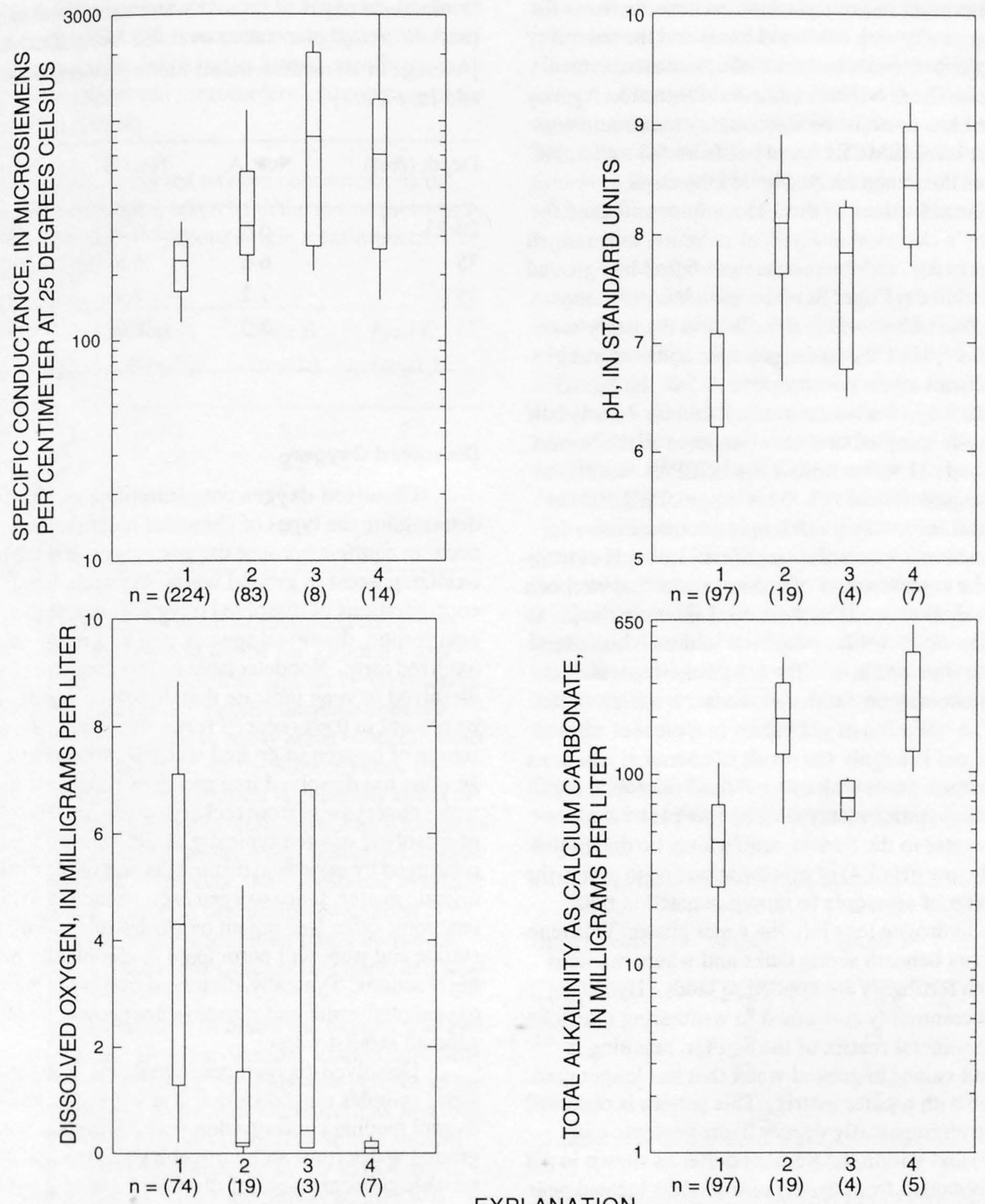

Hydrogeologic unit sampled
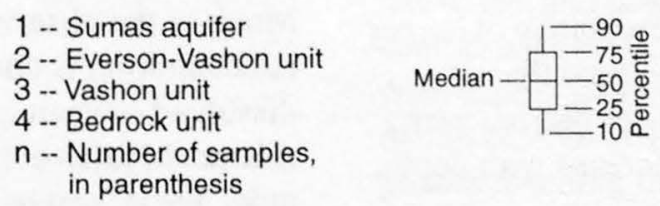

Figure 13. Distribution and median values of specific conductance, $\mathrm{pH}$, and concentration of alkalinity and dissolved oxygen in ground water from four hydrogeologic units of the Lynden-Everson-Nooksack-Sumas (LENS) study area. 
$\mathrm{pH}$ is important in ground water because it affects the dissociation of weak acids and bases and the solubility of many constituents and thus affects most chemical reactions. The U.S. Environmental Protection Agency (USEPA) has established a secondary maximum contaminant level (SMCL) for $\mathrm{pH}$ of from 6.5 to 8.5 ; HC considers this range an Aesthetic Objective.

The $\mathrm{pH}$ values of the 125 samples collected for this study's chemical analysis of common ions ranged from 5.6 to 9.2, and the median was 6.9. Most ground water within the Puget Sound region has $\mathrm{pH}$ values ranging from about 6.0 to 8.5 . Within the study area, the median $\mathrm{pH}$ of the hydrogeologic units increased steadily from top to bottom--from 6.5 in the Sumas aquifer to 8.4 in the bedrock unit (table 6). Nearly half of the wells sampled that are completed in the Sumas aquifer had $\mathrm{pH}$ values below the USEPA's and HC's aesthetic guideline of 6.5 . This range of $\mathrm{pH}$ and the proportion below the guideline is not uncommon for ground water from shallow aquifers. Low $\mathrm{pH}$ contributes to the corrosiveness of ground water that has been noted in shallow wells in the area. Likewise, the $\mathrm{pH}$ in two of the seven wells completed in the bedrock semiconfining unit was above the 8.5 guideline, which is also not uncommon for deeper bedrock wells.

The variation in $\mathrm{pH}$ values is typical of natural systems and is largely the result of chemical reactions of the ground water with minerals and microbial organisms in the aquifer material. The low $\mathrm{pH}$ of shallow ground water in the Sumas aquifer may be due to the naturally low $\mathrm{pH}$ (5.4) of precipitation and in part to the conversion of ammonia to nitrate, a reaction that releases hydrogen ions into the water phase. This reaction occurs beneath septic tanks and where manures and some fertilizers are applied to lands. Hydrogen ions are commonly consumed in weathering reactions with the mineral matrix of the aquifer, resulting in larger $\mathrm{pH}$ values in ground water that has longer contact time with aquifer matrix. This pattern is observed in the stratigraphically deeper hydrogeologic units (table 6) and within the Sumas aquifer as shown in $\mathrm{pH}$ values obtained from nested piezometers located near the Abbotsford Airport. The ground-water flow in the area of the piezometers is such that ground water taken from the deeper piezometers is representative of longer flow paths and thus longer residence time than is ground water taken from the shallower piezometers. Therefore, $\mathrm{pH}$ values predictably increase with depth, as shown below.
Comparison of $\mathrm{pH}$ of ground-water samples obtained from the nested piezometer near the Abbotsford Airport [Average of 10 measurements made between June 1988 and June 1992]

\begin{tabular}{lccc}
\hline Depth (feet) & Nest A & Nest B & Nest C \\
\hline $20-25$ & 6.6 & 6.5 & 6.4 \\
35 & 6.6 & 6.6 & 6.3 \\
55 & 7.2 & 7.3 & 7.3 \\
75 & 8.0 & 8.0 & 8.0 \\
\hline
\end{tabular}

\section{Dissolved Oxygen}

Dissolved-oxygen concentrations are useful in determining the types of chemical reactions that can occur in aquifers because oxygen is typically the initial oxidizing agent in ground water. As such, large concentrations of dissolved oxygen indicate that, at equilibrium, dissolved species will be present in their oxidized form. Nondetectable or low concentrations of dissolved oxygen indicate that dissolved species may be present in their reduced form. Normally, the only source of oxygen in ground water is atmospheric oxygen that has dissolved into recharge water. As ground water moves away from recharge areas, concentrations of dissolved oxygen typically diminish as oxygen is consumed by microbial respiration and the oxidation of organic matter. Once oxygen is consumed in oxidizing reactions, other less potent oxidizers, such as nitrate sulfate and iron, will participate in chemically oxidizing reactions. Typically, dissolved iron is not present in oxygenated water and nitrate is not present in deoxygenated ground water.

Dissolved-oxygen concentrations in groundwater samples ranged from 0.0 to $9.8 \mathrm{mg} / \mathrm{L}$, and the overall median concentration was $2.8 \mathrm{mg} / \mathrm{L}$. Some ground water from all hydrogeologic units had nondetectable concentrations of dissolved oxygen; however, only ground-water samples from the Sumas aquifer had dissolved-oxygen concentrations above $7.0 \mathrm{mg} / \mathrm{L}$. Much of the observed variation in dissolved-oxygen concentration is due to natural reactions between dissolved oxygen in the water and minerals or organic matter. Median concentrations varied considerably by units, the largest being in the Sumas aquifer $(4.3 \mathrm{mg} / \mathrm{L})$ 
and smallest in the bedrock unit $(0.1 \mathrm{mg} / \mathrm{L})$, as shown in figure 13. Like $\mathrm{pH}$, concentrations of dissolved oxygen decrease with depth in the Sumas aquifer, as seen in data from the nested piezometers located south of the Abbotsford Airport.

Comparison of dissolved oxygen concentrations in ground-water samples taken from the nested piezometer near the Abbotsford Airport; single measurement, December 1991

\begin{tabular}{lccc}
\hline Depth (feet) & $\begin{array}{c}\text { Nest A } \\
(\mathrm{mg} / \mathrm{L})\end{array}$ & $\begin{array}{l}\text { Nest B } \\
(\mathrm{mg} / \mathrm{L})\end{array}$ & $\begin{array}{c}\text { Nest C } \\
(\mathrm{mg} / \mathrm{L})\end{array}$ \\
\hline $20-25$ & 8.1 & 8.8 & 9.0 \\
35 & 7.6 & 8.5 & 9.2 \\
55 & 6.0 & 6.4 & 5.0 \\
75 & 1.0 & 0.2 & 0.8 \\
\hline
\end{tabular}

The areal distribution of dissolved oxygen in ground water is shown in figure 14. Ground water throughout much of the Sumas aquifer is oxygenated, meaning that dissolved-oxygen concentrations are larger than $1.0 \mathrm{mg} / \mathrm{L}$ and in many areas concentrations are larger than $4.0 \mathrm{mg} / \mathrm{L}$. In the Sumas Valley the dissolved-oxygen concentration is generally small or absent. The lack of suitable wells from which to obtain samples limited the locations where dissolved oxygen could be measured; however, the widespread evidence of iron staining indicates that dissolved oxygen is absent in ground water throughout much of Sumas Valley. Similar conditions were present north and west of Lynden.

The concentration of dissolved oxygen was generally small in the Everson-Vashon, Vashon, and bedrock hydrogeologic units. Seventy-five percent of the samples from these wells had concentrations less than $1 \mathrm{mg} / \mathrm{L}$. The four samples from non-Sumas aquifer wells, which had concentrations larger than $4 \mathrm{mg} / \mathrm{L}$, were all in locations where the Sumas aquifer was directly overlying or in close proximity to the sampled well.

\section{Alkalinity}

Alkalinity is the capacity of water to react with and neutralize acids. Generally in natural water this capacity is the result of several individual constituents within the water. In most ground water, bicarbonate is the most prominent alkalinity species; however, other ions such as carbonate, ammonia, phosphate, and some silicates can also contribute to alkalinity. For example, several of the ground-water samples from the Sumas aquifer that had large alkalinities also contained large concentrations of ammonia, which normally was below detection levels in this hydrogeologic unit. These samples were from observation wells near manure storage lagoons.

Alkalinity concentrations in the study area ranged from 9 to $610 \mathrm{mg} / \mathrm{L}$ as $\mathrm{CaCO}_{3}$, with median concentrations in the Sumas, Everson-Vashon, Vashon, and bedrock hydrogeologic units of $45,190,75$, and $230 \mathrm{mg} / \mathrm{L}$ as $\mathrm{CaCO}_{3}$, respectively. The distribution of alkalinities within these units is shown graphically in figure 13. For comparison, the alkalinity in ground water from the 12 Puget Sound counties sampled by Turney (1986) ranged from 49 to $220 \mathrm{mg} / \mathrm{L}$ as $\mathrm{CaCO}_{3}$.

Alkalinity, like specific conductance, displayed a general trend of increasing concentrations in samples from wells that were deeper and had lower water levels. This same relation between alkalinity and well depth is observed in multiple wells completed within the same hydrogeologic unit, as shown below in the data from the three sets of nested piezometers located near the Abbotsford Airport.

Comparison of alkalinity concentrations in ground water from the nested piezometer near the Abbotsford Airport

\begin{tabular}{lccc}
\hline Depth (feet) & $\begin{array}{l}\text { Nest A } \\
(\mathrm{mg} / \mathrm{L})\end{array}$ & $\begin{array}{c}\text { Nest B } \\
(\mathrm{mg} / \mathrm{L})\end{array}$ & $\begin{array}{c}\text { Nest C } \\
(\mathrm{mg} / \mathrm{L})\end{array}$ \\
\hline $20-25$ & 8.7 & 9.8 & 18 \\
35 & 14 & 13 & 24 \\
55 & 53 & 51 & 53 \\
75 & 71 & 65 & 66
\end{tabular}

A likely explanation for this pattern of changing water quality is that the increased levels of specific conductance, $\mathrm{pH}$, and alkalinity and the declining oxygen concentrations are the results of increasing residence times with depth. Increasing residence times allow for oxidation of organic matter and the dissolution of mineral phases resulting in an increase in $\mathrm{pH}$, alkalinity, and specific conductance. Declining dissolved oxygen is also consistent with the longer residence times, as 


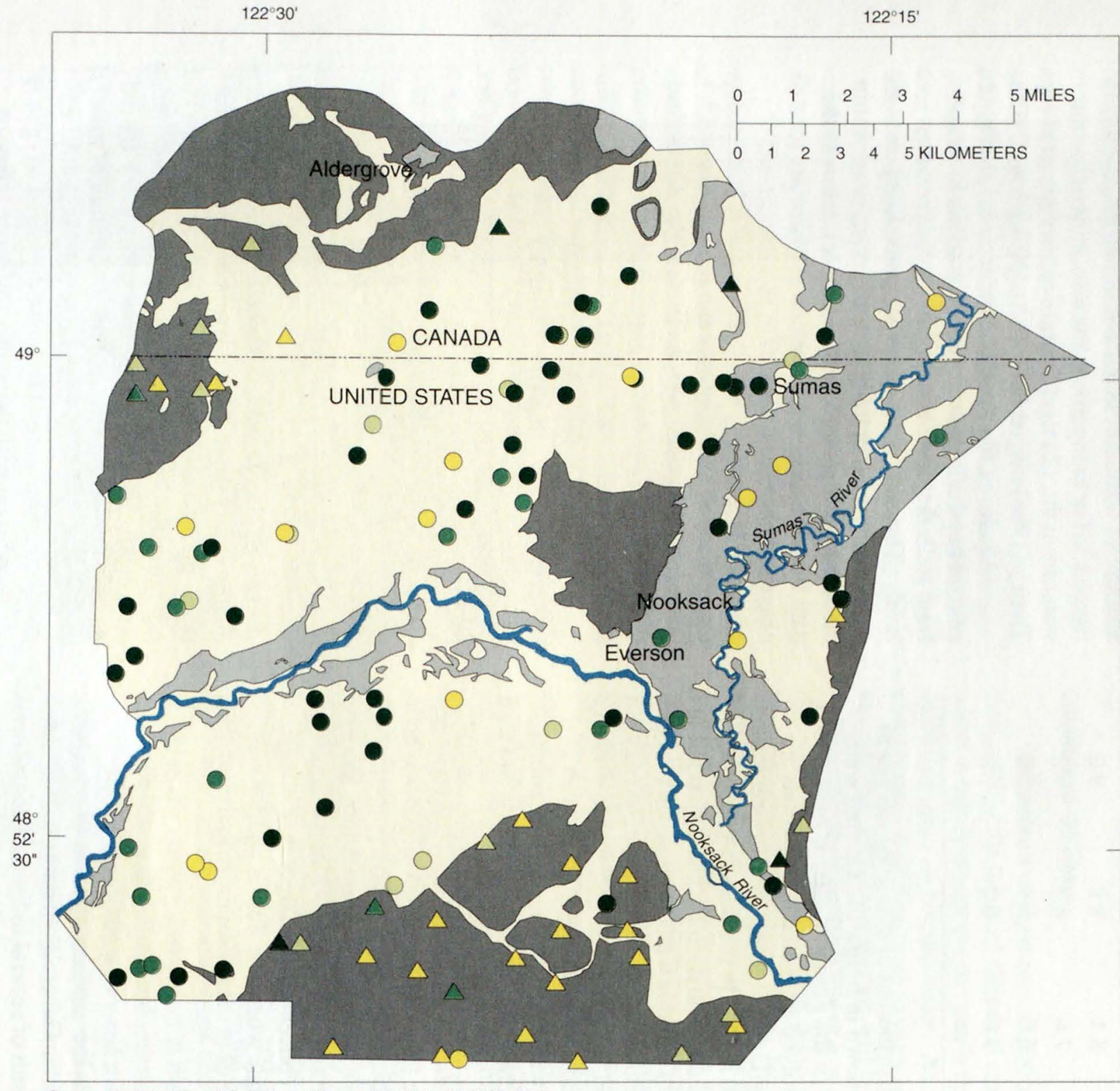

\section{EXPLANATION}

Sumas aquifer under water table conditions

Sumas aquifer with fine-grained sediment near land surface creating confined or partially confined conditions

Non-Sumas fine-grained sediments and bedrock

Dissolved oxygen, in milligrams per liter, in wells completed in the Sumas aquifer

Less than 0.1

0.1 to less than 1

1 to less than 4

- Greater than or equal to 4

Dissolved oxygen, in milligrams per liter, wells tapping all non-Sumas hydrogeologic units

$\triangle$ Less than 0.1

$\triangle 0.1$ to less than 1

A 1 to less than 4

- Greater than or equal to 4 
ground water is further removed from the atmospheric source of oxygen and is consumed by reactions with the mineral phases and organic material.

\section{Major Dissolved Chemical Species}

Generally over 95 percent of all the dissolved matter in ground water is made up of 8 to 10 individual chemical species that are commonly referred to as the major ions. Positively charged ions, referred to as cations, typically include calcium, magnesium, sodium, and potassium. Negatively charged ions, referred to as anions, typically include bicarbonate, chloride, sulfate, fluoride, and in some ground water, including many from the study area, nitrate. Silica, which is uncharged, is included in discussions of major ions because it is a major component of dissolved solids in ground water. Other constituents, such as carbonate and fluoride, or metals, such as iron and manganese, are also common components of dissolved solids, but are rarely found in large enough concentrations to make a significant difference.

The total concentration of all of the chemical species dissolved in the water is referred to as the total dissolved-solids concentration. Dissolved-solids concentrations ranged from 53 to $5,630 \mathrm{mg} / \mathrm{L}$, with a median concentration of $161 \mathrm{mg} / \mathrm{L}$. The median dissolved-solids concentration in the Sumas aquifer was $147 \mathrm{mg} / \mathrm{L}$, and there was a general increase in median dissolved-solids concentrations in the stratigraphically deeper hydrogeologic units. For example, the median dissolved-solids concentration in the bedrock unit was $567 \mathrm{mg} / \mathrm{L}$. Some of this variation is undoubtedly due to increased residence time of water in the lower units, but some is likely due to the different types of aquifer material, some of which appear to contain some remnant seawater. Water that has been in the ground for a longer time generally has had the opportunity to dissolve more minerals than water with a shorter residence time.

The characteristic variability in concentration and distribution of the major ions in water samples can be schematically represented by the shape and size of a Stiff diagram. Stiff diagrams have been plotted for wells along two of the hydrogeologic cross sections (see fig. 15) to illustrate characteristic difference in the major ion composition of ground water from the LENS study area. Highly mineralized water from deep in the Everson-Vashon unit and the bedrock unit can be seen as the large Stiff diagrams with large sodium and chloride components. Concentrations in ground water from the Sumas aquifer are smaller and are typified by calcium, bicarbonate, and nitrate components. Water samples from bedrock wells typically have large sodium and bicarbonate components. Ground-water from wells in the Sumas River Valley is distinctive because of its large magnesium concentrations. Section I-I' (fig. 15) also shows Stiff diagrams from two of the nested sets of piezometers located near the Abbotsford Airport, which show both decreasing nitrate concentrations with depth and an increasing overall amount of dissolved material in the deeper ground water. Section A-A' (fig. 15) shows changes in major ion composition in the Sumas aquifer between areas of the outwash plain north of Lynden and wells from the Sumas Valley, the latter of which were found to have proportionately larger magnesium concentrations. Also shown on section A-A' are differences in the composition of major ions from wells completed in the Everson-Vashon unit in the upland areas along the northwest margin of the study area.

\section{Major Cations}

The distribution of the concentrations of major cations (calcium, magnesium, sodium, and potassium) observed in ground water from the four hydrogeologic units is shown in the boxplot diagram in figure 16. Ground water in the study area shows noticeable differences in the concentration of the major cations among the four hydrogeologic units. In contrast to the pattern described for specific conductance where total dissolved solids was found to increase in deeper, less permeable units, the concentrations of calcium and magnesium tend to decline (fig. 16) in the deeper units. However, the concentrations of sodium increase significantly in the deeper units and offset the decline of the other cations. The median sodium concentration in the Sumas aquifer was about $6 \mathrm{mg} / \mathrm{L}$, and 75 percent of the samples were below $8.7 \mathrm{mg} / \mathrm{L}$. Median sodium concentrations in the Everson-Vashon, Vashon, and bedrock units were $98 \mathrm{mg} / \mathrm{L}, 190 \mathrm{mg} / \mathrm{L}$, and $220 \mathrm{mg} / \mathrm{L}$, respectively. Concentrations of sodium in groundwater samples from the Everson-Vashon, Vashon, and bedrock units were large compared to the USEPA and $\mathrm{HC}$ aesthetic guideline of $200 \mathrm{mg} / \mathrm{L}$ for individuals on salt-restricted diets. Four of the five samples from the bedrock unit exceeded this drinking water guideline. The concentration of potassium was generally small in all hydrogeologic units. 


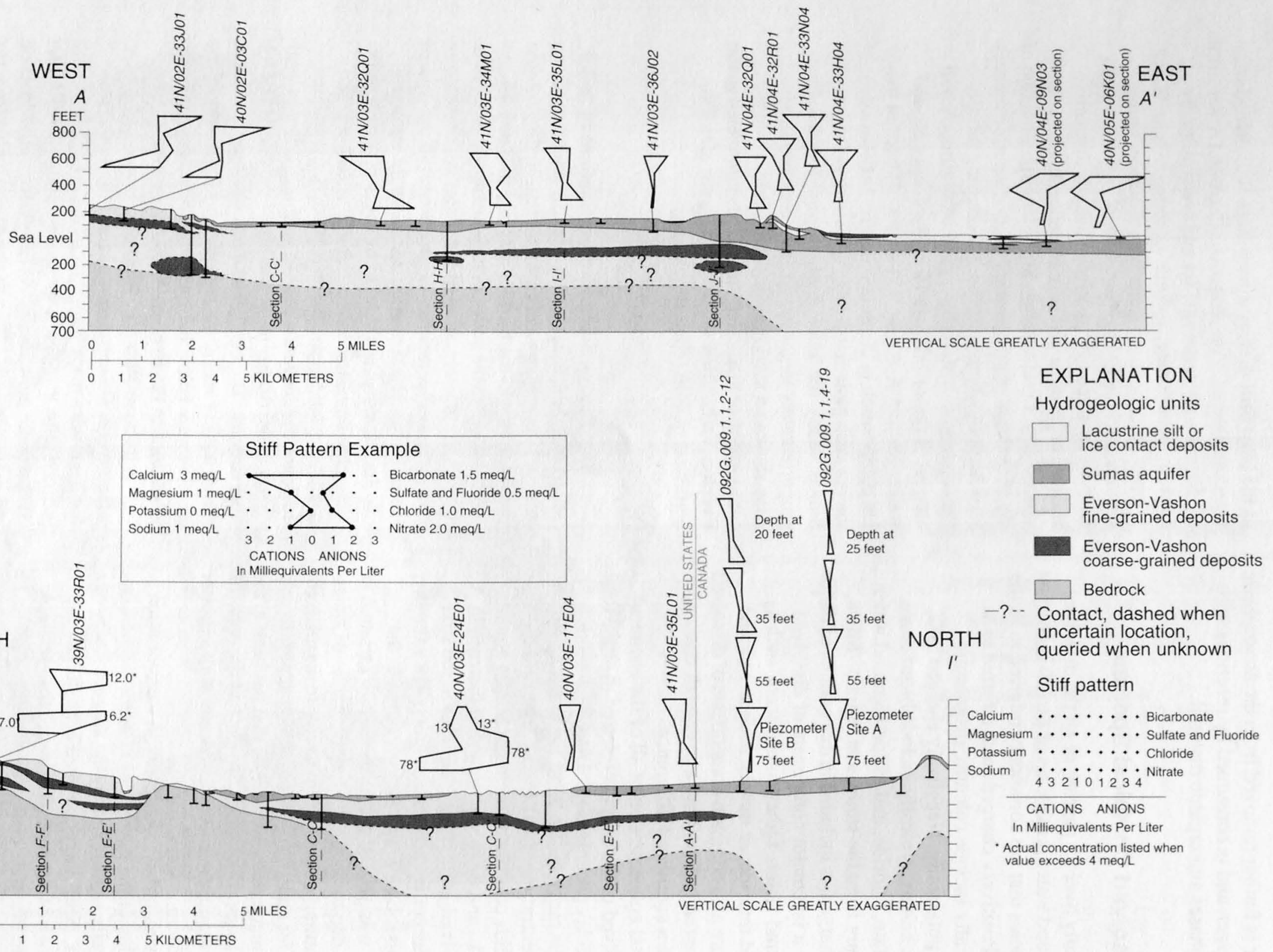

Figure 15. Stiff diagrams showing distribution of major ion chemistry in wells along hydrogeologic sections $A-A^{\prime}$ and $I I^{\prime}$. See plate 2 for location of hydrogeologic sections. 


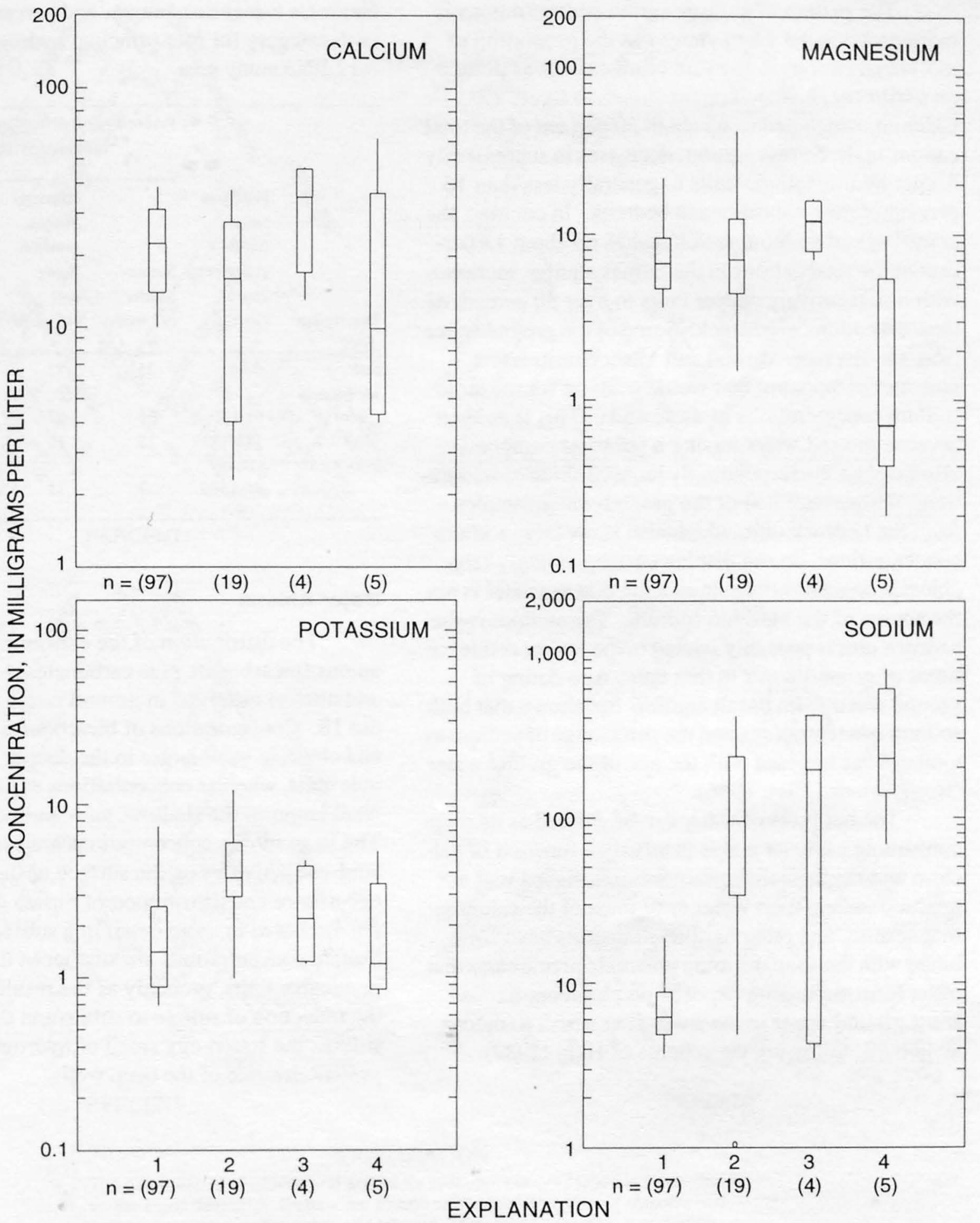

Hydrogeologic unit sampled

$$
\begin{aligned}
& 1 \text {-- Sumas aquifer } \\
& 2 \text {-- Everson-Vashon unit } \\
& 3 \text {-- Vashon unit } \\
& 4 \text {-- Bedrock unit } \\
& \mathrm{n} \text {-- Number of samples, } \\
& \quad \text { in parenthesis }
\end{aligned}
$$

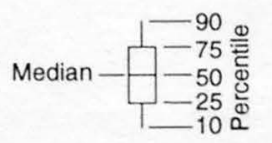

Figure 16. Distribution of concentrations of cations in milligrams per liter in ground water from four hydrogeologic units in the Lynden-Everson-Nooksack-Sumas (LENS) study area. 
The pattern of shifting cation concentrations is more pronounced when viewed as the proportion of individual cations to the sum of all cations as plotted on a trilinear (Piper) diagram shown in figure 17.

Calcium, which makes up about 50 percent of the total cations in the Sumas aquifer, decreases in successively deeper hydrogeologic units to generally less than 10 percent of the total cations in bedrock. In contrast, the percentage of sodium, which makes up about 13 percent of the total cations in the Sumas aquifer, increases within successively deeper units to over 90 percent of the total cations in bedrock. Some of the ground water from the Everson-Vashon and Vashon units has a seawater component that would account for the large sodium concentrations in these units. This is evident because ground water having a seawater component also displays correspondingly large chloride concentrations. However, most of the ground-water samples from the bedrock unit, which also show large sodium concentrations, do not display correspondingly large chloride concentrations, indicating that seawater is not the source of the elevated sodium. The sodium in the bedrock unit is probably related to the longer residence times of ground water in that unit. Age-dating of ground water from basalt aquifers has shown that both sodium concentrations and the percentage of sodium to total cations increase with the age of the ground water (Bortleson and Cox, 1986).

The hardness of water can be defined as its soapconsuming capacity and is primarily a function of calcium and magnesium concentrations. Soaps will not produce suds in hard water until most of the calcium, magnesium, and other hardness minerals have combined with the soap, forming insoluble precipitates that often form encrusting deposits on plumbing fixtures. Most ground water in the study area is soft to moderately hard, following the scheme of Hem (1989):
Hardness categories, ranges, and percentage of wells in each category for four principal hydrogeologic units in the LENS study area

Percentage of wells from each hydrogeologic unit in each hardness class

\begin{tabular}{|c|c|c|c|c|c|}
\hline Description & $\begin{array}{l}\text { Hardness } \\
\text { range } \\
\text { (milli- } \\
\text { grams per } \\
\text { liter of } \\
\mathrm{CaCO}_{3} \text { ) }\end{array}$ & $\begin{array}{l}\text { Sumas } \\
\text { aquifer } \\
\text { ( } 97 \text { wells) }\end{array}$ & $\begin{array}{l}\text { Everson- } \\
\text { Vashon } \\
\text { semicon- } \\
\text { fining } \\
\text { unit } \\
\text { (19 wells) }\end{array}$ & $\begin{array}{l}\text { Vashon } \\
\text { semicon- } \\
\text { fining } \\
\text { unit } \\
\text { ( } 4 \text { wells) }\end{array}$ & $\begin{array}{l}\text { Bedrock } \\
\text { semicon- } \\
\text { fining } \\
\text { unit } \\
\text { ( } 5 \text { wells) }\end{array}$ \\
\hline Soft & $0-60$ & 25 & 37 & 0 & 80 \\
\hline $\begin{array}{l}\text { Moderately } \\
\text { hard }\end{array}$ & $61-120$ & 55 & 37 & 50 & 0 \\
\hline Hard & $121-180$ & 13 & 16 & 50 & 0 \\
\hline Very hard & $\begin{array}{l}\text { Greater } \\
\text { than } 180\end{array}$ & 7 & 11 & 0 & 20 \\
\hline
\end{tabular}

\section{Major Anions}

The distribution of the concentrations of major anions (bicarbonate plus carbonate, chloride, sulfate, and nitrate) observed in ground water is shown in figure 18. Concentrations of bicarbonate plus carbonate and chloride were larger in the deeper and less permeable units, whereas concentrations of nitrate and sulfate were larger in the shallow, more permeable aquifer. The large nitrate concentrations are associated with land-use activities on the surface of the aquifer; the occurrence and distribution of nitrate in ground water are discussed in more detail in a subsequent section. Sulfate concentrations are smaller in the deeper, less permeable units, probably as the result of dilution or the reduction of sulfate to sulfite and then to hydrogen sulfide; the rotten-egg smell of hydrogen sulfide was present in some of the deep wells. 


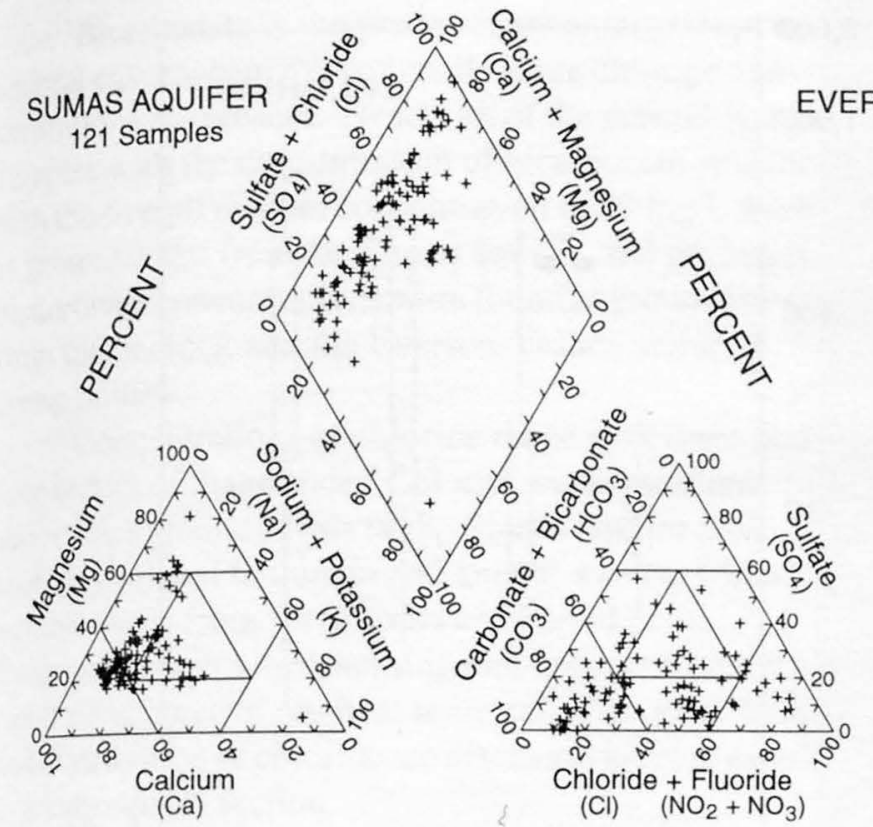

PERCENT

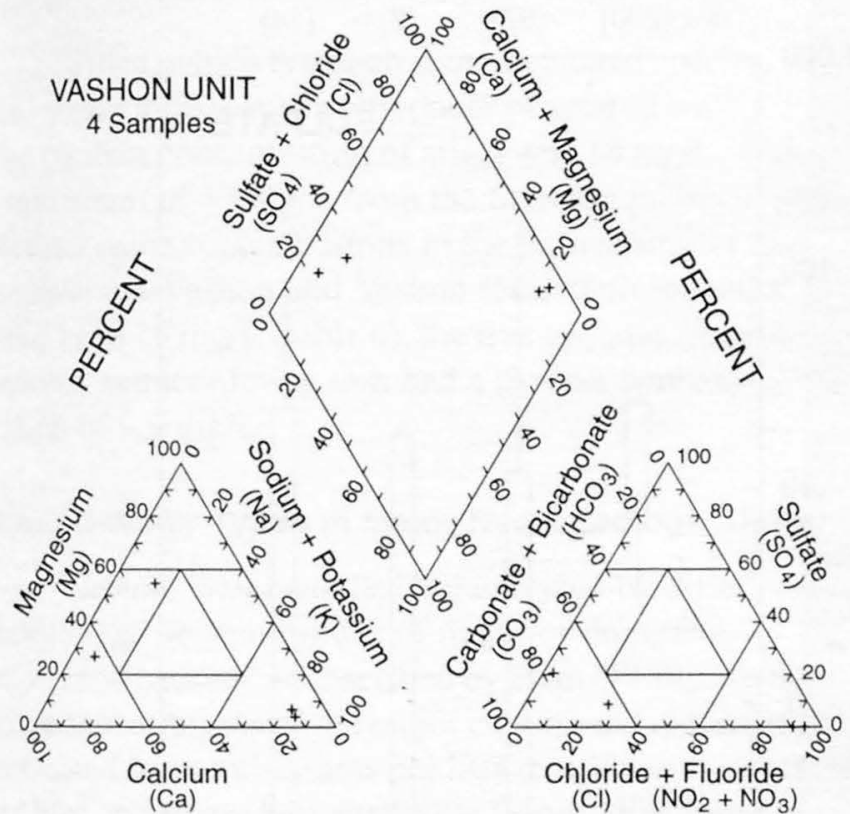

PERCENT

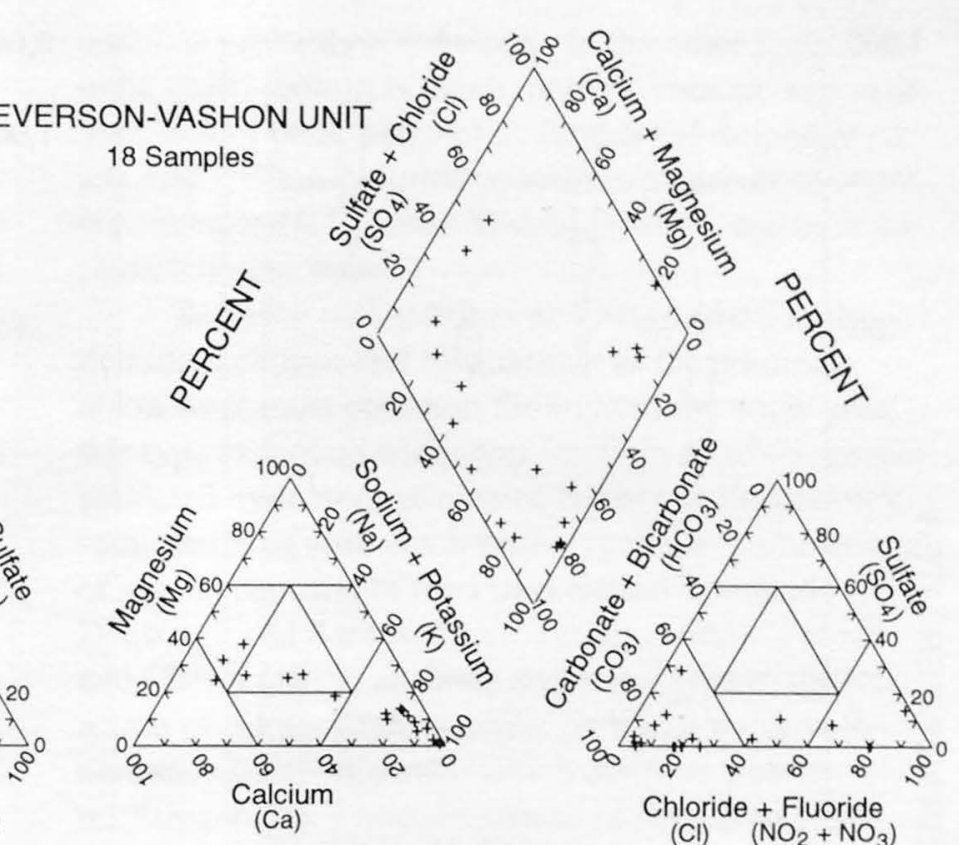

PERCENT

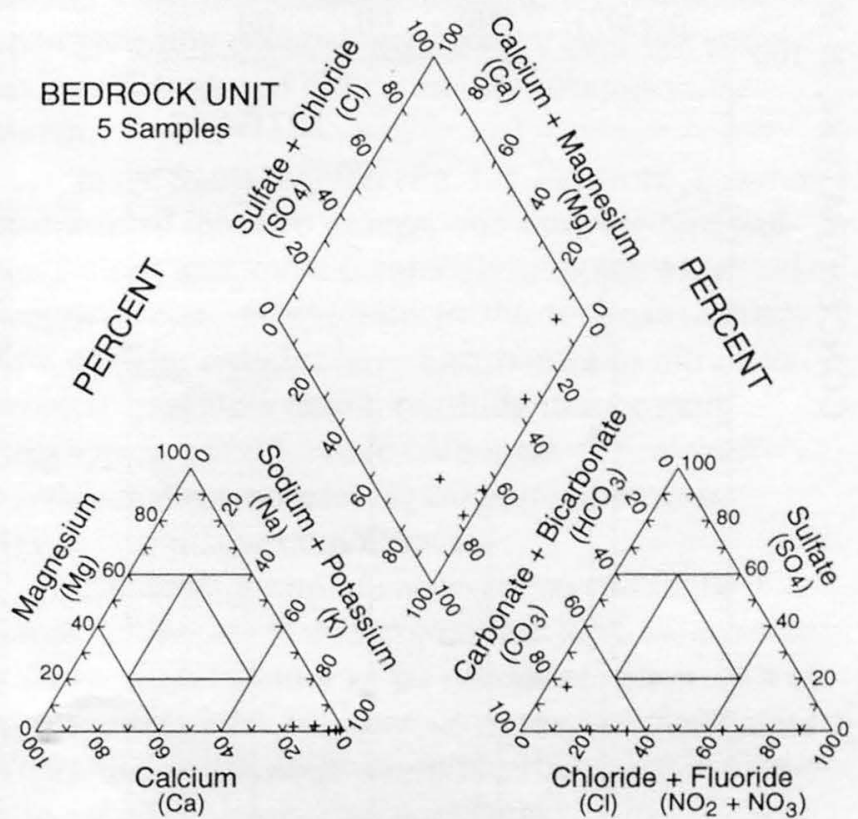

PERCENT

\section{EXPLANATION}

The percentages of cations and anions for each sample are plotted in three places on the Piper diagrams. Cations are plotted on the left hand trilinear diagram and anions are plotted on the right hand trilinear. Their plotting location is projected onto the quadralinear diagram to show the major water type. Additional explanatory material can be found in the Appendix on page 126.

Figure 17. Piper diagrams showing the percentage of major ions in water samples from four hydrogeologic units in the Lynden-Everson-Nooksack-Sumas (LENS) study area. 


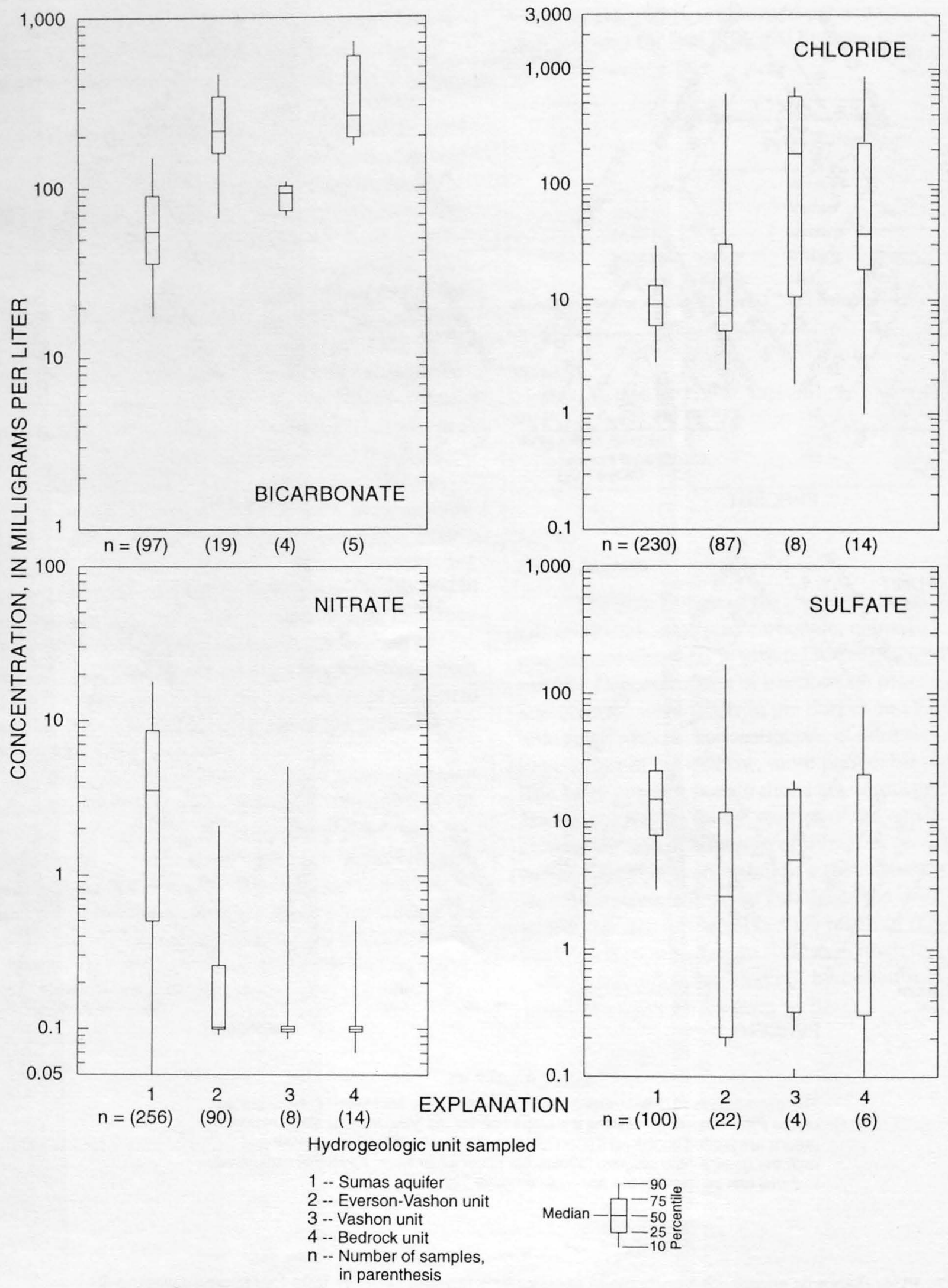

Figure 18. Distribution of concentrations of anions in milligrams per liter in ground water from four hydrogeologic units in the Lynden-Everson-Nooksack-Sumas (LENS) study area. 
Bicarbonate is the predominant anion except in several cases where exceptionally large chloride concentrations are present. Nearly all of the ground-water samples with the concentration of bicarbonate smaller than the overall median concentration of $79 \mathrm{mg} / \mathrm{L}$ were in ground water from the Sumas aquifer, and the larger bicarbonate concentrations were found in ground water from the bedrock and the Everson-Vashon semiconfining units.

Concentrations of chloride range over three and four orders of magnitude. Chloride concentrations above background levels in the Sumas aquifer are probably related to human and animal wastes, while ground water from some wells completed in the Everson-Vashon semiconfining unit appears to show a small percentage of remnant seawater. The occurrence and distribution of chloride are discussed in more detail in a subsequent section.

\section{Silica}

Silica, which is a neutral or uncharged species, is also a major dissolved component of ground water.

The median concentration of silica was $18 \mathrm{mg} / \mathrm{L}$, with a maximum of $53 \mathrm{mg} / \mathrm{L}$ from the Sumas aquifer.

Median silica concentrations in the Sumas aquifer and the Everson-Vashon and Vashon semiconfining units were 17 to $19 \mathrm{mg} / \mathrm{L}$ (table 6), the five samples from the bedrock semiconfining unit had a median concentration of $9.9 \mathrm{mg} / \mathrm{L}$.

\section{Ground-Water Types in Major Hydrogeologic Units}

Ground water can be characterized by differences in the concentrations of major or dominant anions and cations, as described by Hem (1989). To do this, concentrations of the major cations and anions are converted from milligrams per liter to milliequivalents per liter and plotted on a trilinear (Piper) diagram; see the Appendix section for additional details.

For this study, all samples with complete major ion analysis were plotted on one trilinear diagram for each hydrogeologic unit (fig. 17); this allowed differences between units to be easily seen, as well as allowing trends and anomalies to be more easily discerned. Significant differences are apparent in the general patterns of cations, anions, and water types observed in different hydrogeologic units. In the Sumas aquifer, calcium and magnesium are the predominant cations, while sodium is predominant in only one sample, which is probably anomalous. In the other hydrogeologic units, sodium is much more prominent, and in at least half of these samples sodium is the dominant cation, and sodium-chloride or sodium bicarbonate water is present in the Everson-Vashon, Vashon, and bedrock semiconfining units.

Samples with calcium and magnesium as the dominant cations and bicarbonate as the dominant anion were most common throughout the study area; this type of ground water was found in all of the unconsolidated hydrogeologic units, but not in the bedrock semiconfining unit. Such water types are characteristic of glacial deposits of the Puget Sound Lowlands (Van Denburgh and Santos, 1965; Turney, 1986). Freeze and Cherry (1979) attribute this water type to the interaction of dilute, slightly acidic recharge water with aluminosilicate minerals, which dissolve slowly, resulting in small concentrations of dissolved solids and $\mathrm{pH}$ values that commonly do not exceed 7.0. Ground water that includes nitrate as the dominant anion generally occurs where nearby land-use activities have introduced nitrate into the ground-water system.

In the Sumas aquifer (fig. 17), the plots of cations are clustered into two groups, one showing no dominant cations and, more commonly, another where calcium or calcium-magnesium are the dominant cations. Most of these samples have bicarbonate or nitrate as the complementary anion, resulting in four main water types: (1) calcium/bicarbonate, (2) calciummagnesium/bicarbonate, (3) calcium/nitrate, and (4) calcium-magnesium/nitrate.

The other group of cations observed in the Sumas aquifer are from samples that have magnesium or magnesium-calcium as the dominant cation. All of these samples have bicarbonate as the complementary anion and result in magnesium/bicarbonate and magnesium-calcium/bicarbonate water types. Most of these samples are from wells located in the Sumas River Valley. The larger magnesium concentrations in the Sumas Valley are likely the result of differences in the mineralogy of the sediments making up the aquifer material. Sediments in the Sumas Valley are composed primarily of basaltic and andesitic clasts derived from Mt. Baker (Cameron, 1989). The Mt. Baker area above the Sumas and Nooksack Valleys is also known to include areas of peridotite and dunite, rocks that contain substantial amounts of olivine, an iron-magnesium mineral that is easily weathered. Olivine is also more 
prominent in volcanic rocks like basalts and andesite than in granitic or metamorphic rocks, which make up most of the Sumas outwash (Armstrong, 1981). Consequently, ground water from different locations in the Sumas aquifer may be distinguished by this chemical difference.

The characteristic ground-water types from the Everson-Vashon and Vashon units (see fig. 17) show considerably more variation than ground water from the Sumas aquifer. In general, cations varied between calcium and sodium while anions varied between bicarbonate and chloride. Calcium-bicarbonate water similar to the Sumas aquifer were often found in wells completed in the Everson-Vashon and Vashon units and whose depths were less than 100 feet. In deeper wells, the predominant cation shifted toward magnesium in two cases, but mostly the predominant cation shifted toward sodium, resulting in largely sodium-bicarbonate water at depth. Sodium-chloride water was also common in the deepest wells, and this water probably reflect the presence of remnant seawater trapped in the aquifer during previous glaciation. The possibility of remnant seawater is discussed in more detail in a subsequent section on chloride in ground water.

In the bedrock semiconfining unit, which is composed of nonmarine sandstone, three of four well water samples had a sodium-bicarbonate water type; the remaining well had a sodium-chloride water type.

Ground-water samples containing nitrate as a dominant anion or magnesium as a dominant cation is limited to the Sumas aquifer. Ground water that has chloride as the dominant anion can be from either the Everson-Vashon, Vashon or Bedrock semiconfining units. Sodium is a dominant cation in all bedrock wells and in some Everson-Vashon and Vashon samples.

\section{Nitrate and Other Nitrogen Compounds}

Nitrogen is present throughout the natural environment and may undergo a variety of biologically mediated transformations of one form to another. The most common form of nitrogen found in ground water of the United Sates is nitrate, which is highly soluble and moves easily within ground water. Other forms of nitrogen commonly found in ground water include ammonia, organic nitrogen, and nitrite. Additional information on nitrogen forms and transformations is provided in the Appendix section at the end of this report.
The presence of nitrate in ground water is impor. tant because large concentrations of nitrate in drinking water are toxic to some humans and animals. The health effects and implications of nitrate and nitrate toxicity have been reviewed by the National Research Council (1978). Of widest concern is the consumption of drinking water with concentrations of nitrate above $10 \mathrm{mg} / \mathrm{L}$ by infants less than 3 months of age and other sensitive individuals. Consumption of such drinking water may lead to methemoglobinemia, a condition that deprives the body of oxygen by interfering with the blood's ability to carry oxygen. As a precaution, the USEPA and Health Canada, as well as state and provincial health agencies, have established a maximum contaminant level (MCL) for drinking water of $10 \mathrm{mg} / \mathrm{L}$ nitrate as nitrogen in public drinking water. The presence of nitrate in ground water is also of concern because in many instances where pesticides have been detected, the concentrations of nitrate have generally been elevated well above natural background levels. Thus, the presence of elevated nitrate concentrations in ground water substantially increases the likelihood of detecting measurable concentrations of pesticides.

Nitrate was the most common form of nitrogen found in ground water of the study area, and 15 percent of the wells sampled had concentrations of nitrate that equalled or exceeded the primary drinking water $\mathrm{MCL}$ of $10 \mathrm{mg} / \mathrm{L}$. Ammonia and organic nitrogen were present in generally small concentrations in some ground water; exceptions were noted near source areas such as manure lagoons. Nitrite, which is chemically unstable in an oxygenated environment, was occasionally found in deeper ground water of the study area.

The statistical distributions of nitrate, ammonia, and organic nitrogen in ground water of the study area are shown in general on figure 19. These plots represent concentrations of 568 samples collected from 368 wells between March 1990 and December 1992.

Nitrate concentrations are plotted on plate 4; most are from single samples collected during the well inventory period, March 1990 to August 1990. If two or more samples were collected from the same well, such as the monthly observation wells, the concentrations plotted on figure 19 and plate 4 are the arithmetic mean of the individual samples. Data from multiple samples for all nitrogen species measured in ground-water samples are shown in appendix table 8 . 

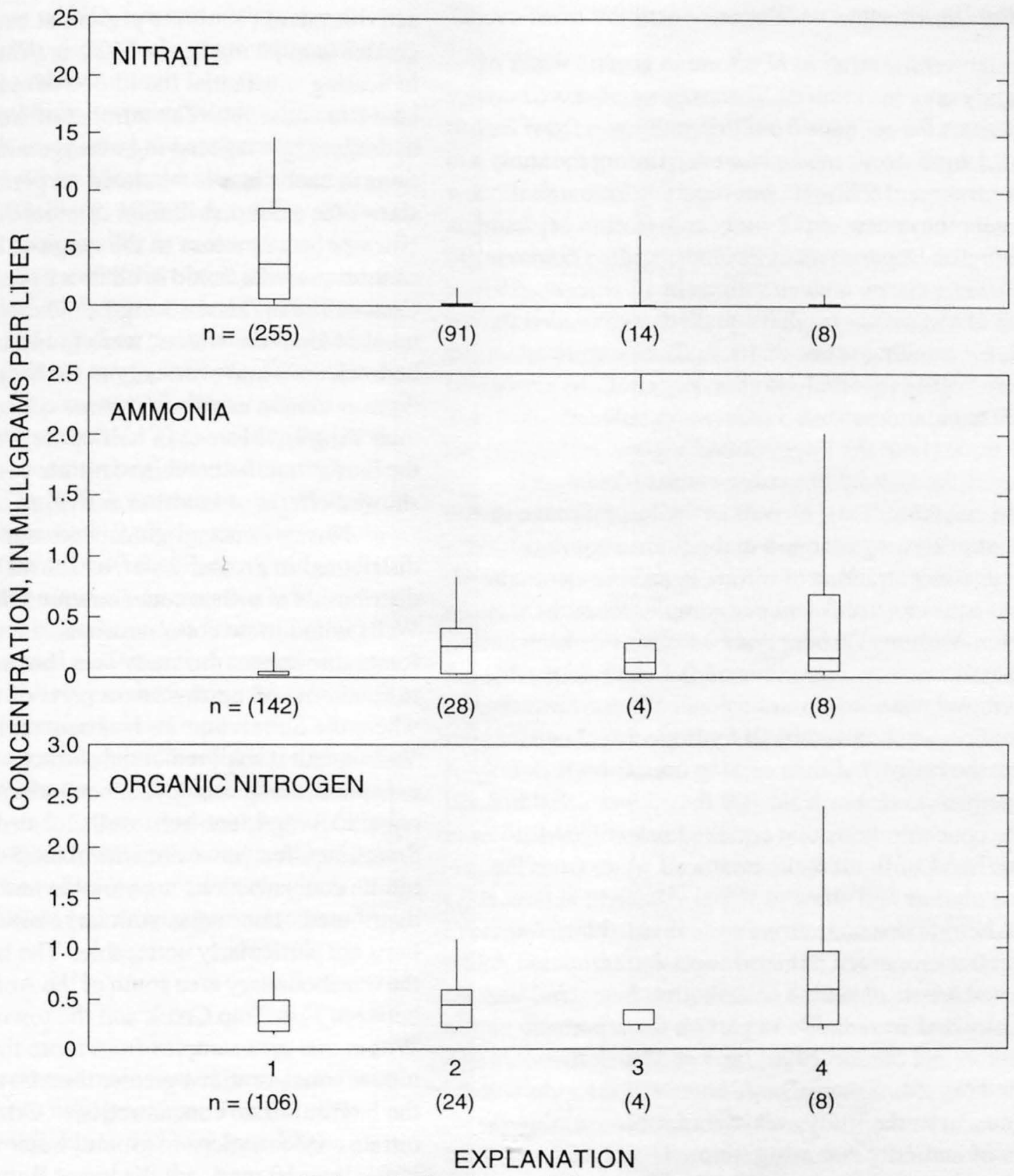

Hydrogeologic unit sampled

$$
\begin{aligned}
& 1 \text {-- Sumas aquifer } \\
& 2 \text {-- Everson-Vashon unit } \\
& 3 \text {-- Vashon unit } \\
& 4 \text {-- Bedrock unit } \\
& \mathrm{n} \text {-- Number of samples, } \\
& \quad \text { in parenthesis }
\end{aligned}
$$

(8)

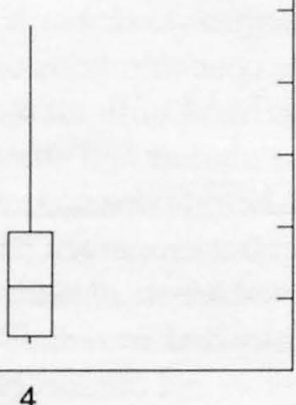

(8)

Figure 19. Distribution of concentrations of nitrate, ammonia and organic nitrogen by hydrogeologic unit in the Lynden-Everson-Nooksack-Sumas (LENS) study area. 


\section{Spatial Distribution of Nitrate}

The concentration of nitrate in ground water of the study area is variable. The range of observed concentrations for samples from this study was from less than $0.1 \mathrm{mg} / \mathrm{L}$ to $43 \mathrm{mg} / \mathrm{L}$; however, during the study a concentration of $99 \mathrm{mg} / \mathrm{L}$ was reported from a shallow well near the center of the study area (Denis Erickson, Washington Department of Ecology, written commun., 1993). The nitrate concentrations in 15 percent ( 55 wells) of the wells sampled equalled or exceeded the MCL for drinking water of $10 \mathrm{mg} / \mathrm{L}$. By comparison, Turney (1986) reported nitrate concentrations exceeding $10 \mathrm{mg} / \mathrm{L}$ in less than 3 percent of wells sampled in 1981 throughout the Puget Sound region.

Of the four hydrogeologic units, the largest nitrate concentrations, as well as the largest range in concentrations, were found in the Sumas aquifer. Median concentrations of nitrate in samples from the Sumas aquifer were $3.8 \mathrm{mg} / \mathrm{L}$; samples from the Everson-Vashon, Vashon, and bedrock units each had median nitrate concentrations of $0.1 \mathrm{mg} / \mathrm{L}$ (see table

6). Ground water with nitrate concentrations less than $0.1 \mathrm{mg} / \mathrm{L}$ was observed in all hydrogeologic units except the bedrock semiconfining unit, for which only six samples were available. Of the 55 wells that had nitrate concentrations that equalled or exceeded $10 \mathrm{mg} / \mathrm{L}, 54$ of those wells produced water from the Sumas aquifer.

Nitrate concentrations were divided into four concentration ranges. These ranges differentiated expected levels of nitrate contribution from land-use activities and were based in part on the reports of Hamilton and others (1993), and of Madison and Brunett (1985). Because large undeveloped areas were not present in the study area, data for determining the range of naturally occurring nitrate levels were obtained from studies in undeveloped areas with similar geologic settings in southwestern Thurston and eastern King Counties (Drost and others, 1998; Turney and others, 1995). The four concentration ranges are: (1) less than $1.0 \mathrm{mg} / \mathrm{L}$, indicating little or no nitrate present, and represents the probable range of naturally occurring nitrate concentrations in ground water with no significant contribution of nitrate from land-use sources; (2) 1.0 to $2.9 \mathrm{mg} / \mathrm{L}$, the transitional range between natural concentrations and concentrations showing probable land-use influences; (3) 3.0 to $9.9 \mathrm{mg} / \mathrm{L}$, nitrate present at concentrations indicating substantial likelihood of contribution from land-use activities; and (4) nitrate present at concentrations greater than $10 \mathrm{mg} / \mathrm{L}$, the $\mathrm{MCL}$ in drinking water, also indicating substantial likelihood of contribution from land-use activities. The number of wells from each hydrogeologic unit having average nitrate concentrations in each class is tabulated on plate 4, which also shows the areal distribution of nitrate concentrations. Nitrate concentrations in the range of background concentrations were found in all four hydrogeologic units. Concentrations above $3 \mathrm{mg} / \mathrm{L}$, indicating a large likelihood of land-use effects, were found in all but the bedrock unit; however, only in the Sumas aquifer were there extensive areas with nitrate concentrations larger than $3 \mathrm{mg} / \mathrm{L}$. More than half of the wells sampled in the Sumas aquifer contained nitrate concentrations that showed effects of land-use activities.

Nitrate concentrations were not uniformly distributed in ground water, as shown by the areal distribution of nitrate concentrations shown on plate 4 . Wells with nitrate concentrations less than $3 \mathrm{mg} / \mathrm{L}$ are found throughout the study area, but are concentrated in southern and northwestern parts of the study area where the Sumas aquifer is absent and the EversonVashon unit is exposed at the surface. Almost without exception, samples with concentrations greater than or equal to $3 \mathrm{mg} / \mathrm{L}$ are from wells located within the Sumas aquifer; however, within the Sumas aquifer, nitrate concentrations are variable and are unevenly distributed. Four areas with large nitrate concentrations are particularly noticeable. The largest of these is the transboundary area south of the Abbotsford Airport between Fish Trap Creek and the town of Sumas. Within this area samples from more than 25 wells had nitrate concentrations greater than $10 \mathrm{mg} / \mathrm{L}$, including the largest nitrate concentrations. Other areas where nitrate concentrations in ground water were commonly larger than $10 \mathrm{mg} / \mathrm{L}$ are the lower Bertrand Creek area west of Lynden (sections 14, 15, 21, 22, and 23 of township 40 north, range 3 east). South of the Nooksack River the Wiser Lake area (sections 31 and 32 of township 40 north, range 2 east) and the southwest corner of the study area (sections 24 and 25 of township 39 north, range 2 east) also had nitrate concentrations that were predominantly larger than $3 \mathrm{mg} / \mathrm{L}$. The area east of Lynden near sections 17 and 18 of township 40 north, range 3 east, had nitrate concentrations that generally were between 3 and $10 \mathrm{mg} / \mathrm{L}$, with samples from several wells having concentrations greater than $10 \mathrm{mg} / \mathrm{L}$. This is the same area sampled for EDB by Black and Veatch (1986). 
Large concentrations of $\mathrm{NO}_{3}$ are noticeably absent from the Sumas Valley area, the Everson area, and the area northwest of Lynden.

An inverse relation between nitrate concentration and well depth is reported to be a general feature of shallow aquifers where elevated nitrate concentrations are common (Halberg, 1989). A similar pattern was noted in the Sumas aquifer in areas where large nitrate concentrations greater than $10 \mathrm{mg} / \mathrm{L}$ are prevalent. However, when all the nitrate data for the Sumas aquifer are considered together, the relation is absent or much less pronounced, in large part because areas where nitrates are not present have low concentrations throughout the vertical profile. Thus, it is common to find small nitrate concentrations, less than $1 \mathrm{mg} / \mathrm{L}$, at all depths, whereas large concentrations, particularly concentrations that exceed $10 \mathrm{mg} / \mathrm{L}$, are almost exclusively from wells less than 40 feet deep. This general pattern of decreasing nitrate concentration with increasing depth can be seen in data (shown below) from three sets of nested piezometers installed near the Abbotsford Airport. As these data show, the relation is not perfect and is expected to vary with time. The distribution of nitrate with depth is related to the presence of a source of nitrates at the land surface, vertical ground-water flow, and the presence or absence of clay or silt layers that retard downward movement and can create localized zones of anoxic conditions where denitrification of nitrate to nitrogen gas can occur.

Average nitrate concentration in nested piezometer near Abbotsford Airport, in milligrams per liter from 10 measurements between June 1988 and June 1993

\begin{tabular}{lccc}
\hline $\begin{array}{l}\text { Depth } \\
\text { (feet) }\end{array}$ & $\begin{array}{l}\text { Site A } \\
(\mathrm{mg} / \mathrm{L})\end{array}$ & $\begin{array}{l}\text { Site B } \\
(\mathrm{mg} / \mathrm{L})\end{array}$ & $\begin{array}{l}\text { Site C } \\
(\mathrm{mg} / \mathrm{L})\end{array}$ \\
\hline 20 to 25 & 4.2 & 20 & 9.5 \\
35 & 4.4 & 19 & 16 \\
55 & 5.0 & 9 & 8.2 \\
75 & 6.3 & 3.3 & 2.5 \\
\hline
\end{tabular}

\section{Short-Term Variation in Nitrate Concentrations}

During the course of this study, water samples were collected approximately 10 to 12 times per year from 25 observation wells. The samples were collected in a manner similar to the reconnaissance samples and were analyzed for nitrates and chloride concentrations and for specific conductance. Time-series plots showing seasonal variation of nitrate concentrations in these wells are shown on plate 4 . The data on the monthly variation in nitrate concentration are summarized in table 11, along with similar information from 15 wells sampled at least twice yearly by other investigators. The monthly observation data collected by this study are included in appendix table 1.

The analysis of short-term variations indicates that for the Sumas aquifer, the variation in nitrate concentration is often large; and depending on the time of the year, concentrations in many wells, particularly shallow wells, can be expected to either increase or decrease substantially over a period of several months. As a result, there is a substantial chance that a single sample from a well with elevated nitrate concentrations may represent the nitrate concentration in the aquifer for only a short period of time and that the concentration of nitrate in that well may be significantly different in as little as 3 to 6 months.

The range of short-term variation in nitrate concentration is generally larger in wells that have larger average nitrate concentrations, as shown in figure 20 , which shows the relations between average nitrate concentration and the standard deviation, and average nitrate concentration and the coefficient of variance. The standard deviation is an expression of the variability of the individual nitrate concentrations around the mean concentration, and the plot shows that as the mean concentration increases, the standard deviation, or variability about the mean, also increases. However, the range of variation expressed by the coefficient of variance is similar at most concentration levels above $3 \mathrm{mg} / \mathrm{L}$ (fig. 20).

Concentrations of nitrate in ground water in the study area vary with time and show generally consistent patterns in some but not all hydrogeologic units. Variations were greatest in the Sumas aquifer. Nitrate concentrations varied by less than $3 \mathrm{mg} / \mathrm{L}$ in 24 percent of the Sumas wells and in nearly all wells from other hydrogeologic units where multiple samples had been collected. In wells that are completed in the Sumas aquifer, seasonal variations in nitrate concentration exceeded $5 \mathrm{mg} / \mathrm{L}$ in 62 percent of the wells, and 
(a) Well 40N/03E-05M05
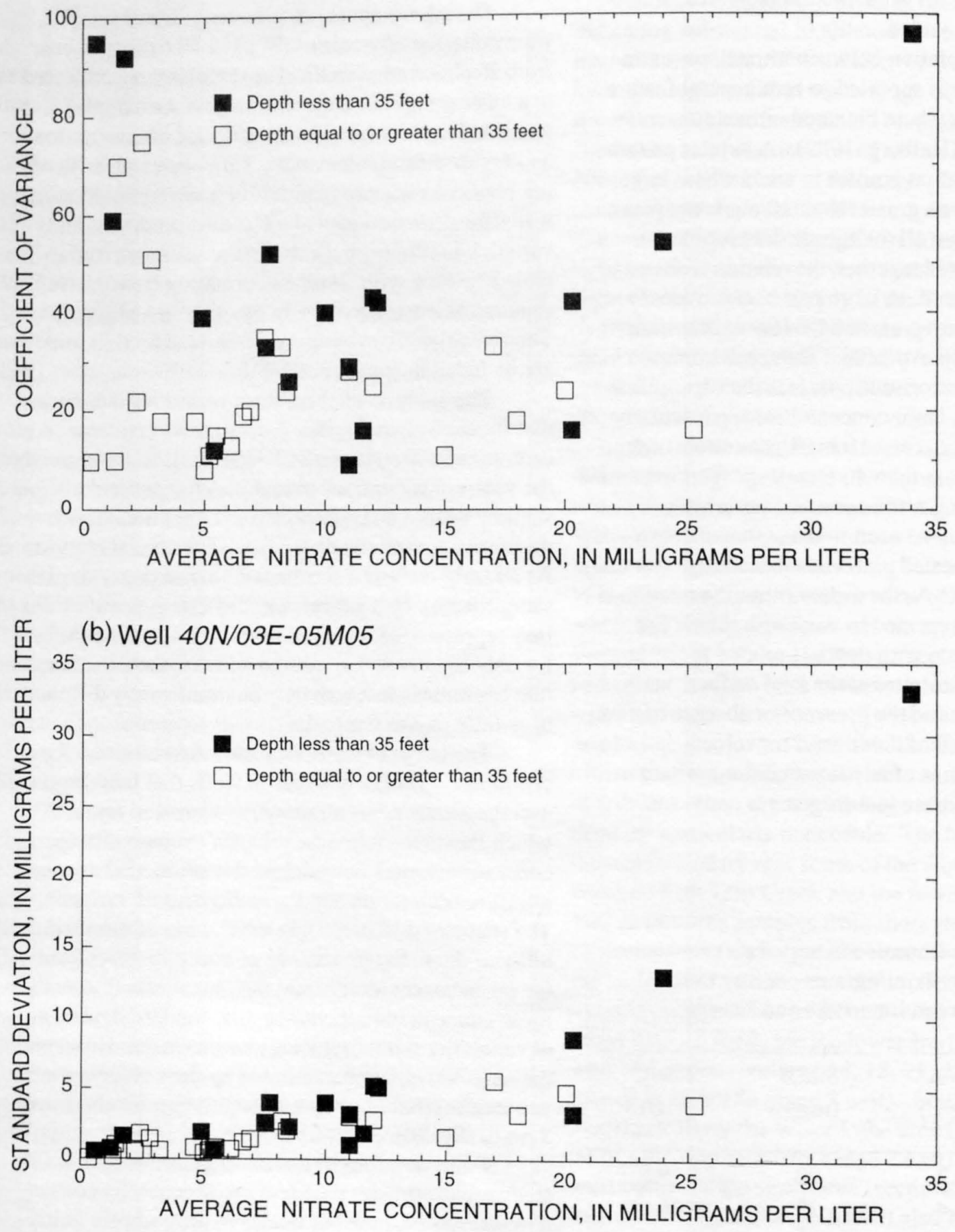

Figure 20. Variability of nitrate concentrations in Sumas aquifer showing (a) average nitrate concentration and coefficient of variance and (b) average nitrate concentration and standard deviation. 
exceeded $10 \mathrm{mg} / \mathrm{L}$ in 36 percent of the wells. The largest seasonal variability was observed from a concurrent study of the Sumas aquifer, which reported $99 \mathrm{mg} / \mathrm{L}$ from a shallow piezometer (well 40N/03E-05M05) in a grassland pasture that received regular applications of dairy manure (Denis Erickson, Washington Department of Ecology, written commun., 1993).

Within the shallow water table of the Sumas aquifer, there appears to be a pattern of larger nitrate concentrations in the winter and early spring, which then decline in late spring and summer; however, that pattern of variation in nitrate concentrations was not observed in all wells. In the time-series plots of nitrate concentrations for shallow (less than $40 \mathrm{ft}$ ) wells in the water-table part of the Sumas aquifer that are shown on plate 4 , nitrate concentrations increased between October and January in 7 of 11 cases and then decreased between April and August in 4 of the wells. Another example of this pattern is seen in the data from Erickson (1991) for the 12-foot piezometer $40 \mathrm{~N} / 03 \mathrm{E}-05 \mathrm{M} 05$, which is shown in figure 21 . This piezometer is screened at the water table and located in a field where dairy manures were reportedly applied approximately every 30 days. This well was sampled 18 times between February 1990 and April 1993, with 8 samplings occurring during 1990. During this period, nitrate concentrations from 2.5 to $99 \mathrm{mg} / \mathrm{L}$ were observed, with highs of 99,37 , and $91 \mathrm{mg} / \mathrm{L}$ during January 1991, April 1992, and April 1993, respectively; low concentrations of $2.9,21$, and $29 \mathrm{mg} / \mathrm{L}$ were observed in June 1990, August 1991, and July 1992. Samples obtained during the fall and winter of 1990 and 1992 show rapidly increasing nitrate concentrations. The concentrations observed in the summer of 1991 and spring of 1992 are not inconsistent with the possibility that a large concentration, similar to the 99 and $91 \mathrm{mg} / \mathrm{L}$ observed during other winter periods, may have been present at some time during the fall or winter of 1991-1992.

The period of rapidly rising nitrate concentrations observed in well 40N/03E-05M05 coincides with the period of rising water table. As was discussed in the section on water-level fluctuations, the seasonal variation in shallow ground-water levels is correlated to the period of winter rains, when deep percolation and most ground-water recharge occur. Two processes related to this cycle explain much of the large variation in nitrate concentration. The rising water table may intersect a portion of the unsaturated zone in which nitrates have accumulated from the nitrification of organic matter during the previous low water-level period. Moreover, the major recharge event for the Sumas aquifer is seasonal, occurring in the fall and winter, probably causing nitrates in the unsaturated zone to be carried down to the water table with the fall-winter recharge event.

The similarity in the variation of the concentration of chloride (fig. 21) suggests that seasonal recharge has the larger influence on short-term temporal variation because concentrations of nitrate and chloride in animal manures are well correlated, whereas chloride is not a prominent component of soil organic matter and large chloride concentrations would not be expected to correlate with large concentrations of nitrate from the nitrification of soil organic matter. Thus, unless there is extensive irrigation during the summer months in excess of the cumulative soil moisture deficit of 15 inches (table 5), water probably does not percolate completely through the soil and into the ground-water system. Nitrate may be moved deeper into the soil profile during summer rains or irrigation, but unless the entire soil column is saturated, most of the nitrate likely will not move below the unsaturated zone. As a result, in the fall, the first pulse of water to completely pass through the soil profile and into the shallow ground-water system will carry a large load of dissolved nitrate with it, resulting in larger nitrate concentrations near the water table at this time.

Although the first pulse of recharge water to reach the water table in the fall may carry a large load of nitrate, subsequent recharge pulses may not encounter as much nitrate available for leaching within the soil profile. The varying concentrations of nitrate in recharge water will therefore lead to varying concentrations in the ground water. As ground water moves along its flow path, mixing and dispersion will occur. Thus for wells at greater distances from the recharge location, such as the Sumas City Municipal wells and most Sumas wells located in the Sumas Valley, the variability in nitrate concentration will be much smaller.

If the seasonal recharge explanation is correct, nitrate concentrations in shallow ground water fluctuate in the short term largely because of variability in the rate that nitrate is introduced into the ground water. Other factors such as the rate of ground-water flow and the rate of biochemical reactions also can cause nitrate concentrations to fluctuate; however, in the study area these factors may be less important. During the fall, the temperature in parts of the soil profile is still warm enough that nitrifying bacteria can continue to convert 


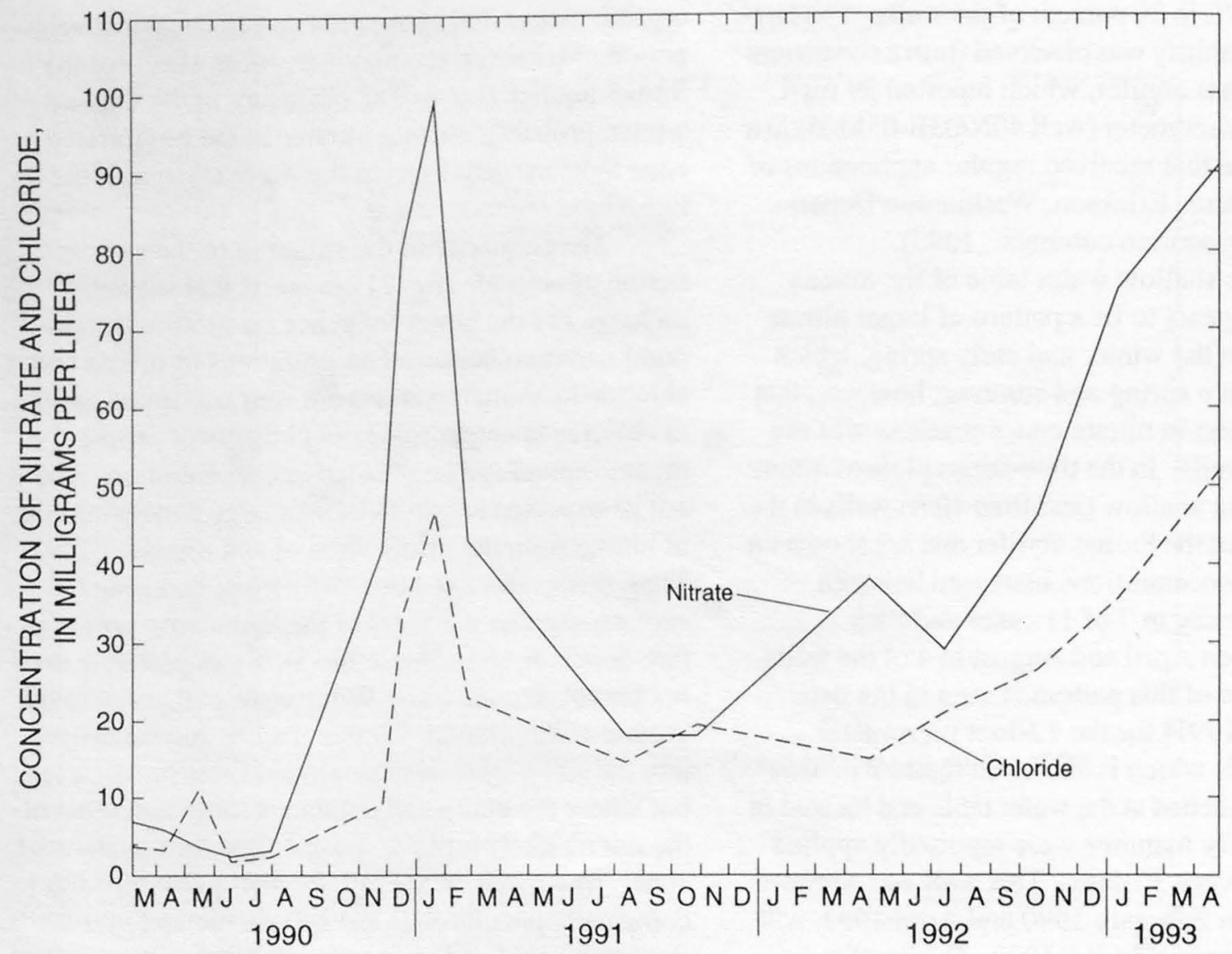

Figure 21. Short-term variation in concentrations of nitrate and chloride in a water table piezometer in the Lynden-Everson-Nooksack-Sumas (LENS) study area. (Data are from piezometer 40N/03E-05M05, Erickson, 1991, and Denis Erickson, Washington Department of Ecology,1994, written communication.) 
ammonia and organic nitrogen to nitrate. However, the use of nitrate by plants is declining during this time as most perennial plants become dormant and winter crops, if present, may not be well established. The result is that during the fall there may be significant quantities of nitrate in the soil profile, and because they are not used by plants, they will be available to be leached to the ground water by the winter recharge event.

Less variability in nitrate concentrations may occur in shallow wells affected by recharge from septic tanks and dairy lagoons because these sources generally are more constant throughout the year and should generate recharge to the ground-water system on a year-round basis. Some variability will still be present because of the seasonality of precipitation and possible temperature cycles that may affect the bacterial community.

As expected, the seasonal variability in nitrate concentrations in the Everson-Vashon unit and the Vashon unit was generally small. In three wells, the nitrate concentrations never exceeded the analytical detection limit of $0.1 \mathrm{mg} / \mathrm{L}$. Two wells in the EversonVashon unit yielded ground water with detectable nitrate concentrations that averaged 1.3 and $6.9 \mathrm{mg} / \mathrm{L}$. Nitrate concentrations in the first well varied from 1.1 to $1.4 \mathrm{mg} / \mathrm{L}$, with a coefficient of variance of 9.9 percent, and in the second varied from 5.0 to $10.0 \mathrm{mg} / \mathrm{L}$, with a coefficient of variance of 20 percent (see table 11).

\section{Long-Term Variation in Nitrate Concentrations}

Data used to assess long-term (3 years or more) variations in nitrate concentrations included historical data for 21 sampling sites where repetitive samples have been collected and monitoring data for wells with more than 3 years of record. Because of the large degree of short-term variations in nitrate concentrations, long-term trends are difficult to assess without extensive time series data.

Long-term variability in nitrate concentration in ground water is demonstrated in data from the 21 wells in the Bertrand Creek area that were sampled in midAugust of 1988 (Erickson, 1992) and again in midAugust of 1991 for this study (table 12). Eleven wells showed larger concentrations in the second sampling, and 10 wells had smaller concentrations in the second sampling. The overall median nitrate concentration rose from $5.0 \mathrm{mg} / \mathrm{L}$ in 1988 to $6.7 \mathrm{mg} / \mathrm{L}$ in 1991 ; however, the variability observed in the change in concentration from one sampling to the next is so large that the change in median concentrations is not statistically different when evaluated using the nonparametric matched-pair sign test (Helsel and Hirsch, 1992).

Previous studies that included areal surveys of nitrate concentrations in ground water in the study area include those by Obbert (1973), Kwong (1986), Kohut and others (1989), Erickson (1991), and Liebscher and others (1992). The studies by Kwong, Kohut and others, and Liebscher and others are confined to the Canadian part of the study area. All of those studies conclude that nitrate concentrations in ground water are increasing in the Canadian part of the study area, which is also the area where large nitrate concentrations were most prevalent. Obbert (1973), who conducted a survey of nitrate concentrations in ground water in western Whatcom County, collected 31 of 45 ground-water samples from wells within the present study area. The median concentration of all of Obbert's ground-water nitrate data was $1.25 \mathrm{mg} / \mathrm{L}$, while the median nitrate concentration from Obbert's sites located within the LENS area was $2.8 \mathrm{mg} / \mathrm{L}$. This compares similarly to a median nitrate concentration of $3.8 \mathrm{mg} / \mathrm{L}$ in samples from wells completed in the Sumas aquifer. The distribution of the sample data from these two studies, shown in figure 22 , shows similar median values (less than $1 \mathrm{mg} / \mathrm{L}$ difference); however, the more recent data includes larger maximum and 75 percentile values. The sample populations of the two studies are not identical, and there were seasonal differences in the time that samples were collected; thus, it is difficult to assess whether the data actually represent a change in nitrate concentrations in ground water or are artifacts of the differences in the sample populations.

The long-term trend in nitrate concentrations in ground water from individual wells varies, with the LENS study area containing areas of both increasing and decreasing nitrate concentrations, and thus showing no consistent overall pattern. Data available for this study show about the same number of cases of increasing and decreasing nitrate concentrations. Time-series plots of nitrate concentrations from 18 wells and 1 spring all of which have had data gathered for a period of 3 years or longer, are shown in figure 23 . The majority of these wells are near the Abbotsford Airport and the town of Sumas. Of the 18 wells shown in figure 23, there are examples which show increasing, decreasing, and essentially unchanged nitrate 


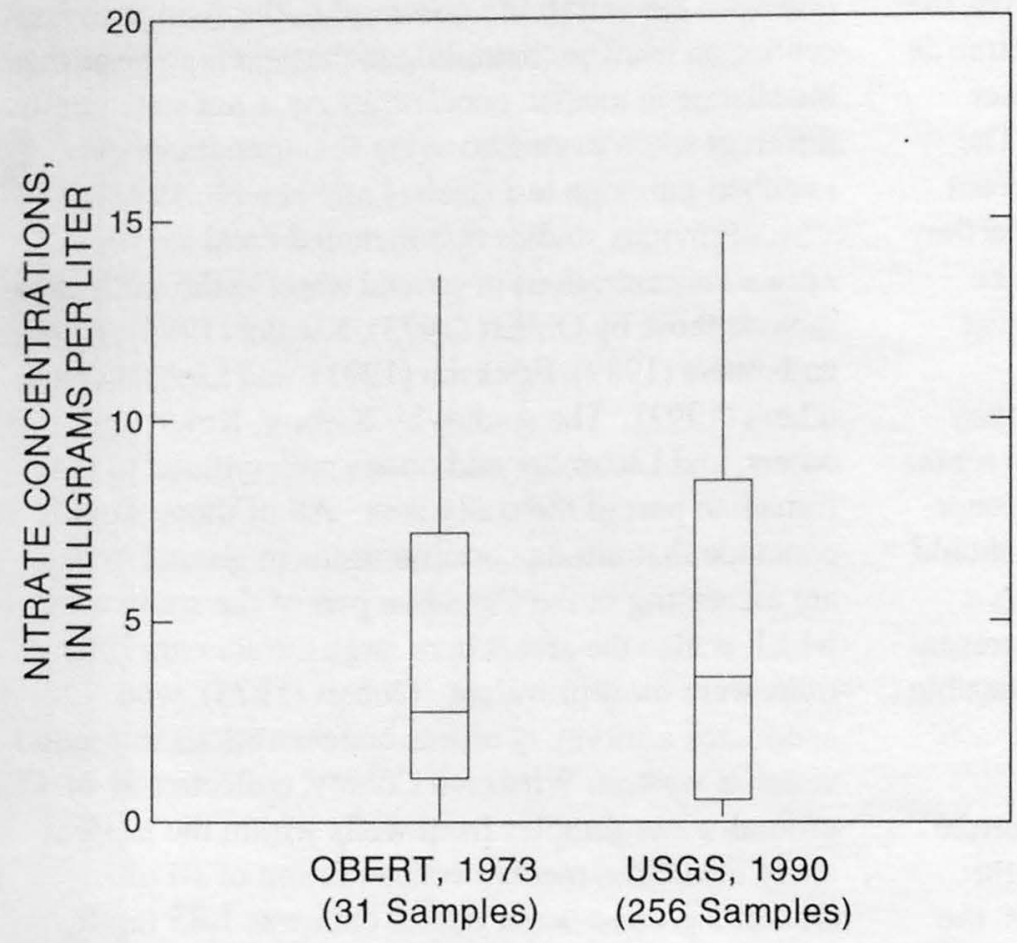

\section{EXPLANATION}

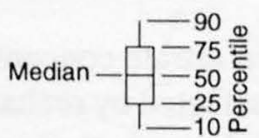

Figure 22. Comparison of median nitrate concentrations in ground water in the Lynden-EversonNooksack-Sumas (LENS) study area in 1972 (Obbert, 1973) and in 1990 (for this study). 
(a)

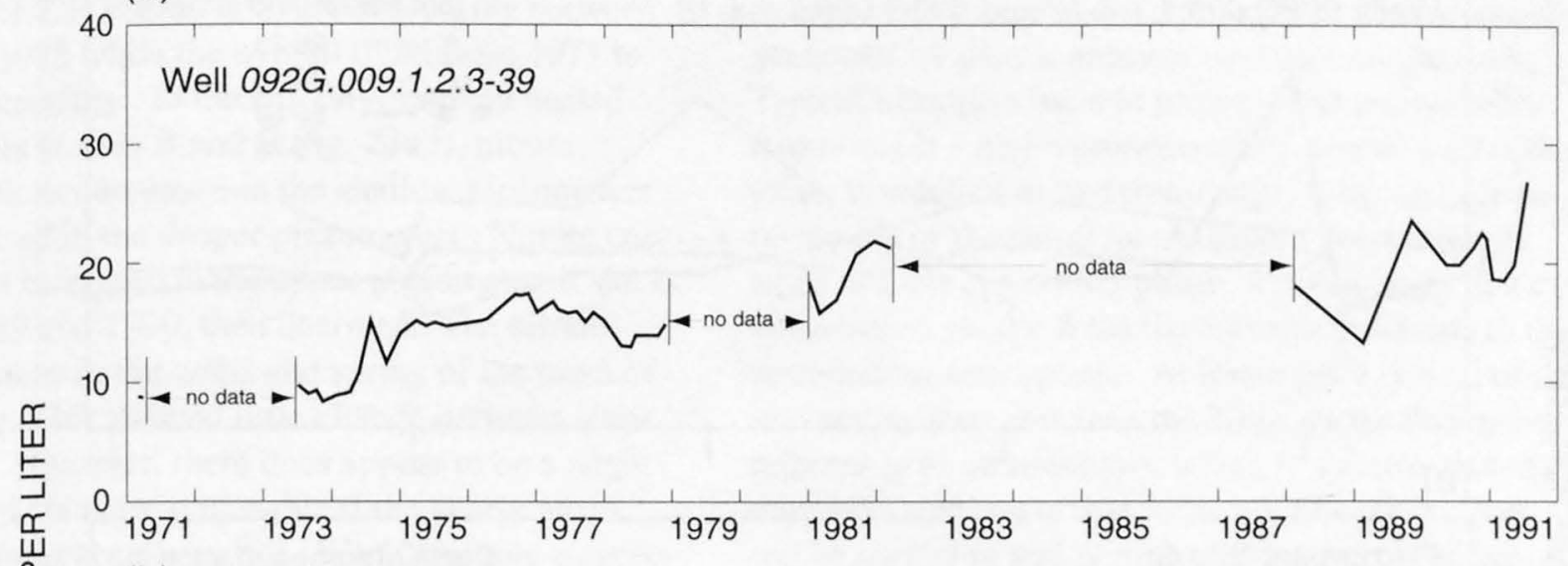

(b)

40

Well 39N/03E-10L01

30

20

10

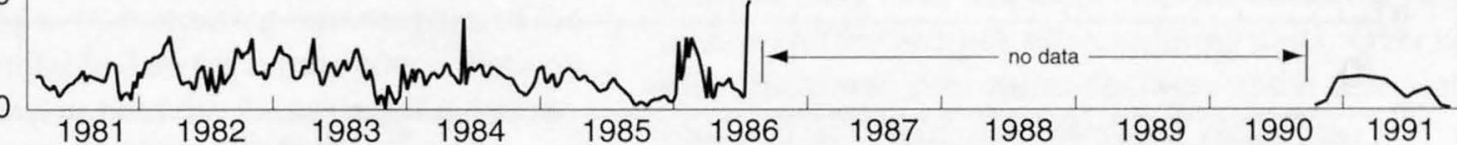

(c)

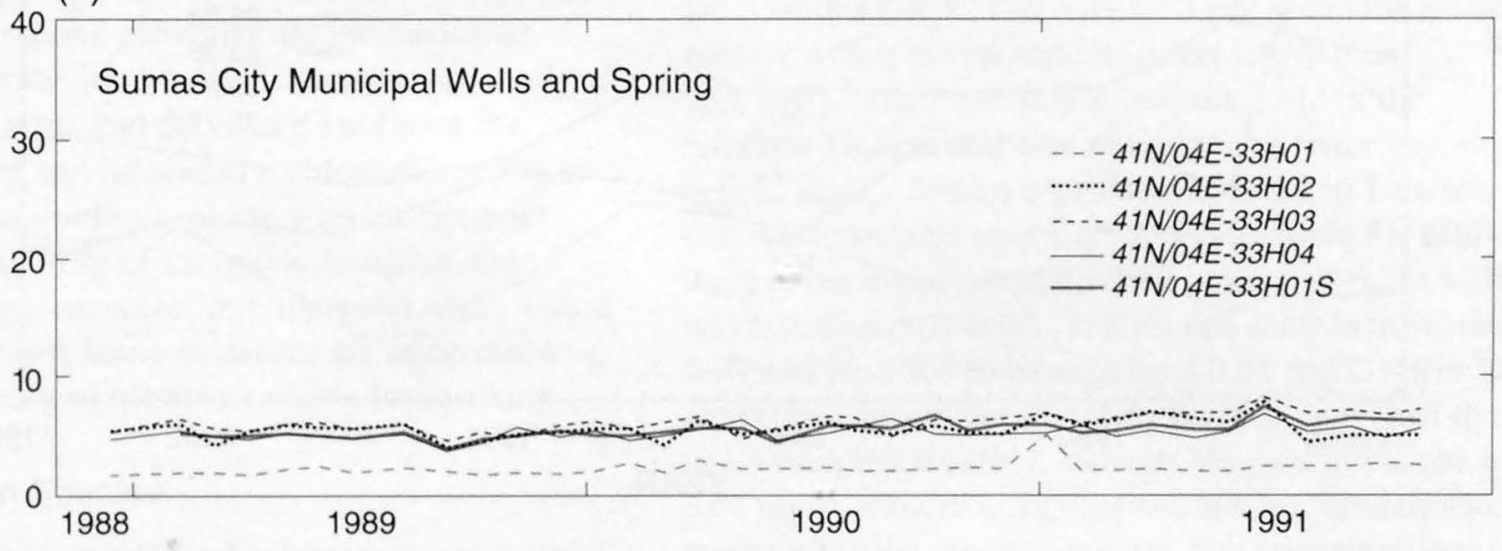

YEAR

Figure 23. Long-term variability of nitrate concentrations at (a) well 092G.009.1.2.3-39, (b) well 39N/03E-10L01, (c) Sumas City wells and spring, (d) piezometer site A, (e) piezometer site B, and (f) piezometer site C. 
(d)

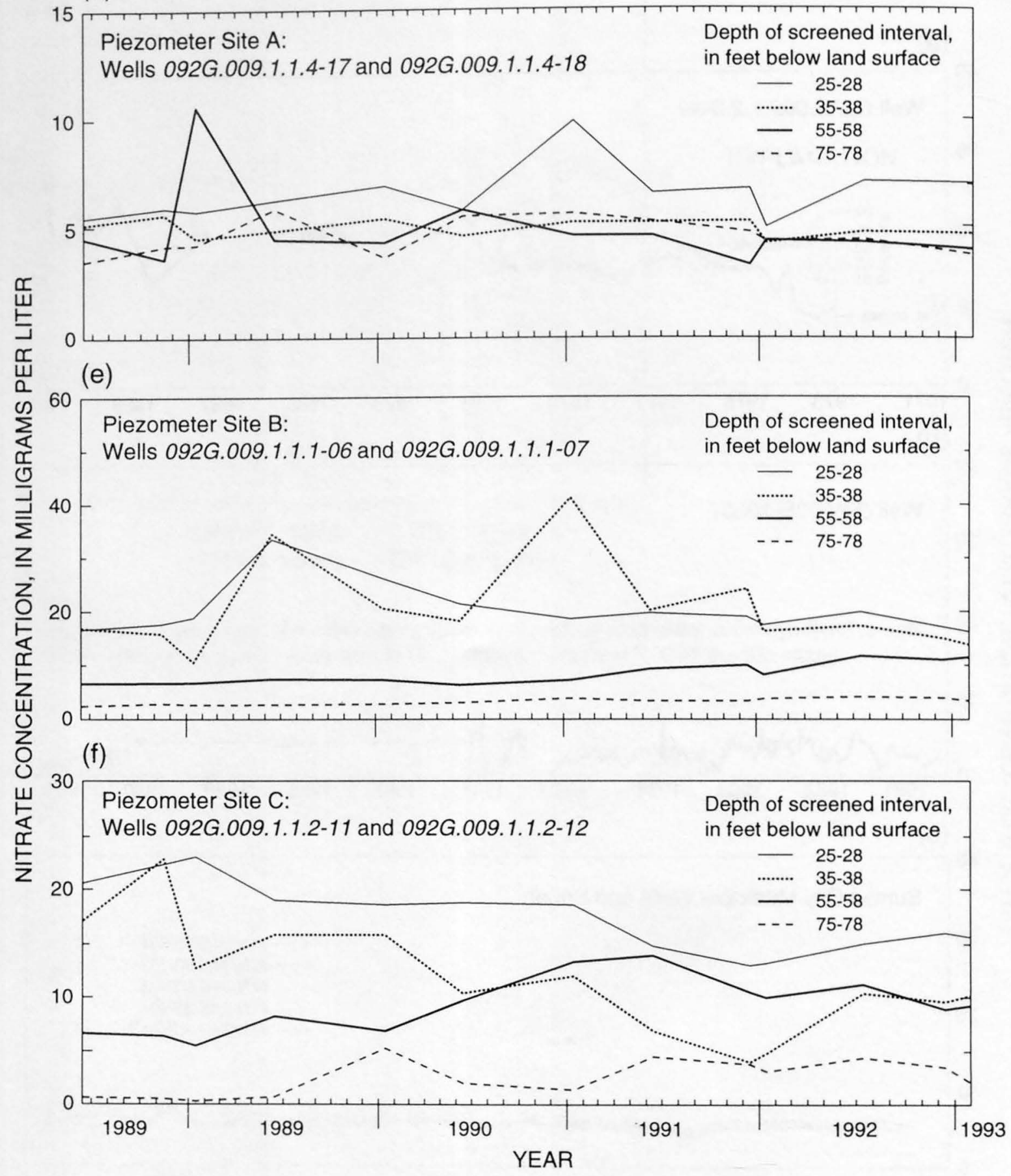

Figure 23. continued. 
concentrations. Some wells show periods of a nonseasonal reversal in the trend of nitrate concentrations. For example, the nitrate concentrations in well 092 G.009.1.2.3-39 (fig. 23a) are decreasing between 1976 and 1978 while the overall trend from 1971 to 1991 is increasing. In the BC Environment nested piezometers at sites $\mathrm{B}$ and $\mathrm{C}$ (fig. 23e,f), nitrate concentrations decreased in the shallow piezometers and increased in the deeper piezometers. Nitrate concentrations increased in the upper piezometer at site B during 1989 and 1990, then declined. The nitrate concentrations in the wells and spring of the town of Sumas (fig. 23c) showed little change between 1989 and 1993. However, there does appear to be a slight increase that is more noticeable if the yearly mean concentrations are compared. Weekly nitrate samples collected from well 39N/03E-10L01 from 1981 to 1986 (fig. 23b) show signs of seasonal patterns and periods of generally increasing and decreasing nitrate concentrations (Charles Flora, Western Washington University, written commun., 1991). Monthly samples obtained from that well during 1991 generally have smaller concentrations than observed in the early 1980's.

In summary, although nitrate concentrations have been reported to be increasing in some parts of the study area, the available data for nitrate concentrations in ground water throughout the Sumas aquifer are highly variable in both space and time and are not sufficient to support definitive statements of whether nitrate concentrations generally are increasing or decreasing over the long term. If the general trends of increased herd sizes and decreased land base for manure disposal and increased residential housing in unsewered areas continue, along with the national trend of increased use of inorganic fertilizer, then increased nitrate concentrations in ground water would be expected, unless some measures are undertaken to reduce the amount of nitrate available for leaching.

\section{Other Nitrogen Species}

In addition to nitrate, other nitrogen species were also sampled, including nitrite, ammonia, and organic nitrogen. At some water-quality observation wells, bimonthly samples included the analysis of nitrite, ammonia, and organic nitrogen. Data for all nitrogen species are tabulated in appendix table 8 .

Nitrite is an intermediate nitrogen species, but generally it is not found in significant concentrations in shallow ground water because it is unstable in the presence of dissolved oxygen. Ammonia and organic nitrogen are the predominant forms of nitrogen associated with biological systems. Organic nitrogen refers to the numerous nitrogen-containing organic molecules generated by plants, animals, and microorganisms. Typical examples include proteins and amino acids. Ammonia is a major component of animal wastes that exists in solution in two states depending, in large part, on the $\mathrm{pH}$ of the solution. At higher $\mathrm{pH}$, ammonia tends to exist in the $\mathrm{NH}_{3}$ phase, which is a gas that can volatilize or escape from the aqueous solutions to the surrounding atmosphere. At lower $\mathrm{pH}$ 's typical of natural water, ammonia is in the $\mathrm{NH}_{4}{ }^{+}$phase (commonly referred to as ammonium), which is a cation that may remain in solution in that form, but like other cations it can be sorbed to soil particles and mineral surfaces.

\section{Nitrite}

Concentrations of nitrite were at or above the measurement detection limit of $0.01 \mathrm{mg} / \mathrm{L}$ in 53 of 187 wells where nitrite was measured (appendix table 8). Of the 53 wells with measured nitrite concentrations, 42 were wells that are completed in the Sumas aquifer, 9 were wells that are completed in the Everson-Vashon semiconfining unit, and there was one each from the Vashon and the bedrock semiconfining units. Over half of the measured concentrations were at the detection limit of $0.01 \mathrm{mg} / \mathrm{L}$; concentrations larger than $0.01 \mathrm{mg} / \mathrm{L}$ were found at 26 sites, 25 of which were in the Sumas aquifer. The only well site not in the Sumas aquifer with a nitrite concentration larger than $0.01 \mathrm{mg} / \mathrm{L}$ was a monthly monitoring site in the Everson-Vashon unit where nitrite was twice reported at $0.02 \mathrm{mg} / \mathrm{L}$. Nitrite was also measured in 14 wells that were sampled monthly (appendix table 8). While the median nitrite concentration in each of these wells was less than $0.01 \mathrm{mg} / \mathrm{L}$, at least one sample from each well was reported to have at least $0.01 \mathrm{mg} / \mathrm{L}$ nitrite at some time during the sampling period. In five of the wells sampled monthly, measurable concentrations of $0.01 \mathrm{mg} / \mathrm{L}$ or more were reported at least three times or more during the sampling period, and concentrations of 0.02 and $0.03 \mathrm{mg} / \mathrm{L}$ were measured in samples from two of these wells. The larger nitrite concentrations, from 0.09 to $0.66 \mathrm{mg} / \mathrm{L}$, were found in the deeper parts of the Sumas aquifer or in ground-water discharge areas. The persistence of nitrite concentrations in ground water from deeper wells and their variation with well depth is shown in data from the nested piezometers near the Abbotsford Airport. 
Concentration of nitrite in ground water from nested piezometer near the Abbotsford Airport--average of 11 measurements between June 1988 and July 1993

\begin{tabular}{lrrr}
\hline Depth (feet) & $\begin{array}{l}\text { Nest A } \\
(\mathrm{mg} / \mathrm{L})\end{array}$ & $\begin{array}{l}\text { Nest B } \\
(\mathrm{mg} / \mathrm{L})\end{array}$ & $\begin{array}{l}\text { Nest C } \\
(\mathrm{mg} / \mathrm{L})\end{array}$ \\
\hline $20-25$ & $<0.01$ & $<0.01$ & $<0.01$ \\
35 & $<0.01$ & $<0.01$ & $<0.01$ \\
55 & $<0.01$ & $<0.01$ & $<0.01$ \\
75 & 0.69 & 0.21 & 0.04 \\
\hline
\end{tabular}

The presence of nitrite in deeper ground water may indicate that biological denitrification is occurring in parts of the Sumas aquifer. Nitrite is seldom present in most shallow ground water, in part because it is chemically unstable in oxygenated water. However, nitrite is an intermediate product in the microbial denitrification and may accumulate in a denitrifying system where oxygen is absent or present at very low concentrations (Firestone, 1982). Thus the presence of nitrite in ground water having less than $1 \mathrm{mg} / \mathrm{L}$ dissolved oxygen may indicate the occurrence of denitrification.

Although nitrification is another microbial process that produces nitrite, nitrification is restricted to well oxygenated systems where nitrite typically is rapidly converted to nitrate (National Research Council, 1978).

The occurrence of denitrification is important in ground-water systems where nitrate is present because denitrification is the only process other than dilution or utilization by plants that can result in a substantial reduction of nitrates in ground water.

Several additional lines of evidence also suggest that denitrification may be occurring in some of the deeper parts of the Sumas aquifer. Nitrous oxide, which is present in the atmosphere at concentrations ranging from 5 to $20 \mu \mathrm{g} / \mathrm{L}$, is also a product of microbial denitrification. Three dissolved-gas samples were collected at the nested piezometers for analysis of nitrous oxide. Two samples from the 75-foot-deep piezometers at sites $\mathrm{B}$ and $\mathrm{C}$ where dissolved-oxygen concentrations were less than $1 \mathrm{mg} / \mathrm{L}$ were found to have nitrous oxide concentrations of 170 and $340 \mu \mathrm{g} / \mathrm{L}$. The third sample, collected from the 35 -foot-deep piezometer at nest $\mathrm{C}$, which had a dissolved-oxygen concentration of $9.0 \mathrm{mg} / \mathrm{L}$, also contained $8.8 \mu \mathrm{g} / \mathrm{L}$ nitrous oxide. Excess nitrogen was also reported from a gas sample collected from the well at the Nooksack
Valley High School (40N/04E-09N01) leading to an estimate of denitrification on the order of $10 \mathrm{mg} / \mathrm{L}$ (Eurybiades Busenberg, U.S. Geological Survey, written commun., 1992). Other evidence of denitrification is that the microbial process tends to enrich the nitrogen-15 isotope ratios of the nitrate remaining in the ground water--nitrogen-15 isotopes from the deeper piezometers near the Abbotsford Airport were found to be enriched compared to shallow samples collected nearer the water table (Wassenaar, 1994). Lastly, denitrifying bacteria were identified in ground-water samples from the deeper piezometers (Rodney Zimmerman, BC Environment, written commun., 1992). These data provide multiple lines of evidence suggesting that denitrification is occurring and as such is reducing nitrate concentrations in some parts of the Sumas aquifer. Similar conditions also occur in parts of the Sumas aquifer in the Sumas River Valley and may occur at other locations in the Sumas aquifer.

Wassenaar (1994) concluded that denitrification was not widespread in the Sumas aquifer near Abbotsford Airport; however, his data were largely collected from the shallow wells in the recharge areas of the Sumas aquifer and thus do not adequately represent conditions throughout the entire aquifer, particularly the deeper zones or areas where ground water discharges. Nitrate concentrations in the discharge and deeper zones were typically much smaller than median concentrations for the entire aquifer, plate 4 , and may be the result of either denitrification or dilution.

\section{Ammonia}

Ammonia, like nitrate, has natural and human sources. Ammonia, a major component of animal waste, is the predominant form of nitrogen in barnyard manures and septic tank waste water; and as noted by Feth (1966), ammonia is the most prominent form of nitrogen in rainwater. Anhydrous ammonia is also a common form of inorganic nitrogen fertilization. Ammonia is stable in ground-water systems that have oxidation-reduction conditions that are reducing, a common feature of which is the absence or low concentrations of dissolved oxygen.

The distribution of ammonia concentrations in the four hydrogeologic units is shown in figure 19, along with other forms of nitrogen. The concentrations of ammonia in all 182 ground-water samples analyzed for ammonia ranged from less than $0.01 \mathrm{mg} / \mathrm{L}$ to $63 \mathrm{mg} / \mathrm{L}$, with a median concentration of $0.02 \mathrm{mg} / \mathrm{L}$. However, the three largest concentrations, 34, 43, and 
$63 \mathrm{mg} / \mathrm{L}$, were from samples obtained from the piezometers installed adjacent to manure storage lagoons; the next largest concentration was $2.2 \mathrm{mg} / \mathrm{L}$. In the Sumas aquifer, 90 percent of sampled wells had ammonia concentrations below $0.1 \mathrm{mg} / \mathrm{L}$. Concentrations between 0.1 and $2.5 \mathrm{mg} / \mathrm{L}$ were all found in Sumas aquifer wells in which measurements indicated that dissolved oxygen was either absent or present only at low concentrations. These were generally found in either the Sumas River Valley or areas west and northwest of Lynden where extensive subsurface drainage has been installed.

Concentrations of ammonium and nitrate were inversely related; hence the spatial distribution of ammonium shows a general pattern opposite that of the distribution of nitrate. This is largely because nitrate is the dominant nitrogen species under aerobic or oxygenated conditions, and ammonium is the dominant species under anaerobic or deoxygenated conditions.

\section{Organic Nitrogen}

Concentrations of organic nitrogen in ground water ranged from $0.2 \mathrm{mg} / \mathrm{L}$ to $4.0 \mathrm{mg} / \mathrm{L}$, with a median of $0.6 \mathrm{mg} / \mathrm{L}$. Organic nitrogen refers to nitrogencontaining organic compounds typically associated with biological material such as proteins and amino acids. The distribution of organic nitrogen concentrations in the four hydrogeologic units is shown in figure 19. Median concentrations were largest, $0.6 \mathrm{mg} / \mathrm{L}$, in samples from wells completed in bedrock semiconfining unit. Continental sandstones that make up this unit contain large coal deposits that are likely the source of the organic nitrogen and ammonia found in the ground water. Drillers' logs often report that peat, wood, or organic material has been encountered during drilling in the Everson-Vashon material. While peat deposits are common on the surface of the Sumas aquifer, wells in the Sumas aquifer that contain large concentrations of organic nitrogen do not appear to be related to these areas.

In parts of the Sumas aquifer, the concentration of organic nitrogen is generally correlated to the concentration of nitrate; however, the wells showing the largest concentration of organic nitrogen were piezometers located downgradient of dairy lagoons where the chemical environment is reducing and thus incompatible with the presence of nitrate. In the Sumas aquifer, over which land application of barnyard manures is common, larger concentrations of organic nitrogen were often found in wells that were screened closer to the land surface. Concentrations of organic nitrogen found in the nests of piezometers near the Abbotsford Airport are shown below. The presence of organic nitrogen in ground water generally indicates the presence of organic wastes or sewage (Hem, 1989).

Concentrations of organic nitrogen from piezometer nests near the Abbotsford Airport

Organic nitrogen concentrations, in milligrams per liter

\begin{tabular}{lrrr}
\cline { 2 - 4 } Depth (feet) & Nest A & Nest B & Nest C \\
\hline $20-25$ & 0.08 & 0.13 & 0.10 \\
35 & 0.09 & 0.11 & 0.12 \\
55 & 0.08 & $<0.04$ & 0.09 \\
75 & $<0.04$ & 0.10 & 0.10
\end{tabular}

\section{Septage-Related Compounds}

Concentrations of boron, organic carbon, and methylene blue active substances (MBAS) in ground water were measured to assist in the identification of ground water that might be influenced by leachate from septic systems. Similar analyses in other areas of western Washington have shown a good relation between MBAS and nitrate concentrations in residential areas (Drost and others, 1998). Boron and MBAS, which are present as detergent residues in household wastewater, have been identified in septage-contaminated ground water (LeBlanc, 1984). Large concentrations of organic carbon may suggest the presence of several types of organic compounds, including those from septic systems and organic compounds such as solvents, oils, and greases. Large concentrations of organic carbon in ground water may also be associated with decaying organic matter. Most of the samples for these constituents were collected near residential areas overlying the Sumas aquifer, where contamination of ground water from septic systems is more likely. Some samples, however, were also collected from the other hydrogeologic units to determine natural variations. The discussion in this section of the text is limited largely to the comparison of concentrations found in 
the different hydrogeologic units and to areal distribution. These compounds and their relation to nitrates in ground water of the Sumas aquifer are also discussed in a later section devoted to the evaluation of the sources of nitrates in ground water.

\section{Boron}

The concentration of boron in ground water was determined in samples from 79 wells that ranged from below the detection limit of $10 \mu \mathrm{g} / \mathrm{L}$ to $860 \mu \mathrm{g} / \mathrm{L}$.

Ground water in the Sumas aquifer generally displayed small boron concentrations, with a median concentration of $20 \mu \mathrm{g} / \mathrm{L}$, while concentrations in the other units were noticeably larger--median concentrations of 120 , 30 , and $60 \mu \mathrm{g} / \mathrm{L}$ in the Everson-Vashon, Vashon, and bedrock hydrogeologic units, respectively (table 6). The large concentrations in the older units are probably attributable to natural conditions rather than to any land-use activities. Natural concentrations of boron in ground water in excess of $100 \mu \mathrm{g} / \mathrm{L}$ are not uncommon (Hem, 1989), and the boron concentration of seawater is typically $4.6 \mathrm{mg} / \mathrm{L}$. The largest concentration of boron in ground water was $860 \mu \mathrm{g} / \mathrm{L}$, observed in well 40N/03E-24E01, which is completed in the EversonVashon hydrogeologic unit. This well also produces water with large chloride and bromide concentrations, indicating the presence of seawater--a boron concentration of $860 \mu \mathrm{g} / \mathrm{L}$ is roughly 18 percent of the concentration found in seawater. All but one of the boron concentrations above $100 \mu \mathrm{g} / \mathrm{L}$ occur in the older units and may also contain relict seawater. The one well completed in the Sumas aquifer having a boron concentration over $100 \mu \mathrm{g} / \mathrm{L}$ is located in an area surrounded by septic systems, which are probably the local source of the boron. Ground-water samples from the Sumas aquifer that had boron concentrations between 50 and $100 \mu \mathrm{g} / \mathrm{L}$ were from areas generally associated with dairy farming. The areal distribution of boron concentrations is shown in figure 24. Most samples with concentrations above $100 \mu \mathrm{g} / \mathrm{L}$ were from wells in the older units and may be similar to 40N/03E-24E01, where there is other water-quality evidence of a component of relict seawater in the sample.

\section{Dissolved Organic Carbon}

Concentrations of dissolved organic carbon (DOC) were typically below $2.0 \mathrm{mg} / \mathrm{L}$, the median concentration being $0.7 \mathrm{mg} / \mathrm{L}$ (table 6 ), which is comparable to the median concentration for $\mathrm{DOC}$ of $0.7 \mathrm{mg} / \mathrm{L}$ for ground water throughout the United States (Leenheer and others, 1974; Thurman, 1985). Only two ground-water samples were obtained from the bedrock unit for DOC analysis. While the concen. trations of these two samples, 1.0 and $1.4 \mathrm{mg} / \mathrm{L}$, were larger than the median concentration found in the overlying hydrogeologic units, the small sample size precludes much interpretation; however, the source of the carbon in these samples may be coal present in the sedimentary bedrock. The two largest DOC concentrations ( 26 and $39 \mathrm{mg} / \mathrm{L}$ ) were found in piezometers associated with monitoring seepage from manure lagoons. Several of the other 11 samples with DOC concentrations larger than $2.0 \mathrm{mg} / \mathrm{L}$ were from areas where the surrounding land use included manure applications. Of the 13 samples that contained DOC concentrations greater than $2 \mathrm{mg} / \mathrm{L}$, dissolved-oxygen concentration data were available for 10 samples; and in all 10 cases, the dissolved-oxygen concentration was below $1 \mathrm{mg} / \mathrm{L}$, generally 0.2 or less. This reflects the general instability of organic carbon in the presence of oxygen, where, under equilibrium conditions organic carbon will be oxidized to carbon dioxide (Pankow, 1991). This relation partially explains the higher DOC concentrations observed in the Sumas Valley area (fig. 25) and in the Everson-Vashon hydrogeologic unit, where lithologic logs generally report more instances of organic or woody material than do lithologic logs of the Sumas aquifer. In the presence of larger quantities of organic material, oxidation of organic carbon would rapidly consume dissolved oxygen in recharge water and lead to anoxic conditions that are more compatible with the presence of DOC.

\section{Methylene Blue Active Substances}

Methylene blue active substances (MBAS) were not widely present in ground-water samples from the study area; of the 67 samples analyzed for MBAS, detectable concentrations at or above $0.02 \mathrm{mg} / \mathrm{L}$ were found in 11 samples. Consequently, the median concentration observed was less than the detection limit. The maximum concentration measured was $0.09 \mathrm{mg} / \mathrm{L}$. which was found in two piezometers adjacent to a manure lagoon. The majority of samples with detectable concentrations were from wells associated with land-use activities where dairy manure was either stored or applied to fields. Additional discussion 


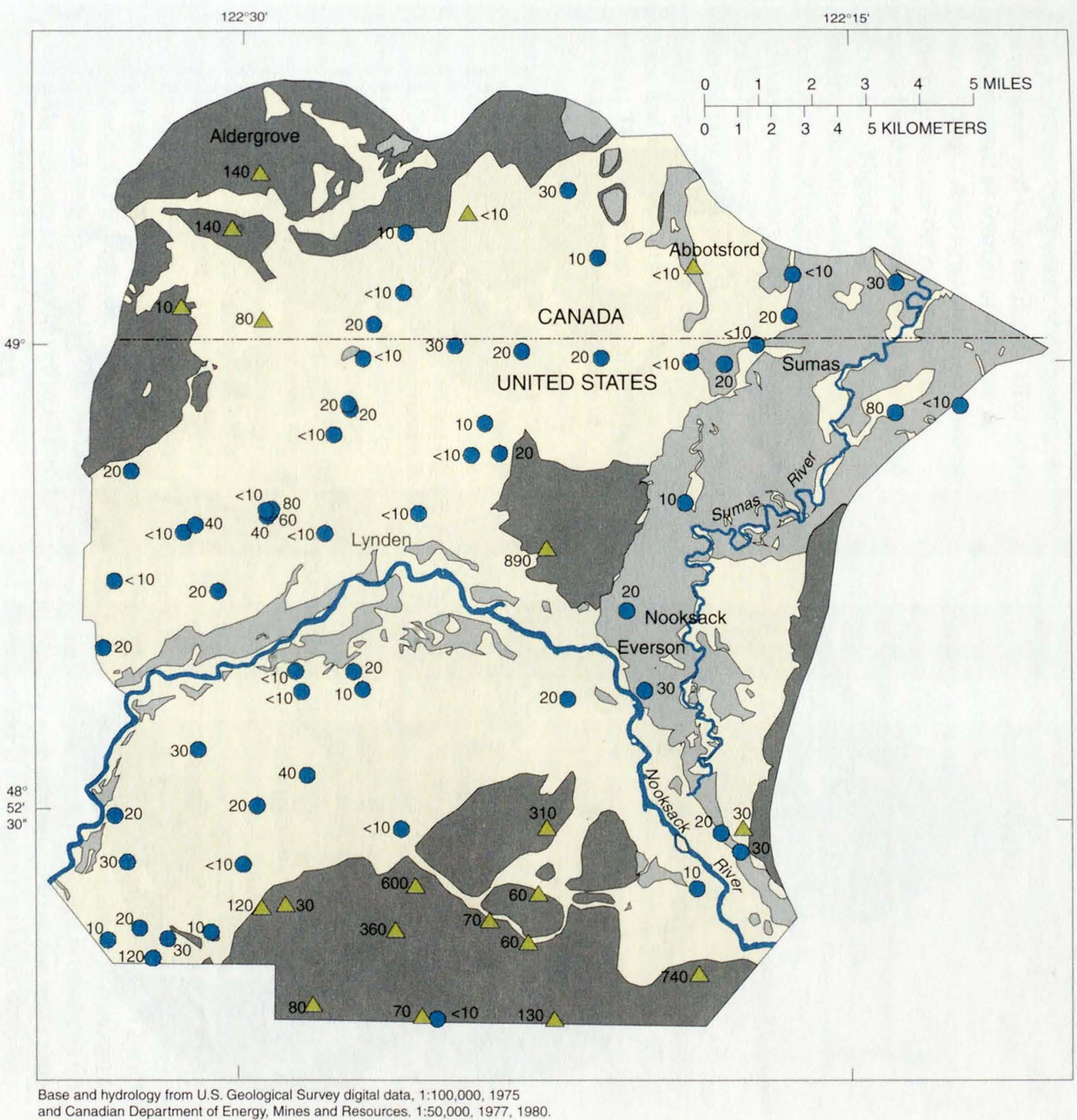

\section{EXPLANATION}

Sumas aquifer with water table conditions

Sumas aquifer with fine-grained sediment at land surface creating confined or partial confined conditions

Fine-grained sediments and bedrock

Concentrations of dissolved boron in wells tapping the Sumas aquifer

70 Concentrations in milligrams per liter

Concentrations of dissolved boron in wells tapping all other hydrogeologic units

$<10 \triangle$ Concentrations in milligrams per lite

Figure 24. Areal distribution of dissolved boron concentrations in ground water in the Lynden-Everson-Nooksack-Sumas (LENS) study area. 


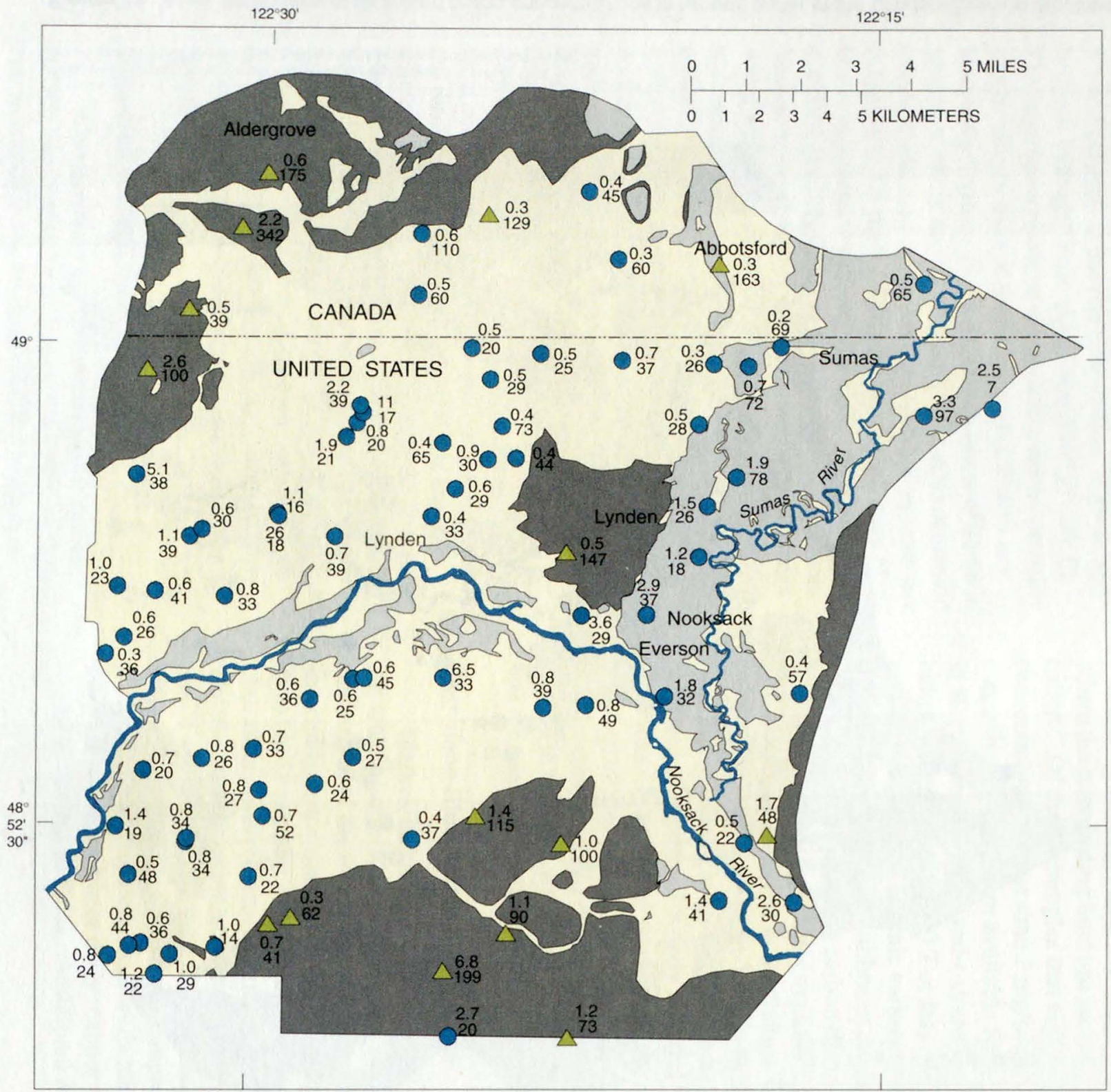

\section{EXPLANATION}

Sumas aquifer with water table conditions

Sumas aquifer with fine-grained sediment at land surface creating confined or partial confined conditions

Fine-grained sediments and bedrock

Concentrations of dissolved organic carbon in wells tapping the Sumas aquifer

0.4 Top value represents concentration, in milligrams per liter; bottom value represents depth to top of well screen, in feet

Concentrations of dissolved organic carbon in wells tapping all other hydrogeologic units

1.2 $\triangle$ Top value represents concentration, in milligrams per liter bottom value represents depth to top of well screen, in feet

Base and hydrology from U.S. Geological Survey digital data, 1:100,000, 1975

and Canadian Department of Energy, Mines and Resources, 1:50,000, 1977, 1980

Figure 25. Areal distribution of dissolved organic carbon concentrations in ground water in the Lynden-Everson-Nooksack-Sumas (LENS) study area. 
concerning MBAS can be found in a later section of this report on the evaluation of sources of nitrate in the Sumas aquifer.

\section{Chloride Concentrations in Ground Water}

Chloride is highly soluble and a common constituent of natural water. Because chloride does not sorb to aquifer materials or soil particles, it can be used as a tracer in some ground-water systems. Chloride is not, however, a common constituent of geologic materials within the Fraser-Whatcom Lowland, and except for areas of relict seawater and brine solutions, the concentration of chloride in natural water is generally small. Chloride is a prominent component of domestic sewage, animal manures, and some fertilizers; all of which have been documented as sources of chloride in ground-water systems. Also irrigation using shallow ground water may increase the concentration of chloride within the shallow ground water because of evapoconcentration (Nightingale and Bianchi, 1974). Chloride imparts a definite salty taste to water at concentrations above $250 \mathrm{mg} / \mathrm{L}$, the concentration set by the USEPA as a Secondary Maximum Contaminant level and by $\mathrm{HC}$ as an aesthetic objective.

Within the four hydrogeologic units, chloride concentrations varied, in part because of differences in the hydrologic and water-quality characteristics of the individual units. The concentration of chloride ranged from 0.3 to $2,800 \mathrm{mg} / \mathrm{L}$, with a median value of $8.8 \mathrm{mg} / \mathrm{L}$ in the 344 wells sampled for this study. The largest chloride concentration $(2,800 \mathrm{mg} / \mathrm{L})$ was observed in a well completed in the Everson-Vashon unit. The largest seasonal variation of from 6.8 to $20 \mathrm{mg} / \mathrm{L}$ was from a well completed in the Sumas aquifer. The largest net change in chloride concentration was observed in the observation well completed in the Vashon unit where the chloride concentration rose steadily from 640 to $840 \mathrm{mg} / \mathrm{L}$ from May, 1990 to October 1991. Chloride concentrations within the Sumas and Everson-Vashon units were generally smaller than concentrations in the stratigraphically deeper Vashon and bedrock units. Median chloride concentrations within the four hydrogeologic units were $8.8 \mathrm{mg} / \mathrm{L}$ in the Sumas aquifer, $7.7 \mathrm{mg} / \mathrm{L}$ in the Everson-Vashon unit, $182 \mathrm{mg} / \mathrm{L}$ in the Vashon unit, and $37 \mathrm{mg} / \mathrm{L}$ in the bedrock unit. For comparison, the range of median chloride concentration observed in 12 Puget Sound counties was from 1.8 to $86 \mathrm{mg} / \mathrm{L}$ (Turney,
1986), however, several of these counties include areas where seawater intrusion has affected chloride concentrations.

The areal distribution of chloride in ground water in the study area is shown on plate 5 along with time series and cumulative frequency distribution plots of chloride concentrations. The time series plots are of chloride data collected repeatedly (generally monthly) at observation wells throughout the study area. The cumulative frequency distribution plots show the range and distribution of chloride concentrations within individual hydrogeologic units.

The observed chloride concentrations were divided into four ranges of concentrations: (1) background concentrations, and (2) slightly, (3) moderately, and (4) significantly elevated concentrations. Because there were few undeveloped areas within the study area, the estimated range of background chloride concentrations in the Sumas aquifer $(0.5$ to $4 \mathrm{mg} / \mathrm{L})$ is based on data from undeveloped areas of Thurston and east King Counties that have similar hydrogeologic environments. This range is similar to the range determined by Gilliom and Patmont (1982) for a shallow glacial aquifer in the Puget Sound region. The estimated range of background chloride concentrations in the lower permeable units, the Everson-Vashon, Vashon, and bedrock units, is from 0 to $7 \mathrm{mg} / \mathrm{L}$ and was based primarily on the cumulative frequency distribution of chloride in the Everson-Vashon unit, for which there were many more samples than for the other semiconfining units. The larger range of background chloride concentrations in the Everson-Vashon unit may be due, in part, to the lower permeabilities and longer ground-water residence times but also may be due to the different geologic materials and presence of more clay particles in these units. Chloride concentrations above background levels and below $25 \mathrm{mg} / \mathrm{L}$ were considered slightly elevated, while concentrations between $25 \mathrm{mg} / \mathrm{L}$ and $250 \mathrm{mg} / \mathrm{L}$ were considered moderately elevated. The percentage of wells sampled with chloride concentrations larger than $25 \mathrm{mg} / \mathrm{L}$ in the Sumas aquifer, the Everson-Vashon unit, and the Vashon and bedrock units was 9, 26, 62, and 57, respectively. Chloride concentrations above $250 \mathrm{mg} / \mathrm{L}$, the USEPA and HC drinking water guideline, were considered significantly elevated and were found in 12 wells (3.5 percent). The distribution of chloride concentrations in the four concentration groups is tabulated on plate 5. Seventy-five percent (260) of the wells sampled showed chloride concentrations larger than the range of background concentrations. 


\section{Sumas Aquifer}

Chloride concentrations in 231 wells completed in the Sumas aquifer ranged from 0.3 to $210 \mathrm{mg} / \mathrm{L}$, with a median concentration of $8.8 \mathrm{mg} / \mathrm{L}$. Eighty-four percent of the wells sampled had chloride concentrations larger than the range of background concentrations found in glacial outwash deposits. The chloride concentration in the majority of wells sampled ( 74 percent) fell within the range of slightly elevated chloride concentrations. The spatial distribution of chloride in the Sumas aquifer (plate 5) indicates that slightly elevated chloride concentrations occur throughout most of the aquifer. In general, ground water that contains background levels of chloride has small values of specific conductance, indicating low levels of dissolved material, and also contained background levels of nitrates. These wells were found throughout most of the study area. Nine percent ( 21 wells) of the wells completed in the Sumas aquifer had moderately elevated chloride concentrations between 25 and $250 \mathrm{mg} / \mathrm{L}$; about half (9) of these wells are located in the area south and west of the town of Everson, while the remainder (12 wells) generally were spread out throughout the rest of the extent of the Sumas aquifer. The cause of the moderately elevated levels of chloride in ground water from these nine wells near the town of Everson is not known. None of the 231 wells completed in the Sumas aquifer had what is considered significantly elevated chloride concentrations greater than $250 \mathrm{mg} / \mathrm{L}$. Median depths of sampled wells completed in the Sumas aquifer within the three chloride concentration classes were between 29 and 37 feet, with no noticeable variation associated with depth. Likewise, consistent variation of chloride concentrations with depth was not observed in the three sets of piezometers located near the Abbotsford Airport.

Depths and chloride concentrations in ground water from the nested piezometers near the Abbotsford Airport; average of 12 measurements between June 1988 and July 1993

\begin{tabular}{lccc}
\hline Depth (feet) & $\begin{array}{c}\text { Nest A } \\
(\mathrm{mg} / \mathrm{L})\end{array}$ & $\begin{array}{l}\text { Nest B } \\
(\mathrm{mg} / \mathrm{L})\end{array}$ & $\begin{array}{c}\text { Nest C } \\
(\mathrm{mg} / \mathrm{L})\end{array}$ \\
\hline $20-25$ & 2.8 & 9.9 & 6.8 \\
35 & 2.4 & 8.8 & 9.9 \\
55 & 2.2 & 5.0 & 5.5 \\
75 & 5.2 & 5.1 & 6.0
\end{tabular}

\section{Everson-Vashon Semiconfining Unit}

Chloride concentrations in 91 wells completed in the Everson-Vashon unit ranged from 0.8 to $2,800 \mathrm{mg} / \mathrm{L}$, with a median concentration of $7.9 \mathrm{mg} / \mathrm{L}$. Nearly half of the wells in the Everson-Vashon unit had chloride concentrations within the range of natural background concentrations. No definite areal pattem was apparent in the distribution of chloride concentrations in the Everson-Vashon unit, however, chloride concentrations in this unit tended to increase with depth. The median depth of Everson-Vashon wells that had chloride concentrations in the range of background was 96 feet, while median depths of wells with chloride concentrations in the slightly, moderately, and signifcantly elevated ranges were 134, 116, and 219 feet, respectively. Monthly chloride concentrations in the Everson-Vashon wells monitored between August 1990 and September 1991 showed fairly uniform concentrations varying by less than $3 \mathrm{mg} / \mathrm{L}$ (plate 5).

\section{Vashon and Bedrock Semiconfining Units}

Chloride concentrations were larger in the Vashon and bedrock semiconfining units, where more than half of the sampled wells had chloride concentrations in the moderately or significantly elevated concentration ranges. In the nine wells completed in the Vashon semiconfining unit, which is located along the eastern margin of the study area (plate 5), one well had moderately elevated chloride concentrations, while four had significantly elevated chloride concentrations. One Vashon well had a chloride concentration in the range of background concentrations. In the one Vashon well monitored repeatedly between May 1990 and October 1991, chloride concentrations rose steadily from 640 to $840 \mathrm{mg} / \mathrm{L}$. In the wells completed in the bedrock unit, six wells had chloride concentrations in the moderately elevated range, and two had chloride levels in the significantly elevated range, while both the background and slightly elevated chloride concentrations were found in three wells apiece. The median depth of sampled wells classified by concentration category varied from 12 feet for wells with background concentrations, to 131 feet for the wells that had significantly elevated chlorides. The chloride concentration in the one bedrock well that was monitored repeatedly was consistent; 13 of the 14 samples had $52 \mathrm{mg} / \mathrm{L}$ chloride, while the remaining sample was reported to have $56 \mathrm{mg} / \mathrm{L}$ chloride. 


\section{potential Sources of Chloride in Ground Water}

Within the Puget Sound area, elevated chloride concentrations occurring near the coast line are typically attributed to seawater intrusion, while large chloride concentrations found further inland have been attributed to older marine sediments (Van Denburgh and Santos, 1965) or remnant seawater. The LENS study area is outside of the range of potential seawater intrusion. However, the older bedrock within the study area is a nonmarine sedimentary unit that, during the last glacial episode, was partially submerged beneath seawater.

The chloride in ground water within the study area is derived largely from three sources: (1) chloride in precipitation that recharges the entire ground-water system; (2) land-use activities such as septic tank effluent, spreading and handling of barnyard manures, or application of chloride containing fertilizers; and (3) remnant seawater trapped within hydrogeologic units during earlier geologic times. There is no evidence that the Sumas aquifer was ever inundated by seawater; however, the aquifer is generally exposed at the surface and highly permeable, which would lead to relatively rapid flushing of any seawater that might have been present. The Everson unit was deposited in a marine environment, and older nonmarine sediments, like the Vashon outwash and bedrock unit, were inundated by seawater when the area submerged during glacial episodes as recent as 11,000 to 13,000 years ago (Easterbrook, 1973).

Ground water and hydrocarbon exploration activities within the study area have reported large concentrations of chloride in deep ground water. These large chloride concentrations generally are attributed to seawater. Bromide, a conservative water-quality constituent, is generally present in large amounts in seawater, relative to uncontaminated ground water. Consequently, in ground water that contains a substantial fraction of seawater, the concentrations of chloride and bromide will be elevated, and the ratio of bromide to chloride should remain comparable to that of seawater. However, it should be noted that bromide also can be present in ground water as the result of some land-use activities. The largest single commercial use of bromide is as the gasoline additive ethylene dibromide (Hem, 1989); however, the use of ethylene dibromide in parts of the study area as a soil fumigant is also well documented.
The concentrations of bromide and chloride in ground-water samples from the LENS study area are plotted in figure $26 \mathrm{a}$, along with the present day bromide-chloride concentration in seawater and a line showing how seawater concentrations would vary upon dilution. Bromide and chloride concentrations in ground water of the LENS study area plot along the seawater dilution line, indicating that many of the samples, particularly those with large chloride concentrations, may contain substantial fractions of seawater. Two samples had large bromide concentrations but had relatively small chloride concentrations and plotted well away from the seawater dilution line. The sample from well 40N/02E-23D01 is from an area where EDB is reported to have been applied as a soil fumigant (Black and Veatch, 1986); the other well, 40N/03E$31 \mathrm{P} 03$, is located where residential housing is the predominant land use. The bromide present in these two samples is likely the result of land-use activities.

When plotted on a cumulative frequency diagram, bromide concentrations in ground-water samples from the study area show a sharp break between 0.04 to $0.06 \mathrm{mg} / \mathrm{L}$ (fig. 26b). Bromide concentrations below this break are interpreted to have little or no seawater component, while samples with greater than $0.06 \mathrm{mg} / \mathrm{L}$ of bromide and proportionally large chloride concentrations probably contain varying, but significant quantities of seawater. Samples from wells completed in the Everson-Vashon and bedrock units make up most of the points on the upper curve of the frequency distribution plot. Bromide concentrations between 0.04 and $0.06 \mathrm{mg} / \mathrm{L}$ correspond to chloride concentrations of 15 to $25 \mathrm{mg} / \mathrm{L}$ and indicate that ground water with chloride concentrations above this level may include a small but substantial component of seawater; ground water with 2 percent seawater would exceed the drinking water guideline for chloride. Therefore, small but significant quantities of remnant seawater trapped during the last glacial episode are believed to be the source of chloride in most ground water with concentrations larger than $25 \mathrm{mg} / \mathrm{L}$.

Large concentrations of chloride or "salty water" have been reported in deeper ground water throughout the study area, the locations and altitudes of which are plotted on figure 27. The widespread occurrence of large chloride concentrations indicates that it is unlikely that large sustainable quantities of potable water (chloride concentrations less than $250 \mathrm{mg} / \mathrm{L}$ ) will be found in or below the Everson-Vashon unit. While some samples from all hydrogeologic units had small 


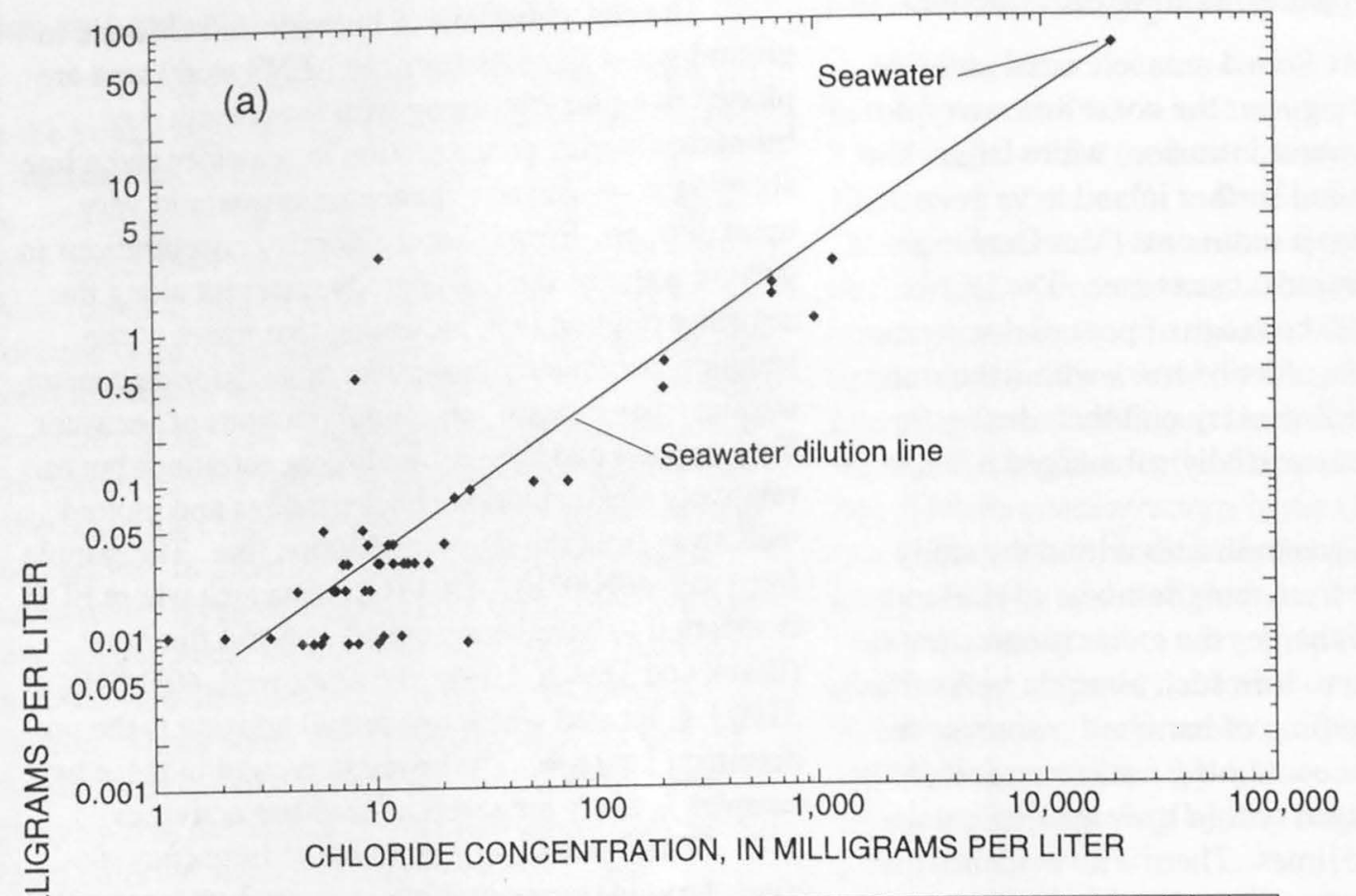

(b)

2.8

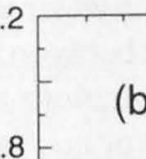

1.6

1.2

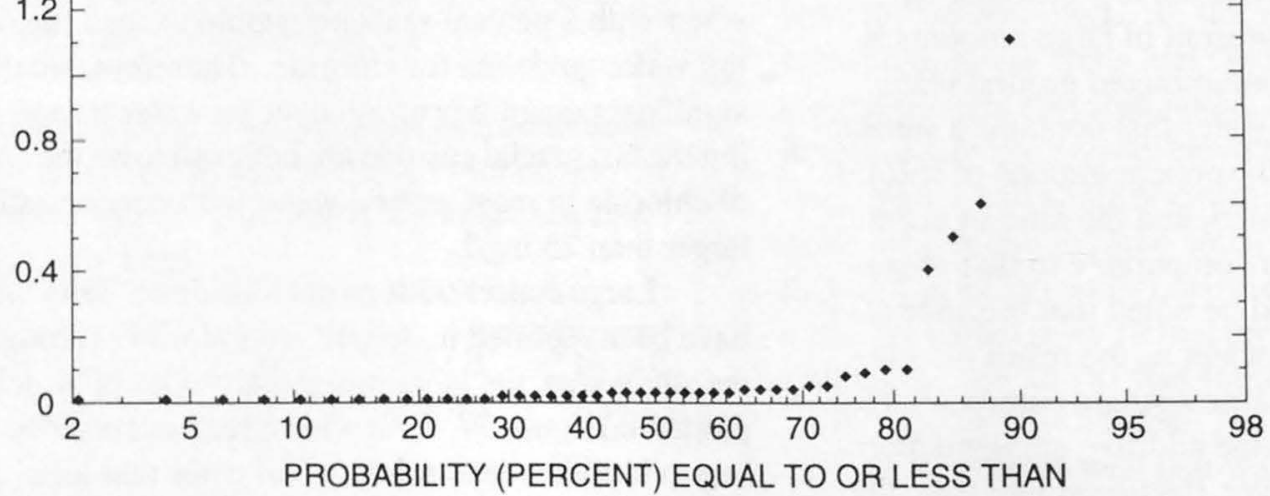

Figure 26. Plots of (a) bromide and chloride concentrations in ground water from aquifers in the Lynden-Everson-Nooksack-Sumas (LENS) study area and in seawater; and (b) normal probability of dissolved bromide concentrations in ground water from aquifers in the LENS study area. 


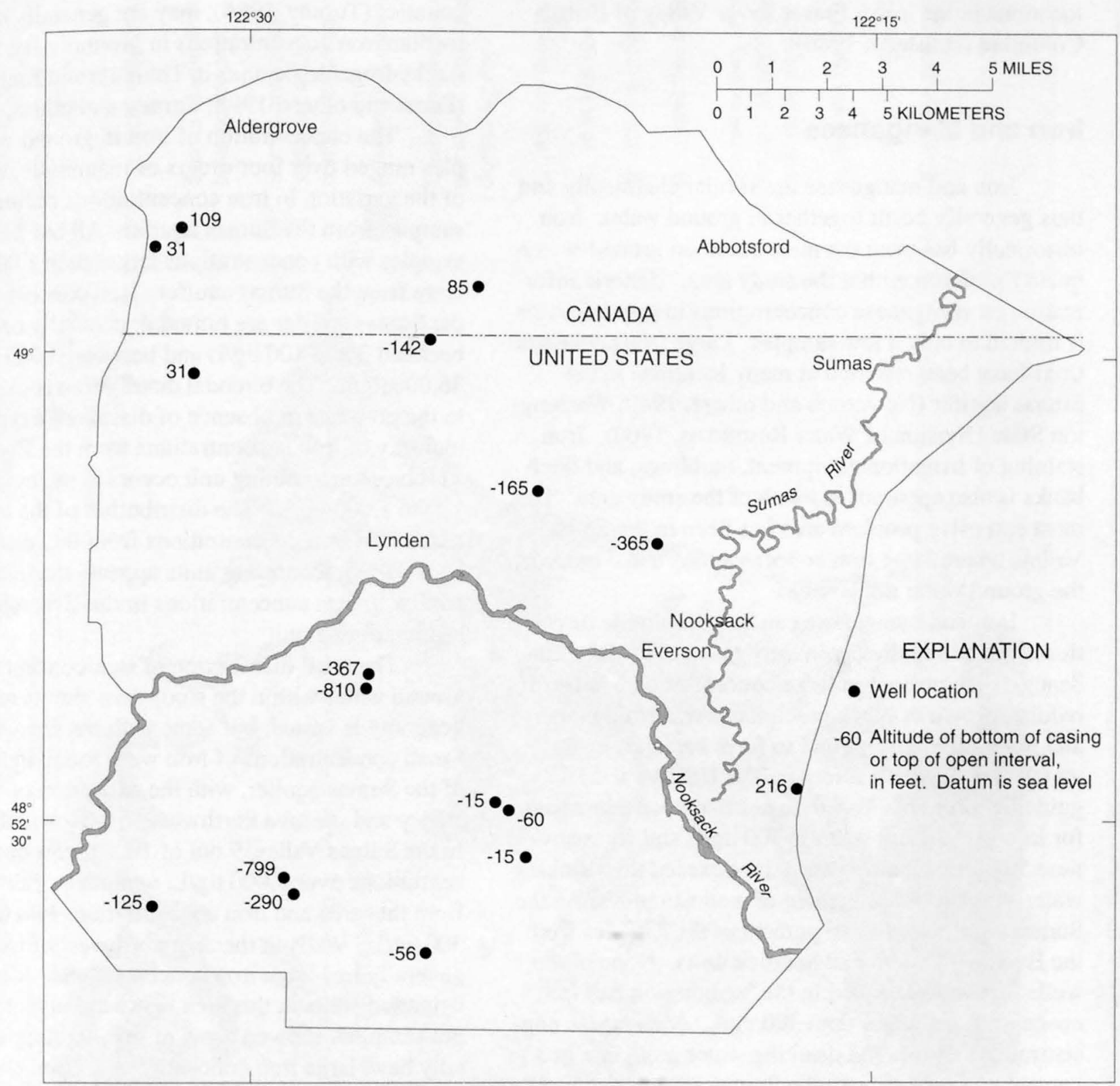

Base and hydrology from U.S. Geological Survey digital data, 1:100,000, 1975 and Canadian Department of Energy, Mines and Resources, 1:50,000, 1977, 1980.

Figure 27. Locations of wells in the Lynden-Everson-Nooksack-Sumas (LENS) study area with concentrations of chloride greater than 250 milligrams per liter or described as "salty water" by well driller. 
bromide and chloride concentrations, larger chloride concentrations characteristic of seawater were found predominantly in the stratigraphically lower hydrogeologic units. Large chloride concentrations have been reported in ground-water samples from hydrogeologic units equivalent to the Everson-Vashon in many locations in the lower Fraser River Valley of British Columbia (Halstead, 1986).

\section{Iron and Manganese}

Iron and manganese are similar chemically and thus generally occur together in ground water. Iron historically has been the most common ground-waterquality problem within the study area. Historic information on manganese concentrations in ground water is limited to only a few samples. Large iron concentrations have been reported at many locations in the Sumas aquifer (Newcomb and others, 1949; Washington State Division of Water Resources, 1960). Iron staining of irrigation equipment, buildings, and ditch banks is also apparent in much of the study area. The most extensive problem area has been in the Sumas Valley, where large iron concentrations make much of the ground water nonpotable.

Iron and manganese can be undesirable impurities in water supplies, primarily because of their tendency, when present in large concentrations, to form reddish-brown or black precipitates that stain laundry and plumbing fixtures, and to form bacterial mats, which can clog well screens. The USEPA and HC guideline primarily based on aesthetic considerations for iron in drinking water is $300 \mu \mathrm{g} / \mathrm{L}$ and for manganese $50 \mu \mathrm{g} / \mathrm{L}$. Iron concentrations exceed this drinking water standard in 22 percent of well samples from the Sumas aquifer and in 20 percent of the samples from the Everson-Vashon and bedrock units. None of the wells that were sampled in the Vashon unit had iron concentrations larger than $300 \mu \mathrm{g} / \mathrm{L}$. Manganese concentrations exceed the drinking water guideline in 33 percent of samples from the Sumas aquifer and in 47 percent of samples from the Everson-Vashon unit. One of four samples from the Vashon and two of five samples from the bedrock unit exceeded the drinking water guideline.

Iron concentrations measured in 152 wells in the study area ranged from less than $3 \mu \mathrm{g} / \mathrm{L}$ to $36,000 \mu \mathrm{g} / \mathrm{L}$, with a median concentration of $30 \mu \mathrm{g} / \mathrm{L}$. Median iron concentrations in samples from the four principal hydrogeologic units were: $26 \mu \mathrm{g} / \mathrm{L}$ in the
Sumas aquifer (118 sites), $80 \mu \mathrm{g} / \mathrm{L}$ in the EversonVashon unit ( 25 sites), $54 \mu \mathrm{g} / \mathrm{L}$ in the Vashon unit (4 sites), and $48 \mu \mathrm{g} / \mathrm{L}$ in the bedrock unit (5 sites). While median iron concentrations observed in ground water in the LENS area are within the range of median concentrations reported for the 12 Puget Sound counties (Turney, 1986), they are generally larger than median iron concentrations in ground water from sim. ilar hydrogeologic units in Thurston and King Counties (Drost and others, 1998; Turney and others, 1995).

The concentration of iron in ground-water sam. ples ranged over four orders of magnitude, with most of the variation in iron concentrations occurring in samples from the Sumas aquifer. All but 1 of the 25 samples with concentrations larger than $1,000 \mu \mathrm{g} / \mathrm{L}$ were from the Sumas aquifer. Iron concentrations in the Sumas aquifer are bimodal, generally occurring between 3 and $100 \mu \mathrm{g} / \mathrm{L}$ and between 3,000 and $36,000 \mu \mathrm{g} / \mathrm{L}$. The bimodal distribution is likely related to the presence or absence of dissolved oxygen. The majority of iron concentrations from the EversonVashon semiconfining unit occurs in the range of from 100 to $1,000 \mu \mathrm{g} / \mathrm{L}$. The distribution of the limited number of iron concentrations from the Vashon and bedrock semiconfining units appears to cover ranges similar to iron concentrations in the Everson-Vashon semiconfining unit.

The areal distribution of iron concentrations in ground water within the study area shown in figure 28 generally is varied, but some patterns are apparent. Small concentrations of iron were found in most areas of the Sumas aquifer, with the exception of the Sumas Valley and the area northwest of the town of Lynden. In the Sumas Valley, 9 out of 10 samples had iron concentrations over 3,000 $\mu \mathrm{g} / \mathrm{L}$, and none of the samples from this area had iron concentrations less than $300 \mu \mathrm{g} / \mathrm{L}$. Wells in the area northwest of Lynden also generally had large iron concentrations. Many of the irrigation wells in this area that were inventoried, but not sampled, showed signs of iron staining and reportedly have large iron concentrations. Iron concentrations in the area around the Abbotsford Airport generally were less than $30 \mu \mathrm{g} / \mathrm{L}$. Little vertical variation was observed in the iron concentrations from the nested piezometers located near the airport. Iron concentrations in the Everson-Vashon unit located south of the Nooksack River were generally between 30 and $300 \mu \mathrm{g} / \mathrm{L}$. 


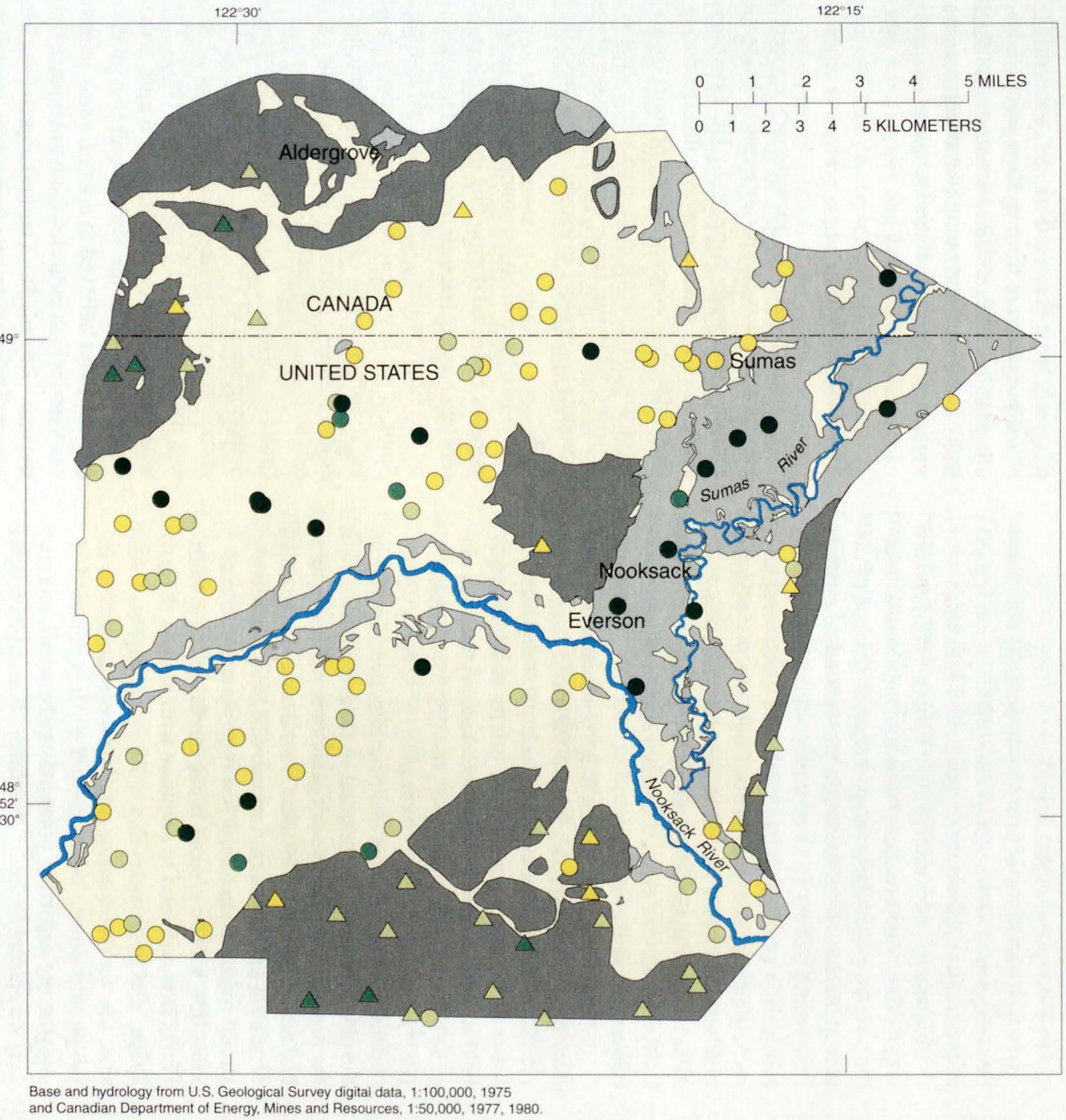

\section{EXPLANATION}

Sumas aquifer with water table conditions

Sumas aquifer with fine-grained sediment at land surface creating confined or partial confined conditions

Fine-grained sediments and bedrock

Concentrations of iron, in micrograms per liter in wells tapping the Sumas aquifer
0 to less than 30
30 to less than 300
300 to less than 3000
- greater than or equal to 3000

Concentrations of iron, in micrograms per liter, in wells tapping all other hydrogeologic units
$\triangle 0$ to less than 30
$\triangle 30$ to less than 300
A 300 to less than 3000

Figure 28. Areal distribution of iron concentration in ground water in the Lynden-Everson-Nooksack-Sumas (LENS) study area. 
Manganese concentrations measured in 125 wells ranged from less than 1 to $3,500 \mu \mathrm{g} / \mathrm{L}$, with a median concentration of $12 \mu \mathrm{g} / \mathrm{L}$. Median manganese concentrations in samples from the hydrogeologic units were $8 \mu \mathrm{g} / \mathrm{L}$ in the Sumas aquifer (96 sites), $17 \mu \mathrm{g} / \mathrm{L}$ in the Everson-Vashon semiconfining unit (19 sites), $20 \mu \mathrm{g} / \mathrm{L}$ in the Vashon semiconfining unit ( 4 sites), and $13 \mu \mathrm{g} / \mathrm{L}$ in the bedrock semiconfining unit ( 5 sites). While median manganese concentrations observed in ground water of the LENS area are within the range of median concentrations reported for the 12 Puget Sound counties (Turney, 1986), they are also generally larger than median manganese concentrations in ground water from similar hydrogeologic units in Thurston and King Counties (Drost and others, 1998; Turney and others, 1995).

The variations of iron and manganese concentrations in ground water within the study area are typical of ground water from the Puget Sound Lowlands (Van Denberg and Santos, 1965; Turney, 1986) and are largely due to natural geochemical conditions within the aquifer, particularly the presence or absence of dissolved oxygen. Iron, the fourth most abundant element in the earth's crust, is a component of many accessory minerals in granites and volcanic and metamorphic rock, which are the type of rock fragments that make up much of the Sumas glacial sediments (Armstrong, 1981). These sediments, being geologically young and unweathered, can provide a ready source of iron for dissolution into ground water.

The chemistry of iron in ground water has been described extensively by Hem (1989) and Drever (1982), some aspects of which relate to the ground water of the study area and are briefly summarized below. Iron can exist in ground-water systems as one of two interchangeable forms, the divalent ferrous $\left(\mathrm{Fe}^{+2}\right)$ form or the trivalent ferric $\left(\mathrm{Fe}^{+3}\right)$ form. The chemical form and behavior of iron depend largely on the $\mathrm{pH}$ and oxidizing potential of the ground water, but the presence of dissolved organic material and microbial activity is also a factor. Ground water in the range of neutral $\mathrm{pH}$, between 5 and 9 , will have a relatively strong oxidizing potential if oxygen is present; thus most iron will be present in the insoluble ferric form. Ferric iron will tend to combine with oxygen to form oxides and hydroxides that will precipitate out of solution, the net result being small iron concentrations in the ground water. When ground water is depleted of oxygen, the oxidizing potential can be small, and iron may be present in the ferrous form. Ferrous iron is soluble and stable, and large ferrous iron concentrations in ground water are possible under these conditions. When ground water with large concentrations of ferrous iron is brought to the land surface and reoxy. genated from the atmosphere, iron in the ferrous form will rapidly convert to the ferric form (which is insolu. ble) and precipitate from solution, primarily as an oxide. The iron precipitate adheres to most surfaces and results in the iron staining prevalent in many parts of the study area. Ninety-one percent of ground water with iron concentrations larger than $200 \mu \mathrm{g} / \mathrm{L}$ had dissolved-oxygen concentrations less than $0.5 \mathrm{mg} / \mathrm{L}$. Samples that had less than $100 \mu \mathrm{g} / \mathrm{L}$ iron had dissolved-oxygen concentrations ranging from 0 to $13 \mathrm{mg} / \mathrm{L}$, with a median concentration of $5.5 \mathrm{mg} / \mathrm{L}$. The two samples with large iron concentrations and relatively large dissolved-oxygen concentrations of about $3 \mathrm{mg} / \mathrm{L}$ were from wells reported by the well owner to have large iron concentrations. Small air leaks in the well and pump plumbing were the likely sources of oxygen in these samples.

\section{Trace Elements}

An evaluation of trace element concentrations in ground water was conducted using existing data for 22 samples from wells sampled by BC Environment and analyses of 23 water samples collected during this study. Overall, concentrations of most trace elements were generally small in ground water from glacial deposits; however, larger concentrations of some trace elements are present in ground water from the bedrock unit.

The trace element concentration data for water samples collected during this investigation, plus current and historic trace element data from wells sampled by BC Environment, are summarized in table 13. Some of the historical data contain analyses with vary. ing detection levels. All of the reporting limits are below USEPA's reference levels, with the exception of two historical analyses for arsenic, which had reporting limits of $250 \mu \mathrm{g} / \mathrm{L}$. Excluding the 2 samples with a detection level of $250 \mu \mathrm{g} / \mathrm{L}$, the median and maximum arsenic concentrations of the remaining 25 samples are less than $1 \mu \mathrm{g} / \mathrm{L}$ and $6 \mu \mathrm{g} / \mathrm{L}$, respectively. The sample with the arsenic concentration of $6 \mu \mathrm{g} / \mathrm{L}$ was from a well completed in the Vashon unit that produces ground water believed to contain some remnant seawater, which indicates a long residence time within the unit. Arsenic from natural sources has been reported in ground water from older glacial deposits in 
east King County at median concentrations of 6 and $12 \mu \mathrm{g} / \mathrm{L}$ in ground water (Turney and others, 1995); therefore, it is possible that the arsenic present in this well water is also from natural sources.

Barium was one of the most common trace elements found in ground-water samples collected for this sudy. In 30 samples, barium concentrations ranged from 4 to $1,100 \mu \mathrm{g} / \mathrm{L}$, with a median concentration of $12 \mu \mathrm{g} / \mathrm{L}$. Barium is present naturally, and the larger concentrations were generally found in deep wells that pump ground water with long residence times. Samples from wells within the bedrock unit had concentrations between 43 and $1,100 \mu \mathrm{g} / \mathrm{L}$, and well $40 \mathrm{~N} / 4 \mathrm{E}-09 \mathrm{~N} 03$, which is in the confined part of the Sumas aquifer, had a sample with a barium concentration of $390 \mu \mathrm{g} / \mathrm{L}$.

Zinc and copper were present in most samples, and the concentrations were variable. The presence of these trace elements in small concentrations is not surprising because many wells sampled were domestic wells that may have copper and galvanized pipes from which copper and zinc can be readily leached, especially if the water is slightly acidic or low in dissolvedsolids concentrations, as is much of the ground water in this area. Concentrations of copper and zinc were all significantly below applicable drinking water reference levels and should be considered as artifacts of the well plumbing.

Strontium was present in all six samples for which it was analyzed at concentrations ranging from 120 to $1,700 \mu \mathrm{g} / \mathrm{L}$. Strontium is a common replacement element for calcium in rock-forming minerals, and its presence in ground water is common, although concentrations are generally less than $200 \mu \mathrm{g} / \mathrm{L}$ (Skougstad and Horr, 1963).

The remaining trace elements that were analyzed for were rarely present and, if present, were at concentrations that were not significant in terms of drinking water standards. Silver was present in nine samples at concentrations of from 1 to $2 \mu \mathrm{g} / \mathrm{L}$. Molybdenum was detected in three samples between 10 and $40 \mu \mathrm{g} / \mathrm{L}$. Cadmium, lead, and lithium were detected in two samples, and chromium and selenium were detected in only one sample. Vanadium, cobalt, and beryllium were not detected.

\section{Organic Compounds}

Organic chemicals have been detected in at least 60 wells within the study area between 1984 and 1993. Although the concentrations of most organic compounds found in ground water were generally small with respect to drinking water guidelines, concentrations of the most commonly detected compounds, 1,2-dichloropropane and ethylene dibromide, generally exceeded drinking water guidelines. The presence of synthetic organic compounds in ground water of the Sumas aquifer confirms the aquifer's vulnerability to contamination and showed clearly that parts of the aquifer have already been contaminated by land-use activities.

The presence of organic compounds in ground water of the Sumas aquifer was evaluated from existing data and the analyses of water samples collected from 24 wells for this study. Existing data generally focus on three subareas within the LENS study area: (1) south of the Abbotsford Airport; (2) the Bertrand Creek area west of Lynden; and (3) the area northeast of Lynden. These areas are apparent by the cluster of wells plotted on figure 29, which shows the location of the wells sampled for organic compounds. Most of the analyses are for a limited group of organic compounds. The 24 water samples collected for this study were collected from wells located throughout the Sumas aquifer and were analyzed for 63 organic compounds. These samples were collected to provide a broad view of the presence of organic chemicals in ground water of the Sumas aquifer, and data collected for this study are summarized in table 14 and itemized in appendix table 7.

Samples for this study were analyzed for selected compounds from 3 classes of organic chemicals, including 41 volatile organic compounds, 12 triazine or nitrogen-containing herbicides, and 10 carbamate insecticides or metabolites. The volatile organic compounds include the soil fumigant 1,2dibromoethane, commonly referred to as ethylene dibromide or EDB, 1,2-dichloropropane, (1,2-DCP), 1,3-dichloropropene (cis- and trans-), and 1,2-dibromo-3-chloropropane. 


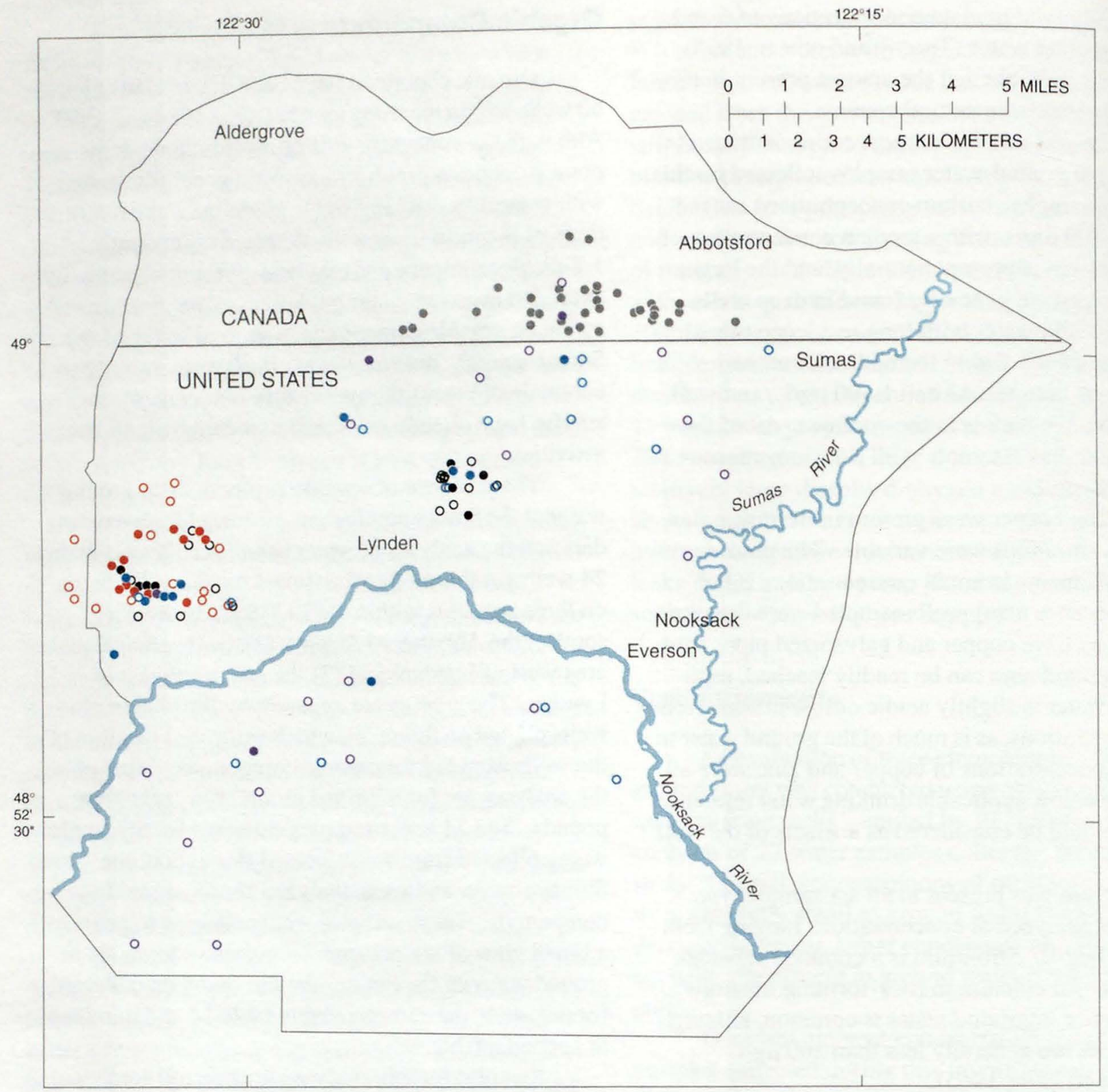

Base and hydrology from U.S. Geological Survey digital data, 1:100,000, 1975 and Canadian Department of Energy, Mines and Resources, 1:50,000, 1977, 1980.

\section{EXPLANATION}

Location of well sampled, agency, year(s) sampled, and reference

Solid circle indicates detectable concentrations of pesticide or volatile organic compounds; open circle indicates concentrations below analytical detection limits. Locations of nondetectable samples not available for data from Environment Canada

- U.S. Geological Survey, 1990-1991, present investigation

- Washington Department of Ecology, 1988, Erickson ana Norton, 1990

- Washington Department of Health, 1993, Stephen Hulsman, written communication

Figure 29. Locations of wells sampled for pesticides and volatile organic compounds in the Lynden-EversonNooksack-Sumas (LENS) study area.
- Environment Canada, 1984-1990, Liebscher and others, 1992

- Department of Ecology, 1984, Black and Veatch, 1986 
Of the 24 wells for which samples were collected, organic compounds were detected in ground water from 4 wells. A total of six compounds were detected, four volatile organics, including EDB and 1.2-DCP, one carbamate insecticide, oxamyl, and one triazine herbicide, atrazine. The concentrations of these six compounds within ground water from the four wells are shown below.

Concentrations of organic compounds detected in ground water from four wells in the LENS study area [<, less than]

\begin{tabular}{|c|c|c|c|c|c|c|}
\hline \multirow[b]{2}{*}{$\begin{array}{l}\text { Well } \\
\text { number }\end{array}$} & \multicolumn{6}{|c|}{$\begin{array}{l}\text { Concentrations of organic compounds detected, } \\
\text { in micrograms per liter }\end{array}$} \\
\hline & $\begin{array}{l}\underline{\text { EDB }} \\
\text { 1,2-di- } \\
\text { bromo- } \\
\text { ethane }\end{array}$ & $\begin{array}{l}\frac{1,2-\mathrm{DCP}}{1,2 \text {-di- }} \\
\text { chloro- } \\
\text { propane }\end{array}$ & $\begin{array}{l}\text { 1,3-di- } \\
\text { chloro- } \\
\text { propane }\end{array}$ & $\begin{array}{l}\text { 1,2,3-tri- } \\
\text { chloro- } \\
\text { propane }\end{array}$ & Oxamyl & $\begin{array}{l}\text { Atra- } \\
\text { zine }\end{array}$ \\
\hline \multirow[t]{2}{*}{$39 \mathrm{~N} / 02 \mathrm{E}-01 \mathrm{P} 02$} & $<0.2$ & 1.6 & $<0.2$ & $<0.2$ & $<0.5$ & $<0.1$ \\
\hline & $<0.2$ & 2.8 & $<0.2$ & $<0.2$ & $<0.5$ & $<0.1$ \\
\hline \multirow[t]{2}{*}{$40 \mathrm{~N} / 02 \mathrm{E}-27 \mathrm{~B} 01$} & 0.3 & 5.6 & 0.2 & 1.4 & $<0.5$ & $<0.1$ \\
\hline & 0.3 & 5.6 & 0.2 & 1.2 & $<0.5$ & $<0.1$ \\
\hline $\begin{array}{l}\text { 092G.009.1.1.4- } \\
18-20\end{array}$ & $<0.2$ & $<0.2$ & $<0.2$ & $<0.2$ & 0.5 & $<0.1$ \\
\hline 4IN/03E-32Q01 & $<0.2$ & $<0.2$ & $<0.2$ & $<0.2$ & $<0.5$ & 0.1 \\
\hline
\end{tabular}

Organic compounds have been detected in at least 60 wells sampled in either concurrent or previous studies (table 15 and fig. 29). Several of these studies focus on the presence of EDB in ground water of two areas near Lynden, and EDB has been detected in at least eight different wells within these areas. When Erickson and Norton (1990) sampled 27 wells within the subarea west of Lynden for the presence of more than 40 different organic compounds used in agricultural application, they detected five organic compounds, including nine occurrences of 1,2-DCP, two occurrences each of EDB and prometon, and single occurrences of carbofuran and dibromochloropropane. $\mathrm{EC}$ has been sampling ground water from the Sumas aquifer, referred to as the Abbotsford aquifer in British Columbia, for the presence of pesticides since 1984. Through 1990, EC found 11 different organic compounds in at least 30 different wells. The most commonly found compounds were 1,2-DCP in 27 wells, atrazine in 11 wells, dinoseb in 9 wells, and simizine and diazinon in 7 wells each (Liebscher and others,
1992). A concurrent study by Washinton State Department of Health sampled 26 wells in the LENS study area for 23 organic compounds in June 1993 and again after the winter rains. The most commonly found compounds were EDB, 1,2-DCP, atrazine and 1,2,3 trichloropropane, and in general, concentrations were slightly larger in samples collected after the winter rains (Stephen Hulsman, Washington State Department of Health, written commun., April 26, 1994).

Most of the organic compounds found (table 15) are pesticides associated with commercial agricultural activity; however, some compounds, including diazinon and prometon, are also associated with products sold for home use. Several of the detected compounds, including EDB, dinoseb, and alachlor, are not currently registered for use as pesticides in either the United States or Canada. EDB is known to remain in soils for up to 19 years following applications as a soil fumigant (Steinberg and others, 1987). The presence of these compounds, particularly EDB, in recent ground-water samples is likely due to historical use. EDB concentrations in two wells near Lynden generally decreased from April 1984 to September 1988, (Sweet-Edwards/EMCON, 1989) also suggesting an historical source.

\section{Water-Quality Characteristics of Major Hydrogeologic Units}

Although the preceding discussion has described a ground-water system with highly variable waterquality characteristics, some generalities can summarize the more typical water-quality characteristics of ground water within the study area. A more detailed discussion on factors affecting regional ground-water quality is presented by Runnells (1993).

Ground water within the study area originates largely as precipitation. Although the chemistry of rain water is dilute, common water-quality constituents found in ground water within the study area are present in smaller concentrations in precipitation samples collected within the Puget Sound region and adjoining area (National Atmospheric Deposition Program, 1991; Laird and others, 1986) (table 16). Irrigation is believed to make up a small fraction of the recharge water in the study area; however, because the source of most irrigation water is ground water or streamflow derived from ground-water base flow, the concentrations of constituents in irrigation water are larger. 
Table 16. Average concentration of major ions and yearly depositional rates at three locations in western Washington [mg/L, milligrams per liter; $\mathrm{kg} / \mathrm{ha}$, kilograms per hectare]

\begin{tabular}{|c|c|c|c|c|c|c|}
\hline \multirow[b]{2}{*}{$\begin{array}{l}\text { Water- } \\
\text { quality } \\
\text { constituent }\end{array}$} & \multicolumn{2}{|c|}{$\begin{array}{c}\text { Hoh Ranger Station } \\
1980-1992\end{array}$} & \multicolumn{2}{|c|}{$\begin{array}{c}\text { LeGrand } \\
1984-1992\end{array}$} & \multicolumn{2}{|c|}{$\begin{array}{c}\text { Marblemount } \\
1984-1992\end{array}$} \\
\hline & $\begin{array}{l}\text { Concen- } \\
\text { tration } \\
\text { in } \mathrm{mg} / \mathrm{L}\end{array}$ & $\begin{array}{l}\text { Deposition } \\
\text { in } \mathrm{lb} / \text { acre } \\
(\mathrm{kg} / \mathrm{ha})\end{array}$ & $\begin{array}{l}\text { Concen- } \\
\text { tration } \\
\text { in } \mathrm{mg} / \mathrm{L}\end{array}$ & $\begin{array}{l}\text { Deposition } \\
\text { in lb/acre } \\
(\mathrm{kg} / \mathrm{ha})\end{array}$ & $\begin{array}{l}\text { Concen- } \\
\text { tration } \\
\text { in } \mathrm{mg} / \mathrm{L}\end{array}$ & $\begin{array}{l}\text { Deposition } \\
\text { in lb/acre } \\
(\mathrm{kg} / \mathrm{ha})\end{array}$ \\
\hline Calcium & 0.04 & $1.2(1.3)$ & 0.04 & $0.4(0.4)$ & 0.03 & $0.5(0.6)$ \\
\hline Magnesium & 0.06 & $1.9(2.1)$ & 0.04 & $0.3(0.3)$ & 0.03 & $0.4(0.5)$ \\
\hline Potassium & 0.02 & $0.7(0.8)$ & 0.02 & $0.2(0.2)$ & 0.01 & $0.2(0.2)$ \\
\hline Sodium & 0.55 & $15(17)$ & 0.28 & $2.0(2.3)$ & 0.14 & $2.4(2.7)$ \\
\hline Ammonia & 0.01 & $0.4(0.5)$ & 0.04 & $0.4(0.4)$ & 0.03 & $0.5(0.6)$ \\
\hline Nitrate & 0.08 & $2.3(2.6)$ & 0.33 & $2.5(2.8)$ & 0.30 & $5.3(5.9)$ \\
\hline Chloride & 0.99 & $28(32)$ & 0.49 & $0.8(0.9)$ & 0.26 & $4.5(5)$ \\
\hline Sulfate & 0.30 & $8.5(9.5)$ & 0.57 & $36(4)$ & 0.37 & $6.3(7.1)$ \\
\hline
\end{tabular}

\section{Sumas Aquifer}

Ground water from the Sumas aquifer is typically calcium or magnesium bicarbonate, with varying amounts of nitrate and chloride replacing the bicarbonate as the dominant anion. This ground water is also generally dilute, slightly acidic with low alkalinity, and typically well oxygenated, although there are localized areas where dissolved oxygen is absent or present at low concentrations. Throughout the aquifer, chloride concentrations are above background levels, suggesting that effects of land-use activities are widespread. The presence of synthetic organic compounds demonstrates that this aquifer is vulnerable to contamination and has in fact been contaminated in several locations. While elevated nitrate concentrations are not found throughout the entire aquifer, they are found in nearly every area where nitrate is chemically stable. The source of nitrate in ground water of the Sumas aquifer is believed to be land-use activities. In areas where nitrate is not present, dissolved oxygen is also typically not present; in most of these areas, the concentrations of iron and manganese are typically so large that they preclude the use of the ground water for domestic or municipal supplies.

\section{Everson-Vashon and Vashon Semiconfining Units}

Ground-water quality in the Everson-Vashon and Vashon semiconfining units is highly variable without a characteristic water type. This ground water contains more dissolved matter than found in the Sumas aquifer and has a higher specific conductance, typically between 300 to 700 microSiemens per centimeter $(\mu \mathrm{S} / \mathrm{cm})$, with higher $\mathrm{pH}$, between 7.5 and 8.5 , and a larger alkalinity, 100 to $200 \mathrm{mg} / \mathrm{L}$. Nitrate concentrations are generally low, with many in the range of background concentrations, indicating that land-use impact on the water quality in these hydrogeologic units is not widespread. Seven percent of wells in these units showed signs of water-quality degradation from land-use activities, and only one well had a nitrate concentration equal to or greater than the MCL of $10 \mathrm{mg} / \mathrm{L}$. Dissolved-oxygen concentrations are typically low, less than or equal to $1 \mathrm{mg} / \mathrm{L}$. Large concentrations of iron, manganese, and chloride are common at many locations in these hydrogeologic units; these large concentrations are the result of natural occurrences in the hydrogeologic deposits. 


\section{Bedrock Semiconfining Unit}

The ground-water type for samples from the bedrock semiconfining unit was either sodium-bicarbonate or sodium-chloride. This ground water had a larger concentration of dissolved constituents having the highest $\mathrm{pHs}$ and alkalinity, and specific conductance, while also having low concentrations of dissolved oxygen. These conditions indicate ground water from this unit likely has had longer residence time within the ground-water system.

\section{EVALUATION OF SOURCES OF NITRATE IN GROUND WATER OF THE STUDY AREA}

\section{Sources of Nitrates in Ground Water}

Sources of nitrates in ground water of the United States have been reviewed by several authors (Spalding and Exner, 1993; Halberg, 1989; Keeney, 1986 and 1989; and Madison and Brunett, 1985). They concluded that the increased use of nitrogen fertilizers is the major cause of the widespread increase in nitrates in ground water at many locations throughout the United States. Other activities such as dryland farming, concentrated animal farming, high-density use of residential septic systems, lawn and garden fertilization, and the disposal of municipal biosolid wastes by land application can also be major sources of nitrates in ground water in some regions. Geologic deposits and soil organic matter can be important natural sources of nitrogen in some areas. Initial deforestation and cultivation of land areas may release nitrogen from soil organic matter or peat (Keeney and Bremner, 1964; Kreitler and Jones, 1975; Boyce and others, 1976; Reinhorn and Avnimelech, 1974; and Allison, 1955), which can be transported to ground water. Also affecting more limited areas is the installation of artificial drainage systems that lower the level of ground water and allow peat and soil organic matter to be oxidized and thus making nitrates available for leaching (Avnimelech, 1971, Grootjans and others, 1986).

Potential sources of nitrate in ground water of the LENS study area include dairy and poultry manure; residential septic systems; fertilizers applied to croplands, lawns, and gardens; irrigation with ground water containing nitrates; land disposal of municipal biosolid wastes; and naturally occurring nitrogen in soils, peat material, and precipitation. These sources, with the exception of land disposal of municipal biosolid wastes, are present throughout much of the study area, although the spatial distribution is uneven and has changed with time. Evaluation of these sources indicates that agricultural activities, through land applications of manure, manure storage, and the use of fertilizers, have the greatest effect on the quantity of nitrates in ground water. Although residential sources contribute a small percentage to the total nitrogen input to ground water, in areas where domestic wells are located, residential sources of nitrates are often closest to the well and may have the greatest impact on the concentration of nitrate in some well water.

The identification of sources of nitrate in an area as large as the LENS study area is complicated by several factors. Within the study area, a variety of land-use activities may be potential sources of nitrates in ground water, and the areas where these land-use activities occur are often mixed and have changed over time. Because the chemical characteristics of nitrate in ground water from these sources may be similar, it can be difficult to distinguish individual sources based on chemical characteristics alone. The origin of nitrates in ground water can be further complicated because nitrogen compounds from many sources that enter soil can temporarily be incorporated into the large pool of soil organic matter. Subsequent release of this nitrate from the soil organic matter pool is difficult to distinguish from nitrates pre-existing in that pool.

Regardless of the source, the amount of nitrate that enters ground water is controlled by a complex set of hydrologic and biochemical processes that occur largely in the soil and unsaturated zone. Through a series of chemical transformations, most of which are mediated by bacteria, nitrogen can change chemical form in what is referred to as the soil nitrogen cycle (Stevenson, 1982). The basic features are shown schematically in figure 30 , and more complete information on the soil nitrogen cycle is presented in Delwiche, 1970; Stevenson, 1982; and National Research Council, 1978. The soil nitrogen cycle largely controls the amount of nitrogen in the soil column that is available for leaching to ground water. Two hydrologic conditions that most affect the leaching of nitrate to ground water are (1) the availability of water to transport the nitrate and (2) the hydraulic conductivity of the soil and unsaturated zone materials that control the rate of movement of soil moisture and ground water. 


\section{Soil - Biological Nitrogen Cycle}

\section{Sources of nitrogen input}

Precipitation, $\mathrm{NH}_{4}, \mathrm{NO}_{3}$

Irrigation, $\mathrm{NO}_{3}$

Domestic septic system, $\mathrm{NH}_{4}, \mathrm{NO}_{3}$, organic $\mathrm{N}$

Seepage from manure storage, $\mathrm{NH}_{4}$, organic $\mathrm{N}$

Field application of manure, $\mathrm{NH}_{4}$, organic $\mathrm{N}$

Fertilizers applied to crops, $\mathrm{NH}_{4}, \mathrm{NO}_{3}$

Fertilizers applied to lawn and garden, $\mathrm{NH}_{4}, \mathrm{NO}_{3}>$

Nitrogen fixation, $\mathrm{NH}_{4}$

Other sources

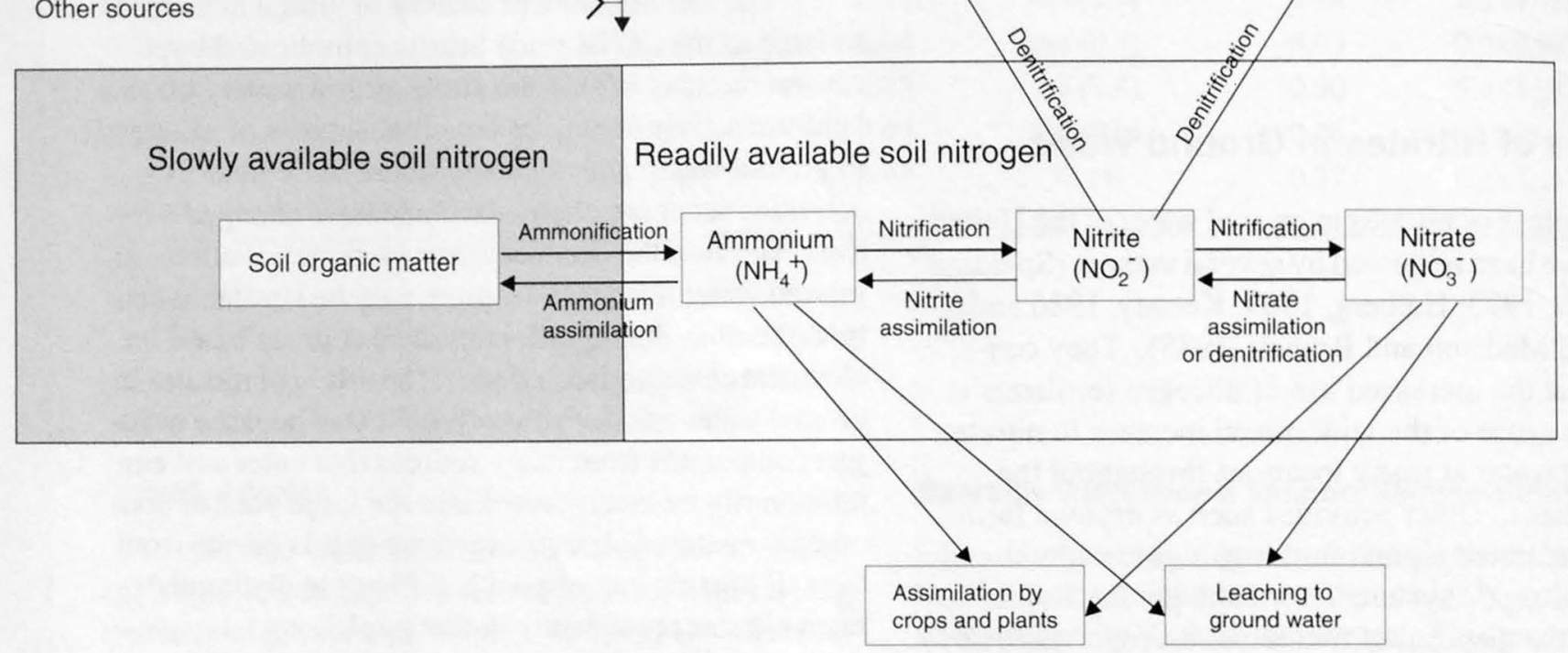

\section{Major Nitrogen Transformations}

Ammonification: microbial decomposition of organic matter resulting in production of ammonia.

Assimilation: incorporation into organic forms of nitrate, nitrite and ammonia into microorganisms and plant tissues.

Nitrogen fixation: microbial reduction of nitrogen gas to ammonia and organic nitrogen
Nitrification: microbial oxidation of
ammonia producing nitrite and nitrate.

Denitrification: microbial reduction of nitrate producing nitrous oxide or nitrogen gas.

Soil organic matter: microorganism and plant tissues containing nitrogen and forming a large nitrogen reservoir, which undergoes heterotrophic cycling.

Figure 30. Simplified diagram showing biologically mediated nitrogen transformations in soils, showing major processes of nitrogen addition and removal from soils in parts of the LENS study area. 
Several environmental conditions within the study area are conducive to the migration of nitrates to ground water. Coarse-textured soils cover much of the study area, particularly overlying the Sumas aquifer, and have large hydraulic conductivities that permit relatively rapid percolation of water. Heavy precipitation from October to May generally is sufficient to permit yearly flushing of nitrogen through the unsaturated zone. Large quantities of nitrogen are continually being added to soils throughout the study area. Consequently, the presence of large nitrate concentrations in ground water of the Sumas aquifer is not unexpected. Nitrate concentrations in ground water of the Sumas aquifer are similar to concentrations in ground water in other parts of the United States where either extensive agricultural activities or numerous septic systems occur.

\section{Estimates of Nitrate Loading From Individual Nitrate Sources}

A qualitative estimate of the annual nitrate loading to ground water was made for part of the study area. The estimate was based on yearly amounts of nitrogen applied to soils of the study area and an estimate of the fraction of that nitrogen that is leached by percolating recharge. Estimates of the quantity of nitrate reaching the aquifer from different nitrogen sources within the study area are useful in determining the relative contribution from these sources. In spite of limitations described below, qualitative estimates of nitrate loading of ground water can provide organizational and conceptual models to gage the relative importance of different nitrate sources and components of the soil nitrogen cycle that affect the nitrogen content of ground water.

An extensive review by Legg and Meisinger (1982) of soil nitrogen budget studies indicated that while these studies have provided substantial insights into processes affecting soil nitrogen transformations, difficulties often occurred in quantifying the amount of nitrogen following each of the individual nitrogen pathways. In particular, difficulties often were encountered when distinguishing between losses due to denitrification or to leaching to ground water. Labelled nitrogen studies using different isotopes of nitrogen have been useful in quantifying soil nitrogen losses but are generally limited to small study plot areas. Nitrogen budgets that examine both inputs and outputs of nitrogen have been used with some success to examine the effects of nitrogen management on nitrate concentrations in ground water at the scale of individual farms (Hall and Risser, 1992) and to estimate the concentration of nitrate in ground water beneath croplands (Barry and others, 1993). Nitrogen budget studies on the scale of entire watersheds have been hampered by uncertainties and limited to qualitative estimates (Kohl and others, 1978, and Viets, 1978).

Because land-use data was limited for the study area in British Columbia, nitrate loading was estimated only for the Whatcom County portion of the study area. The sources of nitrate considered were limited to processes and or activities that are present throughout much of the study area and did not include potential small-scale point sources. Estimates were made of the annual loading of nitrogen from the following nitrate sources: atmospheric deposition, irrigation water, inorganic fertilizers applied to croplands, septic tanks, lawn fertilizers, seepage from manure storage lagoons, land application of manures, nitrogen from legumes, and mineralization of soil organic matter. Data used to estimate the nitrogen loading to the soil zones were physical features of the study area such as the number of acres of corn, the number of cows, and the number of people, which are tabulated in table 17. After the processes that affect each source were considered, an estimate was made of the percentage of nitrate nitrogen from that source that would be leached from the soil zone to ground water (table 18). The estimates of nitrate entering the ground water, which are subject to greater uncertainty than the estimate of nitrogen loading to the soil system, are based largely on the extensive literature of nitrogen in agricultural soils, much of which is reviewed by Stevenson (1982).

Data used in developing the estimates of nitrate loading were acquired through public records, discussions with agricultural extension agents working within the area, information from other nitrate studies, and data collected for this study. In many cases, individual data values of nitrate-loading parameters, such as concentration of nitrogen in rainwater, septic tank effluent, or manure slurry, covered a wide range of values. An attempt was made to select a value that would best represent the parameter for the entire area, or a weighted average was used. The information, procedures, and rationale used in developing the nitrate loading estimate are outlined in table 17 and described in subsequent text. 
Table 17. Estimates of annual amounts of nitrogen applied and deposited in the Whatcom County portion of the Lynden-Everson-Nooksack-Sumas study area, Whatcom County; Wash., and British Columbia, Canada [mg/L, milligrams per liter; $\mathrm{N}$, nitrogen]

\section{$\underline{\text { Areas }}$}

Total area of study area

Subarea of study area within Whatcom County

144,000 acres
110,000 acres
86,000 acres
70,000 acres
10,000 acres
35,000 acres
37,000 acres
9,000 acres
21,000 acres
1,625 acres

Sumas aquifer area within Whatcom County

Commercially farmed area

Non-commercially farmed areas

Irrigated area (50 percent of commercially farmed area)

Dairy farm land base in Whatcom County subarea

Urban/suburban area

Undeveloped/wood and brushland

Cultivated residential lawns and garden

1,625 acres

\section{Precipitation and applied irrigation water}

Precipitation

Less 15 percent for direct runoff

Precipitation that infiltrates soil

Irrigation
41 inches over 110,000 acres

12 inches over 35,000 acres
376,000 acre-feet 56,000 acre-feet 320,000 acre-feet 35,000 acre-feet

\section{Nitrogen in wet deposition}

The concentration of nitrogen in precipitation is the sum of the precipitation-weighted mean of nitrate and ammonia. Estimate is the average of samples collected for National Atmospheric Deposition Program 1989-1990 at Hoh Ranger Station, Le Grand, and Marblemont, Washington.

$$
(320,000 \text { acre-feet })\left(0.26 \mathrm{mg} / \mathrm{L} \mathrm{NO}_{3} \text { as } \mathrm{N}\right)=226,000 \text { pounds } \mathrm{NO}_{3} \text { as } \mathrm{N}
$$

\section{Nitrogen in dry deposition}

\section{Regional}

Dairy landbase
$(110,000$ acres $)(1.0$ pounds $\mathrm{N}$ per acre $)=110,000$ pounds $\mathrm{NO}_{3}$ as $\mathrm{N}$

$(37,000$ acres $)(15$ pounds- $\mathrm{N}$ per acre $)=550,000$ pounds $\mathrm{NO}_{3}$ as $\mathrm{N}$

\section{Nitrogen in irrigation water}

The concentration of nitrogen in irrigation water is the median concentration in ground water from the Sumas aquifer.

$$
(35,000 \text { acre-feet })\left(3.8 \mathrm{mg} / \mathrm{L} \mathrm{NO}_{3} \text { as } \mathrm{N}\right)=362,000 \text { pounds } \mathrm{NO}_{3} \text { as } \mathrm{N}
$$

\section{Nitrogen mineralized from soil organic matter}

(70,000 farmed acres) (195 pounds $\mathrm{NO}_{3}$ as $\mathrm{N}$ per acre) $=13,600,000$ pounds $\mathrm{NO}_{3}$ as $\mathrm{N}$ 5 percent of total leached to ground water $=680,000$ pounds $\mathrm{NO}_{3}$ as $\mathrm{N}$ 
Table 17. Estimates of annual amounts of nitrogen applied and deposited in the Whatcom County portion of the Lynden-Everson-Nooksack-Sumas study area, Whatcom County, Wash., and British Columbia, Canada--Continued

Application of inorganic nitrogen fertilizer

\begin{tabular}{|c|c|c|c|c|}
\hline$\underline{\text { Crop }}$ & Acreage & $\begin{array}{l}\text { Percent of crop- } \\
\text { land fertilized } \\
\text { each year } \\
\end{array}$ & $\begin{array}{l}\text { Fertilizer applica- } \\
\text { tion rate (pounds } \\
\text { per acre) }\end{array}$ & $\begin{array}{l}\text { Total nitro- } \\
\text { gen applied } \\
\text { (pounds) }\end{array}$ \\
\hline Peas & 2,500 & 20 & 25 & 12,500 \\
\hline Carrots & 50 & 100 & 100 & 5,000 \\
\hline Potatoes (seed) & 1,000 & 100 & 70 & 70,000 \\
\hline Blueberries (mineral soil) & 100 & 100 & 100 & 10,000 \\
\hline Blueberries (peat soil) & 50 & 100 & 50 & 2,500 \\
\hline Raspberries & 2,500 & 100 & 80 & 200,000 \\
\hline Sweet corn & 300 & 100 & 125 & 37,500 \\
\hline Pasture/Hay (nondairy) & 10,000 & 25 & 45 & 112,000 \\
\hline Pasture (dairy) & 30,800 & 55 & 60 & $1,020,000$ \\
\hline Silage/feed corn (dairy) & 6,200 & 100 & 90 & $\underline{558,000}$ \\
\hline
\end{tabular}

\section{$\underline{\text { Residential fertilizer }}$}

Population 26,000 Residential cultivated acreage estimate to be 1,625 acres to which 200 pounds per acre is applied.

$(1,625$ acres $)(200$ pounds per acre $)=325,000$ pounds $\mathrm{N}$

\section{$\underline{\text { Nitrogen from septic system }}$}

Population in unincorporated portions of the LENS study area utilizing domestic septic system.

$$
1990 \text { Census } \quad 17,600
$$

Per capita nitrogen loading rate to soil, 10 pounds $\mathrm{N}$ per person, per year.

$(17,600$ persons) (10 pounds $\mathrm{N}$ per person $)=176,000$ pounds $\mathrm{N}$

Thirty-two percent of nitrogen retained in soil as organic nitrogen or volatilized as ammonia.

Per capita nitrate loading rate to ground water, 6.8 pounds per year.

$$
\text { (6.8 pounds } \left.\mathrm{NO}_{3} \text { as } \mathrm{N}\right)(17,600 \text { persons })=120,000 \text { pounds } \mathrm{NO}_{3} \text { as } \mathrm{N}
$$

\section{Nitrogen from dairy manure storage and handling applied to field}

Daily nitrogen production of manure from average dairy herd.

150 lactating cows

30 dry cows

20 immature
Nitrogen produced

(pounds per day)

94.5

15.1

8.7 
Table 17. Estimates of annual amounts of nitrogen applied and deposited in the Whatcom County portion of the Lynden-Everson-Nooksack-Sumas study area, Whatcom County, Wash., and British Columbia, Canada--Continued

Nitrogen from dairy manure storage and handling applied to field--continued

$$
\text { (308 farms) (118 pounds } \mathrm{N} \text { per day) (365 days) }=13,300,000 \text { pounds } \mathrm{N} \text { per year }
$$

70 percent of annual production of nitrogen in manures is lost to volatilization and denitrification during handling and application to field. Available nitrogen to field is 0.3 of total produced.

$$
(13,300,000 \text { pounds })(0.3)=3,990,000 \text { pounds } \mathrm{N}
$$

Nitrogen from poultry manure storage, handling, and application to fields

$$
\text { (900,000 broilers) (50 days) } \frac{1.1 \text { pounds } \mathrm{N}}{1,000 \text { broiler } \bullet \text { days }}=50,000 \text { pounds } \mathrm{N}
$$

50 percent of annual production of nitrogen is lost to volatalization and denitrification during handling, storage, and application to field. Available nitrogen is 0.5 of total produced.

$$
\text { ( } 50,000 \text { pounds) }(0.5)=25,000 \text { pounds } \mathrm{N}
$$

\section{Nitrogen from seepage of ammonia from dairy manure lagoon}

85 percent of dairies estimated to have earthen lagoons

Average surface area of lagoon 30,000 square feet (2,790 square meters)

Seepage rate $\approx 1$ millimeter per day $\approx 0.365$ meter per year

Ammonia concentration 7 pounds per 1,000 gallons $\approx 840$ milligrams per liter

$=(2,790$ square meters) ( 0.365 meter per year) ( 1,000 liters per cubic meter) ( 840 milligrams per liter)

$\left(2.2 \times 10^{-6}\right.$ pounds per milligram $)=1,880$ pounds per year-dairy $)$

$(1,880$ pounds per year-dairy) (308 dairies $x 0.85)=492,000$ pounds $N$ per year 
Table 18. Estimate of annual amount of nitrogen loading to soils and nitrate entering the ground-water system in the Whatcom County portion of the study area $[--$, not applicable; $<$, less than $]$

\begin{tabular}{|c|c|c|c|c|c|}
\hline $\begin{array}{l}\text { Natural processor } \\
\text { land-use activity }\end{array}$ & $\begin{array}{l}\text { Nitrogen } \\
\text { deposited, } \\
\text { applied, or } \\
\text { released } \\
\text { to soils } \\
\text { (pounds) }\end{array}$ & $\begin{array}{l}\text { Fraction } \\
\text { of nitrogen } \\
\text { transported } \\
\text { to ground- } \\
\text { water } \\
\text { system }\end{array}$ & $\begin{array}{l}\text { Nitrogen } \\
\text { entering } \\
\text { ground- } \\
\text { water } \\
\text { system as } \\
\text { nitrate } \\
\text { (pounds) }\end{array}$ & $\begin{array}{l}\text { Percentage } \\
\text { of total, } \\
\text { including } \\
\text { mineral- } \\
\text { ization } \\
\text { of soil } \\
\text { organic } \\
\text { matter }\end{array}$ & $\begin{array}{l}\text { Percentage } \\
\text { of total, } \\
\text { excluding } \\
\text { mineral- } \\
\text { ization } \\
\text { of soil } \\
\text { organic } \\
\text { matter }\end{array}$ \\
\hline \multicolumn{6}{|c|}{ Natural sources } \\
\hline Precipitation, wet & 226,000 & 0.50 & 113,000 & 3.2 & 3.9 \\
\hline Precipitation, dry & 110,000 & 0.40 & 44,000 & 1.2 & 1.5 \\
\hline Legumes, (alder) & -- & -- & 75,000 & 2.1 & 2.6 \\
\hline
\end{tabular}

\begin{tabular}{ll} 
Septic tank effluent & 176,000 \\
Fertilizers, lawns, and gardens & 325,000 \\
\hline
\end{tabular}

Residential sources

$\begin{array}{lrrr}0.68 & 120,000 & 3.4 & 4.2 \\ 0.25 & 81,200 & 2.3 & 2.8\end{array}$

Redeposition of nitrogen
volatilized from manure

Agricultural sources

\begin{abstract}
volatilized from manure
\end{abstract}
Irrigation

550,000

0.40

220,000

6.2

7.6

Mineralization of

soil organic matter

$13,600,000$

0.05

680,000

19

Inorganic nitrogen

fertilizers

$2,030,000$

0.25

508,000

14

18

\title{
Manure storage
}

(lagoon leakage)

492,000

0.85

418,000

12

14

Manure applied to

cropland, dairy

cropland, poultry

$\begin{array}{rr}3,990,000 & 0.30 \\ 25,000 & 0.30\end{array}$
$1,200,000$
7,500

34

42

.30

$<1$

$<1$

Legumes, (peas)

$-$

10,000

$<1$

$<1$

TOTAL

$21,900,000$

$3,570,000$ 
A check of the loading estimates was calculated from the combined nitrate-loading estimate and the estimate of ground-water recharge. The resulting concentration was compared to median nitrate concentrations observed in samples of ground water. The equation used to compute the average nitrate concentration in shallow ground water is expressed as

\section{Concentration of nitrate $=$ Annual load of nitrogen \\ Annual volume of recharge}

This relation between concentrations, nitrogen load, and recharge assumes that (1) the flux of water into the ground-water system is entirely recharge, as opposed to inflow from adjacent or deeper ground water; (2) the annual average concentrations of nitrate in ground water do not change with time (which implies that the system is in steady state); and (3) all of the nitrogen leached to ground water is in the form of nitrate or is converted to nitrate. These assumptions are largely true for the study area, although none are completely valid; nevertheless, the computations are still useful to check the loading values.

\section{Nitrogen from Atmospheric Deposition}

Nitrogen inputs to soils from atmospheric deposition are ubiquitous across the study area. Atmospheric deposition includes precipitation, or wet deposition, and dry deposition, which includes particulate fallout and sorption of gaseous materials. Nitrogen loading from precipitation was calculated from an areaweighted volume of precipitation and the precipitationweighted mean concentration of nitrate and ammonia in precipitation. The concentration of nitrate and ammonia used for these calculations was the average concentration from the three precipitation chemistry stations located in western Washington that are operated by the National Atmospheric Deposition Program. Average concentration data and depositional rates for these stations (table 16) show that nitrogen (ammonia plus nitrate) concentrations range from 0.1 to $0.4 \mathrm{mg} / \mathrm{L}$, with an average of $0.26 \mathrm{mg} / \mathrm{L}$, and that annual depositional rates at the rain gage locations vary from 2.7 to 5.8 pounds per acre.

The average precipitation for the part of the study area located in Whatcom County is about 41 inches per year, which generates a volume of 376,000 acre-feet of precipitation. Using an average nitrogen concentration of $0.26 \mathrm{mg} / \mathrm{L}$ in precipitation, the gross yearly wet precipitation nitrogen input to the land surface is 266,000 pounds. Direct surface runoff from glacial outwash in the Puget Sound region is small (Dinicola, 1990 and R. Dinicola, U.S. Geological Survey, oral commun., 1994), and is estimated to remove 15 percent of the total precipitation, resulting in the deposition of 226,000 pounds of nitrogen or 2.05 pounds of nitrogen per acre. Some of the nitrogen in the precipitation that enters soil will be taken up by plants; however, in the study area, most of the nitrogen deposition associated with precipitation will occur during the winter and early spring when the plants are less active and likely to assimilate less nitrogen. Accordingly, half of the nitrogen in regional precipitation entering the soil profile is estimated to move through it and eventually reach the ground-water system. Thus about 42 percent of the total nitrogen in precipitation falling on the study area is estimated to reach ground water.

Dry deposition, which includes particulate fallout, submicron particle deposition to vegetation, water, or bare ground, and gaseous adsorption and absorption, has been shown to make a measurable contribution to nitrogen deposition in some areas (Dasch and Cadle, 1985). Because there are many avenues of dry deposition, it is difficult to measure. Sisterson (1990) estimates that regionally for western Washington, dry deposition is about 46 percent of wet deposition or about 1 pound per acre, which results in 110,000 pounds for the subarea. However, additional dry deposition is expected in areas where substantial amounts of manures are present due to volatilization of a large fraction of the ammonia in manures (Ivens and others, 1988). Sanderson and LaValle (1979) found that bulk deposition (combined wet and dry) at six farm sites in southern Ontario was 30 to 37 pounds of nitrogen per acre. In the dairy and agricultural region of southern Ontario, Barry and others (1993) estimated that dry deposition of nitrogen ranged from 5.9 to 15 pounds per acre and made up 44 to 55 percent of the bulk atmospheric nitrogen across the region. Similar rates were found by Goulding (1990) on adjacent farm lands in southern England. Barry and others (1993) suggest that nitrogen deposition on farms where large volumes of manure are susceptible to volatilization should include from 13 to 19 pounds of nitrogen per acre for dry redeposition of nitrogen resulting from manure volatilization.

Within the study area in Whatcom County, there were 308 dairies that annually generate approximately 13 million pounds of nitrogen in manure. 
Approximately 70 percent of the nitrogen in manure is estimated to volatilize to the atmosphere; the portion that is redeposited is not well known. Based on the research of Sanderson and LaValle (1979) and of Goulding (1990), a minimum estimate of the redeposition of manure-volatilized nitrogen would be 15 pounds per acre, which would apply to the 37,000 acres of the dairy land base. This would result in the deposition of 550,000 pounds of nitrogen or about 6 percent of the estimated volatilized nitrogen from manure. Manure spreading is reported year round but is more frequent during the growing season. Thus a large percentage, on the order of from 30 to 50 percent, of the nitrogen in dry deposition resulting from manure volatilization may be assimilated by plants and less likely to reach the ground-water system. As such, only 40 percent of the manure based redeposition of nitrogen is estimated to reach the ground-water system as nitrate.

\section{Nitrogen from Irrigation Water}

Nitrogen loading from irrigation water was calculated from the concentration of nitrate in ground water used for irrigation and from the estimated volume of irrigation water applied to croplands. Roughly half of the area farmed in the study area, or about 35,000 acres, is irrigated. Whatcom County Conservation District's survey of on-farm irrigation indicated that 35 percent of the irrigators in the study area reported that they apply about 7 to 9 inches of irrigation water, whereas previous estimates of irrigation water use had been 18 inches (Bierlink, 1994). The recommended irrigation water use for the study area for pasture, corn, and raspberries is 13,10 , and 11 inches of irrigation water, respectively. Based on these values, a value of 12 inches of irrigation water was used to estimate nitrate loading. Because most of the irrigation water is taken from ground water, the concentration of nitrate in irrigation water used in the loading estimate is the median concentration observed in water samples collected from the Sumas aquifer, which is $3.8 \mathrm{mg} / \mathrm{L}$. Irrigators using stream water rather than ground water are expected to have similar nitrate concentrations because much of the streamflow during irrigation season (July-September) is derived largely from discharging ground water. The resulting annual loading from irrigation water is estimated to be about 10 pounds per acre in the irrigated parts of the subarea, totaling 362,000 pounds (table 17). The percentage of nitrogen in irrigation water eventually reaching ground water is considered similar to the percentage for fertilizers, which is estimated to be 25 percent, or in other words, a loading of 90,400 pounds to the ground-water system.

\section{Nitrogen from Septic Tanks}

Because septic tanks are used for the disposal of domestic waste water throughout most of the unincorporated parts of the study area, nitrogen loading from septic tanks was calculated by estimating the number of people in the unincorporated part of the study area in Whatcom County and also estimating the per capita load of nitrate transported to ground water from septic tank effluent. The population in the unincorporated part of the study area within Whatcom County was based on the 1990 census and estimated to be 17,600 individuals (Diane Harper, Whatcom County Planning Department, written commun., 1992). The per capita total nitrogen load rate of septic systems to the soils was calculated from estimates of the per capita volume and the total nitrogen content of septic tank effluent. The estimate of the daily volume of waste water leaving septic tanks ranged from 40 to 80 gallons per person (Cantor and Knox, 1986; Porter, 1980; and Reddy and Dunn, 1984). For this study, the per capita volume used was 60 gallons per day. Measurement of the total nitrogen concentration of septic tank effluent ranged from 30 to $90 \mathrm{mg} / \mathrm{L}$ (Dudley and Stephenson, 1973; Porter, 1980; Alhajjar and others, 1987; and Cantor and Knox, 1986). The concentration of total nitrogen in septic tank effluent used in this study was $55 \mathrm{mg} / \mathrm{L}$, which resulted in a yearly septic loading rate of 10 pounds per person or 176,000 pounds of nitrogen per year deposited to soils within the study subarea.

Ammonia generally makes up more than 75 percent of the total nitrogen in septic tank effluent, and the remaining 25 percent is largely organic nitrogen. Organic nitrogen generally is retained in the soil absorption field, while the ammonia fraction is converted to nitrate and percolates to the ground-water system. Walker and others (1973a, b) and Dudley and Stephenson (1973) concluded that in coarse-textured, well-aerated soils such as those that overlie much of Sumas aquifer, complete conversion of ammonia to nitrate is expected in the immediate vicinity of the soil absorption trench, resulting in little or no denitrification or absorption of ammonia. The result is that most of the ammonia nitrogen in the septic tank effluent is destined to enter the ground-water system and that dilution is the primary mechanism for reducing nitrate 
concentrations. In the estimates used for this study, 10 percent of the ammonia fraction is allowed to undergo denitrification. Thus, the septic loading to ground water was derived from septic tank loading estimates to soil (listed in table 18) being reduced by 25 percent to account for the retention of organic nitrogen in the soil zone and the remaining fraction is further reduced by 10 percent to account for possible denitrification that may occur in areas underlain with a greater amount of fine sediment. The resulting estimate of nitrate that reaches ground water was 120,000 pounds or about 68 percent of the 176,000 pounds of nitrogen added to soils. This equates to an annual per capita loading rate of 6.8 pounds.

\section{Nitrogen from Inorganic Fertilizers}

Inorganic nitrogen fertilizers are applied to many crops grown in the study area. Estimates of applied nitrogen fertilizer were made following discussions with personnel from the Natural Resources Conservation Service and the Washington State University Extension Service to determine crop acreage and fertilizer application rates. These data for 78 percent of the farmed area within the Whatcom County subarea of the study area are listed in table 17. A total of $2,030,000$ pounds are estimated to be applied annually. These values may be considered low since no estimate of fertilizer application was made for about 20 percent of the farmed areas. In addition, no fertilizer application estimates were made for nurseries or golf courses, several of which are present in the area.

Studies that addressed the leaching of applied nitrogen fertilizers to ground water were included in a review by Legg and Meisinger (1982) of research examining soil nitrogen budgets. The results showed that the percentage of nitrogen applied that leached to ground water was quite variable, ranging from 0 to 102 percent. However, the typical range was from 25 to 50 percent. Factors that appear to govern the leaching of nitrogen fertilizers to ground water are the amount of inorganic nitrogen present in the soil zone, the amount of water percolating through the soil zone, the soil texture, the depth of the root zone, and the depth to the water table. In the loading estimates in table 18, 25 percent of the total amount of inorganic fertilizer applied to fertilized cropland was assumed to leach to ground water, which results in an average of 16.9 pounds per acre over 30,140 acres or 508,000 pounds for the area (table 18).
Residential fertilizer use was based on a popula tion of 26,000 maintaining 1,625 acres of cultivated lawns and gardens. Morton and others (1988) report that home owner and commercial domestic lawn fertil. izer application rates range from 110 to 260 pounds pe acre. Many of the lawns in the area are well maintained. Based on this information, an application rate of 200 pounds per acre was used to estimate residentia fertilizer applications. Twenty-five percent of the nitrogen applied was estimated to be transported to ground water.

\section{Nitrogen from Livestock Manures}

Large quantities of manure are generated by the numerous dairy and poultry farms located within the study area. Most manure is disposed of by spreading on cropland, where some of its nutrient value can be utilized by crops. Nitrogen in manure, which is largely in either the ammonia or the organic nitrogen form, can be lost by either volatilization, denitrification, or leaching. Ammonia is easily volatilized if not incorporated into soils and generally must be mineralized before it can be either used by plants or leached from the soil. Volatilization of ammonia is largely a physical process and will occur at a greater rate in warm or windy conditions. Mineralization of organic nitrogen to nitrate is a microbial process and is reduced but not stopped during the cooler winter periods. Nitrates, which will continue to be mineralized during this period when they cannot be utilized by crops, are subject to an increased probability of leaching. Since it is common practice for most lagoons to be emptied before winter to provide storage during the winter rainy period, there may be a large potential for any nitrates mineralized during the winter from the manure spread on fields to be leached to below the root system before crops can utilize the nutrients.

Estimates of nitrogen applied to soils of the study area from dairy manure are based on the average herd made up of 150 lactating, 30 nonlactating, and 20 immature cows and the number of dairies (308) (table 17; John Gillies, Natural Resources Conservation Service, written commun., 1993). On the basis of average nutrient production figures (U.S. Department of Agriculture, Soil Conservation Service, 1992a) a herd of this makeup will generate manure with roughly 118 pounds of nitrogen per day. Thus for the area which has 308 dairy herds, the yearly quantity of dairymanure nitrogen produced will be 13,300,000 pounds of nitrogen. This manure was spread on approximately 
37,000 acres of cropland. Nitrogen in dairy manure operations such as used in Whatcom County can be educed by 50 to 80 percent due to volatilization and denitrification (U.S. Department of Agriculture, Soil Conservation Service, 1992a). For this study a 70 percent reduction was used; seventy percent of the $13,300,000$ pounds of dairy-produced nitrogen is estimated to be lost by these processes, leaving 3990,000 pounds (table 17) of nitrogen incorporated into the soils of croplands. While the manure is applied tocropland for its nutrient value, it is primarily applied as a method of disposal. Compared to fertilizer applied for the same purpose, more of the nitrogen in manure may be lost to leaching because the manure is applied at times when it cannot be fully utilized by crops. This is particularly true of the manure that is spread in the fall. Consequently, it is estimated that 30 percent of the nitrogen in manure applied to croplands or $1,200,000$ pounds (table 18) reaches the groundwater system.

Poultry farming in Whatcom County has declined over the last 10 to 20 years. In 1990 , 1.8 million broilers were raised in Whatcom County, according to the Washington Agricultural Statistics Service (1991). About half of these chickens were raised within the study area. Broilers have a life span of about 7 weeks (50 days) and produce 1.1 pounds of nitrogen per day per 1,000 broilers (U.S. Department of Agriculture, Soil Conservation Service, 1992a). The yearly quantity of nitrogen produced is about 50,000 pounds; however, volatilization and denitrification probably reduce this number by about 50 percent, leaving about 25,000 pounds added to the soil (table 17) of which 30 percent is leached to ground water for a final loading of 7,500 pounds (table 18). The percentage reaching the ground-water system is estimated to be similar to that for dairy manures.

Earthen-lined manure storage basins, commonly referred to as manure lagoons, are used in about 85 percent of the dairies in the study area to temporarily store animal waste and waste water before they are applied to cropland. Seepage from dairy lagoons has been shown to result in elevated ground-water concentrations of chloride and nitrate in studies in Wisconsin (Bickford, 1983 and Cates, 1983) and near two lagoons located in the study area (Erickson, 1991 and 1992). Lagoons are used throughout the year and are partially emptied in the fall to provide maximum storage during the rainy winter season when the potential for surface nunoff is greatest. Past studies have reported that settled solids and a microbial mat form a physical barrier along the interface of the manure slurry and the walls and bottom of the lagoon structure (Roswell and others, 1985; Miller and others, 1985; Davis and others, 1973). Estimates of seepage rates from these and other studies (Reese and Loudon, 1983; DeTar, 1979; Barrington and Jutras, 1983; and Phillips and Culley, 1985 ) indicate that seepage rates vary from less than $0.1 \mathrm{~mm} /$ day (considered to be effectively sealed) up to $5 \mathrm{~mm} /$ day. However, even at optimum sealing, seepage rates on the order of $0.1 \mathrm{~mm} /$ day can be expected (Barrington and Jutras, 1983) and can result in significant quantities of nitrogen being transported to the subsurface (Culley and Phillips, 1989, and Dalen and others, 1983).

For this study, the seepage rate for lagoons is estimated to be 1 millimeter or 0.04 inches per day. The average surface area of earthen dairy lagoons in the study area is 30,000 square feet. Ammonia is the predominant form of nitrogen in lagoon seepage. Ammonia concentrations in samples collected from 25 lagoons are about $840 \mathrm{mg} / \mathrm{L}$ or about 7 pounds per 1,000 gallons (John Gillies, Natural Resources Conservation Service, written commun., 1993). The resulting estimate of nitrogen applied to soils from lagoon seepage is 492,000 pounds per year (table 17). Denitrification in the unsaturated zone is estimated to reduce this amount by 15 percent, resulting in 418,000 pounds of nitrogen entering the ground-water system (table 18).

\section{Nitrogen from Legumes}

Peas, clover, and red alder are leguminous plants common in the study area. Peas are a minor crop, covering about 2,000 acres; clover and red alder are prominent components of the extensive pasture and woodlands. Red alder stands cover about 15,000 acres. Symbiotic bacteria associated with these legumes are capable of nitrogen fixation and can contribute nitrogen to the reservoir of soil organic matter. The quantity of nitrogen added to soils varies with plant species; red alder may contribute about 50 pounds of nitrogen per acre per year, whereas clover can add in excess of 250 pounds per acre per year. However, legumes generally do not produce more nitrogen than can be used by the host plant, and most of the nitrogen is retained in the plant until the plant is significantly disturbed, such as during harvesting or deforestation activities, at which time significant quantities of nitrogen may be released (Bormann and Likens, 1981). Nitrate concentrations ranging from 0 to $40 \mathrm{mg} / \mathrm{L}$ have been found in soil 
solutions beneath stands of red alder (Compton and Cole, 1993; Van Miegroet and Cole, 1985), suggesting that some leaching of symbiotically fixed nitrogen to ground water does occur beneath red alder stands.

The extent to which legumes are a potential source of nitrates in ground water in the study area is not well known. Pasture lands within the study area are routinely cropped, and most of the nitrogen fixed by legumes is believed to be tied up in the harvested biomass. If the 17,000 acres of peas and alder were to contribute nitrate to the ground-water system on the order of 5 pounds per acre, the total contribution from legumes would be 85,000 pounds, which would make up roughly 2.5 percent of the total nitrate load to the ground water.

\section{Nitrogen from Soil Organic Matter}

Soil organic matter, composed of material from plants and bacteria, is a large reservoir of nitrogen within soils. Many soils in the study area are reported to contain from 3 to 9 percent soil organic matter (table 1) in the upper 6 to 12 inches of the soil profile (U.S. Department of Agriculture, 1992b). Nitrogen typically makes up about 5 percent of soil organic matter; the nitrogen content of a soil to a depth of 40 inches can range from 6,600 to 200,000 pounds per acre (Severson and Shacklette, 1988). The amount of nitrogen that would be present in the upper foot of a soil with 5 percent organic matter and bulk density of 1.1 would be about 7,400 pounds per acre.

Nitrogen released from soil organic matter via mineralization forms nitrate, which is mobile and susceptible to leaching to ground water. Conversely, nitrate can be immobilized by being incorporated into plant and bacterial biomass. Agricultural cultivation results in large initial releases of soil nitrogen through mineralization (Reinhorn and Avnimelech, 1974; Keeney and Bremner, 1964). However, following a period of initial nitrogen loss, soil nitrogen level stabilizes within 20 to 80 years, more rapidly in soils amended with manure (Stevenson, 1982). Since much of the study area was initially cultivated following deforestation in the late 1800's (Mangum and Hurst, 1907) and manure is widely applied to much of the cultivated soils, it is probable that the annual rate of mineralization of soil nitrogen in Whatcom County soil is now fairly constant.

The amount of nitrogen mineralized and immobilized is difficult to determine. The process of mineralization of soil organic nitrogen is mediated by bacteria, and the rate depends in large part on soil temperature and moisture. Mineralization is believed to be a year-round process in areas such as the Puget Sound that do not experience severe cold winters, although larger amounts of nitrogen are mineralized during warm moist summer periods. Estimates of yearly mineralization within the lower Puget Sound area and near the Fraser-Whatcom Lowland range from 150 to 240 pounds per acre per year (Dan Sullivan, Washington State University Extension, written commun., 1993, and Grant Kowalenko, Agriculture Canada, written commun., 1992). Most of the nitrate mineralized during the growing season is incorporated into plant material and soil biomass; however, if nitrate is mineralized during the winter period when plant growth is at a minimum and soil water percolation at a maximum, it may be transported to ground water.

A simplifying assumption proposed by Fried and others (1976) contends that under conditions of continued agricultural practices the rates of mineralization and immobilization should become equal and thus there would be no net contribution from soil organic matter to nitrate leached to ground water. This rationale was adopted by Barry and others (1993) in their estimate of ground-water nitrate concentrations based on whole farm nitrogen budget.

For this study, two cases have been evaluated-one in which the net mineralization is zero, as assumed by Barry and others (1993), where none of the soil nitrogen mineralized is leached to ground water and the other in which net mineralization reaching the groundwater system is 5 percent of the total nitrogen mineralized. The mineralization rate of 195 pounds of nitrogen per acre was used to estimate nitrogen loading to soils for the 70,000 acres of commercially farmed area resulting in a total of $13,600,000$ pounds of nitratenitrogen released within the soil (table 17). Five percent of the mineralized nitrogen is presumed to be leached to ground water as 680,000 pounds of nitrate (table 18).

\section{Estimate of Nitrogen Loading to Ground Water}

Estimates of nitrate inputs to ground water from different sources are summarized in table 18. Within the subarea the total annual nitrate loading to ground water is 3.7 million pounds of nitrogen. The weighted recharge estimate for the subarea is 20.1 inches per year over 110,000 acres, which is equivalent to 
184,000 acre-feet. The resulting nitrate concentration computed from the mass of nitrate entering ground water and volume of ground-water recharge is $7.4 \mathrm{mg} / \mathrm{L}$ nitrate as $\mathrm{N}$; if there is no net input from the mineralization of soil organic matter, the calculated concentration is reduced to $6.0 \mathrm{mg} / \mathrm{L}$.

The computed loading concentrations are five to six times larger than median nitrate concentrations $(1.2 \mathrm{mg} / \mathrm{L})$ observed in all samples collected in the subarea for which nitrogen loading estimates were compiled; however, those samples include many from wells that were screened in parts of the aquifer distant from recently recharged ground water or from areas where nitrate was unstable because of the surrounding geochemical environment. A more reasonable comparison might be to limit measured nitrate concentrations to shallow (depth less than 50 feet) wells in the Sumas aquifer for which the ground water was oxygenated (dissolved-oxygen concentration greater than or equal to $1 \mathrm{mg} / \mathrm{L}$ ). Nitrate concentration in this group of wells covers the range from the detection limit to $43 \mathrm{mg} / \mathrm{L}$, and has a median concentration of $6.7 \mathrm{mg} / \mathrm{L}$. While this concentration agrees closely with the calculated concentration based on the nitrogen loading from the soil, it should not be considered confirmation of the exactness of those estimates, only that they are reasonable approximations.

These data suggest that about 18 percent of the flux of nitrogen in the soil zone ends up in the groundwater system. However, this estimate of loading is sensitive to the large component of mineralization of soil nitrogen that was estimated from uncertain data. When the mineralization figures are not included in the budget, then the nitrogen flux in the soil is 8.3 million pounds, with 2.9 million pounds leached to ground water. The estimate of nitrogen from soil mineralization makes up over 60 percent of the input to soils, but the flux of nitrogen that reaches ground water was limited to 5 percent. Clearly, additional data regarding soil mineralization rates in the Fraser-Whatcom Lowlands would improve estimates of soil nitrogen budgets in this area.

The estimates from individual sources have also been grouped into the following general categories in table 18--natural, residential, and agricultural sources. The total of natural and residential ground-water inputs of nitrates accounts for about 12 to 15 percent of the total nitrogen input. Agricultural activities, which are the predominant land use in about 75 percent of the study area and include the largest individual potential nitrate sources, account for about 85 to 88 percent of the total estimated nitrogen input to ground water. In the estimate made here, the largest single source of nitrate loading to ground water is the application of dairy manure to pastures and croplands, which is estimated to account for 34 percent of the total nitrate input; if nitrate inputs from mineralization are assumed to be zero, dairy manure applied to croplands accounts for 42 percent of the total nitrate load to ground water. Seepage from manure lagoons is estimated to contribute another 12 to 14 percent of the total nitrogen input, or about one-third of the loading resulting from land application of manure. Together, estimates of land applications and storage of dairy manures account for over half of the total input of nitrogen to ground water. Redeposition of volatilized nitrogen to land areas accounts for 6 to 8 percent, which is larger than either natural or residential sources. Residential activities, which account for about 6 percent of the land-use area, account for about 7 percent of the nitrate loading. Natural sources, which account for about 7 percent of the total nitrate loading, are largely distributed throughout the area because the largest natural nitrate source is precipitation. The area of alder woodlands, which accounts for about 13 percent of the study area, is estimated to account for only about 2 percent of the total nitrate loading.

In terms of the regional picture, the majority of nitrates found in the Sumas aquifer comes from agricultural activities. Although residential sources make up a much smaller percentage of the total nitrogen input to the subarea than agricultural sources, in areas where domestic wells are located, residential sources of nitrogen are often the closest potential nitrogen source and may have the greatest influence on nitrogen in domestic well water.

A general comparison between loading rates for residential and agricultural land use using the agricultural data and some assumed values for residential space utilization can be made. Yearly nitrate loading for the 70,000 acres of commercial agricultural areas was $3,130,000$ pounds or about 45 pounds per acre. Residential loading from septic systems and lawn or garden fertilization was estimated to range from 14 to 34 pounds per acre. Even though agricultural sources contribute nearly 10 times the quantity of nitrates to ground water than do residential sources, on a per-acre basis, the rates of nitrates entering ground water from agricultural sources are typically only 1.5 to 3 times greater than residential sources. 


\section{Nitrate-Related Water-Quality Characteristics}

Six water-quality constituents associated with nitrates in ground water were examined to try to determine the source of the nitrate present in ground water in the LENS study area. The six nitrate-related water-quality constituents were the ratio of stable nitrogen isotopes $\left(\delta^{15} \mathrm{~N}\right)$, and the concentrations of chloride, boron, MBAS, dissolved organic carbon, and dissolved oxygen. Because of the multiplicity of nitrate sources and the nonconservative nature of some of the waterquality constituents, this approach was not able to identify the individual sources of nitrates in ground water. However, these data were able to eliminate natural nitrate as a significant source of nitrate in the Sumas aquifer and confirmed that there are a variety of sources contributing to the presence of nitrates in ground water. In addition, the constituents MBAS and boron, which are commonly associated with domestic septage sources, were found to have the largest concentrations in ground water associated with dairy manure storage and application to fields and thus could not be used to discriminate between livestock and domestic septage sources of nitrogen.

These six parameters were selected because their concentrations have been shown to vary under differing hydrologic settings where nitrates were present and, with the exception of $\delta^{15} \mathrm{~N}$, they are often included in water-quality data collections. The expected range of concentrations for these constituents was based on previous ground-water investigations in the glacial aquifers in the Puget Sound and published investigations of nitrates in ground water, and are shown in table 19 , along with median concentrations measured in samples from shallow wells completed in the Sumas aquifer. Concentrations of these constituents are shown in table 20.

The ratios of stable nitrogen isotopes (referred to as $\delta^{15} \mathrm{~N}$ and reported in units of per mil using the symbol \%o, see the Appendix section for additional details) have been used in many studies to determine the source of nitrates in ground water (Kreitler and Jones, 1975; Kreitler and others, 1978; Gromly and Spalding, 1979; Spalding and others, 1982; Flipse and Bonner, 1985; and Heaton, 1986). The $\delta^{15} \mathrm{~N}$ in nitrogen-containing materials varies primarily because of isotopic fractionation in which certain chemical and biological reactions have proportionally accumulated more of the lighter isotope in the reaction product. As such, the $\delta^{15} \mathrm{~N}$ of inorganic nitrogen fertilizer typically ranges from -2 to $+2 \%$, whereas nitrogen in plant material is typically in the range of +4 to $+10 \%$, and animal matter ranges from +5 to $+20 \%$.

While a number of successful studies have used $\delta^{15} \mathrm{~N}$ in identifying nitrate sources in ground water, the method is not without limitations. Bacteria-mediated transformations of nitrogen occurring in the soil, unsaturated zone, and within the aquifer leads to additional fractionation, which can significantly alter the original characteristic $\delta^{15} \mathrm{~N}$ of the source material. Flipse and Bonner (1985) found that nitrate in shallow ground water beneath a fertilized golf course has an isotopic ratio of $\delta^{15} \mathrm{~N}=6.5 \%$, which is in the range of soil organic matter. Inorganic fertilizer, which was considered to be the source of the nitrates in the ground water, had a ratio of $\delta^{15} \mathrm{~N}=-5.9 \%$ indicating that there was substantial fractionation between the nitrate source and its appearance in ground water. Berndt (1990) also noted that further complications arise in situations where the nitrate in ground water is from multiple sources, which can result in a ground water $\delta^{15} \mathrm{~N}$ value intermediate between that of the source materials.

For this study, $\delta^{15} \mathrm{~N}$ was determined at 22 sites, and additional data were available for 10 of the 12 piezometers located near Abbotsford Airport (table $20)$. The $\delta^{15} \mathrm{~N}$ data ranged from +1.5 to $19 \%$. The $\delta^{15} \mathrm{~N}$ of the measured samples covers the entire range of potential nitrogen sources and likely includes the effects of mixing from multiple sources. However, samples in which $\delta^{15} \mathrm{~N}$ was less than $4.0 \%$ may largely originate from inorganic fertilizers. Two samples of ground water were collected adjacent to two dairy manure lagoons where seepage from the lagoons had been shown to impact ground water; the $\delta^{15} \mathrm{~N}$ of these samples was 7.2 and $7.4 \%$. The $\delta^{15} \mathrm{~N}$ in poultry manure from near the Abbotsford Airport was 7.9 to $8.6 \%$, while $\delta^{15} \mathrm{~N}$ of inorganic fertilizer was less than $0.0 \%$ (Leonard Wassenaar, Environment Canada, written commun., 1994).

While it was not possible to sort out the combined effects of denitrification and mixing, it is likely that samples in which the $\delta^{15} \mathrm{~N}$ is less than $4.0 \%$ are largely from fertilizer sources. Five of the $32 \delta^{15} \mathrm{~N}$ values shown in table 20 are less than $4.0 \%$; four of these were from pasture settings, and the other from berry or row crop areas. As shown in table 17, inorganic fertilizers are typically applied in these areas. Samples with $\delta^{15} \mathrm{~N}$ larger than $4.0 \%$ could be explained as either the result of mixed source material or the effects of denitrification. Evidence that denitrification is occurring is indicated by the increasing $\delta^{15} \mathrm{~N}$ 
Table 19. Characteristic ranges of selected water-quality constituents in ground waters containing nitrate from different sources and concentrations observed in wells in the Sumas aquifer

[Number in parentheses indicates number of wells sampled; >, greater than; < less than]

\begin{tabular}{|c|c|c|c|c|c|c|c|}
\hline $\begin{array}{l}\text { Nitrate } \\
\text { source }\end{array}$ & & $\begin{array}{l}\text { Nitrogen } \\
\text { isotopes } \\
\delta^{15} \mathrm{~N}-\mathrm{NO}_{3}{ }^{-} \\
\text {(per mil) }\end{array}$ & $\begin{array}{l}\text { Chloride } \\
\text { concentration } \\
(\mathrm{mg} / \mathrm{L})\end{array}$ & $\begin{array}{l}\text { Dissolved } \\
\text { oxygen } \\
(\mathrm{mg} / \mathrm{L})\end{array}$ & $\begin{array}{l}\text { Boron } \\
\text { concentration } \\
(\mathrm{mg} / \mathrm{L})\end{array}$ & $\begin{array}{l}\text { Methylene } \\
\text { Blue Active } \\
\text { Substances } \\
(\mathrm{mg} / \mathrm{L})\end{array}$ & $\begin{array}{l}\text { Organic } \\
\text { carbon } \\
(\mathrm{mg} / \mathrm{L})\end{array}$ \\
\hline
\end{tabular}

Characteristic range of water-quality constituents

\begin{tabular}{|c|c|c|c|c|c|c|}
\hline Inorganic fertilizer & $-2-+2$ & $>5$ & $>1$ & $<50$ & $<0.02$ & $<0.7$ \\
\hline Natural peat & $+2-+8$ & $<5$ & $<1$ & $<50$ & $<0.02$ & $>0.7$ \\
\hline Septic tanks & $+5--15$ & $>5$ & variable & $>50$ & $>0.02$ & $>0.7$ \\
\hline Barnyard manures & $+5-+18$ & $>5$ & variable & $<50$ & $<0.02$ & $>0.7$ \\
\hline
\end{tabular}

Median and range of concentration of water-quality constituents from Sumas aquifer wells with differing surrounding land use (number of data points in parenthesis)

\begin{tabular}{|c|c|c|c|c|c|c|}
\hline Undeveloped & $\begin{array}{l}8.5(4) \\
3.1-9.7\end{array}$ & $\begin{array}{r}7.0(6) \\
3.0-9.2\end{array}$ & $\begin{array}{l}2.5(5) \\
0.0-8.5\end{array}$ & $\begin{array}{l}<10(6) \\
<10-20\end{array}$ & $\begin{array}{r}<0.02(5) \\
<0.02-<0.02\end{array}$ & $\begin{array}{r}0.7(5) \\
0.2-1.4\end{array}$ \\
\hline Residential & $8.0(1)$ & $\begin{array}{r}11(7) \\
4.4-14\end{array}$ & $\begin{array}{l}6.8(7) \\
2.2-9.0\end{array}$ & $\begin{array}{r}20(7) \\
<10-120\end{array}$ & $\begin{array}{r}<0.02(7) \\
<0.02-0.06\end{array}$ & $\begin{array}{l}0.6(6) \\
0.3-1.2\end{array}$ \\
\hline Manure lagoon & $\begin{array}{l}7.3(2) \\
7.2-7.4\end{array}$ & $\begin{array}{l}54(4) \\
44-76\end{array}$ & $\begin{array}{c}0.1(4) \\
0.0-0.2\end{array}$ & $\begin{array}{l}50(4) \\
20-80\end{array}$ & $\begin{array}{r}0.05(4) \\
<0.02-0.09\end{array}$ & $\begin{array}{l}26(4) \\
21-39\end{array}$ \\
\hline Pasture and grasslands & $\begin{array}{l}6.8(9) \\
2.0-12\end{array}$ & $\begin{array}{r}10(27) \\
2.7-40\end{array}$ & $\begin{array}{r}3.2(26) \\
0.0-9.0\end{array}$ & $\begin{array}{r}15(24) \\
<10-120\end{array}$ & $\begin{array}{l}<0.02(27) \\
<0.02-0.04\end{array}$ & $\begin{array}{r}0.9(27) \\
0.3-5.1\end{array}$ \\
\hline Berry and rowcrops & $\begin{array}{r}7.3(15) \\
1.5-19\end{array}$ & $\begin{array}{l}9(18) \\
2.3-17\end{array}$ & $\begin{array}{r}7.6(18) \\
0.2-9.2\end{array}$ & $\begin{array}{r}<10(16) \\
<10-40\end{array}$ & $\begin{array}{r}<0.02(12) \\
<0.02-<0.02\end{array}$ & $\begin{array}{l}0.7(5) \\
0.6-1.1\end{array}$ \\
\hline
\end{tabular}


$\overrightarrow{\vec{N}}$ Table 20. Concentration of selected water-quality constituents and land use information

[P, pasture; B, berries; U, undeveloped woodlands or brushlands; L, manure lagoon; M, mixed; S, Sumas aquifer; E, Everson-Vashon hydrogeologic unit; V, Vashon hydrogeologic unit; PC, partially or completely confined condition; - - no data; $<$, less than]

\begin{tabular}{|c|c|c|c|c|c|c|c|c|c|c|c|c|c|c|}
\hline $\begin{array}{l}\text { Hydro- } \\
\text { geo- } \\
\text { logic } \\
\text { unit }\end{array}$ & $\begin{array}{l}\text { Local } \\
\text { identifier }\end{array}$ & $\begin{array}{l}\text { Well } \\
\text { depth } \\
\text { (feet) }\end{array}$ & $\begin{array}{l}\delta^{15} \mathrm{~N} \\
\text { isotope } \\
\text { ratio, } \\
\text { per mil }\end{array}$ & $\begin{array}{l}\text { Nitro- } \\
\text { gen, } \\
\mathrm{NO}_{2}+ \\
\mathrm{NO}_{3} \text {, } \\
\text { dissolved } \\
\text { (mg/L } \\
\text { as } \mathrm{N})\end{array}$ & $\begin{array}{l}\text { Nitro- } \\
\text { gen, am- } \\
\text { monia + } \\
\text { organic, } \\
\text { dissolved } \\
\text { (mg/L } \\
\text { as } \mathrm{N} \text { ) }\end{array}$ & $\begin{array}{l}\text { Nitro- } \\
\text { gen, } \\
\text { ammo- } \\
\text { nia, dis- } \\
\text { solved } \\
\text { (mg/L } \\
\text { as N) }\end{array}$ & $\begin{array}{l}\text { Carbon, } \\
\text { organic } \\
\text { dis- } \\
\text { solved } \\
(\mathrm{mg} / \mathrm{L} \\
\text { as C) }\end{array}$ & $\begin{array}{l}\text { Methy- } \\
\text { lene } \\
\text { blue } \\
\text { active } \\
\text { sub- } \\
\text { stance } \\
(\mathrm{mg} / \mathrm{L})\end{array}$ & $\begin{array}{l}\text { Boron, } \\
\text { dis- } \\
\text { solved } \\
(\mu \mathrm{g} / \mathrm{L} \\
\text { as B) }\end{array}$ & $\begin{array}{l}\text { Iron, } \\
\text { dis- } \\
\text { solved } \\
(\mu \mathrm{g} / \mathrm{L} \\
\text { as FE) }\end{array}$ & $\begin{array}{l}\text { Oxygen, } \\
\text { dis- } \\
\text { solved } \\
(\mathrm{mg} / \mathrm{L})\end{array}$ & $\begin{array}{l}\text { Alka- } \\
\text { linity, } \\
\text { lab } \\
(\mathrm{mg} / \mathrm{L} \\
\text { as } \\
\left.\mathrm{CACO}_{3}\right)\end{array}$ & $\begin{array}{l}\text { Chlo- } \\
\text { ride, } \\
\text { dis- } \\
\text { solved } \\
\text { (mg/L } \\
\text { as CL) }\end{array}$ & $\begin{array}{l}\text { Predom- } \\
\text { inate land } \\
\text { use at } \\
\text { well site }\end{array}$ \\
\hline $\mathrm{E}$ & $092 \mathrm{G} .008 .1 .2 .2-01$ & 39 & - & 1.0 & $<0.0$ & $<0.01$ & - & $<0.02$ & 10 & 5 & 0.3 & 97 & ... & $\mathrm{U}$ \\
\hline E & $39 \mathrm{~N} / 03 \mathrm{E}-01 \mathrm{C} 01$ & 49 & -- & 0.37 & $<0.2$ & 0.01 & 0.8 & $<0.02$ & 20 & 54 & 1.2 & 46 & 54 & $\mathrm{U}$ \\
\hline $\mathrm{E}$ & 39N/03E-36P01 & 73 & -. & $<0.05$ & 0.4 & 0.29 & 1.2 & $<0.02$ & 130 & 100 & 0.1 & 162 & 11 & U \\
\hline $\mathrm{S}$ & $39 \mathrm{~N} / 04 \mathrm{E}-20 \mathrm{H} 01$ & 41 & & 0.7 & $<0.2$ & $<0.01$ & 1.4 & $<0.02$ & 10 & 73 & 2.7 & 42 & - & $\mathrm{U}$ \\
\hline $\mathrm{S}$ & 40N/03E-16K01 & 33 & 7.60 & 3.70 & 0.50 & $<0.010$ & - & $<0.02$ & $<10$ & 50 & 2.5 & 23 & 7.4 & $\mathrm{U}$ \\
\hline$S$ & 40N/03E-19A01 & 40 & -- & $<0.05$ & $<0.0$ & 0.10 & - & $<0.02$ & $<10$ & 13,000 & 0.0 & 29 & 10 & $\mathrm{U}$ \\
\hline $\mathrm{S}$ & $40 \mathrm{~N} / 03 \mathrm{E}-31 \mathrm{~L} 01$ & 50 & 3.10 & 7.20 & 0.50 & $<0.010$ & - & -- & $<10$ & 8 & 8.5 & 29 & -. & $\mathrm{U}$ \\
\hline $\mathrm{S}(\mathrm{PC})$ & $41 \mathrm{~N} / 04 \mathrm{E}-33 \mathrm{H} 04$ & 89 & 9.40 & 5.60 & 0.40 & 0.020 & -- & $<0.02$ & $<10$ & $<3$ & 0.8 & 85 & -. & $\mathrm{U}$ \\
\hline $\mathrm{S}(\mathrm{PC})$ & $41 \mathrm{~N} / 04 \mathrm{E}-33 \mathrm{~N} 04$ & 72 & 9.70 & 15.0 & 0.70 & 0.030 & -- & $<0.02$ & 20 & 4 & - & 70 & 10 & $\mathrm{U}$ \\
\hline $\mathrm{S}$ & $39 \mathrm{~N} / 02 \mathrm{E}-13 \mathrm{~B} 01$ & 52 & $-\cdot$ & 0.13 & 0.2 & 0.06 & 0.7 & $<0.02$ & 20 & 5,300 & 5.7 & 79 & 12 & $\mathrm{R}$ \\
\hline$S$ & $39 \mathrm{~N} / 02 \mathrm{E}-27 \mathrm{~F} 04$ & 36 & -- & 2.6 & $<0.2$ & 0.01 & 0.6 & $<0.02$ & 20 & 30 & 2.2 & 98 & 9.2 & $\mathrm{R}$ \\
\hline S & $39 \mathrm{~N} / 02 \mathrm{E}-27 \mathrm{Q} 04$ & 22 & -- & 5.8 & 0.6 & $<0.01$ & 1.2 & $<0.02$ & 120 & 4 & 3.2 & 36 & 13 & $\mathrm{R}$ \\
\hline$S$ & $40 \mathrm{~N} / 02 \mathrm{E}-33 \mathrm{~B} 02$ & 36 & 8.00 & 1.80 & $<0.0$ & $<0.010$ & 0.3 & $<0.02$ & 20 & 12 & 9.4 & 27 & 14 & $\mathrm{R}$ \\
\hline$S$ & 40N/03E-31P03 & 36 & -. & 19 & 0.8 & $<0.01$ & 0.6 & 0.06 & $<10$ & 58 & 7.7 & 35 & 11 & $\mathrm{R}$ \\
\hline$S$ & 40N/03E-32L01 & 50 & -- & 12 & 0.6 & $<0.01$ & 0.6 & $<0.02$ & 20 & 20 & 9.0 & 24 & 4.4 & $\mathrm{R} / \mathrm{P}$ \\
\hline S & $40 \mathrm{~N} / 03 \mathrm{E}-32 \mathrm{Q} 01$ & 25 & -- & 2.8 & $<0.2$ & 0.01 & -- & $<0.02$ & 10 & $<10$ & 6.8 & 24 & 5.2 & $\mathrm{R} / \mathrm{U}$ \\
\hline $\mathrm{S}$ & $40 \mathrm{~N} / 02 \mathrm{E}-13 \mathrm{~J} 05$ & 16 & -- & $<0.05$ & 50 & 46 & $25 \mathrm{D}$ & $<0.02$ & 40 & 19,000 & - & -- & $76 \mathrm{D}$ & $\mathrm{L}$ \\
\hline S & $40 \mathrm{~N} / 02 \mathrm{E}-13 \mathrm{~J} 06$ & 18 & - & - & -- & $70 \mathrm{E}$ & $21 \mathrm{D}$ & $<0.02$ & 60 & 3,700 & - & -- & $44 \mathrm{D}$ & $\mathrm{L}$ \\
\hline S & $40 \mathrm{~N} / 02 \mathrm{E}-13 \mathrm{~J} 07$ & 16 & 7.20 & $<0.050$ & 63 & 63.0 & 26 & 0.09 & 80 & 1,600 & 0.2 & 451 & 49 & $\mathrm{~L}$ \\
\hline$S$ & $40 \mathrm{~N} / 03 \mathrm{E}-05 \mathrm{~L} 01$ & 18 & 7.40 & $<0.050$ & 35 & 34.0 & 39 & 0.09 & 20 & 36,000 & 0.2 & 559 & 58 & $\mathrm{~L}$ \\
\hline $\mathrm{S}$ & 092G.008.2.2.3-03 & 60 & -. & 4.2 & -- & $<0.01$ & 0.5 & $<0.02$ & $<10$ & 7 & 4.3 & 56 & 5.8 & $\mathrm{P}$ \\
\hline $\mathrm{E}$ & $092 \mathrm{G} .009 .2 \cdot 2.3-11$ & 60 & -. & 0.058 & - & 1.4 & 0.5 & $<0.02$ & 30 & 34,000 & 0.0 & 17 & 210 & $P$ \\
\hline E & $092 \mathrm{G} .008 \cdot 1 \cdot 4.2-15$ & 342 & - & $<0.05$ & -- & 0.56 & 2.2 & $<0.02$ & 140 & 340 & 0.2 & 146 & 620 & $\mathrm{P}$ \\
\hline $\mathrm{S}(\mathrm{PC})$ & 092G.008.2.4.1-18 & 116 & 5.60 & 8.10 & - & 0.010 & 0.6 & $<0.02$ & 10 & 5 & 1.7 & 79 & 2.7 & $\mathrm{P}$ \\
\hline $\mathrm{S}(\mathrm{PC})$ & 092G.009.1.1.4-17 & 60 & 11.80 & 16.0 & - & $<0.010$ & 0.3 & $<0.02$ & 10 & 46 & 5.8 & 50 & 8.5 & $\mathrm{P} / \mathrm{B}$ \\
\hline S & $39 \mathrm{~N} / 02 \mathrm{E}-11 \mathrm{~B} 01$ & 26 & -- & 3.3 & -- & 0.01 & 0.8 & $<0.02$ & 30 & 14 & 2.2 & 14 & 8.9 & $\mathrm{P}$ \\
\hline S & $39 \mathrm{~N} / 02 \mathrm{E}-16 \mathrm{H} 03$ & 19 & -- & 0.83 & - & $<0.01$ & 1.4 & $<0.02$ & 20 & 20 & 2.1 & 56 & 11 & $\mathrm{P}$ \\
\hline S & $39 \mathrm{~N} / 02 \mathrm{E}-24 \mathrm{C} 02$ & 22 & - & 2.6 & - & 0.02 & 0.7 & $<0.02$ & $<10$ & 960 & 3.2 & 24 & 14 & $\mathrm{P}$ \\
\hline E & $39 \mathrm{~N} / 02 \mathrm{E}-24 \mathrm{R} 02$ & 41 & -- & 5.2 & -- & $<0.01$ & 0.7 & $<0.02$ & 120 & 40 & 4.7 & 55 & 17 & $\mathrm{P}$ \\
\hline S & $39 \mathrm{~N} / 02 \mathrm{E}-26 \mathrm{H} 01$ & 14 & - & 12 & - & 0.01 & 1.0 & $<0.02$ & 10 & $<3$ & 7.1 & 74 & 10 & $P$ \\
\hline S & $39 \mathrm{~N} / 04 \mathrm{E}-16 \mathrm{Q} 02$ & 33 & - & 3.6 & -- & $<0.01$ & - & 0.03 & 30 & 30 & 4.1 & 54 & 5.6 & $\mathrm{P}, \mathrm{B}$ \\
\hline S & $39 \mathrm{~N} / 04 \mathrm{E}-22 \mathrm{~L} 01$ & 30 & 12.50 & 15 & -- & $<0.01$ & 2.6 & $<0.02$ & - & 7 & 0.2 & 269 & 40 & $P$ \\
\hline S & $40 \mathrm{~N} / 02 \mathrm{E}-10 \mathrm{~N} 02$ & 38 & -- & 1.4 & 2.7 & 2.2 & 5.1 & 0.04 & 20 & 8,200 & 0.0 & 187 & 43 & $P$ \\
\hline
\end{tabular}


Table 20. Concentration of selected water-quality constituents and land use information--Continued

\begin{tabular}{|c|c|c|c|c|c|c|c|c|c|c|c|c|c|c|}
\hline $\begin{array}{l}\text { Hydro- } \\
\text { geo- } \\
\text { logic } \\
\text { unit }\end{array}$ & $\begin{array}{l}\text { Local } \\
\text { identifier }\end{array}$ & $\begin{array}{l}\text { Well } \\
\text { depth } \\
\text { (feet) }\end{array}$ & $\begin{array}{l}\delta^{15} \mathrm{~N} \\
\text { isotope } \\
\text { ratio, } \\
\text { per mil }\end{array}$ & $\begin{array}{l}\text { Nitro- } \\
\text { gen, } \\
\mathrm{NO}_{2}+ \\
\mathrm{NO}_{3} \text {, } \\
\text { dissolved } \\
\text { (mg/L } \\
\text { as } \mathrm{N})\end{array}$ & $\begin{array}{l}\text { Nitro- } \\
\text { gen, am- } \\
\text { monia + } \\
\text { organic, } \\
\text { dissolved } \\
(\mathrm{mg} / \mathrm{L} \\
\text { as } \mathrm{N})\end{array}$ & $\begin{array}{l}\text { Nitro- } \\
\text { gen, } \\
\text { ammo- } \\
\text { nia, dis- } \\
\text { solved } \\
(\mathrm{mg} / \mathrm{L} \\
\text { as } \mathrm{N})\end{array}$ & $\begin{array}{l}\text { Carbon, } \\
\text { organic } \\
\text { dis- } \\
\text { solved } \\
\text { (mg/L } \\
\text { as C) }\end{array}$ & $\begin{array}{l}\text { Methy- } \\
\text { lene } \\
\text { blue } \\
\text { active } \\
\text { sub- } \\
\text { stance } \\
(\mathrm{mg} / \mathrm{L})\end{array}$ & $\begin{array}{l}\text { Boron, } \\
\text { dis- } \\
\text { solved } \\
(\mu \mathrm{g} / \mathrm{L} \\
\text { as B) }\end{array}$ & $\begin{array}{l}\text { Iron, } \\
\text { dis- } \\
\text { solved } \\
(\mu \mathrm{g} / \mathrm{L} \\
\text { as FE) }\end{array}$ & $\begin{array}{l}\text { Oxygen, } \\
\text { dis- } \\
\text { solved } \\
(\mathrm{mg} / \mathrm{L})\end{array}$ & $\begin{array}{l}\text { Alka- } \\
\text { linity, } \\
\text { lab } \\
(\mathrm{mg} / \mathrm{L} \\
\text { as } \\
\left.\mathrm{CACO}_{3}\right)\end{array}$ & $\begin{array}{l}\text { Chlo- } \\
\text { ride, } \\
\text { dis- } \\
\text { solved } \\
\text { (mg/L } \\
\text { as CL) }\end{array}$ & $\begin{array}{l}\text { Predom- } \\
\text { inate land } \\
\text { use at } \\
\text { well site }\end{array}$ \\
\hline $\mathrm{S}$ & $40 \mathrm{~N} / 02 \mathrm{E}-13 \mathrm{~J} 04$ & 16 & 3.30 & $<0.050$ & 0.30 & 0.220 & 1.1 & $<0.02$ & $<10$ & 24,000 & 0.0 & 34 & 6.0 & $\mathrm{P}$ \\
\hline S & $40 \mathrm{~N} / 02 \mathrm{E}-26 \mathrm{~A} 03$ & 33 & .. & 13 & -. & $<0.01$ & 0.8 & $<0.02$ & 20 & 28 & 6.8 & 48 & 11 & $\mathrm{P} / \mathrm{B}$ \\
\hline S & 40N/03E-03R02 & 73 & -. & 12 & -. & 0.02 & 0.4 & $<0.02$ & 10 & 6 & -. & 49 & 11 & $\mathrm{P}$ \\
\hline S & 40N/03E-05M05 & 12 & 6.80 & 18 & -. & 0.08 & 2.2 & $<0.02$ & 20. & 58 & 7.0 & 26 & 15 & $\mathrm{P}$ \\
\hline S & $40 \mathrm{~N} / 05 \mathrm{E}-06 \mathrm{~K} 01$ & 7 & - & $<0.05$ & 0.2 & 0.04 & 2.5 & $<0.02$ & $<10$ & 5 & 0.1 & 144 & 11 & $\mathrm{P}$ \\
\hline$S$ & $40 \mathrm{~N} / 03 \mathrm{E}-07 \mathrm{~A} 02$ & 21 & 4.50 & 11.0 & -. & $<0.010$ & 1.9 & $<0.02$ & $<10$ & 15 & 4.0 & 18 & 4.9 & $\mathrm{P}$ \\
\hline$S$ & $40 \mathrm{~N} / 03 \mathrm{E}-09 \mathrm{G} 01$ & 65 & .. & $<0.05$ & -. & 0.03 & 0.4 & $<0.02$ & -- & 3,800 & 0.0 & 77 & -. & $\mathrm{P}$ \\
\hline $\mathrm{S}$ & $40 \mathrm{~N} / 03 \mathrm{E}-10 \mathrm{~K} 01$ & 30 & 6.50 & 7.60 & -. & 0.020 & 0.9 & $<0.02$ & $<10$ & 27 & 3.4 & 59 & 12 & $\mathrm{P}$ \\
\hline $\mathrm{S}$ & $40 \mathrm{~N} / 03 \mathrm{E}-11 \mathrm{E} 04$ & 44 & -- & 1.5 & -- & $<0.01$ & 0.4 & $<0.02$ & 20 & 17 & 6.9 & 37 & 7.9 & $\mathrm{P}$ \\
\hline S & $40 \mathrm{~N} / 03 \mathrm{E}-25 \mathrm{~F} 01$ & 29 & - & 1.2 & - & 0.41 & 3.6 & 0.03 & -- & -. & - & - & - & $\mathrm{P}$ \\
\hline S & $40 \mathrm{~N} / 04 \mathrm{E}-30 \mathrm{G} 01$ & 37 & -- & $<0.05$ & -- & 0.59 & 2.9 & $<0.02$ & 20 & 5,100 & -. & 192 & 28 & $\mathrm{P}$ \\
\hline S & 40N/04E-31R02 & 34 & - & 0.14 & -. & 0.19 & 1.8 & 0.02 & 30 & 5,300 & 2.6 & 167 & 19 & $\mathrm{P}$ \\
\hline S & $41 \mathrm{~N} / 03 \mathrm{E}-35 \mathrm{~L} 01$ & 25 & 10.40 & 21.0 & -. & 0.180 & 0.5 & 0.02 & 20 & 46 & 9.0 & 21 & 9.4 & $\mathrm{P} / \mathrm{B}$ \\
\hline S & $41 \mathrm{~N} / 04 \mathrm{E}-32 \mathrm{Q} 01$ & 26 & 8.90 & 16.0 & -- & $<0.010$ & 0.3 & $<0.02$ & $<10$ & 9 & 7.8 & 53 & 9.1 & $\mathrm{P}$ \\
\hline $\mathrm{S}$ & $41 \mathrm{~N} / 03 \mathrm{E}-34 \mathrm{M} 01$ & 20 & - & 20 & - & $<0.01$ & 0.5 & $<0.02$ & 30 & 32 & 5.4 & 18 & 9.5 & $\mathrm{P}$ \\
\hline $\mathrm{S}$ & 092G.009.1.1.1-06-20 & 20 & $5.5 \mathrm{~K}$ & $17 . \mathrm{K}$ & $<0.01 \mathrm{~K}$ & $<0.01 \mathrm{~K}$ & -- & $<0.02$ & $30 \mathrm{~K}$ & $<10 \mathrm{~K}$ & 8.8 & $8.7 \mathrm{~K}$ & $10 . \mathrm{K}$ & $\mathrm{B}$ \\
\hline $\mathrm{S}$ & 092G.009.1.1.1-06-35 & 35 & $7.3 \mathrm{~K}$ & 17.K & $<0.01 \mathrm{~K}$ & $<0.01 \mathrm{~K}$ & -- & -- & $20 \mathrm{~K}$ & $<10 \mathrm{~K}$ & 8.5 & $14 . \mathrm{K}$ & $8.4 \mathrm{~K}$ & B \\
\hline $\mathrm{S}$ & 092G.009.1.1.1-07-55 & 55 & $14 . \mathrm{K}$ & $6.6 \mathrm{~K}$ & $0.03 \mathrm{~K}$ & $0.03 \mathrm{~K}$ & -- & $<0.02$ & $<10 \mathrm{~K}$ & $<10 \mathrm{~K}$ & 6.4 & $53 . \mathrm{K}$ & $4.5 \mathrm{~K}$ & B \\
\hline S & 092G.009.1.1.1-07-75 & 75 & -- & $2.3 \mathrm{~K}$ & $0.04 \mathrm{~K}$ & $0.03 \mathrm{~K}$ & - & $<0.02$ & $<10 \mathrm{~K}$ & $<10 \mathrm{~K}$ & 0.2 & 71.K & $4.1 \mathrm{~K}$ & $\mathrm{~B}$ \\
\hline $\mathrm{S}$ & 092G.009.1.1.2-11-25 & 25 & $5.4 \mathrm{~K}$ & 17. K & $0.03 \mathrm{~K}$ & $0.01 \mathrm{~K}$ & -- & $<0.02$ & $20 \mathrm{~K}$ & $10 \mathrm{~K}$ & 9.0 & $9.8 \mathrm{~K}$ & $10 . \mathrm{K}$ & B \\
\hline $\mathrm{S}$ & 092G.009.1.1.2-11-35 & 35 & $7.3 \mathrm{~K}$ & $21 . \mathrm{K}$ & $0.03 \mathrm{~K}$ & $0.02 \mathrm{~K}$ & -. & $<0.02$ & $30 \mathrm{~K}$ & $<10 \mathrm{~K}$ & 9.2 & $13 . \mathrm{K}$ & $12 . \mathrm{K}$ & B \\
\hline $\mathrm{S}$ & $092 \mathrm{G} .009 .1 .1 .2-12-55$ & 55 & 13. K & $4.9 \mathrm{~K}$ & $<0.02 \mathrm{~K}$ & $0.02 \mathrm{~K}$ & -- & $<0.02$ & $<10 \mathrm{~K}$ & $10 \mathrm{~K}$ & 5.0 & $51 . \mathrm{K}$ & $4.6 \mathrm{~K}$ & B \\
\hline $\mathrm{S}$ & 092G.009.1.1.2-12-75 & 75 & - & $0.6 \mathrm{~K}$ & $0.06 \mathrm{~K}$ & $0.02 \mathrm{~K}$ & - & $<0.02$ & $<10 \mathrm{~K}$ & $<10 \mathrm{~K}$ & 0.8 & $65 . \mathrm{K}$ & $7.9 \mathrm{~K}$ & $\mathrm{~B}$ \\
\hline $\mathrm{S}$ & 092G.009.1.1.4-18-25 & 25 & $14.2 \mathrm{~K}$ & $4.6 \mathrm{~K}$ & $<0.01 \mathrm{~K}$ & $<0.01 \mathrm{~K}$ & - & -. & $<10 \mathrm{~K}$ & $20 \mathrm{~K}$ & 8.1 & $18 . \mathrm{K}$ & $3.5 \mathrm{~K}$ & $\mathrm{~B}$ \\
\hline $\mathrm{S}$ & 092G.009.1.1.4-18-35 & 35 & $15.3 \mathrm{~K}$ & $3.5 \mathrm{~K}$ & $<0.01 \mathrm{~K}$ & $<0.01 \mathrm{~K}$ & -. & -- & $<10 \mathrm{~K}$ & $<10 \mathrm{~K}$ & 7.6 & $24 . K$ & $2.3 \mathrm{~K}$ & B \\
\hline $\mathrm{S}$ & 092G.009.1.1.4-19-55 & 55 & $12.5 \mathrm{~K}$ & $5.5 \mathrm{~K}$ & $<0.01 \mathrm{~K}$ & $<0.01 \mathrm{~K}$ & - & -- & $<10 \mathrm{~K}$ & $<10 \mathrm{~K}$ & 6.0 & $53 . \mathrm{K}$ & $2.6 \mathrm{~K}$ & B \\
\hline $\mathrm{S}$ & 092G.009.1.1.4-19-75 & 75 & $19.1 \mathrm{~K}$ & $5.2 \mathrm{~K}$ & $<0.01 \mathrm{~K}$ & $<0.01 \mathrm{~K}$ & - & - & $<10 \mathrm{~K}$ & $<10 \mathrm{~K}$ & 1.0 & $66 . \mathrm{K}$ & $5.4 \mathrm{~K}$ & B \\
\hline $\mathrm{S}$ & $40 \mathrm{~N} / 02 \mathrm{E}-14 \mathrm{P} 02$ & 39 & 4.20 & 16.0 & 1.4 & $<0.010$ & 0.6 & $<0.02$ & 40 & 30 & 8.8 & 21 & 8.9 & B \\
\hline $\mathrm{S}$ & 40N/02E-21R01 & 23 &.- & 20 & 0.8 & $<0.01$ & 1.0 & 0.04 & $<10$ & 26 & 7.7 & 9.2 & 17 & B \\
\hline $\mathrm{S}$ & $40 \mathrm{~N} / 02 \mathrm{E}-23 \mathrm{D} 01$ & 30 & 6.90 & 4.00 & 0.40 & $<0.010$ & 1.1 & $<0.02$ & $<10$ & 26 & 3.4 & 30 & 9.0 & B \\
\hline $\mathrm{S}$ & $40 \mathrm{~N} / 02 \mathrm{E}-27 \mathrm{~N} 02$ & 36 & 1.50 & 9.00 & 0.60 & $<0.010$ & 0.6 & $<0.02$ & -. & 50 & 8.4 & 8 & 9.4 & B \\
\hline $\mathrm{S}$ & $40 \mathrm{~N} / 03 \mathrm{E}-03 \mathrm{~A} 02$ & 26 & 7.20 & 9.90 & 0.70 & 0.010 & -- & -- & -. & 10 & 9.8 & -. & 2.2 & $\mathrm{~B} / \mathrm{P}$ \\
\hline
\end{tabular}


$\vec{\Delta}$ Table 20. Concentration of selected water-quality constituents and land use information--Continued

\begin{tabular}{|c|c|c|c|c|c|c|c|c|c|c|c|c|c|c|}
\hline $\begin{array}{l}\text { Hydro- } \\
\text { geo- } \\
\text { logic } \\
\text { unit }\end{array}$ & $\begin{array}{l}\text { Local } \\
\text { identifier }\end{array}$ & $\begin{array}{l}\text { Well } \\
\text { depth } \\
\text { (feet) }\end{array}$ & $\begin{array}{l}\delta^{15} \mathrm{~N} \\
\text { isotope } \\
\text { ratio, } \\
\text { per mil }\end{array}$ & $\begin{array}{l}\text { Nitro- } \\
\text { gen, } \\
\mathrm{NO}_{2+} \\
\mathrm{NO}_{3} \text {, } \\
\text { dissolved } \\
(\mathrm{mg} / \mathrm{L} \\
\text { as } \mathrm{N})\end{array}$ & $\begin{array}{l}\text { Nitro- } \\
\text { gen, am- } \\
\text { monia + } \\
\text { organic, } \\
\text { dissolved } \\
(\mathrm{mg} / \mathrm{L} \\
\text { as } \mathrm{N})\end{array}$ & $\begin{array}{l}\text { Nitro- } \\
\text { gen, } \\
\text { ammo- } \\
\text { nia, dis- } \\
\text { solved } \\
\text { (mg/L } \\
\text { as N) }\end{array}$ & $\begin{array}{l}\text { Carbon, } \\
\text { organic } \\
\text { dis- } \\
\text { solved } \\
\text { ( } \mathrm{mg} / \mathrm{L} \\
\text { as C) }\end{array}$ & $\begin{array}{l}\text { Methy- } \\
\text { lene } \\
\text { blue } \\
\text { active } \\
\text { sub- } \\
\text { stance } \\
\text { (mg/L) }\end{array}$ & $\begin{array}{l}\text { Boron, } \\
\text { dis- } \\
\text { solved } \\
(\mu \mathrm{g} / \mathrm{L} \\
\text { as B) }\end{array}$ & $\begin{array}{l}\text { Iron, } \\
\text { dis- } \\
\text { solved } \\
(\mu \mathrm{g} / \mathrm{L} \\
\text { as FE) }\end{array}$ & $\begin{array}{l}\text { Oxygen, } \\
\text { dis- } \\
\text { solved } \\
(\mathrm{mg} / \mathrm{L})\end{array}$ & $\begin{array}{l}\text { Alka- } \\
\text { linity, } \\
\text { lab } \\
(\mathrm{mg} / \mathrm{L} \\
\text { as } \\
\left.\mathrm{CACO}_{3}\right)\end{array}$ & $\begin{array}{l}\text { Chlo- } \\
\text { ride, } \\
\text { dis- } \\
\text { solved } \\
\text { (mg/L } \\
\text { as CL) }\end{array}$ & $\begin{array}{l}\text { Predom- } \\
\text { inate land } \\
\text { use at } \\
\text { well site }\end{array}$ \\
\hline$S$ & $41 \mathrm{~N} / 03 \mathrm{E}-36 \mathrm{~J} 01$ & 37 & 3.50 & 7.30 & 0.40 & 0.010 & 0.7 & $<0.02$ & 20 & 13 & 6.9 & 15 & 4.0 & $\mathrm{~B} / \mathrm{P}$ \\
\hline $\mathrm{S}$ & 092G.009.2.1.2-19 & 145 & -. & 9.1 & $<0.0$ & $<0.01$ & -. & $<0.02$ & 20 & $<3$ & 4.5 & 50 & 5.8 & M \\
\hline $\mathrm{S}$ & 092G.009.2.1.4-26 & 265 & -. & 6.9 & $<0.0$ & $<0.01$ & -. & $<0.02$ & $<10$ & 12 & 2.8 & 94 & 8.1 & M \\
\hline $\mathrm{E}$ & 092G.009.1.2.4-31 & 163 & -- & 9.9 & $<0.0$ & $<0.01$ & 0.3 & 0.03 & $<10$ & 22 & 6.4 & 47 & 10 & M \\
\hline $\mathrm{S}$ & $39 \mathrm{~N} / 02 \mathrm{E}-22 \mathrm{D} 02$ & 48 & -. & $<0.05$ & $<0.2$ & 0.03 & 0.5 & $<0.02$ & 30 & 87 & 1.2 & 81 & 27 & M \\
\hline S & $39 \mathrm{~N} / 02 \mathrm{E}-28 \mathrm{~J} 03$ & 24 & -. & 1.4 & $<0.2$ & $<0.01$ & 0.8 & $<0.02$ & 10 & 10 & 12.9 & 44 & 26 & M \\
\hline V & $39 \mathrm{~N} / 04 \mathrm{E}-16 \mathrm{H} 01$ & 50 & .. & 5.0 & 0.4 & $<0.01$ & 1.7 & $<0.02$ & 30 & 11 & 6.8 & 69 & 7.8 & M \\
\hline$S$ & $39 \mathrm{~N} / 03 \mathrm{E}-07 \mathrm{~K} 02$ & 24 & -- & 19 & -. & $<0.01$ & 0.6 & 0.04 & 40 & 10 & 6.6 & 27 & 13 & $\mathrm{P}$ \\
\hline$s$ & $39 \mathrm{~N} / 03 \mathrm{E}-08 \mathrm{C} 02$ & 27 & 2.00 & $<0.100$ & -. & $<0.010$ & 0.5 & -. & -- & 11 & -. & 26 & 7.2 & $\mathrm{P}$ \\
\hline$S$ & $39 \mathrm{~N} / 03 \mathrm{E}-34 \mathrm{NO} 1$ & 20 & - & $<0.05$ & -- & 0.02 & 2.7 & $<0.02$ & $<10$ & 93 & $<1$ & 116 & 3.2 & $\mathrm{P} / \mathrm{U}$ \\
\hline
\end{tabular}

D Data from concurrent sample collected by Washington Department of Ecology, concentration or total whole water values (Denis Erickson, Washington Department of Ecology, written commun.). K Data from Kohut and others, 1987. 
found in the deeper piezometers which also have larger alkalinity concentrations and smaller dissolved-oxygen concentrations.

Concentrations of chloride above background concentrations of $4 \mathrm{mg} / \mathrm{L}$ indicate influences of landuse activities. Elevated concentrations of chloride in shallow ground water larger than background concentrations have been attributed to disposal of domestic sewage (Dudley and Stephenson, 1973); livestock manures (Erickson, 1991); and the applications of fertilizers to crops (Saffigna and Keeney, 1977). Except, for instance, where evapoconcentrations might occur, natural soil and peat deposits are not expected to increase the concentration of chloride in shallow ground water. As described in an earlier section of this report, the range of background concentrations of chloride in the Sumas aquifer is from 0.5 to $4 \mathrm{mg} / \mathrm{L}$. Sixty-four of the 69 chloride analyses in table 20 are larger than $4.0 \mathrm{mg} / \mathrm{L}$; of the five chloride concentrations less than $4.0 \mathrm{mg} / \mathrm{L}$, only one was from an area in which the immediate area surrounding the well is undeveloped. Because nearly all the samples had elevated chloride concentrations, peat and decaying plant matter are not considered a significant source of nitrates in ground water. In addition, the areas where large nitrate concentrations were widespread were generally upgradient of the peat deposits shown in plate 2 .

Boron and MBAS are present in household waste water as residues of detergents and have been used to identify septage-contaminated ground water (Le Blanc, 1984; Drost and others 1998). These two constituents were included to distinguish septic sources from livestock manures. However, the largest concentrations of these constituents were found routinely in ground water associated with either dairy lagoons, or pastures on which dairy manures were applied. Consequently, it was not possible to distinguish septic sources from livestock manures based on the concentrations of boron or MBAS in the Sumas aquifer. It is suspected that cleaning agents used to clean dairy facilities are the source for these constituents that were found associated with dairy manure storage and field applications.

\section{Concentrations of dissolved organic carbon}

(DOC) may be large in ground-water systems associated with organic materials or synthetic organic compounds from various land-use activities. Organic carbon is found in animal waste as well as drainage from peat lands (Urban and others, 1989) and as such, concentrations larger than typically found in ground water $(0.7 \mathrm{mg} / \mathrm{L})$ might indicate the presence of recharge from these sources. With the exception of the four ground-water samples collected adjacent to a manure lagoon, concentrations of organic carbon were typically small, less than $2.0 \mathrm{mg} / \mathrm{L}$. The concentrations of dissolved organic carbon in the piezometers adjacent to the manure lagoons ranged from $21-39 \mathrm{mg} / \mathrm{L}$, while total organic carbon (TOC) from those same wells reported by Garland and Erickson (1994) was roughly an order of magnitude larger, and the TOC of a manure sample from the lagoon itself was on the order of $1,000-2,000 \mathrm{mg} / \mathrm{L}$. Roughly half of the samples from the pasture and row crop settings contained DOC concentrations larger than $1 \mathrm{mg} / \mathrm{L}$ while only 20 percent of the samples from the undeveloped and residential areas were larger than $1.0 \mathrm{mg} / \mathrm{L}$. Much of the DOC present in ground water of the Sumas aquifer is probably derived from livestock manures or recalcitrant soil organic matter; however, the range of concentrations is not distinct enough to be a reliable indicator of the source of nitrates in ground water.

The concentration of dissolved oxygen varied and covered similar ranges in all land-use areas, except adjacent to manure lagoons. Outside of such sitespecific areas as septic tank drain fields or areas adjacent to manure lagoons, the concentration of dissolved oxygen in the shallow unconfined portions of the Sumas aquifer appears to be more a function of depth than specific land-use activity or nitrate source material. As described in a previous section on dissolved oxygen, concentrations tended to decrease with depth and length of ground-water flow path. This nonconservative property of dissolved-oxygen concentrations in ground water limits its use as an indicator of source material or area.

While the evaluation of nitrate-related waterquality constituents was not able to identify the source of nitrates in many instances, it was able to identify samples in which nitrates were largely from fertilizers. This evaluation also provided support for the estimates of nitrate loading to ground water which indicated that most of the nitrates in ground water were the result of agricultural activity. The large range in the nitrogen isotope data indicated that there were multiple nitrate sources in the LENS study area and that fertilizer nitrogen could account for about 15 percent of the samples tested, the remaining samples being a mixture of fertilizers and either animal sources or decaying plant material. Because nearly all samples contained elevated chloride concentrations, decaying plant matter was not considered a significant source. With respect to animal sources, a distinction between livestock and 
domestic sources was ambiguous because both boron and MBAS were present in large concentrations near both source areas. However, the DOC data did provide some indication that livestock manures were more significant than domestic sources.

\section{SUMMARY}

Ground water is an important source of domestic, municipal, and irrigation supply in a 225 -squaremile agricultural area of the Fraser-Whatcom Lowland. Population growth and the increasing concerns about ground-water quality have increased the demand for additional sources of high-quality ground water, leading to the need for a regional appraisal of the groundwater system. During a U.S. Geological Survey study conducted from 1990 to 1992 in cooperation with the Whatcom County Planning Department, water-level, lithologic, and water-quality data were collected from 608 wells and were used with existing information to describe the ground-water system and its water quality.

The objectives of this study were to describe the regional hydrogeology and ground-water quality of the shallow lowland aquifers in parts of Whatcom County and British Columbia that surround the communities of Lynden, Everson, Nooksack, and Sumas and to evaluate potential sources of existing water-quality problems found in ground water in this area. Specific study objectives were to (1) define, to the extent that available data allow, the general lithology of glacial sediments within the study area; (2) delineate and characterize hydrogeologic units; (3) characterize the water quality of individual hydrogeologic units; (4) delineate the extent of existing water-quality problems; and (5) evaluate potential sources of nitrates found in ground water in the study area.

The area is underlain largely by glacial sediments that overlie Tertiary bedrock and range in thickness from 0 to 1,500 feet. Lithologic information from geologic maps and well logs was used to construct 10 lithologic sections, which were used to identify four principal hydrogeologic units: a coarse-grained glacial unit that overlies two predominantly fine-grained glacial units, which in turn overlie the bedrock unit. These units are referred to as the Sumas aquifer, the Everson-Vashon semiconfining unit, the Vashon semiconfining unit, and the bedrock semiconfining unit. Seventy-five percent of wells within the study area are finished in the Sumas aquifer, which is highly permeable and capable of supplying large quantities of water; the other units are much less permeable and supply smaller quantities of water. Estimates of the horizonta] ground-water velocity in the Sumas aquifer are on the order of 2.5 feet per day. The Sumas aquifer allows more precipitation to recharge the ground-water system than do the less permeable units, but it is also much more susceptible to contamination from land-use activities. Ground water can be obtained in varying quantities and quality from all of the hydrogeologic units. Even so, all of these units are connected hydraulically, and all units contain zones of low permeability, which can create local confined conditions. A major distinction between units is the extent of the lowpermeability zones. Within the Sumas aquifer, lowpermeability zones are minor occurrences within an otherwise permeable unit; however, in the EversonVashon unit low-permeability zones make up nearly all of the unit, with only minor occurrences of more permeable zones.

The Sumas aquifer is the most productive and extensively used aquifer in the study area. This unit is composed largely of sands and gravels that were deposited as a glacial outwash plain. These outwash deposits also include local deposits of peat, silt and clay, and ice-contact tills, all of which are significantly less permeable than the sands and gravels and which affect local hydrologic conditions within the aquifer. The most extensive occurrence of the lower-permeability deposits is in the Sumas River floodplain, where the sands and gravels have been overlain by a thin layer of lacustrine and alluvial silts, creating local confined conditions. The upland area northwest of Sumas is covered by ice-contact deposits that also create confined conditions; however, this area is much less extensive than the Sumas River floodplain. Because much of the Sumas aquifer is composed of permeable sands and gravels that are exposed at land surface, the aquifer is susceptible to contamination from surface activities.

The other three hydrogeologic units are composed of much less permeable material and are not used as extensively as the Sumas aquifer as a ground-water source. The less permeable nature of these units provides them some protection from contamination from surface activities, resulting in fewer human-caused water-quality problems. However, the lower permeability has also reduced the degree of flushing of remnant seawater from these units so that salty water is found in parts of these units that have not been completely flushed by recharging precipitation. 
The principal source of ground water is recharge from precipitation. In the study area precipitation ranges from 32 to 60 inches per year, and estimates of recharge range from 11 to 45 inches per year. The general movement of ground water is from recharge areas in the uplands to discharge areas at lower altitudes. The major discharge areas are along streams, though the extensive areas of artificially drained farmlands are also significant discharge areas. Seasonal water-level fluctuations in all hydrogeologic units range from 2 to 8 feet per year; averages in the Sumas unit are about 5 feet per year. Long-term water levels appear to be unchanged in the last forty years.

Ground-water samples from more than 368 wells were analyzed for concentrations of nitrate and chloride. Nitrate concentrations ranged from less than 0.1 to 43 milligrams per liter as nitrogen. Median concentrations of nitrate were 3.8 milligrams per liter in the Sumas aquifer and less than 0.1 milligram per liter in each of the other hydrogeologic units. Locally within the Sumas aquifer, anaerobic conditions precluded the presence of nitrogen as nitrate; in these areas, any nitrogen present was in the ammonia form. Nitrite and nitrous oxide were found in some ground water that was anaerobic, and indicating that denitrification is occurring in some parts of the aquifer; thus, the quantity of nitrate in ground water is being reduced locally.

In the Sumas aquifer, nitrate concentrations exceeded the primary drinking water standard of 10 milligrams per liter in more than 25 percent of the wells sampled. In the deeper hydrogeologic units, nitrate concentrations exceeded the drinking water standard in less than 2 percent of the wells sampled. The primary sources of nitrate in ground water are attributable to land-use activities, which include the storage of barnyard manures and their subsequent application to fields, the application of nitrogenous fertilizers to crops, and the use of domestic septic systems.

Nitrate concentrations in the Sumas aquifer were variable over the short-term; concentrations were generally larger in the late fall and winter and smaller during late spring and summer. Long-term trends were more difficult to discern, but concentrations appeared to be increasing. Nitrate concentrations did not vary as much over time in the fine-grained glacial and bedrock hydrogeologic units, where concentrations remained consistently at background levels in samples from most wells.

Chloride concentrations in ground water from individual wells ranged from 0.3 to 2,800 milligrams per liter. In the shallow and highly permeable Sumas aquifer, which is most vulnerable to contamination, chloride concentrations ranged from 0.2 to 210 milligrams per liter. More than 70 percent of wells sampled in the Sumas aquifer had chloride concentrations larger than the estimated range of background concentrations of from 0.5 to 4 milligrams per liter indicating widespread effects of land-use activities. In areas where nitrate concentrations were largest, chloride concentrations were typically larger, indicating that these constituents had similar sources. Within these areas, agricultural activities were much more prevalent and involved much larger quantities of nitrogen than did septic systems, so they were the likely sources of chloride also.

Many water samples from the Everson-Vashon unit had large chloride concentrations. However, these samples also had large concentrations of bromide, suggesting that this ground water was associated with seawater. Seawater is believed to have been incorporated into the Everson-Vashon and Vashon semiconfining units either at the time of their deposition or during a subsequent marine submergence. This remnant seawater has not been completely flushed from the units by post-glacial precipitation and recharge. The widespread occurrence of ground water containing remnant seawater indicates that there is little chance that large sustainable supplies of fresh water can be developed from these deeper, generally fine-grained units.

The pesticides ethylene dibromide, 1,2-dichloropropane, 1,3-dichloropropane, atrazine, and oxamyl, along with the volatile organic compound 1,2,3-trichloropropane, were detected in 4 of 24 ground-water samples collected for this study. The sampled wells, however, did not represent a random vertical distribution; only wells open to the shallow coarse-grained glacial aquifer were sampled. Within the Sumas aquifer, additional sampling by Environment Canada and the Washington State Department of Health in areas of suspected pesticide contamination has identified many additional wells with detectable pesticides or volatile organic compounds. Most of the pesticides detected in ground water are associated with commercial agriculture; however, diazinon and prometon, which were also detected, are compounds sold for home use. The presence of several of these compounds, particularly EDB, is likely related to historical use.

Sources of nitrate in ground water of the study area include farming practices; residential septic systems; fertilizers applied to croplands, lawns, and 
gardens; irrigation with ground water containing nitrates; and naturally occurring soil nitrogen and precipitation. On a regional basis, estimates of nitrogen loading to ground water indicate that agricultural activities, which occupy approximately 75 percent of the land area, account for about 87 percent of the nitrate loading to ground water, the remainder being about evenly divided between domestic and natural sources. Land applications of manure, the use of fertilizers, and manure storage are the farming practices that contribute the greatest quantity of nitrates in ground water. Agricultural activities also affect the storage and release of nitrogen in soil organic matter, which can also be a substantial source of nitrate in ground water. Residential sources are estimated to contribute only 6 percent of the total nitrogen input to the ground water of the study area; however, this often occurs near areas where domestic wells are located. Thus, potential residential sources of nitrates are often the closest to some wells and may have the greatest impact on the concentration of nitrates in well water. Even though agricultural sources contribute much larger quantities of nitrates to ground water than do residential sources, on a per-acre basis, the rates of nitrates entering ground water from agricultural sources are roughly 1.5 to 3 times greater than residential sources.

Evaluation of nitrate-related water-quality characteristics did not enable identification of individual sources of nitrate in ground water; however, it did indicate that inorganic fertilizers were the source of nitrate in at least 15 percent of the samples analyzed. In addition, the combined results of this evaluation were consistent with ground-water nitrate-loading estimates that indicated that nitrates in ground water were the result of multiple sources and that farming practices were the greatest source of nitrates to ground water.

\section{SELECTED REFERENCES}

Alhajjar, B.J., 1985, Groundwater contamination from septic systems receiving detergents of two types of formulation: Madison, Wisconsin, University of Wisconsin, Ph.d thesis, 372 p.

Alhajjar, B.J., Harkin, J.M., Chesters, G., 1987, Chemical tracers of pollution plumes from septic systems receiving two types of detergents, in Proceedings of the National Water Well Association Focus Conference on Northwestern Ground Water Issues: Dublin, Ohio, National Water Well Association, p. 527-555
Allison, F.E., 1955, The enigma of soil nitrogen balance sheets: Advances in Agronomy, v. 7, p. 213-250.

American Public Health Association, American Public Water Works Association, and Water Pollution Control Federation, 1989, Standard methods for the examina. tion of water and waste water (17th ed.): Washington, D.C., American Public Health Association, variously paginated.

Armstrong, J.E., 1960, Surficial geology of the Sumas Map Area, British Columbia: Geological Survey of Canada Paper 59-9, 27 p., map.

-1976, Surficial geology map of Mission, British Columbia: Geological Survey of Canada, Map 1485A 1 sheet, scale 1:50,000.

1977, Quaternary stratigraphy of the Fraser Lowland, in Brown, E.H., and Ellis, R.C., eds., Geological excursions in the Pacific Northwest: Bellingham, Wash., Western Washington University, p. 204-226. 1981, Post-Vashon Wisconsin Glaciation, Fraser Lowland, British Columbia: Geological Survey of Canada Bulletin 322, 34 p.

Armstrong, J.E., Crandell, D.R., Easterbrook, D.J., and Noble, J.B., 1965, Late Pleistocene stratigraphy and chronology of southwestern British Columbia and northwestern Washington: Geological Society of America Bulletin, v. 76, p. 321-330.

Armstrong, J.E., and Hicock, S.R., compilers, 1976, Surficial geology map of New Westminster, British Columbia: Geological Survey of Canada, Map 1484A, 1 sheet, scale 1:50,000.

Avnimelech, Yoram, 1971, Nitrate transformation in peat: Soil Science Journal, v. 111, p. 113-118.

Barber, L.B., II, Thurman, E.M., and Schroeder, M.P., 1986, Identification of trace organic substances in sewagecontaminated ground water, Cape Cod, Massachusetts, in Ragone, S.E., ed., U.S. Geological Survey program on toxic waste--ground-water contamination--Proceedings of the second technical meeting, Cape Cod, Massachusetts, October 21-25, 1985: U.S. Geological Survey Open-File Report 86-481, p. B-19 to B-20.

Barrington, Suzelle, and Jutras, P.J., 1983, Soil sealing by manure in various soil types: American Society of Agricultural Engineers winter meeting, Chicago, December 13-16, 1983, paper no. 83-4571, 28 p.

Barry, D.A.J., Goorahoo, D., and Goss, M.J., 1993, Estimation of nitrate concentrations in ground water using whole farm nitrogen budgets: Journal of Environmental Quality, v. 22, no. 4, p. 767-775.

Bear, Jacob, 1979, Hydraulics of ground water: New York McGraw Hill, 569 p.

Berndt, M.P., 1990, Sources and distribution of nitrate in ground water at a farmed field irrigated with sewage treatment plant effluent, Tallahassee, Florida: U.S. Geological Survey Water-Resources Investigations Report 90-4006, 33 p. 
Bickford, B.J., 1983, Analysis of contaminant movement from a manure storage facility: Madison, Wisconsin, University of Wisconsin, M.A. thesis, $195 \mathrm{p}$.

Bierlink, H., 1994, Irrigation water use survey: Whatcom farm report, v. 1, no. 3, 3 p.

Black and Veatch, Architects and Engineers, 1986, Draft phase I investigation ethylene dibromide sites, Whatcom County, February 26, 1986: Olympia, Wash., State of Washington Department of Ecology Remedial Action Division, p. 90.

Bormann, F.H., and Likens, G.E., 1981, Pattern and process in a forested ecosystem: New York, Springer-Verlag, $253 \mathrm{p}$.

Bortleson, G.C., and Cox, S.E., 1986, Occurrence of dissolved sodium in ground waters in basalt underlying the Columbia Plateau, Washington: U.S. Geological Survey Water-Resources Investigations Report 85-4005, $24 \mathrm{p}$.

Boyce, J.S., Muir, John, Edwards, A.P., Seim, E.C., and Olson, R.A., 1976, Geologic nitrogen in Pleistocene loess of Nebraska: Journal of Environmental Quality, v. 5 , p. $93-96$.

Britton, L.J., and Greeson, P.E., eds., 1988, Methods for collection and analysis of aquatic biological and microbiological samples: U.S. Geological Survey Techniques of Water-Resources Investigations, book 5 , chap. A-4, Open-File Report 88-190, 685 p.

Cameron, V.J., 1989, The late Quaternary geomorphic history of the Sumas Valley: Vancouver, British Columbia, Simon Fraser University, M.A. thesis, 154 p.

Campbell, G.S., 1985, Soil physics with basic transport models for soil-plant systems: New York, Elsevier Science Publishing Co., $150 \mathrm{p}$.

Cantor, Larry, and Knox, R.C., 1986, Septic tank system effects on ground water quality: Chelsea, Michigan, Lewis Publishers, Inc., 301 p.

Carnahan, B., Luther, H.A., and Wilkos, J.O., 1969, Applied numerical methods: New York, John Wiley and Sons, Inc., $604 \mathrm{p}$.

Carr and Associates, 1985, City of Lynden Greenwood test well drilling report: Gig Harbor, Wash., J.R. Carr and Associates, $7 \mathrm{p}$.

Cates, Kim Johnson, 1983, The movement of selected waste constituents through the earthen liner of a manure holding pond: Madison, Wis., University of Wisconsin, M.A. thesis, 79 p.

Compton, Jana, and Cole, D.W., 1993, Nitrate leading associated with $\mathrm{N}_{2}$-fixing red alder [abs.]: Transactions, American Geophysical Union, v. 74, p. 256.

Creahan, K., and Kelsey, H.M., 1988, Hydrogeology and groundwater flow near Lynden, Washington: Bellingham, Wash., Western Washington University, M.A. thesis, $55 \mathrm{p}$.
Culley, J.L.B., and Phillips, P.A., 1989, Retention and loss of nitrogen and solids from unlined earthen manure storages: Transactions of the American Society of Agricultural Engineers, v. 32, no. 2, p. 677-683.

Dalen, L.D., Anderson, W.P., and Rovang, R.M., 1983, Animal manure storage pond--groundwater quality evaluation: American Society of Agricultural Engineers winter meeting, paper no. 83-4572, 48 p.

Daly, R.A., 1912, Geology of the North American Cordillera at the 49th parallel: Canada Geological Survey Memorandum 38, $857 \mathrm{p}$.

Dasch, J.M., and Cadle, S.H., 1985, Wet and dry deposition monitoring in southeastern Michigan: Atmospheric Environment, v. 19, p. 789-796.

Davis, S., Fairbank, W., and Weisheit, H., 1973, Dairy wash ponds effectively self-sealing: Transactions of the American Society of Agricultural Engineers, v. 54, p. 69-71.

Delwiche, C.C., 1970, The nitrogen cycle: Scientific American, v. 223, p. 136-146.

DeTar, W.R., 1979, Infiltration of liquid dairy manure into soil: Transactions of the American Society of Agricultural Engineers, v. 22, p. 520-531.

Dinicola, R.S., 1990, Characterization and simulation of rainfall-runoff relations for headwater basins in western King and Snohomish Counties, Washington: U.S. Geological Survey Water-Resources Investigations Report 89-4052, $52 \mathrm{p}$.

Drever, J.I., 1982, The geochemistry of natural waters (2nd ed.): Engelwood Cliffs, N.J., Prentice Hall, 437 p.

Drost, B.W., Turney, G.L., Dion, N.P., and Jones, M.A., 1998, Hydrology and quality of ground water in northern Thurston County, Washington: U.S. Geological Survey Water-Resources Investigations Report 92-4109 (Revised), 230 p.

Dudley, John G., and Stephenson, David A., 1973, Nutrient enrichment of ground water from septic tank disposal systems: Madison, Wis., Upper Great Lakes Regional Commission, $131 \mathrm{p}$.

Easterbrook, D.J., 1963, Late Pleistocene glacial events and relative sea-level changes in the northern Puget Lowland, Washington: Geological Society of America Bulletin, v. 74, no. 12, p. 1,465-1,484.

1966a, Radiocarbon chronology of late Pleistocene deposits in northwest Washington: Science, v. 152, no. 3,723 , p. $764-767$.

-1966b, Glaciomarine environments and the Fraser Glaciation in northwest Washington: Friends of the Pleistocene, Guidebook for the First Pacific Field Conference, $52 \mathrm{p}$.

1969, Pleistocene chronology of the Puget Lowland and San Juan Islands, Washington: Geological Society of America Bulletin, v. 80, no. 11, p. 2,273-2,286. 
-1971, Geology and geomorphology of western Whatcom County, Washington: Bellingham, Wash., Western Washington University Department of Geology, 68 p.

1973, Environmental geology of western Whatcom County, Washington: Bellingham, Wash., Western Washington University, 78 p.

1976a, Geologic map of western Whatcom County, Washington: U.S. Geological Survey Miscellaneous Investigations Map I-854-B, 1 pl., scale 1:62,000.

1976b, Map showing engineering characteristics of geologic materials, western Whatcom County, Washington: U.S. Geological Survey Miscellaneous Investigations Map I-854-D, 1 pl., scale 1:62,000.

1982, Characteristic features of glacial sediments, in Scholle, P.A., and Spearing, D., eds., Sandstone depositional environments: Tulsa, Okla., American Association of Petroleum Geologists, p. 1-10.

England, T.D.J., 1991, Late Cretaceous to Paleogene structural and stratigraphic evolution of Georgia Basin, southwestern British Columbia--implications for hydrocarbon potential: Washington Geology, v. 19, no. 4 , p. 10-11.

Environment Canada, n.d., Canadian climate normals, 1951 1980, temperature and precipitation, British Columbia: Atmosphere Environment Service, Canadian Climate Program, UDC:551.582(711), 268 p.

Erickson, Denis, 1991, Edaleen Dairy Lagoon ground water quality assessment--February 1990-February 1991: Olympia, Wash., Washington State Department of Ecology, Open-File Report, 33 p.

-1992, Ground water quality assessment Whatcom County Dairy Lagoon \#2, Lynden, Washington: Olympia, Wash., Washington State Department of Ecology, Open-File Report, 26 p.

Erickson, Denis, and Norton, Dale, 1990, Washington State agricultural chemicals pilot study: Washington State Department of Ecology, 90-46, 76 p.

Ferris, J.G., Knowles, D.B., Brown, R.H., and Stallman, R.W., 1962, Theory of aquifer tests: U.S. Geological Survey Water-Supply Paper 1536-E, $174 \mathrm{p}$.

Feth, J.H., 1966, Nitrogen compounds in natural waters--a review: Water Resources Research, v. 2, p. 41-58.

Firestone, M.K., 1982, Biological denitrification, in Stevenson, F.J., ed., Nitrogen in agricultural soils: Madison, Wis., American Society of Agronomy Monograph no. 22 , p. 289-318.

Fishman, M.J., and Friedman, L.C., eds., 1989, Methods for determination of inorganic substances in water and fluvial sediments: U.S. Geological Survey Techniques of Water-Resources Investigations, book 5, chap. A1, $545 \mathrm{p}$.

Flipse, W.J., Jr., and Bonner, F.T., 1985, Nitrogen-isotope ratios of nitrate in ground water under fertilized fields, Long Island, New York: Ground Water, v. 23, p. 59-67.
Flipse, W.J., Jr., Katz, B.G., Lindner, J.B., and Markel Richard, 1984, Sources of nitrate in ground water in sewered housing development, Central Long Island, New York: Ground Water, v. 22, p. 418-426.

Flora, C.J., 1980, Profile of a dug well: Bellingham, Wash, Western Washington University, Institute for Freshwater Studies, Technical Report no. 28, p. 162.

Freeze, R.A., and Cherry, J.A., 1979, Groundwater: Engle. wood Cliffs, N.J., Prentice-Hall, Inc., 604 p.

Fried, M., Tanji, K.K., and Van de Poi, R.M., 1976, Simpli. fied long term concept for evaluating leaching of nitro. gen from agricultural lands: Journal of Environmental Quality, v. 5, p. 197-200.

Friedman, L.C., and Erdmann, D.E., 1982, Quality assurance practices for the chemical and biological analyses of water and fluvial sediments: U.S. Geological Survey Techniques of Water-Resources Investigations, book 5 , chap. A6, $181 \mathrm{p}$.

Garland, D.P., and Erickson, Denis, 1994, Ground water quality survey near Edaleen Dairy, Whatcom County, Washington: Washington State Department of Ecology, 94-37, $120 \mathrm{p}$.

Gat, J.R., 1980, The isotopes of hydrogen and oxygen in precipitation, in Fritz, Peter, and Fontes, J.C., eds., Hand. book of environmental isotope geochemistry, v. 1: New York, Elsevier Scientific Publishing Co., p. 21-48.

Gilliom, R.J., and Patmont, C.R., 1982, Lake phosphorus loading from septic systems by seasonally perched ground water, Puget Sound region, Washington: U.S. Geological Survey Open-File Report 82-907, 25 p.

Golder Associates, 1987, Report to City of Lynden of groundwater exploration program, May Road site: Redmond, Wash., Golder Associates Inc., unpaginated.

Golder Associates, 1989, Draft hydrogeologic investigation, Cedarville Landfill, Whatcom County, Washington: Redmond, Wash., Golder Associates, Inc., unpaginated. Goulding, K.W.T., 1990, Nitrogen deposition to land from the atmosphere: Soil Use Management, v. 6, no. 2, p. 61-63.

Greeson, P.E., Ehlke, T.A., Irwin, G.A., Lium, B.W., and Slack, K.V., 1977, Methods for collection and analysis of aquatic biological and microbiological samples: U.S. Geological Survey Techniques of WaterResources Investigations, book 5, chap. A4, 332 p.

Gromly, J.R., and Spalding, R.F., 1979, Sources and concentrations of nitrate-nitrogen in ground water of the Central Platte Region, Nebraska: Ground Water, v. 17 p. 291-301.

Grootjans, A.P., Schipper, P.C., and Van der Windt, H.J., 1986, Influence of drainage on $\mathrm{N}$-mineralization and vegetation response in wet meadows: ACTA Ecological/Ecological Plantarum, v. 7, p. 3-14. 
Halberg, G.R., 1989, Nitrate in ground water of the United States, in Follett, R.F., ed., Development in agriculture and managed-forest ecology 21--nitrogen management and ground water protection: New York, Elsevier, p. 35-74.

Hall, D.W., and Risser, D.W., 1992, Effects of nutrient management on nitrogen flux through a karst aquifer, Conestoga River headwaters basin, Pennsylvania; in Proceedings of the National Rural Clean Water Program Symposium, September 1992: U.S. Environmental Protection Agency EPA/625/R-92/006, p. 115-130.

Halstead, E.C., 1959, Ground-water resources of Matsqui Municipality, British Columbia: Geological Survey of Canada, Water Supply Paper 328, 43 p.

1966, Aldergrove test hole, Fraser Valley, British Columbia: Geological Survey of Canada, Paper 64-51, $17 \mathrm{p}$.

1986, Ground Water Supply-Fraser Lowland, British Columbia: Environment Canada, National Hydrology Research Paper no. 26, 80 p.

Hamilton, P.A., Denver, J.M., Phillips, P.J., and Shedlock, R.J., 1993, Water-quality assessment of the Delmarva Peninsula, Delaware, Maryland, and Virginia--effects of agricultural activities on, and distribution of, nitrate and other inorganic constituents in the surficial aquifer: U.S. Geological Survey Open-File Report 93-40, 87 p. Harding Lawson Associates, 1990, Hydrogeology and water quality, Cedarville Landfill, Whatcom County, Washington: Seattle, Harding Lawson Associates, unpaginated.

Health Canada, 1993, Guidelines for Canadian drinking water quality: Canadian Ministry of Health and Welfare, $26 \mathrm{p}$.

Heath, R.C., 1983, Basic ground-water hydrology: U.S. Geological Survey Water-Supply Paper 2220, 84 p.

Heaton, T.H.E., 1986, Isotopic studies of nitrogen pollution in the hydrosphere and atmosphere--a review:

Chemical Geology, v. 59, p. 87-102.

Helsel, D.R., and Hirsch, R.M., 1992, Statistical methods in water resources: New York, Elsevier, 522 p.

Hem, J.D., 1989, Study and interpretation of the chemical characteristics of natural water (3rd ed.): U.S. Geological Survey Water-Supply Paper 2254, 263 p.

Ivens, W.P.M.F., Draaijers, G.P.J., and Bleuten, W., 1988, Atmospheric nitrogen deposition in a forest next to an intensively used agricultural area, in Mathy, P., ed., Air Pollution and Ecosystems: Dordrecht, Reidel Publishing Co., p. 536-541.

Johanson, David, 1988, Fishtrap/Pepin/Bertrand Creeks water management basin plan--groundwater component: Victoria, British Columbia, Province of British Columbia Ministry of Environment and Parks, Water Management Branch-Groundwater Section, Open-File Report 16 p.
Johnson, A.I., 1967, Specific yield---compilation of specific yields for various materials: U.S. Geological Survey Water-Supply Paper 1662-D, 74 p.

Johnson, S.Y., 1984a, Stratigraphy, age and paleogeography of the Eocene Chuckanut Formation, northwest Washington: Canadian Journal of Earth Science, v. 21, p. 92-106.

-1984b, Cyclic fluvial sedimentation in a rapidly subsiding basin, northwest Washington: Sedimentary Geology, v. 38, p. 361-391.

1991, Sedimentation and tectonic setting of the Chuckanut Formation, northwest Washington: Washington State Department of Natural Resources, Washington Geology, v. 19, no. 4, p. 12-13.

Jones, M.A., 1996, Thickness of unconsolidated deposits in the Puget Sound Lowland, Washington and British Columbia: U.S. Geological Survey Water-Resources Investigations Report 94-4133, 1 pl., scale 1:500,000.

Kahle, S.C., 1990, Hydrostratigraphy and groundwater flow in the Sumas area, Whatcom County, Washington: Bellingham, Wash., Western Washington University, M.A. thesis, 92 p.

Keeney, D.R., 1986, Sources of nitrate in ground water: CRC Critical Reviews in Environment Control, v. 16, p. 257-304.

1989, Sources of nitrate in ground water, in Follett, R.F., ed., Development in agriculture and managedforest ecology 21--nitrogen management and ground water protection: New York, Elsevier, p. 373-392.

Keeney, D.R., and Bremner, J.M., 1964, Effect of cultivation on the nitrogen distribution in soils: Proceedings of the Soils Science Society of America, v. 28, p. 653-656.

Kohl, H.D., Shearer, G., Vithayanthil, F., 1978, Critique of "Nitrogen inputs and outputs--a valley basin study," nitrogen mass balance studies, in Neilsen, D.R. and MacDonald, J.G., eds., Nitrogen in the environment, v. 1: New York, Academic Press, Inc., p. 183-200.

Kohut, A.P., 1987, Groundwater supply capability Abbotsford Upland: Victoria, British Columbia, British Columbia Ministry of Environment, Open File Report, $18 \mathrm{p}$.

Kohut, A.P., Sather, S., Kwong, J., and Chwojka, F., 1989, Nitrate contamination of the Abbotsford Aquifer, British Columbia: Victoria, British Columbia, British Columbia Ministry of Environment, p. 24.

Kowalenko, Grant, 1992, What happens to nitrogen in the region? in Paul, J.W., Hughes-Games, G., and Zebarth, B.J., eds., Manure Management Workshop, January 30, 1992 [proceedings]: [no place of publication] Agriculture Canada, Agassiz Research Station; British Columbia Ministry of Agriculture, Fisheries and Food, Soils and Engineering Branch; and Canada-British Columbia Soil Conservation Program, p. 7-14. 
Kreitler, C.W., and Jones, D.C., 1975, Natural soil nitrate-the cause of the nitrate contamination of ground water in Runnels County, Texas: Groundwater, v. 13, p. $53-61$.

Kreitler, C.W., Ragone, S.E., Katz, B.G., 1978, $\mathrm{N}^{15} / \mathrm{N}^{14}$ ratios of ground-water nitrate, Long Island, New York: Ground Water, v. 16, p. 404-409.

Kwong, J.C., 1986, Groundwater quality monitoring and assessment program--the occurrence of nitrate-nitrogen in groundwater in the Langley-Abbotsford area: Victoria, British Columbia, British Columbia Ministry of Environment, Water Management Branch-Groundwater section, Memorandum report, file 0329563-A, unpaginated.

Laird, L.B., Taylor, H.E., and Lombard, R.E., 1986, Data on snow chemistry of the Cascade-Sierra Nevada Mountains: U.S. Geological Survey Open-File Report 86-61, $25 \mathrm{p}$.

Lawrence, R.R., and Pionke, H.B., 1989, Transformations and movement of nitrate in aquifer systems, in Follett, R.F., ed., Development in Agriculture and ManagedForest Ecology 21--nitrogen management and ground water protection: New York, Elsevier, p. 373-392.

LeBlanc, D.R., 1984, Sewage plume in a sand and gravel aquifer, Cape Cod, Massachusetts: U.S. Geological Survey Water-Supply Paper 2218, 28 p.

Leenheer, J.A., Malcolm, R.L., McKinley, P.W., and Eccles, L.A., 1974, Occurrence of dissolved organic carbon in selected ground-water samples in the United States: U.S. Geological Survey Journal of Research, 2 , p. 361-369.

Legg, J.O., and Meisinger, J.J., 1982, Soil nitrogen budgets, in Nitrogen in agricultural soils: Agronomy Monograph no. 22, Madison, American Society of Agronomy Inc., p. 503-566.

Liebscher, Hugh, Hii, Basil, and McNoughton, Duane, 1992, Nitrates and pesticides in the Abbotsford Aquifer, southwestern British Columbia: North Vancouver, British Columbia, Environment Canada, Inland Waters Directorate, $83 \mathrm{p}$.

Lindsay, C.S., 1988, The effects of urbanization on the water balance of the Fishtrap Creek Basin, northwest Washington and south-central British Columbia: Bellingham, Wash., Western Washington State University, M.A. thesis, p. 65.

Luttmerding, H.A., 1981, Soils of the Langley-Vancouver map area: Kelowna, British Columbia, British Columbia Ministry of Environment-Assessment and Planning Division, Resource Analysis Branch Bulletin 18, v. 1,2, and 3 .

Madison, R.J., and Brunett, J.O., 1985, Overview of the occurrence of nitrate in ground water of the United States--National Water Summary 1984: U.S. Geological Survey Water-Supply Paper 2275, p. 93-105.
Mangum, A.W., and Hurst, L.A., 1907, Soil survey of the Bellingham area, Washington: U.S. Department of Agriculture, Bureau of Soils, 39 p., 1 pl.

McCurdy, M., and McSweeney, K., 1993, The origin and identification of macropores in an earthen-lined dain manure storage basin: Journal of Environmental Quality, v. 22, p. 148-154.

McLellan, R.D., 1927, The geology of the San Juan Islands: Washington University Publication, Geology, v. 2 , $185 \mathrm{p}$.

Miller, J.F., Frederick, R.H., and Tracey, R.J., 1973, Precipi. tation frequency atlas of the western United States-. NOAA Atlas 2, National Oceanographic and Atmospheric Administration: Silver Spring, Maryland, National Weather Service, 43 p.

Miller, M.H., Robinson, J.B., and Gillham, R.W., 1985, Self-sealing of earthen liquid manure storage ponds--I. a case study: Journal of Environmental Quality, v. 14 no. 4 , p. 533-538.

Morris, D.A., and Johnson, A.I., 1967, Summary of hydro. logic and physical properties of rock and soil materials, as analyzed by the hydrologic laboratory of the U.S. Geological Survey: U.S. Geological Survey WaterSupply Paper 1839-D, 42 p.

Morton, T.G., Could, A.J., and Sullivan, W.M., 1988, Influence of over watering and fertilization on nitrogen losses from home lawns: Journal of Environmental Quality, v. 17, p. 124-130.

National Atmospheric Deposition Program, 1990-91, NADP/NTN annual data summary, precipitation chemistry in the United States: Fort Collins, Colo., National Resource Ecology Laboratory, Colorado State University, variously paginated.

National Research Council, 1978, Nitrates, an environmental assessment: Washington, D.C., National Academy Press, $723 \mathrm{p}$.

Newcomb, R.C., Sceva, J.E., and Olaf, Strome, 1949, Ground-water resources, Western Whatcom County, Washington: U.S. Geological Survey Open-file Report 50-7, $134 \mathrm{p}$.

Nightingale, H.I., and Bianchi, W.C., 1974, Ground-water quality related to irrigation with imported surface or local ground water: Journal of Environmental Quality, v. 3 , p. $356-361$.

Obbert, W.C., 1973, Nitrate in ground water, western Whatcom County, Washington: Bellingham, Wash., Western Washington State University, M.A. thesis, $130 \mathrm{p}$.

Pankow, J.F., 1991, Aquatic chemistry concepts: Chelsea, Mich., Lewis Publishers, 673 p.

Phillips, E.L., 1966, Washington climate for these counties --Callam, Jefferson, Island, San Jaun, Skagit, Snohomish, Whatcom: Washington State University, Cooperative Extension Service, Pub. E.M. 2626, 63 p. 
Phillips, P.A., and Culley, J.L.B., 1985, Groundwater nutrient concentrations below small-scale earthen manure storages: Agricultural Waste Utilization and Management, Proceedings of the Fifth International Symposium on Agricultural Waste, p. 672-679.

Porter, K.S., 1980, An evaluation of sources of nitrogen as causes of ground-water contamination in Nassau County, Long Island: Groundwater, v. 18, no. 6, p. 617-623

Poulson, E.N., and Flannery, R.D., 1953, Soil survey of Whatcom County, Washington: Washington, D.C., Soil Conservation Service, U.S. Department of Agriculture, p. 153.

Pratt, P.F., Davis, S., and Sharpless, R.G., 1976, A four-year field trial with animal manures--I. nitrogen balances and yields: Hilgardia, v. 44, p. 99-125.

Pritt, Jeffrey, and Jones, B.E., 1989, National Water Quality Laboratory service catalog: U.S. Geological Survey Open-File Report 89-386, unpaginated.

Reddy, M.R., and Dunn, S.J., 1984, Effect of domestic effluents on ground water quality--a case study: The Science of the Total Environment, v. 40, p. 115-124. Reddy, K.R., Sacco, P.D., and Graets, D.A., 1980, Nitrate reduction in an organic soil-water system: Journal of Environmental Quality, v. 9, p. 283-288.

Reese, L.E., and Loudon, T.L., 1983, Seepage from earthen manure storages and lagoons--a literature review: American Society of Agricultural Engineers winter meeting, Chicago, Illinois, December 13-16, 1983, paper no. 83-4569, $10 \mathrm{p}$.

Reinhorn, Tova, and Avnimelech, Yoram, 1974, Nitrogen release associated with the decrease in soil organic matter in newly cultivated soils: Journal of Environmental Quality, v. 3, no. 2, p. 118-123.

Riggs, G.B., 1958, Peat resources of Washington: Olympia, Wash., State of Washington Department of Conservation, Division of Mines and Geology, 272 p.

Roswell, T.G., Miller, M.H., and Groenevelt, P.H., 1985, Self-sealing of earthen liquid manure storage ponds--II. rate and mechanism of sealing: Journal of Environmental Quality, v. 14, no. 4, p. 539-543.

Runnells, D.D., 1993, Inorganic chemical processes and reactions, in Alley, W.M., ed., Regional groundwater quality: New York, Van Nostrand Reinhold, p. 131-154.

Saffigna, P.G., and Keeney, D.R., 1977, Nitrate and chloride in ground water under irrigated agriculture in Central Wisconsin: Ground Water, v. 15, p. 170-177.

Sanderson, M., and LaValle, P.D., 1979, Surface loading from pollutants in precipitation in southern Ontario-some climatic and statistical aspects: Journal of Great Lakes Research, v. 5, no. 1, p. 52-60.
Severson, R.C., and Shacklette, H.T., 1988, Essential elements and soils amendments for plants--sources and use for agriculture: U.S. Geological Survey Circular 1017, 48 p.

Sisterson, D.L., 1990, Detailed $\mathrm{SO}_{\mathrm{x}}-\mathrm{S}$ and $\mathrm{NO}_{\mathrm{x}}-\mathrm{N}$ mass budgets for the United States and Canada--appendix A, in Venkatram, Akula, and others, Relationships between atmospheric emissions and depositions/air quality: National Acid Precipitation Assessment Program Report 8, variously paginated.

Skougstad, M.W., and Horr, C.A., 1963, Occurrence and distribution of strontium in natural water: U.S. Geological Survey Water-Supply Paper 1496-D, p. D55-D97.

Spalding, R.F., and Exner, M.E., 1993, Occurrence of nitrate in groundwater--a review: Journal of Environmental Quality, v. 22, no. 3, p. 392-401.

Spalding, R.F., Exner, M.E., Lindau, C.W., and Eaton, D.W., 1982, Investigation of sources of groundwater nitrate contamination in the Burbank-Wallula area of Washington, U.S.A.: Journal of Hydrology, v. 58, p. 307-324.

Steinberg, S.M., Pignatello, J.J., Sawhney, B.L., 1987, Persistence of 1,2-Dibromoethane in soils--entrapment in intraparticle micropores: Environmental Science and Technology, v. 21, p. 1,201-1,208.

Stephenson, D.A., Fleming, A.H., and Mickelson, D.M., 1988, Glacial deposits, in Back, William, Rosenshein, J.S., and Seaber, P.R., eds., The geology of North America, v. 0-2 Hydrogeology: Boulder, Colo., Geologic Society of America, p. 301-314.

Stevenson, F.J., 1982, Origin and distribution of nitrogen in soil, in Stevenson, F.J., ed., Nitrogen in agricultural soils--agronomy monograph no. 22: Madison, Wis., American Society of Agronomy, p. 1-42.

Stevenson, F.J., editor, 1982, Nitrogen in agricultural soils-agronomy monograph no. 22: Madison, Wis, American Society of Agronomy, p. 940.

Sweet-Edwards, 1984, Hydrogeologic investigation Cedarville site, Whatcom County leachate study, phase II report: Kelso, Wash., Sweet-Edwards and Associates, $24 \mathrm{p}$.

Sweet-Edwards/EMCON, 1989, Evaluation of ground water contamination from agricultural application of ethylene dibromide at four primary sites in Washington: Bothell, Wash., Sweet-Edwards/EMCON, 150 p.

Tanji, K.K., Fried, Maurice, and Van de Pol, R.M., 1977, A steady-state conceptual nitrogen model for estimating nitrogen emissions from cropped lands: Journal of Environmental Quality, v. 6, no. 2, p. 155-159.

Thornthwaite, C.W., and Mather, J.R., 1957, Instructions and tables for computing potential evapotranspiration and the water balance: Centernon, New Jersey, Drexel Institute of Technology, Publications in Climatology, v. 10, no. 3,38 p. 
Thurman, E.M., 1985, A conceptual chemical process model for sewage contamination of a sand and gravel aquifer, in Franks, B.J., ed., U.S. Geological Survey program on toxic waste--ground-water contamination--Proceedings of the third technical meeting, Pensacola, Florida, March 23-27, 1987: U.S. Geological Survey Open-File Report 87-109, p. B-37 to B-42.

Thurman, E.M., Barber, L.B., II, and LeBlanc, D.R., 1985, Movement and fate of detergents in ground water--a field study: Contaminant Hydrology, v. 1, no. 1, p. 143-161.

Todd, D.K., 1980, Groundwater hydrology: New York, John Wiley and Sons, $535 \mathrm{p}$.

Turney, G.L., 1986, Quality of ground water in the Puget Sound region, Washington, 1981: U.S. Geological Survey Water-Resources Investigations Report 84-4258, 169 p.

Turney, G.L., Kahle, S.C., and Dion, N.P., 1995, Geohydrology and ground-water quality of East King County, Washington: U.S. Geological Survey Water-Resources Investigations Report 94-4082, 123 p.

Urban, N.R., Bayley, S.E., and Eisenreich, S.J., 1989, Export of dissolved organic carbon and acidity from peatlands: Water Resources Research, v. 25, p. 1,619-1,628.

U.S. Department of Agriculture, 1985, State of Washington irrigation guide: Spokane, Wash., Soil Conservation Service, variously paginated.

-1992a, Agricultural waste management field handbook: Soil Conservation Service, National Engineering Handbook, part 651, variously paginated.

-1992b, Soil survey of Whatcom County area, Washington: Soil Conservation Service, 481 p.

U.S. Environmental Protection Agency, 1993, Drinking water regulations and health advisories: Washington, D.C., U.S. Environmental Protection Agency, Office of Water, $11 \mathrm{p}$.

U.S. Geological Survey, 1979, Land use and land cover, 1973-74, Bellingham, Washington: U.S. Geological Survey Land Use Series Map L-3, 1 pl., scale 1:100,000.

U.S. Weather Bureau, 1965, Mean annual precipitation, 1930-1957, State of Washington: Portland, Oreg., Soil Conservation Service, 1 pl.

Van Denburgh, A.S., and Santos, J.F., 1965, Ground water in Washington--its chemical and physical quality: Washington Division of Water Resources Water-Supply Bulletin 24, 93 p.

Van Miegroet, H., and Cole, D.W., 1985, Acidification sources in red alder and douglas fir soils--importance of nitrification: Soil Science American Journal, v. 49, p. 1,274-1,279.
Viets, F.G., 1978, Critique of "Nitrogen inputs and outputs. a valley basin study," mass balance and flux of nitrogen as aids in control and prevention of water pollution, in Neilsen, D.R., and MacDonald, J.G., eds., Nitrogen in the environment, v. 1: New York, Academic Press, p. 173-182.

Walker, W.G., Bouma, J., Keeney, D.R., and Magdoff, F.R 1973a, Nitrogen transformations during subsurface disposal of septic tank effluent in sands--I. soil transfor. mations: Journal of Environmental Quality, v. 2, no. 4 , p. 475-480.

Walker, W.G., Bouma, J., Keeney, D.R., and Olcott, P.G., 1973b, Nitrogen transformations during subsurface disposal of septic tank effluent in sands--II. ground water quality: Journal of Environmental Quality, v. 2, no. 4, p. 521-525.

Wassenaar, L.I., 1994, Evaluation of the origin and fate of nitrate in the Abbotsford aquifer using isotopes of ${ }^{15} \mathrm{~N}$ and ${ }^{18} \mathrm{O}$ in $\mathrm{NO}_{3}$ : Saskatoon, Saskatchewan, National Hydrology Research Institute, NHRI Contribution no. CS-94009, 28 p.

Washington Agricultural Statistics Service, 1991, Washing. ton agricultural statistics 1990-1991 annual report: Tumwater, Wash., Washington Agricultural Statistics, $140 \mathrm{p}$.

Washington State Division of Water Resources, Department of Conservation, 1960, Water resources of the Nooksack River Basin and certain adjacent streams: Olympia, Wash., Division of Water Resources, Water Supply Bulletin no. 12, 187 p.

Wershaw, R.L., Fishman, M.J., Grabbe, R.R., and Lowe, L.E., editors, 1987, Methods for the determination of organic substances in water and fluvial sediments: U.S. Geological Survey Techniques of Water-Resources Investigations, book 5, chap. A3, 80 p.

Whatcom County Planning Department, 1983, The Lynden Nooksack Valley subarea--an inventory and analysis of existing conditions: Bellingham, Wash., Whatcom County Planning Department, $130 \mathrm{p}$.

White, A.F., Peterson, M.L., and Solbau, R.D., 1990, Measurement and interpretation of low levels of dissolved oxygen in ground water: Ground Water, v. 28 , no. 4 , p. 584-590.

Wood, W.W., 1981, Guidelines for collection and field analysis of ground-water samples for selected unstable constituents: U.S. Geological Survey Techniques of Water-Resources Investigations, book 1, chap. D2, $24 \mathrm{p}$. 
APPENDIX 


\section{APPENDIX}

\section{Computation of Hydraulic Conductance from Specific Capacity Data}

Estimations of the horizontal hydraulic conductivity for each hydrogeologic unit were made using specific-capacity data. Only data from those wells that had the most complete and reliable set of specificcapacity information (discharge rate, drawdown, longterm test, well-construction data, and geologic log) were used. Of the 608 wells inventoried, 219 had such information. Two different sets of equations were used, depending on how the well was finished. For wells that had a screened, perforated, or open-hole interval, the modified Theis equation (Ferris and others, 1962) was first used to estimate transmissivity values. This equation is

$$
T=\frac{Q}{4 \pi s} \ln \frac{2.25 T t}{r^{2} S},
$$

where

$S=$ storage coefficient, a dimensionless decimal;

$Q=$ discharge, or pumping rate, of the well, in cubic feet per day;

$T=$ transmissivity of the hydrogeologic unit, in square feet per day;

$t=$ length of time the well was pumped, in days;

$r=$ radius of the well, in feet; and

$s=$ drawdown in the well, in feet.

The equation was solved for transmissivity (T) using Newton's iterative method (Carnahan and others, 1969, p. 171). Next, the following equation was used to calculate horizontal hydraulic conductivity.

$$
K_{h}=\frac{T}{b},
$$

where

$K_{h}=$ horizontal hydraulic conductivity of the hydrogeologic unit, in feet per day;

$T=$ transmissivity, as calculated above; and

$b=$ thickness of the hydrogeologic unit, in feet (approximated using length of the open interval).
The use of the open interval to approximate the thickness of the hydrogeologic unit assumes that a well is open to the entire thickness of the unit, which was almost never the case. Nevertheless, this assumption is necessary because the equations are derived on the assumption that flow to the well is horizontal only; that is, vertical flow is insignificant. In a homogeneous unit, these conditions are present only if a well penetrates the entire thickness of the unit. However, in glacial systems, horizontal flow is likely to be much greater than vertical flow because the unit's heterogeneity leads to horizontal hydraulic conductivities that are generally much larger than the vertical hydraulic conductivities. Thus, even though the wells are rarely open to the entire thickness of the unit, the assumption that they are is reasonable for glacial systems.

Another equation was used to estimate hydraulic conductivities for wells having only an open end and thus no vertical dimension to the opening. Bear (1979) provides an equation for hemispherical flow to an open-ended well just penetrating an aquifer. When modified for spherical flow to an open-ended well within an aquifer, the equation becomes

$$
K_{h}=\frac{Q}{4 \pi s} \times \frac{1}{r},
$$

where

$K_{h}=$ horizontal hydraulic conductivity of the hydrogeologic unit, in feet per day;

$Q=$ discharge, or pumping rate of the well, in cubic feet per day;

$s=$ drawdown in the well, in feet; and

$r=$ the well radius, in feet.

Equation 3 is based on the assumption that flow can occur equally in all directions, specifically, that horizontal and vertical hydraulic conductivities are equal. As discussed above, this is not likely to be true for glacial systems. However, the errors associated with violating this assumption are likely to be less than those that would occur in trying to fit the Theis equation to the open-ended well geometry. In fact, hydraulic conductivities were calculated using both approaches for open-ended wells, and the values obtained using the Bear equation for open-ended wells more closely resembled the hydraulic conductivities calculated for the screened wells. 


\section{Reconnaissance Sampling for Nitrates and Chloride}

All nitrate concentrations are reported in units of milligrams per liter as nitrate nitrogen $\left(\mathrm{NO}_{3}-\mathrm{N}\right)$. For samples collected during this study, concentrations should properly be reported as nitrate-plus-nitrite because the analytical method used (Fishman and Friedman, 1989) includes both species. In most natural waters, nitrite is a short-lived species produced during the oxidation of ammonia to nitrate or the denitrification of nitrate to nitrogen gas; as such, it is not usually present in significant quantities unless the total concentration of all nitrogen species is small. This is verified in the data on nitrogen species listed in appendix table 8 .

In reporting nitrate and chloride concentrations in this study, the operational definition of whether the concentration is "total" or "dissolved" was ignored. This designation depends on whether a sample was filtered at the time of collection through a membrane filter with a nominal pore size of 0.45 micrometers. Filtering, which may have substantial effect on the concentrations of constituents that sorb to sediment or colloidal matter, has little effect on the concentration of either nitrate or chloride, which are soluble in water.

All nitrate samples, both filtered and unfiltered, were treated with mercuric chloride and chilled to inhibit biologically mediated reactions that could alter the concentration of nitrate.

\section{Transformations of Nitrogen}

Nitrogen compounds may undergo several transformations during the process of infiltration and percolation to ground water (Lawrence and Pionke, 1989). Nitrogen sources commonly are compounds containing nitrogen in a low-oxidation state. These compounds, referred to as reduced nitrogen species, include organic nitrogen compounds and ammonia. Oxidation of these reduced species to nitrate occurs in the presence of oxygen and the required bacteria, which utilize the energy released during the reactions. The oxidation (or nitrification) of ammonia in water percolating through the unsaturated zone is generally complete if oxygen is present. Alhajjar (1985) found that ammonia was rapidly and almost completely converted to nitrate in the unsaturated zone beneath septic tank drain fields. He also found that much of the organic nitrogen present in septage was converted to ammonia, which in turn was oxidized to nitrate. An exception was observed in a water-logged drain field where lack of oxygen prevented the nitrification of ammonia.

Under anaerobic conditions, nitrate may undergo denitrification to nitrogen gas or nitrous oxide, or it may be reduced to ammonia. Denitrification is believed to occur more readily than reduction except in organic-rich soils (Reddy and others, 1980). In denitrification, the bacteria usually responsible for the biological reduction require organic carbon as an energy source. It is entirely possible that nitrate introduced or formed in the upper soil zones may undergo denitrification in deeper zones where oxygen is not present and organic carbon is available.

Once infiltrating water has reached the water table, some of the same transformations that occur in the unsaturated zone may also occur under saturated conditions. Small concentrations of ammonia in ground water in the study area indicate that inorganic nitrogen is present primarily as nitrate. Nitrate in ground water is relatively stable in the presence of oxygen.

\section{Stable Isotopes of Nitrogen}

Two naturally occurring stable isotopes of nitrogen are known: ${ }^{14} \mathrm{~N}$ and ${ }^{15} \mathrm{~N}$. The ${ }^{15} \mathrm{~N}$ atom, which is the heavier of the two isotopes, makes up only about 0.4 percent of the nitrogen in the earth's atmosphere. Although the isotopic composition of the nitrogen in the earth's atmosphere is relatively constant, the isotopic composition of nitrogen in other compounds is variable and is often different from that of the atmosphere. The variability in the isotopic composition of the nitrogen in the nitrate sometimes makes it possible to infer the source of nitrate in ground water.

Stable-isotope concentrations of nitrogen are generally expressed in delta units $(\delta)$ given in per mil $(0 / 00)$ or parts per thousand (Gat, 1980). These units represent relative deviations in the heavy isotope fraction in water and are defined as 


$$
\delta^{15} N=\left[\frac{R_{\text {sample }}}{R_{\text {standard }}}-1\right] \times 1,000,
$$

$$
\begin{aligned}
& \begin{aligned}
\text { where } & \text { ratio of isotopic concentration }\left({ }^{15} N /{ }^{14} N\right) \\
R_{\text {sample }} & \text { of the sample, and } \\
R_{\text {standard }} & =\text { ratio of isotopic concentration }\left({ }^{15} N /{ }^{14} N\right) \\
& \text { of atmospheric nitrogen. }
\end{aligned}
\end{aligned}
$$

The isotopic composition of nitrogen in ground water is governed by the isotopic composition of the source material and the effects of chemical, biological, and physical processes that may alter the isotopic composition of the source material. The effects of many of the individual processes that alter the isotopic composition of source materials are known, but net effects are difficult to quantify in a field setting where multiple processes are likely to occur. For this reason, the use of nitrogen isotope ratios to infer sources of nitrate in ground water is most suitable in settings where few, if any, chemical, physical, or biological processes occur to alter the isotopic composition of the source material.

\section{Explanation of Milliequivalents and Piper Diagrams}

Ground water can be characterized by differences in the concentrations of major cations and anions. Water types as described by Hem (1989) use dominant cations and anions to characterize water samples. To do this, concentrations of the major cations and anions need to be converted from milligrams per liter to milliequivalents per liter to account for differences in atomic weight and electrical charge. A milliequivalent is the amount of a compound, in this case one of the ions, that reacts with a given amount of $\mathrm{H}^{+}$or $\mathrm{OH}^{-}$. When expressed as milliequivalents, all cations and anions are equivalent for the purpose of balancing equations governing electrical charge of the dissolved ions. A milliequivalent of sulfate will combine with a milliequivalent of calcium, as would a milliequivalent of chloride. The milliequivalents of all the cations and anions are then summed separately to obtain a cation sum and anion sum, in milliequivalents. Because the water is electrically neutral, the cation and anion sums should be close in value. The contribution of each ion to the appropriate sum then is calculated as a percentage. The cations and anions that are the largest contributors to their respective sums define the water types. For example, the water type of seawater is sodium/chloride.

To make the determination of water types easier, the percentages of cations and anions for a given sample are plotted on a trilinear diagram, as shown in figure 18. The water type then is determined from the area of the diagram in which the sample is plotted. Piper diagrams consist of three separate plots; two of the plots are trilinear plots that show the percentage contribution of individual or pairs of cations and anions to their respective sums, and a third plot shows the predominant cation and anion association. Combined water types, where more than one cation or anion dominate, are possible and are actually common. For combined water types, the ions are listed in order of dominance. For example, a calcium-magnesium/bicarbonate type has more calcium than magnesium, a mag. nesium-calcium/bicarbonate type has more magnesium than calcium, but both plot in the same section of the diagram. An inspection of the diagram shows that to be defined as a sole dominant ion, an ion must account for 60 percent or more of the cation or anion sum, and the analysis will be plotted near one of the corners of the trilinear plot. On the other hand, an ion that accounts for less than 20 percent of the sum will not be included in the water type. An exception to the latter case occurs when two ions are included on a single axis of the plot, such as chloride and nitrate. If both together contribute 20 percent, then the sample will plot as though chloride is a dominate anion, even though individually chloride and nitrate contributions may be less than 20 percent. For this study, the actual percentages were used to determine the water type, and if both were less than 20 percent, neither was considered dominant. Also it should be noted that the diagram, which is based on percentages, does not show actual concentrations. 
Appendix Table 1. Well, water-level, hydrogeologic, and reconnaissance water-quality data

[Ground-water site type: W, well; X, test hole; S, spring. Site use: W, withdrawal; U, unused; O, observation; T, test well; Z, destroyed. Water use: C, commercial; F, fire; D, dewater; H, domestic supply; irrigation; P, public supply; R, recreation; S, stock; U, unused. Hydrogeologic units: EVRS, Everson-Vashon semiconfining unit; SUMS, Sumas aquifer; EVRS* and SUMS*, Hydrogeologic units based on data from nearby wells, no log available; VSHN, Vashon semiconfining unit; BDRK, bedrock unit. Lithologic units: 10, unconfined sand and gravel, occasional clay lenses; 11 , sand and gravel overlain by pea or peat and clay; 12 , sand and gravel overlain by clay; 13, sand and gravel with bog iron; 14, sand and gravel with lenses of clay or till; 15 , alluvial sand and gravel; 20 , confined sand and gravel in Sumas Valley; 21 , confined sand and gravel in Sumas Valley, peat associated with confining clay; 22, sand and gravel unit underlying a second deeper clay in Sumas Valley; 23, thin producing sand lense in surficial silt; 30, confined sand or sand and gravel, confined by glaciomarine drift or till; 31, deeper confined sand or gravel; 40, bedrock; 50, undifferentiated glacial deposits. Source of data: USGS, U.S. Geological Survey; BCME, British Columbia Ministry of Environment; EC, Environment Canada; WDOE, Washington State Department of Ecology; WCPH, Whatcom County Public Health Department; Drill, driller's log;

,- not analyzed]

\begin{tabular}{|c|c|c|c|c|c|c|c|c|c|c|c|c|c|c|c|c|}
\hline Local well number & $\begin{array}{l}\text { Lati- } \\
\text { tude }\end{array}$ & $\begin{array}{l}\text { Longi- } \\
\text { tude }\end{array}$ & $\begin{array}{l}\text { Ground } \\
\text { water } \\
\text { site } \\
\text { type }\end{array}$ & Site & $\begin{array}{l}\text { Wat- } \\
\text { er } \\
\text { use }\end{array}$ & $\begin{array}{l}\text { Hydro- } \\
\text { geo- } \\
\text { logic } \\
\text { unit }\end{array}$ & $\begin{array}{l}\text { Litho- } \\
\text { logic } \\
\text { unit }\end{array}$ & $\begin{array}{l}\text { Well } \\
\text { depth } \\
\text { (feet) }\end{array}$ & $\begin{array}{l}\text { Well } \\
\text { dia- } \\
\text { meter } \\
\text { (inches) }\end{array}$ & $\begin{array}{l}\text { Alti- } \\
\text { tude } \\
\text { (feet) }\end{array}$ & $\begin{array}{l}\text { Source } \\
\text { of } \\
\text { data }\end{array}$ & $\begin{array}{l}\text { Water- } \\
\text { level or } \\
\text { sample } \\
\text { date }\end{array}$ & $\begin{array}{l}\text { Water } \\
\text { level, } \\
\text { feet below } \\
\text { land surface }\end{array}$ & $\begin{array}{l}\text { Specific } \\
\text { conduc- } \\
\text { tance } \\
(\mu \mathrm{S} / \mathrm{cm})\end{array}$ & $\begin{array}{l}\text { Chloride, } \\
\text { dissolved } \\
(\mathrm{mg} / \mathrm{L} \\
\text { as } \mathrm{Cl} \text { ) }\end{array}$ & $\begin{array}{l}\text { Nitrogen } \\
\mathrm{NO}_{2}+\mathrm{NO}_{3} \\
\text { total } \\
(\mathrm{mg} / \mathrm{L} \text { as } \mathrm{N})\end{array}$ \\
\hline $092 \mathrm{G} .008 \cdot 1 \cdot 2 \cdot 1-02$ & 490040 & 1223215 & $\mathrm{~W}$ & $\mathrm{~W}$ & S & EVRS & 30 & 109 & 6 & 230 & USGS & 19900605 & 33.03 & 99 & 86 & $<0.1$ \\
\hline $092 \mathrm{G} .008 .1 .2 .1-03$ & 490034 & 1223202 & W & W & $\mathrm{H}$ & EVRS & 30 & 99 & 6 & 220 & USGS & 19900605 & 41.10 & 280 & 0.9 & $<0.1$ \\
\hline $092 \mathrm{G} .008 \cdot 1 \cdot 2.2-01$ & 490034 & 1223129 & W & W & $\mathrm{H}$ & EVRS & 30 & 39 & 6 & 205 & USGS & 19900605 & 4.19 & 229 & 4.8 & 0.9 \\
\hline $092 G \cdot 008 \cdot 1 \cdot 2 \cdot 3-10$ & 490124 & 1223214 & $\mathrm{~W}$ & $\mathrm{~W}$ & $\mathrm{R}$ & EVRS & 30 & 230 & 8 & 250 & USGS & 19900605 & 56.2 & 4,390 & 1,100 & $<0.1$ \\
\hline $092 \mathrm{G} .008 .1 .4 .1-07$ & 490214 & 1223139 & W & W & $\mathrm{H}$ & EVRS & 30 & 51 & 6 & 275 & USGS & 19900606 & 30.90 & 260 & 19 & $<0.1$ \\
\hline $092 \mathrm{G} .008 .1 .4 .2-01$ & 490150 & 1223024 & W & $\mathrm{U}$ & $\mathrm{U}$ & EVRS & -- & 395 & 6 & 300 & Drill & 19720614 & 115 & 6,800 & 1,920 & 1.6 \\
\hline $092 \mathrm{G} .008 .1 .4 .2-08$ & 490156 & 1223122 & W & W & $\mathrm{H}$ & EVRS & 30 & 153 & 6 & 251 & USGS & 19900606 & 33.32 & 300 & 15 & $<0.1$ \\
\hline $092 \mathrm{G} .008 \cdot 1 \cdot 4 \cdot 2-15$ & 490153 & 1223018 & W & $\mathrm{W}$ & $\mathrm{s}$ & EVRS & 30 & 342 & 6 & 300 & USGS & 19900607 & -- & 2,560 & 670 & $<0.1$ \\
\hline $092 \mathrm{G} .008 .1 .4 .4-03$ & 490248 & 1223052 & W & W & $\mathrm{H}$ & EVRS & 30 & 81 & 6 & 305 & USGS & 19900606 & 56.16 & 909 & 1.6 & $<0.1$ \\
\hline $092 \mathrm{G} .008 .1 .4 .4-06$ & 490259 & 1223009 & W & W & $\mathrm{H}$ & EVRS & 30 & 117 & 6 & 320 & USGS & 19910607 & 92.3 & 777 & 1.6 & $<0.1$ \\
\hline $092 \mathrm{G} .008 .2 .1 .1-02$ & 490023 & 1222926 & W & W & $\mathrm{H}$ & EVRS & 30 & 164 & 6 & 164 & USGS & 19900607 & 12.40 & 259 & 3.8 & $<0.1$ \\
\hline $092 \mathrm{G} .008 \cdot 2.1 .1-04$ & 490036 & 1222932 & W & W & $\mathrm{H}$ & EVRS & 30 & 68 & 6 & 180 & USGS & 19900607 & 13.19 & 359 & 5.8 & $<0.1$ \\
\hline $092 \mathrm{G} .008 \cdot 2 \cdot 1.2-03$ & 490017 & 1222736 & W & W & $\mathrm{H}$ & EVRS & 30 & 39 & 6 & 180 & USGS & 19900607 & 10.26 & 190 & 1 & $<0.1$ \\
\hline $092 \mathrm{G} .008 .2 .1 .2-04$ & 490017 & 1222821 & W & W & $\mathrm{P}$ & SUMS & 10 & 52 & 8 & 154 & USGS & 19900607 & 13.92 & 205 & 8.4 & 11 \\
\hline $092 \mathrm{G} .008 \cdot 2 \cdot 1.3-08$ & 490100 & 1222929 & W & $\mathrm{U}$ & $\mathrm{U}$ & EVRS & 30 & 302 & 6 & 240 & USGS & 19900608 & 74.86 & -- & -- & -- \\
\hline $092 \mathrm{G} .008 .2 .1 .4-01$ & 490052 & 1222808 & w & W & & EVRS & 30 & 102 & 8 & 291 & USGS & 19900607 & 45.24 & -- & -- & -- \\
\hline $092 \mathrm{G} .008 .2 .1 .4-09$ & 490106 & 1222750 & $\mathrm{~W}$ & W & $\mathrm{H}$ & SUMS & 14 & 96 & 6 & 295 & USGS & 19900607 & 54.34 & 145 & 11 & $<0.1$ \\
\hline $092 \mathrm{G} .008 .2 .2 .1-03$ & 490022 & 1222644 & W & w & $\mathrm{H}$ & SUMS & 14 & 100 & 6 & 150 & USGS & 19900611 & 4.43 & 185 & 1.8 & 0.4 \\
\hline $092 \mathrm{G} .008 \cdot 2 \cdot 2 \cdot 1-04$ & 490012 & 1222636 & W & W & $\mathrm{H}$ & EVRS & 31 & 160 & 6 & 150 & USGS & 19900612 & 5.65 & 279 & 25 & $<0.1$ \\
\hline $092 \mathrm{G} .008 \cdot 2 \cdot 2 \cdot 2-10$ & 490043 & 1222405 & w & W & $\mathrm{H}$ & EVRS & 30 & 220 & 6 & 152 & USGS & 19900612 & 39.33 & 726 & 110 & $<0.1$ \\
\hline $092 \mathrm{G} .008 \cdot 2 \cdot 2 \cdot 2-11$ & 490043 & 1222405 & W & $\mathrm{U}$ & U & SUMS & 10 & 50 & 6 & 152 & USGS & 19900612 & 9.99 & -- & -- & - \\
\hline $092 \mathrm{G} .008 \cdot 2 \cdot 2 \cdot 2-12$ & 490036 & 1222406 & W & $\mathrm{W}$ & $\mathrm{U}$ & SUMS & 10 & 80 & 8 & 152 & USGS & 19900612 & 9.44 & -- & -- & -- \\
\hline $092 \mathrm{G} .008 \cdot 2 \cdot 2 \cdot 2-15$ & 490011 & 1222432 & W & W & $\mathrm{s}$ & SUMS & 10 & 70 & 6 & 148 & USGS & 19900612 & 11.24 & 295 & 11 & 4.5 \\
\hline $092 \mathrm{G} .008 .2 .2 .2-\mathrm{ABB} 1$ & 490042 & 1222410 & $\mathrm{~W}$ & 0 & $\mathrm{U}$ & SUMS & 10 & 26 & 2 & 150 & USGS & 19900618 & 8.46 & 255 & 9.2 & 11 \\
\hline $092 \mathrm{G} .008 .2 .2 .3-03$ & 490053 & 1222600 & W & W & $\mathrm{H}$ & SUMS & 10 & 60 & 6 & 210 & USGS & 19900611 & 35.53 & 179 & 6.2 & 5 \\
\hline $092 \mathrm{G} .008 .2 .2 .4-16$ & 490102 & 1222437 & $\mathrm{~W}$ & W & I & EVRS & 30 & 98 & 6 & 170 & USGS & 19900612 & 2.47 & -- & -- & -- \\
\hline $092 \mathrm{G} .008 \cdot 2 \cdot 3 \cdot 1-11$ & 490212 & 1222837 & $\mathrm{w}$ & W & $\mathrm{H}$ & EVRS* & -- & 44 & 6 & 305 & USGS & 19900608 & 19.39 & 198 & 2 & $<0.1$ \\
\hline $092 \mathrm{G} .008 \cdot 2 \cdot 3 \cdot 1-12$ & 490154 & 1222842 & W & $\mathrm{W}$ & $\mathrm{H}$ & EVRS & 30 & 50 & 6 & 300 & USGS & 19900608 & 13.66 & 215 & 3.2 & $<0.1$ \\
\hline $092 \mathrm{G} .008 \cdot 2 \cdot 3 \cdot 2-10$ & 490155 & 1222738 & W & $\mathrm{W}$ & $\mathrm{U}$ & SUMS & 10 & 85 & 6 & 362 & USGS & 19900608 & 32.54 & -- & -- & -- \\
\hline $092 \mathrm{G} \cdot 008 \cdot 2 \cdot 3 \cdot 2-16$ & 490157 & 1222739 & W & W & $\mathrm{H}$ & EVRS & 30 & 164 & 6 & 358 & USGS & 19900608 & 57.58 & 177 & 4.2 & 4.1 \\
\hline $092 \mathrm{G} .008 \cdot 2 \cdot 3 \cdot 3-09$ & 490247 & 1222932 & W & W & $\mathrm{H}$ & EVRS & 30 & 73 & 6 & 298 & USGS & 19900608 & 12.84 & 269 & 1 & $<0.1$ \\
\hline
\end{tabular}


$\vec{\omega} \quad$ Appendix Table 1. Well, water-level, hydrogeologic, and reconnaissance water-quality data--Continued

\begin{tabular}{|c|c|c|c|c|c|c|c|c|c|c|c|c|c|c|c|c|}
\hline Local well number & $\begin{array}{l}\text { Lati- } \\
\text { tude }\end{array}$ & $\begin{array}{l}\text { Longi- } \\
\text { tude }\end{array}$ & $\begin{array}{l}\text { Grounc } \\
\text { water } \\
\text { site } \\
\text { type }\end{array}$ & $\begin{array}{l}\text { d } \\
\text { Site } \\
\text { use }\end{array}$ & $\begin{array}{l}\text { Wat- } \\
\text { er } \\
\text { use }\end{array}$ & $\begin{array}{l}\text { Hydro- } \\
\text { geo- } \\
\text { logic } \\
\text { unit }\end{array}$ & $\begin{array}{l}\text { Litho- } \\
\text { logic } \\
\text { unit }\end{array}$ & $\begin{array}{l}\text { Well } \\
\text { depth } \\
\text { (feet) }\end{array}$ & $\begin{array}{l}\text { Well } \\
\text { dia- } \\
\text { meter } \\
\text { (inches) }\end{array}$ & $\begin{array}{l}\text { Alti- } \\
\text { tude } \\
\text { (feet) }\end{array}$ & $\begin{array}{l}\text { Source } \\
\text { of } \\
\text { data }\end{array}$ & $\begin{array}{l}\text { Water- } \\
\text { level or } \\
\text { sample } \\
\text { date }\end{array}$ & $\begin{array}{l}\text { Water } \\
\text { level, } \\
\text { feet below } \\
\text { land surface }\end{array}$ & $\begin{array}{l}\text { Specific } \\
\text { conduc- } \\
\text { tance } \\
(\mu \mathrm{S} / \mathrm{cm})\end{array}$ & $\begin{array}{l}\text { Chloride, } \\
\text { dissolved } \\
(\mathrm{mg} / \mathrm{L} \\
\text { as } \mathrm{Cl} \text { ) }\end{array}$ & $\begin{array}{l}\text { Nitrogen } \\
\mathrm{NO}_{2}+\mathrm{NO}_{3} \\
\text { total } \\
(\mathrm{mg} / \mathrm{L} \text { as } \mathrm{N})\end{array}$ \\
\hline $092 \mathrm{G} \cdot 008 \cdot 2 \cdot 3 \cdot 3-14$ & 490246 & 1222938 & W & W & $\mathrm{H}$ & EVRS & 30 & 175 & 6 & 298 & USGS & 19900608 & 2.18 & 288 & 0.6 & $<0.1$ \\
\hline $092 \mathrm{G} .008 \cdot 2 \cdot 3.4-04$ & 490241 & 1222749 & w & w & I & SUMS & -- & 125 & 8 & 315 & USGS & 19900608 & -- & -- & -- & 9.8 \\
\hline $092 \mathrm{G} .008 .2 .4 .1-18$ & 490151 & 1222557 & w & W & $\mathrm{H}$ & SUMS & 14 & 110 & 6 & 325 & USGS & 19900608 & 58.42 & 179 & 1.4 & 1.2 \\
\hline $092 \mathrm{G} .008 .2 .4 .1-19$ & 490148 & 1222534 & W & w & $\mathrm{H}$ & SUMS & 14 & 118 & 6 & 325 & USGS & 19900611 & 81.92 & 249 & 9.8 & 12 \\
\hline $092 \mathrm{G} .008 .2 .4 .1-41$ & 490150 & 1222559 & W & 0 & $\mathrm{U}$ & SUMS & 14 & 135 & 6 & 326 & $\mathrm{BCME}$ & 19880930 & -- & 192 & 7.4 & 1 \\
\hline & & & & & & & & & & & BCME & 19881027 & 57.85 & & & \\
\hline & & & & & & & & & & & BCME & 19881128 & 49.87 & & & \\
\hline & & & & & & & & & & & BCME & 19881129 & 49.60 & & & \\
\hline & & & & & & & & & & & BCME & 19881229 & 46.85 & & & \\
\hline & & & & & & & & & & & BCME & 19890130 & 43.96 & & & \\
\hline & & & & & & & & & & & BCME & 19890227 & 51.23 & & & \\
\hline & & & & & & & & & & & BCME & 19890331 & 51.70 & & & \\
\hline & & & & & & & & & & & BCME & 19890415 & 49.10 & & & \\
\hline & & & & & & & & & & & BCME & 19890428 & 49.99 & & & \\
\hline & & & & & & & & & & & BCME & 19890525 & 54.79 & & & \\
\hline & & & & & & & & & & & BCME & 19890629 & 56.13 & & & \\
\hline & & & & & & & & & & & BCME & 19890730 & 58.33 & & & \\
\hline & & & & & & & & & & & BCME & 19890731 & 58.31 & & & \\
\hline & & & & & & & & & & & BCME & 19890823 & 58.88 & & & \\
\hline & & & & & & & & & & & BCME & 19890924 & 59.61 & & & \\
\hline & & & & & & & & & & & BCME & 19890925 & 59.56 & & & \\
\hline & & & & & & & & & & & BCME & 19891026 & 60.12 & & & \\
\hline & & & & & & & & & & & BCME & 19891127 & 52.25 & & & \\
\hline & & & & & & & & & & & BCME & 19891128 & 52.17 & & & \\
\hline & & & & & & & & & & & BCME & 19891227 & 51.89 & & & \\
\hline & & & & & & & & & & & BCME & 19900125 & 53.26 & & & \\
\hline & & & & & & & & & & & BCME & 19900226 & 48.43 & & & \\
\hline & & & & & & & & & & & BCME & 19900228 & 48.85 & & & \\
\hline & & & & & & & & & & & BCME & 19900330 & 53.24 & & & \\
\hline & & & & & & & & & & & BCME & 19900424 & 56.42 & & & \\
\hline & & & & & & & & & & & BCME & 19900528 & 58.01 & & & \\
\hline & & & & & & & & & & & BCME & 19900608 & 57.35 & & & \\
\hline & & & & & & & & & & & BCME & 19900630 & 57.22 & & & \\
\hline & & & & & & & & & & & $\mathrm{BCME}$ & 19900703 & 57.28 & & & \\
\hline & & & & & & & & & & & $\mathrm{BCME}$ & 19900802 & 58.81 & & & \\
\hline & & & & & & & & & & & BCME & 19900903 & 59.99 & & & \\
\hline & & & & & & & & & & & $\begin{array}{l}\text { BCME } \\
\text { BCME }\end{array}$ & $\begin{array}{l}19900904 \\
19901005\end{array}$ & $\begin{array}{l}60.03 \\
60.85\end{array}$ & & & \\
\hline
\end{tabular}


Appendix Table 1. Well, water-level, hydrogeologic, and reconnaissance water-quality data--Continued

\begin{tabular}{|c|c|c|c|c|c|c|c|c|c|c|c|c|c|c|c|c|}
\hline Local well number & $\begin{array}{l}\text { Lati- } \\
\text { tude }\end{array}$ & $\begin{array}{l}\text { Longi- } \\
\text { tude }\end{array}$ & $\begin{array}{l}\text { Ground } \\
\text { water } \\
\text { site } \\
\text { type }\end{array}$ & $\begin{array}{l}\text { Site } \\
\text { use }\end{array}$ & $\begin{array}{l}\text { Wat- } \\
\text { er } \\
\text { use }\end{array}$ & $\begin{array}{l}\text { Hydro- } \\
\text { geo- } \\
\text { logic } \\
\text { unit }\end{array}$ & $\begin{array}{l}\text { Litho- } \\
\text { logic } \\
\text { unit }\end{array}$ & $\begin{array}{l}\text { Well } \\
\text { depth } \\
\text { (feet) }\end{array}$ & $\begin{array}{l}\text { Well } \\
\text { dia- } \\
\text { meter } \\
\text { (inches) }\end{array}$ & $\begin{array}{l}\text { Alti- } \\
\text { tude } \\
\text { (feet) }\end{array}$ & $\begin{array}{l}\text { Source } \\
\text { of } \\
\text { data }\end{array}$ & $\begin{array}{l}\text { Water- } \\
\text { level or } \\
\text { sample } \\
\text { date }\end{array}$ & $\begin{array}{l}\text { Water } \\
\text { level, } \\
\text { feet below } \\
\text { land surface }\end{array}$ & $\begin{array}{l}\text { Specific } \\
\text { conduc- } \\
\text { tance } \\
(\mu \mathrm{S} / \mathrm{cm})\end{array}$ & $\begin{array}{l}\text { Chloride, } \\
\text { dissolved } \\
\text { (mg/L } \\
\text { as } \mathrm{Cl})\end{array}$ & $\begin{array}{l}\text { Nitrogen } \\
\mathrm{NO}_{2}+\mathrm{NO}_{3} \\
\text { total } \\
(\mathrm{mg} / \mathrm{L} \text { as } \mathrm{N} \text { ) }\end{array}$ \\
\hline & 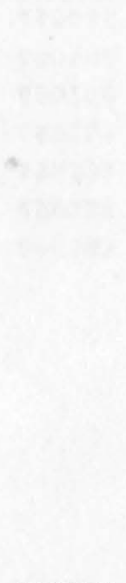 & & & & & & & & & & 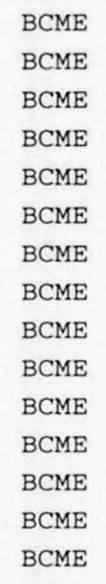 & $\begin{array}{l}19901106 \\
19901206 \\
19910107 \\
19910114 \\
19910211 \\
19910306 \\
19910405 \\
19910502 \\
19910603 \\
19910604 \\
19910704 \\
19910805 \\
19910807 \\
19910905 \\
19911004\end{array}$ & $\begin{array}{l}60.80 \\
49.74 \\
51.50 \\
52.59 \\
52.55 \\
52.74 \\
54.82 \\
55.22 \\
57.54 \\
57.61 \\
58.86 \\
60.42 \\
60.48 \\
61.08 \\
61.21\end{array}$ & & & \\
\hline $092 \mathrm{G} .008 \cdot 2 \cdot 4 \cdot 2-13$ & 490136 & 1222404 & W & W & $\mathrm{H}$ & SUMS & 10 & 110 & 6 & 321 & USGS & 19900612 & 76.58 & 334 & 5.6 & 5.8 \\
\hline $092 \mathrm{G} .008 \cdot 2 \cdot 4 \cdot 2-14$ & 490209 & 1222420 & W & $\mathrm{W}$ & $\mathrm{H}$ & EVRS & 30 & 129 & 6 & 330 & USGS & 19900612 & 105.69 & 191 & 5.2 & 8.2 \\
\hline $092 \mathrm{G} .008 .2 .4 .2-\mathrm{xx}$ & 490141 & 1222513 & W & W & $Q$ & EVRS * & & 135 & 8 & 210 & USGS & 19900611 & -- & 347 & 9.2 & 5.8 \\
\hline $092 \mathrm{G} .008 \cdot 2 \cdot 4 \cdot 3-14$ & 490219 & 1222645 & W & W & I & SUMS & 14 & 61 & 6 & 360 & USGS & 19900619 & 47.62 & 108 & 2 & 2.8 \\
\hline $092 \mathrm{G} .008 .2 .4 .4-10$ & 490250 & 1222408 & W & $\mathrm{U}$ & $\mathrm{x}$ & -- & -- & 110 & 10 & 345 & USGS & -- & -- & -- & -- & -- \\
\hline $092 \mathrm{G} .008 .2 .4 .4-12$ & 490223 & 1222352 & $\mathrm{~W}$ & W & $\mathrm{H}$ & EVRS & 30 & 175 & 6 & 270 & USGS & 19900612 & 140.58 & 164 & 1 & 2.2 \\
\hline $092 \mathrm{G} .008 .2 .4 .4-18$ & 490253 & 1222405 & W & W & I & SUMS & 10 & 96 & 8 & 340 & USGS & 19900613 & 70.03 & 253 & 10 & 0.7 \\
\hline $092 \mathrm{G} .008 \cdot 4 \cdot 2 \cdot 1-31$ & 490311 & 1222647 & w & w & I & EVRS* & -- & 85 & 6 & 390 & USGS & 19900611 & 14.75 & 280 & 1.2 & $<0.1$ \\
\hline $092 \mathrm{G} .008 .4 .2 .2-22$ & 490310 & 1222516 & W & W & $\mathrm{H}$ & EVRS * & -- & 132 & 6 & 412 & USGS & 19900611 & -- & 188 & 14 & $<0.1$ \\
\hline $092 \mathrm{G} .008 .4 .2 .2-27$ & 490338 & 1222430 & $\mathrm{~W}$ & W & $\mathrm{H}$ & EVRS & 30 & 127 & 6 & 400 & USGS & 19900613 & 106.89 & 183 & 1.2 & 0.9 \\
\hline $092 \mathrm{G} .009 .1 .1 .1-06-20$ & 490031 & 1222253 & w & 0 & $\mathrm{U}$ & SUMS & 10 & 20 & 2 & 160 & USGS & 19900611 & 9.36 & 225 & 8.5 & 18 \\
\hline $092 G .009 .1 .1 .1-06-35$ & 490031 & 1222253 & $\mathrm{~W}$ & 0 & $\mathrm{U}$ & SUMS & 10 & 35 & 2 & 160 & USGS & 19900611 & 9.36 & 257 & 10 & 21 \\
\hline $092 G .009 .1 .1 .1-07-55$ & 490030 & 1222253 & w & 0 & $\mathrm{U}$ & SUMS & 10 & 55 & 2 & 160 & USGS & 19900611 & 9.42 & 168 & 0.3 & 6.9 \\
\hline $092 \mathrm{G} .009 .1 .1 .1-07-75$ & 490030 & 1222253 & W & 0 & $\mathrm{U}$ & SUMS & 10 & 75 & 2 & 160 & USGS & 19900611 & 9.42 & 202 & 0.5 & 1.2 \\
\hline $092 \mathrm{G} .009 .1 .1 .1-\mathrm{ABB} 5$ & 490009 & 1222331 & W & 0 & $\mathrm{U}$ & SUMS & 10 & 29 & 2 & 151 & USGS & 19900618 & 6.69 & 204 & 9 & 15 \\
\hline $092 \mathrm{G} .009 \cdot 1.1 .2-11-25$ & 490031 & 1222215 & W & 0 & $\mathrm{U}$ & SUMS & 10 & 25 & 2 & 168 & USGS & 19900611 & 11.60 & 154 & 5.8 & 11 \\
\hline $092 \mathrm{G} .009 .1 .1 .2-11-35$ & 490031 & 1222215 & W & 0 & $\mathrm{U}$ & SUMS & 10 & 35 & 2 & 168 & USGS & 19900611 & 11.60 & 258 & 12 & 19 \\
\hline $092 \mathrm{G} .009 .1 .1 .2-12-55$ & 490030 & 1222215 & W & 0 & $\mathrm{U}$ & SUMS & 10 & 55 & 2 & 168 & USGS & 19900611 & 11.56 & 198 & 6.9 & 2.7 \\
\hline $092 \mathrm{G} .009 \cdot 1 \cdot 1 \cdot 2-12-75$ & 490030 & 1222215 & $\mathrm{~W}$ & 0 & $\mathrm{U}$ & SUMS & 10 & 75 & 2 & 168 & USGS & 19900611 & 11.71 & 209 & 8.5 & 2 \\
\hline $092 \mathrm{G} .009 \cdot 1 \cdot 1 \cdot 2-29$ & 490011 & 1222133 & W & w & I & SUMS & 10 & 48 & 8 & 166 & USGS & 19900615 & 14.54 & 110 & 3.8 & 0.1 \\
\hline \multirow[t]{2}{*}{$092 \mathrm{G} .009 .1 .1 .2-\mathrm{ABB} 2$} & 490020 & 1222132 & W & 0 & $\mathrm{U}$ & SUMS & 10 & 25 & 2 & 167 & EC & 19891115 & 13.22 & & & \\
\hline & & & & & & & & & & & $\begin{array}{l}\mathrm{EC} \\
\mathrm{EC}\end{array}$ & $\begin{array}{l}19891215 \\
19900115\end{array}$ & $\begin{array}{l}10.79 \\
10.00\end{array}$ & & & \\
\hline
\end{tabular}


$\vec{\omega}$ Appendix Table 1. Well, water-level, hydrogeologic, and reconnaissance water-quality data--Continued

\begin{tabular}{|c|c|c|c|c|c|c|c|c|c|c|c|c|c|c|c|c|}
\hline Local well number & $\begin{array}{l}\text { Lati- } \\
\text { tude }\end{array}$ & $\begin{array}{l}\text { Longi- } \\
\text { tude }\end{array}$ & $\begin{array}{l}\text { Ground } \\
\text { water } \\
\text { site } \\
\text { type }\end{array}$ & Site & $\begin{array}{l}\text { Wat- } \\
\text { er } \\
\text { use }\end{array}$ & $\begin{array}{l}\text { Hydro- } \\
\text { geo- } \\
\text { logic } \\
\text { unit }\end{array}$ & $\begin{array}{l}\text { Litho- } \\
\text { logic } \\
\text { unit }\end{array}$ & $\begin{array}{l}\text { Well } \\
\text { depth } \\
\text { (feet) }\end{array}$ & $\begin{array}{l}\text { Well } \\
\text { dia- } \\
\text { meter } \\
\text { (inches) }\end{array}$ & $\begin{array}{l}\text { Alti- } \\
\text { tude } \\
\text { (feet) }\end{array}$ & $\begin{array}{l}\text { Source } \\
\text { of } \\
\text { data }\end{array}$ & $\begin{array}{l}\text { Water- } \\
\text { level or } \\
\text { sample } \\
\text { date }\end{array}$ & $\begin{array}{l}\text { Water } \\
\text { level, } \\
\text { feet below } \\
\text { land surface }\end{array}$ & $\begin{array}{l}\text { Specific } \\
\text { conduc- } \\
\text { tance } \\
(\mu \mathrm{S} / \mathrm{cm})\end{array}$ & $\begin{array}{ll}\text { Chloride, } \\
\text { dissolved } \\
(\mathrm{mg} / \mathrm{L} \\
\text { as } \mathrm{Cl})\end{array}$ & $\begin{array}{l}\text { Nitrogen } \\
\mathrm{NO}_{2}+\mathrm{NO}_{3} \\
\text { total } \\
(\mathrm{mg} / \mathrm{L} \text { as } \mathrm{N})\end{array}$ \\
\hline & & & & & & & & & & & EC & 19900215 & 7.94 & & & \\
\hline & & & & & & & & & & & EC & 19900315 & 7.54 & & & \\
\hline & & & & & & & & & & & $\mathrm{EC}$ & 19900415 & 8.92 & & & \\
\hline & & & & & & & & & & & EC & 19900515 & 10.00 & & & \\
\hline . & & & & & & & & & & & EC & 19900615 & 10.63 & & & \\
\hline & & & & & & & & & & & USGS & 19900618 & -- & 180 & 8.8 & 11 \\
\hline & & & & & & & & & & & EC & 19900715 & 11.74 & & & \\
\hline & & & & & & & & & & & $\mathrm{EC}$ & 19900815 & 13.35 & & & \\
\hline & & & & & & & & & & & EC & 19900915 & 14.56 & & & \\
\hline & & & & & & & & & & & EC & 19901015 & 15.29 & & & \\
\hline & & & & & & & & & & & $\mathrm{EC}$ & 19901115 & 11.55 & & & \\
\hline & & & & & & & & & & & $\mathrm{EC}$ & 19901215 & 7.84 & & & \\
\hline & & & & & & & & & & & $\mathrm{EC}$ & 19910115 & 7.31 & & & \\
\hline & & & & & & & & & & & $\mathrm{EC}$ & 19910215 & 7.02 & & & \\
\hline & & & & & & & & & & & $\mathrm{EC}$ & 19910315 & 7.45 & & & \\
\hline & & & & & & & & & & & EC & 19910415 & 8.23 & & & \\
\hline & & & & & & & & & & & EC & 19910515 & 9.32 & & & \\
\hline & & & & & & & & & & & EC & 19910615 & 10.66 & & & \\
\hline & & & & & & & & & & & $\mathrm{EC}$ & 19910715 & 11.87 & & & \\
\hline & & & & & & & & & & & EC & 19910815 & 13.45 & & & \\
\hline & & & & & & & & & & & $\mathrm{EC}$ & 19910915 & 14.11 & & & \\
\hline & & & & & & & & & & & EC & 19911015 & 14.73 & & & \\
\hline & & & & & & & & & & & EC & 19911115 & 14.24 & & & \\
\hline $092 \mathrm{G} .009 .1 .1 .4-10$ & 490043 & 1222107 & W & $\mathrm{W}$ & $\mathrm{H}$ & SUMS & 10 & 41 & 6 & 180 & USGS & 19900614 & 10.02 & 265 & 5.4 & 17 \\
\hline $092 \mathrm{G} .009 .1 .1 .4-17$ & 490128 & 1222112 & W & $\mathrm{W}$ & $\mathrm{H}$ & SUMS & 10 & 60 & 6 & 200 & USGS & 19900614 & 19.37 & 267 & 9 & 15 \\
\hline $092 \mathrm{G} .009 .1 .1 .4-18-25$ & 490101 & 1222215 & $\mathrm{~W}$ & 0 & $\mathrm{U}$ & SUMS & 10 & 25 & 2 & 170 & USGS & 19900611 & 10.24 & 93 & 2.7 & 5.9 \\
\hline $092 \mathrm{G} .009 .1 .1 .4-18-35$ & 490101 & 1222215 & W & 0 & $\mathrm{U}$ & SUMS & 10 & 35 & 2 & 170 & USGS & 19900611 & 10.24 & 96 & 2.9 & 5.5 \\
\hline $092 \mathrm{G} .009 .1 .1 .4-19-55$ & 490100 & 1222215 & $\mathrm{~W}$ & 0 & $\mathrm{U}$ & SUMS & 10 & 55 & 2 & 170 & USGS & 19900611 & 10.31 & 144 & 0.4 & 4.6 \\
\hline $092 \mathrm{G} .009 .1 .1 .4-19-75$ & 490100 & 1222215 & W & 0 & $\mathrm{U}$ & SUMS & 10 & 75 & 2 & 170 & USGS & 19900611 & 10.31 & 217 & 1 & 5 \\
\hline $092 \mathrm{G} .009 .1 .1 .4-\mathrm{ABB} 6$ & 490046 & 1222133 & $\mathrm{~W}$ & 0 & $\mathrm{U}$ & SUMS & 10 & 30 & 2 & 180 & USGS & 19900618 & 17.3 & 199 & 5.2 & 11 \\
\hline \multirow[t]{7}{*}{$092 \mathrm{G} .009 .1 .2 .1-23$} & 490042 & 1222007 & $\mathrm{~W}$ & $\mathrm{~W}$ & I & SUMS & 10 & 161 & 8 & 190 & EC & 19891115 & 47.97 & & & \\
\hline & & & & & & & & & & & $\mathrm{EC}$ & 19891215 & 46.33 & & & \\
\hline & & & & & & & & & & & $\mathrm{EC}$ & 19900115 & 44.59 & & & \\
\hline & & & & & & & & & & & EC & 19900215 & 43.44 & & & \\
\hline & & & & & & & & & & & EC & 19900315 & 38.81 & & & \\
\hline & & & & & & & & & & & $\mathrm{EC}$ & 19900415 & 38.48 & & & \\
\hline & & & & & & & & & & & $\begin{array}{l}\text { EC } \\
\text { USGS }\end{array}$ & $\begin{array}{l}19900515 \\
19900615\end{array}$ & $\begin{array}{l}39.66 \\
41.17\end{array}$ & 340 & 11 & 24 \\
\hline
\end{tabular}


Appendix Table 1. Well, water-level, hydrogeologic, and reconnaissance water-quality data--Continued

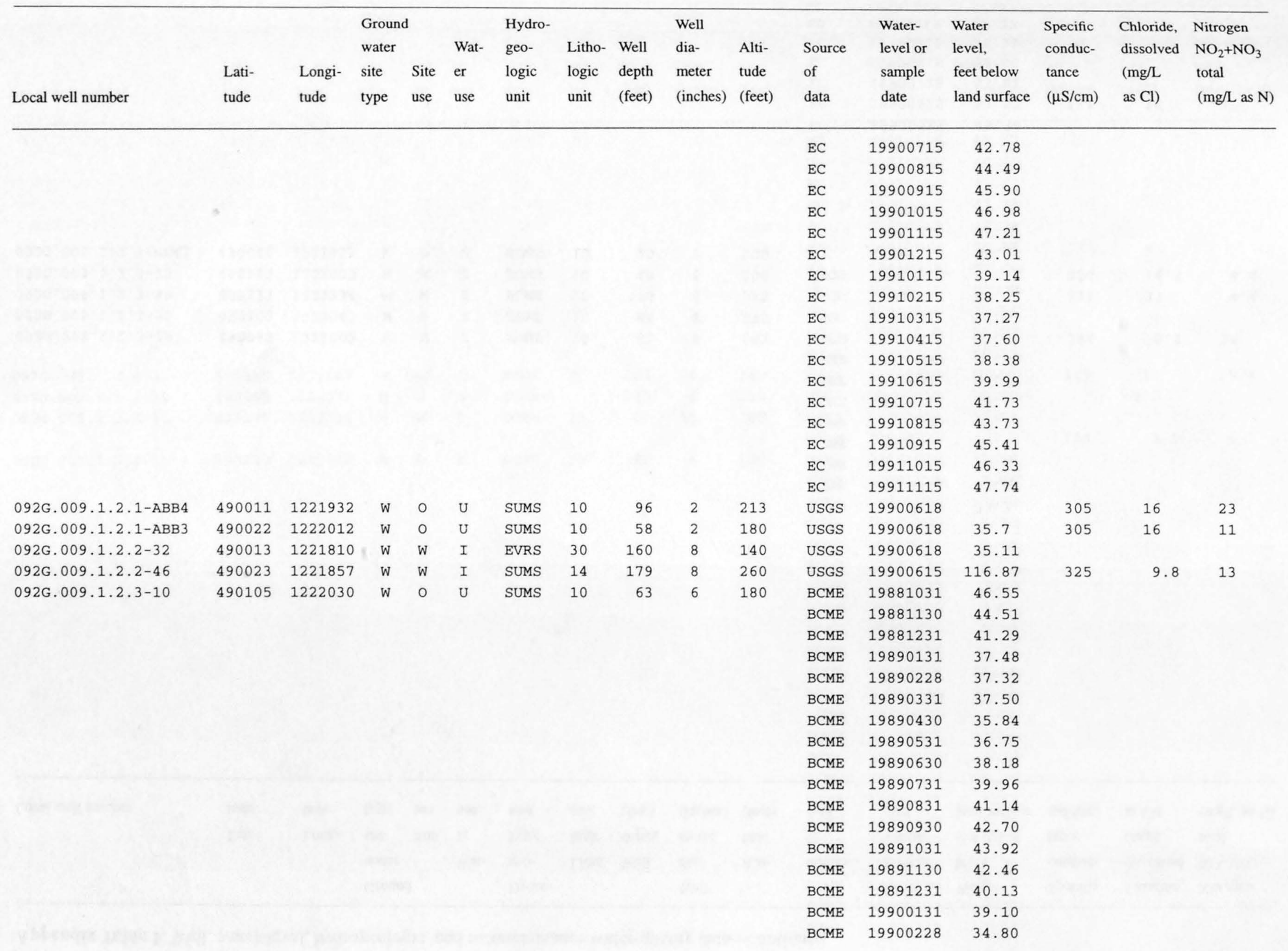


$\vec{\omega} \quad$ Appendix Table 1. Well, water-level, hydrogeologic, and reconnaissance water-quality data--Continued

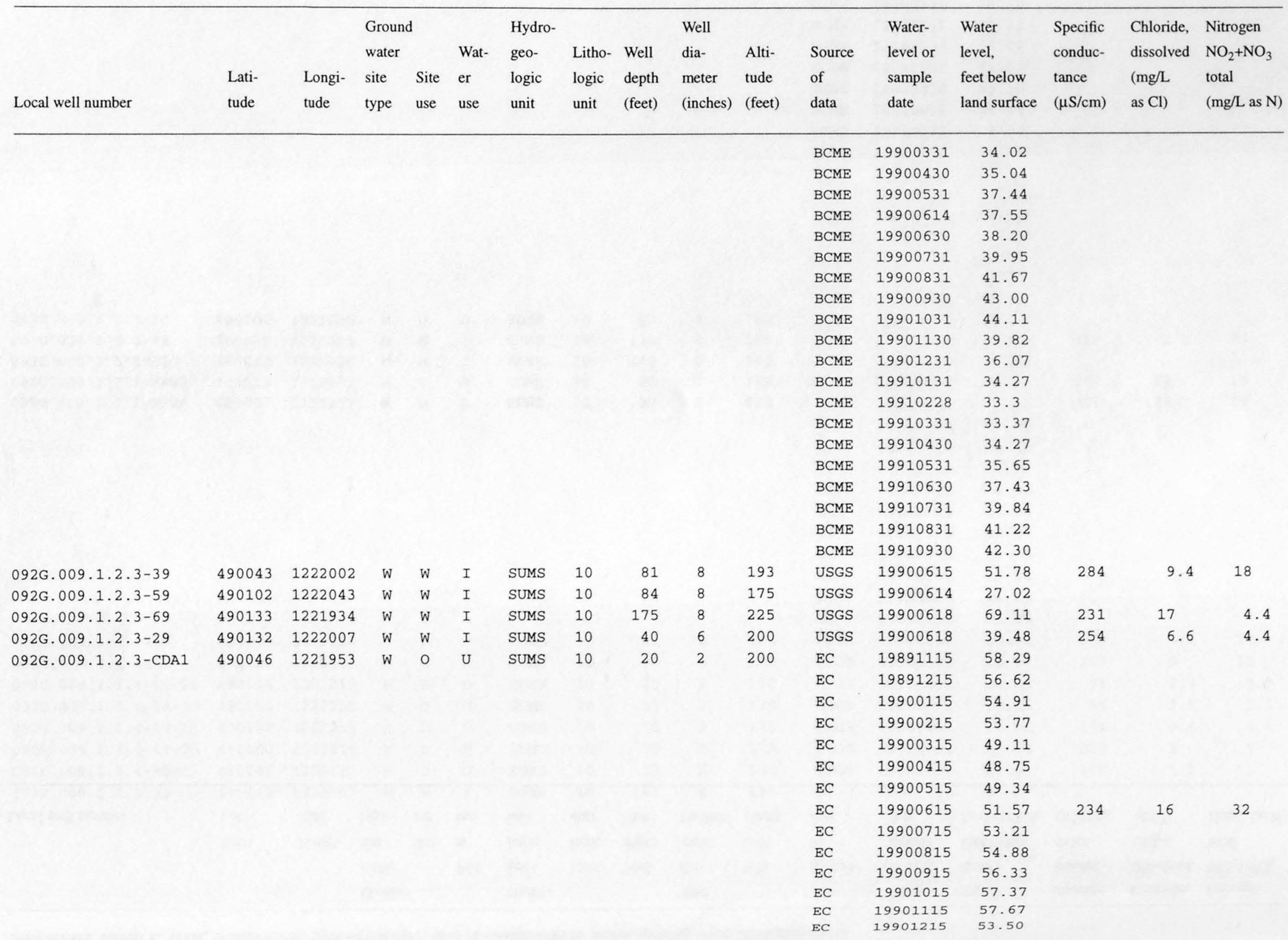


Appendix Table 1. Well, water-level, hydrogeologic, and reconnaissance water-quality data--Continued

\begin{tabular}{|c|c|c|c|c|c|c|c|c|c|c|c|c|c|c|c|c|}
\hline Local well number & $\begin{array}{l}\text { Lati- } \\
\text { tude }\end{array}$ & $\begin{array}{l}\text { Longi- } \\
\text { tude }\end{array}$ & $\begin{array}{l}\text { Ground } \\
\text { water } \\
\text { site } \\
\text { type }\end{array}$ & Site & $\begin{array}{l}\text { Wat- } \\
\text { er } \\
\text { use }\end{array}$ & $\begin{array}{l}\text { Hydro- } \\
\text { geo- } \\
\text { logic } \\
\text { unit }\end{array}$ & $\begin{array}{l}\text { Litho- } \\
\text { logic } \\
\text { unit }\end{array}$ & $\begin{array}{l}\text { Well } \\
\text { depth } \\
\text { (feet) }\end{array}$ & $\begin{array}{l}\text { Well } \\
\text { dia- } \\
\text { meter } \\
\text { (inches) }\end{array}$ & $\begin{array}{l}\text { Alti- } \\
\text { tude } \\
\text { (feet) }\end{array}$ & $\begin{array}{l}\text { Source } \\
\text { of } \\
\text { data }\end{array}$ & $\begin{array}{l}\text { Water- } \\
\text { level or } \\
\text { sample } \\
\text { date }\end{array}$ & $\begin{array}{l}\text { Water } \\
\text { level, } \\
\text { feet below } \\
\text { land surface }\end{array}$ & $\begin{array}{l}\text { Specific } \\
\text { conduc- } \\
\text { tance } \\
(\mu \mathrm{S} / \mathrm{cm})\end{array}$ & $\begin{array}{l}\text { Chloride, } \\
\text { dissolved } \\
\text { (mg/L } \\
\text { as } \mathrm{Cl} \text { ) }\end{array}$ & $\begin{array}{l}\text { Nitrogen } \\
\mathrm{NO}_{2}+\mathrm{NO}_{3} \\
\text { total } \\
(\mathrm{mg} / \mathrm{L} \text { as } \mathrm{N})\end{array}$ \\
\hline & $\approx$ & & & 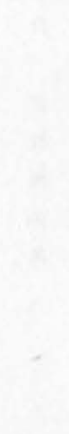 & & & & & & & $\begin{array}{l}\text { EC } \\
\text { EC } \\
\text { EC } \\
\text { EC } \\
\text { EC } \\
\text { EC } \\
\text { EC } \\
E C \\
\text { EC } \\
\text { EC } \\
\text { EC }\end{array}$ & $\begin{array}{l}19910115 \\
19910215 \\
19910315 \\
19910415 \\
19910515 \\
19910615 \\
19910715 \\
19910815 \\
19910915 \\
19911015 \\
19911115\end{array}$ & $\begin{array}{l}49.57 \\
48.61 \\
47.63 \\
47.99 \\
48.78 \\
50.35 \\
52.06 \\
54.09 \\
55.96 \\
56.72 \\
58.13\end{array}$ & & & \\
\hline $092 \mathrm{G} .009 .1 .2 .4-31$ & 490120 & 1221847 & $\mathrm{~W}$ & $\mathrm{~W}$ & $\mathrm{H}$ & EVRS & 30 & 163 & 6 & 240 & USGS & 19900619 & 91.20 & 269 & 13 & 5.4 \\
\hline $092 \mathrm{G} \cdot 009 \cdot 1 \cdot 3 \cdot 1-16$ & 490205 & 1222331 & $\mathrm{~W}$ & $\mathrm{U}$ & $\mathrm{U}$ & EVRS* & & 140 & 6 & 210 & USGS & 19900613 & 38.20 & & $>250$ & \\
\hline $092 \mathrm{G} .009 \cdot 1 \cdot 3 \cdot 2-40$ & 490147 & 1222116 & $\mathrm{~W}$ & w & I & SUMS & 10 & 55 & 36 & 200 & $\begin{array}{l}\text { USGS } \\
\text { USGS }\end{array}$ & $\begin{array}{l}19900614 \\
19870729\end{array}$ & 17.63 & 175 & 3.1 & 6.1 \\
\hline $092 \mathrm{G} \cdot 009 \cdot 1 \cdot 3 \cdot 3-08$ & 490230 & 1222248 & W & 0 & $\mathrm{U}$ & SUMS & 10 & 52 & 8 & 180 & $\begin{array}{l}\text { BCME } \\
\text { BCME } \\
B C M E \\
B C M E \\
B C M E \\
B C M E \\
B C M E \\
B C M E \\
B C M E \\
B C M E \\
B C M E \\
B C M E \\
B C M E \\
B C M E \\
B C M E \\
B C M E \\
B C M E \\
B C M E \\
B C M E \\
B C M E \\
B C M E \\
B C M E \\
B C M E\end{array}$ & $\begin{array}{l}19881027 \\
19881128 \\
19881129 \\
19881229 \\
19890227 \\
19890331 \\
19890428 \\
19890525 \\
19890626 \\
19890628 \\
19890730 \\
19890731 \\
19890823 \\
19890924 \\
19890925 \\
19891026 \\
19891127 \\
19891128 \\
19891227 \\
19900125 \\
19900226 \\
19900227 \\
19900330\end{array}$ & $\begin{array}{r}11.88 \\
7.06 \\
7.10 \\
7.35 \\
7.69 \\
6.75 \\
7.67 \\
9.07 \\
9.98 \\
10.15 \\
11.69 \\
11.66 \\
12.56 \\
13.53 \\
13.56 \\
14.20 \\
6.83 \\
6.94 \\
7.92 \\
6.30 \\
5.86 \\
5.87 \\
7.34\end{array}$ & & & \\
\hline
\end{tabular}


$\vec{\omega} \quad$ Appendix Table 1. Well, water-level, hydrogeologic, and reconnaissance water-quality data--Continued

\begin{tabular}{|c|c|c|c|c|c|c|c|c|c|c|c|c|c|c|c|c|}
\hline Local well number & $\begin{array}{l}\text { Lati- } \\
\text { tude }\end{array}$ & $\begin{array}{l}\text { Longi- } \\
\text { tude }\end{array}$ & $\begin{array}{l}\text { Ground } \\
\text { water } \\
\text { site } \\
\text { type }\end{array}$ & Site & $\begin{array}{l}\text { Wat- } \\
\text { er } \\
\text { use }\end{array}$ & $\begin{array}{l}\text { Hydro- } \\
\text { geo- } \\
\text { logic } \\
\text { unit }\end{array}$ & $\begin{array}{l}\text { Litho- } \\
\text { logic } \\
\text { unit }\end{array}$ & $\begin{array}{l}\text { Well } \\
\text { depth } \\
\text { (feet) }\end{array}$ & $\begin{array}{l}\text { Well } \\
\text { dia- } \\
\text { meter } \\
\text { (inches) }\end{array}$ & $\begin{array}{l}\text { Alti- } \\
\text { tude } \\
\text { (feet) }\end{array}$ & $\begin{array}{l}\text { Source } \\
\text { of } \\
\text { data }\end{array}$ & $\begin{array}{l}\text { Water- } \\
\text { level or } \\
\text { sample } \\
\text { date }\end{array}$ & $\begin{array}{l}\text { Water } \\
\text { level, } \\
\text { feet below } \\
\text { land surface }\end{array}$ & $\begin{array}{l}\text { Specific } \\
\text { conduc- } \\
\text { tance } \\
(\mu \mathrm{S} / \mathrm{cm})\end{array}$ & $\begin{array}{l}\text { Chloride, } \\
\text { dissolved } \\
(\mathrm{mg} / \mathrm{L} \\
\text { as } \mathrm{Cl})\end{array}$ & $\begin{array}{l}\text { Nitrogen } \\
\mathrm{NO}_{2}+\mathrm{NO}_{3} \\
\text { total } \\
(\mathrm{mg} / \mathrm{L} \text { as } \mathrm{N})\end{array}$ \\
\hline & & & & & & & & & & & $\mathrm{BCME}$ & 19900427 & 8.65 & & & \\
\hline & & & & & & & & & & & $\mathrm{BCME}$ & 19900529 & 10.08 & & & \\
\hline & & & & & & & & & & & $\mathrm{BCME}$ & 19900630 & 9.69 & & & \\
\hline & & & & & & & & & & & $\mathrm{BCME}$ & 19900703 & 9.86 & & & \\
\hline & & & & & & & & & & & $\mathrm{BCME}$ & 19900802 & 11.70 & & & \\
\hline & & & & & & & & & & & BCME & 19900903 & 13.09 & & & \\
\hline & & & & & & & & & & & $\mathrm{BCME}$ & 19900904 & 13.13 & & & \\
\hline & & & & & & & & & & & BCME & 19901005 & 13.73 & & & \\
\hline & & & & & & & & & & & BCME & 19901106 & 13.32 & & & \\
\hline & & & & & & & & & & & BCME & 19901206 & 4.77 & & & \\
\hline & & & & & & & & & & & BCME & 19910107 & 7.62 & & & \\
\hline & & & & & & & & & & & $\mathrm{BCME}$ & 19910111 & 7.77 & & & \\
\hline & & & & & & & & & & & $\mathrm{BCME}$ & 19910211 & 6.15 & & & \\
\hline & & & & & & & & & & & $\mathrm{BCME}$ & 19910308 & 6.28 & & & \\
\hline & & & & & & & & & & & $\mathrm{BCME}$ & 19910403 & 8.17 & & & \\
\hline & & & & & & & & & & & BCME & 19910502 & 8.70 & & & \\
\hline & & & & & & & & & & & $\mathrm{BCME}$ & 19910603 & 10.32 & & & \\
\hline & & & & & & & & & & & BCME & 19910606 & 10.44 & & & \\
\hline & & & & & & & & & & & BCME & 19910704 & 11.68 & & & \\
\hline & & & & & & & & & & & BCME & 19910805 & 13.26 & & & \\
\hline & & & & & & & & & & & $\begin{array}{l}\text { BCME } \\
\text { BCME }\end{array}$ & $\begin{array}{l}19910807 \\
19910905\end{array}$ & $\begin{array}{l}13.33 \\
13.16\end{array}$ & & & \\
\hline & & & & & & & & & & & BCME & 19911004 & 13.88 & & & \\
\hline $092 \mathrm{G} \cdot 009 \cdot 1 \cdot 3 \cdot 3-20$ & 490224 & 1222303 & w & w & $\mathrm{H}$ & SUMS & 10 & 49 & 6 & 183 & USGS & 19900613 & 13.87 & 289 & 17 & 5.7 \\
\hline $092 \mathrm{G} .009 \cdot 1 \cdot 3 \cdot 4-26$ & 490233 & 1222156 & w & W & $\mathrm{H}$ & SUMS & 10 & 45 & 6 & 195 & USGS & 19900614 & 17.05 & 145 & 6.4 & 5.9 \\
\hline $092 \mathrm{G} \cdot 009 \cdot 1 \cdot 3 \cdot 4-34$ & 490216 & 1222133 & W & W & I & SUMS & 10 & 85 & 6 & 195 & USGS & 19900614 & 30.42 & 167 & 12 & 1.9 \\
\hline $092 \mathrm{G} .009 \cdot 1 \cdot 4 \cdot 2-50$ & 490157 & 1221853 & W & W & $\mathrm{H}$ & SUMS & 14 & 88 & 6 & 230 & USGS & 19400619 & -- & 245 & 7 & 5.4 \\
\hline \multirow[t]{2}{*}{$092 \mathrm{G} .009 .2 .1 .1-37$} & 490036 & 1221641 & W & 0 & $\mathrm{U}$ & SUMS & 10 & 112 & 6 & 50 & BCME & 19860304 & -- & 190 & 4.6 & 0.7 \\
\hline & & & & & & & & & & & USGS & 19900618 & 24.80 & & & \\
\hline $092 \mathrm{G} .009 .2 .1 .1-38$ & 490036 & 1221644 & W & W & $\mathrm{P}$ & SUMS & 14 & 133 & 12 & 50 & USGS & 19900619 & -- & 254 & 7 & 4.6 \\
\hline $092 \mathrm{G} .009 \cdot 2 \cdot 1 \cdot 2-19$ & 490033 & 1221628 & w & W & $\mathrm{P}$ & SUMS & 10 & 145 & 18 & 45 & USGS & 19911002 & - & 231 & 5.8 & 9.1 \\
\hline $092 \mathrm{G} .009 \cdot 2 \cdot 1 \cdot 2-24$ & 490031 & 1221628 & W & 0 & $\mathrm{U}$ & SUMS & 10 & 119 & 6 & 45 & USGS & 19900618 & 18.63 & & & \\
\hline \multirow[t]{5}{*}{$092 \mathrm{G} .009 \cdot 2 \cdot 1 \cdot 3-41$} & 490058 & 1221632 & W & 0 & U & SUMS & 10 & 220 & 6 & 150 & BCME & 19881014 & 138.33 & & & \\
\hline & & & & & & & & & & & BCME & 19881027 & 138.21 & & & \\
\hline & & & & & & & & & & & ВСME & 19881128 & 137.98 & & & \\
\hline & & & & & & & & & & & BCME & 19881129 & 137.96 & & & \\
\hline & & & & & & & & & & & $\begin{array}{l}\text { BCME } \\
\text { BCME }\end{array}$ & $\begin{array}{l}19881229 \\
19890116\end{array}$ & $\begin{array}{l}137.52 \\
136.97\end{array}$ & & & \\
\hline
\end{tabular}


Appendix Table 1. Well, water-level, hydrogeologic, and reconnaissance water-quality data-Continued

\begin{tabular}{|c|c|c|c|c|c|c|c|c|c|c|c|c|c|c|c|c|}
\hline Local well number & $\begin{array}{l}\text { Lati- } \\
\text { tude }\end{array}$ & $\begin{array}{l}\text { Longi- } \\
\text { tude }\end{array}$ & $\begin{array}{l}\text { Grounc } \\
\text { water } \\
\text { site } \\
\text { type }\end{array}$ & $\begin{array}{l}\text { Site } \\
\text { use }\end{array}$ & $\begin{array}{l}\text { Wat- } \\
\text { er } \\
\text { use }\end{array}$ & $\begin{array}{l}\text { Hydro- } \\
\text { geo- } \\
\text { logic } \\
\text { unit }\end{array}$ & $\begin{array}{l}\text { Litho- } \\
\text { logic } \\
\text { unit }\end{array}$ & $\begin{array}{l}\text { Well } \\
\text { depth } \\
\text { (feet) }\end{array}$ & $\begin{array}{l}\text { Well } \\
\text { dia- } \\
\text { meter } \\
\text { (inches) }\end{array}$ & $\begin{array}{l}\text { Alti- } \\
\text { tude } \\
\text { (feet) }\end{array}$ & $\begin{array}{l}\text { Source } \\
\text { of } \\
\text { data }\end{array}$ & $\begin{array}{l}\text { Water- } \\
\text { level or } \\
\text { sample } \\
\text { date }\end{array}$ & $\begin{array}{l}\text { Water } \\
\text { level, } \\
\text { feet below } \\
\text { land surface }\end{array}$ & $\begin{array}{l}\text { Specific } \\
\text { conduc- } \\
\text { tance } \\
(\mu \mathrm{S} / \mathrm{cm})\end{array}$ & $\begin{array}{l}\text { Chloride, } \\
\text { dissolved } \\
(\mathrm{mg} / \mathrm{L} \\
\text { as } \mathrm{Cl})\end{array}$ & $\begin{array}{l}\text { Nitrogen } \\
\mathrm{NO}_{2}+\mathrm{NO}_{3} \\
\text { total } \\
(\mathrm{mg} / \mathrm{L} \text { as } \mathrm{N})\end{array}$ \\
\hline & & & & & & & & & & & BCME & 19890130 & 136.24 & & & \\
\hline & & & & & & & & & & & BCME & 19890204 & 136.15 & & & \\
\hline & & & & & & & & & & & BCME & 19890227 & 135.78 & & & \\
\hline & & & & & & & & & & & BCME & 19890304 & 135.84 & & & \\
\hline & & & & & & & & & & & BCME & 19890331 & 135.40 & & & \\
\hline & & & & & & & & & & & BCME & 19890428 & 134.99 & & & \\
\hline & & & & & & & & & & & BCME & 19890525 & 134.77 & & & \\
\hline & & & & & & & & & & & BCME & 19890526 & 134.74 & & & \\
\hline & & & & & & & & & & & BCME & 19890625 & 135.24 & & & \\
\hline & & & & & & & & & & & BCME & 19890628 & 135.25 & & & \\
\hline & & & & & & & & & & & BCME & 19890730 & 135.53 & & & \\
\hline & & & & & & & & & & & BCME & 19890731 & 135.51 & & & \\
\hline & & & & & & & & & & & BCME & 19890823 & 135.63 & & & \\
\hline & & & & & & & & & & & BCME & 19890924 & 135.94 & & & \\
\hline & & & & " & & & & & & & BCME & 19890925 & 135.96 & & & \\
\hline & & * & & & & & & & & & BCME & 19891026 & 136.36 & & & \\
\hline & & & & & & & & & & & BCME & 19891127 & 136.29 & & & \\
\hline & & & & & & & & & & & BCME & 19891227 & 136.45 & & & \\
\hline & & & & & & & & & & & BCME & 19900125 & 136.44 & & & \\
\hline & & & & & & & & & & & BCME & 19900226 & 135.84 & & & \\
\hline & & & & & & & & & & & ВСME & 19900228 & 135.75 & & & \\
\hline & & & & & & & & & & & BCME & 19900330 & 134.99 & & & \\
\hline & & & & & & & & & & & BCME & 19900427 & 134.61 & & & \\
\hline & & & & & & & & & & & BCME & 19900527 & 135.06 & & & \\
\hline & & & & & & & & & & & BCME & 19900529 & 135.11 & & & \\
\hline & & & & & & & & & & & USGS & 19900618 & 135.08 & & & \\
\hline & & & & & & & & & & & BCME & 19900630 & 135.30 & & & \\
\hline & & & & & & & & & & & BCME & 19900703 & 135.38 & & & \\
\hline & & & & & & & & & & & BCME & 19900802 & 136.04 & & & \\
\hline & & & & & & & & & & & BCME & 19900904 & 136.79 & & & \\
\hline & & & & & & & & & & & BCME & 19900926 & 137.11 & & & \\
\hline & & & & & & & & & & & BCME & 19901005 & 136.98 & & & \\
\hline & & & & & & & & & & & BCME & 19901025 & 136.52 & & & \\
\hline & & & & & & & & & & & BCME & 19901106 & 136.48 & & & \\
\hline & & & & & & & & & & & BCME & 19901114 & 136.30 & & & \\
\hline & & & & & & & & & & & BCME & 19901128 & 136.21 & & & \\
\hline & & & & & & & & & & & BCME & 19901206 & 136.12 & & & \\
\hline & & & & & & & & & & & BCME & 19910105 & 135.32 & & & \\
\hline
\end{tabular}


$\vec{\infty} \quad$ Appendix Table 1. Well, water-level, hydrogeologic, and reconnaissance water-quality data--Continued

\begin{tabular}{|c|c|c|c|c|c|c|c|c|c|c|c|c|c|c|c|c|}
\hline Local well number & $\begin{array}{l}\text { Lati- } \\
\text { tude }\end{array}$ & $\begin{array}{l}\text { Longi- } \\
\text { tude }\end{array}$ & $\begin{array}{l}\text { Ground } \\
\text { water } \\
\text { site } \\
\text { type }\end{array}$ & Site & $\begin{array}{l}\text { Wat- } \\
\text { er } \\
\text { use }\end{array}$ & $\begin{array}{l}\text { Hydro- } \\
\text { geo- } \\
\text { logic } \\
\text { unit }\end{array}$ & $\begin{array}{l}\text { Litho- } \\
\text { logic } \\
\text { unit }\end{array}$ & $\begin{array}{l}\text { Well } \\
\text { depth } \\
\text { (feet) }\end{array}$ & $\begin{array}{l}\text { Well } \\
\text { dia- } \\
\text { meter } \\
\text { (inches) }\end{array}$ & $\begin{array}{l}\text { Alti- } \\
\text { tude } \\
\text { (feet) }\end{array}$ & $\begin{array}{l}\text { Source } \\
\text { of } \\
\text { data }\end{array}$ & $\begin{array}{l}\text { Water- } \\
\text { level or } \\
\text { sample } \\
\text { date }\end{array}$ & $\begin{array}{l}\text { Water } \\
\text { level, } \\
\text { feet below } \\
\text { land surface }\end{array}$ & $\begin{array}{l}\text { Specific } \\
\text { conduc- } \\
\text { tance } \\
(\mu \mathrm{S} / \mathrm{cm})\end{array}$ & $\begin{array}{l}\text { Chloride, } \\
\text { dissolved } \\
\text { (mg/L } \\
\text { as } \mathrm{Cl} \text { ) }\end{array}$ & $\begin{array}{l}\text { Nitrogen } \\
\mathrm{NO}_{2}+\mathrm{NO}_{3} \\
\text { total } \\
(\mathrm{mg} / \mathrm{L} \text { as } \mathrm{N} \text { ) }\end{array}$ \\
\hline & & & & & & & & & & & BCME & 19910111 & 135.20 & & & \\
\hline & & & & & & & & & & & $\mathrm{BCME}$ & 19910211 & 134.55 & & & \\
\hline & & & & & & & & & & & $\mathrm{BCME}$ & 19910228 & 134.24 & & & \\
\hline & & & & & & & & & & & $\mathrm{BCME}$ & 19910403 & 133.85 & & & \\
\hline & & & & & & & & & & & $\mathrm{BCME}$ & 19910430 & 133.77 & & & \\
\hline & & & & & & & & & & & BCME & 19910530 & 133.93 & & & \\
\hline & & & & & & & & & & & $\mathrm{BCME}$ & 19910628 & 134.20 & & & \\
\hline & & & & & & & & & & & $\mathrm{BCME}$ & 19910727 & 134.65 & & & \\
\hline & & & & & & & & & & & BCME & 19910731 & 134.69 & & & \\
\hline & & & & & & & & & & & BCME & 19910830 & 135.53 & & & \\
\hline & & & & & & & & & & & BCME & 19910927 & 135.43 & & & \\
\hline \multirow[t]{26}{*}{$092 \mathrm{G} .009 \cdot 2 \cdot 1 \cdot 3-47$} & 49010 & 1221714 & w & 0 & $\mathrm{U}$ & SUMS & 10 & 87 & 6 & 175 & BCME & 19881014 & 63.91 & & & \\
\hline & & & & & & & & & & & BCME & 19881027 & 63.99 & & & \\
\hline & & & & & & & & & & & BCME & 19881128 & 63.96 & & & \\
\hline & & & & & & & & & & & BCME & 19881229 & 62.87 & & & \\
\hline & & & & & & & & & & & $\mathrm{BCME}$ & 19890130 & 60.75 & & & \\
\hline & & & & & & & & & & & $\mathrm{BCME}$ & 19890227 & 59.43 & & & \\
\hline & & & & & & & & & & & $\mathrm{BCME}$ & 19890331 & 58.84 & & & \\
\hline & & & & & & & & & & & BCME & 19890428 & 57.86 & & & \\
\hline & & & & & & & & & & & $\mathrm{BCME}$ & 19890524 & 57.71 & & & \\
\hline & & & & & & & & & & & $\mathrm{BCME}$ & 19890626 & 58.40 & & & \\
\hline & & & & & & & & & & & $\mathrm{BCME}$ & 19890730 & 59.60 & & & \\
\hline & & & & & & & & & & & $\mathrm{BCME}$ & 19890823 & 60.22 & & & \\
\hline & & & & & & & & & & & $\mathrm{BCME}$ & 19890924 & 61.04 & & & \\
\hline & & & & & & & & & & & $\mathrm{BCME}$ & 19891026 & 61.82 & & & \\
\hline & & & & & & & & & & & BCME & 19891127 & 62.29 & & & \\
\hline & & & & & & & & & & & BCME & 19891227 & 61.66 & & & \\
\hline & & & & & & & & & & & $\mathrm{BCME}$ & 19900125 & 60.97 & & & \\
\hline & & & & & & & & & & & BCME & 19900226 & 58.70 & & & \\
\hline & & & & & & & & & & & BCME & 19900228 & 58.86 & & & \\
\hline & & & & & & & & & & & $\mathrm{BCME}$ & 19900330 & 57.47 & & & \\
\hline & & & & & & & & & & & BCME & 19900427 & 56.97 & & & \\
\hline & & & & & & & & & & & $\mathrm{BCME}$ & 19900529 & 57.72 & & & \\
\hline & & & & & & & & & & & USGS & 19900618 & 58.62 & & & \\
\hline & & & & & & & & & & & BCME & 19900703 & 58.72 & & & \\
\hline & & & & & & & & & & & BCME & 19900802 & 59.90 & & & \\
\hline & & & & & & & & & & & $\begin{array}{l}\text { BCME } \\
\text { BCME }\end{array}$ & $\begin{array}{l}19900903 \\
19901005\end{array}$ & $\begin{array}{l}60.83 \\
61.66\end{array}$ & & & \\
\hline
\end{tabular}


Appendix Table 1. Well, water-level, hydrogeologic, and reconnaissance water-quality data-Continued

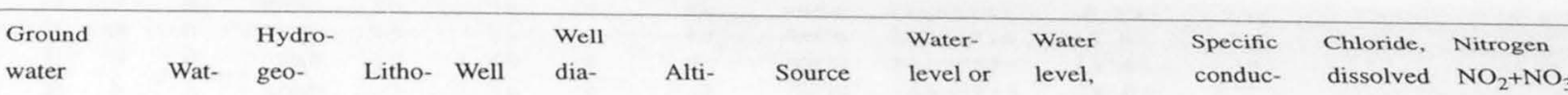

logic depth meter tude of

level

level,

ond

$\mathrm{NO}_{2}+\mathrm{NO}$

tude tude type use use unit unit (feet) (inches) (feet) data
date

land surface $(\mu \mathrm{S} / \mathrm{cm})$

as $\mathrm{Cl}$ )

$(\mathrm{mg} / \mathrm{L}$ as $\mathrm{N})$

092G.009.2.1.4-20 $092 \mathrm{G} .009 .2 .1 .4-23$

092G.009.2.1.4-26

$092 \mathrm{G} .009 .2 \cdot 2.1-03$

092G.009.2.2.3-11

092G.009.2.3.1-32

092G.009.3.1.2-20

092G.009.3.1.2-23

$38 \mathrm{~N} / 03 \mathrm{E}-04 \mathrm{E} 01$

$38 \mathrm{~N} / 04 \mathrm{E}-06 \mathrm{D} 01$

$39 \mathrm{~N} / 02 \mathrm{E}-01 \mathrm{~N} 01$

$39 \mathrm{~N} / 02 \mathrm{E}-01 \mathrm{P} 02$

$\begin{array}{lllll}490123 & 1221621 & \text { W } & \text { O } & \text { U } \\ 490112 & 1221621 & \text { W } & \text { O } & \text { U } \\ 490113 & 1221623 & \text { W } & \text { W } & \text { P } \\ 490010 & 1221439 & \text { W } & \text { W } & \text { I } \\ 490106 & 1221350 & \text { W } & \text { W } & \text { I } \\ 490140 & 1221735 & \text { W } & \text { W } & \text { H } \\ 490338 & 1222149 & \text { W } & \text { W } & \text { H } \\ 490310 & 1222137 & \text { W } & \text { U } & \text { U } \\ 484848 & 1222628 & \text { W } & \text { T } & \text { U } \\ 484902 & 1222102 & \text { W } & \text { W } & \text { H } \\ 485335 & 1223015 & \text { W } & \text { W } & \text { H } \\ 485337 & 1222948 & \text { W } & \text { W } & \text { H }\end{array}$

$\begin{array}{ll}\text { SUMS } & 10 \\ \text { SUMS } & \\ \text { SUMS } & 10 \\ \text { SUMS } & 20 \\ \text { SUMS } & 20 \\ \text { SUMS } & 14 \\ \text { EVRS } & 30 \\ \text { SUMS } & 10 \\ & \\ \text { EVRS } & 30 \\ \text { SUMS } & 10 \\ \text { SUMS } & 10\end{array}$

\section{BCME}

\section{BCME}

\section{BCME}

BCME

BCME

BCME

BCME

BCME

BCME

BCME

BCME

BCME

BCME

BCME

USG

USGS

USGS

USGS

USGS

USGS

USGS

USGS

Drill

USGS

USG

USGS

USGS

USGS

USGS

USGS

USGS

USGS

USGS

USGS

USGS

USGS

USGS

USGS
19901106

19901206

19910107

9910111

19910228

19910401

19910403

19910430

9910530

19910628

910927

19900618

19900618

19911002

19900619

19900619

19900619

19900614

19900614

19900427

19900410

19900412

19901018

19901114

19901218

19910119

19910220

19910313

199103425

19910521

19910626

19910718

19910823

19910925
62.23

61.56

59.31

59.10

56.54

56.02

55.92

56.35

57.09

57.85

59.02

59.06

60.11

60.87

42.54

--

3.59

5.16

58.33

84.80

13.93

3.1

9.83

11.28

15.11

13.22

10.43

9.70

9. 89

10.00

10.66

11.39

12.65

13.68

14.75

14.60

$\begin{array}{rcc}-- & -- & -- \\ -- & -- & -- \\ 327 & 8.1 & 6.9 \\ -- & -- & -- \\ 752 & 210 & 0.05 \\ 254 & 15 & 0.1 \\ 180 & 0.8 & 0.3 \\ -- & -- & -- \\ & & \\ 687 & 49 & <0.05 \\ 114 & 4.8 & 3.8 \\ 223 & 14 & 10 \\ 247 & 17 & 14 \\ 205 & 13 & 9.5 \\ 152 & 7.8 & 6.1 \\ 153 & 7 & -- \\ 165 & 10 & -- \\ 171 & 11 & 7.6 \\ 167 & -- & 6.5 \\ 238 & 20 & 5.4 \\ 240 & 20 & 9.9 \\ 239 & 20 & 9.6 \\ -- & -- & 7.9 \\ 240 & 18 & 7.9\end{array}$


$\vec{\Delta} \quad$ Appendix Table 1. Well, water-level, hydrogeologic, and reconnaissance water-quality data--Continued

\begin{tabular}{|c|c|c|c|c|c|c|c|c|c|c|c|c|c|c|c|c|}
\hline Local well number & $\begin{array}{l}\text { Lati- } \\
\text { tude }\end{array}$ & $\begin{array}{l}\text { Longi- } \\
\text { tude }\end{array}$ & $\begin{array}{l}\text { Ground } \\
\text { water } \\
\text { site } \\
\text { type }\end{array}$ & $\begin{array}{l}\text { Site } \\
\text { use }\end{array}$ & $\begin{array}{l}\text { Wat- } \\
\text { er } \\
\text { use }\end{array}$ & $\begin{array}{l}\text { Hydro- } \\
\text { geo- } \\
\text { logic } \\
\text { unit }\end{array}$ & $\begin{array}{l}\text { Litho- } \\
\text { logic } \\
\text { unit }\end{array}$ & $\begin{array}{l}\text { Well } \\
\text { depth } \\
\text { (feet) }\end{array}$ & $\begin{array}{l}\text { Well } \\
\text { dia- } \\
\text { meter } \\
\text { (inches) }\end{array}$ & $\begin{array}{l}\text { Alti- } \\
\text { tude } \\
\text { (feet) }\end{array}$ & $\begin{array}{l}\text { Source } \\
\text { of } \\
\text { data }\end{array}$ & $\begin{array}{l}\text { Water- } \\
\text { level or } \\
\text { sample } \\
\text { date }\end{array}$ & $\begin{array}{l}\text { Water } \\
\text { level, } \\
\text { feet below } \\
\text { land surface }\end{array}$ & $\begin{array}{l}\text { Specific } \\
\text { conduc- } \\
\text { tance } \\
(\mu \mathrm{S} / \mathrm{cm})\end{array}$ & $\begin{array}{l}\text { Chloride, } \\
\text { dissolved } \\
(\mathrm{mg} / \mathrm{L} \\
\text { as } \mathrm{Cl})\end{array}$ & $\begin{array}{l}\text { Nitrogen } \\
\mathrm{NO}_{2}+\mathrm{NO}_{3} \\
\text { total } \\
\text { (mg/L as } \mathrm{N} \text { ) }\end{array}$ \\
\hline & & & & & & & & & & & USGS & 19911023 & 14.90 & 238 & -- & 8.4 \\
\hline $39 \mathrm{~N} / 02 \mathrm{E}-01 \mathrm{Q} 01$ & 485340 & 1222927 & W & w & I & SUMS & 10 & 31 & 36 & 80 & USGS & 19900410 & 10.14 & -- & -- & -- \\
\hline $39 \mathrm{~N} / 02 \mathrm{E}-02 \mathrm{~A} 01$ & 485412 & 1223040 & $\mathrm{~W}$ & $\mathrm{U}$ & $\mathrm{U}$ & SUMS & 11 & 40 & 6 & 60 & USGS & 19900413 & 9.18 & -- & -- & - \\
\hline $39 \mathrm{~N} / 02 \mathrm{E}-02 \mathrm{H} 01$ & 485408 & 1223040 & W & w & I & SUMS & 10 & 19 & 36 & 60 & USGS & 19900412 & 7.03 & -- & -- & -- \\
\hline $39 \mathrm{~N} / 02 \mathrm{E}-03 \mathrm{G} 01$ & 485358 & 1223207 & $\mathrm{~W}$ & w & $\mathrm{H}$ & SUMS & 10 & 32 & 36 & 35 & USGS & 19900410 & 4.90 & 146 & 12 & 3.5 \\
\hline $39 \mathrm{~N} / 02 \mathrm{E}-05 \mathrm{~B} 02$ & 485419 & 1223449 & $\mathrm{~W}$ & $\mathrm{~T}$ & $\mathrm{U}$ & & & 735 & & 60 & Drill & & & & & \\
\hline \multirow[t]{14}{*}{$39 \mathrm{~N} / 02 \mathrm{E}-10 \mathrm{~F} 01$} & 485316 & 1223226 & W & w & $\mathrm{H}$ & SUMS & 10 & 20 & 12 & 55 & USGS & 19900412 & 8.16 & 248 & 15 & 14 \\
\hline & & & & & & & & & & & USGS & 19901016 & 11.91 & 180 & 14 & 3.7 \\
\hline & & & & & & & & & & & USGS & 19901116 & 9.27 & 161 & 14 & 1.6 \\
\hline & & & & & & & & & & & USGS & 19901218 & 6.78 & 186 & 14 & 8.6 \\
\hline & & & & & & & & & & & USGS & 19910116 & 6.62 & 243 & 16.4 & 15 \\
\hline & & & & & & & & & & & USGS & 19910220 & 6.23 & 214 & 13.5 & 12 \\
\hline & & & & & & & & & & & USGS & 19910313 & 6.70 & 208 & 15 & 9.8 \\
\hline & & & & & & & & & & & USGS & 19910425 & 7.46 & 201 & -- & 8.3 \\
\hline & & & & & & & & & & & USGS & 19910521 & 8.39 & 236 & 15 & 12 \\
\hline & & & & & & & & & & & USGS & 19910626 & 9.45 & 233 & 15 & 11 \\
\hline & & & & & & & & & & & USGS & 19910718 & 10.20 & 214 & 14 & 8.4 \\
\hline & & & & & & & & & & & USGS & 19910823 & 11.96 & 216 & 16 & 6.3 \\
\hline & & & & & & & & & & & USGS & 19910925 & 11.67 & 198 & 14 & 3.7 \\
\hline & & & & & & & & & & & USGS & 19911023 & 11.84 & 187 & 13 & 3 \\
\hline $39 \mathrm{~N} / 02 \mathrm{E}-10 \mathrm{~J} 01$ & 485253 & 1223155 & $\mathrm{~W}$ & w & I & SUMS & 11 & 21 & 36 & 75 & USGS & 19900411 & 5.07 & -- & -- & -- \\
\hline $39 \mathrm{~N} / 02 \mathrm{E}-10 \mathrm{Q} 02$ & 485239 & 1223216 & W & $\mathrm{U}$ & $\mathrm{U}$ & SUMS & 10 & 27 & 24 & 60 & USGS & 19900411 & 3.27 & -- & -- & -- \\
\hline $39 \mathrm{~N} / 02 \mathrm{E}-11 \mathrm{~B} 01$ & 485328 & 1223102 & $\mathrm{~W}$ & w & $\mathrm{H}$ & SUMS & 10 & 26 & 36 & 65 & USGS & 19900410 & 9.45 & 162 & 8.2 & 6.9 \\
\hline $39 \mathrm{~N} / 02 \mathrm{E}-11 \mathrm{~B} 02$ & 485322 & 1223102 & w & $\mathrm{T}$ & $\mathrm{U}$ & & & 525 & & 71 & Drill & & & & & \\
\hline $39 \mathrm{~N} / 02 \mathrm{E}-11 \mathrm{M} 01$ & 485258 & 1223141 & W & w & $\mathrm{H}$ & SUMS & 10 & 40 & 6 & 75 & USGS & 19900410 & 2.79 & 50 & 1 & 0.6 \\
\hline $39 \mathrm{~N} / 02 \mathrm{E}-12 \mathrm{H} 04$ & 485305 & 1222921 & $\mathrm{~W}$ & w & I & SUMS & 10 & 45 & 36 & 82 & USGS & 19900501 & 5.48 & -- & -- & -- \\
\hline $39 \mathrm{~N} / 02 \mathrm{E}-12 \mathrm{~K} 03$ & 485258 & 1222939 & W & w & $\mathrm{H}$ & SUMS & 10 & 27 & 6 & 85 & USGS & 19900413 & 9.57 & 195 & 3.4 & 12. \\
\hline $39 \mathrm{~N} / 02 \mathrm{E}-12 \mathrm{Q} 01$ & 485244 & 1222939 & w & W & $\mathrm{H}$ & SUMS & 10 & 44 & 6 & 80 & USGS & 19900413 & 2.68 & 180 & 7 & $<0.1$ \\
\hline $39 \mathrm{~N} / 02 \mathrm{E}-13 \mathrm{~B} 01$ & 485234 & 1222934 & W & W & $\mathrm{P}$ & SUMS & 10 & 52 & 5 & 80 & USGS & 19900413 & 9.73 & 244 & 12 & $<0.1$ \\
\hline $39 \mathrm{~N} / 02 \mathrm{E}-14 \mathrm{~L} 01$ & 485202 & 1223106 & W & w & $\mathrm{H}$ & SUMS & 10 & 21 & 36 & 60 & USGS & 19900412 & 5.45 & 360 & 23 & $<0.1$ \\
\hline $39 \mathrm{~N} / 02 \mathrm{E}-14 \mathrm{M} 01$ & 485209 & 1223125 & w & w & $\mathrm{H}$ & SUMS & 10 & 34 & 36 & 60 & USGS & 19900411 & 5.91 & 280 & 14 & 8 \\
\hline $39 \mathrm{~N} / 02 \mathrm{E}-16 \mathrm{~A} 01$ & 485229 & 1223305 & W & $\mathrm{U}$ & & SUMS & 10 & 19 & 12 & 48 & USGS & 19900418 & 3.22 & -- & -- & -- \\
\hline $39 \mathrm{~N} / 02 \mathrm{E}-16 \mathrm{H} 03$ & 485223 & 1223305 & w & $\mathrm{w}$ & $\mathrm{H}$ & SUMS & 11 & 19 & 12 & 50 & USGS & 19900418 & 2.54 & 198 & 11 & 0.7 \\
\hline $39 \mathrm{~N} / 02 \mathrm{E}-21 \mathrm{~K} 01$ & 485117 & 1223328 & $\mathrm{~W}$ & $\mathrm{U}$ & $\mathrm{U}$ & SUMS & 12 & 19 & 8 & 50 & USGS & 19900410 & 4.87 & & & \\
\hline $39 \mathrm{~N} / 02 \mathrm{E}-22 \mathrm{D} 02$ & 485138 & 1223246 & $\mathrm{w}$ & w & $\mathrm{H}$ & SUMS & 10 & 48 & 6 & 50 & USGS & 19900410 & 17.49 & 307 & 27 & $<0.1$ \\
\hline $39 \mathrm{~N} / 02 \mathrm{E}-22 \mathrm{~K} 02$ & 485112 & 1223215 & $w$ & w & $\mathrm{H}$ & SUMS & 10 & 17 & 6 & 45 & USGS & 19900410 & 2.87 & 259 & 14 & $<0.1$ \\
\hline $39 \mathrm{~N} / \mathrm{O} 2 \mathrm{E}-22 \mathrm{~K} 03$ & 485106 & 1223221 & $\mathrm{w}$ & w & $\mathrm{H}$ & sums & 10 & 25 & 12 & 58 & USGS & 19900411 & 5.18 & 131 & 3.2 & 0.3 \\
\hline $39 \mathrm{~N} / 02 \mathrm{E}-22 \mathrm{~L} 01$ & 485118 & 1223226 & w & $\mathrm{z}$ & u & & & 175 & & 45 & Drill & & & & & \\
\hline
\end{tabular}


Appendix Table 1. Well, water-level, hydrogeologic, and reconnaissance water-quality data--Continued

\begin{tabular}{|c|c|c|c|c|c|c|c|c|c|c|c|c|c|c|c|c|}
\hline Local well number & $\begin{array}{l}\text { Lati- } \\
\text { tude }\end{array}$ & $\begin{array}{l}\text { Longi- } \\
\text { tude }\end{array}$ & $\begin{array}{l}\text { Ground } \\
\text { water } \\
\text { site } \\
\text { type }\end{array}$ & Site & $\begin{array}{l}\text { Wat- } \\
\text { er } \\
\text { use }\end{array}$ & $\begin{array}{l}\text { Hydro- } \\
\text { geo- } \\
\text { logic } \\
\text { unit }\end{array}$ & $\begin{array}{l}\text { Litho- } \\
\text { logic } \\
\text { unit }\end{array}$ & $\begin{array}{l}\text { Well } \\
\text { depth } \\
\text { (feet) }\end{array}$ & $\begin{array}{l}\text { Well } \\
\text { dia- } \\
\text { meter } \\
\text { (inches) }\end{array}$ & $\begin{array}{l}\text { Alti- } \\
\text { tude } \\
\text { (feet) }\end{array}$ & $\begin{array}{l}\text { Source } \\
\text { of } \\
\text { data }\end{array}$ & $\begin{array}{l}\text { Water- } \\
\text { level or } \\
\text { sample } \\
\text { date }\end{array}$ & $\begin{array}{l}\text { Water } \\
\text { level, } \\
\text { feet below } \\
\text { land surface }\end{array}$ & $\begin{array}{l}\text { Specific } \\
\text { conduc- } \\
\text { tance } \\
(\mu \mathrm{S} / \mathrm{cm})\end{array}$ & $\begin{array}{l}\text { Chloride, } \\
\text { dissolved } \\
(\mathrm{mg} / \mathrm{L} \\
\text { as } \mathrm{Cl} \text { ) }\end{array}$ & $\begin{array}{l}\text { Nitrogen } \\
\mathrm{NO}_{2}+\mathrm{NO}_{3} \\
\text { total } \\
(\mathrm{mg} / \mathrm{L} \text { as } \mathrm{N})\end{array}$ \\
\hline $39 \mathrm{~N} / 02 \mathrm{E}-23 \mathrm{~F} 01$ & 485121 & 1223113 & $\mathrm{~W}$ & w & $\mathrm{S}$ & SUMS & 10 & 20 & 12 & 61 & USGS & 19900412 & 2.40 & 241 & 3.4 & $<0.1$ \\
\hline $39 \mathrm{~N} / 02 \mathrm{E}-23 \mathrm{G} 02$ & 485131 & 1223058 & $\mathrm{~W}$ & w & $\mathrm{H}$ & SUMS & 10 & 10 & 36 & 50 & USGS & 19900410 & 2.63 & 309 & 19 & $<0.1$ \\
\hline $39 \mathrm{~N} / 02 \mathrm{E}-23 \mathrm{~J} 01$ & 485118 & 1223039 & W & $\mathrm{T}$ & U & & & 1060 & & 75 & Drill & & & & & \\
\hline $39 \mathrm{~N} / 02 \mathrm{E}-24 \mathrm{~B} 01$ & 485144 & 1222938 & W & $\mathrm{T}$ & $\mathrm{U}$ & & & 869 & & 68 & Drill & & & & & \\
\hline $39 \mathrm{~N} / 02 \mathrm{E}-24 \mathrm{CO} 2$ & 485137 & 1222954 & W & W & $\mathrm{H}$ & SUMS & 10 & 22 & 12 & 62 & USGS & 19900410 & 7.95 & 159 & 12 & 3.8 \\
\hline $39 \mathrm{~N} / 02 \mathrm{E}-24 \mathrm{~F} 02$ & 485130 & 1222948 & W & $\mathrm{T}$ & $\mathrm{U}$ & & & 846 & & 70 & Drill & & & & & \\
\hline $39 \mathrm{~N} / 02 \mathrm{E}-24 \mathrm{~K} 01$ & 485118 & 1222931 & W & $\mathrm{T}$ & $\mathrm{U}$ & & & 380 & & 90 & Drill & & & & & \\
\hline $39 \mathrm{~N} / 02 \mathrm{E}-24 \mathrm{~N} 02$ & 485055 & 1223009 & W & w & $\mathrm{H}$ & SUMS & 10 & 29 & 12 & 76 & USGS & 19900412 & 2.58 & 303 & 19 & $<0.1$ \\
\hline $39 \mathrm{~N} / 02 \mathrm{E}-24 \mathrm{Q} 01$ & 485056 & 1222925 & W & $\mathrm{U}$ & $\mathrm{U}$ & EVRS & 30 & 59 & 6 & 110 & USGS & 19900411 & 4.66 & -- & -- & -- \\
\hline $39 \mathrm{~N} / 02 \mathrm{E}-24 \mathrm{RO} 2$ & 485054 & 1222924 & W & w & $\mathrm{H}$ & EVRS & 30 & 41 & 6 & 134 & USGS & 19900421 & 19.56 & 280 & 17 & 10 \\
\hline $39 \mathrm{~N} / 02 \mathrm{E}-25 \mathrm{C} 01$ & 485045 & 1222955 & W & $\mathrm{T}$ & & & & 867 & & 75 & Drill & & & & & \\
\hline $39 \mathrm{~N} / 02 \mathrm{E}-26 \mathrm{C} 01$ & 485052 & 1223119 & W & w & $\mathrm{H}$ & SUMS & 12 & 30 & 36 & 70 & USGS & 19900418 & 5.91 & 278 & 10 & 1.7 \\
\hline $39 \mathrm{~N} / 02 \mathrm{E}-26 \mathrm{H} 01$ & 485031 & 1223041 & $\mathrm{~W}$ & w & $\mathrm{H}$ & SUMS & 12 & 14 & 36 & 110 & USGS & 19900418 & 6.46 & 309 & 8.8 & 12 \\
\hline $39 \mathrm{~N} / 02 \mathrm{E}-26 \mathrm{~N} 01$ & 485003 & 1223139 & w & w & $\mathrm{H}$ & SUMS & 12 & 24 & 36 & 92 & USGS & 19900412 & 3.34 & 121 & 3.8 & 3.6 \\
\hline \multirow[t]{14}{*}{$39 \mathrm{~N} / 02 \mathrm{E}-27 \mathrm{~F} 03$} & 485031 & 1223242 & W & w & $\mathrm{H}$ & SUMS & 12 & 44 & 6 & 106 & USGS & 19900411 & 15.00 & 304 & 16 & 14 \\
\hline & & & & & & & & & & & USGS & 19901018 & 18.45 & 268 & 15 & 14 \\
\hline & & & & & & & & & & & USGS & 19901114 & 18.18 & 271 & 12 & 12 \\
\hline & & & & & & & & & & & USGS & 19901218 & 15.14 & 274 & 12 & 12 \\
\hline & & & & & & & & & & & USGS & 19910116 & 13.77 & 287 & 13 & 13 \\
\hline & & & t & & & & & & & & USGS & 19910220 & 13.85 & 297 & 14 & 13 \\
\hline & & & 1 & & & & & & & & USGS & 19910314 & 13.76 & 298 & 14 & 14 \\
\hline & & & & & & & & & & & USGS & 19910425 & 14.32 & 294 & 13 & 14 \\
\hline & & & & & & & & & & & USGS & 19910521 & 15.08 & 303 & 12 & 13 \\
\hline & & & & & & & & & & & USGS & 19910626 & 15.99 & 294 & 13 & 13 \\
\hline & & & & & & & & & & & USGS & 19910717 & 16.70 & 283 & 12 & 12 \\
\hline & & & & & & & & & & & USGS & 19910823 & 17.59 & -- & 11 & 11 \\
\hline & & & & & & & & & & & USGS & 19910925 & 18.15 & 258 & -- & 11 \\
\hline & & & & & & & & & & & USGS & 19911023 & 18.60 & 265 & 11 & 11 \\
\hline $39 \mathrm{~N} / 02 \mathrm{E}-27 \mathrm{~F} 04$ & 485034 & 1223227 & $\mathrm{~W}$ & $\mathrm{w}$ & $\mathrm{H}$ & SUMS & 12 & 36 & 36 & 108 & USGS & 19900411 & 17.39 & 283 & 9.2 & 2.5 \\
\hline $39 \mathrm{~N} / 02 \mathrm{E}-27 \mathrm{~J} 01$ & 485024 & 1223145 & $\mathrm{~W}$ & $\mathrm{~W}$ & $\mathrm{H}$ & SUMS & 12 & 29 & 36 & 110 & USGS & 19900418 & 16.54 & 287 & 11 & 15 \\
\hline $39 \mathrm{~N} / 02 \mathrm{E}-27 \mathrm{~K} 01$ & 485023 & 1223219 & w & w & $\mathrm{H}$ & SUMS & 12 & 35 & 18 & 110 & USGS & 19900411 & 11.84 & 149 & 2.6 & 2.8 \\
\hline $39 \mathrm{~N} / 02 \mathrm{E}-27 \mathrm{NO} 1$ & 485005 & 1223255 & $\mathrm{~W}$ & w & $\mathrm{H}$ & SUMS & 10 & 32 & 12 & 95 & USGS & 19900411 & 4.08 & 335 & 40 & 8.9 \\
\hline $39 N / 02 E-27 P 01$ & 485009 & 1223238 & $\mathrm{~W}$ & $\mathrm{~T}$ & & & & 923 & & 100 & USGS & & & & & \\
\hline $39 \mathrm{~N} / 02 \mathrm{E}-27 \mathrm{Q} 04$ & 485005 & 1223207 & $\mathrm{~W}$ & $\mathrm{~W}$ & $\mathrm{P}$ & SUMS & 10 & 22 & 36 & 95 & USGS & 19910710 & -- & 198 & 13 & 5.8 \\
\hline $39 \mathrm{~N} / 02 \mathrm{E}-28 \mathrm{~J} 02$ & 485015 & 1223316 & $\mathrm{~W}$ & w & $\mathrm{H}$ & SUMS & 10 & 25 & 18 & 93 & USGS & 19900501 & 5.20 & 251 & 3 & 6.7 \\
\hline $39 \mathrm{~N} / 02 \mathrm{E}-28 \mathrm{~J} 03$ & 485022 & 1223314 & $\mathrm{~W}$ & w & $\mathrm{H}$ & SUMS & 12 & 24 & 18 & 90 & USGS & 19900501 & 9.76 & 120 & 26 & 1.3 \\
\hline \multirow[t]{2}{*}{$39 \mathrm{~N} / 03 \mathrm{E}-01 \mathrm{C} 01$} & 485420 & 1222153 & $\mathrm{~W}$ & w & $\mathrm{H}$ & SUMS & 10 & 49 & 6 & 96 & USGS & 19900427 & 9.39 & 285 & 54 & 0.4 \\
\hline & & & & & & & & & & & USGS & 19901018 & 14.27 & 295 & 54 & 0.4 \\
\hline
\end{tabular}


$\overrightarrow{\mathrm{N}}$ Appendix Table 1. Well, water-level, hydrogeologic, and reconnaissance water-quality data--Continued

\begin{tabular}{|c|c|c|c|c|c|c|c|c|c|c|c|c|c|c|c|c|}
\hline Local well number & $\begin{array}{l}\text { Lati- } \\
\text { tude }\end{array}$ & $\begin{array}{l}\text { Longi- } \\
\text { tude }\end{array}$ & $\begin{array}{l}\text { Ground } \\
\text { water } \\
\text { site } \\
\text { type }\end{array}$ & $\begin{array}{l}\text { Site } \\
\text { use }\end{array}$ & $\begin{array}{l}\text { Wat- } \\
\text { er } \\
\text { use }\end{array}$ & $\begin{array}{l}\text { Hydro- } \\
\text { geo- } \\
\text { logic } \\
\text { unit }\end{array}$ & $\begin{array}{l}\text { Litho- } \\
\text { logic } \\
\text { unit }\end{array}$ & $\begin{array}{l}\text { Well } \\
\text { depth } \\
\text { (feet) }\end{array}$ & $\begin{array}{l}\text { Well } \\
\text { dia- } \\
\text { meter } \\
\text { (inches) }\end{array}$ & $\begin{array}{l}\text { Alti- } \\
\text { tude } \\
\text { (feet) }\end{array}$ & $\begin{array}{l}\text { Source } \\
\text { of } \\
\text { data }\end{array}$ & $\begin{array}{l}\text { Water- } \\
\text { level or } \\
\text { sample } \\
\text { date }\end{array}$ & $\begin{array}{l}\text { Water } \\
\text { level, } \\
\text { feet below } \\
\text { land surface }\end{array}$ & $\begin{array}{l}\text { Specific } \\
\text { conduc- } \\
\text { tance } \\
(\mu \mathrm{S} / \mathrm{cm})\end{array}$ & $\begin{array}{l}\text { Chloride, } \\
\text { dissolved } \\
(\mathrm{mg} / \mathrm{L} \\
\text { as } \mathrm{Cl})\end{array}$ & $\begin{array}{l}\text { Nitrogen } \\
\mathrm{NO}_{2}+\mathrm{NO}_{3} \\
\text { total } \\
(\mathrm{mg} / \mathrm{L} \text { as } \mathrm{N} \text { ) }\end{array}$ \\
\hline & & & & & & & & & & & USGS & 19901115 & 12.54 & 289 & 54 & 0.3 \\
\hline & & & & & & & & & & & USGS & 19901217 & 7.67 & 282 & 51 & 0.3 \\
\hline & & & & & & & & & & & USGS & 19910116 & 6.8 & 280 & 52 & 0.3 \\
\hline & & & & & & & & & & & USGS & 19910220 & 7.48 & 284 & 50 & 0.3 \\
\hline & & & & & & & & & & & USGS & 19910313 & 8.05 & 278 & 50 & 0.3 \\
\hline & & & & & & & & & & & USGS & 19910422 & 9.57 & 286 & 54 & 0.4 \\
\hline & & & & & & & & & & & USGS & 19910522 & 10.82 & 291 & 51 & 0.3 \\
\hline & & & & & & & & & & & USGS & 19910625 & 12.16 & 296 & 52 & 0.3 \\
\hline & & & & & & & & & & & USGS & 19910717 & 12.84 & 270 & 51 & 0.3 \\
\hline & & & & & & & & & & & USGS & 19910822 & 13.67 & 281 & 47 & 0.3 \\
\hline & & & & & & & & & & & USGS & 19910926 & 13.13 & 261 & 46 & 0.3 \\
\hline & & & & & & & & & & & USGS & 19911023 & 14.63 & 274 & 47 & 0.3 \\
\hline $39 \mathrm{~N} / 03 \mathrm{E}-01 \mathrm{D} 01$ & 485410 & 1222223 & W & w & $\mathrm{N}$ & SUMS & 10 & 39 & 36 & 100 & USGS & 19900320 & 13.21 & 229 & 44 & 0.5 \\
\hline $39 \mathrm{~N} / 03 \mathrm{E}-01 \mathrm{R} 01$ & 485330 & 1222124 & $\mathrm{~W}$ & W & $\mathrm{H}$ & SUMS & 12 & 46 & 6 & 120 & USGS & 19900320 & -- & 263 & 46 & 1.2 \\
\hline $39 \mathrm{~N} / 03 \mathrm{E}-02 \mathrm{~A} 01$ & 485411 & 1222235 & W & w & $\mathrm{H}$ & SUMS & 10 & 39 & 6 & 100 & USGS & 19900330 & 15.77 & 229 & 43 & 0.7 \\
\hline $39 \mathrm{~N} / 03 \mathrm{E}-02 \mathrm{~B} 02$ & 485418 & 1222254 & W & W & $\mathrm{H}$ & SUMS & 10 & 40 & 6 & 93 & USGS & 19900319 & 6.42 & 362 & 59 & 0.2 \\
\hline $39 \mathrm{~N} / 03 \mathrm{E}-02 \mathrm{~B} 03$ & 485413 & 1222259 & $\mathrm{x}$ & $\mathrm{T}$ & & & & 180 & & 93 & Drill & & & & & \\
\hline $39 \mathrm{~N} / 03 \mathrm{E}-02 \mathrm{~K} 01$ & 485353 & 1222254 & W & U & $\mathrm{U}$ & SUMS & 10 & 39 & 6 & 100 & USGS & 19900329 & 13.58 & -- & -- & -- \\
\hline $39 \mathrm{~N} / 03 \mathrm{E}-02 \mathrm{~N} 02$ & 485330 & 1222330 & W & W & $\mathrm{H}$ & SUMS & 10 & 30 & 6 & 100 & USGS & 19900319 & -- & 75 & 3.2 & 1.5 \\
\hline $39 \mathrm{~N} / 03 \mathrm{E}-02 \mathrm{~N} 03$ & 485333 & 1222344 & W & W & $\mathrm{H}$ & SUMS & 10 & 36 & 6 & 95 & USGS & 19900320 & 15.02 & 80 & 3.6 & 1.8 \\
\hline $39 \mathrm{~N} / 03 \mathrm{E}-02 \mathrm{Q} 01$ & 485332 & 1222258 & w & W & $\mathrm{H}$ & SUMS & 10 & 32 & 6 & 106 & USGS & 19900321 & - & 57 & 2.6 & 0.5 \\
\hline $39 N / 03 E-03 E 01$ & 485358 & 1222504 & $\mathrm{w}$ & W & $\mathrm{H}$ & SUMS & 10 & 43 & 6 & 100 & USGS & 19900320 & 20.38 & 133 & 8.6 & 0.3 \\
\hline $39 \mathrm{~N} / 03 \mathrm{E}-03 \mathrm{G} 01$ & 485408 & 1222421 & w & W & I & SUMS & 10 & 24 & 36 & 80 & USGS & 19900411 & 4.32 & -- & -- & -- \\
\hline $39 \mathrm{~N} / 03 \mathrm{E}-03 \mathrm{M} 01$ & 485346 & 1222448 & W & z & $\mathrm{U}$ & & & 262 & & 95 & USGS & & & & & \\
\hline $39 \mathrm{~N} / 03 \mathrm{E}-03 \mathrm{R} 02$ & 485332 & 1222357 & $\mathrm{~W}$ & w & I & SUMS & 10 & 40 & 6 & 95 & USGS & 19900320 & 12.95 & 173 & 7.8 & $<0.1$ \\
\hline $39 \mathrm{~N} / 03 \mathrm{E}-04 \mathrm{~B} 01$ & 485422 & 1222530 & W & W & I & SUMS & 10 & 31 & 6 & 83 & USGS & 19900321 & 15.21 & 521 & 35 & $<0.1$ \\
\hline $39 \mathrm{~N} / 03 \mathrm{E}-04 \mathrm{M} 01$ & 485346 & 1222618 & W & W & I & SUMS & 10 & 41 & 36 & 100 & USGS & 19900321 & 23.56 & -- & -- & -- \\
\hline $39 \mathrm{~N} / 03 \mathrm{E}-04 \mathrm{MO} 2$ & 485346 & 1222619 & $\mathrm{~W}$ & W & $\mathrm{H}$ & SUMS & 10 & 37 & 6 & 100 & USGS & 19900321 & 22.96 & 242 & 8.4 & 10 \\
\hline $39 \mathrm{~N} / 03 \mathrm{E}-04 \mathrm{P} 01$ & 485338 & 1222557 & W & W & I & SUMS & 10 & 41 & 36 & 97 & USGS & 19900321 & 21.43 & -- & -- & -- \\
\hline $39 \mathrm{~N} / 03 \mathrm{E}-04 \mathrm{R} 02$ & 485334 & 1222509 & $\mathrm{w}$ & W & I & SUMS & 10 & 20 & 36 & 80 & USGS & 19900320 & 2.96 & -- & -- & -- \\
\hline $39 \mathrm{~N} / 03 \mathrm{E}-05 \mathrm{~L} 01$ & 485354 & 1222712 & W & W & $\mathrm{H}$ & SUMS & 10 & 30 & 36 & 83 & USGS & 19900321 & 14.83 & & & \\
\hline $39 \mathrm{~N} / 03 \mathrm{E}-05 \mathrm{~L} 02$ & 485356 & 1222713 & w & $\mathrm{W}$ & $\mathrm{H}$ & SUMS & 10 & 38 & 6 & 83 & USGS & 19900321 & -- & 228 & 12 & 4.9 \\
\hline $39 \mathrm{~N} / 03 \mathrm{E}-05001$ & 485333 & 1222657 & w & w & $\mathrm{H}$ & SUMS & 10 & 9 & - & 90 & USGS & 19900321 & -- & 106 & 4.6 & 5.3 \\
\hline $39 \mathrm{~N} / 03 \mathrm{E}-05 \mathrm{Q} 02$ & 485334 & 1222658 & $\mathrm{w}$ & w & I & SUMS & 10 & 28 & 36 & 90 & USGS & 19900321 & 9.42 & & & \\
\hline $\begin{array}{l}39 \mathrm{~N} / 03 \mathrm{E}-06 \mathrm{KO} 1 \\
39 \mathrm{~N} / \mathrm{O} \mathrm{E}-06 \mathrm{MOI}\end{array}$ & $\begin{array}{l}485402 \\
485353\end{array}$ & $\begin{array}{l}1222816 \\
1222902\end{array}$ & $\begin{array}{l}w \\
w\end{array}$ & $\begin{array}{l}\mathrm{T} \\
\mathrm{T}\end{array}$ & $\begin{array}{l}u \\
u\end{array}$ & & & $\begin{array}{l}3490 \\
2000\end{array}$ & & $\begin{array}{l}65 \\
75\end{array}$ & $\begin{array}{l}\text { Drill } \\
\text { Drill }\end{array}$ & & & & & \\
\hline
\end{tabular}


Appendix Table 1. Well, water-level, hydrogeologic, and reconnaissance water-quality data--Continued

\begin{tabular}{|c|c|c|c|c|c|c|c|c|c|c|c|c|c|c|c|c|}
\hline Local well number & $\begin{array}{l}\text { Lati- } \\
\text { tude }\end{array}$ & $\begin{array}{l}\text { Longi- } \\
\text { tude }\end{array}$ & $\begin{array}{l}\text { Ground } \\
\text { water } \\
\text { site } \\
\text { type }\end{array}$ & $\begin{array}{l}\text { Site } \\
\text { use }\end{array}$ & $\begin{array}{l}\text { Wat- } \\
\text { er } \\
\text { use }\end{array}$ & $\begin{array}{l}\text { Hydro- } \\
\text { geo- } \\
\text { logic } \\
\text { unit }\end{array}$ & $\begin{array}{l}\text { Litho- } \\
\text { logic } \\
\text { unit }\end{array}$ & $\begin{array}{l}\text { Well } \\
\text { depth } \\
\text { (feet) }\end{array}$ & $\begin{array}{l}\text { Well } \\
\text { dia- } \\
\text { meter } \\
\text { (inches) }\end{array}$ & $\begin{array}{l}\text { Alti- } \\
\text { tude } \\
\text { (feet) }\end{array}$ & $\begin{array}{l}\text { Source } \\
\text { of } \\
\text { data }\end{array}$ & $\begin{array}{l}\text { Water- } \\
\text { level or } \\
\text { sample } \\
\text { date }\end{array}$ & $\begin{array}{l}\text { Water } \\
\text { level, } \\
\text { feet below } \\
\text { land surface }\end{array}$ & $\begin{array}{l}\text { Specific } \\
\text { conduc- } \\
\text { tance } \\
(\mu \mathrm{S} / \mathrm{cm})\end{array}$ & $\begin{array}{l}\text { Chloride, } \\
\text { dissolved } \\
(\mathrm{mg} / \mathrm{L} \\
\text { as } \mathrm{Cl})\end{array}$ & $\begin{array}{l}\text { Nitrogen } \\
\mathrm{NO}_{2}+\mathrm{NO}_{3} \\
\text { total } \\
(\mathrm{mg} / \mathrm{L} \text { as } \mathrm{N})\end{array}$ \\
\hline $39 \mathrm{~N} / 03 \mathrm{E}-07 \mathrm{~K} 01$ & 485256 & 1222823 & w & $\mathrm{w}$ & I & SUMS & 10 & 26 & 36 & 80 & USGS & 19900322 & 2.57 & -- & -- & -- \\
\hline $39 \mathrm{~N} / 03 \mathrm{E}-07 \mathrm{~K} 02$ & 485304 & 1222820 & w & w & $\mathrm{H}$ & SUMS & 10 & 24 & 36 & 83 & USGS & 19900322 & 3.57 & 304 & 14 & 18 \\
\hline $39 \mathrm{~N} / 03 \mathrm{E}-07 \mathrm{~L} 01$ & 485304 & 1222830 & W & w & I & SUMS & 10 & 30 & 36 & 83 & USGS & 19900322 & 2.07 & -- & -- & -- \\
\hline \multirow[t]{2}{*}{$39 \mathrm{~N} / 03 \mathrm{E}-08 \mathrm{C} 02$} & 485330 & 1222726 & W & w & $\mathrm{H}$ & SUMS & 10 & 27 & 12 & 90 & USGS & 19900322 & 12.03 & 208 & 7.8 & 15 \\
\hline & & & & & & & & & & & USGS & 19900830 & 15.40 & 218 & 7.2 & -- \\
\hline $39 \mathrm{~N} / 03 \mathrm{E}-08 \mathrm{~F} 02$ & 485307 & 1222720 & W & W & $\mathrm{H}$ & SUMS & 10 & 20 & 12 & 85 & USGS & 19900322 & 5.98 & 223 & 8.4 & 14 \\
\hline $39 \mathrm{~N} / 03 \mathrm{E}-09 \mathrm{C0} 1$ & 485328 & 1222554 & W & W & I & SUMS & 10 & 25 & 36 & 82 & USGS & 19900323 & 4.89 & -- & -- & -- \\
\hline $39 \mathrm{~N} / 03 \mathrm{E}-09 \mathrm{D} 02$ & 485324 & 1222624 & W & $\mathrm{W}$ & $\mathrm{P}$ & SUMS & 10 & 38 & 8 & 95 & USGS & 19900323 & 15.76 & 279 & 16 & 9.5 \\
\hline $39 \mathrm{~N} / 03 \mathrm{E}-09 \mathrm{Q} 02$ & 485241 & 1222534 & $w$ & $\mathrm{w}$ & $\mathrm{H}$ & SUMS & 10 & 20 & 18 & 95 & USGS & 19900329 & 7.63 & 255 & 5.6 & 0.7 \\
\hline $39 \mathrm{~N} / 03 \mathrm{E}-10 \mathrm{E} 01$ & 485313 & 1222447 & w & $\mathrm{U}$ & $\mathrm{U}$ & SUMS & 10 & 40 & 6 & 90 & USGS & 19900327 & 9.58 & -- & - & -- \\
\hline $39 \mathrm{~N} / 03 \mathrm{E}-10 \mathrm{H} 02$ & 485317 & 1222402 & w & w & $\mathrm{H}$ & SUMS & 10 & 47 & 6 & 97 & USGS & 19900329 & 19.89 & 167 & 8.2 & $<0.1$ \\
\hline $39 \mathrm{~N} / 03 \mathrm{E}-10 \mathrm{~J} 04$ & 485254 & 1222351 & w & w & $\mathrm{H}$ & BDRK & 40 & 160 & 6 & 117 & USGS & 19900329 & 2.39 & - & -- & -- \\
\hline \multirow[t]{14}{*}{$39 \mathrm{~N} / 03 \mathrm{E}-10 \mathrm{~L} 01$} & 485257 & 1222441 & W & W & $\mathrm{H}$ & SUMS & 10 & 35 & 36 & 96 & USGS & 19900430 & 12.17 & 147 & 9 & 1.9 \\
\hline & & & & & & & & & & & USGS & 19901015 & 15.58 & & 8.8 & 0.3 \\
\hline & & & & & & & & & & & USGS & 19901116 & 13.73 & -- & 10 & 0.7 \\
\hline & & & & & & & & & & & USGS & 19901217 & 9.6 & 140 & 7.8 & 2.6 \\
\hline & & & & & & & & & & & USGS & 19910116 & 8.68 & 153 & 11.3 & -- \\
\hline & & & & & & & & & & & USGS & 19910221 & 9.80 & 150 & 10.6 & 2.8 \\
\hline & & & & & & & & & & & USGS & 19910314 & 10.27 & 147 & 10.6 & -- \\
\hline & & & 1 & & & & & & & & USGS & 19910429 & -- & -- & 9.6 & 2.5 \\
\hline & 2 & & & & & & & & & & USGS & 19910522 & 13.12 & 158 & 11 & 1.9 \\
\hline & & & & & & & & & & & USGS & 19910625 & -- & -- & 12 & 1 \\
\hline & & & & & & & & & & & USGS & 19910717 & 14.79 & 166 & 11 & 1.4 \\
\hline & & & & & & & & & & & USGS & 19910823 & 15.58 & 168 & 11 & 1.8 \\
\hline & & & & & & & & & & & USGS & 19910926 & 16.16 & 165 & 12 & 0.34 \\
\hline & & & & & & & & & & & USGS & 19911024 & 16.81 & 163 & 12 & 0.14 \\
\hline $39 \mathrm{~N} / 03 \mathrm{E}-10 \mathrm{Q} 01$ & 485239 & 1222409 & w & $\mathrm{z}$ & $\mathrm{H}$ & & & 210 & & 140 & USGS & & & & & \\
\hline $39 \mathrm{~N} / 03 \mathrm{E}-10 \mathrm{Q} 02$ & 485245 & 1222422 & w & w & $\mathrm{H}$ & SUMS & & 28 & & 100 & USGS & 19900323 & 11.7 & -- & -- & -- \\
\hline $39 \mathrm{~N} / 03 \mathrm{E}-10003$ & 485245 & 1222424 & w & $\mathrm{U}$ & $\mathrm{U}$ & BDRK & & 120 & & 105 & USGS & 19900323 & Flow & -- & $>250$ & -- \\
\hline $39 \mathrm{~N} / 03 \mathrm{E}-11 \mathrm{~A} 02$ & 485326 & 1222236 & w & W & $\mathrm{H}$ & SUMS & 10 & 37 & 6 & 105 & Drill & 19900412 & 14.5 & 84 & 3.6 & 0.4 \\
\hline $39 \mathrm{~N} / 03 \mathrm{E}-11 \mathrm{M} 01$ & 485253 & 1222337 & w & w & $\mathrm{H}$ & BDRK & 40 & 80 & 6 & 125 & USGS & 19900329 & Flow & 414 & 19 & $<0.1$ \\
\hline $39 \mathrm{~N} / 03 \mathrm{E}-11 \mathrm{P} 01$ & 485241 & 1222314 & w & U & $\mathrm{U}$ & BDRK & 40 & 101 & 6 & 150 & USGS & 19900328 & 7.19 & -- & -- & -- \\
\hline $39 \mathrm{~N} / 03 \mathrm{E}-12 \mathrm{C0} 1$ & 485325 & 1222153 & w & U & $\mathrm{U}$ & SUMS & 12 & 37 & 6 & 117 & USGS & 19900327 & 23.54 & -- & -- & -- \\
\hline $39 \mathrm{~N} / 03 \mathrm{E}-12 \mathrm{D} 02$ & 485328 & 1222207 & w & w & $\mathrm{H}$ & SUMS & 12 & 43 & 6 & 115 & USGS & 19900409 & 23.16 & 187 & 35 & 0.4 \\
\hline $39 \mathrm{~N} / 03 \mathrm{E}-12 \mathrm{G} 01$ & 485314 & 1222138 & W & W & $\mathrm{H}$ & SUMS & 10 & 48 & 6 & 125 & USGS & 19900327 & 27.84 & 167 & 5 & $<0.1$ \\
\hline $39 \mathrm{~N} / 03 \mathrm{E}-12 \mathrm{~J} 02$ & 485257 & 1222122 & w & U & U & SUMS & 12 & 50 & 6 & 130 & USGS & 19900412 & 32.28 & -- & -- & -- \\
\hline $39 \mathrm{~N} / 03 \mathrm{E}-12 \mathrm{R} 03$ & 485237 & 1222128 & w & $\mathrm{z}$ & $\mathrm{U}$ & SUMS & 10 & 47 & 6 & 135 & USGS & 19900328 & -- & -- & -- & -- \\
\hline $39 \mathrm{~N} / 03 \mathrm{E}-13 \mathrm{E} 01$ & 485211 & 1222225 & w & w & $\mathrm{H}$ & BDRK & 40 & 100 & 6 & 145 & USGS & 19900412 & 7.83 & 1,030 & 210 & $<0.1$ \\
\hline
\end{tabular}


$\overrightarrow{+} \quad$ Appendix Table 1. Well, water-level, hydrogeologic, and reconnaissance water-quality data--Continued

\begin{tabular}{|c|c|c|c|c|c|c|c|c|c|c|c|c|c|c|c|c|}
\hline Local well number & $\begin{array}{l}\text { Lati- } \\
\text { tude }\end{array}$ & $\begin{array}{l}\text { Longi- } \\
\text { tude }\end{array}$ & $\begin{array}{l}\text { Ground } \\
\text { water } \\
\text { site } \\
\text { type }\end{array}$ & Site & $\begin{array}{l}\text { Wat- } \\
\text { er } \\
\text { use }\end{array}$ & $\begin{array}{l}\text { Hydro- } \\
\text { geo- } \\
\text { logic } \\
\text { unit }\end{array}$ & $\begin{array}{l}\text { Litho- } \\
\text { logic } \\
\text { unit }\end{array}$ & $\begin{array}{l}\text { Well } \\
\text { depth } \\
\text { (feet) }\end{array}$ & $\begin{array}{l}\text { Well } \\
\text { dia- } \\
\text { meter } \\
\text { (inches) }\end{array}$ & $\begin{array}{l}\text { Alti- } \\
\text { tude } \\
\text { (feet) }\end{array}$ & $\begin{array}{l}\text { Source } \\
\text { of } \\
\text { data }\end{array}$ & $\begin{array}{l}\text { Water- } \\
\text { level or } \\
\text { sample } \\
\text { date }\end{array}$ & $\begin{array}{l}\text { Water } \\
\text { level, } \\
\text { feet below } \\
\text { land surface }\end{array}$ & $\begin{array}{l}\text { Specific } \\
\text { conduc- } \\
\text { tance } \\
(\mu \mathrm{S} / \mathrm{cm})\end{array}$ & $\begin{array}{l}\text { Chloride, } \\
\text { dissolved } \\
(\mathrm{mg} / \mathrm{L} \\
\text { as } \mathrm{Cl})\end{array}$ & $\begin{array}{l}\text { Nitrogen } \\
\mathrm{NO}_{2}+\mathrm{NO}_{3} \\
\text { total } \\
(\mathrm{mg} / \mathrm{L} \text { as } \mathrm{N})\end{array}$ \\
\hline $39 \mathrm{~N} / 03 \mathrm{E}-13 \mathrm{R} 01$ & 485147 & 1222111 & W & W & $\mathrm{H}$ & BDRK & 40 & 120 & 6 & 210 & USGS & 19900327 & 19.05 & 219 & 2.8 & 0.4 \\
\hline $39 \mathrm{~N} / 03 \mathrm{E}-13 \mathrm{R} 02$ & 485149 & 1222135 & w & w & $\mathrm{H}$ & SUMS & 12 & 20 & 36 & 142 & USGS & 19900409 & -- & 424 & 10 & 0.7 \\
\hline $39 \mathrm{~N} / 03 \mathrm{E}-14 \mathrm{~A} 01$ & 485230 & 1222248 & W & W & I & BDRK & 40 & 130 & 6 & 130 & USGS & 19900328 & Flow & -- & -- & -- \\
\hline $39 \mathrm{~N} / 03 \mathrm{E}-15 \mathrm{CO} 2$ & 485233 & 1222428 & W & W & $\mathrm{H}$ & BDRK & 40 & 115 & 6 & 122 & USGS & 19900328 & 10.18 & 584 & 40 & $<0.1$ \\
\hline $39 \mathrm{~N} / 03 \mathrm{E}-15 \mathrm{D} 02$ & 485234 & 1222503 & W & W & $\mathrm{H}$ & SUMS & 10 & 35 & 12 & 97 & USGS & 19900329 & 13.13 & 84 & 1.2 & 3 \\
\hline $39 \mathrm{~N} / 03 \mathrm{E}-15 \mathrm{~J} 01$ & 485208 & 1222408 & w & w & $\mathrm{H}$ & BDRK & 40 & 72 & 6 & 180 & USGS & 19900328 & 7.82 & 256 & 4.6 & $<0.1$ \\
\hline $39 \mathrm{~N} / 03 \mathrm{E}-15 \mathrm{~L} 01$ & 485209 & 1222445 & $\mathrm{~W}$ & $\mathrm{w}$ & $\mathrm{H}$ & BDRK & 40 & 99 & 6 & 150 & USGS & 19900328 & 17.46 & 668 & 100 & 1.6 \\
\hline $39 \mathrm{~N} / 03 \mathrm{E}-16 \mathrm{~B} 02$ & 485237 & 1222536 & W & W & $\mathrm{H}$ & SUMS & 10 & 23 & 12 & 95 & USGS & 19900329 & 8.63 & 240 & 5 & 5.9 \\
\hline $39 \mathrm{~N} / 03 \mathrm{E}-16 \mathrm{~F} 01$ & 485214 & 1222604 & w & w & $\mathrm{H}$ & SUMS & 10 & 28 & 36 & 100 & USGS & 19900411 & 14.02 & 221 & 12 & 10 \\
\hline $39 \mathrm{~N} / 03 \mathrm{E}-16 \mathrm{~F} 02$ & 485213 & 1222559 & $\mathrm{~W}$ & $\mathrm{w}$ & $\mathrm{H}$ & SUMS & 10 & 37 & 8 & 95 & USGS & 19910430 & -- & 120 & 3.3 & -- \\
\hline $39 \mathrm{~N} / 03 \mathrm{E}-16 \mathrm{~L} 03$ & 485203 & 1222608 & $\mathrm{~W}$ & $\mathrm{~W}$ & I & SUMS & 10 & 21 & 36 & 100 & USGS & 19900411 & 9.78 & -- & -- & -- \\
\hline $39 \mathrm{~N} / 03 \mathrm{E}-16 \mathrm{NO} 2$ & 485149 & 1222620 & w & $\mathrm{T}$ & $\mathrm{U}$ & & & 140 & & 98 & USGS & & & & & \\
\hline $39 \mathrm{~N} / 03 \mathrm{E}-17 \mathrm{R} 03$ & 485148 & 1222640 & W & W & $\mathrm{H}$ & SUMS & 10 & 60 & 6 & 97 & USGS & 19900409 & 18.84 & 528 & 42 & $<0.1$ \\
\hline $39 \mathrm{~N} / 03 \mathrm{E}-18 \mathrm{Q} 01$ & 485147 & 1222808 & W & w & $\mathrm{H}$ & SUMS & 10 & 21 & 36 & 90 & USGS & 19900411 & 5.61 & 184 & 6.8 & 6.5 \\
\hline $39 \mathrm{~N} / 03 \mathrm{E}-19 \mathrm{~L} 01$ & 485110 & 1222830 & W & $\mathrm{w}$ & $\mathrm{H}$ & EVRS & 30 & 54 & 6 & 140 & USGS & 19900328 & 23.33 & 217 & 5.4 & 1.1 \\
\hline \multirow[t]{14}{*}{$39 \mathrm{~N} / 03 \mathrm{E}-19 \mathrm{~N} 01$} & 485056 & 1222853 & w & w & $\mathrm{C}$ & EVRS & 30 & 62 & 6 & 141 & USGS & 19900328 & 27.62 & 302 & 6 & 1.3 \\
\hline & & & & & & & & & & & USGS & 19901016 & 31.26 & 287 & 6 & 1.4 \\
\hline & & & & & & & & & & & USGS & 19901116 & 29.27 & 293 & 6 & 1.4 \\
\hline & & & & & & & & & & & USGS & 19901218 & 26.7 & -- & -- & -- \\
\hline & & & & & & & & & & & USGS & 19910116 & 26.69 & & 5.7 & 1.3 \\
\hline & & & & & & & & & & & USGS & 19910220 & 26.58 & 287 & 5.7 & 1.3 \\
\hline & & & & & & & & & & & USGS & 19910313 & 26.68 & 297 & 5.7 & 1.3 \\
\hline & & & & & & & & & & & USGS & 19910423 & 27.28 & 304 & 7.8 & $<0.05$ \\
\hline & & & & & & & & & & & USGS & 19910521 & 28.44 & 302 & 6.3 & 1.1 \\
\hline & & & & & & & & & & & USGS & 19910626 & 29.40 & -- & -- & -- \\
\hline & & & & & & & & & & & USGS & 19910717 & 29.89 & -- & -- & -- \\
\hline & & & & & & & & & & & USGS & 19910823 & 30.53 & 283 & 6 & 1.1 \\
\hline & & & & & & & & & & & USGS & 19910926 & 30.92 & 272 & 6 & 1.1 \\
\hline & & & & & & & & & & & USGS & 19911023 & 31.23 & 276 & 6 & 1.3 \\
\hline $39 \mathrm{~N} / 03 \mathrm{E}-19 \mathrm{Q} 01$ & 485055 & 1222808 & $\mathrm{w}$ & w & $\mathrm{H}$ & EVRS & 30 & 97 & 6 & 181 & USGS & 19900409 & 72.65 & 276 & 5.8 & 0.2 \\
\hline $39 \mathrm{~N} / 03 \mathrm{E}-20 \mathrm{~F} 02$ & 485129 & 1222713 & W & w & $\mathrm{H}$ & EVRS & 30 & 40 & 6 & 141 & USGS & 19900329 & 15.42 & 202 & 4.4 & 1.6 \\
\hline $39 \mathrm{~N} / 03 \mathrm{E}-20 \mathrm{~K} 01$ & 485117 & 1222652 & W & w & $\mathrm{H}$ & EVRS & 30 & 45 & 6 & 153 & USGS & 19900329 & 33.58 & 228 & 4.6 & 1.5 \\
\hline $39 \mathrm{~N} / 03 \mathrm{E}-20 \mathrm{~L} 01$ & 485117 & 1222712 & W & w & $\mathrm{H}$ & EVRS & 30 & 51 & 6 & 150 & USGS & 19900329 & 39.55 & 171 & 3.4 & 1 \\
\hline $39 \mathrm{~N} / 03 \mathrm{E}-20 \mathrm{R} 01$ & 485054 & 1222637 & W & w & $\mathrm{H}$ & EVRS & 31 & 287 & 6 & 220 & USGS & 19900421 & 122.98 & $>2,000$ & 170 & $<0.1$ \\
\hline 39N/03E-21E01 & 485123 & 1222623 & W & w & $\mathrm{H}$ & EVRS & 30 & 40 & 6 & 140 & USGS & 19900407 & 11.01 & 216 & 7 & 1 \\
\hline $39 \mathrm{~N} / 03 \mathrm{E}-21 \mathrm{~K} 01$ & 485118 & 1222538 & $\mathrm{w}$ & $w$ & $\mathrm{H}$ & EVRS & 31 & 158 & 6 & 190 & USGS & 19900420 & 96.96 & 1,160 & 23 & -- \\
\hline $39 \mathrm{~N} / 03 \mathrm{E}-21 \mathrm{M} 01$ & $\begin{array}{l}485117 \\
485115\end{array}$ & $\begin{array}{l}1222621 \\
1222502\end{array}$ & $\mathrm{~W}$ & $\underset{\mathrm{T}}{\mathrm{T}}$ & $\begin{array}{l}\mathrm{U} \\
\mathrm{H}\end{array}$ & EVRS & 30 & 163 & 6 & $\begin{array}{l}160 \\
210\end{array}$ & $\begin{array}{l}\text { USGS } \\
\text { USGS }\end{array}$ & 19900322 & 105.77 & 295 & 20 & $<0.1$ \\
\hline
\end{tabular}


Appendix Table 1. Well, water-level, hydrogeologic, and reconnaissance water-quality data--Continued

\begin{tabular}{|c|c|c|c|c|c|c|c|c|c|c|c|c|c|c|c|c|}
\hline Local well number & $\begin{array}{l}\text { Lati- } \\
\text { tude }\end{array}$ & $\begin{array}{l}\text { Longi- } \\
\text { tude }\end{array}$ & $\begin{array}{l}\text { Ground } \\
\text { water } \\
\text { site } \\
\text { type }\end{array}$ & Site & $\begin{array}{l}\text { Wat- } \\
\text { er } \\
\text { use }\end{array}$ & $\begin{array}{l}\text { Hydro- } \\
\text { geo- } \\
\text { logic } \\
\text { unit }\end{array}$ & $\begin{array}{l}\text { Litho- } \\
\text { logic } \\
\text { unit }\end{array}$ & $\begin{array}{l}\text { Well } \\
\text { depth } \\
\text { (feet) }\end{array}$ & $\begin{array}{l}\text { Well } \\
\text { dia- } \\
\text { meter } \\
\text { (inches) }\end{array}$ & $\begin{array}{l}\text { Alti- } \\
\text { tude } \\
\text { (feet) }\end{array}$ & $\begin{array}{l}\text { Source } \\
\text { of } \\
\text { data }\end{array}$ & $\begin{array}{l}\text { Water- } \\
\text { level or } \\
\text { sample } \\
\text { date }\end{array}$ & $\begin{array}{l}\text { Water } \\
\text { level, } \\
\text { feet below } \\
\text { land surface }\end{array}$ & $\begin{array}{l}\text { Specific } \\
\text { conduc- } \\
\text { tance } \\
(\mu \mathrm{S} / \mathrm{cm})\end{array}$ & $\begin{array}{l}\text { Chloride, } \\
\text { dissolved } \\
(\mathrm{mg} / \mathrm{L} \\
\text { as } \mathrm{Cl})\end{array}$ & $\begin{array}{l}\text { Nitrogen } \\
\mathrm{NO}_{2}+\mathrm{NO}_{3} \\
\text { total } \\
(\mathrm{mg} / \mathrm{L} \text { as } \mathrm{N})\end{array}$ \\
\hline $39 \mathrm{~N} / 03 \mathrm{E}-23 \mathrm{~A} 01$ & 485142 & 1222240 & $\mathrm{~W}$ & w & $\mathrm{H}$ & SUMS & 10 & 32 & 6 & 165 & USGS & 19900323 & 11.39 & 131 & 5 & $<0.1$ \\
\hline \multirow[t]{14}{*}{$39 \mathrm{~N} / 03 \mathrm{E}-23 \mathrm{D} 01$} & 485138 & 1222339 & $\mathrm{~W}$ & $\mathrm{U}$ & $\mathrm{U}$ & BDRK & 40 & 185 & 6 & 165 & USGS & 19900322 & 19.28 & -- & -- & -- \\
\hline & & & & & & & & & & & USGS & 19901016 & 20.75 & -- & -- & -- \\
\hline & $s$ & & & & & & & & & & USGS & 19901116 & 20.09 & -- & -- & -- \\
\hline & & & & & & & & & & & USGS & 19901218 & 19.07 & -- & -- & -- \\
\hline & & & & & & & & & & & USGS & 19910117 & 19.08 & -- & -- & -- \\
\hline & & & & & & & & & & & USGS & 19910220 & 18.93 & -- & -- & -- \\
\hline & & & & & & & & & & & USGS & 19910313 & 18.85 & -- & -- & -- \\
\hline & & & & & & & & & & & USGS & 19910422 & 18.88 & -- & -- & -- \\
\hline & & & & & & & & & & & USGS & 19910522 & 19.13 & -- & -- & -- \\
\hline & & & & & & & & & & & USGS & 19910626 & 20.71 & -- & -- & -- \\
\hline & & & & & & & & & & & USGS & 19910717 & 19.80 & -- & -- & -- \\
\hline & & & & & & & & & & & USGS & 19910823 & 20.23 & -- & -- & -- \\
\hline & & & & & & & & & & & USGS & 19910926 & 20.25 & -- & -- & - \\
\hline & & & & & & & & & & & USGS & 19911023 & 20.40 & -- & -- & -- \\
\hline $39 \mathrm{~N} / 03 \mathrm{E}-23 \mathrm{E} 01$ & 485131 & 1222333 & $\mathrm{~W}$ & $\mathrm{w}$ & $\mathrm{H}$ & SUMS & 12 & 21 & 12 & 135 & USGS & 19900322 & 1.82 & 130 & 6.6 & 0.2 \\
\hline $39 \mathrm{~N} / 03 \mathrm{E}-23 \mathrm{~J} 01$ & 485109 & 1222238 & $\mathrm{~W}$ & $\mathrm{w}$ & $\mathrm{H}$ & BDRK & 40 & 126 & 6 & 192 & USGS & 19900406 & 65.71 & 2,300 & 990 & $<0.1$ \\
\hline $39 \mathrm{~N} / 03 \mathrm{E}-23 \mathrm{M} 01$ & 485113 & 1222338 & $w$ & w & $\mathrm{H}$ & EVRS & 30 & 100 & 6 & 165 & USGS & 19900406 & 62.99 & 1,040 & 110 & $<0.1$ \\
\hline $39 \mathrm{~N} / 03 \mathrm{E}-24 \mathrm{~B} 01$ & 485136 & 1222136 & W & w & $\mathrm{H}$ & SUMS & 10 & 18 & 36 & 149 & USGS & 19900409 & 9.29 & 75 & 0.80 & 0.2 \\
\hline $39 \mathrm{~N} / 03 \mathrm{E}-24 \mathrm{D} 01$ & 485134 & 1222227 & W & $\mathrm{T}$ & $\mathrm{U}$ & & & 100 & 6 & 169 & Drill & & & & & \\
\hline $39 \mathrm{~N} / 03 \mathrm{E}-25 \mathrm{~A} 01$ & 485046 & 1222113 & $\mathrm{~W}$ & $\mathrm{w}$ & $\mathrm{H}$ & EVRS & 30 & 148 & 6 & 227 & USGS & 19900404 & 47.7 & 1,330 & 240 & $<0.1$ \\
\hline $39 \mathrm{~N} / 03 \mathrm{E}-25 \mathrm{E} 01$ & 485025 & 1222215 & W & w & $\mathrm{H}$ & EVRS & 30 & 131 & 6 & 208 & USGS & 19900320 & 76.09 & 1,210 & 170 & $<0.1$ \\
\hline $39 \mathrm{~N} / 03 \mathrm{E}-26 \mathrm{D} 01$ & 485043 & 1222343 & W & $\mathrm{w}$ & $\mathrm{H}$ & EVRS & 30 & 90 & 6 & 190 & USGS & 19900320 & 68.70 & 324 & 5.6 & $<0.1$ \\
\hline $39 \mathrm{~N} / 03 \mathrm{E}-26 \mathrm{E} 01$ & 485029 & 1222342 & W & $\mathrm{w}$ & $\mathrm{H}$ & EVRS & 30 & 129 & 6 & 230 & USGS & 19900322 & 99.11 & 339 & 5.2 & $<0.1$ \\
\hline $39 \mathrm{~N} / 03 \mathrm{E}-26 \mathrm{~J} 01$ & 485020 & 1222247 & $\mathrm{~W}$ & $\mathrm{w}$ & $\mathrm{H}$ & EVRS & 31 & 182 & 6 & 230 & USGS & 19900320 & 114.7 & 3,690 & 1,100 & $<0.1$ \\
\hline \multirow[t]{13}{*}{$39 \mathrm{~N} / 03 \mathrm{E}-26 \mathrm{P} 02$} & 485005 & 1222311 & w & $\mathrm{w}$ & $P$ & EVRS & 31 & 155 & 6 & 262 & USGS & 19900323 & -- & 655 & 52 & $<0.1$ \\
\hline & & & & & & & & & & & USGS & 19901017 & 135.62 & 676 & 52 & $<0.1$ \\
\hline & & & & & & & & & & & USGS & 19901116 & -- & 643 & 52 & $<0.1$ \\
\hline & & & & & & & & & & & USGS & 19901218 & -- & 650 & 52 & $<0.1$ \\
\hline & & & & & & & & & & & USGS & 19900117 & -- & 658 & 52 & $<0.1$ \\
\hline & & & & & & & & & & & USGS & 19910221 & -- & 663 & -- & -- \\
\hline & & & & & & & & & & & USGS & 19910313 & -- & 663 & -- & $<0.05$ \\
\hline & & & & & & & & & & & USGS & 19910422 & -- & 660 & 52 & $<0.05$ \\
\hline & & & & & & & & & & & USGS & 19910522 & -- & 700 & 52 & $<0.05$ \\
\hline & & & & & & & & & & & USGS & 19910620 & -- & 694 & 52 & $<0.05$ \\
\hline & & & & & & & & & & & USGS & 19910717 & -- & 663 & 52 & $<0.05$ \\
\hline & & & & & & & & & & & USGS & 19910823 & -- & 692 & 52 & $<0.05$ \\
\hline & & & & & & & & & & & USGS & 19910926 & -- & 662 & 52 & $<0.05$ \\
\hline
\end{tabular}




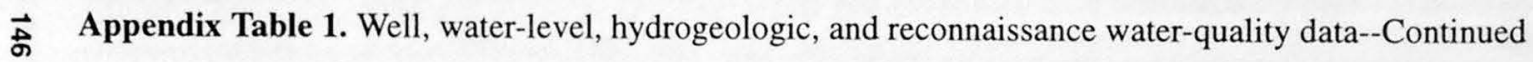

\begin{tabular}{|c|c|c|c|c|c|c|c|c|c|c|c|c|c|c|c|c|}
\hline Local well number & $\begin{array}{l}\text { Lati- } \\
\text { tude }\end{array}$ & $\begin{array}{l}\text { Longi- } \\
\text { tude }\end{array}$ & $\begin{array}{l}\text { Ground } \\
\text { water } \\
\text { site } \\
\text { type }\end{array}$ & $\begin{array}{l}\text { Site } \\
\text { use }\end{array}$ & $\begin{array}{l}\text { Wat- } \\
\text { er } \\
\text { use }\end{array}$ & $\begin{array}{l}\text { Hydro- } \\
\text { geo- } \\
\text { logic } \\
\text { unit }\end{array}$ & $\begin{array}{l}\text { Litho- } \\
\text { logic } \\
\text { unit }\end{array}$ & $\begin{array}{l}\text { Well } \\
\text { depth } \\
\text { (feet) }\end{array}$ & $\begin{array}{l}\text { Well } \\
\text { dia- } \\
\text { meter } \\
\text { (inches) }\end{array}$ & $\begin{array}{l}\text { Alti- } \\
\text { tude } \\
\text { (feet) }\end{array}$ & $\begin{array}{l}\text { Source } \\
\text { of } \\
\text { data }\end{array}$ & $\begin{array}{l}\text { Water- } \\
\text { level or } \\
\text { sample } \\
\text { date }\end{array}$ & $\begin{array}{l}\text { Water } \\
\text { level, } \\
\text { feet below } \\
\text { land surface }\end{array}$ & $\begin{array}{l}\text { Specific } \\
\text { conduc- } \\
\text { tance } \\
(\mu \mathrm{S} / \mathrm{cm})\end{array}$ & $\begin{array}{l}\text { Chloride, } \\
\text { dissolved } \\
(\mathrm{mg} / \mathrm{L} \\
\text { as } \mathrm{Cl})\end{array}$ & $\begin{array}{l}\text { Nitrogen } \\
\mathrm{NO}_{2}+\mathrm{NO}_{3} \\
\text { total } \\
(\mathrm{mg} / \mathrm{L} \text { as } \mathrm{N})\end{array}$ \\
\hline & & & & & & & & & & & USGS & 19911023 & -- & 703 & 52 & $<0.05$ \\
\hline $39 \mathrm{~N} / 03 \mathrm{E}-27 \mathrm{~A} 01$ & 485041 & 1222406 & w & w & $\mathrm{H}$ & EVRS & 30 & 150 & 6 & 195 & USGS & 19900407 & 15.69 & 388 & 4.6 & $<0.1$ \\
\hline \multirow{14}{*}{$39 \mathrm{~N} / 03 \mathrm{E}-27 \mathrm{HO}$} & 485038 & 1222353 & w & U & $\mathrm{U}$ & EVRS & 30 & 62 & & 190 & USGS & 19900407 & 20.15 & -- & -- & -- \\
\hline & & & & & & & & & & & USGS & 19901016 & 21.92 & -- & -- & -- \\
\hline & & & & & & & & & & & USGS & 19901116 & 14.37 & -- & -- & -- \\
\hline & & & & & & & & & & & USGS & 19901218 & 17.13 & -. & - & -- \\
\hline & & & & & & & & & & & USGS & 19910117 & 16.86 & -- & -- & -- \\
\hline & & & & & & & & & & & USGS & 19910220 & 17.76 & -- & -- & -- \\
\hline & & & & & & & & & & & USGS & 19910313 & 16.72 & -- & -- & -- \\
\hline & & & & & & & & & & & USGS & 19910422 & 17.15 & -- & -- & -- \\
\hline & & & & & & & & & & & USGS & 19910522 & 18.40 & - & -- & -- \\
\hline & & & & & & & & & & & USGS & 19910625 & 19.40 & -- & -- & -- \\
\hline & & & & & & & & & & & USGS & 19910717 & 19.96 & -- & -- & -- \\
\hline & & & & & & & & & & & USGS & 19910823 & 20.82 & -- & -- & -- \\
\hline & & & & & & & & & & & USGS & 19910926 & 21.00 & -- & -- & -- \\
\hline & & & & & & & & & & & USGS & 19911023 & 21.14 & -- & -- & -- \\
\hline $39 \mathrm{~N} / 03 \mathrm{E}-27 \mathrm{H} 02$ & 485036 & 1222353 & W & w & $\mathrm{H}$ & EVRS & 30 & 98 & 6 & 218 & USGS & 19900420 & 79.95 & -- & 6 & $<0.1$ \\
\hline $39 \mathrm{~N} / 03 \mathrm{E}-28 \mathrm{~F} 01$ & 485031 & 1222604 & W & $\mathrm{w}$ & $\mathrm{H}$ & EVRS & 30 & 286 & 6 & 225 & USGS & 19900420 & -- & 2,400 & 680 & $<0.1$ \\
\hline $39 \mathrm{~N} / 03 \mathrm{E}-28 \mathrm{~J} 01$ & 485023 & 1222518 & W & W & $\mathrm{H}$ & EVRS & 30 & 85 & 6 & 230 & USGS & 19900420 & 43.70 & 725 & 6.6 & $<0.1$ \\
\hline $39 \mathrm{~N} / 03 \mathrm{E}-28 Q 02$ & 485003 & 1222547 & w & $\mathrm{w}$ & $\mathrm{H}$ & EVRS & 31 & 180 & 6 & 290 & USGS & 19900404 & 158.70 & 262 & 4 & $<0.1$ \\
\hline $39 \mathrm{~N} / 03 \mathrm{E}-28 \mathrm{R} 01$ & 485008 & 1222513 & W & w & $\mathrm{H}$ & EVRS & 31 & 199 & 6 & 270 & USGS & 19900420 & 148.96 & 541 & 9.2 & $<0.1$ \\
\hline $39 \mathrm{~N} / 03 \mathrm{E}-29 \mathrm{~B} 01$ & 485050 & 1222656 & $\mathrm{~W}$ & $\mathrm{~W}$ & & EVRS & 30 & 97 & 6 & 180 & USGS & 19900327 & -- & 389 & 15 & 0.1 \\
\hline $39 \mathrm{~N} / 03 \mathrm{E}-29 \mathrm{CO} 01$ & 485044 & 1222719 & w & w & $\mathrm{H}$ & EVRS & 30 & 105 & 6 & 180 & USGS & 19900327 & 68.32 & 294 & 5.2 & $<0.1$ \\
\hline $39 \mathrm{~N} / 03 \mathrm{E}-29 \mathrm{D} 01$ & 485043 & 1222734 & W & W & $\mathrm{H}$ & EVRS & 30 & 74 & & 160 & USGS & 19900407 & 49.99 & 161 & 5.8 & 0.9 \\
\hline $39 \mathrm{~N} / 03 \mathrm{E}-30 \mathrm{~A} 01$ & 485044 & 1222758 & $\mathrm{~W}$ & $\mathrm{~W}$ & $\mathrm{H}$ & EVRS & 30 & 82 & & 160 & USGS & 19900501 & 49.98 & 260 & 7 & 0.2 \\
\hline $39 \mathrm{~N} / 03 \mathrm{E}-30 \mathrm{~B} 02$ & 485052 & 1222818 & W & $\mathrm{W}$ & $\mathrm{H}$ & EVRS & 30 & 59 & 6 & 161 & USGS & 19900328 & 45.29 & 244 & 6.4 & 2 \\
\hline $39 \mathrm{~N} / 03 \mathrm{E}-30 \mathrm{D} 02$ & 485050 & 1222847 & W & W & $\mathrm{H}$ & EVRS & 30 & 68 & 6 & 150 & USGS & 19900328 & 35.55 & 309 & 5.2 & 1.5 \\
\hline $39 \mathrm{~N} / 03 \mathrm{E}-30 \mathrm{~N} 01$ & 485005 & 1222850 & W & W & $\mathrm{H}$ & EVRS & 30 & 131 & 6 & 190 & USGS & 19900328 & 72.39 & 425 & 8 & $<0.1$ \\
\hline $39 \mathrm{~N} / 03 \mathrm{E}-30 \mathrm{R} 01$ & 485010 & 1222754 & W & w & $\mathrm{H}$ & EVRS & 30 & 217 & 6 & 302 & USGS & 19900327 & -- & 437 & 10 & $<0.1$ \\
\hline $39 \mathrm{~N} / 03 \mathrm{E}-31 \mathrm{~B} 02$ & 484959 & 1222818 & W & $\mathrm{T}$ & $\mathrm{U}$ & & & 1,990 & & 250 & Drill & & & & & \\
\hline $39 N / 03 E-31 Q 02$ & 484909 & 1222814 & $\mathrm{~W}$ & W & $\mathrm{H}$ & EVRS & 30 & 215 & 6 & 282 & USGS & 19900403 & 177.26 & 470 & 12 & $<0.1$ \\
\hline $39 \mathrm{~N} / 03 \mathrm{E}-31 \mathrm{R} 02$ & 484919 & 1222805 & w & w & $\mathrm{H}$ & EVRS & 30 & 214 & 6 & 310 & USGS & 19900407 & 199.69 & 429 & 6.6 & $<0.1$ \\
\hline $39 \mathrm{~N} / 03 \mathrm{E}-31 \mathrm{R} 03$ & 484915 & 1222805 & W & W & $\mathrm{H}$ & EVRS & 30 & 232 & 6 & 305 & USGS & 19900407 & 194.53 & 440 & 9.4 & $<0.1$ \\
\hline $39 \mathrm{~N} / 03 \mathrm{E}-32 \mathrm{AO} 2$ & 484959 & 1222632 & $\mathrm{~W}$ & $\mathrm{~T}$ & $\mathrm{U}$ & & & 1,520 & & 278 & Drill & & & & & \\
\hline $39 \mathrm{~N} / 03 \mathrm{E}-32 \mathrm{E} 01$ & 484947 & 1222735 & w & w & $\mathrm{H}$ & EVRS & 30 & 244 & 6 & 330 & USGS & 19900330 & 220.52 & 480 & 12 & $<0.1$ \\
\hline $39 N / 03 E-32 J 01$ & 484925 & 1222637 & $w$ & W & $\mathrm{H}$ & EVRS & 31 & 218 & 6 & 310 & USGS & 19900420 & 186.14 & 445 & 30 & $<0.1$ \\
\hline $\begin{array}{l}39 \mathrm{~N} / 03 \mathrm{E}-32 \mathrm{MOI} \\
39 \mathrm{~N} / \mathrm{OB}-33 \mathrm{KO1}\end{array}$ & $\begin{array}{l}484922 \\
484923\end{array}$ & $\begin{array}{l}1222731 \\
1222537\end{array}$ & $\begin{array}{l}w \\
w\end{array}$ & $\begin{array}{l}\mathrm{T} \\
\mathrm{W}\end{array}$ & $\begin{array}{l}\mathrm{U} \\
\mathrm{H}\end{array}$ & EVRS & 30 & $\begin{array}{r}1.720 \\
198\end{array}$ & 6 & $\begin{array}{l}290 \\
325\end{array}$ & $\begin{array}{l}\text { Drill } \\
\text { usGs }\end{array}$ & 19900330 & 192.49 & 342 & 5.4 & $<0.1$ \\
\hline
\end{tabular}


Appendix Table 1. Well, water-level, hydrogeologic, and reconnaissance water-quality data--Continued

\begin{tabular}{|c|c|c|c|c|c|c|c|c|c|c|c|c|c|c|c|c|}
\hline Local well number & $\begin{array}{l}\text { Lati- } \\
\text { tude }\end{array}$ & $\begin{array}{l}\text { Longi- } \\
\text { tude }\end{array}$ & $\begin{array}{l}\text { Ground } \\
\text { water } \\
\text { site } \\
\text { type }\end{array}$ & $\begin{array}{l}\text { Site } \\
\text { use }\end{array}$ & $\begin{array}{l}\text { Wat- } \\
\text { er } \\
\text { use }\end{array}$ & $\begin{array}{l}\text { Hydro- } \\
\text { geo- } \\
\text { logic } \\
\text { unit }\end{array}$ & $\begin{array}{l}\text { Litho- } \\
\text { logic } \\
\text { unit }\end{array}$ & $\begin{array}{l}\text { Well } \\
\text { depth } \\
\text { (feet) }\end{array}$ & $\begin{array}{l}\text { Well } \\
\text { dia- } \\
\text { meter } \\
\text { (inches) }\end{array}$ & $\begin{array}{l}\text { Alti- } \\
\text { tude } \\
\text { (feet) }\end{array}$ & $\begin{array}{l}\text { Source } \\
\text { of } \\
\text { data }\end{array}$ & $\begin{array}{l}\text { Water- } \\
\text { level or } \\
\text { sample } \\
\text { date }\end{array}$ & $\begin{array}{l}\text { Water } \\
\text { level, } \\
\text { feet below } \\
\text { land surface }\end{array}$ & $\begin{array}{l}\text { Specific } \\
\text { conduc- } \\
\text { tance } \\
(\mu \mathrm{S} / \mathrm{cm})\end{array}$ & $\begin{array}{l}\text { Chloride, } \\
\text { dissolved } \\
(\mathrm{mg} / \mathrm{L} \\
\text { as } \mathrm{Cl} \text { ) }\end{array}$ & $\begin{array}{l}\text { Nitrogen } \\
\mathrm{NO}_{2}+\mathrm{NO}_{3} \\
\text { total } \\
(\mathrm{mg} / \mathrm{L} \text { as } \mathrm{N})\end{array}$ \\
\hline $39 \mathrm{~N} / 03 \mathrm{E}-33 \mathrm{M} 01$ & 484933 & 1222627 & W & W & $\mathrm{H}$ & EVRS & 30 & 205 & 6 & 318 & USGS & 19900330 & 193.37 & 406 & 4.8 & $<0.1$ \\
\hline $39 \mathrm{~N} / 03 \mathrm{E}-33 \mathrm{R} 01$ & 484911 & 1222528 & $\mathrm{~W}$ & $\mathrm{~W}$ & $\mathrm{H}$ & BDRK & 40 & 270 & 6 & 310 & USGS & 19900403 & 170.8 & 1,660 & 190 & $<0.1$ \\
\hline $39 \mathrm{~N} / 03 \mathrm{E}-34 \mathrm{CO} 1$ & 484957 & 1222439 & W & $\mathrm{T}$ & $\mathrm{U}$ & & & 500 & & 295 & Drill & & , & & & \\
\hline $39 \mathrm{~N} / 03 \mathrm{E}-34 \mathrm{NO} 1$ & 484909 & 1222504 & W & W & $\mathrm{H}$ & SUMS & 10 & 20 & 12 & 303 & USGS & 19900330 & 4.66 & 262 & 3.0 & -- \\
\hline $39 \mathrm{~N} / 03 \mathrm{E}-34 \mathrm{PO} 2$ & 484911 & 1222447 & W & W & $\mathrm{H}$ & EVRS & 31 & 198 & 6 & 310 & USGS & 19900403 & 173.93 & 277 & 3.8 & $<0.1$ \\
\hline $39 \mathrm{~N} / 03 \mathrm{E}-34 \mathrm{Q} 01$ & 484913 & 1222418 & W & W & $\mathrm{H}$ & EVRS & 31 & 206 & 6 & 304 & USGS & 19900403 & 173.79 & 222 & 7.8 & $<0.1$ \\
\hline $39 \mathrm{~N} / 03 \mathrm{E}-35 \mathrm{~L} 01$ & 484931 & 1222328 & W & W & $\mathrm{H}$ & EVRS & 30 & 100 & 6 & 232 & USGS & 19900407 & 84.88 & 571 & 48 & $<0.1$ \\
\hline $39 \mathrm{~N} / 03 \mathrm{E}-35 \mathrm{R} 01$ & 484908 & 1222249 & W & W & $\mathrm{H}$ & EVRS & 30 & 60 & 6 & 260 & USGS & 19900403 & -- & 354 & 8 & $<0.1$ \\
\hline \multirow[t]{13}{*}{$39 \mathrm{~N} / 03 \mathrm{E}-36 \mathrm{~B} 01$} & 484958 & 1222138 & W & $\mathrm{U}$ & $\mathrm{H}$ & EVRS & 30 & 166 & 8 & 305 & USGS & 19900323 & 141.82 & -- & -- & -- \\
\hline & & & & & & & & & & & USGS & 19901015 & 141.90 & -- & -- & -- \\
\hline & & & & & & & & & & & USGS & 19901116 & 142.06 & -- & -- & -- \\
\hline & & & & & & & & & & & USGS & 19901218 & 141.37 & -- & -- & -- \\
\hline & & & & & & & & & & & USGS & 19910117 & 141.98 & -- & -- & -- \\
\hline & & & & & & & & & & & USGS & 19910220 & 141.67 & -- & -- & -- \\
\hline & & & & & & & & & & & USGS & 19910313 & 141.44 & -- & -- & -- \\
\hline & & & & & & & & & & & USGS & 19910422 & 141.38 & -- & -- & -- \\
\hline & & & & & & & & & & & USGS & 19910522 & 142.42 & -- & -- & -- \\
\hline & & & & & & & & & & & USGS & 19910717 & 141.52 & -- & -- & -- \\
\hline & & & & & & & & & & & USGS & 19910823 & 141.60 & -- & -- & -- \\
\hline & & & $f$ & & & & & & & & USGS & 19910926 & 141.53 & -- & -- & -- \\
\hline & & & & & & & & & & & USGS & 19911023 & 141.53 & -- & -- & -- \\
\hline \multirow[t]{14}{*}{$39 \mathrm{~N} / 03 \mathrm{E}-36 \mathrm{~B} 03$} & 484956 & 1222138 & w & U & U & EVRS & 30 & 31 & & 315 & USGS & 19900323 & 12.97 & -- & -- & -- \\
\hline & & & & & & & & & & & USGS & 19901015 & 21.63 & -- & -- & -- \\
\hline & & & & & & & & & & & USGS & 19901116 & 15.48 & -- & -- & -- \\
\hline & & & & & & & & & & & USGS & 19901218 & 8.78 & -- & -- & -- \\
\hline & & & & & & & & & & & USGS & 19910117 & 8.54 & -- & -- & -- \\
\hline & & & & & & & & & & & USGS & 19910220 & 8.71 & -- & -- & -- \\
\hline & & & & & & & & & & & USGS & 19910313 & 9.91 & -- & -- & -- \\
\hline & & & & & & & & & & & USGS & 19910422 & 13.02 & -- & -- & -- \\
\hline & & & & & & & & & & & USGS & 19910522 & 17.15 & -- & -- & -- \\
\hline & & & & & & & & & & & USGS & 19910626 & 18.74 & -- & -- & -- \\
\hline & & & & & & & & & & & USGS & 19910717 & 19.66 & -- & -- & -- \\
\hline & & & & & & & & & & & USGS & 19910823 & 20.76 & -- & -- & -- \\
\hline & & & & & & & & & & & USGS & 19910926 & 21.19 & -- & -- & -- \\
\hline & & & & & & & & & & & USGS & 19911023 & 21.80 & -- & -- & -- \\
\hline $39 \mathrm{~N} / 03 \mathrm{E}-36 \mathrm{~L} 01$ & 484922 & 1222154 & W & W & $\mathrm{H}$ & EVRS & 30 & 223 & 6 & 275 & USGS & 19900404 & 32.89 & 1,250 & 180 & $<0.1$ \\
\hline $39 \mathrm{~N} / 03 \mathrm{E}-36 \mathrm{P} 01$ & 484908 & 1222213 & w & w & $\mathrm{H}$ & EVRS & 30 & 73 & 6 & 260 & USGS & 19900404 & 31.26 & 329 & 11 & $<0.1$ \\
\hline $39 \mathrm{~N} / 03 \mathrm{E}-36 \mathrm{PO} 2$ & 48490 & 1222158 & w & w & $\mathrm{H}$ & EVRS & 30 & 107 & 6 & 260 & USGS & 19900404 & -- & 279 & 6.8 & $<0.1$ \\
\hline
\end{tabular}


$\vec{\Phi} \quad$ Appendix Table 1. Well, water-level, hydrogeologic, and reconnaissance water-quality data--Continued

\begin{tabular}{|c|c|c|c|c|c|c|c|c|c|c|c|c|c|c|c|c|}
\hline Local well number & $\begin{array}{l}\text { Lati- } \\
\text { tude }\end{array}$ & $\begin{array}{l}\text { Longi- } \\
\text { tude }\end{array}$ & $\begin{array}{l}\text { Ground } \\
\text { water } \\
\text { site } \\
\text { type }\end{array}$ & Site & $\begin{array}{l}\text { Wat- } \\
\text { er } \\
\text { use }\end{array}$ & $\begin{array}{l}\text { Hydro- } \\
\text { geo- } \\
\text { logic } \\
\text { unit }\end{array}$ & $\begin{array}{l}\text { Litho- } \\
\text { logic } \\
\text { unit }\end{array}$ & $\begin{array}{l}\text { Well } \\
\text { depth } \\
\text { (feet) }\end{array}$ & $\begin{array}{l}\text { Well } \\
\text { dia- } \\
\text { meter } \\
\text { (inches) }\end{array}$ & $\begin{array}{l}\text { Alti- } \\
\text { tude } \\
\text { (feet) }\end{array}$ & $\begin{array}{l}\text { Source } \\
\text { of } \\
\text { data }\end{array}$ & $\begin{array}{l}\text { Water- } \\
\text { level or } \\
\text { sample } \\
\text { date }\end{array}$ & $\begin{array}{l}\text { Water } \\
\text { level, } \\
\text { feet below } \\
\text { land surface }\end{array}$ & $\begin{array}{l}\text { Specific } \\
\text { conduc- } \\
\text { tance } \\
(\mu \mathrm{S} / \mathrm{cm})\end{array}$ & $\begin{array}{l}\text { Chloride, } \\
\text { dissolved } \\
(\mathrm{mg} / \mathrm{L} \\
\text { as } \mathrm{Cl})\end{array}$ & $\begin{array}{l}\text { Nitrogen } \\
\mathrm{NO}_{2}+\mathrm{NO}_{3} \\
\text { total } \\
\text { ( } \mathrm{mg} / \mathrm{L} \text { as } \mathrm{N} \text { ) }\end{array}$ \\
\hline $39 \mathrm{~N} / 04 \mathrm{E}-03 \mathrm{C} 01$ & 485410 & 1221642 & W & W & $\mathrm{H}$ & VSHN & 50 & 37 & 6 & 150 & USGS & 19900522 & 16.73 & 1,250 & 310 & $<0.1$ \\
\hline \multirow[t]{11}{*}{$39 \mathrm{~N} / 04 \mathrm{E}-03 \mathrm{P} 01$} & 485336 & 1221634 & W & W & $\mathrm{H}$ & VSHN & 50 & 117 & 6 & 370 & USGS & 19900522 & 45.41 & 2,050 & 640 & $<0.1$ \\
\hline & & & & & & & & & & & USGS & 19900831 & 55.25 & 2,290 & 690 & $<0.1$ \\
\hline & & & & & & & & & & & USGS & 19901016 & -- & 2,160 & 690 & $<0.1$ \\
\hline & & & & & & & & & & & USGS & 19901115 & -- & 2,360 & 731 & $<0.1$ \\
\hline & & & & & & & & & & & USGS & 19910117 & -- & -- & 750 & $<0.1$ \\
\hline & & & & & & & & & & & USGS & 19910219 & -- & -- & 743 & $<0.1$ \\
\hline & & & & & & & & & & & USGS & 19910424 & -- & 2,510 & 815 & $<0.1$ \\
\hline & & & & & & & & & & & USGS & 19910522 & -- & -- & 793 & $<0.1$ \\
\hline & & & & & & & & & & & USGS & 19910717 & - & -- & 779 & $<0.1$ \\
\hline & & & & & & & & & & & USGS & 19910925 & -- & 2,610 & 820 & $<0.1$ \\
\hline & & & & & & & & & & & USGS & 19911023 & -- & 2,680 & 840 & \\
\hline \multirow[t]{13}{*}{$39 \mathrm{~N} / 04 \mathrm{E}-03 \mathrm{P} 02$} & 485337 & 1221634 & $\mathrm{~W}$ & $\mathrm{U}$ & $\mathrm{U}$ & VSHN & 40 & 260 & 6 & 370 & USGS & 19900831 & 53.40 & -- & -- & -- \\
\hline & & & & & & & & & & & USGS & 19901016 & 53.77 & -- & -- & -- \\
\hline & & & & & & & & & & & USGS & 19901115 & 53.68 & -- & -- & -- \\
\hline & & & & & & & & & & & USGS & 19910117 & 55.13 & -- & -- & -- \\
\hline & & & & & & & & & & & USGS & 19910219 & 54.14 & -- & -- & -- \\
\hline & & & & & & & & & & & USGS & 19910315 & 54.01 & -- & -- & -- \\
\hline & & & & & & & & & & & USGS & 19910423 & 53.46 & -- & -- & -- \\
\hline & & & & & & & & & & & USGS & 19910522 & 53.20 & -- & -- & -- \\
\hline & - & & & & & & & & & & USGS & 19910625 & 53.57 & -- & -- & -- \\
\hline & & & & & & & & & & & USGS & 19910717 & 54.72 & -- & -- & -- \\
\hline & & & & & & & & & & & USGS & 19910822 & 56.50 & -- & -- & -- \\
\hline & & & & & & & & & & & USGS & 19910925 & 58.50 & -- & -- & -- \\
\hline & & & & & & & & & & & USGS & 19911023 & 57.74 & -- & -- & -- \\
\hline $39 \mathrm{~N} / 04 \mathrm{E}-04 \mathrm{H} 01$ & 485355 & 1221719 & $\mathrm{~W}$ & W & $\mathrm{H}$ & SUMS & 12 & 41 & 6 & 135 & USGS & 19900522 & 32.10 & 290 & 12 & 1.1 \\
\hline $39 \mathrm{~N} / 04 \mathrm{E}-04 \mathrm{Q} 01$ & 485329 & 1221749 & W & W & $\mathrm{H}$ & SUMS & 12 & 74 & 6 & 140 & USGS & 19900523 & 29.10 & 233 & 8.6 & 4.5 \\
\hline $39 \mathrm{~N} / 04 \mathrm{E}-04 \mathrm{Q02}$ & 485332 & 1221748 & $\mathrm{~W}$ & W & I & SUMS & 12 & 58 & 8 & 138 & USGS & 19900523 & 29.21 & -- & -- & -- \\
\hline $39 \mathrm{~N} / 04 \mathrm{E}-06 \mathrm{D} 01$ & 485411 & 1222051 & $\mathrm{x}$ & $\mathrm{T}$ & & & & 188 & & 100 & Drill & & & & & \\
\hline $39 \mathrm{~N} / 04 \mathrm{E}-06 \mathrm{E} 01$ & 485404 & 1222104 & $\mathrm{~W}$ & W & $\mathrm{H}$ & SUMS & 12 & 63 & 8 & 105 & USGS & 19900423 & 20.27 & 161 & 7.4 & 1.5 \\
\hline $39 \mathrm{~N} / 04 \mathrm{E}-06 \mathrm{E} 02$ & 485407 & 1222050 & W & W & I & SUMS & 12 & 67 & 8 & 107 & USGS & & -- & -- & -- & -- \\
\hline $39 \mathrm{~N} / 04 \mathrm{E}-08 \mathrm{CO} 2$ & 485324 & 1221925 & W & W & I & SUMS & 15 & 46 & 8 & 107 & USGS & 19900522 & 9.91 & 305 & 14 & 2.8 \\
\hline $39 \mathrm{~N} / 04 \mathrm{E}-10 \mathrm{D} 01$ & 485316 & 1221654 & W & w & $\mathrm{H}$ & VSHN & 50 & 51 & & 260 & USGS & 19900522 & 10.83 & 438 & 61 & $<0.1$ \\
\hline $39 \mathrm{~N} / 04 \mathrm{E}-10 \mathrm{M} 01$ & 485251 & 1221658 & W & $\mathrm{w}$ & $\mathrm{H}$ & VSHN & 50 & 44 & 6 & 260 & USGS & 19900522 & 8.04 & $>2,060$ & 620 & $<0.1$ \\
\hline $39 \mathrm{~N} / 04 \mathrm{E}-16 \mathrm{~B} 01$ & 485231 & 1221740 & W & W & $\mathrm{s}$ & VSHN & 50 & 57 & 6 & 145 & USGS & 19900524 & 35.10 & -- & -- & -- \\
\hline $39 \mathrm{~N} / 04 \mathrm{E}-16 \mathrm{~B} 02$ & 485229 & 1221743 & W & w & $\mathrm{s}$ & SUMS & 10 & 77 & 6 & 130 & USGS & 19900524 & 35.38 & -- & -- & -- \\
\hline $39 \mathrm{~N} / 04 \mathrm{E}-16 \mathrm{DO} 01$ & 485223 & 1221818 & w & w & I & SUMS & 15 & 26 & 36 & 125 & USGS & 19900524 & 23.98 & -- & -- & -- \\
\hline $39 \mathrm{~N} / 04 \mathrm{E}-16 \mathrm{~F} 01$ & 485212 & 1221805 & $w$ & w & $\mathrm{H}$ & sums & 15 & 22 & 36 & 130 & USGS & 19900524 & 24.93 & 143 & 3.4 & 1.6 \\
\hline
\end{tabular}


Appendix Table 1. Well, water-level, hydrogeologic, and reconnaissance water-quality data--Continued

\begin{tabular}{|c|c|c|c|c|c|c|c|c|c|c|c|c|c|c|c|c|}
\hline Local well number & $\begin{array}{l}\text { Lati- } \\
\text { tude }\end{array}$ & $\begin{array}{l}\text { Longi- } \\
\text { tude }\end{array}$ & $\begin{array}{l}\text { Groun } \\
\text { water } \\
\text { site } \\
\text { type }\end{array}$ & $\begin{array}{l}\text { Site } \\
\text { use }\end{array}$ & $\begin{array}{l}\text { Wat- } \\
\text { er } \\
\text { use }\end{array}$ & $\begin{array}{l}\text { Hydro- } \\
\text { geo- } \\
\text { logic } \\
\text { unit }\end{array}$ & $\begin{array}{l}\text { Litho- } \\
\text { logic } \\
\text { unit }\end{array}$ & $\begin{array}{l}\text { Well } \\
\text { depth } \\
\text { (feet) }\end{array}$ & $\begin{array}{l}\text { Well } \\
\text { dia- } \\
\text { meter } \\
\text { (inches) }\end{array}$ & $\begin{array}{l}\text { Alti- } \\
\text { tude } \\
\text { (feet) }\end{array}$ & $\begin{array}{l}\text { Source } \\
\text { of } \\
\text { data }\end{array}$ & $\begin{array}{l}\text { Water- } \\
\text { level or } \\
\text { sample } \\
\text { date }\end{array}$ & $\begin{array}{l}\text { Water } \\
\text { level, } \\
\text { feet below } \\
\text { land surface }\end{array}$ & $\begin{array}{l}\text { Specific } \\
\text { conduc- } \\
\text { tance } \\
(\mu \mathrm{S} / \mathrm{cm})\end{array}$ & $\begin{array}{l}\text { Chloride, } \\
\text { dissolved } \\
\text { (mg/L } \\
\text { as } \mathrm{Cl} \text { ) }\end{array}$ & $\begin{array}{l}\text { Nitrogen } \\
\mathrm{NO}_{2}+\mathrm{NO}_{3} \\
\text { total } \\
(\mathrm{mg} / \mathrm{L} \text { as } \mathrm{N} \text { ) }\end{array}$ \\
\hline $39 \mathrm{~N} / 04 \mathrm{E}-16 \mathrm{H} 01$ & 485217 & 1221731 & W & W & $\mathrm{H}$ & VSHN & 50 & 48 & 6 & 130 & USGS & 19900525 & 33.39 & 298 & 13 & 6.2 \\
\hline $39 \mathrm{~N} / 04 \mathrm{E}-16 \mathrm{LO} 2$ & 485209 & 1221811 & W & W & $\mathrm{H}$ & SUMS & 15 & 29 & 4 & 130 & USGS & 19900524 & -- & 181 & 4.8 & 3.6 \\
\hline $39 \mathrm{~N} / 04 \mathrm{E}-16 \mathrm{QO} 2$ & 485154 & 1221736 & W & W & $\mathrm{H}$ & SUMS & 15 & 33 & 6 & 130 & USGS & 19900523 & 20.98 & 167 & 5.6 & 2.7 \\
\hline $39 \mathrm{~N} / 04 \mathrm{E}-17 \mathrm{C} 01$ & 485224 & 1221918 & W & $\mathrm{W}$ & $\mathrm{H}$ & SUMS & 15 & 53 & 6 & 120 & USGS & 19900523 & 10.72 & 133 & 3 & 0.2 \\
\hline $39 \mathrm{~N} / 04 \mathrm{E}-18 \mathrm{E} 01$ & 485209 & 1222104 & W & $\mathrm{U}$ & $\mathrm{U}$ & BDRK & 40 & 121 & 6 & 210 & USGS & 19900424 & -- & -- & -- & -- \\
\hline $39 \mathrm{~N} / 04 \mathrm{E}-18 \mathrm{MO} 1$ & 485202 & 1222107 & W & W & $\mathrm{H}$ & BDRK & 40 & 154 & 6 & 190 & USGS & 19900424 & & 461 & 41 & $<0.1$ \\
\hline $39 \mathrm{~N} / 04 \mathrm{E}-18 \mathrm{R} 01$ & 485144 & 1221956 & W & w & $\mathrm{H}$ & EVRS & 30 & 28 & & 125 & USGS & 19900425 & 10.0 & 274 & 24 & $<0.1$ \\
\hline $39 \mathrm{~N} / 04 \mathrm{E}-19 \mathrm{C} 01$ & 485141 & 1222036 & W & W & $\mathrm{H}$ & BDRK & 40 & 167 & 6 & 230 & USGS & 19900424 & 56.42 & 974 & 120 & $<0.1$ \\
\hline $39 \mathrm{~N} / 04 \mathrm{E}-19 \mathrm{E} 01$ & 485119 & 1222105 & W & $\mathrm{z}$ & $\mathrm{U}$ & & & 242 & 6 & 215 & USGS & 19900424 & -- & -- & -- & -- \\
\hline $39 \mathrm{~N} / 04 \mathrm{E}-19 \mathrm{E} 02$ & 485122 & 1222049 & W & W & $\mathrm{H}$ & BDRK & 40 & 110 & 6 & 200 & USGS & 19900424 & 1.54 & 88 & 1.4 & 0.5 \\
\hline $39 \mathrm{~N} / 04 \mathrm{E}-19 \mathrm{~F} 02$ & 485122 & 1222042 & w & $\mathrm{w}$ & $\mathrm{H}$ & BDRK & 40 & 170 & 6 & 190 & USGS & 19900424 & 7.06 & 751 & 20 & $<0.1$ \\
\hline $39 \mathrm{~N} / 04 \mathrm{E}-19 \mathrm{MO} 1$ & 485110 & 1222106 & $\mathrm{~W}$ & w & $\mathrm{H}$ & BDRK & 40 & 200 & 6 & 220 & USGS & 19900424 & 69.32 & 886 & 18 & $<0.1$ \\
\hline $39 \mathrm{~N} / 04 \mathrm{E}-20 \mathrm{H} 01$ & 485118 & 1221840 & W & W & $\mathrm{H}$ & SUMS & 15 & 41 & 6 & 130 & USGS & 19900426 & 14.19 & 109 & 3 & 0.4 \\
\hline $39 \mathrm{~N} / 04 \mathrm{E}-20 \mathrm{~L} 01$ & 485104 & 1221925 & W & W & $\mathrm{H}$ & SUMS & 10 & 37 & 6 & 150 & USGS & 19900424 & 21.06 & 181 & 3.6 & $<0.1$ \\
\hline $39 \mathrm{~N} / 04 \mathrm{E}-20 \mathrm{MO} 2$ & 485105 & 1221940 & w & w & $\mathrm{H}$ & SUMS & 10 & 33 & 6 & 155 & USGS & 19900424 & 21.33 & 293 & 18 & $<0.1$ \\
\hline $39 \mathrm{~N} / \mathrm{O} 4 \mathrm{E}-20 \mathrm{MO} 3$ & 485105 & 1221946 & W & $\mathrm{U}$ & $\mathrm{U}$ & SUMS & 10 & 26 & 6 & 155 & USGS & 19900424 & 9.73 & -- & -- & -- \\
\hline $39 \mathrm{~N} / 04 \mathrm{E}-22 \mathrm{~F} 01$ & 485125 & 1221642 & W & W & $\mathrm{H}$ & VSHN & 50 & 71 & 6 & 180 & USGS & 19900524 & 30.51 & 1,530 & 410 & $<0.1$ \\
\hline $39 \mathrm{~N} / 04 \mathrm{E}-22 \mathrm{~L} 01$ & 485117 & 1221654 & W & $\mathrm{w}$ & $\mathrm{H}$ & SUMS & 15 & 30 & 6 & 155 & USGS & 19900523 & 13.50 & 722 & 50 & 15 \\
\hline $39 \mathrm{~N} / 04 \mathrm{E}-22 \mathrm{~N} 01$ & 485103 & 1221702 & W & $\mathrm{w}$ & $\mathrm{H}$ & SUMS & 15 & 39 & 6 & 150 & USGS & 19900524 & 12.51 & 342 & 19 & 2.4 \\
\hline $39 \mathrm{~N} / 04 \mathrm{E}-28 \mathrm{~F} 01$ & 485032 & 1221758 & w & w & $\mathrm{H}$ & SUMS & & 52 & 6 & 160 & USGS & 19900425 & 23.6 & 119 & 4.4 & 0.9 \\
\hline $39 \mathrm{~N} / 04 \mathrm{E}-28 \mathrm{KO} 2$ & 485018 & 1221734 & W & w & $\mathrm{H}$ & & & 54 & 6 & 170 & USGS & 19900525 & 27.25 & & & \\
\hline $39 \mathrm{~N} / 04 \mathrm{E}-29 \mathrm{~A} 01$ & 485040 & 1221839 & $\mathrm{~W}$ & $\mathrm{U}$ & $\mathrm{U}$ & BDRK & 40 & 275 & & 200 & USGS & 19900508 & -- & -- & -- & -- \\
\hline $39 \mathrm{~N} / 04 \mathrm{E}-29 \mathrm{~B} 01$ & 485038 & 1221908 & W & W & $\mathrm{H}$ & EVRS & 10 & 79 & 6 & 203 & USGS & 19900426 & 69.09 & 263 & 8.2 & 0.3 \\
\hline $39 \mathrm{~N} / 04 \mathrm{E}-29 \mathrm{H} 01$ & 485028 & 1221844 & $\mathrm{~W}$ & w & $\mathrm{H}$ & SUMS & 12 & 20 & 5 & 205 & USGS & 19900425 & 3.42 & 621 & 25 & $<0.1$ \\
\hline $39 \mathrm{~N} / 04 \mathrm{E}-29 \mathrm{HO} 2$ & 485034 & 1221839 & $\mathrm{~W}$ & w & $\mathrm{H}$ & EVRS & 30 & 73 & 6 & 200 & USGS & 19900425 & 66.68 & 213 & 4.2 & 0.3 \\
\hline $39 \mathrm{~N} / 04 \mathrm{E}-29 \mathrm{MO} 1$ & 485021 & 1221938 & $\mathrm{~W}$ & W & I & EVRS & 30 & 30 & 36 & 200 & USGS & 19900426 & 2.63 & -- & -- & -- \\
\hline $39 \mathrm{~N} / 04 \mathrm{E}-29 \mathrm{~N} 01$ & 485009 & 1221937 & w & $\mathrm{U}$ & $\mathrm{U}$ & BDRK & 40 & 610 & 6 & 210 & USGS & 19900426 & 5.88 & -- & -- & -- \\
\hline $39 \mathrm{~N} / 04 \mathrm{E}-30 \mathrm{D} 01$ & 485044 & 1222049 & $\mathrm{~W}$ & $\mathrm{w}$ & $\mathrm{H}$ & EVRS & 30 & 99 & 6 & 185 & USGS & 19900426 & 28.01 & 1,110 & 180 & $<0.1$ \\
\hline $39 \mathrm{~N} / 04 \mathrm{E}-30 \mathrm{~F} 01$ & 485025 & 1222047 & w & $\mathrm{T}$ & $\mathrm{U}$ & & & 70 & & 225 & Drill & 19900426 & -- & -- & -- & -- \\
\hline $39 \mathrm{~N} / 04 \mathrm{E}-30 \mathrm{MO} 1$ & 485023 & 1222107 & W & W & $\mathrm{H}$ & EVRS & & 65 & & 235 & USGS & 19900323 & 48.79 & & & \\
\hline $39 \mathrm{~N} / 04 \mathrm{E}-31 \mathrm{~B} 01$ & 484948 & 1222029 & W & w & $\mathrm{H}$ & EVRS & 30 & 225 & 6 & 220 & USGS & 19900425 & Flow & 1,150 & 260 & $<0.1$ \\
\hline $39 \mathrm{~N} / 04 \mathrm{E}-31 \mathrm{D} 01$ & 484951 & 1222111 & $\mathrm{x}$ & $\mathrm{T}$ & $\mathrm{U}$ & & & 311 & & 250 & Drill & 19900426 & -- & -- & -- & -- \\
\hline $39 \mathrm{~N} / 04 \mathrm{E}-31002$ & 484907 & 1222014 & W & w & $\mathrm{H}$ & EVRS & 30 & 92 & 6 & 265 & USGS & 19900427 & Flow & 606 & 16 & $<0.1$ \\
\hline $39 \mathrm{~N} / 04 \mathrm{E}-32 \mathrm{~A} 01$ & 484954 & 1221838 & W & w & $\mathrm{H}$ & EVRS & 30 & 71 & 6 & 270 & USGS & 19900425 & 23.81 & 1,030 & 77 & 0.2 \\
\hline $39 \mathrm{~N} / 04 \mathrm{E}-32 \mathrm{D} 01$ & 484957 & 1221950 & $\mathrm{x}$ & $\mathrm{T}$ & U & & & 230 & 6 & 215 & Drill & Flow & -- & -- & -- & -- \\
\hline $39 \mathrm{~N} / 04 \mathrm{E}-32 \mathrm{E} 01$ & 484939 & 1221948 & $\mathrm{w}$ & w & $\mathrm{H}$ & EVRS & 30 & 139 & 6 & 230 & USGS & 19900425 & Flow & 1,030 & 210 & $<0.1$ \\
\hline $39 \mathrm{~N} / 04 \mathrm{E}-32 \mathrm{~F} 01$ & 484932 & 1221921 & W & W & $\mathrm{H}$ & BDRK & 40 & 231 & 6 & 290 & USGS & 19900920 & -- & -- & -- & -- \\
\hline $39 \mathrm{~N} / 04 \mathrm{E}-32 \mathrm{M} 01$ & 484932 & 1221939 & $\mathrm{~W}$ & W & $\mathrm{H}$ & EVRS & 30 & 101 & 6 & 265 & USGS & 19900920 & Flow & -- & -- & -- \\
\hline
\end{tabular}


जे Appendix Table 1. Well, water-level, hydrogeologic, and reconnaissance water-quality data--Continued

\begin{tabular}{|c|c|c|c|c|c|c|c|c|c|c|c|c|c|c|c|c|}
\hline Local well number & $\begin{array}{l}\text { Lati- } \\
\text { tude }\end{array}$ & $\begin{array}{l}\text { Longi- } \\
\text { tude }\end{array}$ & $\begin{array}{l}\text { Ground } \\
\text { water } \\
\text { site } \\
\text { type }\end{array}$ & $\begin{array}{l}\text { Site } \\
\text { use }\end{array}$ & $\begin{array}{l}\text { Wat- } \\
\text { er } \\
\text { use }\end{array}$ & $\begin{array}{l}\text { Hydro- } \\
\text { geo- } \\
\text { logic } \\
\text { unit }\end{array}$ & $\begin{array}{l}\text { Litho- } \\
\text { logic } \\
\text { unit }\end{array}$ & $\begin{array}{l}\text { Well } \\
\text { depth } \\
\text { (feet) }\end{array}$ & $\begin{array}{l}\text { Well } \\
\text { dia- } \\
\text { meter } \\
\text { (inches) }\end{array}$ & $\begin{array}{l}\text { Alti- } \\
\text { tude } \\
\text { (feet) }\end{array}$ & $\begin{array}{l}\text { Source } \\
\text { of } \\
\text { data }\end{array}$ & $\begin{array}{l}\text { Water- } \\
\text { level or } \\
\text { sample } \\
\text { date }\end{array}$ & $\begin{array}{l}\text { Water } \\
\text { level, } \\
\text { feet below } \\
\text { land surface }\end{array}$ & $\begin{array}{l}\text { Specific } \\
\text { conduc- } \\
\text { tance } \\
(\mu \mathrm{S} / \mathrm{cm})\end{array}$ & $\begin{array}{l}\text { Chloride, } \\
\text { dissolved } \\
(\mathrm{mg} / \mathrm{L} \\
\text { as } \mathrm{Cl})\end{array}$ & $\begin{array}{l}\text { Nitrogen } \\
\mathrm{NO}_{2}+\mathrm{NO}_{3} \\
\text { total } \\
\text { (mg/L as } \mathrm{N} \text { ) }\end{array}$ \\
\hline $39 \mathrm{~N} / 04 \mathrm{E}-32 \mathrm{~N} 01$ & 484916 & 1221947 & W & $\mathrm{W}$ & $\mathrm{H}$ & EVRS & 30 & 107 & 6 & 280 & USGS & 19900426 & 3.83 & 887 & 56 & $<0.1$ \\
\hline $39 \mathrm{~N} / 04 \mathrm{E}-33 \mathrm{E} 01$ & 484943 & 1221829 & W & W & $\mathrm{H}$ & EVRS & 30 & 123 & 6 & 340 & USGS & 19900426 & -- & 927 & 70 & $<0.1$ \\
\hline $39 \mathrm{~N} / 04 \mathrm{E}-34 \mathrm{CO} 2$ & 484952 & 1221649 & W & $\mathrm{w}$ & $\mathrm{H}$ & EVRS & 31 & 146 & 6 & 300 & USGS & 19900425 & 142.88 & 418 & 7.6 & $<0.1$ \\
\hline $40 \mathrm{~N} / 02 \mathrm{E}-01 \mathrm{C} 01$ & 485931 & 1222959 & W & $\mathrm{U}$ & $\mathrm{U}$ & SUMS & 10 & 40 & 36 & 125 & USGS & 19900814 & 4.56 & -- & -- & -- \\
\hline $40 \mathrm{~N} / 02 \mathrm{E}-01 \mathrm{~F} 02$ & 485917 & 1222958 & W & W & I & SUMS & 10 & 28 & 36 & 121 & USGS & 19900814 & 4.3 & -- & -- & -- \\
\hline $40 \mathrm{~N} / 02 \mathrm{E}-01 \mathrm{~N} 01$ & 485851 & 1223002 & W & W & I & SUMS & 10 & 21 & 36 & 115 & USGS & 19900816 & 5.77 & -- & -- & -- \\
\hline \multirow[t]{11}{*}{$40 \mathrm{~N} / 02 \mathrm{E}-02 \mathrm{~B} 01$} & 485934 & 1223059 & W & $\mathrm{W}$ & $\mathrm{P}$ & EVRS & 31 & 149 & 8 & 180 & USGS & 19901218 & 48.8 & -- & -- & -- \\
\hline & & & & & & & & & & & USGS & 19910118 & 49.16 & -- & -- & -- \\
\hline & & & & & & & & & & & USGS & 19910220 & 48.82 & -- & -- & -- \\
\hline & & & & & & & & & & & USGS & 19910314 & 49.02 & -- & -- & -- \\
\hline & & & & & & & & & & & USGS & 19910423 & 49.20 & -- & -- & -- \\
\hline & & & & & & & & & & & USGS & 19910606 & 49.76 & -- & -- & -- \\
\hline & & & & & & & & & & & USGS & 19910625 & 50.02 & -- & -- & -- \\
\hline & & & & & & & & & & & USGS & 19910717 & 50.53 & -- & -- & -- \\
\hline & & & & & & & & & & & USGS & 19910822 & 51.01 & -- & -- & -- \\
\hline & & & & & & & & & & & USGS & 19910925 & 50.74 & -- & -- & -- \\
\hline & & & & & & & & & & & USGS & 19911023 & 50.85 & -- & -- & -- \\
\hline $40 \mathrm{~N} / 02 \mathrm{E}-02 \mathrm{D} 01$ & 485935 & 1223127 & W & W & $\mathrm{H}$ & EVRS & 31 & 138 & & 220 & USGS & 19900810 & 70.44 & 187 & 2.4 & $<0.1$ \\
\hline $40 \mathrm{~N} / 02 \mathrm{E}-02 \mathrm{D} 02$ & 485931 & 1223132 & W & $\mathrm{U}$ & $\mathrm{U}$ & & & 8 & & 220 & USGS & 19900815 & 6.19 & -- & -- & -- \\
\hline $40 \mathrm{~N} / 02 \mathrm{E}-02 \mathrm{D} 03$ & 485931 & 1223132 & $\mathrm{x}$ & $\mathrm{z}$ & $\mathrm{U}$ & & & 155 & & 220 & USGS & 19900815 & -- & -- & -- & -- \\
\hline $40 \mathrm{~N} / 02 \mathrm{E}-02 \mathrm{Q} 01$ & 485854 & 1223048 & w & W & I & SUMS & 10 & 23 & 36 & 114 & USGS & 19900815 & 8.19 & 310 & 12 & 0.8 \\
\hline $40 \mathrm{~N} / 02 \mathrm{E}-02 \mathrm{Q} 02$ & 485854 & 1223100 & W & W & I & SUMS & 10 & 23 & 36 & 115 & USGS & 19900830 & 8.67 & -- & -- & -- \\
\hline \multirow[t]{10}{*}{$40 \mathrm{~N} / 02 \mathrm{E}-03 \mathrm{CO} 01$} & 485936 & 1223229 & W & W & $\mathrm{H}$ & EVRS & 30 & 100 & 6 & 240 & USGS & 19900810 & 50.52 & 390 & 2.6 & $<0.1$ \\
\hline & & & & & & & & & & & USGS & 19901116 & 49.85 & 369 & 3.2 & $<0.1$ \\
\hline & & & & & & & & & & & USGS & 19910220 & 48.93 & 383 & 3 & $<0.1$ \\
\hline & & & & & & & & & & & USGS. & 19910314 & 48.82 & 378 & 5.1 & $<0.05$ \\
\hline & & & & & & & & & & & USGS & 19910521 & 49.18 & 391 & 2.8 & $<0.05$ \\
\hline & & & & & & & & & & & USGS & 19910625 & 50.41 & 387 & 2.5 & $<0.05$ \\
\hline & & & & & & & & & & & USGS & 19910717 & 49.90 & 374 & 2.8 & $<0.05$ \\
\hline & & & & & & & & & & & USGS & 19910822 & 50.50 & 378 & 3 & $<0.05$ \\
\hline & & & & & & & & & & & USGS & 19910925 & 50.10 & 380 & 3 & $<0.05$ \\
\hline & & & & & & & & & & & USGS & 19911023 & 49.99 & 391 & 3 & 0.14 \\
\hline $40 \mathrm{~N} / 02 \mathrm{E}-03 \mathrm{~K} 01$ & 485903 & 1223207 & w & W & $\mathrm{P}$ & EVRS & 30 & 208 & 6 & 250 & USGS & 19990815 & -- & -- & -- & -- \\
\hline $40 \mathrm{~N} / 02 \mathrm{E}-04 \mathrm{~A} 02$ & 485927 & 1223305 & W & W & $\mathrm{H}$ & EVRS & 30 & 51 & 6 & 237 & USGS & 19900810 & 41.55 & 303 & 5.4 & $<0.1$ \\
\hline $40 \mathrm{~N} / 02 \mathrm{E}-09 \mathrm{H} 01$ & 485829 & 1223306 & w & $\mathrm{U}$ & $\mathrm{U}$ & EVRS & 30 & 80 & 6 & 200 & USGS & 19900816 & 61.45 & -- & -- & -- \\
\hline $40 \mathrm{~N} / 02 \mathrm{E}-10 \mathrm{~N} 02$ & 485758 & 1223244 & w & w & $\mathrm{H}$ & SUMS & 10 & 38 & 6 & 107 & USGS & 19900814 & -- & 566 & 43 & 0.3 \\
\hline $4 \mathrm{ON} / 02 \mathrm{E}-11 \mathrm{MO} 1$ & 485814 & 1223135 & $\mathrm{w}$ & w & I & SUMS & 13 & 19 & 36 & 107 & USGS & 19900815 & 5.42 & 435 & -- & -- \\
\hline $40 N / O 2 E-12 C 01$ & 485834 & 1222948 & $w$ & $w$ & $x$ & sums & 10 & 26 & 36 & 112 & usGS & 19910822 & & 435 & -- & \\
\hline
\end{tabular}


Appendix Table 1. Well, water-level, hydrogeologic, and reconnaissance water-quality data--Continued

\begin{tabular}{|c|c|c|c|c|c|c|c|c|c|c|c|c|c|c|c|c|}
\hline Local well number & $\begin{array}{l}\text { Lati- } \\
\text { tude }\end{array}$ & $\begin{array}{l}\text { Longi- } \\
\text { tude }\end{array}$ & $\begin{array}{l}\text { Groun } \\
\text { water } \\
\text { site } \\
\text { type }\end{array}$ & $\begin{array}{l}\text { Site } \\
\text { use }\end{array}$ & $\begin{array}{l}\text { Wat- } \\
\text { er } \\
\text { use }\end{array}$ & $\begin{array}{l}\text { Hydro- } \\
\text { geo- } \\
\text { logic } \\
\text { unit }\end{array}$ & $\begin{array}{l}\text { Litho- } \\
\text { logic } \\
\text { unit }\end{array}$ & $\begin{array}{l}\text { Well } \\
\text { depth } \\
\text { (feet) }\end{array}$ & $\begin{array}{l}\text { Well } \\
\text { dia- } \\
\text { meter } \\
\text { (inches) }\end{array}$ & $\begin{array}{l}\text { Alti- } \\
\text { tude } \\
\text { (feet) }\end{array}$ & $\begin{array}{l}\text { Source } \\
\text { of } \\
\text { data }\end{array}$ & $\begin{array}{l}\text { Water- } \\
\text { level or } \\
\text { sample } \\
\text { date }\end{array}$ & $\begin{array}{l}\text { Water } \\
\text { level, } \\
\text { feet below } \\
\text { land surface }\end{array}$ & $\begin{array}{l}\text { Specific } \\
\text { conduc- } \\
\text { tance } \\
(\mu \mathrm{S} / \mathrm{cm})\end{array}$ & $\begin{array}{l}\text { Chloride, } \\
\text { dissolved } \\
(\mathrm{mg} / \mathrm{L} \\
\text { as } \mathrm{Cl})\end{array}$ & $\begin{array}{l}\text { Nitrogen } \\
\mathrm{NO}_{2}+\mathrm{NO}_{3} \\
\text { total } \\
(\mathrm{mg} / \mathrm{L} \text { as } \mathrm{N})\end{array}$ \\
\hline $40 \mathrm{~N} / 02 \mathrm{E}-12 \mathrm{~L} 01$ & 485820 & 1222959 & W & $\mathrm{w}$ & I & SUMS & 10 & 31 & 36 & 111 & USGS & 19900814 & 9.84 & -- & -- & -- \\
\hline $40 \mathrm{~N} / 02 \mathrm{E}-13 \mathrm{H} 01$ & 485734 & 1222912 & W & W & I & SUMS & 12 & 26 & 36 & 103 & USGS & 19900815 & -- & 335 & 13 & $<0.1$ \\
\hline $40 \mathrm{~N} / 02 \mathrm{E}-13 \mathrm{~J} 02$ & 485720 & 1222919 & W & W & I & SUMS & 10 & 40 & 36 & 100 & USGS & 19900817 & -- & 390 & 18 & $<0.1$ \\
\hline $40 \mathrm{~N} / 02 \mathrm{E}-13 \mathrm{~J} 03$ & 485720 & 1222920 & W & w & I & SUMS & 10 & 20 & 36 & 100 & USGS & 19900817 & 9.34 & -- & -- & -- \\
\hline $40 \mathrm{~N} / 02 \mathrm{E}-13 \mathrm{~J} 04$ & 485721 & 1222920 & W & 0 & $\mathrm{U}$ & SUMS & 10 & 16 & 1 & 99 & USGS & 19910521 & 3.85 & 323 & 6 & -- \\
\hline $40 \mathrm{~N} / 02 \mathrm{E}-13 \mathrm{~J} 05$ & 485719 & 1222920 & W & 0 & $\mathrm{U}$ & SUMS & 10 & 16 & 1 & 99 & USGS & 19910521 & 3.79 & -- & -- & -- \\
\hline $40 \mathrm{~N} / 02 \mathrm{E}-13 \mathrm{~J} 06$ & 485719 & 1222918 & W & 0 & $\mathrm{U}$ & SUMS & 10 & 18 & 1 & 99 & USGS & 19910521 & 5.18 & -- & -- & -- \\
\hline $40 \mathrm{~N} / 02 \mathrm{E}-13 \mathrm{~J} 07$ & 485719 & 1222917 & W & 0 & $\mathrm{U}$ & SUMS & 10 & 16 & 1 & 99 & USGS & 19910521 & 3.64 & 1,090 & 49 & -- \\
\hline $40 \mathrm{~N} / 02 \mathrm{E}-14 \mathrm{PO} 2$ & 485706 & 1223108 & W & w & $\mathrm{H}$ & SUMS & 10 & 39 & 36 & 91 & USGS & 19900814 & 21.62 & 307 & 12 & 23 \\
\hline $40 \mathrm{~N} / 02 \mathrm{E}-14 \mathrm{R} 01$ & 485704 & 1223039 & W & w & I & SUMS & 10 & 30 & 36 & 95 & USGS & 19900815 & -- & 207 & 9.4 & 2.6 \\
\hline $40 \mathrm{~N} / 02 \mathrm{E}-15 \mathrm{~A} 02$ & 485754 & 1223146 & w & w & I & SUMS & 10 & 12 & 18 & 106 & USGS & 19900821 & -- & 90 & -- & 3.2 \\
\hline $40 \mathrm{~N} / 02 \mathrm{E}-15 \mathrm{C} 01$ & 485748 & 1223233 & W & w & I & SUMS & 10 & & -- & 99 & USGS & 19900821 & & 373 & & 0.1 \\
\hline $40 \mathrm{~N} / 02 \mathrm{E}-15 \mathrm{H} 03$ & 485736 & 1223158 & W & w & I & SUMS & 10 & & 36 & 97 & USGS & 19900822 & & 251 & & 0.7 \\
\hline $40 \mathrm{~N} / 02 \mathrm{E}-15 \mathrm{HO} 2$ & 485736 & 1223148 & W & w & $\mathrm{U}$ & SUMS & 10 & 15 & 10 & 100 & USGS & 19900821 & & 156 & & 3.2 \\
\hline $40 \mathrm{~N} / 02 \mathrm{E}-15 \mathrm{~J} 01$ & 485726 & 1223147 & W & $\mathrm{w}$ & $\mathrm{H}$ & SUMS & 10 & 24 & 36 & 95 & USGS & 19900816 & 9.26 & 351 & 6.4 & $<0.1$ \\
\hline $40 \mathrm{~N} / 02 \mathrm{E}-15 \mathrm{P} 01$ & 485705 & 1223241 & W & w & $\mathrm{H}$ & SUMS & 10 & 24 & 36 & 90 & USGS & 19900814 & -- & 182 & 6.8 & 3 \\
\hline $40 \mathrm{~N} / 02 \mathrm{E}-15 \mathrm{Q} 01$ & 485708 & 1223221 & W & $\mathrm{z}$ & $\mathrm{U}$ & & & 26 & 36 & 90 & USGS & -- & -- & -- & -- & -- \\
\hline $40 \mathrm{~N} / 02 \mathrm{E}-15 \mathrm{R} 03$ & 485709 & 1223147 & w & W & $\mathrm{H}$ & SUMS & 10 & 26 & 36 & 92 & USGS & 19900821 & -- & 223 & -- & 8.2 \\
\hline $40 \mathrm{~N} / 02 \mathrm{E}-16 \mathrm{~B} 02$ & 485753 & 1223329 & w & w & $\mathrm{H}$ & SUMS & 10 & 20 & 30 & 105 & USGS & 19900815 & -- & 237 & 12 & 6.7 \\
\hline $40 \mathrm{~N} / 02 \mathrm{E}-21 \mathrm{~A} 01$ & 485658 & 1223312 & W & W & $\mathrm{H}$ & SUMS & 13 & 21 & 36 & 90 & USGS & 19900814 & -- & 178 & 4 & 0.6 \\
\hline $40 \mathrm{~N} / 02 \mathrm{E}-21 \mathrm{D} 01$ & 485658 & 1223409 & w & w & $\mathrm{s}$ & SUMS & 10 & 18 & 18 & 88 & USGS & 19900820 & -- & 306 & -- & 0.59 \\
\hline $40 \mathrm{~N} / 02 \mathrm{E}-21 \mathrm{~J} 01$ & 485629 & 1223305 & w & w & $\mathrm{H}$ & SUMS & 10 & 21 & 36 & 83 & USGS & 19900817 & 7.60 & 178 & 9.6 & 8 \\
\hline $40 \mathrm{~N} / 02 \mathrm{E}-21 \mathrm{~J} 05$ & 485632 & 1223317 & W & w & $\mathrm{H}$ & SUMS & 10 & 17 & 24 & 82 & USGS & 19900821 & -- & 128 & -- & 4.8 \\
\hline $40 \mathrm{~N} / 02 \mathrm{E}-21 \mathrm{~N} 02$ & 485704 & 1223422 & W & w & $\mathrm{F}$ & SUMS & 10 & 24 & 36 & 71 & USGS & 19910822 & -- & -- & -- & 8.2 \\
\hline $40 \mathrm{~N} / 02 \mathrm{E}-21 \mathrm{RO} 01$ & 485611 & 1223308 & W & w & $\mathrm{H}$ & SUMS & 10 & 24 & 36 & 73 & USGS & 19900814 & 8.02 & 318 & 24 & 18 \\
\hline $40 \mathrm{~N} / 02 \mathrm{E}-21 \mathrm{RO} 2$ & 485611 & 1223314 & W & w & I & SUMS & 10 & 23 & 36 & 74 & USGS & 19900816 & -- & 244 & 11 & 16 \\
\hline $40 \mathrm{~N} / 02 \mathrm{E}-21 \mathrm{R} 03$ & 485607 & 1223307 & W & w & $\mathrm{H}$ & SUMS & 10 & -- & 18 & 74 & USGS & 19910823 & -- & 318 & -- & 22 \\
\hline $40 \mathrm{~N} / 02 \mathrm{E}-22 \mathrm{E} 02$ & 485638 & 1223301 & w & w & $\mathrm{H}$ & SUMS & 10 & 21 & 36 & 86 & USGS & 19900814 & 7.23 & 130 & 6 & 4.3 \\
\hline $40 \mathrm{~N} / 02 \mathrm{E}-22 \mathrm{NO} 2$ & 485614 & 1223301 & W & w & $\mathrm{H}$ & SUMS & 10 & & 24 & 74 & USGS & 19910822 & -- & 313 & -- & 13 \\
\hline $40 \mathrm{~N} / 02 \mathrm{E}-22 \mathrm{~N} 07$ & 485609 & 1223246 & W & w & $\mathrm{H}$ & SUMS & 10 & 30 & 30 & 74 & USGS & 19910822 & -- & 142 & -- & 5 \\
\hline $40 \mathrm{~N} / 02 \mathrm{E}-22 \mathrm{RO} 2$ & 485608 & 1223201 & W & W & $\mathrm{H}$ & SUMS & 10 & 30 & 6 & 60 & USGS & 19900815 & 19.46 & 134 & 6.8 & 3.8 \\
\hline $40 \mathrm{~N} / 02 \mathrm{E}-23 \mathrm{~A} 03$ & 485650 & 1223043 & W & W & $\mathrm{H}$ & SUMS & 10 & 23 & 6 & 90 & USGS & 19910820 & -- & 194 & -- & 6.7 \\
\hline $40 \mathrm{~N} / 02 \mathrm{E}-23 \mathrm{~B} 02$ & 485659 & 1223102 & w & w & $\mathrm{H}$ & SUMS & 10 & & & 92 & USGS & 19910821 & -- & 222 & -- & 11 \\
\hline $40 \mathrm{~N} / 02 \mathrm{E}-23 \mathrm{CO} 1$ & 485701 & 1223121 & W & w & $\mathrm{H}$ & SUMS & 10 & 38 & 18 & 90 & USGS & 19900814 & 24.20 & 139 & 4 & 5.6 \\
\hline $40 \mathrm{~N} / 02 \mathrm{E}-23 \mathrm{D} 01$ & 485659 & 1223126 & W & w & $\mathrm{H}$ & SUMS & 10 & 30 & 18 & 91 & USGS & 19900710 & 21.3 & 206 & 7.4 & 5.6 \\
\hline $40 \mathrm{~N} / 02 \mathrm{E}-23 \mathrm{D} 02$ & 485700 & 1223134 & w & w & $\mathrm{H}$ & SUMS & 10 & 48 & 6 & 90 & USGS & 19900814 & 19.15 & 357 & 25 & 8 \\
\hline $40 \mathrm{~N} / 02 \mathrm{E}-23 \mathrm{D} 04$ & 48565 & 1223133 & W & w & $\mathrm{H}$ & SUMS & 10 & 42 & 36 & 83 & USGS & 19910822 & -- & 248 & -- & 13 \\
\hline $40 \mathrm{~N} / 02 \mathrm{E}-23 \mathrm{~N} 01$ & 485612 & 1223141 & W & W & $\mathrm{H}$ & SUMS & 10 & 34 & 36 & 75 & USGS & 19900816 & 18.1 & 205 & 10 & 3.6 \\
\hline
\end{tabular}


Appendix Table 1. Well, water-level, hydrogeologic, and reconnaissance water-quality data--Continued

\begin{tabular}{|c|c|c|c|c|c|c|c|c|c|c|c|c|c|c|c|c|}
\hline Local well number & $\begin{array}{l}\text { Lati- } \\
\text { tude }\end{array}$ & $\begin{array}{l}\text { Longi- } \\
\text { tude }\end{array}$ & $\begin{array}{l}\text { Ground } \\
\text { water } \\
\text { site } \\
\text { type }\end{array}$ & $\begin{array}{l}\text { Site } \\
\text { use }\end{array}$ & $\begin{array}{l}\text { Wat- } \\
\text { er } \\
\text { use }\end{array}$ & $\begin{array}{l}\text { Hydro- } \\
\text { geo- } \\
\text { logic } \\
\text { unit }\end{array}$ & $\begin{array}{l}\text { Litho- } \\
\text { logic } \\
\text { unit }\end{array}$ & $\begin{array}{l}\text { Well } \\
\text { depth } \\
\text { (feet) }\end{array}$ & $\begin{array}{l}\text { Well } \\
\text { dia- } \\
\text { meter } \\
\text { (inches) }\end{array}$ & $\begin{array}{l}\text { Alti- } \\
\text { tude } \\
\text { (feet) }\end{array}$ & $\begin{array}{l}\text { Source } \\
\text { of } \\
\text { data }\end{array}$ & $\begin{array}{l}\text { Water- } \\
\text { level or } \\
\text { sample } \\
\text { date }\end{array}$ & $\begin{array}{l}\text { Water } \\
\text { level, } \\
\text { feet below } \\
\text { land surface }\end{array}$ & $\begin{array}{l}\text { Specific } \\
\text { conduc- } \\
\text { tance } \\
(\mu \mathrm{S} / \mathrm{cm})\end{array}$ & $\begin{array}{l}\text { Chloride, } \\
\text { dissolved } \\
(\mathrm{mg} / \mathrm{L} \\
\text { as } \mathrm{Cl})\end{array}$ & $\begin{array}{l}\text { Nitrogen } \\
\mathrm{NO}_{2}+\mathrm{NO}_{3} \\
\text { total } \\
\text { (mg/L as } \mathrm{N} \text { ) }\end{array}$ \\
\hline $40 \mathrm{~N} / 02 \mathrm{E}-23 \mathrm{P} 01$ & 485613 & 1223104 & W & $\mathrm{U}$ & $\mathrm{U}$ & SUMS & 10 & 29 & 36 & 77 & USGS & 19900816 & 13.03 & 291 & -- & 20 \\
\hline $40 \mathrm{~N} / 02 \mathrm{E}-23 \mathrm{Q} 01$ & 485612 & 1223047 & w & W & I & SUMS & 10 & 25 & 36 & 78 & USGS & 19900816 & 9.46 & -- & -- & -- \\
\hline $40 \mathrm{~N} / 02 \mathrm{E}-26 \mathrm{AO} 3$ & 485602 & 1223034 & W & W & $\mathrm{P}$ & SUMS & 10 & 33 & 36 & 76 & USGS & 19900817 & 20.23 & 390 & 24 & 14 \\
\hline $40 \mathrm{~N} / 02 \mathrm{E}-26 \mathrm{~A} 04$ & 485555 & 1223024 & W & w & I & SUMS & 10 & 25 & & 60 & USGS & 19900816 & -- & 288 & 16 & 11 \\
\hline $40 \mathrm{~N} / 02 \mathrm{E}-26 \mathrm{~B} 02$ & 485502 & 1223054 & W & W & $\mathrm{H}$ & SUMS & 10 & 32 & 36 & 65 & USGS & 19910822 & -- & 220 & -- & 7.6 \\
\hline $40 \mathrm{~N} / 02 \mathrm{E}-26 \mathrm{CO} 3$ & 485602 & 1223107 & W & w & $\mathrm{H}$ & SUMS & 10 & -- & 36 & 62 & USGS & 19910905 & -- & 202 & -- & 2.2 \\
\hline $40 \mathrm{~N} / 02 \mathrm{E}-26 \mathrm{C} 04$ & 485602 & 1223104 & $\mathrm{~W}$ & w & $\mathrm{H}$ & SUMS & 10 & 25 & 24 & 65 & USGS & 19910805 & -- & 206 & -- & 4 \\
\hline $40 \mathrm{~N} / 02 \mathrm{E}-26 \mathrm{D} 02$ & 485559 & 1223128 & W & w & I & SUMS & 10 & 25 & 36 & 70 & USGS & 19910905 & -- & 190 & - & 5.6 \\
\hline $40 \mathrm{~N} / 02 \mathrm{E}-26 \mathrm{E} 01$ & 485542 & 1223125 & W & W & $\mathrm{P}$ & SUMS & 10 & 35 & 10 & 73 & USGS & 19900817 & 21.89 & -- & -- & -- \\
\hline \multirow[t]{14}{*}{$40 \mathrm{~N} / 02 \mathrm{E}-27 \mathrm{~B} 01$} & 485607 & 1223214 & W & w & $\mathrm{H}$ & SUMS & 10 & 41 & 18 & 65 & USGS & 19900815 & 25.56 & 219 & 9.8 & 9.3 \\
\hline & & & & & & & & & & & & 19900830 & -- & 220 & 9.1 & 11 \\
\hline & & & & & & & & & & & USGS & 19901017 & 25.12 & 235 & 7 & 12 \\
\hline & & & & & & & & & & & USGS & 19901114 & 22.21 & -- & 7.5 & 11 \\
\hline & & & & & & & & & & & USGS & 19901218 & 21.62 & 206 & 6.2 & 10 \\
\hline & & & & & & & & & & & USGS & 19910118 & 21.24 & 201 & 5.7 & \\
\hline & & & & & & & & & & & USGS & 19910220 & 22.21 & 198 & 5.3 & 7.4 \\
\hline & & & & & & & & & & & USGS & 19910314 & 22.84 & 195 & 3.9 & 6.3 \\
\hline & & & & & & & & & & & USGS & 19910521 & 23.95 & 200 & 3.9 & 7.9 \\
\hline & & & & & & & & & & & USGS & 19910626 & 25.10 & 194 & 3.4 & 8.1 \\
\hline & & & & & & & & & & & USGS & 19910718 & 24.95 & 190 & 4.2 & 9.2 \\
\hline & & & & & & & & & & & USGS & 19910813 & 25.20 & 194 & 5 & 9.2 \\
\hline & & & & & & & & & & & USGS & 19910925 & 25.53 & 203 & -- & 9.2 \\
\hline & & & & & & & & & & & USGS & 19911023 & 25.48 & 205 & 6 & \\
\hline $40 \mathrm{~N} / 02 \mathrm{E}-27 \mathrm{C} 01$ & 485607 & 1223224 & W & w & $\mathrm{H}$ & SUMS & 10 & -- & 18 & 74 & USGS & 19910822 & -- & 267 & -- & 7.8 \\
\hline $40 \mathrm{~N} / 02 \mathrm{E}-27 \mathrm{DO} 2$ & 485558 & 1223248 & W & w & $\mathrm{H}$ & SUMS & 10 & 32 & 36 & 60 & USGS & 19910822 & -- & -- & -- & 7.2 \\
\hline $40 \mathrm{~N} / 02 \mathrm{E}-27 \mathrm{NO} 2$ & 485522 & 1223257 & W & W & $\mathrm{H}$ & SUMS & 10 & 26 & 36 & 65 & USGS & 19900817 & 14.82 & 229 & 9.4 & 10 \\
\hline $40 \mathrm{~N} / 02 \mathrm{E}-28 \mathrm{G} 01$ & 485551 & 1223343 & $\mathrm{~W}$ & W & $\mathrm{H}$ & SUMS & 10 & -- & 8 & 65 & USGS & 19910823 & -- & -- & -- & 7.4 \\
\hline $40 \mathrm{~N} / 02 \mathrm{E}-33 \mathrm{~B} 02$ & 485506 & 1223324 & w & w & $P$ & SUMS & 10 & 36 & 36 & 65 & USGS & 19911002 & -- & 213 & 14 & 1.8 \\
\hline $40 \mathrm{~N} / 02 \mathrm{E}-35 \mathrm{GO} 1$ & 485448 & 1223058 & w & $\mathrm{U}$ & $\mathrm{U}$ & SUMS & 15 & 18 & 36 & 35 & USGS & 19900816 & 8.60 & -- & -- & -- \\
\hline $40 \mathrm{~N} / 02 \mathrm{E}-36 \mathrm{~N} 01$ & 485425 & 1223003 & $\mathrm{~W}$ & $\mathrm{~W}$ & I & SUMS & 10 & 44 & 36 & 68 & USGS & 19900501 & 12.92 & -- & -- & -- \\
\hline $40 \mathrm{~N} / 03 \mathrm{E}-01 \mathrm{R} 01$ & 485847 & 1222104 & W & W & I & SUMS & 10 & 26 & 36 & 119 & USGS & 19900622 & 11.66 & -- & -- & -- \\
\hline $40 \mathrm{~N} / 03 \mathrm{E}-02 \mathrm{~B} 01$ & 485935 & 1222242 & W & W & $\mathrm{H}$ & SUMS & 10 & 25 & 36 & 157 & USGS & 19900706 & 12.59 & 131 & 5.6 & 7.5 \\
\hline $40 \mathrm{~N} / 03 \mathrm{E}-02 \mathrm{~B} 03$ & 485927 & 1222252 & W & w & I & SUMS & 10 & 59 & 8 & 153 & USGS & 19900706 & 11.37 & -- & -- & -- \\
\hline $40 \mathrm{~N} / 03 \mathrm{E}-02 \mathrm{CO} 1$ & 485930 & 1222308 & w & w & I & SUMS & 10 & 24 & 36 & 152 & USGS & 19900709 & 11.99 & -- & -- & -- \\
\hline $40 \mathrm{~N} / 03 \mathrm{E}-02 \mathrm{M} 02$ & 485858 & 1222339 & W & w & I & SUMS & 10 & 57 & 8 & 141 & USGS & 19900725 & 8.37 & -- & -- & -- \\
\hline $40 \mathrm{~N} / 03 \mathrm{E}-02 \mathrm{~N} 01$ & 485849 & 1222321 & $w$ & w & I & SUMS & 10 & 20 & 36 & 134 & USGS & 19900725 & $\begin{array}{l}10.75 \\
10.88\end{array}$ & 54 & $-\overline{2.2}$ & $--\overline{1.2}$ \\
\hline $40 \mathrm{~N} / 03 \mathrm{E}-03 \mathrm{AO} 2$ & 485936 & 1222355 & w & w & $\mathrm{H}$ & SUMS & 10 & 26 & 6 & 147 & USGS & 19900710 & 10.88 & 54 & & \\
\hline
\end{tabular}


Appendix Table 1. Well, water-level, hydrogeologic, and reconnaissance water-quality data--Continued

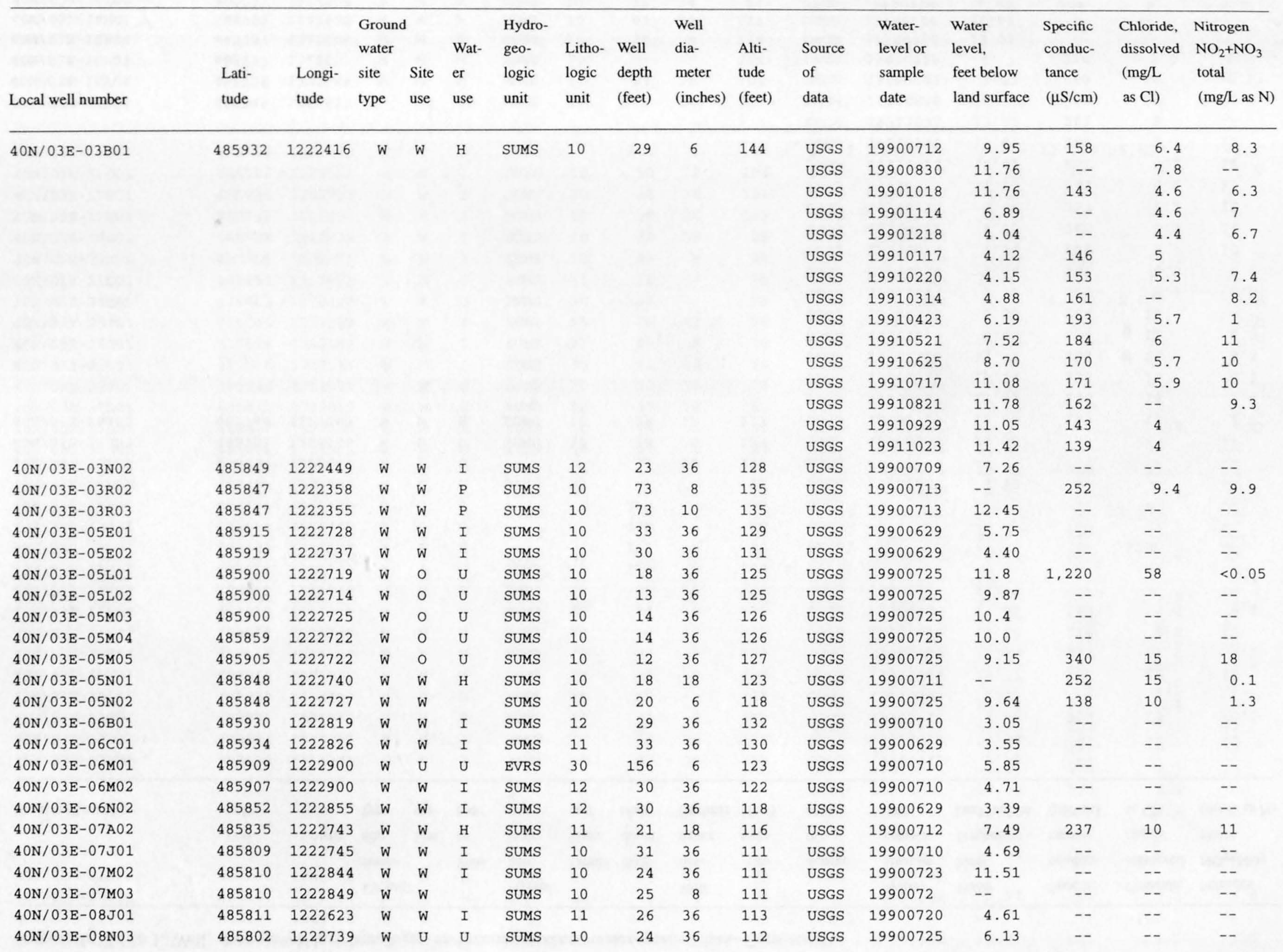


$\vec{f} \quad$ Appendix Table 1. Well, water-level, hydrogeologic, and reconnaissance water-quality data--Continued

\begin{tabular}{|c|c|c|c|c|c|c|c|c|c|c|c|c|c|c|c|c|}
\hline Local well number & $\begin{array}{l}\text { Lati- } \\
\text { tude }\end{array}$ & $\begin{array}{l}\text { Longi- } \\
\text { tude }\end{array}$ & $\begin{array}{l}\text { Ground } \\
\text { water } \\
\text { site } \\
\text { type }\end{array}$ & $\begin{array}{l}\text { Site } \\
\text { use }\end{array}$ & $\begin{array}{l}\text { Wat- } \\
\text { er } \\
\text { use }\end{array}$ & $\begin{array}{l}\text { Hydro- } \\
\text { geo- } \\
\text { logic } \\
\text { unit }\end{array}$ & $\begin{array}{l}\text { Litho- } \\
\text { logic } \\
\text { unit }\end{array}$ & $\begin{array}{l}\text { Well } \\
\text { depth } \\
\text { (feet) }\end{array}$ & $\begin{array}{l}\text { Well } \\
\text { dia- } \\
\text { meter } \\
\text { (inches) }\end{array}$ & $\begin{array}{l}\text { Alti- } \\
\text { tude } \\
\text { (feet) }\end{array}$ & $\begin{array}{l}\text { Source } \\
\text { of } \\
\text { data }\end{array}$ & $\begin{array}{l}\text { Water- } \\
\text { level or } \\
\text { sample } \\
\text { date }\end{array}$ & $\begin{array}{l}\text { Water } \\
\text { level, } \\
\text { feet below } \\
\text { land surface }\end{array}$ & $\begin{array}{l}\text { Specific } \\
\text { conduc- } \\
\text { tance } \\
(\mu \mathrm{S} / \mathrm{cm})\end{array}$ & $\begin{array}{l}\text { Chloride, } \\
\text { dissolved } \\
(\mathrm{mg} / \mathrm{L} \\
\text { as } \mathrm{Cl})\end{array}$ & $\begin{array}{l}\text { Nitrogen } \\
\mathrm{NO}_{2}+\mathrm{NO}_{3} \\
\text { total } \\
\text { (mg/L as } \mathrm{N} \text { ) }\end{array}$ \\
\hline $40 \mathrm{~N} / 03 \mathrm{E}-09 \mathrm{~A} 04$ & 485838 & 1222512 & W & w & I & SUMS & 12 & 27 & 36 & 123 & USGS & 19900712 & 7.94 & -- & -- & -- \\
\hline $40 N / 03 E-09 D 01$ & 485837 & 1222612 & W & w & I & SUMS & 12 & 22 & 36 & 118 & USGS & 19900712 & 4.94 & -- & -- & -- \\
\hline $40 \mathrm{~N} / 03 \mathrm{E}-09 \mathrm{G} 01$ & 485830 & 1222523 & W & w & s & SUMS & 10 & 65 & 6 & 122 & USGS & 19900712 & 7.41 & 252 & 13 & $<0.1$ \\
\hline $40 \mathrm{~N} / 03 \mathrm{E}-10 \mathrm{C} 02$ & 485839 & 1222425 & W & W & $\mathrm{H}$ & SUMS & 10 & 18 & -- & 132 & USGS & 19910503 & 5.58 & -- & 5.7 & 6.2 \\
\hline $40 \mathrm{~N} / 03 \mathrm{E}-10 \mathrm{~K} 01$ & 485816 & 1222418 & W & w & $\mathrm{H}$ & SUMS & 10 & 30 & 6 & 132 & USGS & 19900803 & 15.27 & 286 & 12 & 10 \\
\hline $40 \mathrm{~N} / 03 \mathrm{E}-10 \mathrm{R} 02$ & 485752 & 1222346 & W & w & $\mathrm{H}$ & SUMS & 10 & 38 & 36 & 115 & USGS & 19900809 & 13.96 & 237 & 11.5 & 1.1 \\
\hline $40 \mathrm{~N} / 03 \mathrm{E}-11 \mathrm{E} 03$ & 485818 & 1222340 & $\mathrm{~W}$ & w & $\mathrm{H}$ & SUMS & 10 & 36 & 18 & 130 & USGS & 19900808 & 17.40 & 219 & 8.8 & 12 \\
\hline $40 \mathrm{~N} / 03 \mathrm{E}-11 \mathrm{E} 04$ & 485818 & 1222336 & W & w & $\mathrm{H}$ & SUMS & 10 & 44 & 6 & 130 & USGS & 19900808 & 17.05 & 188 & 6.6 & 8.1 \\
\hline $40 \mathrm{~N} / 03 \mathrm{E}-12 \mathrm{~A} 05$ & 485841 & 1222106 & W & w & I & SUMS & 10 & 80 & 10 & 133 & USGS & 19900621 & 23.97 & -- & -- & - \\
\hline $40 \mathrm{~N} / 03 \mathrm{E}-12 \mathrm{H} 01$ & 485824 & 1222105 & w & $\mathrm{T}$ & $\mathrm{U}$ & SUMS & 10 & 120 & 8 & 100 & Drill & -- & -- & -- & -- & -- \\
\hline $40 \mathrm{~N} / 03 \mathrm{E}-13 \mathrm{~N} 01$ & 485705 & 1222222 & $\mathrm{x}$ & $\mathrm{z}$ & $\mathrm{U}$ & & & 175 & & 85 & Drill & -- & -- & -- & $>250$ & -- \\
\hline $40 \mathrm{~N} / 03 \mathrm{E}-13 \mathrm{Q} 01$ & 485659 & 1222142 & $\mathrm{~W}$ & $\mathrm{U}$ & $\mathrm{U}$ & & & 225 & -- & 86 & USGS & - & -- & -- & -- & -- \\
\hline $40 \mathrm{~N} / 03 \mathrm{E}-14 \mathrm{~B} 01$ & 485747 & 1222254 & W & $\mathrm{z}$ & $\mathrm{U}$ & & & 265 & -- & 95 & USGS & -- & -- & -- & -- & -- \\
\hline $40 \mathrm{~N} / 03 \mathrm{E}-14 \mathrm{~B} 02$ & 485748 & 1222255 & W & $\mathrm{U}$ & $\mathrm{H}$ & EVRS & 99 & 9 & & 95 & USGS & 19900807 & 4.13 & -- & -- & -- \\
\hline $40 \mathrm{~N} / 03 \mathrm{E}-15 \mathrm{~B} 02$ & 485750 & 1222407 & W & $\mathrm{z}$ & $\mathrm{U}$ & & & 33 & 18 & 125 & USGS & -- & -- & -- & -- & -- \\
\hline $40 \mathrm{~N} / 03 \mathrm{E}-15 \mathrm{~B} 03$ & 485751 & 1222406 & W & $\mathrm{U}$ & U & SUMS & 10 & 30 & 6 & 125 & USGS & 19900807 & 24.06 & -- & -- & -- \\
\hline \multirow[t]{15}{*}{$40 \mathrm{~N} / 03 \mathrm{E}-16 \mathrm{~A} 02$} & 485746 & 1222503 & W & W & $\mathrm{H}$ & SUMS & 10 & 29 & 12 & 117 & USGS & 19900723 & 11.60 & 197 & 10 & 2.7 \\
\hline & & & & & & & & & & & USGS & 19900827 & 12.93 & 216 & 14 & 7.4 \\
\hline & & & & & & & & & & & USGS & 19901017 & 13.24 & 235 & 15 & 8.3 \\
\hline & & & & & & & & & & & USGS & 19901114 & 11.71 & 239 & 14 & 8.3 \\
\hline & & & & & & & & & & & USGS & 19901217 & 6.45 & 216 & 12 & 8.2 \\
\hline & & & & & & & & & & & USGS & 19910119 & 5.50 & 224 & 12 & -- \\
\hline & & & & & & & & & & & USGS & 19910221 & 5.78 & 200 & 9.6 & 6.5 \\
\hline & & & & & & & & & & & USGS & 19910314 & 6.04 & 185 & 8.9 & 6.4 \\
\hline & & & & & & & & & & & USGS & 19910423 & 7.18 & 228 & 9 & 12 \\
\hline & & & & & & & & & & & USGS & 19910521 & 8.39 & 260 & 8.9 & 14 \\
\hline & & & & & & & & & & & USGS & 19910625 & 9.64 & 257 & 8.2 & 15 \\
\hline & & & & & & & & & & & USGS & 19910717 & 11.10 & 241 & 8.2 & 13 \\
\hline & & & & & & & & & & & USGS & 19910822 & 12.42 & 261 & 7.2 & 14 \\
\hline & & & & & & & & & & & USGS & 19910926 & 13.07 & 284 & 9 & 16 \\
\hline & & & & & & & & & & & USGS & 19911023 & 13.07 & 281 & 8 & -- \\
\hline $40 \mathrm{~N} / 03 \mathrm{E}-16 \mathrm{D} 01$ & 485745 & 1222617 & W & W & I & SUMS & 10 & 27 & 36 & 111 & USGS & 19900808 & 10.71 & 356 & 27 & 4.6 \\
\hline $40 \mathrm{~N} / 03 \mathrm{E}-16 \mathrm{~F} 01$ & 485736 & 1222559 & W & w & $\mathrm{H}$ & SUMS & 10 & 21 & 12 & 106 & USGS & 19900723 & 5.07 & 260 & 14 & $<0.1$ \\
\hline $40 \mathrm{~N} / 03 \mathrm{E}-16 \mathrm{HO} 3$ & 485737 & 1222507 & W & w & $\mathrm{H}$ & SUMS & 10 & -- & -- & 114 & USGS & 19900720 & -- & 214 & 7.6 & 6.3 \\
\hline $40 \mathrm{~N} / 03 \mathrm{E}-16 \mathrm{H} 04$ & 485737 & 1222509 & W & W & I & SUMS & 10 & 58 & 6 & 114 & USGS & 19900720 & 13.21 & -- & -- & -- \\
\hline $40 \mathrm{~N} / 03 \mathrm{E}-16 \mathrm{H} 05$ & 485727 & 1222520 & w & W & $\mathrm{P}$ & SUMS & 10 & 45 & 36 & 117 & USGS & 19900808 & 31.69 & -- & -- & -- \\
\hline $40 \mathrm{~N} / 03 \mathrm{E}-16 \mathrm{HO} 6$ & 485727 & 1222508 & $\mathrm{w}$ & w & I & sums & 10 & 28 & $\begin{array}{l}36 \\
36\end{array}$ & $\begin{array}{r}96 \\
105\end{array}$ & $\begin{array}{l}\text { USGS } \\
\text { USGS }\end{array}$ & $\begin{array}{l}19900808 \\
19900723\end{array}$ & $\begin{array}{r}6.96 \\
--\end{array}$ & $\begin{array}{l}202 \\
166\end{array}$ & $\begin{array}{l}9 \\
6.8\end{array}$ & $\begin{array}{l}5.2 \\
7.2\end{array}$ \\
\hline $4 \mathrm{ON} / 03 \mathrm{E}-16 \mathrm{KO} 1$ & 485719 & 1222536 & $w$ & w & $\mathrm{H}$ & sUMS & 10 & 33 & 36 & 105 & & 19900723 & & 100 & 6.8 & \\
\hline
\end{tabular}


Appendix Table 1. Well, water-level, hydrogeologic, and reconnaissance water-quality data--Continued

\begin{tabular}{|c|c|c|c|c|c|c|c|c|c|c|c|c|c|c|c|c|}
\hline Local well number & $\begin{array}{l}\text { Lati- } \\
\text { tude }\end{array}$ & $\begin{array}{l}\text { Longi- } \\
\text { tude }\end{array}$ & $\begin{array}{l}\text { Grounc } \\
\text { water } \\
\text { site } \\
\text { type }\end{array}$ & $\begin{array}{l}\text { Site } \\
\text { use }\end{array}$ & $\begin{array}{l}\text { Wat- } \\
\text { er } \\
\text { use }\end{array}$ & $\begin{array}{l}\text { Hydro- } \\
\text { geo- } \\
\text { logic } \\
\text { unit }\end{array}$ & $\begin{array}{l}\text { Litho- } \\
\text { logic } \\
\text { unit }\end{array}$ & $\begin{array}{l}\text { Well } \\
\text { depth } \\
\text { (feet) }\end{array}$ & $\begin{array}{l}\text { Well } \\
\text { dia- } \\
\text { meter } \\
\text { (inches) }\end{array}$ & $\begin{array}{l}\text { Alti- } \\
\text { tude } \\
\text { (feet) }\end{array}$ & $\begin{array}{l}\text { Source } \\
\text { of } \\
\text { data }\end{array}$ & $\begin{array}{l}\text { Water- } \\
\text { level or } \\
\text { sample } \\
\text { date }\end{array}$ & $\begin{array}{l}\text { Water } \\
\text { level, } \\
\text { feet below } \\
\text { land surface }\end{array}$ & $\begin{array}{l}\text { Specific } \\
\text { conduc- } \\
\text { tance } \\
(\mu \mathrm{S} / \mathrm{cm})\end{array}$ & $\begin{array}{l}\text { Chloride, } \\
\text { dissolved } \\
(\mathrm{mg} / \mathrm{L} \\
\text { as } \mathrm{Cl})\end{array}$ & $\begin{array}{l}\text { Nitrogen } \\
\mathrm{NO}_{2}+\mathrm{NO}_{3} \\
\text { total } \\
\text { (mg/L as } \mathrm{N} \text { ) }\end{array}$ \\
\hline $40 \mathrm{~N} / 03 \mathrm{E}-16 \mathrm{M} 01$ & 485723 & 1222622 & W & $\mathrm{T}$ & $\mathrm{U}$ & EVRS & & 344 & 6 & 100 & Drill & 19840223 & 30 & 12,200 & $>5,000$ & $<0.1$ \\
\hline $40 \mathrm{~N} / 03 \mathrm{E}-16 \mathrm{Q} 01$ & 485706 & 1222533 & w & w & I & SUMS & 10 & 50 & 8 & 104 & USGS & 19900719 & 1.30 & 205 & 9.6 & 1.5 \\
\hline $40 \mathrm{~N} / 03 \mathrm{E}-17 \mathrm{E} 01$ & 485734 & 1222733 & W & W & I & SUMS & 10 & 28 & 36 & 104 & USGS & 19900719 & 4.10 & -- & -- & -- \\
\hline $40 \mathrm{~N} / 03 \mathrm{E}-18 \mathrm{E} 01$ & 485737 & 1222857 & w & W & I & SUMS & 10 & 36 & 36 & 103 & USGS & 19900713 & 5.15 & -- & -- & -- \\
\hline $40 \mathrm{~N} / 03 \mathrm{E}-18 \mathrm{G} 01$ & 485738 & 1222818 & w & w & I & SUMS & 10 & 30 & 36 & 106 & USGS & 19900709 & 3.68 & -- & -- & -- \\
\hline $40 \mathrm{~N} / 03 \mathrm{E}-19 \mathrm{~A} 01$ & 485659 & 1222756 & W & W & I & SUMS & 12 & 40 & 8 & 98 & USGS & 19900719 & 6.06 & 148 & 8.2 & 0.2 \\
\hline $40 \mathrm{~N} / 03 \mathrm{E}-22 \mathrm{CO} 1$ & 485654 & 1222431 & $w$ & $\mathrm{U}$ & $\mathrm{U}$ & SUMS & 15 & 15 & -- & 55 & USGS & 19900809 & 10.0 & -- & -- & -- \\
\hline $40 \mathrm{~N} / 03 \mathrm{E}-24 \mathrm{E} 01$ & 485643 & 1222222 & w & w & U & EVRS & 30 & 147 & -- & 75 & USGS & 19911002 & 7.93 & 10,100 & 2,800 & 0.06 \\
\hline $40 \mathrm{~N} / 03 \mathrm{E}-25 \mathrm{~F} 01$ & 485545 & 1222159 & $\mathrm{~W}$ & W & I & SUMS & 15 & 29 & 12 & 76 & USGS & 19900621 & 5.03 & 467 & -- & 1.2 \\
\hline $40 \mathrm{~N} / 03 \mathrm{E}-25 \mathrm{~J} 01$ & 485538 & 1222107 & W & W & I & SUMS & 21 & 45 & 8 & 78 & USGS & 19900621 & 2.98 & -- & -- & -- \\
\hline $40 \mathrm{~N} / 03 \mathrm{E}-26 \mathrm{H} 01$ & 485546 & 1222233 & W & W & I & SUMS & 15 & 24 & 36 & 70 & USGS & 19900622 & 6.93 & -- & -- & -- \\
\hline $40 \mathrm{~N} / 03 \mathrm{E}-31 \mathrm{~J} 01$ & 485948 & 1222751 & w & w & $\mathrm{H}$ & SUMS & 10 & 12 & 36 & 73 & WCHD & 19910129 & 7.1 & -- & -- & 13 \\
\hline $40 \mathrm{~N} / 03 \mathrm{E}-31 \mathrm{~L} 01$ & 485445 & 1222838 & w & w & $\mathrm{H}$ & SUMS & 10 & 30 & 18 & 62 & USGS & 19900424 & 16.66 & 118 & 5 & 3.4 \\
\hline $40 \mathrm{~N} / 03 \mathrm{E}-31 \mathrm{~L} 02$ & 485447 & 1222830 & $\mathrm{~W}$ & W & $\mathrm{H}$ & SUMS & 10 & 19 & 6 & 61 & USGS & 19900424 & 10.4 & -- & 3.6 & 3.4 \\
\hline $40 \mathrm{~N} / 03 \mathrm{E}-31 \mathrm{NO} 2$ & 485428 & 1222903 & W & w & $\mathrm{U}$ & SUMS & 10 & 53 & 6 & 80 & USGS & 19900424 & 26.42 & -- & -- & -- \\
\hline $40 \mathrm{~N} / 03 \mathrm{E}-31 \mathrm{PO} 3$ & 485425 & 1222829 & $\mathrm{~W}$ & W & $\mathrm{H}$ & SUMS & 10 & 36 & 18 & 75 & USGS & 19900424 & 23.81 & 308 & 12 & 18 \\
\hline $40 \mathrm{~N} / 03 \mathrm{E}-31 \mathrm{R} 01$ & 485430 & 1222749 & $w$ & w & $\mathrm{H}$ & SUMS & 10 & 16 & 36 & 70 & WCHD & 19910129 & 8.9 & -- & -- & 9.4 \\
\hline $40 \mathrm{~N} / 03 \mathrm{E}-32 \mathrm{G} 01$ & 485453 & 1222706 & W & $\mathrm{T}$ & $\mathrm{U}$ & EVRS & & 442 & 4 & 77 & Drill & 19850315 & 80 & -- & $>2,500$ & -- \\
\hline $40 \mathrm{~N} / 03 \mathrm{E}-32 \mathrm{~K} 02$ & 485438 & 1222658 & w & w & $\mathrm{H}$ & SUMS & 10 & 57 & 6 & 90 & USGS & 19900425 & 23.8 & 117 & 23 & $<0.1$ \\
\hline $40 \mathrm{~N} / 03 \mathrm{E}-32 \mathrm{~L} 01$ & 485445 & 1222712 & w & w & & SUMS & 10 & 50 & 36 & 87 & USGS & 19900425 & 27.55 & 203 & 4.4 & 12 \\
\hline $40 \mathrm{~N} / 03 \mathrm{E}-32 \mathrm{~L} 03$ & 485443 & 1222711 & w & w & $\mathrm{H}$ & SUMS * & 10 & 41 & 24 & 89 & WCHD & 19910121 & 24.3 & -- & -- & 3.6 \\
\hline \multirow[t]{13}{*}{$40 \mathrm{~N} / 03 \mathrm{E}-32 \mathrm{M} 01$} & 485444 & 1222728 & w & w & $\mathrm{H}$ & SUMS & 10 & 26 & 18 & 76 & USGS & 19900427 & 12.93 & 187 & 8.2 & 11 \\
\hline & & & & & & & & & & & USGS & 19901017 & 15.29 & 181 & 6 & 11 \\
\hline & & & & & & & & & & & USGS & 19901116 & 13.86 & -- & 6.8 & 11 \\
\hline & & & & & & & & & & & USGS & 19901217 & 12.23 & 162 & 6.2 & 8.9 \\
\hline & & & & & & & & & & & USGS & 19910119 & 11.73 & 195 & 7.9 & 11 \\
\hline & & & & & & & & & & & USGS & 19910221 & 11.72 & 194 & 7.4 & 11 \\
\hline & & & & & & & & & & & USGS & 19910313 & 11.91 & 185 & 7.1 & 12 \\
\hline & & & & & & & & & & & USGS & 19910424 & 12.36 & 190 & 8 & 13 \\
\hline & & & & & & & & & & & USGS & 19910521 & 12.80 & 175 & 7.1 & 11 \\
\hline & & & & & & & & & & & USGS & 19910625 & 13.30 & 175 & 6.4 & 10 \\
\hline & & & & & & & & & & & USGS & 19910718 & 12.80 & 184 & 6.7 & 12 \\
\hline & & & & & & & & & & & USGS & 19910823 & 14.55 & 188 & 8 & 12 \\
\hline & & & & & & & & & & & USGS & 19910926 & 14.94 & 190 & 8 & 12 \\
\hline $40 \mathrm{~N} / 03 \mathrm{E}-32 \mathrm{M} 02$ & 485438 & 1222735 & W & W & $\mathrm{H}$ & SUMS & 10 & 23 & 24 & 73 & WCHD & 19910129 & 8.6 & & & \\
\hline $40 \mathrm{~N} / 03 \mathrm{E}-32 \mathrm{P} 01$ & 485427 & 1222717 & w & w & $\mathrm{H}$ & SUMS & 10 & 40 & 6 & 85 & USGS & 19900424 & 17.77 & 153 & 3.2 & 5.6 \\
\hline $40 \mathrm{~N} / 03 \mathrm{E}-32 \mathrm{P} 02$ & 485434 & 1222720 & w & $\mathrm{T}$ & & & & 900 & & 92 & Drill & & -- & -- & $>250$ & -- \\
\hline $40 N / 03 E-32 Q 01$ & 485428 & 1222658 & $\mathrm{~W}$ & W & $\mathrm{H}$ & SUMS & 10 & 25 & 18 & 83 & USGS & 19900322 & 15.47 & 107 & 5.2 & 1.2 \\
\hline
\end{tabular}


जू Appendix Table 1. Well, water-level, hydrogeologic, and reconnaissance water-quality data--Continued

\begin{tabular}{|c|c|c|c|c|c|c|c|c|c|c|c|c|c|c|c|c|}
\hline Local well number & $\begin{array}{l}\text { Lati- } \\
\text { tude }\end{array}$ & $\begin{array}{l}\text { Longi- } \\
\text { tude }\end{array}$ & $\begin{array}{l}\text { Ground } \\
\text { water } \\
\text { site } \\
\text { type }\end{array}$ & $\begin{array}{l}\text { Site } \\
\text { use }\end{array}$ & $\begin{array}{l}\text { Wat- } \\
\text { er } \\
\text { use }\end{array}$ & $\begin{array}{l}\text { Hydro- } \\
\text { geo- } \\
\text { logic } \\
\text { unit }\end{array}$ & $\begin{array}{l}\text { Litho- } \\
\text { logic } \\
\text { unit }\end{array}$ & $\begin{array}{l}\text { Well } \\
\text { depth } \\
\text { (feet) }\end{array}$ & $\begin{array}{l}\text { Well } \\
\text { dia- } \\
\text { meter } \\
\text { (inches) }\end{array}$ & $\begin{array}{l}\text { Alti- } \\
\text { tude } \\
\text { (feet) }\end{array}$ & $\begin{array}{l}\text { Source } \\
\text { of } \\
\text { data }\end{array}$ & $\begin{array}{l}\text { Water- } \\
\text { level or } \\
\text { sample } \\
\text { date }\end{array}$ & $\begin{array}{l}\text { Water } \\
\text { level, } \\
\text { feet below } \\
\text { land surface }\end{array}$ & $\begin{array}{l}\text { Specific } \\
\text { conduc- } \\
\text { tance } \\
(\mu \mathrm{S} / \mathrm{cm})\end{array}$ & $\begin{array}{l}\text { Chloride, } \\
\text { dissolved } \\
(\mathrm{mg} / \mathrm{L} \\
\text { as } \mathrm{Cl})\end{array}$ & $\begin{array}{l}\text { Nitrogen } \\
\mathrm{NO}_{2}+\mathrm{NO}_{3} \\
\text { total } \\
(\mathrm{mg} / \mathrm{L} \text { as N) }\end{array}$ \\
\hline $40 \mathrm{~N} / 03 \mathrm{E}-33 \mathrm{~F} 01$ & 485450 & 1222555 & $\mathrm{~W}$ & W & U & SUMS & 10 & 29 & 12 & 76 & USGS & 19900424 & 17.27 & -- & -- & -- \\
\hline $40 \mathrm{~N} / 03 \mathrm{E}-33 \mathrm{G} 01$ & 485450 & 1222546 & W & $\mathrm{w}$ & $\mathrm{H}$ & SUMS & 10 & 28 & 12 & 74 & USGS & 19900427 & 19.16 & 200 & 6 & 1.3 \\
\hline $40 \mathrm{~N} / 03 \mathrm{E}-33 \mathrm{~J} 02$ & 485446 & 1222517 & w & $\mathrm{w}$ & $\mathrm{H}$ & SUMS & 10 & 33 & 6 & 65 & USGS & 19900425 & 10.54 & 263 & 17 & $<0.1$ \\
\hline $40 \mathrm{~N} / 03 \mathrm{E}-34 \mathrm{E} 01$ & 485454 & 1222504 & W & w & I & SUMS & 11 & 18 & 30 & 58 & USGS & 19900425 & 5.53 & -- & -- & -- \\
\hline $40 \mathrm{~N} / 03 \mathrm{E}-34 \mathrm{P} 01$ & 485427 & 1222429 & $\mathrm{w}$ & w & I & SUMS & 10 & 34 & 36 & 80 & USGS & 19900320 & 9.34 & -- & -- & -- \\
\hline $40 \mathrm{~N} / 03 \mathrm{E}-34 \mathrm{Q} 01$ & 485434 & 1222425 & $\mathrm{x}$ & $\mathrm{T}$ & $\mathrm{U}$ & & & 256 & 6 & 80 & Drill & 19900825 & 19.03 & -- & -- & -- \\
\hline $40 \mathrm{~N} / 03 \mathrm{E}-35 \mathrm{R} 01$ & 485423 & 1222228 & W & $\mathrm{U}$ & $\mathrm{U}$ & SUMS & 10 & 23 & 36 & 108 & USGS & 19900425 & 18.96 & -- & -- & -- \\
\hline $40 \mathrm{~N} / 03 \mathrm{E}-35 \mathrm{R} 02$ & 485425 & 1222232 & w & w & $\mathrm{H}$ & SUMS & 10 & 51 & 6 & 105 & USGS & 19900425 & 20.34 & 392 & 59 & 0.1 \\
\hline $40 \mathrm{~N} / 03 \mathrm{E}-36 \mathrm{~J} 01$ & 485446 & 1222121 & w & $\mathrm{z}$ & $\mathrm{U}$ & SUMS & 10 & 30 & 84 & 90 & USGS & -- & -- & -- & -- & -- \\
\hline $40 \mathrm{~N} / 03 \mathrm{E}-36 \mathrm{~J} 02$ & 485445 & 1222123 & W & w & $\mathrm{P}$ & SUMS & 10 & 32 & 36 & 86 & USGS & 19900426 & 9.9 & -- & -- & -- \\
\hline $40 \mathrm{~N} / 03 \mathrm{E}-36 \mathrm{~J} 03$ & 485446 & 1222117 & $w$ & w & $\mathrm{P}$ & SUMS & 10 & 36 & 36 & 90 & USGS & 19900426 & 10.65 & -- & -- & -- \\
\hline $40 N / 03 E-36 Q 01$ & 485431 & 1222127 & $\mathrm{w}$ & w & $P$ & SUMS & 10 & 45 & 8 & 105 & Drill & 19900426 & 18.2 & 237 & 33 & -- \\
\hline $40 \mathrm{~N} / 04 \mathrm{E}-01 \mathrm{C} 01$ & 485932 & 1221400 & $\mathrm{w}$ & w & I & SUMS & 22 & 119 & 8 & 44 & USGS & 19900515 & -- & -- & -- & -- \\
\hline $40 \mathrm{~N} / 04 \mathrm{E}-01 \mathrm{KO} 2$ & 485900 & 1221350 & W & w & I & SUMS & 22 & 97 & 8 & 40 & USGS & 19900516 & 11.1 & 283 & 10 & $<0.05$ \\
\hline $40 \mathrm{~N} / 04 \mathrm{E}-02 \mathrm{~L} 02$ & 485907 & 1221524 & $\mathrm{w}$ & w & I & SUMS & 22 & 69 & 8 & 35 & USGS & 19900516 & 3.49 & -- & -- & -- \\
\hline $40 \mathrm{~N} / 04 \mathrm{E}-03 \mathrm{~J} 01$ & 485856 & 1221558 & w & $\mathrm{w}$ & I & SUMS & 20 & 59 & 8 & 45 & USGS & 19900518 & 4.83 & -- & -- & -- \\
\hline $40 \mathrm{~N} / 04 \mathrm{E}-04 \mathrm{D} 01$ & 485934 & 1221812 & W & w & $\mathrm{H}$ & SUMS & 14 & 95 & 6 & 154 & USGS & 19900522 & 62.8 & 252 & 7.6 & 8.4 \\
\hline $40 \mathrm{~N} / 04 \mathrm{E}-05 \mathrm{D} 01$ & 485935 & 1221938 & $w$ & $\mathrm{U}$ & $\mathrm{U}$ & SUMS & 10 & 61 & 36 & 183 & USGS & 19790523 & 56.65 & -- & -- & - \\
\hline $40 \mathrm{~N} / 04 \mathrm{E}-05 \mathrm{D} 02$ & 485934 & 1221944 & w & $\mathrm{w}$ & I & SUMS & 10 & 80 & 8 & 181 & USGS & 19900518 & 45.03 & -- & -- & -- \\
\hline $40 \mathrm{~N} / 04 \mathrm{E}-05 \mathrm{E} 01$ & 485910 & 1221932 & w & w & I & SUMS & 10 & 34 & 8 & 95 & USGS & 19900516 & 4.16 & -- & - & -- \\
\hline $40 \mathrm{~N} / 04 \mathrm{E}-05 \mathrm{E} 02$ & 485921 & 1221944 & w & $\mathrm{w}$ & I & SUMS & 10 & 77 & 8 & 162 & USGS & 19900516 & 29.40 & -- & -- & -- \\
\hline $40 \mathrm{~N} / 04 \mathrm{E}-05 \mathrm{~L} 01$ & 485906 & 1221927 & w & w & $\mathrm{H}$ & SUMS & 10 & 38 & 6 & 100 & USGS & -- & -- & -- & 12.8 & -- \\
\hline $40 \mathrm{~N} / 04 \mathrm{E}-05 \mathrm{~N} 01$ & 485846 & 1221935 & W & w & $\mathrm{H}$ & SUMS & 14 & 28 & 6 & 70 & USGS & 19900515 & 14.30 & -- & 4.6 & -- \\
\hline $40 \mathrm{~N} / 04 \mathrm{E}-05 \mathrm{~N} 02$ & 485853 & 1221946 & w & w & $\mathrm{H}$ & SUMS & 14 & 85 & 6 & 139 & USGS & 19900515 & 62.72 & 250 & 6.1 & -- \\
\hline $40 \mathrm{~N} / 04 \mathrm{E}-05 \mathrm{P} 01$ & 485848 & 1221913 & w & w & $\mathrm{H}$ & SUMS & 14 & 23 & 36 & 74 & USGS & 19900530 & 15.72 & 216 & 6.8 & 8.4 \\
\hline $40 \mathrm{~N} / 04 \mathrm{E}-05 \mathrm{P} 02$ & 485850 & 1221914 & w & w & $\mathrm{H}$ & SUMS & 14 & 28 & 36 & 56 & USGS & 19900530 & 14.72 & -- & 13 & -- \\
\hline $40 \mathrm{~N} / 04 \mathrm{E}-06 \mathrm{~B} 01$ & 485935 & 1222017 & w & w & $\mathrm{H}$ & SUMS & 10 & 75 & 6 & 168 & USGS & 19900518 & 31.78 & 134 & 3 & $<0.1$ \\
\hline $40 \mathrm{~N} / 04 \mathrm{E}-06 \mathrm{BO} 2$ & 485935 & 1222023 & W & w & I & SUMS & 10 & 88 & 8 & 166 & USGS & 19900518 & 28.28 & -- & -- & -- \\
\hline $40 \mathrm{~N} / 04 \mathrm{E}-06 \mathrm{G} 01$ & 485911 & 1222021 & $w$ & $\mathrm{w}$ & $\mathrm{H}$ & SUMS & 10 & 32 & 36 & 155 & USGS & 19900522 & 23.21 & -- & -- & -- \\
\hline $40 \mathrm{~N} / 04 \mathrm{E}-06 \mathrm{G} 02$ & 485910 & 1222022 & W & $\mathrm{U}$ & $\mathrm{U}$ & SUMS & 10 & 25 & 6 & 136 & USGS & 19900522 & 8.69 & -- & -- & -- \\
\hline $40 \mathrm{~N} / 04 \mathrm{E}-07 \mathrm{G} 01$ & 485829 & 1222019 & $\mathrm{w}$ & w & C & SUMS & 10 & 78 & 8 & 110 & USGS & 19900522 & 2.39 & - & -- & -- \\
\hline $40 \mathrm{~N} / 04 \mathrm{E}-07 \mathrm{H} 04$ & 485826 & 1221948 & $\mathrm{w}$ & w & $P$ & SUMS & 14 & 89 & -- & 74 & USGS & -- & -- & -- & -- & -- \\
\hline $40 \mathrm{~N} / 04 \mathrm{E}-08 \mathrm{A0} 2$ & 485839 & 1221839 & $\mathrm{~W}$ & w & I & SUMS & 20 & 57 & 10 & 56 & USGS & 19900522 & 7.18 & -- & -- & -- \\
\hline $40 \mathrm{~N} / 04 \mathrm{E}-08 \mathrm{~L} 01$ & 485811 & 1221913 & $\mathrm{~W}$ & $\mathrm{w}$ & I & SUMS & 20 & 58 & 8 & 60 & USGS & 19900524 & 7.37 & -- & -- & -- \\
\hline $40 \mathrm{~N} / 04 \mathrm{E}-09 \mathrm{~B} 01$ & 485830 & 1221732 & $w$ & $\mathrm{w}$ & I & SUMS & 20 & 49 & 9 & 48 & $\begin{array}{l}\text { USGS } \\
\text { USGS } \\
\text { USGS } \\
\text { USGS }\end{array}$ & $\begin{array}{l}19900522 \\
19910314 \\
19910626 \\
19910717\end{array}$ & $\begin{array}{r}0.89 \\
-0.83 \\
0.81 \\
1.77\end{array}$ & 235 & 11 & $<0.1$ \\
\hline
\end{tabular}


Appendix Table 1. Well, water-level, hydrogeologic, and reconnaissance water-quality data--Continued

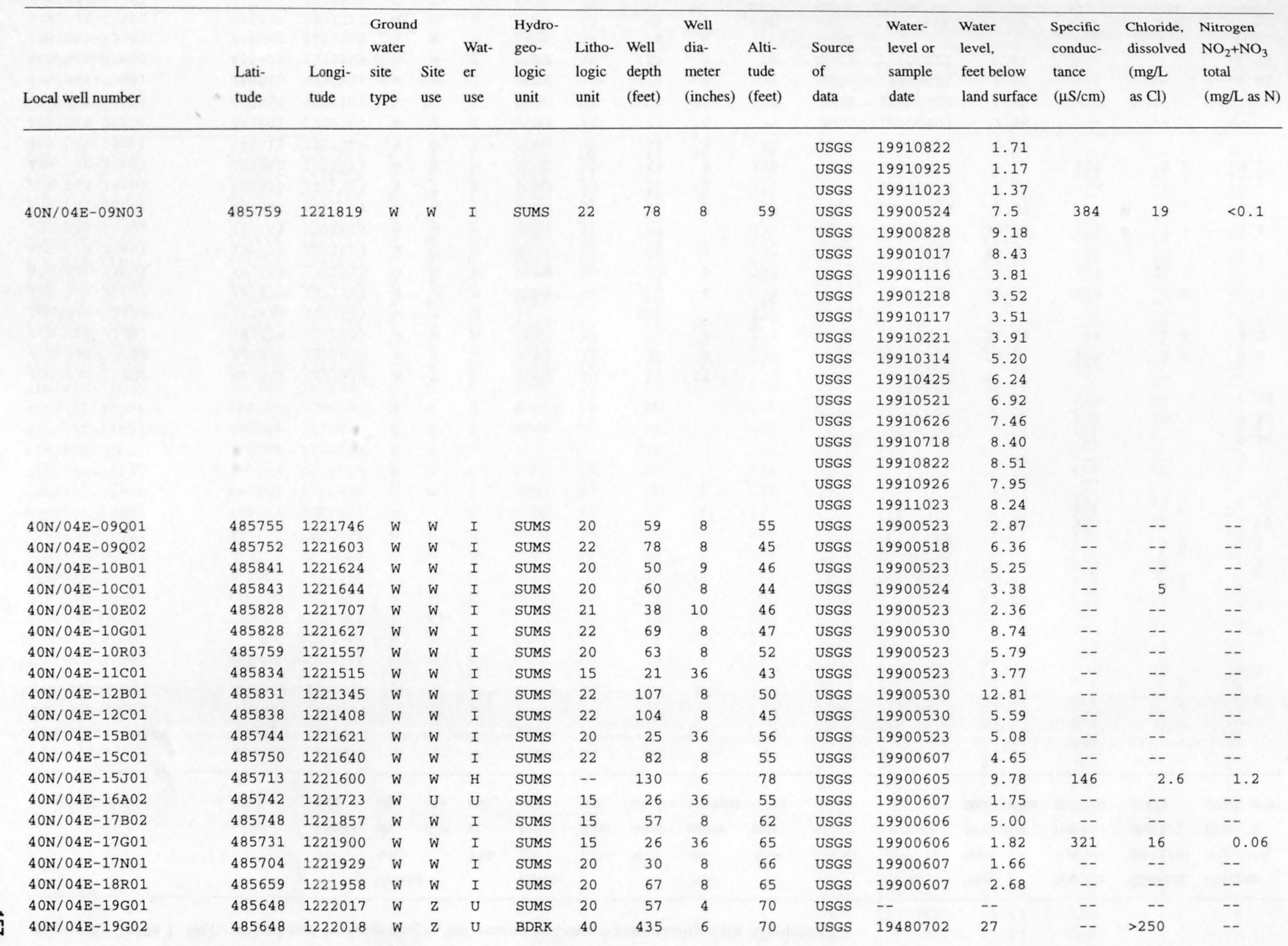


ज़ Appendix Table 1. Well, water-level, hydrogeologic, and reconnaissance water-quality data--Continued

\begin{tabular}{|c|c|c|c|c|c|c|c|c|c|c|c|c|c|c|c|c|}
\hline Local well number & $\begin{array}{l}\text { Lati- } \\
\text { tude }\end{array}$ & $\begin{array}{l}\text { Longi- } \\
\text { tude }\end{array}$ & $\begin{array}{l}\text { Ground } \\
\text { water } \\
\text { site } \\
\text { type }\end{array}$ & $\begin{array}{l}\text { Site } \\
\text { use }\end{array}$ & $\begin{array}{l}\text { Wat- } \\
\text { er } \\
\text { use }\end{array}$ & $\begin{array}{l}\text { Hydro- } \\
\text { geo- } \\
\text { logic } \\
\text { unit }\end{array}$ & $\begin{array}{l}\text { Litho- } \\
\text { logic } \\
\text { unit }\end{array}$ & $\begin{array}{l}\text { Well } \\
\text { depth } \\
\text { (feet) }\end{array}$ & $\begin{array}{l}\text { Well } \\
\text { dia- } \\
\text { meter } \\
\text { (inches) }\end{array}$ & $\begin{array}{l}\text { Alti- } \\
\text { tude } \\
\text { (feet) }\end{array}$ & $\begin{array}{l}\text { Source } \\
\text { of } \\
\text { data }\end{array}$ & $\begin{array}{l}\text { Water- } \\
\text { level or } \\
\text { sample } \\
\text { date }\end{array}$ & $\begin{array}{l}\text { Water } \\
\text { level, } \\
\text { feet below } \\
\text { land surface }\end{array}$ & $\begin{array}{l}\text { Specific } \\
\text { conduc- } \\
\text { tance } \\
(\mu \mathrm{S} / \mathrm{cm})\end{array}$ & $\begin{array}{l}\text { Chloride, } \\
\text { dissolved } \\
(\mathrm{mg} / \mathrm{L} \\
\text { as } \mathrm{Cl})\end{array}$ & $\begin{array}{l}\text { Nitrogen } \\
\mathrm{NO}_{2}+\mathrm{NO}_{3} \\
\text { total } \\
(\mathrm{mg} / \mathrm{L} \text { as } \mathrm{N})\end{array}$ \\
\hline $40 \mathrm{~N} / 04 \mathrm{E}-19 \mathrm{G} 03$ & 485645 & 1222018 & W & $\mathrm{U}$ & $\mathrm{U}$ & SUMS & 20 & 40 & 6 & 70 & USGS & 19900712 & 5.15 & - & -- & -- \\
\hline $40 \mathrm{~N} / 04 \mathrm{E}-19 \mathrm{KO} 1$ & 485626 & 1222026 & W & W & I & SUMS & 20 & 57 & 10 & 70 & USGS & 19900614 & 4.13 & -- & - & -- \\
\hline $40 \mathrm{~N} / 04 \mathrm{E}-20 \mathrm{D} 01$ & 485652 & 1221930 & W & W & I & SUMS & 20 & 57 & 8 & 69 & USGS & 19900607 & 4.94 & -- & -- & -- \\
\hline \multirow[t]{15}{*}{$40 \mathrm{~N} / 04 \mathrm{E}-20 \mathrm{~F} 01$} & 485642 & 1221912 & W & W & $\mathrm{H}$ & SUMS & 15 & 18 & 18 & 72 & USGS & 19900607 & 3.94 & -- & 12 & 0.1 \\
\hline & & & & & & & & & & & USGS & 19900830 & 7.05 & - & 12 & 0.1 \\
\hline & & & & & & & & & & & USGS & 19901017 & 6.74 & 309 & 13 & 0 \\
\hline & & & & & & & & & & & USGS & 19901115 & 2.02 & 267 & 12 & 0.7 \\
\hline & & & & & & & & & & & USGS & 19901217 & 1.15 & 241 & 11 & 1.5 \\
\hline & & & & & & & & & & & USGS & 19910117 & 1.22 & 161 & 9.9 & -- \\
\hline & & & & & & & & & & & USGS & 19910219 & 0.95 & 230 & 10 & 1.5 \\
\hline & & & & & & & & & & & USGS & 19910314 & 2.65 & 252 & 9.9 & 0.8 \\
\hline & & & & & & & & & & & USGS & 19910423 & 3.57 & 260 & 10 & 0.62 \\
\hline & & & & & & & & & & & USGS & 19910522 & 4.50 & 291 & 13 & 0.36 \\
\hline & & & & & & & & & & & USGS & 19910625 & 5.05 & -- & -- & -- \\
\hline & & & & & & & & & & & USGS & 19910717 & 5.92 & -- & -- & -- \\
\hline & & & & & & & & & & & USGS & 19910822 & 6.24 & 320 & -- & 0.14 \\
\hline & & & & & & & & & & & USGS & 19910925 & 5.95 & 306 & 13 & 0.13 \\
\hline & & & & & & & & & & & USGS & 19911023 & 6.36 & 315 & -- & 0.22 \\
\hline $40 \mathrm{~N} / 04 \mathrm{E}-21 \mathrm{~F} 01$ & 485632 & 1221810 & W & $\mathrm{U}$ & $\mathrm{U}$ & SUMS & 10 & 55 & 18 & 130 & USGS & 19900607 & 47.25 & -- & -- & -- \\
\hline $40 \mathrm{~N} / 04 \mathrm{E}-22 \mathrm{G} 01$ & 485639 & 1221618 & $\mathrm{w}$ & W & $\mathrm{H}$ & SUMS & 10 & 42 & 6 & 150 & USGS & 19900621 & 18.02 & 128 & 4.8 & 5.2 \\
\hline $40 \mathrm{~N} / 04 \mathrm{E}-22 \mathrm{~J} 01$ & 485624 & 1221607 & W & W & $\mathrm{H}$ & SUMS & 10 & 56 & 6 & 176 & USGS & 19900608 & 28.14 & 86 & 1.9 & 2.0 \\
\hline $40 \mathrm{~N} / 04 \mathrm{E}-22 \mathrm{~J} 02$ & 485628 & 1221609 & W & $\mathrm{T}$ & $\mathrm{U}$ & -- & & 200 & & 178 & Drill & -- & -- & -- & -- & -- \\
\hline $40 \mathrm{~N} / 04 \mathrm{E}-22 \mathrm{R} 01$ & 485607 & 1221611 & W & $\mathrm{W}$ & $\mathrm{H}$ & VSHN & 50 & 60 & 6 & 178 & USGS & 19900608 & 33.11 & 210 & 1.6 & $<0.1$ \\
\hline $40 \mathrm{~N} / 04 \mathrm{E}-23 \mathrm{~N} 01$ & 485608 & 1221535 & W & W & $\mathrm{H}$ & VSHN & 50 & 82 & 6 & 360 & USGS & 19900606 & 56.72 & 423 & 21 & -- \\
\hline $40 \mathrm{~N} / 04 \mathrm{E}-27 \mathrm{~K} 01$ & 485538 & 1221620 & W & $\mathrm{U}$ & $\mathrm{U}$ & VSHN & 50 & 62 & 6 & 210 & USGS & 19900615 & 22.2 & -- & -- & -- \\
\hline $40 \mathrm{~N} / 04 \mathrm{E}-28 \mathrm{D} 02$ & 485555 & 1221815 & w & w & $\mathrm{H}$ & SUMS & 10 & 67 & & 130 & USGS & 19900613 & 33.86 & 156 & 3.8 & 1.6 \\
\hline $40 \mathrm{~N} / 04 \mathrm{E}-28 \mathrm{H} 01$ & 485544 & 1221714 & W & $\mathrm{W}$ & I & SUMS & 10 & 36 & 8 & 115 & USGS & 19900614 & 0.47 & -- & -- & -- \\
\hline $40 \mathrm{~N} / 04 \mathrm{E}-28 \mathrm{R} 01$ & 485515 & 1221722 & $\mathrm{x}$ & $\mathrm{T}$ & $S$ & SUMS & 10 & 32 & 12 & 111 & USGS & 19900608 & 2.16 & -- & -- & -- \\
\hline $40 \mathrm{~N} / 04 \mathrm{E}-29 \mathrm{HO} 2$ & 485542 & 1221833 & W & W & $\mathrm{H}$ & SUMS & 10 & 59 & 6 & 110 & USGS & 19900614 & 7.11 & 109 & 8.6 & $<0.1$ \\
\hline $40 \mathrm{~N} / 04 \mathrm{E}-29 \mathrm{R} 01$ & 485515 & 1221846 & W & W & I & SUMS & 15 & 31 & 8 & 85 & USGS & 19900614 & 2.58 & & & \\
\hline $40 \mathrm{~N} / 04 \mathrm{E}-30 \mathrm{D} 01$ & 485601 & 1222102 & W & W & I & SUMS & 21 & 27 & 36 & 75 & USGS & 19900807 & 2.84 & -- & -- & -- \\
\hline $40 \mathrm{~N} / 04 \mathrm{E}-30 \mathrm{E} 01$ & 485553 & 1222103 & W & W & I & SUMS & 21 & 33 & 8 & 75 & USGS & 19900807 & 5.82 & -- & -- & -- \\
\hline $40 \mathrm{~N} / 04 \mathrm{E}-30 \mathrm{G} 01$ & 485546 & 1222026 & W & W & I & SUMS & 20 & 37 & 8 & 75 & USGS & 19900621 & 2.55 & 438 & 28 & $<0.05$ \\
\hline $40 \mathrm{~N} / 04 \mathrm{E}-31 \mathrm{R} 02$ & 485429 & 1221959 & w & $\mathrm{w}$ & I & SUMS & 15 & 32 & 8 & 90 & USGS & 19900615 & 6.45 & 393 & 19 & $<0.05$ \\
\hline $40 \mathrm{~N} / 04 \mathrm{E}-33 \mathrm{~A} 03$ & 485505 & 1221718 & $\mathrm{w}$ & w & I & SUMS & 12 & 34 & 8 & 125 & USGS & & & 308 & 5.8 & 2.7 \\
\hline $40 \mathrm{~N} / 04 \mathrm{E}-33 \mathrm{RO} 1$ & 485430 & 1221715 & $w$ & $\mathrm{w}$ & $\mathrm{H}$ & SUMS & 10 & 62 & 6 & 125 & USGS & 19900614 & 33.87 & 284 & 6.8 & 0.9 \\
\hline $40 \mathrm{~N} / 04 \mathrm{E}-34 \mathrm{~F} 01$ & 485454 & 1221651 & w & $\mathrm{w}$ & $\mathrm{H}$ & SUMS & 10 & 51 & 36 & 160 & USGS & 19900614 & 36 & 511 & 3.4 & 1.8 \\
\hline $40 \mathrm{~N} / 04 \mathrm{E}-34 \mathrm{PO} 1$ & 485433 & 1221648 & $w$ & w & c & suMs & 12 & 57 & & 150 & USGS & 19900614 & 27.07 & 235 & 6.4 & 1.2 \\
\hline
\end{tabular}


Appendix Table 1. Well, water-level, hydrogeologic, and reconnaissance water-quality data--Continued

\begin{tabular}{|c|c|c|c|c|c|c|c|c|c|c|c|c|c|c|c|c|}
\hline Local well number & $\begin{array}{l}\text { Lati- } \\
\text { tude }\end{array}$ & $\begin{array}{l}\text { Longi- } \\
\text { tude }\end{array}$ & $\begin{array}{l}\text { Ground } \\
\text { water } \\
\text { site } \\
\text { type }\end{array}$ & $\begin{array}{l}\text { Site } \\
\text { use }\end{array}$ & $\begin{array}{l}\text { Wat- } \\
\text { er } \\
\text { use }\end{array}$ & $\begin{array}{l}\text { Hydro- } \\
\text { geo- } \\
\text { logic } \\
\text { unit }\end{array}$ & $\begin{array}{l}\text { Litho- } \\
\text { logic } \\
\text { unit }\end{array}$ & $\begin{array}{l}\text { Well } \\
\text { depth } \\
\text { (feet) }\end{array}$ & $\begin{array}{l}\text { Well } \\
\text { dia- } \\
\text { meter } \\
\text { (inches) }\end{array}$ & $\begin{array}{l}\text { Alti- } \\
\text { tude } \\
\text { (feet) }\end{array}$ & $\begin{array}{l}\text { Source } \\
\text { of } \\
\text { data }\end{array}$ & $\begin{array}{l}\text { Water- } \\
\text { level or } \\
\text { sample } \\
\text { date }\end{array}$ & $\begin{array}{l}\text { Water } \\
\text { level, } \\
\text { feet below } \\
\text { land surface }\end{array}$ & $\begin{array}{l}\text { Specific } \\
\text { conduc- } \\
\text { tance } \\
(\mu \mathrm{S} / \mathrm{cm})\end{array}$ & $\begin{array}{l}\text { Chloride, } \\
\text { dissolved } \\
(\mathrm{mg} / \mathrm{L} \\
\text { as } \mathrm{Cl})\end{array}$ & $\begin{array}{l}\text { Nitrogen } \\
\mathrm{NO}_{2}+\mathrm{NO}_{3} \\
\text { total } \\
(\mathrm{mg} / \mathrm{L} \text { as } \mathrm{N})\end{array}$ \\
\hline $40 \mathrm{~N} / 05 \mathrm{E}-06 \mathrm{D} 01$ & 485932 & 1221253 & W & w & I & SUMS & 20 & 43 & 36 & 38 & USGS & 19900510 & 5.6 & -- & -- & -- \\
\hline $40 \mathrm{~N} / 05 \mathrm{E}-06 \mathrm{~K} 01$ & 485907 & 1221214 & W & 0 & $\mathrm{z}$ & SUMS & 23 & 7 & 1 & 32 & USGS & 19910702 & 4.3 & 301 & 11 & $<0.05$ \\
\hline $40 \mathrm{~N} / 05 \mathrm{E}-06 \mathrm{~L} 02$ & 485859 & 1221251 & W & W & I & SUMS & 22 & 74 & 8 & 37 & USGS & 19900510 & 6.95 & -- & -- & -- \\
\hline $40 \mathrm{~N} / 05 \mathrm{E}-06 \mathrm{M} 01$ & 485859 & 1221307 & W & w & I & SUMS & 22 & 90 & 8 & 38 & USGS & -- & -- & -- & -- & -- \\
\hline $41 \mathrm{~N} / 02 \mathrm{E}-33 \mathrm{~J} 01$ & 485958 & 1223301 & W & $\mathrm{w}$ & $\mathrm{H}$ & EVRS & 30 & 79 & 6 & 250 & USGS & 19900810 & 48.27 & 498 & 39 & -- \\
\hline $41 \mathrm{~N} / 02 \mathrm{E}-35 \mathrm{P} 01$ & 485939 & 1223106 & W & w & $\mathrm{H}$ & EVRS & 30 & 73 & & 160 & USGS & 19900815 & 28.43 & 328 & 27 & $<0.1$ \\
\hline $41 \mathrm{~N} / 02 \mathrm{E}-35 \mathrm{Q} 02$ & 485944 & 1223049 & W & $\mathrm{T}$ & $\mathrm{U}$ & & & 424 & & 150 & Drill & -- & -- & -- & -- & -- \\
\hline $41 \mathrm{~N} / 02 \mathrm{E}-36 \mathrm{~J} 01$ & 485954 & 1222908 & W & $\mathrm{U}$ & $\mathrm{U}$ & SUMS & 12 & 24 & & 129 & USGS & 19900814 & 6.29 & -- & -- & -- \\
\hline $41 \mathrm{~N} / 02 \mathrm{E}-36 \mathrm{~K} 01$ & 485954 & 1222936 & W & w & I & SUMS & 10 & 29 & 36 & 129 & USGS & 19900814 & 7.80 & 229 & 18 & 6.6 \\
\hline $41 \mathrm{~N} / 02 \mathrm{E}-36 \mathrm{MO} 1$ & 485957 & 1223002 & W & w & I & SUMS & 10 & 30 & 36 & 134 & USGS & 19900814 & 24.5 & -- & -- & -- \\
\hline $41 \mathrm{~N} / 03 \mathrm{E}-31 \mathrm{E} 01$ & 490008 & 1222900 & W & w & $\mathrm{H}$ & SUMS & 10 & 30 & 6 & 141 & USGS & 19900629 & 7.02 & 218 & 14 & 12 \\
\hline $41 \mathrm{~N} / 03 \mathrm{E}-31001$ & 485944 & 1222820 & W & W & I & SUMS & 11 & 33 & & 136 & USGS & 19900629 & 3.61 & -- & -- & -- \\
\hline $41 \mathrm{~N} / 03 \mathrm{E}-32 \mathrm{Q} 01$ & 485949 & 1222700 & W & W & $\mathrm{H}$ & SUMS & 10 & 25 & & 137 & USGS & 19900725 & 9.85 & 517 & 15 & -- \\
\hline $41 \mathrm{~N} / 03 \mathrm{E}-33 \mathrm{E} 01$ & 490005 & 1222620 & W & W & $s$ & SUMS & 10 & 43 & 6 & 146 & USGS & 19900629 & 8.70 & 312 & 16 & 2.3 \\
\hline $41 \mathrm{~N} / 03 \mathrm{E}-33 \mathrm{G} 01$ & 490008 & 1222538 & W & $\mathrm{T}$ & & & & 283 & & 141 & Drill & -- & -- & -- & -- & -- \\
\hline $41 \mathrm{~N} / 03 \mathrm{E}-34 \mathrm{~F} 01$ & 490008 & 1222427 & W & W & $\mathrm{H}$ & SUMS & 10 & 22 & & 146 & USGS & 19900705 & 9.79 & 436 & 14 & 15 \\
\hline $41 \mathrm{~N} / 03 \mathrm{E}-34 \mathrm{G} 01$ & 490003 & 1222420 & W & W & I & SUMS & 10 & 38 & 8 & 141 & USGS & 19900705 & 3.73 & -- & -- & -- \\
\hline $41 \mathrm{~N} / 03 \mathrm{E}-34 \mathrm{M} 01$ & 490002 & 1222443 & W & W & $\mathrm{H}$ & SUMS & 10 & 20 & 36 & 141 & USGS & 19900705 & 4.60 & 388 & 9.5 & 20 \\
\hline $41 \mathrm{~N} / 03 \mathrm{E}-34 \mathrm{Q} 01$ & 485938 & 1222404 & W & w & $\mathrm{H}$ & SUMS & 10 & 61 & 6 & 146 & USGS & 19900706 & 9.62 & 198 & 5.8 & $<0.1$ \\
\hline $41 \mathrm{~N} / 03 \mathrm{E}-35 \mathrm{~L} 01$ & 485957 & 1222304 & W & w & $\mathrm{H}$ & SUMS & 10 & 25 & 6 & 158 & USGS & 19900709 & -- & 271 & 8.4 & 20 \\
\hline $41 \mathrm{~N} / 03 \mathrm{E}-36 \mathrm{~J} 01$ & 485951 & 1222106 & W & W & $\mathrm{H}$ & SUMS & 10 & 37 & 18 & 163 & USGS & 19900706 & 26.3 & 146 & 5.2 & 9.9 \\
\hline $41 \mathrm{~N} / 03 \mathrm{E}-36 \mathrm{~J} 02$ & 485953 & 1222109 & W & w & $\mathrm{H}$ & SUMS & 10 & 92 & 6 & 162 & USGS & 19900607 & 25.00 & 120 & 6.2 & $<0.1$ \\
\hline $41 \mathrm{~N} / 03 \mathrm{E}-36 \mathrm{~N} 01$ & 485946 & 1222218 & W & W & I & SUMS & 10 & 26 & 36 & 159 & USGS & 19900706 & 12.48 & -- & -- & -- \\
\hline $41 \mathrm{~N} / 04 \mathrm{E}-31 \mathrm{~J} 01$ & 485952 & 1221947 & W & U & $\mathrm{U}$ & SUMS & 10 & 59 & 6 & 175 & USGS & -- & -- & -- & -- & -- \\
\hline \multirow[t]{14}{*}{$41 \mathrm{~N} / 04 \mathrm{E}-31 \mathrm{~J} 02$} & 485955 & 1221949 & W & W & $\mathrm{H}$ & SUMS & 10 & 80 & 8 & 185 & USGS & 19900508 & 44.62 & 199 & 6.5 & 13 \\
\hline & & & & & & & & & & & USGS & 19901018 & 50.31 & 231 & 7.4 & 14 \\
\hline & & & & & & & & & & & USGS & 19901114 & 50.45 & 244 & 7.2 & 2.9 \\
\hline & & & & & & & & & & & USGS & 19901218 & 46.4 & 232 & 6.6 & 13 \\
\hline & & & & & & & & & & & USGS & 19910117 & 43.77 & 234 & 6.7 & 13 \\
\hline & & & & & & & & & & & USGS & 19910219 & 43.54 & 220 & 7.1 & 11 \\
\hline & & & & & & & & & & & USGS & 19910314 & 43.01 & 215 & 6.7 & 10 \\
\hline & & & & & & & & & & & USGS & 19910423 & 43.39 & 212 & 7 & 8.1 \\
\hline & & & & & & & & & & & USGS & 19910521 & 44.08 & 215 & 7.1 & 8.6 \\
\hline & & & & & & & & & & & USGS & 19910625 & 45.28 & 224 & 8.4 & 10 \\
\hline & & & & & & & & & & & USGS & 19910717 & 46.33 & 200 & 6.4 & 11 \\
\hline & & & & & & & & & & & USGS & 19910822 & 46.89 & 225 & 6 & 13 \\
\hline & & & & & & & & & & & USGS & 19910929 & 48.92 & 224 & 7 & 13 \\
\hline & & & & & & & & & & & USGS & 19911023 & 49.79 & 219 & 6 & -- \\
\hline
\end{tabular}


क् Appendix Table 1. Well, water-level, hydrogeologic, and reconnaissance water-quality data--Continued

\begin{tabular}{|c|c|c|c|c|c|c|c|c|c|c|c|c|c|c|c|c|}
\hline Local well number & $\begin{array}{l}\text { Lati- } \\
\text { tude }\end{array}$ & $\begin{array}{l}\text { Longi- } \\
\text { tude }\end{array}$ & $\begin{array}{l}\text { Ground } \\
\text { water } \\
\text { site } \\
\text { type }\end{array}$ & Site & $\begin{array}{l}\text { Wat- } \\
\text { er } \\
\text { use }\end{array}$ & $\begin{array}{l}\text { Hydro- } \\
\text { geo- } \\
\text { logic } \\
\text { unit }\end{array}$ & $\begin{array}{l}\text { Litho- } \\
\text { logic } \\
\text { unit }\end{array}$ & $\begin{array}{l}\text { Well } \\
\text { depth } \\
\text { (feet) }\end{array}$ & $\begin{array}{l}\text { Well } \\
\text { dia- } \\
\text { meter } \\
\text { (inches) }\end{array}$ & $\begin{array}{l}\text { Alti- } \\
\text { tude } \\
\text { (feet) }\end{array}$ & $\begin{array}{l}\text { Source } \\
\text { of } \\
\text { data }\end{array}$ & $\begin{array}{l}\text { Water- } \\
\text { level or } \\
\text { sample } \\
\text { date }\end{array}$ & $\begin{array}{l}\text { Water } \\
\text { level, } \\
\text { feet below } \\
\text { land surface }\end{array}$ & $\begin{array}{l}\text { Specific } \\
\text { conduc- } \\
\text { tance } \\
(\mu \mathrm{S} / \mathrm{cm})\end{array}$ & $\begin{array}{l}\text { Chloride, } \\
\text { dissolved } \\
(\mathrm{mg} / \mathrm{L} \\
\text { as } \mathrm{Cl})\end{array}$ & $\begin{array}{l}\text { Nitrogen } \\
\mathrm{NO}_{2}+\mathrm{NO}_{3} \\
\text { total } \\
(\mathrm{mg} / \mathrm{L} \text { as } \mathrm{N} \text { ) }\end{array}$ \\
\hline $41 \mathrm{~N} / 04 \mathrm{E}-31 \mathrm{R} 01$ & 485945 & 1221952 & W & W & I & SUMS & 10 & 71 & 8 & 174 & USGS & 19900509 & 33.37 & -- & -- & -- \\
\hline $41 \mathrm{~N} / 04 \mathrm{E}-31 \mathrm{R} 02$ & 485946 & 1221944 & W & W & $\mathrm{H}$ & SUMS & 10 & 77 & & 169 & USGS & 19900509 & 33.63 & 180 & 5.8 & 3.4 \\
\hline $41 \mathrm{~N} / 04 \mathrm{E}-32 \mathrm{E} 01$ & 490003 & 1221942 & W & $\mathrm{T}$ & & & & 400 & & 206 & Drill & -- & -- & -- & -- & -- \\
\hline $41 \mathrm{~N} / 04 \mathrm{E}-32 \mathrm{M} 01$ & 485953 & 1221937 & W & W & $\mathrm{H}$ & SUMS & 10 & 95 & 8 & 189 & USGS & 19900510 & 49.81 & -- & -- & -- \\
\hline $41 \mathrm{~N} / 04 \mathrm{E}-32 \mathrm{Q} 01$ & 485948 & 1221853 & W & W & $\mathrm{H}$ & SUMS & 10 & 26 & & 132 & USGS & 19900508 & 6.46 & 273 & 8.4 & 15 \\
\hline $41 \mathrm{~N} / 04 \mathrm{E}-32 \mathrm{R} 01$ & 485944 & 1221838 & W & W & $\mathrm{H}$ & SUMS & 14 & 92 & 6 & 194 & USGS & 19900516 & 76.70 & 308 & 8.8 & 15 \\
\hline $41 \mathrm{~N} / 04 \mathrm{E}-33 \mathrm{H} 01$ & 490004 & 1221717 & $\mathrm{~W}$ & w & $P$ & SUMS & 20 & 58 & 8 & 48 & USGS & 19900604 & Flow & 259 & 7.4 & 2 \\
\hline $41 \mathrm{~N} / 04 \mathrm{E}-33 \mathrm{H} 01 \mathrm{~S}$ & 490003 & 1221715 & $\mathrm{~s}$ & & $\mathrm{U}$ & SUMS & -- & -- & -- & 46 & USGS & 19900604 & Flow & 243 & 6.2 & 5 \\
\hline $41 \mathrm{~N} / 04 \mathrm{E}-33 \mathrm{H} 02$ & 490003 & 1221718 & W & $\mathrm{W}$ & $\mathrm{P}$ & SUMS & 20 & 58 & 12 & 48 & USGS & 19900604 & Flow & 268 & 7 & 6.3 \\
\hline $41 \mathrm{~N} / 04 \mathrm{E}-33 \mathrm{H} 03$ & 490006 & 1221718 & $\mathrm{~W}$ & w & $\mathrm{P}$ & SUMS & 20 & 58 & 12 & 49 & USGS & 19900604 & Flow & 265 & 7.2 & 6.3 \\
\hline $41 \mathrm{~N} / 04 \mathrm{E}-33 \mathrm{H} 04$ & 490005 & 1221716 & W & W & $P$ & SUMS & 20 & 69 & & 50 & USGS & 19900604 & Flow & 274 & 7.2 & 5.1 \\
\hline \multirow[t]{13}{*}{$41 \mathrm{~N} / 04 \mathrm{E}-33 \mathrm{~N} 02$} & 485947 & 1221820 & $\mathrm{~W}$ & $\mathrm{~T}$ & $\mathrm{U}$ & SUMS & 14 & 87 & 6 & 119 & USGS & 19900508 & 18.91 & -- & -- & -- \\
\hline & & & & & & & & & & & USGS & 19901017 & 21.97 & -- & -- & -- \\
\hline & & & & & & & & & & & USGS & 19901114 & 21.95 & -- & -- & -- \\
\hline & & & & & & & & & & & USGS & 19901201 & 19.85 & -- & -- & -- \\
\hline & & & & & & & & & & & USGS & 19910117 & 18.14 & -- & -- & -- \\
\hline & & & & & & & & & & & USGS & 19910219 & 18.08 & -- & -- & -- \\
\hline & & & & & & & & & & & USGS & 19910315 & 18.06 & -- & -- & -- \\
\hline & & & & & & & & & & & USGS & 19910522 & 18.88 & -- & -- & -- \\
\hline & & & & & & & & & & & USGS & 19910626 & 19.43 & -- & -- & -- \\
\hline & & & & & & & & & & & USGS & 19910717 & 19.84 & -- & -- & -- \\
\hline & & & & & & & & & & & USGS & 19910821 & 20.53 & -- & -- & -- \\
\hline & & & & & & & & & & & USGS & 19910925 & 21.11 & -- & -- & -- \\
\hline & & & & & & & & & & & USGS & 19911023 & 21.69 & -- & -- & -- \\
\hline $41 \mathrm{~N} / 04 \mathrm{E}-33 \mathrm{~N} 03$ & 485948 & 1221803 & W & $\mathrm{T}$ & $\mathrm{U}$ & SUMS & 14 & 76 & 6 & 86 & USGS & 19900509 & Flow & -- & -- & -- \\
\hline $41 \mathrm{~N} / 04 \mathrm{E}-33 \mathrm{~N} 04$ & 485946 & 1221803 & W & $\mathrm{T}$ & $\mathrm{U}$ & SUMS & 14 & 72 & 6 & 87 & USGS & 19900509 & Flow & 148 & 9.2 & -- \\
\hline \multirow[t]{11}{*}{$41 \mathrm{~N} / 04 \mathrm{E}-33 \mathrm{~N} 05$} & 485938 & 1221803 & W & $\mathrm{T}$ & $\mathrm{U}$ & SUMS & 14 & 73 & 6 & 109 & USGS & 19900508 & 22.86 & -- & -- & -- \\
\hline & & & & & & & & & & & USGS & 19901017 & 24.80 & -- & -- & -- \\
\hline & & & & & & & & & & & USGS & 19901114 & 24.72 & -- & -- & -- \\
\hline & & & & & & & & & & & USGS & 19901217 & 23.23 & -- & -- & -- \\
\hline & & & & & & & & & & & USGS & 19910117 & 21.98 & -- & -- & -- \\
\hline & & & & & & & & & & & USGS & 19910219 & 22.20 & -- & -- & -- \\
\hline & & & & & & & & & & & USGS & 19910315 & 22.22 & -- & -- & -- \\
\hline & & & & & & & & & & & USGS & 19910522 & 22.83 & -- & -- & -- \\
\hline & & & & & & & & & & & USGS & 19910626 & 23.21 & -- & -- & -- \\
\hline & & & & & & & & & & & USGS & 19910717 & 23.50 & -- & -- & -- \\
\hline & & & & & & & & & & & $\begin{array}{l}\text { USGS } \\
\text { USGS }\end{array}$ & $\begin{array}{l}19910821 \\
19910925\end{array}$ & $\begin{array}{l}23.92 \\
24.31\end{array}$ & -- & -- & -- \\
\hline
\end{tabular}


Appendix Table 1. Well, water-level, hydrogeologic, and reconnaissance water-quality data--Continued

\begin{tabular}{|c|c|c|c|c|c|c|c|c|c|c|c|c|c|c|c|c|c|}
\hline Local well number & $\rightarrow$ & $\begin{array}{l}\text { Lati- } \\
\text { tude }\end{array}$ & $\begin{array}{l}\text { Longi- } \\
\text { tude }\end{array}$ & $\begin{array}{l}\text { Ground } \\
\text { water } \\
\text { site } \\
\text { type }\end{array}$ & $\begin{array}{l}\text { Site } \\
\text { use }\end{array}$ & $\begin{array}{l}\text { Wat- } \\
\text { er } \\
\text { use }\end{array}$ & $\begin{array}{l}\text { Hydro- } \\
\text { geo- } \\
\text { logic } \\
\text { unit }\end{array}$ & $\begin{array}{l}\text { Litho- } \\
\text { logic } \\
\text { unit }\end{array}$ & $\begin{array}{l}\text { Well } \\
\text { depth } \\
\text { (feet) }\end{array}$ & $\begin{array}{l}\text { Well } \\
\text { dia- } \\
\text { meter } \\
\text { (inches) }\end{array}$ & $\begin{array}{l}\text { Alti- } \\
\text { tude } \\
\text { (feet) }\end{array}$ & $\begin{array}{l}\text { Source } \\
\text { of } \\
\text { data }\end{array}$ & $\begin{array}{l}\text { Water- } \\
\text { level or } \\
\text { sample } \\
\text { date }\end{array}$ & $\begin{array}{l}\text { Water } \\
\text { level, } \\
\text { feet below } \\
\text { land surface }\end{array}$ & $\begin{array}{l}\text { Specific } \\
\text { conduc- } \\
\text { tance } \\
(\mu \mathrm{S} / \mathrm{cm})\end{array}$ & $\begin{array}{l}\text { Chloride, } \\
\text { dissolved } \\
(\mathrm{mg} / \mathrm{L} \\
\text { as } \mathrm{Cl})\end{array}$ & $\begin{array}{l}\text { Nitrogen } \\
\mathrm{NO}_{2}+\mathrm{NO}_{3} \\
\text { total } \\
(\mathrm{mg} / \mathrm{L} \text { as } \mathrm{N})\end{array}$ \\
\hline & & & & & & & & & & & & USGS & 19911023 & 24.64 & -- & -- & -- \\
\hline $41 \mathrm{~N} / 04 \mathrm{E}-36 \mathrm{H} 01$ & & 490004 & 1221309 & w & $\mathrm{T}$ & U & & & 167 & 8 & 35 & USGS & -- & -- & -- & -- & -- \\
\hline $41 \mathrm{~N} / 04 \mathrm{E}-36 \mathrm{~L} 01$ & & 485954 & 1221343 & w & $\mathrm{W}$ & I & SUMS & 22 & 63 & 8 & 30 & USGS & 19900509 & 6.41 & -- & -- & -- \\
\hline $41 \mathrm{~N} / 05 \mathrm{E}-31 \mathrm{M} 01$ & & 485959 & 1221247 & W & W & I & SUMS & 22 & 71 & 8 & 35 & USGS & 19900515 & 5.81 & -- & -- & -- \\
\hline $41 \mathrm{~N} / 05 \mathrm{E}-31 \mathrm{~N} 02$ & & 485942 & 1221252 & W & W & I & SUMS & 22 & 78 & 8 & 30 & USGS & 19900509 & 8.2 & -- & -- & -- \\
\hline $41 \mathrm{~N} / 05 \mathrm{E}-31 \mathrm{P} 01$ & & 485944 & 1221226 & $\mathrm{w}$ & $\mathrm{W}$ & $I$ & SUMS & 22 & 95 & 8 & 34 & USGS & 19900510 & 8.91 & -- & -- & -- \\
\hline $41 \mathrm{~N} / 05 \mathrm{E}-32 \mathrm{~L} 01$ & & 485953 & 1221059 & W & W & $I$ & SUMS & 15 & 34 & 8 & 27 & USGS & 19900510 & 7.6 & -- & -- & -- \\
\hline $41 \mathrm{~N} / 05 \mathrm{E}-32 \mathrm{~L} 02$ & & 490000 & 1221108 & $\mathrm{x}$ & $\mathrm{z}$ & $\mathrm{U}$ & - & & 180 & 8 & 27 & USGS & -- & $\ldots$ & -- & -- & -- \\
\hline
\end{tabular}


Appendix Table 2. Data used to estimate hydraulic conductivity, by hydrogeologic unit and local well number

\begin{tabular}{|c|c|c|c|c|c|c|}
\hline $\begin{array}{l}\text { Local } \\
\text { well number }\end{array}$ & $\begin{array}{l}\text { Casing } \\
\text { diameter } \\
\text { (inches) }\end{array}$ & $\begin{array}{l}\text { Screen } \\
\text { length } \\
\text { (feet) }\end{array}$ & $\begin{array}{l}\text { Discharge } \\
\text { (gallons } \\
\text { per minute) }\end{array}$ & $\begin{array}{l}\text { Drawdown } \\
\quad \text { (feet) }\end{array}$ & $\begin{array}{l}\text { Time } \\
\text { (minutes) }\end{array}$ & $\begin{array}{l}\text { Hydraulic } \\
\text { conductivity } \\
\text { (feet } \\
\text { per day) }\end{array}$ \\
\hline \multicolumn{7}{|l|}{$\underline{\text { Sumas aquifer }}$} \\
\hline 092G.008.2.2.2-11 & 6 & 5 & 25 & 10.0 & 360 & 80 \\
\hline 092G.008.2.2.2-15 & 36 & 4 & 21 & 8.0 & 120 & 52 \\
\hline 092G.008.2.2.3-03 & 6 & 5 & 12 & 26.0 & 90 & 9.9 \\
\hline 092G.008.2.4.1-41 & 6 & 5 & 30 & 22.0 & 480 & 42 \\
\hline 092G.009.2.1.1-38 & 12 & 20 & 1,100 & 22.6 & 4,300 & 560 \\
\hline 092G.009.2.3.1-32 & 6 & 5 & 20 & 10.0 & 120 & 55 \\
\hline 39N/02E-01P02 & 36 & 1 & 85 & 2.5 & 60 & 350 \\
\hline 39N/02E-02A01 & 6 & 5 & 12 & 16.0 & 30 & 14 \\
\hline 39N/02E-10J01 & 36 & 1 & 100 & 10.0 & 60 & 100 \\
\hline 39N/02E-12Q01 & 6 & 5 & 30 & 20.0 & 60 & 36 \\
\hline 39N/02E-14M01 & 36 & 1 & 175 & 12.0 & 240 & 150 \\
\hline 39N/02E-16A01 & 12 & 4 & 20 & 1.0 & 240 & 830 \\
\hline $39 \mathrm{~N} / 02 \mathrm{E}-16 \mathrm{H} 03$ & 12 & 4 & 20 & 9.0 & 240 & 71 \\
\hline $39 \mathrm{~N} / 02 \mathrm{E}-21 \mathrm{~K} 01$ & 8 & 3 & 100 & 4.0 & 60 & 13 \\
\hline $39 \mathrm{~N} / 02 \mathrm{E}-22 \mathrm{D} 02$ & 6 & 5 & 20 & 8.2 & 120 & 69 \\
\hline $39 \mathrm{~N} / 02 \mathrm{E}-22 \mathrm{~K} 02$ & 6 & 9 & 5 & 5.0 & 60 & 13 \\
\hline $39 \mathrm{~N} / 02 \mathrm{E}-23 \mathrm{~F} 01$ & 12 & 10 & 30 & 4.0 & 240 & 110 \\
\hline 39N/02E-23G02 & 36 & 3 & 7 & 3.5 & 60 & 40 \\
\hline $39 \mathrm{~N} / 02 \mathrm{E}-24 \mathrm{CO} 2$ & 12 & 4 & 30 & 2.0 & 240 & 600 \\
\hline $39 \mathrm{~N} / 02 \mathrm{E}-24 \mathrm{~N} 02$ & 12 & 10 & 15 & 2.0 & 480 & 120 \\
\hline $39 \mathrm{~N} / 02 \mathrm{E}-26 \mathrm{C} 01$ & 36 & 2 & 200 & 14.0 & 48 & 890 \\
\hline $39 \mathrm{~N} / 02 \mathrm{E}-26 \mathrm{~N} 01$ & 36 & 6 & 50 & 5.0 & 120 & 170 \\
\hline $39 \mathrm{~N} / 02 \mathrm{E}-27 \mathrm{~F} 03$ & 6 & 5 & 18 & 4.0 & 180 & 140 \\
\hline 39N/02E-27J01 & 36 & 6 & 20 & 1.5 & 120 & 240 \\
\hline $39 \mathrm{~N} / 02 \mathrm{E}-27 \mathrm{~K} 01$ & 18 & 6 & 16 & 7.5 & 240 & 40 \\
\hline $39 \mathrm{~N} / 02 \mathrm{E}-27 \mathrm{~N} 01$ & 12 & 6 & 80 & 6.0 & 240 & 350 \\
\hline 39N/02E-28J02 & 18 & 6 & 25 & 4.0 & 240 & 140 \\
\hline $39 \mathrm{~N} / 02 \mathrm{E}-28 \mathrm{~J} 03$ & 18 & 6 & 60 & 4.0 & 120 & 340 \\
\hline 39N/03E-01D01 & 36 & 9 & 120 & 5.0 & 240 & 350 \\
\hline 39N/03E-01R01 & 6 & 2 & 18 & 1.0 & 240 & 170 \\
\hline 39N/03E-02B02 & 6 & 8 & 14 & 17.0 & 240 & 15 \\
\hline $39 \mathrm{~N} / 03 \mathrm{E}-02 \mathrm{~N} 02$ & 6 & 1 & 10 & 10.0 & 60 & 61 \\
\hline 39N/03E-03R02 & 8 & 2 & 32 & 5.0 & 120 & 480 \\
\hline 39N/03E-04M02 & 6 & 6 & 10 & 1.0 & 30 & 240 \\
\hline 39N/03E-04R02 & 36 & 1 & 88 & 10.0 & 360 & 90 \\
\hline 39N/03E-07A01 & 36 & 1 & 265 & 21.0 & 120 & 120 \\
\hline 39N/03E-07K02 & 36 & 6 & 40 & 3.0 & 240 & 270 \\
\hline 39N/03E-08C01 & 36 & 1 & 100 & 6.0 & 720 & 170 \\
\hline $39 \mathrm{~N} / 03 \mathrm{E}-08 \mathrm{~F} 02$ & 12 & 1 & 20 & 1.0 & 240 & 613 \\
\hline 39N/03E-09D02 & 8 & 10 & 85 & 5.0 & 300 & 310 \\
\hline 39N/03E-10E01 & 6 & 5 & 15 & 7.0 & 180 & 63 \\
\hline $39 \mathrm{~N} / 03 \mathrm{E}-10 \mathrm{H} 02$ & 6 & 5 & 15 & 6.0 & 120 & 71 \\
\hline $39 \mathrm{~N} / 03 \mathrm{E}-11 \mathrm{~A} 02$ & 6 & 5 & 10 & 4.0 & 30 & 59 \\
\hline 39N/03E-12D02 & 6 & 3 & 18 & 4.0 & 240 & 25 \\
\hline
\end{tabular}


Appendix Table 2. Data used to estimate hydraulic conductivity, by hydrogeologic unit and local well number--Continued

\begin{tabular}{lllllll}
\hline & Casing & Screen & Discharge & & & Hydraulic \\
Local & diameter & length & (gallons & Drawdown & Time & $\begin{array}{l}\text { conductivity } \\
\text { (feet }\end{array}$ \\
well number & (inches) & (feet) & per minute) & (feet) & (minutes) & per day)
\end{tabular}

Sumas aquifer--Cont.

\begin{tabular}{|c|c|c|c|c|c|c|}
\hline 39N/03E-15D02 & 12 & 8 & 60 & 2.0 & 360 & 670 \\
\hline $39 \mathrm{~N} / 03 \mathrm{E}-16 \mathrm{~B} 02$ & 12 & 5 & 20 & 6.0 & 240 & 90 \\
\hline $39 \mathrm{~N} / 03 \mathrm{E}-16 \mathrm{~F} 01$ & 36 & 1 & 85 & 10.0 & 60 & 87 \\
\hline 39N/03E-17R03 & 6 & 5 & 13 & 16.0 & 30 & 16 \\
\hline 39N/03E-18Q01 & 36 & 1 & 50 & 7.0 & 60 & 73 \\
\hline $39 \mathrm{~N} / 03 \mathrm{E}-23 \mathrm{~A} 01$ & 6 & 3 & 15 & 1.5 & 60 & 510 \\
\hline 39N/03E-23E01 & 12 & 3 & 20 & 4.0 & 240 & 240 \\
\hline 39N/03E-24B01 & 36 & 3 & 24 & 0.5 & 1,200 & 2,700 \\
\hline $39 \mathrm{~N} / 03 \mathrm{E}-34 \mathrm{~N} 01$ & 12 & 2 & 8 & 2.5 & 240 & 220 \\
\hline 39N/04E-16Q02 & 6 & 5 & 17 & 20.0 & 360 & 24 \\
\hline $39 \mathrm{~N} / 04 \mathrm{E}-17 \mathrm{C} 01$ & 6 & 5 & 25 & 1.0 & 120 & 900 \\
\hline $39 \mathrm{~N} / 04 \mathrm{E}-20 \mathrm{H} 01$ & 6 & 5 & 15 & 1.7 & 180 & 300 \\
\hline 39N/04E-20M03 & 6 & 10 & 10 & 2.0 & 180 & 80 \\
\hline 39N/04E-22L01 & 6 & 1 & 16 & 1.0 & 60 & 981 \\
\hline 39N/04E-29H01 & 5 & 5 & 10 & 13.2 & 120 & 19 \\
\hline 40N/02E-02Q01 & 36 & 8 & 200 & 10.0 & 240 & 320 \\
\hline $40 \mathrm{~N} / 02 \mathrm{E}-10 \mathrm{~N} 02$ & 6 & 5 & 20 & 4.0 & 30 & 130 \\
\hline 40N/02E-11G01 & 36 & 8 & 180 & 10.0 & 240 & 280 \\
\hline $40 \mathrm{~N} / 02 \mathrm{E}-12 \mathrm{C} 01$ & 36 & 8 & 320 & 11.0 & 240 & 490 \\
\hline 40N/02E-12L01 & 36 & 5 & 300 & 15.0 & 240 & 510 \\
\hline 40N/02E-13H01 & 36 & 8 & 160 & 9.0 & 240 & 280 \\
\hline 40N/02E-15J01 & 36 & 1 & 15 & 6.0 & 480 & 26 \\
\hline 40N/02E-15P01 & 36 & 4 & 300 & 7.0 & 240 & 1,500 \\
\hline $40 \mathrm{~N} / 02 \mathrm{E}-21 \mathrm{~J} 01$ & 36 & 1 & 85 & 10.0 & 60 & 87 \\
\hline 40N/02E-21R01 & 36 & 1 & 85 & 10.0 & 60 & 87 \\
\hline 40N/02E-21R02 & 36 & 1 & 85 & 10.0 & 60 & 87 \\
\hline 40N/02E-22E02 & 36 & 4 & 50 & 13.0 & 60 & 70 \\
\hline 40N/02E-22R02 & 6 & 9 & 10 & 3.0 & 480 & 63 \\
\hline $40 \mathrm{~N} / 02 \mathrm{E}-23 \mathrm{C} 01$ & 18 & 6 & 12 & 5.0 & 240 & 46 \\
\hline 40N/02E-23D02 & 6 & 5 & 7 & 22.0 & 120 & 6.8 \\
\hline 40N/02E-23Q01 & 36 & 8 & 160 & 6.0 & 240 & 440 \\
\hline $40 \mathrm{~N} / 02 \mathrm{E}-27 \mathrm{~B} 01$ & 18 & 6 & 25 & 4.0 & 240 & 140 \\
\hline 40N/02E-27N02 & 36 & 6 & 180 & 8.0 & 240 & 490 \\
\hline 40N/02E-33B02 & 36 & 3 & 210 & 5.0 & 60 & 2,000 \\
\hline 40N/02E-35G01 & 36 & 4 & 120 & 3.0 & 240 & 1,400 \\
\hline 40N/03E-01R01 & 36 & 8 & 200 & 6.0 & 240 & 570 \\
\hline 40N/03E-02B03 & 8 & 16 & 120 & 4.5 & 30 & 250 \\
\hline 40N/03E-02M02 & 8 & 15 & 200 & 3.0 & 30 & 730 \\
\hline 40N/03E-02N01 & 36 & 1 & 140 & 3.0 & 240 & 480 \\
\hline 40N/03E-03A02 & 6 & 20 & 5 & 2.0 & 240 & 19 \\
\hline 40N/03E-03R02 & 8 & 21 & 200 & 5.5 & 30 & 270 \\
\hline 40N/03E-03R03 & 10 & 20 & 150 & 8.0 & 30 & 130 \\
\hline 40N/03E-05E01 & 36 & 1 & 170 & 2.5 & 60 & 700 \\
\hline $40 \mathrm{~N} / 03 \mathrm{E}-05 \mathrm{~N} 01$ & 8 & 1 & 26 & 0.2 & 300 & 4,800 \\
\hline
\end{tabular}


Appendix Table 2. Data used to estimate hydraulic conductivity, by hydrogeologic unit and local well number--Continued

\begin{tabular}{|c|c|c|c|c|c|c|}
\hline $\begin{array}{l}\text { Local } \\
\text { well number }\end{array}$ & $\begin{array}{l}\text { Casing } \\
\text { diameter } \\
\text { (inches) }\end{array}$ & $\begin{array}{l}\text { Screen } \\
\text { length } \\
\text { (feet) }\end{array}$ & $\begin{array}{l}\text { Discharge } \\
\text { (gallons } \\
\text { per minute) }\end{array}$ & $\begin{array}{l}\text { Drawdown } \\
\quad \text { (feet) }\end{array}$ & $\begin{array}{l}\text { Time } \\
\text { (minutes) }\end{array}$ & $\begin{array}{l}\text { Hydraulic } \\
\text { conductivit } \\
\text { (feet } \\
\text { per day) }\end{array}$ \\
\hline \multicolumn{7}{|c|}{ Sumas aquifer--Cont. } \\
\hline 40N/03E-07A02 & 18 & 1 & 85 & 7.0 & 60 & 250 \\
\hline 40N/03E-07M03 & 8 & 5 & 50 & 8.0 & 60 & 170 \\
\hline 40N/03E-08N03 & 36 & 8 & 160 & 14.0 & 240 & 170 \\
\hline 40N/03E-09A04 & 36 & 12 & 150 & 6.0 & 120 & 250 \\
\hline 40N/03E-09D01 & 36 & 8 & 200 & 6.0 & 240 & 510 \\
\hline 40N/03E-09G01 & 6 & 10 & 30 & 8.0 & 120 & 56 \\
\hline 40N/03E-11E03 & 18 & 1 & 500 & 6.0 & 60 & 1,700 \\
\hline 40N/03E-11E04 & 6 & 3 & 27 & 3.0 & 240 & 530 \\
\hline $40 \mathrm{~N} / 03 \mathrm{E}-12 \mathrm{~A} 05$ & 10 & 10 & 300 & 15.0 & 120 & 32 \\
\hline 40N/03E-16A02 & 12 & 10 & 40 & 2.0 & 30 & 26 \\
\hline 40N/03E-16D01 & 36 & 8 & 250 & 12.0 & 240 & 340 \\
\hline 40N/03E-16F01 & 12 & 3 & 20 & 4.0 & 60 & 200 \\
\hline 40N/03E-16H04 & 6 & 5 & 20 & 1.0 & 30 & 620 \\
\hline 40N/03E-16K01 & 36 & 1 & 85 & 4.0 & 60 & 220 \\
\hline 40N/03E-16Q01 & 8 & 11 & 50 & 5.0 & 30 & 130 \\
\hline 40N/03E-17E01 & 36 & 8 & 160 & 8.0 & 600 & 360 \\
\hline 40N/03E-18E01 & 36 & 15 & 250 & 10.0 & 120 & 200 \\
\hline 40N/03E-18G01 & 36 & 30 & 150 & 6.0 & 60 & 90 \\
\hline 40N/03E-19A01 & 8 & 15 & 75 & 12.0 & 30 & 52 \\
\hline 40N/03E-25J01 & 8 & 5 & 200 & 3.0 & 60 & 3,900 \\
\hline 40N/03E-26H01 & 36 & 8 & 200 & 5.0 & 240 & 700 \\
\hline $40 \mathrm{~N} / 03 \mathrm{E}-31 \mathrm{~N} 02$ & 6 & 6 & 20 & 8.2 & 120 & 58 \\
\hline 40N/03E-31P03 & 18 & 6 & 40 & 4.0 & 120 & 210 \\
\hline $40 \mathrm{~N} / 03 \mathrm{E}-32 \mathrm{~K} 02$ & 6 & 5 & 15 & 12.0 & 240 & 36 \\
\hline 40N/03E-32L01 & 36 & 9 & 12 & 6.0 & 120 & 16 \\
\hline 40N/03E-32M01 & 18 & 6 & 10 & 4.0 & 120 & 43 \\
\hline 40N/03E-32P01 & 6 & 3 & 12 & 15.0 & 120 & 33 \\
\hline 40N/03E-32Q01 & 18 & 6 & 10 & 3.0 & 240 & 67 \\
\hline 40N/03E-33G01 & 12 & 10 & 5 & 3.0 & 480 & 22 \\
\hline 40N/03E-33J02 & 6 & 3 & 10 & 1.0 & 30 & 470 \\
\hline 40N/03E-34P01 & 36 & 12 & 440 & 8.0 & 120 & 610 \\
\hline 40N/03E-35R02 & 6 & 5 & 20 & 1.0 & 30 & 690 \\
\hline 40N/03E-36J01 & 84 & 1 & 350 & 10.0 & 270 & 150 \\
\hline 40N/03E-36J02 & 36 & 16 & 350 & 8.5 & 90 & 320 \\
\hline 40N/03E-36J03 & 36 & 1 & 250 & 4.0 & 240 & 640 \\
\hline 40N/04E-01C01 & 8 & 15 & 200 & 10.8 & 120 & 350 \\
\hline 40N/04E-01K02 & 8 & 88 & 225 & 3.0 & 30 & 240 \\
\hline 40N/04E-02L02 & 8 & 10 & 160 & 3.0 & 60 & 1,526 \\
\hline 40N/04E-03J01 & 8 & 10 & 150 & 4.0 & 60 & 1,100 \\
\hline 40N/04E-04D01 & 24 & 9 & 12 & 6.0 & 90 & 18 \\
\hline 40N/04E-05L01 & 6 & 3 & 16 & 4.0 & 60 & 180 \\
\hline 40N/04E-05N01 & 6 & 1 & 10 & 4.0 & 240 & 150 \\
\hline 40N/04E-05P01 & 36 & 1 & 85 & 2.0 & 60 & 440 \\
\hline 40N/04E-07G01 & 8 & 15 & 200 & 2.5 & 30 & 900 \\
\hline
\end{tabular}


Appendix Table 2. Data used to estimate hydraulic conductivity, by hydrogeologic unit and local well number--Continued

\begin{tabular}{|c|c|c|c|c|c|c|}
\hline $\begin{array}{l}\text { Local } \\
\text { well number }\end{array}$ & $\begin{array}{l}\text { Casing } \\
\text { diameter } \\
\text { (inches) }\end{array}$ & $\begin{array}{l}\text { Screen } \\
\text { length } \\
\text { (feet) }\end{array}$ & $\begin{array}{l}\text { Discharge } \\
\text { (gallons } \\
\text { per minute) }\end{array}$ & $\begin{array}{l}\text { Drawdown } \\
\text { (feet) }\end{array}$ & $\begin{array}{l}\text { Time } \\
\text { (minutes) }\end{array}$ & $\begin{array}{l}\text { Hydraulic } \\
\text { conductivity } \\
\text { (feet } \\
\text { per day) }\end{array}$ \\
\hline
\end{tabular}

Sumas aquifer--Cont.

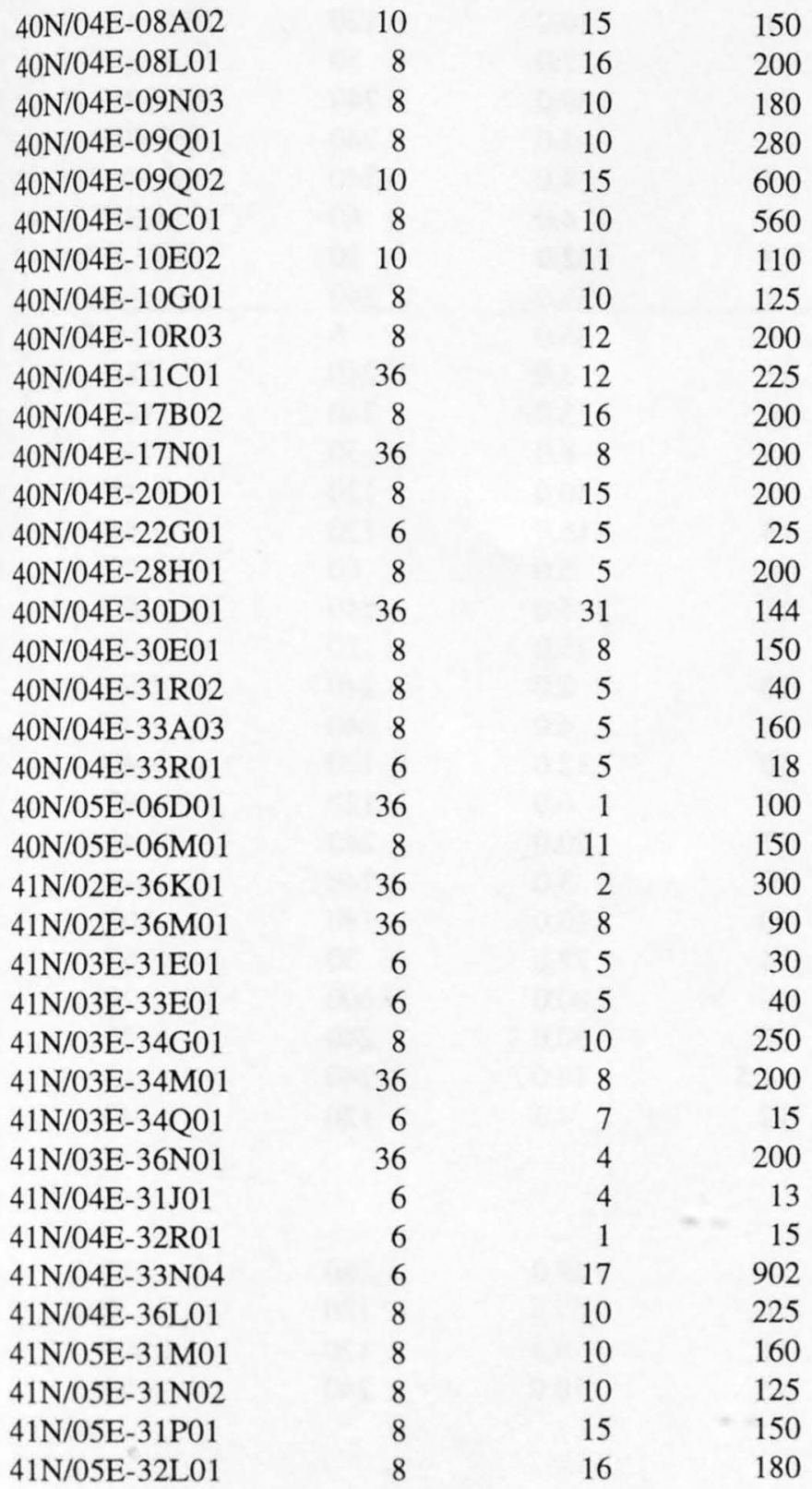

$\begin{array}{rrr}1.5 & 60 & 1,900 \\ 0.5 & 30 & 7,700 \\ 2.0 & 30 & 2,600 \\ 5.0 & 240 & 1,700 \\ 12.0 & 120 & 960\end{array}$

$\begin{array}{lll}7.0 & 240 & 2,500\end{array}$

$\begin{array}{lll}20.0 & 240 & 130\end{array}$

$\begin{array}{lll}5.0 & 60 & 690\end{array}$

$\begin{array}{lll}2.0 & 30 & 2,400\end{array}$

$\begin{array}{lll}9.0 & 240 & 280\end{array}$

$\begin{array}{lll}2.0 & 30 & 1,100\end{array}$

$\begin{array}{lll}10.0 & 240 & 610\end{array}$

$\begin{array}{lll}0.8 & 30 & 5,200\end{array}$

$\begin{array}{lrr}3.0 & 180 & 280\end{array}$

$\begin{array}{lll}5.5 & 30 & 1,100\end{array}$

$21.0 \quad 240 \quad 50$

$\begin{array}{lll}4.0 & 30 & 1,400\end{array}$

$\begin{array}{lll}0.7 & 180 & 2,200\end{array}$

$\begin{array}{lll}20.0 & 240 & 260\end{array}$

$\begin{array}{lll}3.3 & 180 & 180\end{array}$

$\begin{array}{lll}16.0 & 60 & 64\end{array}$

$\begin{array}{lll}4.0 & 30 & 920\end{array}$

$\begin{array}{lll}3.0 & 240 & 7,800\end{array}$

$\begin{array}{lll}16.0 & 240 & 74\end{array}$

$\begin{array}{lll}11.2 & 240 & 83\end{array}$

$\begin{array}{lll}3.0 & 60 & 420\end{array}$

$\begin{array}{lll}6.0 & 30 & 650\end{array}$

$6.0 \quad 240 \quad 570$

$\begin{array}{lll}4.5 & 120 & 66\end{array}$

$\begin{array}{lll}5.0 & 240 & 1,400\end{array}$

$\begin{array}{lll}1.9 & 720 & 370\end{array}$

$\begin{array}{lll}1.5 & 240 & 610\end{array}$

$\begin{array}{lll}39.0 & 1,002 & 290\end{array}$

$\begin{array}{lll}30.0 & 60 & 190\end{array}$

$\begin{array}{lll}5.0 & 60 & 890\end{array}$

$\begin{array}{lll}3.0 & 60 & 1,200\end{array}$

$\begin{array}{lll}4.0 & 60 & 730\end{array}$

$\begin{array}{lll}4.0 & 30 & 460\end{array}$

Everson-Vashon unit

092G.008.1.2.1-2

092G.008.1.2.3-10

$38 \mathrm{~N} / 04 \mathrm{E}-06 \mathrm{D} 01$

6
8
6

8
11
1

15

30

5
28.5

155.0

102.0
240

90

240
17 3.5

3 
Appendix Table 2. Data used to estimate hydraulic conductivity, by hydrogeologic unit and local well number--Continued

\begin{tabular}{|c|c|c|c|c|c|c|}
\hline $\begin{array}{l}\text { Local } \\
\text { well number }\end{array}$ & $\begin{array}{l}\text { Casing } \\
\text { diameter } \\
\text { (inches) }\end{array}$ & $\begin{array}{l}\text { Screen } \\
\text { length } \\
\text { (feet) }\end{array}$ & $\begin{array}{l}\text { Discharge } \\
\text { (gallons } \\
\text { per minute) }\end{array}$ & $\begin{array}{l}\text { Drawdown } \\
\text { (feet) }\end{array}$ & $\begin{array}{l}\text { Time } \\
\text { (minutes) }\end{array}$ & $\begin{array}{l}\text { Hydraulic } \\
\text { conductivity } \\
\text { (feet } \\
\text { per day) }\end{array}$ \\
\hline \multicolumn{7}{|c|}{ Everson-Vashon unit--Cont. } \\
\hline $39 \mathrm{~N} / 02 \mathrm{E}-24 \mathrm{Q} 01$ & 6 & 10 & 17 & 10.0 & 120 & 43 \\
\hline 39N/02E-24R02 & 6 & 4 & 10 & 7.0 & 30 & 80 \\
\hline 39N/03E-19N01 & 6 & 4 & 20 & 39.0 & 240 & 36 \\
\hline 39N/03E-19Q01 & 6 & 3 & 12 & 2.0 & 240 & 570 \\
\hline 39N/03E-20F02 & 6 & 1 & 7 & 4.0 & 240 & 100 \\
\hline 39N/03E-22M01 & 6 & 1 & 15 & 4.0 & 60 & 230 \\
\hline 39N/03E-23M01 & 6 & 5 & 9 & 62.0 & 30 & 5.4 \\
\hline $39 \mathrm{~N} / 03 \mathrm{E}-25 \mathrm{~A} 01$ & 6 & 2 & 4 & 85.0 & 240 & 4.8 \\
\hline 39N/03E-25E01 & 6 & 3 & 4 & 45.0 & 6 & 4.5 \\
\hline 39N/03E-26D01 & 6 & 5 & 15 & 3.0 & 240 & 280 \\
\hline 39N/03E-26P02 & 6 & 5 & 10 & 3.0 & 240 & 180 \\
\hline $39 \mathrm{~N} / 03 \mathrm{E}-27 \mathrm{H} 02$ & 6 & 1 & 15 & 8.0 & 30 & 120 \\
\hline 39N/03E-28F01 & 6 & 1 & 15 & 50.0 & 120 & 18 \\
\hline $39 \mathrm{~N} / 03 \mathrm{E}-28 \mathrm{Q} 02$ & 6 & 3 & 15 & 15.0 & 120 & 81 \\
\hline $39 \mathrm{~N} / 03 \mathrm{E}-29 \mathrm{C} 01$ & 6 & 5 & 20 & 5.0 & 60 & 200 \\
\hline 39N/03E-29D01 & 6 & 1 & 15 & 5.0 & 240 & 180 \\
\hline 39N/03E-30N01 & 6 & 5 & 35 & 15.0 & 120 & 120 \\
\hline 39N/03E-31R03 & 6 & 5 & 10 & 2.0 & 240 & 280 \\
\hline $39 \mathrm{~N} / 03 \mathrm{E}-32 \mathrm{E} 01$ & 6 & 5 & 10 & 4.0 & 240 & 130 \\
\hline 39N/03E-32J01 & 6 & 5 & 10 & 12.0 & 120 & 40 \\
\hline 39N/03E-34Q01 & 6 & 5 & 11 & 6.0 & 120 & 93 \\
\hline $39 \mathrm{~N} / 03 \mathrm{E}-36 \mathrm{~B} 01$ & 8 & 5 & 17 & 20.0 & 240 & 41 \\
\hline 39N/03E-36P01 & 6 & 1 & 20 & 3.0 & 240 & 410 \\
\hline 39N/04E-32A01 & 6 & 5 & 20 & 10.0 & 180 & 100 \\
\hline $39 \mathrm{~N} / 04 \mathrm{E}-32 \mathrm{~N} 01$ & 6 & 1 & 24 & 22.0 & 30 & 67 \\
\hline $40 \mathrm{~N} / 02 \mathrm{E}-02 \mathrm{~B} 01$ & 8 & 11 & 60 & 80.0 & 9,600 & 20 \\
\hline 40N/02E-03K01 & 6 & 9 & 80 & 30.0 & 240 & 80 \\
\hline 40N/02E-09H01 & 6 & 5 & 4.5 & 16.0 & 240 & 13 \\
\hline 41N/02E-33J01 & 6 & 5 & 12 & 4.3 & 120 & 140 \\
\hline \multicolumn{7}{|l|}{ Vashon unit } \\
\hline 39N/04E-10D01 & 6 & 1 & 6 & 29.0 & 180 & 12 \\
\hline 39N/04E-22F01 & 6 & 5 & 4 & 65.5 & 120 & 2.4 \\
\hline 40N/04E-22R01 & 6 & 5 & 15 & 0.5 & 120 & 1,800 \\
\hline 40N/04E-23N01 & 6 & 1 & 15 & 10.0 & 240 & 92 \\
\hline \multicolumn{7}{|l|}{$\underline{\text { Bedrock unit }}$} \\
\hline 39N/03E-13R01 & 6 & 1 & 25 & 20.0 & 60 & 77 \\
\hline 39N/03E-15C02 & 6 & 1 & 2 & 87.0 & 180 & 1.4 \\
\hline 39N/03E-23J01 & 6 & 45 & 11 & 2.0 & 180 & 34 \\
\hline 39N/03E-33R01 & 6 & 1 & 5 & 40.0 & 240 & 7.7 \\
\hline 39N/04E-18E01 & 6 & 102 & 20 & 73.0 & 240 & 0.62 \\
\hline
\end{tabular}


Appendix Table 2. Data used to estimate hydraulic conductivity, by hydrogeologic unit and local well number--Continued

\begin{tabular}{lcccccc}
\hline & $\begin{array}{l}\text { Casing } \\
\text { Local } \\
\text { diameter } \\
\text { (inches) }\end{array}$ & $\begin{array}{l}\text { Screen } \\
\text { length } \\
\text { (feet) }\end{array}$ & $\begin{array}{l}\text { Discharge } \\
\text { (gallons } \\
\text { per minute) }\end{array}$ & $\begin{array}{c}\text { Drawdown } \\
\text { (feet) }\end{array}$ & $\begin{array}{c}\text { Time } \\
\text { (minutes) }\end{array}$ & $\begin{array}{l}\text { Hydraulic } \\
\text { conductivity } \\
\text { (feet } \\
\text { per day) }\end{array}$ \\
\hline Bedrock--Cont. & & & & & & \\
39N/04E-18M01 & 6 & 135 & 20 & 39.0 & 180 & 0.90 \\
39N/04E-19C01 & 6 & 124 & 1.7 & 60.0 & 30 & 0.01 \\
39N/04E-19E02 & 6 & 91 & 15 & 76.0 & 180 & 0.48 \\
39N/04E-19F02 & 8 & 140 & 2 & 150.0 & 60 & 0.01 \\
39N/04E-19M01 & 6 & 135 & 2 & 132.0 & 180 & 0.02 \\
39N/04E-29A01 & 6 & 1 & 1 & 200.0 & 60 & 0.0013 \\
39N/04E-32F01 & 6 & 103 & 2 & 225.0 & 60 & \\
\hline
\end{tabular}


Appendix Table 3. Lithologic logs used in construction of hydrogeologic sections

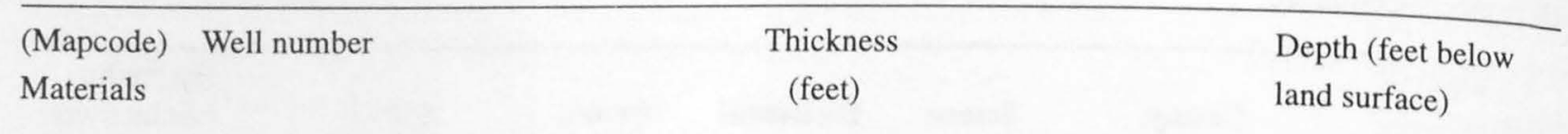

AG 092G.008.1.4.2-01. Altitude 300 feet. Drilled, L Johnson, 1972

Clay, brown $\quad 20$

Clay, blue

17

Clay, blue, and sandy

Clay, blue, and silty

Till, clayey

Clay, blue, and stoney

Till

Sand, water bearing, saltwater

40

Clay and till

Sand, water bearing, and saltwater

36

372

Clay and pebbles

Sand, fine, and silt

Sand, compact

Sand, water bearing

Clay

AJ 092G.008.1.4.4-03. Altitude 305 feet. Drilled by Linder's Well Drilling, 1980.

Clay, brown

16

Clay, blue

74

16

Till

Sand, water bearing, and gravel

Sand, water bearing

AK

Topsoil

Gravel, sandy, and clay

$$
6
$$

Sand, silty, and clay

Sand, silty, and some gravel

Sand and gravel

AL 092G.008.2.1.1-04. Altitude 180 feet. Drilled by John Beers Construction, 1984.

Topsoil 
Appendix Table 3. Lithologic logs used in construction of hydrogeologic sections--Continued

\begin{tabular}{|c|c|c|c|}
\hline $\begin{array}{l}\text { (Mapcode) } \\
\text { Materials }\end{array}$ & Well number & $\begin{array}{l}\text { Thickness } \\
\text { (feet) }\end{array}$ & $\begin{array}{l}\text { Depth (feet below } \\
\text { land surface) }\end{array}$ \\
\hline
\end{tabular}

\section{Gravel}

Clay, stoney

Till

Sand

Silt, clay layers

$\begin{array}{rr}1 & 19 \\ 33 & 52 \\ 4 & 56 \\ 7 & 63 \\ 5 & 68\end{array}$

AO 092G.008.2.1.3-08. Altitude 240 feet. Drilled 1986.

Sand

323

Clay, brown

Clay, blue

73

87

Till

3

90

Clay, stoney

Boulders

Clay, blue

2

Clay, blue, and layers of water bearing silt

Till

Till with layers of water bearing silt

AZ $\quad$ 092G.008.2.2.4-16. Altitude 170 feet. Drilled by Linder's Well Drilling, 1985.

Sand

2

Clay

Sand, water bearing, and gravel

Clay, blue

Till with layers of silt, water bearing

Clay

BN 092G.008.2.4.2-14. Altitude 330 feet.

Drilled by Valley Water, 1981.

\section{Clay}

Gravel

Till

Clay, sandy

Gravel 
Appendix Table 3. Lithologic logs used in construction of hydrogeologic sections--Continued

\begin{tabular}{lcc}
\hline $\begin{array}{l}\text { (Mapcode) } \\
\text { Materials }\end{array}$ & $\begin{array}{c}\text { Thickness } \\
\text { (feet) }\end{array}$ & $\begin{array}{c}\text { Depth (feet below } \\
\text { land surface) }\end{array}$ \\
\hline Till & 35 & 115 \\
Sand, water bearing & 14 & 129
\end{tabular}

BQ 092G.008.2.4.4-10. Altitude 345 feet. Drilled by Western Water Wells, 1960.

Boulders and gravel, with sand $\quad 35$

Gravel, fine to medium, and sand 25

Sand, with some gravel $\quad 5$

Sand, silty

Sand, fine to medium, and gravel

Sand, silty, and fine

Sand, silty, with saturated gravel

Sand

Clay, sandy, with some gravel

Boulders

2

Clay, stickey, with some gravel

Sand, silty, and bearing water

Clay, blue, with pebbles

BW 092G.008.4.2.2-27. Altitude 400 feet.

Drilled by Valley Water, 1981.

Clay, brown, and sandy

Clay, blue, and stoney 20

Gravel, dry

Sand, brown, water bearing

Sand, grey, water bearing

CE 092G.009.1.1.2-12-75. Altitude 168 feet. Drilled by Langley Water Wells, 1988.

Topsoil

Sand and gravel, with lenses of sand

\section{CM} 092G.009.1.1.4-19-75. Altitude 170 feet.

Drilled by Langley Water Wells, 1988.

Topsoil

Sand and gravel, with lenses of sand 
Appendix Table 3. Lithologic logs used in construction of hydrogeologic sections--Continued

\begin{tabular}{lccl}
\hline (Mapcode) & Well number & Thickness & Depth (feet below \\
Materials & (feet) & land surface)
\end{tabular}

CQ 092G.009.1.2.1-ABB4 Altitude 213 feet. Drilled 1988.

Sand and gravel, red-brown

Sand, grey, very coarse

20.9

Sand, grey, fine to very coarse

12.5

33.4

Sand, very fine

10.7

44.1

Sand, coarse

0.50

44.6

7.90

52.5

Sand, grey, fine to very coarse, some silt

0.40

52.9

Sand, grey, very fine, silty

6.10

59.0

Sand, grey, very fine

2.80

61.8

Sand, grey, fine to very coarse

13.0

74.8

Sand and gravel, very fine to coarse, cobbles

0.90

75.7

Sand, very fine to very coarse

4.20

79.9

Sand, greenish-grey, coarse

Sand and gravel, grey, very coarse

7.00

86.9

9.10

96.0

DB 092G.009.1.2.4-31. Altitude 240 feet. Drilled by A \& H, 1970.

Soil

Gravel

Sand

Clay, blue

Sand and gravel

Sand

Sand and gravel

4

77

11

40

13

DI

092G.009.1.3.4-34. Altitude 195 feet.

Drilled by Linder's Well Drilling, 1985.

\section{Unknown}

Sand and gravel, water bearing

Sand, fine, water bearing

Sand and gravel, water bearing

DW

092G.009.3.1.2-20.

Altitude 375 feet.

Drilled by Valley Well Drilling, 1970. 
Appendix Table 3. Lithologic logs used in construction of hydrogeologic sections--Continued

\begin{tabular}{lcc}
\hline $\begin{array}{l}\text { Mapcode) } \\
\text { Materials }\end{array}$ & $\begin{array}{c}\text { Thickness } \\
\text { (feet) }\end{array}$ & $\begin{array}{c}\text { Depth (feet below } \\
\text { land surface) }\end{array}$ \\
\hline Clay, grey, hardpan, and till & 21 & 24 \\
Clay, blue, and sand & 11 & 35 \\
Clay, grey, and sand & 15 & 50 \\
Clay, blue & 10 & 60 \\
Clay, grey, and fine gravel & 45 & 105 \\
Sand, fine, and water & 7 & 112 \\
Clay, blue, fine gravel, and seepage & 40 & 152
\end{tabular}

DX 092G.009.3.1.2-23. Altitude 215 feet. Drilled by Hi-land, 1974.

Gravel 32 32

Clay

DY 38N/03E-04E01. Altitude 308 feet.

Drilled by Hayes Well Drilling \& Pumps, Inc., 1981.

Topsoil 2 2

Clay, tan 13

Clay, grey

Clay, grey, gravel, and sand

Gravel, dry, and little clay

Sand, dry, and little clay

Sand, medium, and dry

Gravel, dry, and sand, course

Sand, little clay, and water

Sand, medium, and water

Sandstone, green

Sandstone, brown

Sandstone, grey

Topsoil

Hardpan

Clay, blue

Clay, black, and fine

Sand, fine, and clay strips 
Appendix Table 3. Lithologic logs used in construction of hydrogeologic sections--Continued

\begin{tabular}{lccc}
\hline (Mapcode) & Well number & Thickness & Depth (feet below \\
Materials & (feet) & land surface)
\end{tabular}

EB 39N/02E-01N01. Altitude 75 feet. Drilled by Don Mulka, 1951.

Topsoil

Sand

$\mathrm{EC}$

39N/02E-01P02.

Sandy loam

Sand, coarse

Sand, fine

Sand, coarse

ED 39N/02E-01Q01.

Sandy loam

Sand

EA 39N/02E-05B02.

Sand, brown

Sand and gravel, brown

Sand

Clay, silty

Clay, silty, shells, and gravel

Clay, silty, and gravel

Sand and gravel with clay, silty

Clay, silty, with sand and gravel

Sand, clay, silty, and gravel

Clay, silty, sand, and gravel

Bedrock at bottom of hole

EI

39N/02E-10F01.

Topsoil

Gravel, sandy brown

Sand, gravel, and water

Clay and silt, fine

$\begin{array}{rr}2 & 2 \\ 23 & 25\end{array}$

Altitude 80 feet. Drilled by Snowden Well Digging, 1974.

$\begin{array}{cl}2 & 2 \\ 24 & 26 \\ 5 & 31 \\ 2.5 & 33.5\end{array}$

Altitude 80 feet. Drilled by G. A. Wetzel, 1951.

$3-3$

$28 \quad 31$

Altitude 60 feet. Drilled by Hayes Well Drilling \& Pumps, Inc., 1981.

$\begin{array}{rr}5 & 5 \\ 10 & 15 \\ 20 & 35 \\ 125 & 160 \\ 40 & 200 \\ 175 & 375 \\ 210 & 585 \\ 50 & 635 \\ 45 & 680 \\ 55 & 735\end{array}$

Altitude 55 feet. Drilled by B \& C Well Drilling Inc., 1987.

78

$12 \quad 20$

22 
Appendix Table 3. Lithologic logs used in construction of hydrogeologic sections--Continued

\begin{tabular}{lcc}
\hline $\begin{array}{l}\text { (Mapcode) Well number } \\
\text { Materials }\end{array}$ & $\begin{array}{c}\text { Thickness } \\
\text { (feet) }\end{array}$ & $\begin{array}{c}\text { Depth (feet below } \\
\text { land surface) }\end{array}$ \\
\hline EM 39 N/02E-11B02. & Altitude 71 feet. & Drilled by Hayes Well Drilling \& Pumps, Inc., 1981. \\
Sand & 15 & 15 \\
Sand, grey, and water & 20 & 35 \\
Sand, fine and gravel, scattered & 10 & 45 \\
Sand, fine, grey, and clay & 11 & 56 \\
Clay, grey & 9 & 65 \\
Sand, grey, fine and clay & 24 & 89 \\
Clay, grey & 121 & 210 \\
Clay, grey and gravel, scattered clam & & 290 \\
shells & 80 & 367 \\
Clay, grey, sandy & 77 & 420 \\
Clay, grey, sand, coarse & 53 & 475 \\
Clay, gravelly, grey, and boulders & 55 & 512 \\
Clay, grey, hard, and sand & 37 & 520 \\
Clay, grey, and cobble & 8 & 525 \\
Sandstone & 5 &
\end{tabular}

EP 39N/02E-12K03. Altitude 85 feet.

Drilled by B \& C Well Drilling Inc., 1985.

Topsoil, sandy

Sand, brown

Clay and brown sand mix

Sand, brown, and fine

$\begin{array}{rr}1 & 1 \\ 8 & 9 \\ 2 & 9 \\ 16 & 11 \\ & 27\end{array}$

EQ

39N/02E-12Q01.

Altitude 80 feet.

Drilled by Livermore \& Son Inc., 1989.

Topsoil

Loam, sandy, brown

Sand, blue, and fine

Sand, fine, and blue clay lenses

Sand and water

$\begin{array}{rr}1 & 1 \\ 4 & 5 \\ 32 & 37 \\ 1 & 38 \\ 6 & 44\end{array}$

ER 39N/02E-13B01. Altitude 80 feet.

Drilled by Hayes Well Drilling \& Pumps, Inc., 1987.

Topsoil

Sand, brown, fine, dry

Sand, rusty-brown, fine, and water 
Appendix Table 3. Lithologic logs used in construction of hydrogeologic sections--Continued

\begin{tabular}{|c|c|c|c|}
\hline $\begin{array}{l}\text { (Mapcode) } \\
\text { Materials }\end{array}$ & Well number & $\begin{array}{l}\text { Thickness } \\
\text { (feet) }\end{array}$ & $\begin{array}{l}\text { Depth (feet below } \\
\text { land surface) }\end{array}$ \\
\hline
\end{tabular}

Sand, dirty grey, fine to medium and

water

6

Sand, clean grey, fine to medium and

water

Sand, dirty grey, fine, little clay,

and water

5

52

Sand, dirty grey, fine, clay, and water

5

EW

39N/02E-21K01.

Altitude 50 feet.

Drilled by James L. Asplund, 1972.

Topsoil, sandy

Clay

Water bearing sand

1

3

Clay, blue at bottom of hole

FA

39N/02E-22L01.

Altitude 45 feet.

Drilled by Hayes Well Drilling \& Pumps, Inc., 1973.

Sandy loam, $\tan$

$$
9
$$

54

9

Clay, grey

8

63

Sand, fine, and clay with slight seepage

Clay, blue, and sandy

69

71

Sandstone

2

140

Clay, grey, sandy, and hard

Gravel and sand

2

150

Sand, medium, and saltwater

Clay and sand

FB

39N/02E-23F01.

Altitude 61 feet.

Drilled by B \& C Well Drilling Inc., 1987.

Hardpan

$$
3
$$

Sand, brown

Clay, grey

Sand, grey-black

FD

39N/02E-23J01.

Altitude 75 feet.

Drilled by Sprague \& Henwood, G.J., Colo., 1959. 
Appendix Table 3. Lithologic logs used in construction of hydrogeologic sections--Continued

\begin{tabular}{llcc}
\hline $\begin{array}{l}\text { (Mapcode) } \\
\text { Materials }\end{array}$ & Well number & $\begin{array}{c}\text { Thickness } \\
\text { (feet) }\end{array}$ & $\begin{array}{c}\text { Depth (feet below } \\
\text { land surface) }\end{array}$ \\
\hline EM & 39N/02E-11B02. & Altitude 71 feet. & Drilled by Hayes Well Drilling \& Pumps, Inc., 1981.
\end{tabular}

Sand $\quad 15$

Sand, grey, and water $\quad 20$

Sand, fine and gravel, scattered $\quad 10$

Sand, fine, grey, and clay

Clay, grey

Sand, grey, fine and clay

Clay, grey

Clay, grey and gravel, scattered clam

Clay, grey, sandy

Clay, grey, sand, coarse

Clay, gravelly, grey, and boulders

Clay, grey, hard, and sand

Topsoil, sandy

Sand, brown

Clay and brown sand mix

Sand, brown, and fine

$\begin{array}{rr}1 & 1 \\ 8 & 9 \\ 2 & 11 \\ 16 & 27\end{array}$

EQ 39N/02E-12Q01.

Altitude 80 feet.

Drilled by Livermore \& Son Inc., 1989.

Topsoil

Loam, sandy, brown

Sand, blue, and fine

$$
1
$$

Sand, fine, and blue clay lenses

Sand and water

ER 39N/02E-13B01.

Altitude 80 feet.

Drilled by Hayes Well Drilling \& Pumps, Inc., 1987.

Topsoil

Sand, brown, fine, dry 
Appendix Table 3. Lithologic logs used in construction of hydrogeologic sections--Continued

\begin{tabular}{lccl}
\hline Mapcode) & Well number & Thickness & Depth (feet below \\
Materials & (feet) & land surface)
\end{tabular}

Sand, dirty grey, fine to medium and

water

6

29

Sand, clean grey, fine to medium and

water

18

47

Sand, dirty grey, fine, little clay,

and water

Sand, dirty grey, fine, clay, and water

EW 39N/02E-21K01. Altitude 50 feet.

Drilled by James L. Asplund, 1972.

Topsoil, sandy

Clay

Water bearing sand

5

57

Clay, blue at bottom of hole

FA

39N/02E-22L01.

Altitude 45 feet.

Drilled by Hayes Well Drilling \& Pumps, Inc., 1973.

Sandy loam, tan

9

9
3

4

19
5

9

54

Clay, grey

8

69

2

6

2

10

15

Clay, blue, and sandy

Sandstone

Clay, grey, sandy, and hard

Gravel and sand

Sand, medium, and saltwater

Clay and sand

63

71

140

142

148

150

160

175

FB

39N/02E-23F01.

Altitude 61 feet.

Drilled by B \& C Well Drilling Inc., 1987.

Hardpan

3

7

3

Sand, brown

1

9

10

11

20

Sand, grey-black

FD 39N/02E-23J01.

Altitude 75 feet.

Drilled by Sprague \& Henwood, G.J., Colo., 1959.
30 
Appendix Table 3. Lithologic logs used in construction of hydrogeologic sections--Continued

\begin{tabular}{|c|c|c|}
\hline $\begin{array}{l}\text { (Mapcode) Well number } \\
\text { Materials }\end{array}$ & $\begin{array}{l}\text { Thickness } \\
\text { (feet) }\end{array}$ & $\begin{array}{l}\text { Depth (feet below } \\
\text { land surface) }\end{array}$ \\
\hline Sand and gravel & 5 & 35 \\
\hline Sand, grey, and medium & 10 & 45 \\
\hline Sand and gravel & 5 & 50 \\
\hline Clay, bluish-grey & 60 & 110 \\
\hline Sand, grey & 5 & 115 \\
\hline Clay, bluish-grey and sand, fine & 25 & 140 \\
\hline Sand and gravel & 10 & 150 \\
\hline Sand & 25 & 175 \\
\hline Sand, gravel, and boulders & 15 & 190 \\
\hline Gravel and boulders & 20 & 210 \\
\hline Sand and gravel & 25 & 235 \\
\hline Sand & 55 & 290 \\
\hline Sand and gravel & 45 & 335 \\
\hline Sand, medium & 15 & 350 \\
\hline Sand and gravel & 15 & 365 \\
\hline Sand, medium & 30 & 395 \\
\hline Sand and clay & 5 & 400 \\
\hline \multicolumn{3}{|l|}{ Sand, medium, gravel, and clay, } \\
\hline bluish-grey & 5 & 405 \\
\hline Sand, fine, gravel, and clay, bluish-grey & 5 & 410 \\
\hline \multicolumn{3}{|l|}{ Sand, medium, gravel, and clay, } \\
\hline bluish-grey & 5 & 415 \\
\hline Sand, gravel, clay, and coal & 5 & 420 \\
\hline Sandstone and shale & 642 & 1,062 \\
\hline
\end{tabular}

FE 39N/02E-24B01. Altitude 68 feet.

Drilled by Hayes Well Drilling \& Pumps, Inc., 1982.

Topsoil

Sand, brown

\section{1}

11

Sand, grey, and dark

Clay, grey

57

Clay, grey, and gravel

Sand, grey, with seeage

Clay, grey

Gravel, grey, and water

Clay, grey

Clay, grey, and gravel

Clay, grey, and some gravel 
Appendix Table 3. Lithologic logs used in construction of hydrogeologic sections--Continued

\begin{tabular}{lccl}
\hline Mapcode) & Well number & $\begin{array}{c}\text { Thickness } \\
\text { (feet) }\end{array}$ & $\begin{array}{l}\text { Depth (feet below } \\
\text { land surface) }\end{array}$
\end{tabular}

Gravel, grey, sand, and water

Gravel, grey, sand, clay sandstone

and coal

Gravel, grey, and clay sandstone

Gravel, grey, and water

Clay, grey, and gravel

Gravel, grey, and water

Clay, grey, and gravel

Quartz rock, hard

Gravel, grey, and clay

Sand, brown, and medium

Sand, brown, medium, and gravel lenses

Clay, silty, grey, and zones of

$$
\text { sand and gravel }
$$

Boulders

Sand and gravel, grey

Clay, silty, grey, with occasional sand and gravel

Sand, fine to medium and gravel

Sand and gravel, grey

Sand, fine

Sand, fine, gravel, and saltwater

Bedrock at bottom of hole

Clay and sand, brown

Sand, brown, and gravel

$\begin{array}{rr}2 & 2 \\ 4 & 6 \\ 18 & 24\end{array}$


Appendix Table 3. Lithologic logs used in construction of hydrogeologic sections--Continued

\begin{tabular}{lccl}
\hline Mapcode) & Well number & Thickness & Depth (feet below \\
Materials & (feet) & land surface)
\end{tabular}

Topsoil, sandy loam

Gravel and some sand

FV $39 \mathrm{~N} / 02 \mathrm{E}-27 \mathrm{P} 01$.

Sand and gravel (undifferentiated deposits)

Shale and sandstone

FW 39N/02E-28J02.

Topsoil

Sand and gravel, brown

Sand, grey, and some gravel

FY

39N/03E-01C01.

Topsoil

Gravel, dry

Gravel and seepage

Gravel and water

Gravel and dirty water

Sand and water

Clay, grey at 50 (bottom of hole)

GA 39N/03E-01R01.

Clay, gravely

Gravel, with sand

GD 39N/03E-02B03.

Sand, brown, and gravel

Sand, brown, gravel, and water

Sand, grey, and gravel

Clay, grey
3

29

Altitude 100 feet. Drilled by Western Core Drilling, Inc., 1959.

269

654
269

923

Altitude 93 feet.

Drilled by B \& K Water Well Inc., 1989.

2

2

6

8

17

Altitude 96 feet.

Drilled by Hayes Well Drilling \& Pumps, Inc., 1985.

$\begin{array}{rr}3 & 3 \\ 14 & 17 \\ 8 & 25 \\ 11 & 36 \\ 7 & 43 \\ 7 & 50\end{array}$

Altitude 120 feet.

Drilled by B \& C Well Drilling, Inc., 1983.

18

18

28

46

Altitude 93 feet.

Drilled by Hayes Well Drilling \& Pumps, Inc., 1981.

60 
Appendix Table 3. Lithologic logs used in construction of hydrogeologic sections--Continued

\begin{tabular}{llll}
\hline Mapcode) & Well number & $\begin{array}{l}\text { Thickness } \\
\text { (feet) }\end{array}$ & $\begin{array}{l}\text { Depth (feet below } \\
\text { land surface) }\end{array}$ \\
\hline
\end{tabular}

Clay, dark grey, and scattered gravel

Clay, lighter grey, and gravel 108

173

Sandstone, grey, and coarse

GJ 39N/03E-03G01. Altitude 80 feet.

Drilled by Snowden Well Digging, 1978.

Gravel and loam

Gravel

Sand, medium

GK 39N/03E-03M01.

Altitude 95 feet.

Drilled by E.W. McClure, 1939.

Gravel, sandy

Sand, gravel, and boulders

5

Boulders, gravel, and sand

5

10

2

12

Gravel, hard 14

Gravel, slightly water bearing 15

Gravel, cemented

Gravel, sand, rock, and water bearing

Quicksand, dark

Clay, yellow

Quicksand, dark

Clay, blue

Sand, silty, fine, and water

Clay, grey, and water runoff

Sand, fine

Clay, grey

Rock, hard

Clay, grey, with gravel

Shale

Clay, gravel, and saltwater

Shale, grey

Shale, brown, and water

Shale, grey

Coal

Sand and water

Shale, sandy, light grey

Sandstone

Sandstone, smell of gas 
Appendix Table 3. Lithologic logs used in construction of hydrogeologic sections--Continued

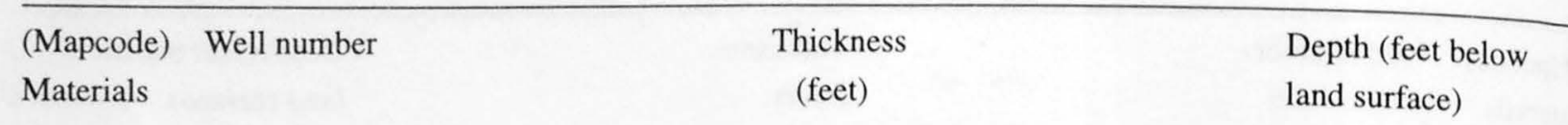

Sandstone, hard

2

262

GM 39N/03E-04B01. Altitude 83 feet. Drilled by Bezona Drill Co., 1981.

Sand and gravel, brown $\quad 10$ 10

Sand, grey, and gravel

22

32

Clay, blue

10

42

Till, glacial, and hardpan

2

44

Sand, silt, gravel, and quicksand

2

46

Silt, fine, and quicksand

8

54

Clay, blue, soft

36

90

GO

39N/03E-04M02. Altitude 100 feet.

Drilled by Hayes Well Drilling \& Pumps, Inc., 1982.

Topsoil 2

Sand, brown

Sand, brown, and gravel

Sand, brown, gravel, and water

Sand, brown

Clay, tan

Sand, brown, and fine

Silt, grey, fine, and sand

Clay, grey at bottom of hole

QU

Sand, grey, and medium

Sand, grey, fine, and clay

Clay and coarse-grained sand

Clay

Clay, grey

Sand and gravel

Clay, grey

Clay, grey, with fine sand

Clay, grey

Gravel

Gravel and boulders 
Appendix Table 3. Lithologic logs used in construction of hydrogeologic sections--Continued

\begin{tabular}{lcc}
\hline $\begin{array}{l}\text { (Mapcode) Well number } \\
\text { Materials }\end{array}$ & $\begin{array}{c}\text { Thickness } \\
\text { (feet) }\end{array}$ & $\begin{array}{c}\text { Depth (feet below } \\
\text { land surface) }\end{array}$ \\
\hline Gravel and cobbles & 50 & 480 \\
Boulders & 6 & 486 \\
Clay, blue, and little sand & 49 & 535 \\
Sand, gravel, and clay & 35 & 570 \\
Sandstone and shale & 1,430 & 2,000
\end{tabular}

HG 39N/03E-09D02. Altitude 95 feet. Drilled by Hayes Well Drilling \& Pumps, Inc., 1984.

Topsoil

Sand, brown, and gravel

Sand, brown, gravel, and clay

Sand, brown, and fine

Clay, $\tan$

HI

39N/03E-10E01.

Topsoil

Sand and gravel, brown

Sand, blue, and fine

Clay, blue

Sand, fine, and clay seams

Clay, blue, and soft

HO

39N/03E-10Q03.

Topsoil

Altitude 90 feet.

$\begin{array}{rr}1 & 1 \\ 17 & 18 \\ 22 & 40 \\ 1 & 41 \\ 2 & 43 \\ 5 & 48\end{array}$

Sand, brown, coarse, and gravel

Altitude 105 feet. $\quad$ Drilled by Hayes Well Drilling \& Pumps, Inc., 1989.

Gravel, brown, sand, and water

Clay, brown

Clay, grey, and some gravel

Sandstone, grey

Coal

Sandstone, grey, and fine

Sandstone, grey, and coarse

Siltstone, grey

Sandstone, grey

Siltstone, grey

Sandstone, grey
Drilled by Livermore \& Son Inc., 1987.

2

6

2

19

27

11

38

40

48 18

$\begin{array}{rr}1 & 1 \\ 21 & 22 \\ 1 & 23 \\ 2 & 25 \\ 8 & 33 \\ 18 & 51 \\ 1 & 52 \\ 13 & 65 \\ 14 & 79 \\ 1 & 80 \\ 22 & 102 \\ 2 & 104 \\ 6 & 110\end{array}$


Appendix Table 3. Lithologic logs used in construction of hydrogeologic sections--Continued

(Mapcode) Well number

Materials
Thickness

(feet)
Depth (feet below

land surface)

\section{Siltstone, grey}

1

Sandstone, grey, green-brown, and hard

Siltstone and sandstone, grey, layered

Sandstone, grey

2

1

114

6

120

Sandstone, grey, and saltwater

2

122

HV

39N/03E-12J02.

Altitude 130 feet.

Drilled by B \& C Well Drilling, Inc., 1979.

Loam, sandy

Gravel, with hardpan

Sand, cemented, and gravel

11

11

17

7

7

15

18

35

50

Clay, with gravel at bottom of hole

HW

39N/03E-12R03.

Altitude 135 feet.

Drilled by B \& C Well Drilling, Inc., 1979.

Sand, fine

Sand, with gravel

37

10

37

47

HY

39N/03E-13R01.

Altitude 210 feet.

Drilled by Hayes Well Drilling \& Pumps, Inc., 1973.

Topsoil
Clay

Shale, sandy

Sandstone

Water

4

8

4

12

73

85

20

105

15

120

IB

39N/03E-15C02.

Altitude 122 feet.

Radke Well Drilling, 1979.

Topsoil

Gravel

2

2

2

Hardpan

25

Sandstone, hard

25

4

81

29

Sandstone, soft, water

Sandstone, hard 
Appendix Table 3. Lithologic logs used in construction of hydrogeologic sections--Continued

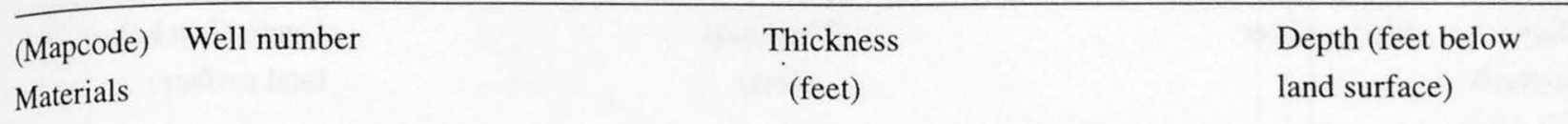

IE 39N/03E-15L01. Altitude 150 feet. Drilled by B \& C Well Drilling, Inc., 1980.

Clay 7 7

Siltstone

13

20

Sandstone

6

Siltstone

Siltstone and coal

Siltstone

7

34

Sandstone

Altitude 100 feet.

Drilled by Snowden Well Digging, 1974.

Topsoil

Sand, brown

Sand and water

II

39N/03E-16L03.

Loan, sandy

Clay and sand, layers

Gravel

IS

39N/03E-16N02.

Sand, brown

Sand, brown, and gravel

Sand, grey, and little clay, brown

Sand, gravel, brown, and water

Clay, brown, and gravel

Gravel, brown, and water

Gravel, brown, clay, and water

Clay, grey

Sand, grey, and water

Clay, grey

Clay, grey, and clam shells

Clay, grey

Siltstone
2

Altitude 100 feet. Drilled by Snowden Well Digging, 1977.

$\begin{array}{rr}3 & 3 \\ 8 & 11 \\ 10 & 21\end{array}$

Drilled by Hayes Well Drilling \& Pumps, Inc., 1982.

Altitude 98 feet. 
Appendix Table 3. Lithologic logs used in construction of hydrogeologic sections--Continued

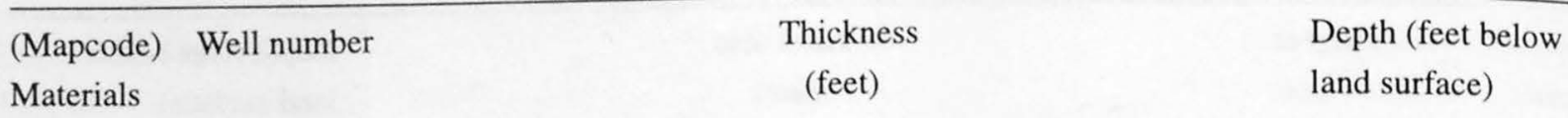

Sandstone

Coal 2

Sandstone

IN

Altitude 140 feet.

Drilled by Livermore \& Son Inc., 1982.

Topsoil

Hardpan

\section{1}

6

16

9

Clay, blue, and sandy

Gravel, sand, and water

IR

39N/03E-20K01.

Clay, red

Hardpan

Clay, grey

Hardpan

Gravel with water

Clay, brown, at bottom of hole

IS

39N/03E-20L01.

Clay, red

Gravel

Clay, grey

Gravel, dry

Hardpan

Gravel with water

Sand, grey, and fine

IU

39N/03E-21E01.

Topsoil

Sand, gravel, and hardpan

Sand, gravel, and clay, blue

Sand, gravel, little clay, and water

Altitude 140 feet.

2
Altitude 153 feet. Drilled by Star Drilling Service, 1986.

10

10

3

13

11

24

18

42

3
1 7

23

32

54

Altitude 150 feet. Drilled by Star Drilling Service, 1986.

Drilled by Livermore \& Son Inc., 1988. 
Appendix Table 3. Lithologic logs used in construction of hydrogeologic sections--Continued

\begin{tabular}{lccl}
\hline Mapcode) & Well number & Thickness & Depth (feet below \\
Materials & (feet) & land surface)
\end{tabular}

Sand, gravel, and water

6

40

Sand, gravel, and clay blue

43

IV

39N/03E-21K01.

Altitude 190 feet.

Drilled by Star Drilling Service, 1989.

Clay, red

12

12

Clay, grey

58

70

Clay, grey, with stones

20

90

Sand, dry

30

120

Clay, hard, and gravel

17

137

Hardpan

19

156

Gravel with water

IW

39N/03E-21M01.

Altitude 160 feet.

Clay, silty, and gravel, brown

Clay, silty, and gravel, grey

Gravel, sandy silty, grey

Sand, medium, brown, and water bearing

Sand and gravel, light brown

Silt, sandy with gravel

Sand and gravel, water bearing

Sand, silty with gravel, grey

Sand, medium, and gravel, water bearing

Sand, fine to medium

275

Silt, sandy with gravel, grey

280

Sand, grey, and fine

Clay, grey, and silty

Sand, grey, fine to medium

Clay, silty, grey, and sandy

Clay, silty, and sandy with gravel

Sand, grey, and fine

Sand, fine to coarse, gravel, grey, water

Sand, fine to medium, and gravel, grey

Gravel

Gravel, with sand and bearing water

Clay, sandy, with gravel, and till hard, and grey

Bedrock at bottom of hole 
Appendix Table 3. Lithologic logs used in construction of hydrogeologic sections--Continued

\begin{tabular}{|c|c|c|c|}
\hline $\begin{array}{l}\text { (Mapcode) } \\
\text { Materials }\end{array}$ & Well number & $\begin{array}{l}\text { Thickness } \\
\text { (feet) }\end{array}$ & $\begin{array}{l}\text { Depth (feet below } \\
\text { land surface) }\end{array}$ \\
\hline
\end{tabular}

IX 39N/03E-22M01. Altitude 210 feet. Drilled by B \& C Well Drilling, Inc., 1980.

Clay, brown $\quad 15$

15

Clay, grey

38

53

Gravel, coarse 5

58

Clay, brown

$\begin{array}{ll}9 & 67\end{array}$

Clay, grey

Clay, grey, and hardpan

Gravel, hardpan

8

75

$16 \quad 91$

Clay, hardpan

Hardpan with boulders

Gravel, grey, and hardpan

Clay, grey, and hardpan

Hardpan, with coarse gravel

10

101

$\begin{array}{ll}8 & 109\end{array}$

92118

Gravel cemented, and grey

Clay, grey, and sandy

Gravel, hardpan and grey

Sand, dark, water, and clay

$8 \quad 126$

$12 \quad 138$

$7 \quad 145$

92154

$3 \quad 157$

$4 \quad 161$

2163

JB

39N/03E-23J01.

Altitude 192 feet.

Drilled by Livermore \& Son Inc., 1986.

Topsoil

Sand, gravel, and hardpan

\section{1}

13

33

23

Sand, gravel, and blue clay soft

Sand, gravel, and blue clay hard

Sand, and water

Sandstone

Sandstone, water

$\mathrm{JC}$

39N/03E-23M01.

Altitude 165 feet.

Drilled by Star Drilling Service, 1984.

Clay, red

Clay, grey

6

Clay and sand

Clay and gravel

19

16

54

Clay, grey, and hard

Gravel, fine

Clay, grey 
Appendix Table 3. Lithologic logs used in construction of hydrogeologic sections--Continued

(Mapcode) Well number

Materials

Sand cemented

Sand, fine

Hardpan at bottom of hole

JF

39N/03E-25A01.

Soil

Clay, with gravel, brown

Clay, blue, with gravel

Gravel with water

JK

39N/03E-26P02.

Topsoil

Clay, brown

Clay, blue

Quicksand

Sand and gravel

Clay, sandy, and gravel

Sand, with gravel

Clay, grey, sand, and gravel

Sand, brown, with clay

Gravel, sandy, with clay

Sand, gravel, and water

Clay, blue, and sandy

JO

39N/03E-28F01.

Clay, brown, and gravel

Clay, blue, and till

Hardpan and till

Hardpan and boulders

Clay, soft, and till

Hardpan

Gravel, layered, and silty

Gravel and sand aquifer
Thickness

(feet)
Depth (feet below

land surface)

10

95

5

Altitude 227 feet. $\quad$ Drilled by B \& C Well Drilling, Inc., 1983.

$\begin{array}{rr}2 & 2 \\ 25 & 27 \\ 112 & 139 \\ 9 & 148\end{array}$

Altitude 262 feet. $\quad$ Drilled by B \& C Well Drilling Inc., 1978.

$\begin{array}{rr}1 & 1 \\ 9 & 10 \\ 12 & 22 \\ 3 & 25 \\ 25 & 50 \\ 14 & 64 \\ 6 & 70 \\ 39 & 109 \\ 20 & 129 \\ 9 & 138 \\ 15 & 153 \\ 2 & 155\end{array}$

Altitude 225 feet. Drilled by Bezona Well Service, 1987.

$\begin{array}{rr}8 & 8 \\ 7 & 15 \\ 58 & 73 \\ 27 & 100 \\ 122 & 222 \\ 3 & 225 \\ 55 & 280 \\ 6 & 286\end{array}$


Appendix Table 3. Lithologic logs used in construction of hydrogeologic sections--Continued

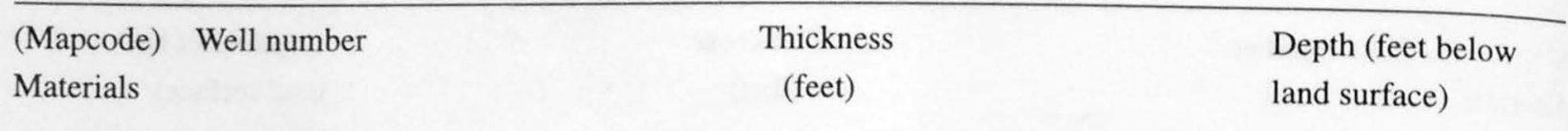

JP 39N/03E-28J01. Altitude 230 feet. $\quad$ Drilled by B \& C Well Drilling Inc., 1977.

Topsoil

Clay, yellow

Sand, brown, and wet

Sand, blue, with clay

Clay, blue, with pebbles

Gravel and sand

Clay, blue, with gravel

Gravel, sandy, with water

Sand and clay, fine

JQ

39N/03E-28Q02.

Altitude 290 feet.

Drilled by Hayes Well Drilling \& Pumps, Inc., 1977.

Sand, tan loam

3

Clay, grey, and gravel

1

4

1

6

5

4

11

51

15

4

66

$\begin{array}{ll}4 & 74\end{array}$

70

10

84

1

85

Gravel, dry, clean

Clay, grey, and sandy

57

25

3

Clay, grey

5

60

5

85

20

90

Sand, grey, dry

10

110

Gravel, dry

20

120

Clay, grey, and sand

37

140

Sand, grey, and water

Sand, clay, brown, and water

3

177

Clay, brown, and gravel

JR

39N/03E-28R01.

Altitude 270 feet.

Drilled by B \& C Well Drilling Inc., 1977.

Topsoil

Gravel, cemented, and boulders 5

Clay, grey, with gravel

Clay, brown, with gravel 20

Sand, brown, and clay

Clay, blue, with gravel

Clay, grey, with gravel

Clay, blue, and hard

Clay, brown, hard, with gravel

Sand, brown, and clay

Sand and clay, brown 
Appendix Table 3. Lithologic logs used in construction of hydrogeologic sections--Continued

\begin{tabular}{lccl}
\hline (Mapcode) & Well number & Thickness & Depth (feet below \\
Materials & (feet) & land surface)
\end{tabular}

Sand and gravel

122

Clay, brown, with gravel

Sand and gravel

127

Clay, brown, with sand and gravel

136

Sand, medium

147

Sand and blue clay

149

Sand and water

155

Silt

180

Clay, blue

192

Sand, gravel, and water

197

Clay, brown, with pebbles

199

JY

39N/03E-30N01.

Altitude 190 feet.

Drilled by Livermore \& Son Inc., 1974.

Topsoil

Hardpan

\section{1}

8

6

11

28

6

8

23

35

5
1

9

15

26

54

60

68

91

126

131

Sand, gravel, and water

Sand, gravel, and blue clay at bottom of hole

JZ 39N/03E-30R01. Altitude 302 feet. Drilled by B \& C Well Drilling Inc., 1978.

Topsoil

1

8

3

6

11

61

10

10

4

6 
Appendix Table 3. Lithologic logs used in construction of hydrogeologic sections--Continued

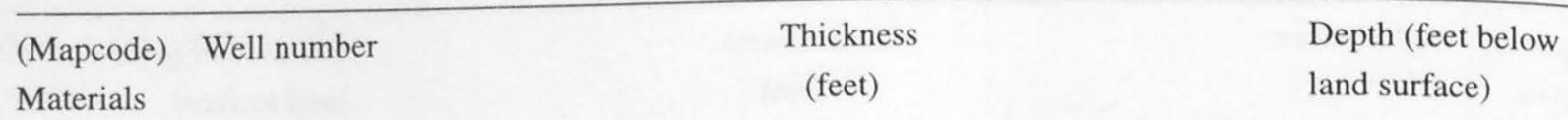

Gravel

Sand with gravel

Clay, grey, and sandy

Gravel

Sand, fine, with gravel

Sand, coarse, with gravel

Sand, medium, gravel, and water

Sand, fine, with gravel, and water

Sand, medium, gravel, and water

KA

39N/03E-31B02.

Soil

Boulders, gravel, clay, and sand

Gravel and sand

Gravel, boulders, sand, and clay

Clay, blue-grey, and few boulders

Clay, boulders, and sand

Gravel and boulders

Gravel

Boulders

Clay

Shale and sandstone

KE

39N/03E-32A02.

Alluvium

Clay

Sand, grey, with few boulders

Gravel

Sand, grey

Sand, gravel, with few boulders

Sand and gravel

Clay, grey

Clay and sand

Clay mainly, with gravel

Shale and sandstone
Altitude 250 feet.

Drilled by Sprague and Henwood, G.J., Colo., 1961.

$\begin{array}{rr}5 & 5 \\ 63 & 68 \\ 65 & 133 \\ 127 & 260 \\ 110 & 370 \\ 30 & 400 \\ 57 & 457 \\ 13 & 470 \\ 4 & 474 \\ 6 & 480 \\ 512 & 1,992\end{array}$

Drilled by Sprague \& Henwood, G.J., Colo., 1961.

Altitude 278 feet.

2 2

8

10

85

95

15

110

10

120

100

220

5

225

17

242

58

300

115

415

1,102 
Appendix Table 3. Lithologic logs used in construction of hydrogeologic sections--Continued

\begin{tabular}{lccl}
\hline Mapcode) & Well number & Thickness & Depth (feet below \\
Materials & (feet) & land surface)
\end{tabular}

KG 39N/03E-32J01. Altitude 310 feet.

Drilled by Bezona Well Service, 1986.

Till, glacial, brown, and soft

$\begin{array}{rr}16 & 16 \\ 26 & 42 \\ 23 & 65 \\ 23 & 88 \\ 17 & 105 \\ 11 & 116 \\ 13 & 129 \\ 11 & 140 \\ 7 & 147 \\ 23 & 170 \\ 7 & 177 \\ 8 & 185 \\ 33 & 218\end{array}$

Clay, blue, and till, soft

42

Till, glacial, and hardpan

65

Gravel, hard-packed, and till

88

Sand, loose, and gravel, alluvium

105

Gravel, coarse, loose, and alluvium

16

Sand and some gravel, alluvium

129

Clay, blue, and sandy

140

Sand, coarse, and alluvium

47

Gravel, coarse, and alluvium

170

Sand, coarse, and alluvium

Gravel, pea, and alluvium

185

Sand and gravel, aquifer

218

KI

39N/03E-33K01.

Altitude 325 feet.

Drilled by Star Drilling Service, 1985.

Sand

Clay, red

3

3

6

9

Clay, grey

Hardpan

22

46

Gravel and traces of water

Hardpan

Clay, hard, and dry

Hardpan

Hardpan took water

Clay, brown, and sandy

Sand, cemented

Hardpan

Gravel with water

Sand, grey, and cemented

Altitude 318 feet.

Drilled by B \& C Well Drilling, Inc., 1987.

Clay, brown

Clay, grey

Gravel, with clay

Clay, fine, and sandy 
Appendix Table 3. Lithologic logs used in construction of hydrogeologic sections--Continued

\begin{tabular}{lccl}
\hline Mapcode) & Well number & Thickness & Depth (feet below \\
Materials & (feet) & land surface)
\end{tabular}

Sand and gravel, with clay

$\begin{array}{rr}24 & 180 \\ 11 & 191 \\ 6 & 197 \\ 3 & 200 \\ 5 & 205\end{array}$

Sand, brown, fine, and dry

Sand and gravel, with clay

Sand, with gravel and water

200

Sand, with water

205

Quicksand at bottom of hole

KK

39N/03E-33R01. Altitude 310 feet.

Drilled by B \& C Well Drilling Inc., 1981.

Topsoi

4

Hardpan

2

Clay, blue

Gravel, dry

2

Clay, blue, with cobbles

Sand, coarse

Sand, coarse, with gravel, dry

Clay, blue

Gravel, dry

Clay, with rock

Sand, soupy

Gravel, fine

Gravel, with sand, dry

Clay, blue, with rock

Oil shale, dark brown

Oil shale, light brown

Shale, grey

Sandstone, white

Clay, grey, and dry

Oil shale, dark brown

Shale, grey

Clay, oil, grey, and blue

\section{4}

KL 39N/03E-34C01. Altitude 295 feet.

Drilled by Hayes Well Drilling and Pumps, Inc., 1981.

\section{Topsoil}

Clay, brown

Clay, grey, and gravel

Gravel, grey, and clay

Sand, grey, dry

40 
Appendix Table 3. Lithologic logs used in construction of hydrogeologic sections--Continued

(Mapcode) Well number

Materials

\section{Thickness}

(feet)
Depth (feet below

land surface)
Gravel, brown, dry

Sand and gravel, dry

Sand, grey, fine, dry

Sand, grey, coarse, dry

Gravel, grey, dry

Sand, fine, and seepage

Sand, grey, coarse, and water

Clay, grey

Clay, wood, and sand

Gravel, grey, and clay, hard

Gravel, grey, and saltwater

Sandstone, siltstone, and coal
Gravel, grey, dry

$\begin{array}{rr}9 & 139 \\ 4 & 143 \\ 7 & 150 \\ 10 & 160 \\ 5 & 165 \\ 10 & 175 \\ 4 & 179 \\ 19 & 198 \\ 7 & 205 \\ 28 & 233 \\ 95 & 328 \\ 15 & 343 \\ 157 & 500\end{array}$

Altitude 305 feet.

Drilled by Livermore \& Son Inc., 1970.

Fill

Hardpan

Boulder

Hardpan and gravel

Clay, blue, and gravel washes

Sand and gravel washes, little clay

Clay, blue, and gravel, soft

Clay, blue, soft, and sandy

Sand, gravel, and blue clay hard

Sand, gravel, and water

Clay, blue at bottom of hole

KY 39N/04E-03P02. Altitude 370 feet.

Drilled by Hayes Well Drilling \& Pumps, Inc., 1990.

Topsoil
3

5

3

16

4

11

76

21

60
3

8

11

27

31

42

118

139

199 
Appendix Table 3. Lithologic logs used in construction of hydrogeologic sections--Continued

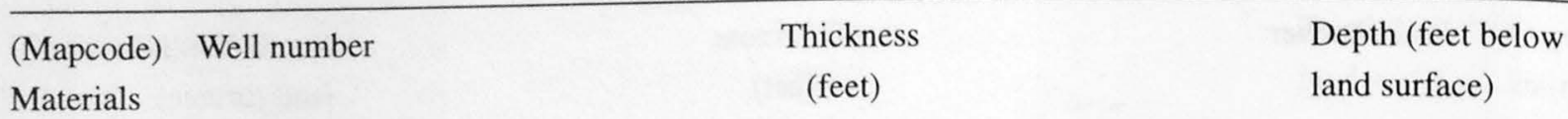

Sandstone, medium

Sandstone, coarse

LA 39N/04E-04Q01. Altitude 140 feet. Drilled by B \& C Well Drilling Inc., 1981.

Clay, with gravel

Sand and gravel, silty

Pebble cobbles, and silty gravel

Gravel, sand, and silty

LC

39N/04E-06D01.

Sand, and gravel, grey

Sand, grey

Clay, grey, silty, and seashells

Clay, grey, silty, and gravel

Sand, medium to coarse

Clay, silty and grey

Sand, grey, and minor silt

Bedrock at bottom of hole

LD

39N/04E-06E01.

Topsoil

Gravel, brown, and clay

Gravel, brown, sand, and water

LF $\quad 39$ N/04E-08C02.

Topsoil

Clay, brownish-grey

Gravel, fine and little sand

Gravel, large, and water

Gravel and less water at bottom of hole
Altitude 105 feet.

16

215

45

260

14

14

31

45

20

65

9

74

Altitude 100 feet. $\quad$ Drilled 1982.

80

80

37

117

13

130

107

237

5

242

108

350

123

473

Drilled by Hayes Well Drilling \& Pumps, Inc., 1980.

2

2

34

36

31

67

Altitude 107 feet.

Drilled by Hayes Well Drilling \& Pumps, Inc., 1977.

\section{2}

2

14

16

4

20

26

46 
Appendix Table 3. Lithologic logs used in construction of hydrogeologic sections--Continued

\begin{tabular}{lcl}
\hline Mapcode) & Well number & Thickness \\
Materials & (feet) & $\begin{array}{l}\text { Depth (feet below } \\
\text { land surface) }\end{array}$
\end{tabular}

LQ 39N/04E-18E01. Altitude 210 feet. $\quad$ Radke Well Drilling, 1977.

Topsoil
Hardpan
Sandstone
Rock, hard
Sandstone
Rock, hard
Sandstone, coal, and water

LR 39N/04E-18M01. Altitude 190 feet. Radke Well Drilling, 1974.

Topsoil
Hardpan
Sandstone
Coal, trace
Sandstone
Sandstone, soft, and water
Sandstone, hard

LV 39N/04E-19E01. Altitude 215 feet. Drilled by Star Drilling Service, 1988.

Clay, red

Sandstone, hard

Sandstone, soft

Sandstone, very soft

Shale, black, and soft

Sandstone, moderate

Sandstone, soft

Sandstone, very soft, and brown

Sandstone, moderate

Sandstone, hard

$\begin{array}{rr}2 & 2 \\ 1 & 3 \\ 52 & 55 \\ 1 & 56 \\ 90 & 146 \\ 4 & 150 \\ 6 & 156\end{array}$

LY 39N/04E-19M01. Altitude 220 feet. Radke Well Drilling, 1978.

Topsoil

Hardpan

Clay, blue

$\begin{array}{rr}6 & 6 \\ 27 & 33 \\ 5 & 38 \\ 49 & 87 \\ 28 & 115 \\ 19 & 134 \\ 53 & 187 \\ 2 & 189 \\ 18 & 207 \\ 35 & 242\end{array}$


Appendix Table 3. Lithologic logs used in construction of hydrogeologic sections--Continued

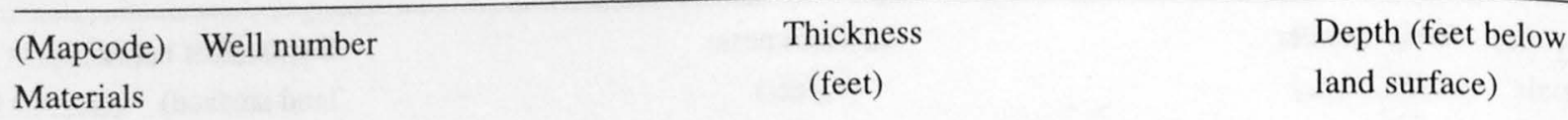

Hardpan

Sandstone, hard

Sandstone, soft, and water

Sandstone, hard

$\mathrm{MB}$

39N/04E-20M02.

Altitude 155 feet.

Clay, brown, gravel, and silt

Sand, black with gravel

Clay, grey, and soft at bottom of hole

MC

39N/04E-20M03.

Topsoil

Hardpan

Gravel coarse

Sand and gravel cemented

Sand, gravel, and water

MD

39N/04E-22F01.

Topsoil

Sand, gravel, and hardpan

Loam, sandy

Sand, gravel, and clay, blue

Sand, gravel, and clay, brown

Sand, gravel, and clay, blue

ME

39N/04E-22L01.

Loam, sandy, and brown

Clay, brown, sand, and gravel

Hardpan, grey, and gravelly

Sand, gravel, and silt, brown

Sand, gravel, and water

Gravel
Altitude 155 feet.

Radke Well Drilling, 1977.

19

15
65

195

196

200

Drilled by B \& C Well Drilling, Inc., 1980.

9219

65


Appendix Table 3. Lithologic logs used in construction of hydrogeologic sections--Continued

\begin{tabular}{|c|c|c|c|}
\hline $\begin{array}{l}\text { (Mapcode) } \\
\text { Materials }\end{array}$ & Well number & $\begin{array}{l}\text { Thickness } \\
\text { (feet) }\end{array}$ & $\begin{array}{l}\text { Depth (feet below } \\
\text { land surface) }\end{array}$ \\
\hline
\end{tabular}

$\mathrm{MF}$

39N/04E-22N01. Altitude 150 feet.

Drilled by Bezona Well Service, 1977.

Alluvial sand

Gravel, medium

Sand and gravel

MI

39N/04E-29A01. Altitude 200 feet.

Drilled by Star Drilling Service, 1983.

Sand, fine, and clay

Sand, coarse

Silt, black, and water

Sand, black, and water

Clay, grey, and hard

Clay, wet, and soft

Hardpan, brown

Silt, fine, and mud

Gravel

Clay, grey, and wet

Clay, grey,

Sandstone, soft

Sandstone and coal

Sandstone, grey

Clay, silty, with gravel and sand, brown

Clay, silty, with gravel and sand, and

$$
\text { occasional boulders }
$$

Sand and gravel, with clay, grey

MS 39N/04E-31B01. Altitude 220 feet.

Drilled by Hayes Well Drilling \& Pumps, Inc., 1982.

Topsoil

Clay, tan

Sand, clay, grey, and gravel

Sand, grey, fine, and clamshells

2

Clay, dark grey

Clay, grey, and gravel 
Appendix Table 3. Lithologic logs used in construction of hydrogeologic sections--Continued

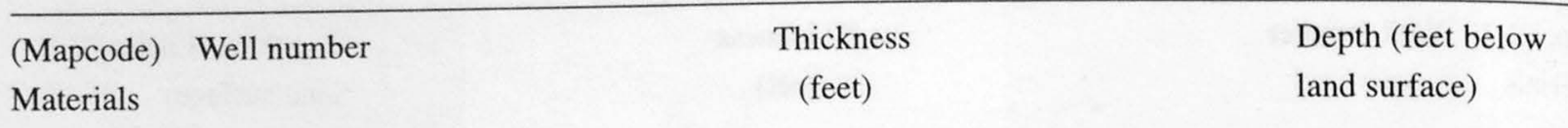

Gravel, dry, and little clay

Rock, green

Sand, coarse, little gravel, and water

MT

39N/04E-31D01.

Topsoil

Clay, brown

Clay, grey, and gravel scattered

Clay, grey, and gravel

Gravel and water

Gravel, clay, grey, and scattered boulders

Gravel and water

Sand, grey, hard

Gravel, little clay and scattered boulders

Clay, grey

Clay, grey, and gravel

Clay, grey

Sand, coarse, little gravel, coal, and water

Clay, grey

Sandstone, grey

MV

39N/04E-31Q02

Hardpan, brown

Clay, grey, and gravel

Hardpan, grey, and coarse

Clay, grey, and sandy

Sand with clay

Sand with gravel

Sand, brown, with gravel

Sand, grey, and fine

Altitude 265 feet.
221

222.5

1.5

225

Altitude 250 feet. $\quad$ Drilled by Hayes Well Drilling \& Pumps, Inc., 1981.

$\begin{array}{rr}2 & 2 \\ 13 & 15 \\ 101 & 116 \\ 34 & 150 \\ 12 & 162 \\ & \\ 63 & 225 \\ 1 & 226 \\ 2 & 228 \\ & \\ 22 & 250 \\ 4 & 254 \\ 1 & 255 \\ 40 & 295 \\ & \\ 5 & 300 \\ 5 & 305 \\ 7 & 312\end{array}$

Sand, grey, with gravel

Drilled by B \& C Well Drilling, Inc., 1979.

Sand, with gravel

Gravel, coarse, sandy, and with water 
Appendix Table 3. Lithologic logs used in construction of hydrogeologic sections--Continued

\begin{tabular}{lcc}
\hline Mapcode) & Well number & Thickness \\
Materials & (feet) & $\begin{array}{l}\text { Depth (feet below } \\
\text { land surface) }\end{array}$
\end{tabular}

MX 39N/04E-32E01.

Clay, brown

Clay, blue, and gravel

Sand, clay, and water

MY

39N/04E-32F01.

Clay, brown, and hard

Clay, blue, and till

Glacial till, hard

Till, light, brown, and sandy

Shale, weathered, carbonaceous

Shale, grey

Sandstone, grey, and hard

Sandstone, coarse

Shale, grey

Shale, carbonaceous, water

Sandstone

NB 39N/03E-33E01.

Hardpan

Clay, blue

Gravel

NC

39N/04E-34C02.

Hardpan

Clay, blue

Gravel and sand

Clay, blue

Sand, fine, with clay, and some water

Bedrock at bottom of hole

NF 40N/02E-01N01. Altitude 115 feet.

Altitude 230 feet.

Altitude 290 feet.
Drilled by Dahlman Pump \& Drilling Inc., 1984.

Drilled by Bezona Well Service, 1990.

17 17

91

108

7

115

5

120

8

128

16

144

36

180

18

198

17

215

10

225

6

231

Altitude 340 feet. Drilled by G. Cowden, 1939.

11

11

109

120

3

217

Altitude 300 feet. Drilled by Aut Hillard, 1946. 
Appendix Table 3. Lithologic logs used in construction of hydrogeologic sections--Continued

\begin{tabular}{lcc}
\hline $\begin{array}{l}\text { Mapcode) } \\
\text { Materials }\end{array}$ & $\begin{array}{c}\text { Thickness } \\
\text { (feet) }\end{array}$ & $\begin{array}{c}\text { Depth (feet below } \\
\text { land surface) }\end{array}$ \\
\hline Clay loam & 1 & 1 \\
Gravel, sandy brown & 4 & 5 \\
Sand, coarse, and gravel & 15 & 20 \\
Clay & 1 & 21
\end{tabular}

NG 40N/02E-02B01. Altitude 180 feet.

Drilled by Hayes Well Drilling \& Pumps, Inc., 1983.

Topsoil

Clay, brown, and gravel

Clay, brown, tan, and gravel

Clay, sandy, and brown and gravel 35

Sand, brown, fine, dirty 66

Siltstone, grey 96

Clay, grey 109

Clay, grey, and gravel

112

Gravel and sand, grey

115

Clay, grey, and gravel

116.5

Peat and wood

123

Clay, grey, hard

126

Clay, grey, and gravel

128.5

Gravel, grey, coarse, and water 134

Sand, grey, and water

Clay, grey

Clay, grey, and gravel, scattered

Clay, brown, hard

Clay, grey, and clam shells

Clay, grey, scattered gravel, and

Clay, grey, and little gravel

Gravel, grey, wood, and water

Gravel, grey and clay

Clay, grey, and little gravel, hard

Gravel, grey, and clay

Clay, grey, gravel, and wood

Clay, brownish-grey, and gravel

Gravel, grey, sand, and clay

Sand, gravel, grey, and saltwater 
Appendix Table 3. Lithologic logs used in construction of hydrogeologic sections--Continued

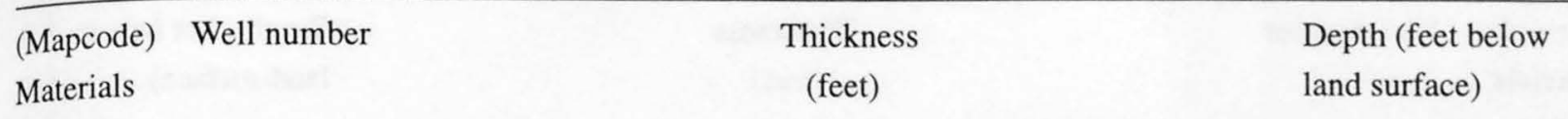

NH 40N/02E-02D01. Altitude 220 feet.

Drilled by B \& C Well Drilling Inc., 1979.

Clay, brown, and sandy

Clay, grey, soft

Clay, grey, hard

Coarse gravel with hard clay

Sand, gravel, and clay

Sand, yellow, very fine

Sand, gravel, and clay

Hardpan

Sand, grey, fine

Clay, grey, soft

Hardpan

6

Sand, and gravel

NK 40N/02E-02Q01. Altitude 114 feet. Dug 1952.

Gravel

Sand 
Appendix Table 3. Lithologic logs used in construction of hydrogeologic sections--Continued

\begin{tabular}{|c|c|c|}
\hline $\begin{array}{l}\text { (Mapcode) Well number } \\
\text { Materials }\end{array}$ & $\begin{array}{l}\text { Thickness } \\
\text { (feet) }\end{array}$ & $\begin{array}{l}\text { Depth (feet below } \\
\text { land surface) }\end{array}$ \\
\hline
\end{tabular}

Clay, brown, and gravel 12

Sand, grey with seepage

5

Clay, grey

Clay, sandy, and grey

Clay, grey

Clay, sandy, and grey

Sand, grey, and dry

Clay, grey, and sandy

Sand, grey, and dry

Clay, grey, and wood

Clay, loam

Clay

Sand

NW 40N/02E-13J02. Altitude 100 feet. Drilled by Snowden Well Digging.

Sand

Gravel 10

Sand

$\mathrm{OC}$ 40N/02E-14P02.

Altitude 91 feet.

Drilled by Snowden Well Digging, 1981.

Sand

Sand, gravel, and clay

Sand, hard 2

Sand, grey, and water

OD 
Appendix Table 3. Lithologic logs used in construction of hydrogeologic sections--Continued

\begin{tabular}{llcl}
\hline (Mapcode) & Well number & Thickness & Depth (feet below \\
Materials & (feet) & land surface)
\end{tabular}

Clay, blue, sand, fine at 30

(bottom of hole)

OJ 40N/02E-15P01. Altitude 90 feet. Drilled by Levy Rice, 1946.

Topsoil

$5-5$

Sand

Sand, gravel, and waterbearing

4

9

15

24

OK 40N/02E-15Q01. Altitude 90 feet.

Drilled by Don Mulka, 1954 .

Clay, red

5

19

5

Sand

9

ON 40N/02E-21A01. Altitude 90 feet.

Drilled by Snowden Well Digging, 1974.

Clay loam

Clay, hard

Bog iron

Sand, hard

Sand, grey

1

2

3

$1-4$

$4-8$

$13-21$

PD

40N/02E-23D02. Altitude 90 feet.

Drilled by Livermore \& Son Inc., 1989.

Topsoil

Sand, with thin clay seams and water

Sand, blue

Alitude 90 feet.

Drilled by Livermore \& Son Inc., 1989.

Clay, blue

$\begin{array}{rr}1 & 1 \\ 46 & 47 \\ 1 & 48 \\ 12 & 60\end{array}$

PJ 40N/02E-26A04. Altitude 60 feet.

Drilled by Snowden Well Digging, 1980.

Loam, sandy

Sand, coarse

Sand, fine 
Appendix Table 3. Lithologic logs used in construction of hydrogeologic sections--Continued

\begin{tabular}{lccc}
\hline Mapcode) & Well number & Thickness & Depth (feet below \\
Materials & (feet) & land surface)
\end{tabular}

QA 40N/03E-02C01. Altitude 152 feet. Drilled by B \& C Well Drilling, Inc., 1986.

Topsoil, sandy 2 2

Gravel, sandy

Gravel, sandy, and water

Boulders at bottom of hole

QB 40N/03E-02M02. Altitude 141 feet. Drilled by Hayes Well Drilling \& Pumps, Inc., 1986.

\section{Topsoil}

Gravel, dry

Gravel, sand, and water

Sand, small gravel, and water

Sand, gravel, and water

$\begin{array}{rr}2 & 2 \\ 2 & 4 \\ 26 & 30 \\ 7 & 37 \\ 20 & 37\end{array}$

QC

40N/03E-02N01.

Altitude 134 feet.

Drilled by Beck \& Zwicker, 1946.

Topsoil 3

Gravel, coarse, and rock

17

20

QF 40N/03E-03N02.

Altitude 128 feet.

Drilled by Al Towe Well Digging, 1982.

Topsoil

Clay, hard 2

2

6

8

Sand, coarse, and gravel,fine

15

23

QG

40N/03E-03R02.

Altitude 135 feet.

Drilled by Hayes Well Drilling \& Pumps, Inc., 1986.

Topsoil

$\begin{array}{rr}2 & 2 \\ 8 & 10 \\ 29 & 39 \\ 9 & 48 \\ 22 & 70 \\ 5 & 75 \\ 2 & 77\end{array}$

Clay, grey

Gravel, dry 10

Gravel, sand, and water 39

Sand, brown, and water 48

Sand, grey, gravel, and water 70

Sand, grey, trace of clay, and water 75

Clay, grey 77 
Appendix Table 3. Lithologic logs used in construction of hydrogeologic sections--Continued

\begin{tabular}{lcc}
\hline Mapcode) & Well number & Thickness \\
Materials & (feet) & $\begin{array}{l}\text { Depth (feet below } \\
\text { land surface) }\end{array}$
\end{tabular}

QH 40N/03E-03R03. Altitude 135 feet. Drilled by Hayes Well Drilling \& Pumps, Inc., 1988.

Topsoil 3

Gravel, brown, dry

12

Gravel, rusty brown

19

15

$19 \quad 34$

Sand, brown, little gravel, and water

22

56

Sand, red, grey, and water

73

Clay, grey at 73 (bottom of hole)

QQ

40N/03E-05N01.

Altitude 123 feet.

Drilled by America Water Well, Inc., 1984.

Topsoil, black

Sand, brown

Sand, brown, and gravel

Sand, blue, grey, gravel, and water

1 1

2 3

326

$12-18$

QR 40N/03E-05N02. Altitude 118 feet. Drilled 1980.

Gravel

QV 40N/03E-06M01. Altitude 123 feet. Drilled by Tilley and Hillard, 1947.

Gravel

Sand, very fine

Clay, soft

Clay with gravel

Clay, hard

Sand and water

4

156

QW 40N/03E-06N02. Altitude 120 feet. Drilled by Snowden Well Digging, 1979.

Loam sandy

Clay, loam

Gravel

Sand, coarse

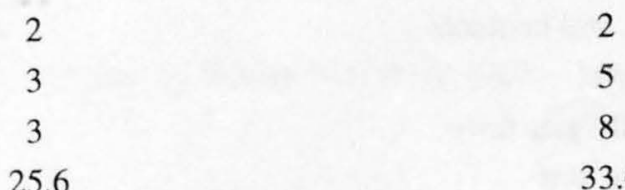

25.6
2

5

8

33.6 
Appendix Table 3. Lithologic logs used in construction of hydrogeologic sections--Continued

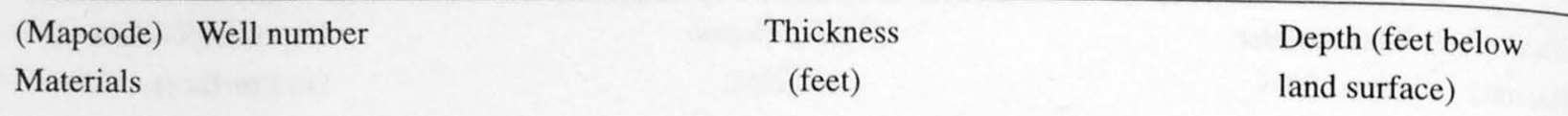

RA 40N/03E-07M03. Altitude 111 feet. Drilled by Hayes Well Drilling \& Pumps Inc., 1979.

Topsoil

Sand, brown

8

10

Gravel and water

15

25

Sand, dirty grey, and little water

31

56

Clay, grey

RB

40N/03E-08J01.

Altitude 113 feet.

Drilled by Frank Otter, 1938.

Loam, black

Clay

1

3

1

Sand, coarse

10

Gravel, coarse

$\mathrm{RD}$ 40N/03E-09A04.

Altitude 123 feet.

Drilled by B \& K Water Wells, 1978.

Topsoil

Clay, brown 2

Gravel, brown 12

Gravel and sand, blue

RE 40N/03E-09D01.

Altitude 118 feet.

Drilled by Dun Mulka, 1953.

\section{Loam}

Clay

Sand and gravel

RF 40N/03E-09G01.

Altitude 122 feet.

Drilled by Livermore \& Son, Inc., 1988.

Road bed

Sand, gravel, and boulders

Sand and gravel

Sand gradually gets finer 
Appendix Table 3. Lithologic logs used in construction of hydrogeologic sections--Continued

\begin{tabular}{lccl}
\hline Mapcode) & Well number & Thickness & Depth (feet below \\
Materials & (feet) & land surface)
\end{tabular}

RK 40N/03E-11E04.

Gravel and sand, fine

Gravel, pea

Gravel and sand, coarse

RM

40N/03E-12H01.

Topsoil

Gravel, brown, and little clay

Gravel, brown, sand, and water

Clay, grey, and sand seepage

Clay, grey

$\mathrm{RN}$

40N/03E-13N01.

Clay, grey

Clay, grey, and sand

Sand, very fine, saline

RO

40N/03E-13Q01.

Topsoil

Clay, blue

Sand, coarse, gravel, and quicksand

RP 40N/03E-14B01. Altitude 95 feet.

Clay, hard blue and cobbles

Sand

Altitude 86 feet.

160

160

10

5

170

175

Drilled by Hayes Well Drilling \& Pumps, Inc., 1982.

$\begin{array}{rr}1 & 1 \\ 11 & 12 \\ 13 & 25 \\ 27 & 52 \\ 68 & 120\end{array}$

Drilled by B \& C Well Drilling, Inc., 1984.

$\begin{array}{ll} & 160 \\ 0 & 170 \\ 5 & 175\end{array}$

Drilled by M. Starkemburg, 1947.

2

178

2

45

225

Drilled by Radke Well Drilling, 1947.

260

260

5

265

RU 40N/03E-16D01. Altitude 111 feet. Drilled by Sumas Well Drill, 1963.

Clay, red, and loam

3

24

27 
Appendix Table 3. Lithologic logs used in construction of hydrogeologic sections--Continued

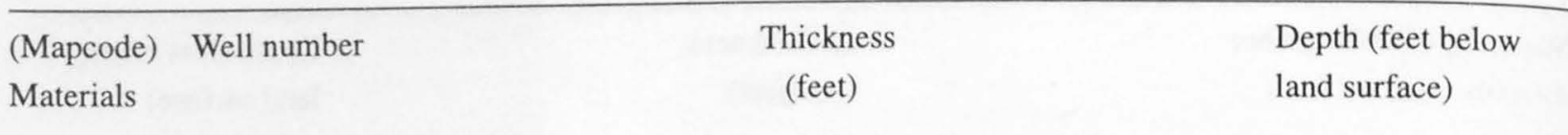

SB 40N/03E-16M01. Altitude 100 feet. Drilled 1984.

Clay, sandy topsoil, brown

Clay, brown

Sand, brown, and gravel

Gravel, grey, sand, and water

Altitude 100 feet.

Sand, grey, and water

$\begin{array}{rr}7 & 7 \\ 3 & 10 \\ 3 & 13 \\ 10 & 13 \\ 36 & 23 \\ 210 & 59 \\ 4 & 269 \\ 2 & 273 \\ 49 & 275 \\ 21 & 324 \\ 5 & 345 \\ 30 & 350 \\ & 380\end{array}$

$\mathrm{SC}$

40N/03E-16Q01.

Altitude 104 feet.

Drilled by Hayes Well Drilling \& Pumps, Inc., 1988.

Topsoil

Sand, dry, and gravel

Sand, brown, and water

Sand, brown, dirty, and water

Sand, fine, grey, and water

Clay, grey

$\begin{array}{rr}1 & 1 \\ 15 & 16 \\ 14 & 30 \\ 8 & 38 \\ 12 & 50 \\ 4 & 54\end{array}$

SE

40N/03E-18E01. Altitude 103 feet.

Drilled by B \& K Water Wells, 1979.

Topsoil

Sand and clay

Sand, grey, and gravel

SG

40N/03E-19A01.

Altitude 98 feet.

Drilled by Hayes Well Drilling \& Pumps, Inc., 1989.

Topsoil

Clay, brown, and sand

2

2

4

6

30

36

Clay, grey, sand, and little gravel

9210

Sand, grey, little gravel, and water

$4 \quad 14$

Sand, coarse, grey, gravel, and water

Sand and water 
Appendix Table 3. Lithologic logs used in construction of hydrogeologic sections--Continued

\begin{tabular}{lccl}
\hline Mapcode) & Well number & Thickness & Depth (feet below \\
Materials & (feet) & land surface)
\end{tabular}

Clay, grey, sand, fine

2

40

$\mathrm{SH}$

40N/03E-22C01. Altitude 55 feet.

Drilled 1945.

Gravel

5

5

Clay, grey-blue

10

SI 40N/03E-24E01. Altitude 75 feet. Drilled by Star Drilling Service, 1990.

Clay, red

11

11

Clay, grey

Hardpan

132

149

Gravel

0.5

150.5

SK

Altitude 78 feet.

Drilled by Hayes Well Drilling \& Pumps, Inc., 1985.

Topsoil

Clay, grey

10

10

7

17

Peat, dark brown

19.5

36.5

Sand and water

2

38.5

Gravel, grey, water, and clay, grey

6.5

45

SR

40N/03E-26H01.

Altitude 70 feet.

Drilled by Sumas Well Drill, 1954.

Clay, loam

Sand

8

8

Gravel

7

15

9

24

SP

40N/03E-31N02.

Altitude 80 feet.

Drilled by Livermore \& Son Inc., 1989.

Sand, coarse

Sand, brown, and fine

Sand, blue, and fine 
Appendix Table 3. Lithologic logs used in construction of hydrogeologic sections--Continued

\begin{tabular}{|c|c|c|c|}
\hline $\begin{array}{l}\text { (Mapcode) } \\
\text { Materials }\end{array}$ & Well number & $\begin{array}{c}\text { Thickness } \\
\text { (feet) }\end{array}$ & $\begin{array}{l}\text { Depth (feet below } \\
\text { land surface) }\end{array}$ \\
\hline
\end{tabular}

SS 40N/03E-32G01. Altitude 77 feet.

Drilled by Hayes Well Drilling \& Pumps, Inc., 1985.

Topsoil

$\begin{array}{rr}2 & 2 \\ 31 & 33 \\ 1 & 34 \\ 3 & 37 \\ 78 & 115 \\ 10 & 125 \\ 27 & 152 \\ 51 & 203 \\ 102 & 305 \\ 48 & 353 \\ 7 & 360 \\ 42 & 402 \\ 5 & 407 \\ 30 & 437 \\ 5 & 442\end{array}$

SW

40N/03E-32L01.

Altitude 87 feet.

Drilled by B \& K Water Well Inc., 1989.

Topsoil

Sand, brown, and coarse

Sand, brown, and fine

Clay, brown

Sand, grey, and fine

$$
2
$$

SZ

Soil, brown, and sandy

Sand, grey, and coarse

Clay, blue

TA 40N/03E-32P02. Altitude 92 feet.

Drilled by Hayes Well Drilling \& Pumps, Inc., 1981.

Topsoil

Sand, brown and coarse 2

Sand, brown, coarse and gravel

Clay, brown 
Appendix Table 3. Lithologic logs used in construction of hydrogeologic sections--Continued

\begin{tabular}{lccl}
\hline Mapcode) & Well number & Thickness & Depth (feet below \\
Materials & (feet) & land surface)
\end{tabular}

Clay, grey

23

Sand, grey

Clay, grey

Sand, grey, and water 207

Clay, sandy grey 13

Sand, grey, and water

Clay, grey, and gravel 371

Sand, grey, and water 12

Gravel, some sand, and water

Gravel and clay, grey 378

Gravel, sand, and water 450

Gravel, grey, and clay 493

Clay, grey 517

Clay, grey, and clam shells 557

Clay, grey, and gravel 569

Clay, grey

Gravel and saltwater

Clay, grey, and gravel

Granite boulder

Drilled by B \& K Water Well Inc., 1988.

Topsoil

Sand, grey, coarse

Clay, brown

Sand, grey, and gravel

$$
2
$$

1

8
2

16

17

25

Clay, blue at bottom of hole

TG

40N/03E-34P01.

Altitude 80 feet.

Drilled by B \& K Water Wells, 1988.

Topsoil

Sand, coarse

Sand and gravel 2

Clay, blue at bottom of hole 
Appendix Table 3. Lithologic logs used in construction of hydrogeologic sections--Continued

\begin{tabular}{lccc}
\hline Mapcode) & Well number & Thickness & Depth (feet below \\
Materials & (feet) & land surface)
\end{tabular}

Sand, fine to coarse

$\begin{array}{rr}10 & 10 \\ 5 & 15 \\ 15 & 30 \\ 5 & 35 \\ 100 & 135 \\ 80 & 215 \\ 41 & 256\end{array}$

Bedrock at bottom of hole

Topsoil

Sand, medium, brown, and water

Clay, grey at bottom of hole

TK

40N/03E-36J01.

Altitude 90 feet.

Drilled 1936.

Gravel, ashy, and grey

Subsoil, gravel, rusty, and gravel, ash-grey

Topsoil

Sand and little gravel

Clay, sandy, and gravel

Gravel and water

Sand, dirty, and little water

TW

40N/04E-05E02.

Altitude 162 feet.

Drilled by Hayes Well Drilling \& Pumps, Inc., 1988.
5

5

40

31

14
5

10

50

81

95
Topsoil

Gravel, brown, and dry

Gravel and water

Gravel, grey, sand, and water 
Appendix Table 3. Lithologic logs used in construction of hydrogeologic sections--Continued

\begin{tabular}{lccc}
\hline Mapcode) & Well number & Thickness & Depth (feet below \\
Materials & (feet) & land surface)
\end{tabular}

Sand, grey, medium, gravel, and water

6

77

Sand, grey, medium, clay, and water at bottom of hole

TZ

40N/04E-05N02. Altitude 139 feet.

Drilled by B \& C Well Drilling, Inc., 1979.

Gravel with cobbles, sandy

17

17

Hardpan, brown

32

49

Hardpan, softer

14

63

Gravel, coarse

10

73

Sand with gravel

80

Sand, coarse, with gravel

UG

40N/04E-07G01.

Altitude 110 feet.

Drilled by Hayes Well Drilling \& Pumps, Inc., 1988.

Sand, brown, coarse, and gravel

Sand, brown

Sand, brown, and little clay

Sand, brown

Sand, brown, and water

Clay, coarse, brown, and sand

Sand, brown, and water

Sand, brown, coarse, gravel, and water

Topsoil

Sand, brown, dry, gravel, and clay

\section{4}

6

4

2

4

Gravel, brown, sand, and water

Sand, brown, medium, and water, dirty

Gravel, sand, and water

Clay, brown

Gravel, sand, and water

Sand, brown, and water

Sand, brown, gravel, and water

Sand, gravel, greyish, and water

$\begin{array}{rr}4 & 4 \\ 4 & 10 \\ 2 & 14 \\ 4 & 16 \\ 6 & 20 \\ 4 & 36 \\ 1 & 30 \\ 1 & 41 \\ 4 & 62 \\ 6 & 72 \\ & 76 \\ \end{array}$


Appendix Table 3. Lithologic logs used in construction of hydrogeologic sections--Continued

(Mapcode) Well number

Materials
Thickness

(feet)
Depth (feet below

land surface)
Sand, coarse, and water

Sand, coarse, gravel, and water

Clay, grey at bottom of hole

UI

40N/04E-08A02.

Topsoil

Sand, brown, slit, and clay

Clay, grey, and some gravel

Gravel, grey, sand, clay, and water

Gravel, grey, sand, and water

UK

40N/04E-09B01.

Clay

Sandy muck, some water

Clay and gravel

Gravel, loose, and water

UR

40N/04E-10E02.

Altitude 46 feet.

Loam, sandy, tan

Clay, grey

Silt, grey, and clay seepage

Clay, grey, chunks of peat and wood

Silt, grey, clay, and wood

Sand, gravel, and water

US

40N/04E-10G01.

Altitude 47 feet.

Drilled by Hayes Well Drilling \& Pumps, Inc., 1979.

Topsoil

3

Clay, sandy brown

Clay, grey

Gravel and water

Clay, grey, and gravel

Gravel and water

2

84

6

90
Drilled by Hayes Well Drilling \& Pumps, Inc., 1980.
3

22

7

3

22
3

25

32

35

57
Drilled by G.A. Bezona, 1962.

10

10

$10-20$

$13-33$

$16-49$

Drilled by Hayes Well Drilling \& Pumps, Inc., 1971. 1

3

2

12

7

1

4

6

18

13

25

38

3

3

6

24

30

15

45

10

55

14

69 
Appendix Table 3. Lithologic logs used in construction of hydrogeologic sections--Continued

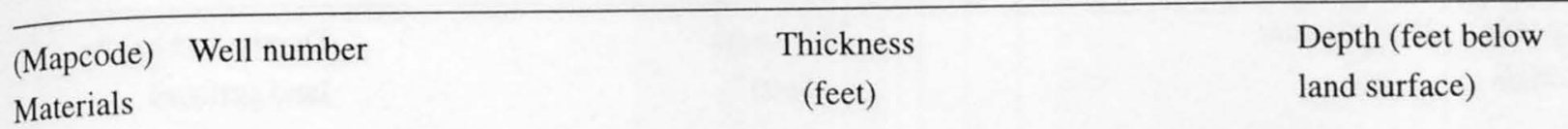

UU 40N/04E-11C01. Altitude 43 feet.

Drilled by America Water Wells Inc., 1980.

Topsoil

Sand and gravel

Sand, gravel, and water

Cemented graveled boulders at bottom of hole

UV

40N/04E-12B01.

Altitude 50 feet.

Topsoil

Sand, dry, and little wood

Sand, medium, and water

Sand, grey, medium, gravel, and water

Clay, grey

Gravel, sand, and little water, dirty

Clay, grey

Gravel, sand, and water

Clay, grey

Gravel, sand, and water

Peat, clay, grey, and wood

Gravel and water

Clay, grey

Gravel, sand, and water

Sand, fine, and water

VI 40N/04E-19K01. Altitude 70 feet.

Topsoil

Clay, blue

Sand and gravel

Gravel and water

\section{VO $\quad 40 \mathrm{~N} / 04 \mathrm{E}-22 \mathrm{~J} 02$.}

Topsoil

Gravel, brown, dry and sand

Gravel, brown, sand, seepage

Gravel, brown, sand, and water

Altitude 178 feet.

Drilled by Hayes Well Drilling \& Pumps, Inc., 1980.

$\begin{array}{rr}3 & 3 \\ 12 & 15 \\ 3 & 18 \\ 7 & 25 \\ 20 & 25 \\ 3 & 45 \\ 7 & 48 \\ 7 & 55 \\ 3 & 62 \\ 1 & 65 \\ 9 & 66 \\ 7 & 75 \\ 8 & 82 \\ 12 & 90 \\ 8 & 102 \\ & 110\end{array}$

Drilled by Dahlman Pump \& Drilling, Inc., 1982.

$\begin{array}{rr}3 & 3 \\ 32 & 35 \\ 15 & 50 \\ 7 & 57\end{array}$

Drilled by Hayes Well Drilling \& Pumps, Inc., 1981.

1
69 
Appendix Table 3. Lithologic logs used in construction of hydrogeologic sections--Continued

\begin{tabular}{lcc}
\hline $\begin{array}{l}\text { Mapcode) Well number } \\
\text { Materials }\end{array}$ & $\begin{array}{c}\text { Thickness } \\
\text { (feet) }\end{array}$ & $\begin{array}{c}\text { Depth (feet below } \\
\text { land surface) }\end{array}$ \\
\hline Clay, brown & 2 & 71 \\
Clay, grey, and soft & 36.5 & 107.5 \\
Sand, grey, coarse, little gravel, & & \\
$\quad$ and water. & 1 & 108.5 \\
Clay, grey, and little gravel & 4.5 & 113 \\
Clay, grey, and soft & 6 & 119 \\
Gravel, sand, and water & 1 & 120 \\
Sand, little gravel, shells, and water & 3 & 123 \\
Sand, grey, and clay, soft & 4 & 127 \\
Clay, grey & 1 & 128 \\
Clay, grey, and gravel, soft & 2 & 130 \\
Clay, grey, and soft & 7 & 137 \\
Clay, grey, and gravel & 7 & 144 \\
Clay, and gravel, grey & 11 & 155 \\
Sandstone & 45 & 200
\end{tabular}

VS 40N/04E-28D02. Altitude 130 feet. Drilled by B \& C Well Drilling, Inc., 1980.

Soil

Gravel, crusted

Gravel, dry, loose

Gravel, dirty

Hardpan

Gravel and water

Silt with sand and water

VX

40N/04E-30D01.

Altitude 75 feet.

Drilled by Herman Ellingson, 1962.
1

1

39

7

1

19

3
Topsoil

Sand

Clay and peat

Gravel

1
2
41
48
49
68
71

71

VY

40N/04E-30E01.

Altitude 75 feet.

Drilled by Hayes Well Drilling \& Pumps, Inc., 1980.

Topsoil 3 3

Clay, brown

7

Clay, grey 
Appendix Table 3. Lithologic logs used in construction of hydrogeologic sections--Continued

\begin{tabular}{lcc}
\hline Mapcode) & Well number & Thickness \\
Materials & (feet) & $\begin{array}{l}\text { Depth (feet below } \\
\text { land surface) }\end{array}$
\end{tabular}

Peat and wood

Gravel, grey, and clay

Gravel, grey, and water

Clay, grey at bottom of hole

WL $\quad 41 \mathrm{~N} / 02 \mathrm{E}-33 \mathrm{~J} 01$.

Topsoil

Hardpan

Sand, gravel, and hardpan

Sand and clay, blue

Sand, fine, and water

Sand and clay, blue

Sand, gravel, and water

WN $41 \mathrm{~N} / 02 \mathrm{E}-35 \mathrm{Q} 02 . \quad$ Altitude 150 feet.

Gravel, greyish-brown

Gravel, grey, and clay

Clay, grey, and gravel

Gravel, grey, and sand

Clay, grey, very hard

Gravel, grey, and clay

Gravel, clean, grey

Gravel, grey, and clay

Gravel, clay, grey, and wood

Altitude 250 feet. Drilled by Livermore and Son, Inc., 1989.

$\begin{array}{ll}5 & 25 \\ 9 & 34\end{array}$

\section{0}

25

34

$\begin{array}{rr}2 & 2 \\ 6 & 8 \\ 6 & 14 \\ 47 & 61 \\ 7 & 68 \\ 6 & 74 \\ 5 & 79\end{array}$

15

15

823

$37 \quad 60$

$35-95$

$26-121$

119

240

242

260

18

263

Gravel, grey and clay, and small layers of clay

Clay, grey, hard

Gravel, grey, and clay, dry

Gravel, brownish-grey, and clay

Gravel, grey, and clay

Clay, grey, and gravel

Drilled by Hayes Well Drilling \& Pumps, Inc., 1979.

Gravel, grey, water wood, and clam shells

Siltstone

314

331

341

345

382

398

424

26

500 
Appendix Table 3. Lithologic logs used in construction of hydrogeologic sections--Continued

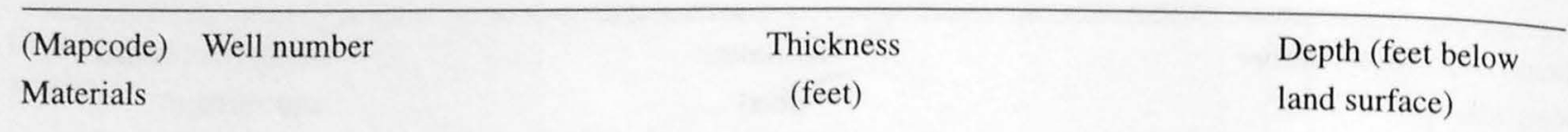

WO 41N/02E-36J01. Altitude 129 feet. Drilled by Snowden Well Digging, 1979.

Sandy loam

Sand, and clay, hard

2

3

10

13
2

5

15

28

Clay, blue at bottom of hole

WP 41N/02E-36K01. Altitude 129 feet. Drilled by Herman Ellingson, 1962.

Topsoil

Gravel, water bearing

3 3

WS

41N/03E-31Q01.

Altitude 136 feet.

Drilled by Snowden Well Digging, 1980.

Peat, soil

Sand and clay

Sand and gravel

4

3

26

4

7

33

WT 41N/03E-32Q01. Altitude 137 feet. Drilled by A \& K Driller, 1974.

Topsoil

Sand, coarse, and gravel

1

29

1

30

WU

41N/03E-33E01.

Altitude 146 feet.

Drilled by Livermore \& Son, Inc., 1987.

Topsoil

Sand and gravel, dry

Sand and gravel

Sand and water

$\begin{array}{rr}3 & 3 \\ 13 & 16 \\ 5 & 21 \\ 22 & 43\end{array}$

WV 41N/03E-33G01. Altitude 141 feet.

Drilled by Hayes Well Drilling \& Pumps, Inc., 1981.

Topsoil, sandy, and some gravel

Sand, brown, and gravel

Gravel, brown, sand, and water 
Appendix Table 3. Lithologic logs used in construction of hydrogeologic sections--Continued

(Mapcode) Well number

Materials
Thickness

(feet)
Depth (feet below land surface)

Sand, brown, and water

$\begin{array}{rr}62 & 85 \\ 150 & 235 \\ 18 & 253 \\ 22 & 275 \\ 8 & 283\end{array}$

WX 41N/03E-34G01. Altitude 141 feet.

Drilled by Hayes Well Drilling \& Pumps, Inc., 1988.

\section{5}

253

275

283
Topsoil

Clay, grey

Gravel, sand, and water

Sand, little gravel, and water
2

1

15

20
Sand, fine, and clay and water at bottom of hole

WY 41N/03E-34M01. Altitude 141 feet.

Drilled by Harold Zwicker, 1954.

Clay loam

Gravel and rock

3

3

17

20

Altitude 158 feet. $\quad$ Drilled by B \& C Well Drilling, Inc., 1988.

$\mathrm{XH}$

41N/03E-35L01.

2

2

Topsoił

25

27

$\mathrm{XC}$

41N/03E-36J02.

Altitude 162 feet.

Drilled by Hayes Well Drilling \& Pumps, Inc., 1987.

Topsoil

Sand, brown, gravel, and wood

Gravel, brown

Gravel, brown, sand, and water

Gravel, rusty-brown, and water

Sand, greenish-grey, gravel, and water

Gravel, grey, sand, and water
1

8

7

32

24

48

11

59

20

79

13
3

18

38

Clay, grey at bottom of hole 
Appendix Table 3. Lithologic logs used in construction of hydrogeologic sections--Continued

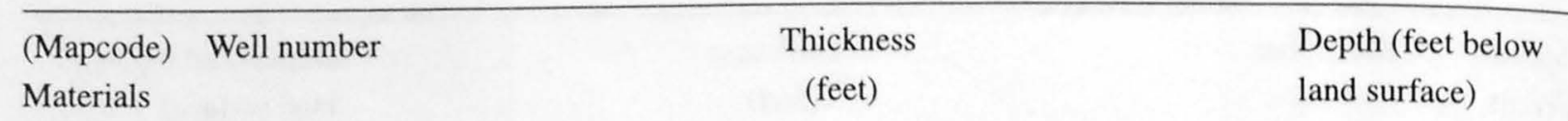

XD 41N/03E-36N01. Altitude 159 feet. Drilled by Don Mulka, 1956.

Clay, red, loam 2

Gravel

$\mathrm{XG}$

Topsoil

Sand and gravel

Sand, fine, and water bearing

Sand and gravel, brown

Sand and gravel, blue

11

XI

41N/04E-32E01.

Altitude 206 feet.

Drilled by Hayes Well Drilling \& Pumps, Inc., 1981.

Topsoil

Sand, brown, dry, and gravel

Sand, brown, gravel, and water

Gravel, brown, sand and water

Sand, brown, gravel, and water

Sand, brown, some gravel, and water

Gravel, grey, sand, and clay

Sand, grey, very little gravel, and water

Sand, grey, fine, and water

Gravel, silty, and topsoil

Gravel, sand, and alluvium 
Appendix Table 3. Lithologic logs used in construction of hydrogeologic sections--Continued

\begin{tabular}{lccl}
\hline Mapcode) & Well number & Thickness & Depth (feet below \\
Materials & (feet) & land surface)
\end{tabular}

Gravel

21

27

XL 41N/04E-32R01. Altitude 194 feet. Drilled by B \& C Well Drilling, Inc., 1974.

Topsoil

Gravel, cemented

Boulders

Gravel, cemented

Sand, with gravel

Clay, sandy

Gravel, cemented

Sand, with gravel

3

Sand and gravel with water

$7 \quad 10$

1 11

$12 \quad 23$

427

$23 \quad 50$

$15 \quad 65$

$17-82$

$10 \quad 92$

XQ 41N/04E-33H04. Altitude 50 feet. Drilled by Kimple Well Drilling, 1971.

$\begin{array}{lll}\text { Peat } & 30 & 30\end{array}$

$\begin{array}{lll}\text { Gravel, clayey } & 5 & 35\end{array}$

$\begin{array}{lll}\text { Gravel with chunks of clay and water } & 10 & 45\end{array}$

Gravel, coarse $\quad 11 \quad 56$

Sand, coarse $\quad 2 \quad 58$

$\begin{array}{lll}\text { Gravel, coarse } & 10 & 68\end{array}$

XR 41N/04E-33N02. Altitude 119 feet.

Sand, brown, fine, and traces of clay,

silt and gravel 32

Silt and traces of sand $\quad 22$

Sand, dark brown and grey, and little gravel

Silt, grey

$50 \quad 104$

$4 \quad 108$

Sand, grey-brown, fine

199

Clay, grey 
Appendix Table 3. Lithologic logs used in construction of hydrogeologic sections--Continued

\begin{tabular}{|c|c|c|c|}
\hline $\begin{array}{l}\text { (Mapcode) } \\
\text { Materials }\end{array}$ & Well number & $\begin{array}{l}\text { Thickness } \\
\text { (feet) }\end{array}$ & $\begin{array}{l}\text { Depth (feet below } \\
\text { land surface) }\end{array}$ \\
\hline
\end{tabular}

XT 41N/04E-33N04. Altitude 87 feet.

Sand brown, fine, and some slit,

trace clay

Clay, grey, traces of fine sand, and silt

Sand, grey to brown, fine, trace clay, and little silt

Clay, grey, trace silt

Sand, grey-brown, and gravel

Clay, brown-grey, some sand

XW

41N/04E-36L01.

Altitude 30 feet.

Topsoil

Gravel, small, brown

Clay, brown, and sand

Clay, grey, and some sand

Sand, grey, some gravel, and water

Clay, brown

Clay, grey

Sand, grey, some gravel, and water

Clay, grey

Sand, grey, some gravel, and water

Clay, grey, some sand, and lots of wood

Sand, grey, fine, dirty, some wood, and water
12

17.5

54

71.5

0.5

72

Drilled by Hayes Well Drilling \& Pumps, Inc., 1982.

$\begin{array}{rr}2 & 2 \\ 6 & 8 \\ 4 & 12 \\ 6 & 18 \\ 11 & 18 \\ 2 & 29 \\ 2 & 31 \\ 4 & 33 \\ 16 & 37 \\ 10 & 53 \\ 5 & 63 \\ & 68\end{array}$

15

83

XX 41N/05E-31M01. Altitude 35 feet.

Drilled by Hayes Well Drilling \& Pumps, Inc., 1979.

Topsoil

Clay, tan, sandy 3

3

Clay, grey

Sand, medium, and water

5

8

26

34

Clay, grey

8

42

10

52

Sand, gravel, and water

20

72

Clay, grey

2

74

Sand, fine, dirty, wood, and water

2 2 8 9 1 7 3 63 8 
Appendix Table 3. Lithologic logs used in construction of hydrogeologic sections--Continued

\begin{tabular}{lccl}
\hline Mapcode) & Well number & Thickness & Depth (feet below \\
Materials & (feet) & land surface)
\end{tabular}

YB 41N/05E-32L02. Altitude 27 feet.

Drilled by Hayes Well Drilling \& Pumps, Inc., 1986.

Topsoil

2

2

Clay, grey, and sand

23

25

Sand and water

10

35

Sand, dirty, wood, and water

7

42

Sand, dirty, fine, grey, and wood

48

90

Silt, grey, sand, clay, and wood

50

140

Clay, grey

40

180 


\begin{tabular}{|c|c|c|c|c|c|c|c|c|}
\hline $\begin{array}{l}\text { Local } \\
\text { well } \\
\text { number }\end{array}$ & Date & $\begin{array}{l}\text { Hydro- } \\
\text { geo- } \\
\text { logic } \\
\text { unit }\end{array}$ & $\begin{array}{l}\mathrm{pH} \\
\text { (stan- } \\
\text { dard) }\end{array}$ & $\begin{array}{l}\text { Alka- } \\
\text { linity } \\
\text { (mg/L } \\
\mathrm{K} \text { as } \\
\mathrm{CaCO} 3 \text { ) }\end{array}$ & $\begin{array}{l}\text { Oxy- } \\
\text { gen } \\
\text { dis- } \\
\text { solved } \\
(\mathrm{mg} / \mathrm{L})\end{array}$ & $\begin{array}{l}\text { Hard- } \\
\text { ness, } \\
\text { total } \\
\text { (mg/L } \\
\quad \text { as } \\
\mathrm{CaCO} 3 \text { ) }\end{array}$ & $\begin{array}{l}\text { Iron, } \\
\text { dis- } \\
\text { solved } \\
(\mu \mathrm{g} / \mathrm{L} \\
\text { as } \mathrm{Fe})\end{array}$ & $\begin{array}{l}\text { Manga- } \\
\text { nese, } \\
\text { dis- } \\
\text { solved } \\
(\mu \mathrm{g} / \mathrm{L} \\
\text { as } \mathrm{Mn})\end{array}$ \\
\hline $092 \mathrm{G} .008 \cdot 1 \cdot 2.2-01$ & $10-01-91$ & EVRS & 7.0 & 97 & 0.3 & 100 & 5 & 11 \\
\hline 092G.008.1.4.2-15 & $10-01-91$ & EVRS & 8.3 & 146 & 0.2 & 258 & 340 & 140 \\
\hline 092G.008.2.1.1-02 & $10-01-91$ & EVRS & 8.2 & 132 & 0.1 & 64 & 110 & 140 \\
\hline $092 \mathrm{G} .008 \cdot 2 \cdot 2 \cdot 1-03$ & $10-01-91$ & SUMS & 8.5 & 74 & 0.1 & 84 & 7 & 27 \\
\hline 092G.008.2.2.3-03 & $10-01-91$ & SUMS & 6.2 & 56 & 4.3 & 66 & 7 & 1 \\
\hline 092G.008.2.3.3-14 & $10-01-91$ & EVRS & 8.9 & 147 & 0.0 & 27 & 34 & 17 \\
\hline 092G.008.2.4.1-18 & $10-01-91$ & SUMS & 7.3 & 79 & 1.7 & 83 & 5 & 0.9 \\
\hline 092G.008.2.4.2-14 & $10-01-91$ & EVRS & 6.7 & 55 & 5.8 & 78 & 3 & 0.9 \\
\hline 092G.009.1.1.1-06-25 & 06-13-90 & SUMS & 5.5 & 9.0 & 8.8 & 76 & 3 & 2 \\
\hline 092G.009.1.1.1-06-35 & $06-13-90$ & SUMS & 5.7 & 13 & 8.5 & 95 & 3 & 0.9 \\
\hline 092G.009.1.1.1-07-55 & $06-13-90$ & SUMS & 6.7 & 44 & 6.4 & 68 & 3 & 0.9 \\
\hline 092G.009.1.1.1-07-75 & $06-13-90$ & SUMS & 8.0 & 69 & 0.2 & 88 & 3 & 5 \\
\hline 092G.009.1.1.2-11-25 & $06-12-90$ & SUMS & 5.5 & 9.0 & 9.0 & 54 & 3 & 3 \\
\hline 092G.009.1.1.2-11-35 & $06-12-90$ & SUMS & 5.8 & 13 & 9.2 & 98 & 3 & 3 \\
\hline 092G.009.1.1.2-12-55 & $06-12-90$ & SUMS & 6.7 & 46 & 5.0 & 82 & 3 & 0.9 \\
\hline 092G.009.1.1.2-12-75 & $06-12-90$ & SUMS & 8.0 & 65 & 0.8 & 85 & 3 & 7 \\
\hline 092G.009.1.1.4-17 & 09-30-91 & SUMS & 6.4 & 50 & 5.8 & 112 & 46 & 4 \\
\hline 092G.009.1.1.4-18-25 & $06-12-90$ & SUMS & 5.5 & 16 & 8.1 & 32 & 4 & 0.9 \\
\hline 092G.009.1.1.4-18-35 & $06-12-90$ & SUMS & 5.7 & 19 & 7.6 & 35 & 3 & 0.9 \\
\hline 092G.009.1.1.4-19-55 & $06-12-90$ & SUMS & 6.4 & 48 & 6.0 & 61 & 3 & 0.9 \\
\hline 092G.009.1.1.4-19-75 & $06-12-90$ & SUMS & 8.1 & 56 & 1.0 & 91 & 3 & 28 \\
\hline 092G.009.1.2.4-31 & $09-30-91$ & EVRS & 6.4 & 47 & 6.4 & 94 & 22 & 0.9 \\
\hline 092G.009.1.3.4-26 & 09-30-91 & SUMS & 6.0 & 27 & 6.4 & 45 & 22 & 7 \\
\hline 092G.009.2.1.2-19 & $10-02-91$ & SUMS & 6.5 & 50 & 4.5 & 92 & 3 & 380 \\
\hline 092G.009.2.1.4-26 & $10-02-91$ & SUMS & 8.0 & 94 & 2.8 & 144 & 12 & 7 \\
\hline 092G.009.2.2.3-11 & $10-01-91$ & SUMS & 6.8 & 17 & $<1$ & 232 & 34,000 & 970 \\
\hline 39N/02E-01P02 & $08-29-90$ & SUMS & 6.6 & 15 & -- & 53 & 6 & 4 \\
\hline $39 \mathrm{~N} / 02 \mathrm{E}-10 \mathrm{~F} 01$ & $08-28-90$ & SUMS & 7.6 & 36 & 2.3 & 85 & 150 & 230 \\
\hline $39 \mathrm{~N} / 02 \mathrm{E}-11 \mathrm{~B} 01$ & $04-23-91$ & SUMS & 6.1 & 13 & 2.2 & 40 & 13 & 66 \\
\hline $39 \mathrm{~N} / 02 \mathrm{E}-12 \mathrm{~K} 03$ & $08-29-90$ & SUMS & 7.0 & 26 & -- & 41 & 5 & 8 \\
\hline $39 \mathrm{~N} / 02 \mathrm{E}-13 \mathrm{~B} 01$ & $04-26-91$ & SUMS & 7.2 & 88 & 5.7 & 109 & 5,300 & 380 \\
\hline $39 \mathrm{~N} / 02 \mathrm{E}-14 \mathrm{M} 01$ & $08-28-90$ & SUMS & 6.8 & 45 & $<0.1$ & 69 & 170 & 66 \\
\hline $39 \mathrm{~N} / 02 \mathrm{E}-22 \mathrm{D} 02$ & $04-25-91$ & SUMS & 8.4 & 83 & 1.3 & 111 & 87 & 200 \\
\hline $39 \mathrm{~N} / 02 \mathrm{E}-24 \mathrm{C} 02$ & $04-26-91$ & SUMS & 6.2 & 24 & 3.2 & 54 & 960 & 63 \\
\hline
\end{tabular}


Appendix Table $4 \mathbf{b}$. Values of common constituents, concentrations of major ions, iron, and manganese--Continued

\begin{tabular}{|c|c|c|c|c|c|c|c|c|c|}
\hline $\begin{array}{l}\text { Sod- } \\
\text { ium } \\
\text { dis- } \\
\text { solved } \\
(\mathrm{mg} / \mathrm{L} \\
\text { as } \mathrm{Na})\end{array}$ & $\begin{array}{l}\text { Po- } \\
\text { tass- } \\
\text { ium } \\
\text { dis- } \\
\text { solved } \\
(\mathrm{mg} / \mathrm{L} \\
\text { as } \mathrm{K})\end{array}$ & $\begin{array}{l}\text { Cal- } \\
\text { cium } \\
\text { dis- } \\
\text { solved } \\
(\mathrm{mg} / \mathrm{L} \\
\text { as } \mathrm{Ca})\end{array}$ & $\begin{array}{l}\text { Magne- } \\
\text { sium } \\
\text { dis- } \\
\text { solved } \\
(\mathrm{mg} / \mathrm{L} \\
\text { as } \mathrm{Mg})\end{array}$ & $\begin{array}{l}\text { Nitrate } \\
\text { plus } \\
\text { nitrite } \\
\text { dis- } \\
\text { solved } \\
\text { (mg/L } \\
\text { as N) }\end{array}$ & $\begin{array}{l}\text { Sul- } \\
\text { fate } \\
\text { dis- } \\
\text { solved } \\
\text { (mg/L } \\
\text { as SO4) }\end{array}$ & $\begin{array}{l}\text { Chlo- } \\
\text { ride } \\
\text { dis- } \\
\text { solved } \\
(\mathrm{mg} / \mathrm{L} \\
\text { as } \mathrm{Cl})\end{array}$ & $\begin{array}{l}\text { Fluo- } \\
\text { ride } \\
\text { dis- } \\
\text { solved } \\
\text { (mg/L } \\
\text { as } \mathrm{F} \text { ) }\end{array}$ & $\begin{array}{l}\text { Sil- } \\
\text { ica } \\
\text { dis- } \\
\text { solved } \\
\text { (mg.L } \\
\text { as Si) }\end{array}$ & $\begin{array}{l}\text { Local } \\
\text { well } \\
\text { number }\end{array}$ \\
\hline 8.0 & 1.7 & 22 & 11 & 1.0 & 14 & 4.9 & 0.1 & 17 & 092G.008.1.2.2-01 \\
\hline 43 & 12 & 36 & 41 & 0.05 & 110 & 620 & 0.2 & 25 & 092G.008.1.4.2-15 \\
\hline 34 & 4.4 & 15 & 6.5 & 0.05 & 0.2 & 4.3 & 0.2 & 31 & 092G.008.2.1.1-02 \\
\hline 8.8 & 2.8 & 24 & 5.9 & 3.6 & 15 & 2.2 & 0.1 & 18 & 092G.008.2.2.1-03 \\
\hline 5.9 & 2.2 & 18 & 5.3 & 4.2 & 5.5 & 5.8 & 0.2 & 20 & 092G.008.2.2.3-03 \\
\hline 57 & 5.3 & 4 & 4.3 & 0.05 & 6.1 & 2.4 & 0.2 & 19 & 092G.008.2.3.3-14 \\
\hline 5.9 & 1.4 & 20 & 8.2 & 8.1 & 10 & 2.7 & 0.1 & 21 & 092G.008.2.4.1-18 \\
\hline 4.7 & 1.0 & 20 & 7.0 & 8.4 & 2.9 & 6.8 & 0.1 & 23 & 092G.008.2.4.2-14 \\
\hline 4.4 & 5.6 & 23 & 4.5 & 18 & 7.4 & 8.5 & 0.1 & 11 & 092G.009.1.1.1-06 \\
\hline 5.5 & 2.0 & 29 & 5.6 & 21 & 8.1 & 10 & 0.1 & 16 & 092G.009.1.1.1-06 \\
\hline 3.8 & 0.9 & 19 & 5.2 & 6.9 & 5.7 & 0.3 & 0.1 & 20 & 092G.009.1.1.1-07 \\
\hline 4.8 & 1.6 & 27 & 5.0 & 1.2 & 16 & 0.5 & 0.1 & 16 & 092G.009.1.1.1-07 \\
\hline 4.7 & 0.7 & 16 & 3.6 & 11 & 12 & 5.8 & 0.2 & 12 & 092G.009.1.1.2-11 \\
\hline 6.1 & 0.8 & 30 & 5.7 & 19 & 14 & 12 & $<0.1$ & 16 & 092G.009.1.1.2-11 \\
\hline 4.6 & 1.0 & 24 & 5.5 & 2.7 & 9.3 & 6.9 & 0.1 & 19 & 092G.009.1.1.2-12 \\
\hline 7.2 & 1.4 & 26 & 5.0 & 2.0 & 20 & 8.5 & $<0.2$ & 17 & 092G.009.1.1.2-12 \\
\hline 6.7 & 1.2 & 32 & 7.9 & 16 & 9.7 & 8.5 & 0.1 & 22 & 092G.009.1.1.4-17 \\
\hline 3.2 & 0.6 & 10 & 1.8 & 5.9 & 2.3 & 2.7 & 0.1 & 15 & 092G.009.1.1.4-18 \\
\hline 3.1 & 0.5 & 11 & 1.9 & 5.5 & 2.1 & 2.9 & 0.1 & 16 & 092G.009.1.1.4-18 \\
\hline 3.3 & 0.7 & 17 & 4.6 & 4.6 & 3.0 & 0.4 & 0.1 & 22 & 092G.009.1.1.4-19 \\
\hline 4.6 & 2.4 & 29 & 4.7 & 5.0 & 23 & 1.0 & 0.1 & 8.7 & 092G.009.1.1.4-19 \\
\hline 6.6 & 1.0 & 27 & 6.5 & 9.9 & 11 & 10 & 0.1 & 23 & 092G.009.1.2.4-31 \\
\hline 7.0 & 0.7 & 14 & 2.5 & 4.9 & 10 & 6.4 & 0.1 & 16 & 092G.009.1.3.4-26 \\
\hline 5.4 & 1.4 & 25 & 7.4 & 9.1 & 15 & 5.8 & 0.4 & 16 & 092G.009.2.1.2-98 \\
\hline 6.3 & 2.1 & 44 & 8.5 & 6.9 & 31 & 8.1 & 0.3 & 16 & 092G.009.2.1.4-98 \\
\hline 34 & 5.4 & 52 & 25 & 0.06 & 10 & 210 & $<0.1$ & 49 & 092G.009.2.2.3-11 \\
\hline 11 & 4.4 & 13 & 5.2 & 9.3 & 23 & 16.8 & $<0.1$ & 17 & $39 \mathrm{~N} / 02 \mathrm{E}-01 \mathrm{P} 02$ \\
\hline 8.4 & 1.5 & 25 & 5.7 & 4.9 & 31 & 15 & 0.4 & 24 & $39 \mathrm{~N} / 02 \mathrm{E}-10 \mathrm{~F} 01$ \\
\hline 5.4 & 0.7 & 11 & 3.1 & 3.3 & 16 & 8.9 & $<0.1$ & 16 & 39N/02E-11B01 \\
\hline 6.0 & 9.4 & 9.9 & 4.1 & 4.5 & 16 & 6.0 & $<0.1$ & 21 & $39 \mathrm{~N} / 02 \mathrm{E}-12 \mathrm{~K} 03$ \\
\hline 10 & 1.6 & 28 & 9.5 & 0.1 & 34 & 12 & $<0.1$ & 26 & $39 \mathrm{~N} / 02 \mathrm{E}-13 \mathrm{~B} 01$ \\
\hline 7.9 & 1.0 & 15 & 7.7 & 3.7 & 25 & 13 & $<0.1$ & 26 & $39 \mathrm{~N} / 02 \mathrm{E}-14 \mathrm{M} 01$ \\
\hline 22 & 1.8 & 29 & 9.4 & 0.05 & 43 & 27 & $<0.1$ & 22 & $39 \mathrm{~N} / 02 \mathrm{E}-22 \mathrm{D} 02$ \\
\hline 6.4 & 0.9 & 13 & 5.4 & 2.6 & 19 & 14 & $<0.1$ & 20 & $39 \mathrm{~N} / 02 \mathrm{E}-24 \mathrm{C} 02$ \\
\hline
\end{tabular}


Appendix Table 4a. Values of common constituents, concentrations of major ions, iron, and manganese--Continued

\begin{tabular}{|c|c|c|c|c|c|c|c|c|}
\hline $\begin{array}{l}\text { Local } \\
\text { well } \\
\text { number }\end{array}$ & Date & $\begin{array}{l}\text { Hydro- } \\
\text { geo- } \\
\text { logic } \\
\text { unit }\end{array}$ & $\begin{array}{l}\mathrm{pH} \\
\text { (stan- } \\
\text { dard) }\end{array}$ & $\begin{array}{l}\text { Alka- } \\
\text { linity } \\
(\mathrm{mg} / \mathrm{L} \\
\mathrm{K} \text { as } \\
\mathrm{CaCO} 3 \text { ) }\end{array}$ & $\begin{array}{l}\text { Oxy- } \\
\text { gen } \\
\text { dis- } \\
\text { solved } \\
(\mathrm{mg} / \mathrm{L})\end{array}$ & $\begin{array}{l}\text { Hard- } \\
\text { ness, } \\
\text { total } \\
\text { (mg/L } \\
\quad \text { as } \\
\text { CaCO3) }\end{array}$ & $\begin{array}{l}\text { Iron, } \\
\text { dis- } \\
\text { solved } \\
(\mu \mathrm{g} / \mathrm{L} \\
\text { as } \mathrm{Fe})\end{array}$ & $\begin{array}{l}\text { Manga- } \\
\text { nese, } \\
\text { dis- } \\
\text { solved } \\
(\mu \mathrm{g} / \mathrm{L} \\
\text { as } \mathrm{Mn})\end{array}$ \\
\hline $39 \mathrm{~N} / 02 \mathrm{E}-26 \mathrm{H} 01$ & $04-23-91$ & SUMS & 6.7 & 73 & 7.1 & 117 & 3 & 0.9 \\
\hline $39 \mathrm{~N} / 02 \mathrm{E}-27 \mathrm{~F} 03$ & $08-28-90$ & SUMS & 7.4 & 48 & 2.2 & 83 & 26 & 5 \\
\hline 39N/02E-27Q04 & $07-10-91$ & SUMS & 6.6 & 36 & 3.2 & 56 & 4 & 8 \\
\hline $39 \mathrm{~N} / 03 \mathrm{E}-01 \mathrm{C} 01$ & $04-22-91$ & SUMS & 6.7 & 45 & 1.2 & 68 & 54 & 69 \\
\hline 39 N/03E-02B02 & $08-28-90$ & SUMS & 7.4 & 60 & 0.2 & 84 & 120 & 97 \\
\hline 39N/03E-07K02 & 04-26-91 & SUMS & 6.5 & 28 & 6.6 & 141 & 10 & 28 \\
\hline $39 \mathrm{~N} / 03 \mathrm{E}-08 \mathrm{C} 02$ & $08-30-90$ & SUMS & 6.7 & 26 & -- & 71 & 11 & 0.9 \\
\hline 39N/03E-13E01 & 04-23-91 & BDRK & 8.6 & 179 & 0.1 & 26 & 170 & 13 \\
\hline $39 \mathrm{~N} / 03 \mathrm{E}-16 \mathrm{~F} 02$ & 04-30-91 & SUMS & 6.6 & 31 & 0.1 & 42 & 100 & 16 \\
\hline 39N/03E-17R03 & 04-23-91 & SUMS & 8.0 & 120 & 0.3 & 225 & 360 & 380 \\
\hline 39N/03E-19N01 & $04-23-91$ & EVRS & 7.9 & 133 & 0.6 & 121 & 3 & 4 \\
\hline $39 \mathrm{~N} / 03 \mathrm{E}-21 \mathrm{~K} 01$ & $04-24-91$ & EVRS & 8.8 & 414 & 0.1 & 54 & 150 & 16 \\
\hline $39 \mathrm{~N} / 03 \mathrm{E}-24 \mathrm{~B} 01$ & 04-26-91 & SUMS & 6.3 & 31 & 7.2 & 27 & 19 & 1 \\
\hline $39 \mathrm{~N} / 03 \mathrm{E}-26 \mathrm{D} 01$ & 04-23-91 & EVRS & 7.1 & 166 & $<0.1$ & 109 & 160 & 360 \\
\hline 39N/03E-26J01 & $04-25-91$ & BDRK & 7.7 & 214 & $<0.1$ & 195 & 1,500 & 110 \\
\hline $39 \mathrm{~N} / 03 \mathrm{E}-28 \mathrm{~F} 01$ & $04-24-91$ & EVRS & 8.5 & 212 & $<0.1$ & 145 & 260 & 50 \\
\hline 39N/03E-32J01 & $04-25-91$ & EVRS & 7.9 & 211 & $<0.1$ & 154 & 580 & 260 \\
\hline 39N/03E-33R01 & $04-24-91$ & BDRK & 8.5 & 606 & $<0.1$ & 12 & 48 & 6 \\
\hline $39 \mathrm{~N} / 03 \mathrm{E}-34 \mathrm{~N} 01$ & $04-25-91$ & SUMS & 6.6 & 118 & $<0.1$ & 129 & 93 & 380 \\
\hline $39 \mathrm{~N} / 03 \mathrm{E}-35 \mathrm{~L} 01$ & $04-24-91$ & EVRS & 8.5 & 229 & 0.1 & 68 & 80 & 72 \\
\hline 39N/04E-03P01 & $08-31-90$ & VSHN & 7.5 & 57 & $<0.1$ & 156 & 190 & 90 \\
\hline 39N/04E-10M01 & $04-27-91$ & VSHN & 8.6 & 95 & 0.4 & 170 & 80 & 20 \\
\hline $39 \mathrm{~N} / 04 \mathrm{E}-16 \mathrm{~F} 01$ & $04-25-91$ & SUMS & 6.6 & 51 & 3.2 & 61 & 15 & 50 \\
\hline $39 \mathrm{~N} / 04 \mathrm{E}-16 \mathrm{H} 01$ & $04-25-91$ & VSHN & 6.5 & 71 & 6.8 & 90 & 11 & 0.9 \\
\hline 39N/04E-16Q02 & 04-24-91 & SUMS & 6.5 & 49 & 4.1 & 69 & 30 & 0.9 \\
\hline $39 \mathrm{~N} / 04 \mathrm{E}-18 \mathrm{M} 01$ & 04-23-91 & BDRK & 8.2 & 143 & 0.1 & 31 & 15 & 99 \\
\hline 39N/04E-19M01 & $04-25-91$ & BDRK & 8.4 & 376 & $<0.1$ & 14 & 5 & 11 \\
\hline $39 \mathrm{~N} / 04 \mathrm{E}-20 \mathrm{H} 01$ & $04-24-91$ & SUMS & 6.4 & 39 & 2.7 & 46 & 73 & 2 \\
\hline $39 \mathrm{~N} / 04 \mathrm{E}-22 \mathrm{~L} 01$ & 04-23-91 & SUMS & 6.6 & 268 & 0.1 & 319 & 7 & 690 \\
\hline $39 \mathrm{~N} / 04 \mathrm{E}-28 \mathrm{~F} 01$ & 04-26-91 & SUMS & 6.2 & 39 & 0.8 & 44 & 94 & 3 \\
\hline 39N/04E-30D01 & 04-26-91 & EVRS & 8.4 & 300 & 0.1 & 65 & 61 & 87 \\
\hline $39 \mathrm{~N} / 04 \mathrm{E}-32 \mathrm{~A} 01$ & $04-26-91$ & EVRS & 8.9 & 444 & 0.2 & 10 & 180 & 11 \\
\hline $39 \mathrm{~N} / 04 \mathrm{E}-32 \mathrm{~N} 01$ & $04-24-91$ & EVRS & 9.0 & 392 & 0.3 & 12 & 75 & 6 \\
\hline 39N/04E-33E01 & 04-26-91 & EVRS & 8.8 & 409 & 1.0 & 12 & 73 & 4 \\
\hline $40 \mathrm{~N} / 02 \mathrm{E}-03 \mathrm{C} 01$ & 04-30-91 & EVRS & 8.0 & 203 & $<0.1$ & 53 & 570 & 270 \\
\hline
\end{tabular}




\begin{tabular}{|c|c|c|c|c|c|c|c|c|c|}
\hline $\begin{array}{l}\text { Sod- } \\
\text { ium } \\
\text { dis- } \\
\text { solved } \\
\text { (mg/L } \\
\text { as } \mathrm{Na})\end{array}$ & $\begin{array}{l}\text { Po- } \\
\text { tass- } \\
\text { ium } \\
\text { dis- } \\
\text { solved } \\
(\mathrm{mg} / \mathrm{L} \\
\text { as } \mathrm{K})\end{array}$ & $\begin{array}{l}\text { Cal- } \\
\text { cium } \\
\text { dis- } \\
\text { solved } \\
(\mathrm{mg} / \mathrm{L} \\
\text { as } \mathrm{Ca})\end{array}$ & $\begin{array}{l}\text { Magne- } \\
\text { sium } \\
\text { dis- } \\
\text { solved } \\
(\mathrm{mg} / \mathrm{L} \\
\text { as } \mathrm{Mg})\end{array}$ & $\begin{array}{l}\text { Nitrate } \\
\text { plus } \\
\text { nitrite } \\
\text { dis- } \\
\text { solved } \\
(\mathrm{mg} / \mathrm{L} \\
\text { as } \mathrm{N})\end{array}$ & $\begin{array}{l}\text { Sul- } \\
\text { fate } \\
\text { dis- } \\
\text { solved } \\
\text { (mg/L } \\
\text { as SO4) }\end{array}$ & $\begin{array}{l}\text { Chlo- } \\
\text { ride } \\
\text { dis- } \\
\text { solved } \\
(\mathrm{mg} / \mathrm{L} \\
\text { as } \mathrm{Cl})\end{array}$ & $\begin{array}{l}\text { Fluo- } \\
\text { ride } \\
\text { dis- } \\
\text { solved } \\
(\mathrm{mg} / \mathrm{L} \\
\text { as F) }\end{array}$ & $\begin{array}{l}\text { Sil- } \\
\text { ica } \\
\text { dis- } \\
\text { solved } \\
\text { (mg.L } \\
\text { as Si) }\end{array}$ & $\begin{array}{l}\text { Local } \\
\text { well } \\
\text { number }\end{array}$ \\
\hline 7.4 & 0.9 & 24 & 14 & 12 & 10 & 10 & $<0.1$ & 25 & $39 \mathrm{~N} / 02 \mathrm{E}-26 \mathrm{H} 01$ \\
\hline 15 & 1.1 & 17 & 9.9 & 12 & 19 & 16 & 0.1 & 28 & $39 \mathrm{~N} / 02 \mathrm{E}-27 \mathrm{~F} 03$ \\
\hline 15 & 1.1 & 15 & 4.6 & 5.8 & 15 & 13 & 0.1 & 17 & 39N/02E-27Q04 \\
\hline 24 & 1.8 & 17 & 6.3 & 0.37 & 9.7 & 54 & $<0.1$ & 21 & $39 \mathrm{~N} / 03 \mathrm{E}-01 \mathrm{C} 01$ \\
\hline 24 & 2.3 & 22 & 7.1 & 0.2 & 16 & 49 & 0.3 & 23 & $39 \mathrm{~N} / 03 \mathrm{E}-02 \mathrm{~B} 02$ \\
\hline 8.0 & 1.7 & 32 & 15 & 19 & 27 & 13 & $<0.1$ & 20 & 39N/03E-07K02 \\
\hline 6.6 & 1.1 & 16 & 7.7 & 0.1 & 3.9 & 7.2 & $<0.1$ & 21 & 39N/03E-08C02 \\
\hline 220 & 0.9 & 9.9 & 0.2 & 0.05 & 1.3 & 230 & 0.5 & 11 & 39N/03E-13E01 \\
\hline 4.7 & 0.8 & 9.4 & 4.7 & 1.2 & 19 & 3.3 & 0.2 & 24 & $39 \mathrm{~N} / 03 \mathrm{E}-16 \mathrm{~F} 02$ \\
\hline 13 & 2.0 & 64 & 16 & 1.4 & 79 & 34 & $<0.1$ & 30 & 39N/03E-17R03 \\
\hline 15 & 2.6 & 32 & 10 & 1.2 & 12 & 7.8 & $<0.1$ & 19 & $39 \mathrm{~N} / 03 \mathrm{E}-19 \mathrm{~N} 01$ \\
\hline 240 & 10 & 6 & 9.6 & 0.05 & 170 & 23 & 0.3 & 19 & $39 \mathrm{~N} / 03 \mathrm{E}-21 \mathrm{~K} 01$ \\
\hline 3.3 & 0.5 & 7.1 & 2.3 & 0.4 & 1.4 & 1.4 & $<0.1$ & 17 & 39N/03E-24B01 \\
\hline 33 & 3.3 & 24 & 12 & 0.05 & 2.6 & 7.5 & $<0.1$ & 20 & 39N/03E-26D01 \\
\hline 760 & 5.3 & 61 & 9.7 & 0.05 & 1.6 & 1,300 & 0.3 & 9.9 & $39 \mathrm{~N} / 03 \mathrm{E}-26 \mathrm{~J} 01$ \\
\hline 390 & 12 & 22 & 22 & 0.1 & 2.2 & 610 & 0.2 & 16 & $39 \mathrm{~N} / 03 \mathrm{E}-28 \mathrm{~F} 01$ \\
\hline 39 & 3.5 & 37 & 15 & 0.05 & 0.1 & 30 & 0.2 & 27 & 39N/03E-32J01 \\
\hline 380 & 1.6 & 4 & 0.7 & 0.05 & 0.1 & 220 & 0.5 & 7.6 & 39N/03E-33R01 \\
\hline 4.8 & 0.8 & 36 & 9.7 & 0.05 & 17 & 3.2 & $<0.1$ & 13 & $39 \mathrm{~N} / 03 \mathrm{E}-34 \mathrm{~N} 01$ \\
\hline 98 & 4.9 & 16 & 6.9 & 0.05 & 0.2 & 55 & 0.5 & 21 & $39 \mathrm{~N} / 03 \mathrm{E}-35 \mathrm{~L} 01$ \\
\hline 400 & 4.7 & 46 & 10 & 0.1 & 1.0 & 689 & 0.5 & 18 & 39N/04E-03P01 \\
\hline 370 & 3.1 & 42 & 16 & 0.05 & 0.1 & 650 & 0.3 & 15 & 39N/04E-10M01 \\
\hline 3.4 & 1.1 & 13 & 7.1 & 1.5 & 11 & 3.2 & $<0.1$ & 15 & $39 \mathrm{~N} / 04 \mathrm{E}-16 \mathrm{~F} 01$ \\
\hline 6.2 & 1.3 & 13 & 14 & 5.0 & 9.1 & 7.8 & $<0.1$ & 21 & $39 \mathrm{~N} / 04 \mathrm{E}-16 \mathrm{H} 01$ \\
\hline 5.3 & 1.0 & 9.5 & 11 & 3.6 & 7.2 & 5.6 & 0.1 & 24 & 39N/04E-16Q02 \\
\hline 67 & 0.8 & 11 & 0.9 & 0.05 & 0.4 & 28 & 0.3 & 13 & 39N/04E-18M01 \\
\hline 210 & 1.2 & 4.6 & 0.6 & 0.05 & 79 & 20 & 0.4 & 9.2 & 39N/04E-19M01 \\
\hline 3.6 & 0.7 & 11 & 4.7 & 0.7 & 5.8 & 3.7 & $<0.1$ & 14 & $39 \mathrm{~N} / 04 \mathrm{E}-20 \mathrm{H} 01$ \\
\hline 33 & 2.7 & 44 & 51 & 15 & 23 & 40 & $<0.1$ & 33 & $39 \mathrm{~N} / 04 \mathrm{E}-22 \mathrm{~L} 01$ \\
\hline 6.6 & 0.9 & 10 & 4.8 & 1.2 & 8.0 & 5.0 & $<0.1$ & 15 & $39 \mathrm{~N} / 04 \mathrm{E}-28 \mathrm{~F} 01$ \\
\hline 220 & 5.9 & 14 & 7.4 & 0.1 & 1,1 & 170 & 0.5 & 22 & 39N/04E-30D01 \\
\hline 230 & 3.5 & 2.6 & 0.9 & 0.05 & 0.1 & 74 & 1.1 & 16 & $39 \mathrm{~N} / 04 \mathrm{E}-32 \mathrm{~A} 01$ \\
\hline 200 & 3.8 & 2.3 & 1.7 & 0.05 & 0.1 & 59 & 0.6 & 15 & $39 \mathrm{~N} / 04 \mathrm{E}-32 \mathrm{~N} 01$ \\
\hline 210 & 3.6 & 2.0 & 1.7 & 0.05 & 0.1 & 70 & 1.0 & 16 & 39N/04E-33E01 \\
\hline 70 & 4.2 & 11 & 6.2 & 0.05 & 0.1 & 5.2 & 0.6 & 28 & $40 \mathrm{~N} / 02 \mathrm{E}-03 \mathrm{C} 01$ \\
\hline
\end{tabular}




\begin{tabular}{|c|c|c|c|c|c|c|c|c|}
\hline $\begin{array}{l}\text { Local } \\
\text { well } \\
\text { number }\end{array}$ & Date & $\begin{array}{l}\text { Hydro- } \\
\text { geo- } \\
\text { logic } \\
\text { unit }\end{array}$ & $\begin{array}{l}\mathrm{pH} \\
\text { (stan- } \\
\text { dard) }\end{array}$ & $\begin{array}{l}\text { Alka- } \\
\text { linity } \\
\text { (mg/L } \\
\mathrm{K} \text { as } \\
\mathrm{CaCO} 3 \text { ) }\end{array}$ & $\begin{array}{l}\text { Oxy- } \\
\text { gen } \\
\text { dis- } \\
\text { solved } \\
(\mathrm{mg} / \mathrm{L})\end{array}$ & $\begin{array}{l}\text { Hard- } \\
\text { ness, } \\
\text { total } \\
(\mathrm{mg} / \mathrm{L} \\
\quad \text { as } \\
\mathrm{CaCO} 3 \text { ) }\end{array}$ & $\begin{array}{l}\text { Iron, } \\
\text { dis- } \\
\text { solved } \\
(\mu \mathrm{g} / \mathrm{L} \\
\text { as } \mathrm{Fe})\end{array}$ & $\begin{array}{l}\text { Manga- } \\
\text { nese, } \\
\text { dis- } \\
\text { solved } \\
(\mu \mathrm{g} / \mathrm{L} \\
\text { as } \mathrm{Mn})\end{array}$ \\
\hline $40 \mathrm{~N} / 02 \mathrm{E}-10 \mathrm{~N} 02$ & $08-21-91$ & SUMS & 6.5 & 216 & 0.0 & 229 & 8,200 & 1,100 \\
\hline 40N/02E-13J04 & $07-19-91$ & SUMS & 6.3 & 1.0 & -- & 99 & 24,000 & 430 \\
\hline 40N/02E-13J07 & $07-19-91$ & SUMS & 7.3 & 451 & 0.2 & 48 & 1,600 & 45 \\
\hline 40N/02E-14P02 & 04-30-91 & SUMS & 6.1 & 20 & 8.8 & 110 & 30 & 3 \\
\hline $40 \mathrm{~N} / 02 \mathrm{E}-15 \mathrm{~J} 01$ & $04-29-91$ & SUMS & 6.5 & 54 & 0.4 & 95 & 5,700 & 870 \\
\hline 40N/02E-15P01 & $08-21-91$ & SUMS & 6.1 & 23 & 3.8 & 41 & 27 & 47 \\
\hline 40N/02E-21R01 & $04-30-91$ & SUMS & 5.7 & 9 & 7.7 & 105 & 26 & 10 \\
\hline 40N/02E-23D01 & $04-30-91$ & SUMS & 5.8 & 30 & 3.4 & 73 & 26 & 23 \\
\hline $40 \mathrm{~N} / 02 \mathrm{E}-26 \mathrm{~A} 03$ & $10-04-91$ & SUMS & 6.7 & 48 & 6.8 & 98 & 28 & 66 \\
\hline 40N/02E-27B01 & $08-30-90$ & SUMS & 6.5 & 17 & -- & 85 & 6 & 0.9 \\
\hline 40N/02E-33B02 & $10-02-91$ & SUMS & 6.4 & 27 & 9.4 & 62 & 12 & 5 \\
\hline 40N/03E-03B01 & $08-30-90$ & SUMS & 6.5 & 19 & -- & 56 & 38 & 4 \\
\hline 40N/03E-03R02 & $05-02-91$ & SUMS & 7.0 & 48 & 5.3 & 113 & 6 & 31 \\
\hline 40N/03E-05L01 & $08-14-91$ & SUMS & 6.6 & 559 & 0.2 & 395 & 36,000 & 3,500 \\
\hline 40N/03E-05M05 & $08-14-91$ & SUMS & 6.1 & 26 & -- & 112 & 58 & 12 \\
\hline $40 \mathrm{~N} / 03 \mathrm{E}-05 \mathrm{~N} 02$ & $08-29-90$ & SUMS & 6.0 & 10 & - & 49 & 1,600 & 58 \\
\hline 40N/03E-07A02 & $05-01-91$ & SUMS & 5.9 & 19 & 4.0 & 65 & 15 & 33 \\
\hline 40N/03E-10K01 & $05-02-91$ & SUMS & 6.2 & 54 & 3.4 & 111 & 27 & 1 \\
\hline 40N/03E-11E04 & $05-02-91$ & SUMS & 6.4 & 37 & 6.9 & 81 & 17 & 3 \\
\hline 40N/03E-16A02 & $08-27-90$ & SUMS & 6.5 & 30 & 8.5 & 70 & 7 & 0.9 \\
\hline 40N/03E-16K01 & $05-01-91$ & SUMS & 6.3 & 22 & 2.5 & 64 & 50 & 93 \\
\hline 40N/03E-19A01 & $10-04-91$ & SUMS & 6.6 & 48 & 0 & 64 & 13,000 & 800 \\
\hline 40N/03E-24E01 & $10-02-91$ & EVRS & 8.0 & 83 & -- & 1,008 & 10 & 200 \\
\hline 40N/03E-31L01 & $05-01-91$ & SUMS & 6.8 & 27 & 8.5 & 58 & 8 & 0.9 \\
\hline 40N/03E-31P03 & $04-26-91$ & SUMS & 6.5 & 35 & 7.7 & 100 & 58 & 0.9 \\
\hline 40N/03E-32M01 & $08-29-90$ & SUMS & 7.1 & 62 & -- & 51 & 8 & 5 \\
\hline 40N/03E-36Q01 & $04-30-91$ & SUMS & 6.2 & 44 & 5.3 & 66 & 4 & 2 \\
\hline 40N/04E-01K02 & $10-04-91$ & SUMS & 6.9 & 134 & 3.4 & 100 & 14,000 & 450 \\
\hline 40N/04E-05N02 & $05-02-91$ & SUMS & 7.9 & 103 & 4.3 & 122 & 7 & 1 \\
\hline 40N/04E-05P01 & $05-02-91$ & SUMS & 6.5 & 43 & 7.6 & 80 & 12 & 1 \\
\hline 40N/04E-05P02 & $08-29-90$ & SUMS & 6.5 & 57 & -- & 106 & 12 & 0.9 \\
\hline 40N/04E-09B01 & $02-21-91$ & SUMS & 7.0 & 109 & $<0.1$ & 101 & 8,400 & 265 \\
\hline 40N/04E-09B01 & $05-03-91$ & SUMS & 7.0 & 109 & -- & 0 & 8,400 & 265 \\
\hline 40N/04E-09N03 & $08-28-90$ & SUMS & 7.2 & 179 & $<0.1$ & 162 & 11,000 & 560 \\
\hline 40N/04E-17G01 & $10-03-91$ & SUMS & 6.7 & 106 & 4.5 & 139 & 2,700 & 320 \\
\hline
\end{tabular}




\begin{tabular}{|c|c|c|c|c|c|c|c|c|c|}
\hline $\begin{array}{l}\text { Sod- } \\
\text { ium } \\
\text { dis- } \\
\text { solved } \\
\text { (mg/L } \\
\text { as } \mathrm{Na})\end{array}$ & $\begin{array}{l}\text { Po- } \\
\text { tass- } \\
\text { ium } \\
\text { dis- } \\
\text { solved } \\
(\mathrm{mg} / \mathrm{L} \\
\text { as } \mathrm{K})\end{array}$ & $\begin{array}{l}\text { Cal- } \\
\text { cium } \\
\text { dis- } \\
\text { solved } \\
(\mathrm{mg} / \mathrm{L} \\
\text { as } \mathrm{Ca})\end{array}$ & $\begin{array}{l}\text { Magne- } \\
\text { sium } \\
\text { dis- } \\
\text { solved } \\
(\mathrm{mg} / \mathrm{L} \\
\text { as } \mathrm{Mg})\end{array}$ & $\begin{array}{l}\text { Nitrate } \\
\text { plus } \\
\text { nitrite } \\
\text { dis- } \\
\text { solved } \\
(\mathrm{mg} / \mathrm{L} \\
\text { as } \mathrm{N} \text { ) }\end{array}$ & $\begin{array}{l}\text { Sul- } \\
\text { fate } \\
\text { dis- } \\
\text { solved } \\
(\mathrm{mg} / \mathrm{L} \\
\text { as SO4) }\end{array}$ & $\begin{array}{l}\text { Chlo- } \\
\text { ride } \\
\text { dis- } \\
\text { solved } \\
(\mathrm{mg} / \mathrm{L} \\
\text { as } \mathrm{Cl})\end{array}$ & $\begin{array}{l}\text { Fluo- } \\
\text { ride } \\
\text { dis- } \\
\text { solved } \\
(\mathrm{mg} / \mathrm{L} \\
\text { as F) }\end{array}$ & $\begin{array}{l}\text { Sil- } \\
\text { ica } \\
\text { dis- } \\
\text { solved } \\
\text { (mg.L } \\
\text { as } \mathrm{Si})\end{array}$ & $\begin{array}{l}\text { Local } \\
\text { well } \\
\text { number }\end{array}$ \\
\hline 18 & 16 & 49 & 26 & 1.4 & 34 & 43 & 0.1 & 27 & $40 \mathrm{~N} / 02 \mathrm{E}-10 \mathrm{~N} 02$ \\
\hline 6.2 & 0.7 & 24 & 9.6 & 0.05 & 120 & 6.0 & $<0.1$ & 35 & $40 \mathrm{~N} / 02 \mathrm{E}-13 \mathrm{~J} 04$ \\
\hline 50 & 110 & 13 & 3.9 & 0.05 & 2.6 & 49 & $<0.1$ & 28 & 40N/02E-13J07 \\
\hline 4.3 & 0.9 & 33 & 6.7 & 16 & 25 & 8.9 & $<0.1$ & 18 & $40 \mathrm{~N} / 02 \mathrm{E}-14 \mathrm{P} 02$ \\
\hline 10 & 14 & 23 & 9.2 & 0.2 & 84 & 8.3 & $<0.1$ & 19 & $40 \mathrm{~N} / 02 \mathrm{E}-15 \mathrm{~J} 01$ \\
\hline 4.5 & 16 & 11 & 3.4 & 1.4 & 31 & 5.4 & 0.1 & 9.9 & 40N/02E-15P01 \\
\hline 7.7 & 12 & 33 & 5.6 & 20 & 25 & 17 & $<0.1$ & 11 & 40N/02E-21R01 \\
\hline 5.9 & 1.0 & 22 & 4.5 & 4.0 & 30 & 9.0 & 0.1 & 15 & 40N/02E-23D01 \\
\hline 18 & 6.9 & 28 & 7.0 & 13 & 32 & 11 & $<0.1$ & 15 & $40 \mathrm{~N} / 02 \mathrm{E}-26 \mathrm{~A} 03$ \\
\hline 5.7 & 1.3 & 25 & 5.6 & 11 & 26 & 9.1 & $<0.1$ & 17 & 40N/02E-27B01 \\
\hline 14 & 6.6 & 18 & 4.3 & 1.8 & 20 & 14 & 0.1 & 17 & $40 \mathrm{~N} / 02 \mathrm{E}-33 \mathrm{~B} 02$ \\
\hline 3.6 & 0.7 & 16 & 4.1 & 7.8 & 13 & 7.8 & $<0.1$ & 15 & 40N/03E-03B01 \\
\hline 5.4 & 1.3 & 34 & 6.9 & 12 & 20 & 11 & $<0.1$ & 16 & 40N/03E-03R02 \\
\hline 61 & 50 & 94 & 39 & 0.05 & 22 & 58 & 0.1 & 17 & 40N/03E-05L01 \\
\hline 11 & 6.6 & 35 & 6.0 & 18 & 38 & 15 & $<0.1$ & 11 & 40N/03E-05M05 \\
\hline 3.2 & 0.8 & 16 & 2.4 & 1.3 & 31 & 10 & $<0.1$ & 13 & 40N/03E-05N02 \\
\hline 5.8 & 9.9 & 19 & 4.4 & 11 & 26 & 4.9 & $<0.1$ & 14 & 40N/03E-07A02 \\
\hline 5.6 & 4.0 & 31 & 8.3 & 7.6 & 27 & 12 & $<0.1$ & 18 & 40N/03E-10K01 \\
\hline 4.7 & 0.7 & 22 & 6.4 & 1.5 & 11 & 7.9 & 0.1 & 20 & 40N/03E-11E04 \\
\hline 4.4 & 0.9 & 17 & 6.8 & 7.4 & 24 & 14 & $<0.1$ & 16 & 40N/03E-16A02 \\
\hline 4.2 & 1.2 & 15 & 6.5 & 3.7 & 28 & 7.4 & $<0.1$ & 17 & 40N/03E-16K01 \\
\hline 5.5 & 0.5 & 18 & 4.7 & 0.05 & 34 & 10 & 0.1 & 31 & 40N/03E-19A01 \\
\hline 1,800 & 44 & 140 & 160 & 0.05 & 620 & 2,800 & 0.4 & 13 & 40N/03E-24E01 \\
\hline 4.7 & 0.7 & 14 & 5.7 & 7.2 & 4.7 & 8.7 & $<0.1$ & 22 & 40N/03E-31L01 \\
\hline 7.8 & 1.5 & 33 & 9.0 & 19 & 12 & 11 & $<0.1$ & 21 & 40N/03E-31P03 \\
\hline 6.0 & 0.9 & 12 & 5.1 & 11 & 3.2 & 8.5 & $<0.1$ & 21 & 40N/03E-32M01 \\
\hline 18 & 1.1 & 18 & 5.2 & 2.3 & 8.1 & 33 & $<0.1$ & 20 & 40N/03E-36Q01 \\
\hline 12 & 2.1 & 14 & 16 & 0.05 & 0.3 & 10 & $<0.1$ & 53 & 40N/04E-01K02 \\
\hline 3.6 & 1.1 & 36 & 7.9 & 2.3 & 11 & 6.1 & 0.1 & 23 & $40 \mathrm{~N} / 04 \mathrm{E}-05 \mathrm{~N} 02$ \\
\hline 5.9 & 2.0 & 21 & 6.9 & 11 & 8.3 & 6.3 & $<0.1$ & 20 & 40N/04E-05P01 \\
\hline 6.5 & 1.1 & 27 & 9.4 & 12 & 5.7 & 13 & 0.2 & 27 & 40N/04E-05P02 \\
\hline 7.2 & 2.1 & 11 & 19 & 0.05 & 1.0 & 11 & 0.1 & 49 & 40N/04E-09B01 \\
\hline 7.2 & 2.1 & 11 & 19 & 0.05 & 1.0 & 11 & 0.2 & 49 & 40N/04E-09B01 \\
\hline 9.0 & 2.5 & 17 & 29 & 0.1 & 1.4 & 19 & 0.2 & 49 & 40N/04E-09N03 \\
\hline 7.6 & 3.2 & 18 & 23 & 0.06 & 8.7 & 16 & $<0.1$ & 45 & 40N/04E-17G01 \\
\hline
\end{tabular}


Appendix Table 4a. Values of common constituents, concentrations of major ions, iron, and manganese--Continued

\begin{tabular}{|c|c|c|c|c|c|c|c|c|}
\hline $\begin{array}{l}\text { Local } \\
\text { well } \\
\text { number }\end{array}$ & Date & $\begin{array}{l}\text { Hydro- } \\
\text { geo- } \\
\text { logic } \\
\text { unit }\end{array}$ & $\begin{array}{l}\mathrm{pH} \\
\text { (stan- } \\
\text { dard) }\end{array}$ & $\begin{array}{l}\text { Alka- } \\
\text { linity } \\
\text { (mg/L } \\
\mathrm{K} \text { as } \\
\mathrm{CaCO} 3 \text { ) }\end{array}$ & $\begin{array}{l}\text { Oxy- } \\
\text { gen } \\
\text { dis- } \\
\text { solved } \\
(\mathrm{mg} / \mathrm{L})\end{array}$ & $\begin{array}{l}\text { Hard- } \\
\text { ness, } \\
\text { total } \\
\text { (mg/L } \\
\quad \text { as } \\
\text { CaCO3) }\end{array}$ & $\begin{array}{l}\text { Iron, } \\
\text { dis- } \\
\text { solved } \\
(\mu \mathrm{g} / \mathrm{L} \\
\text { as } \mathrm{Fe})\end{array}$ & $\begin{array}{l}\text { Manga- } \\
\text { nese, } \\
\text { dis- } \\
\text { solved } \\
(\mu \mathrm{g} / \mathrm{L} \\
\text { as } \mathrm{Mn})\end{array}$ \\
\hline 40N/04E-20F01 & $08-30-90$ & SUMS & 6.9 & 112 & $<0.1$ & 132 & 3,800 & 140 \\
\hline $40 \mathrm{~N} / 04 \mathrm{E}-22 \mathrm{G} 01$ & $05-02-91$ & SUMS & 6.4 & 30 & 10.7 & 39 & 29 & 7 \\
\hline $40 \mathrm{~N} / 04 \mathrm{E}-22 \mathrm{~J} 01$ & $05-02-91$ & SUMS & 6.3 & 27 & 7.8 & 31 & 40 & 4 \\
\hline 40N/04E-22R01 & 05-03-91 & VSHN & 8.3 & 81 & 0.1 & 98 & 29 & 20 \\
\hline 40N/04E-29H02 & $05-03-91$ & SUMS & 6.7 & 54 & $<0.1$ & 37 & 6,300 & 170 \\
\hline 40N/04E-30G01 & $10-03-91$ & SUMS & 7.2 & 192 & 3.1 & 178 & 5,100 & 800 \\
\hline 40N/04E-31R02 & $10-04-91$ & SUMS & 7.0 & 184 & 2.6 & 184 & 5,300 & 890 \\
\hline 40N/05E-06K01 & $07-03-91$ & SUMS & 6.9 & 144 & $<0.1$ & 156 & 5 & 34 \\
\hline $41 \mathrm{~N} / 02 \mathrm{E}-33 \mathrm{~J} 01$ & $04-29-91$ & EVRS & 8.9 & 196 & 0.2 & 12 & 48 & 8 \\
\hline 41N/03E-32Q01 & $05-01-91$ & SUMS & 5.6 & 17 & 4.6 & 210 & 8 & 15 \\
\hline 41N/03E-34M01 & $05-01-91$ & SUMS & 6.0 & 17 & 5.4 & 146 & 32 & 110 \\
\hline 41N/03E-34Q01 & $05-02-91$ & SUMS & 8.4 & 66 & 0.2 & 90 & 78 & 170 \\
\hline 41N/03E-35L01 & $05-01-91$ & SUMS & 6.0 & 22 & 9.0 & 117 & 46 & 8 \\
\hline 41N/03E-36J01 & $05-02-91$ & SUMS & 5.7 & 14 & 6.9 & 40 & 13 & 6 \\
\hline 41N/03E-36J02 & $05-02-91$ & SUMS & 6.6 & 63 & 0.2 & 53 & 11,000 & 200 \\
\hline $41 \mathrm{~N} / 04 \mathrm{E}-31 \mathrm{~J} 02$ & $08-31-90$ & SUMS & 6.7 & 44 & -- & 94 & 29 & 5 \\
\hline 41N/04E-32Q01 & $04-30-91$ & SUMS & 6.6 & 53 & 7.8 & 118 & 9 & 2 \\
\hline 41N/04E-32R01 & $05-01-91$ & SUMS & 7.2 & 64 & 4.3 & 130 & 12 & 1 \\
\hline 41N/04E-33H01S & $05-01-91$ & SUMS & 8.0 & 76 & 2.6 & 117 & 10 & 1 \\
\hline 41N/04E-33H04 & $05-01-91$ & SUMS & 8.2 & 82 & 0.8 & 122 & 3 & 1 \\
\hline 41N/04E-33N04 & $07-20-91$ & SUMS & 7.5 & 70 & 5.3 & 141 & 4 & 0.9 \\
\hline
\end{tabular}


Appendix Table 4b. Values of common constituents, concentrations of major ions, iron, and manganese--Continued

\begin{tabular}{|c|c|c|c|c|c|c|c|c|c|}
\hline $\begin{array}{l}\text { Sod- } \\
\text { ium } \\
\text { dis- } \\
\text { solved } \\
(\mathrm{mg} / \mathrm{L} \\
\text { as } \mathrm{Na})\end{array}$ & $\begin{array}{l}\text { Po- } \\
\text { tass- } \\
\text { ium } \\
\text { dis- } \\
\text { solved } \\
(\mathrm{mg} / \mathrm{L} \\
\text { as } \mathrm{K})\end{array}$ & $\begin{array}{l}\text { Cal- } \\
\text { cium } \\
\text { dis- } \\
\text { solved } \\
\text { (mg/L } \\
\text { as } \mathrm{Ca})\end{array}$ & $\begin{array}{l}\text { Magne- } \\
\text { sium } \\
\text { dis- } \\
\text { solved } \\
(\mathrm{mg} / \mathrm{L} \\
\text { as } \mathrm{Mg})\end{array}$ & $\begin{array}{l}\text { Nitrate } \\
\text { plus } \\
\text { nitrite } \\
\text { dis- } \\
\text { solved } \\
(\mathrm{mg} / \mathrm{L} \\
\text { as } \mathrm{N})\end{array}$ & $\begin{array}{l}\text { Sul- } \\
\text { fate } \\
\text { dis- } \\
\text { solved } \\
\text { (mg/L } \\
\text { as } \mathrm{SO} 4 \text { ) }\end{array}$ & $\begin{array}{l}\text { Chlo- } \\
\text { ride } \\
\text { dis- } \\
\text { solved } \\
(\mathrm{mg} / \mathrm{L} \\
\text { as } \mathrm{Cl})\end{array}$ & $\begin{array}{l}\text { Fluo- } \\
\text { ride } \\
\text { dis- } \\
\text { solved } \\
(\mathrm{mg} / \mathrm{L} \\
\text { as } \mathrm{F})\end{array}$ & $\begin{array}{l}\text { Sil- } \\
\text { ica } \\
\text { dis- } \\
\text { solved } \\
\text { (mg.L } \\
\text { as } \mathrm{Si})\end{array}$ & $\begin{array}{l}\text { Local } \\
\text { well } \\
\text { number }\end{array}$ \\
\hline 9.3 & 2.8 & 15 & 23 & 0.1 & 31 & 12 & 0.2 & 40 & 40N/04E-20F01 \\
\hline 4.4 & 0.6 & 9.5 & 3.7 & 3.7 & 3.5 & 2.8 & $<0.1$ & 18 & 40N/04E-22G01 \\
\hline 3.8 & 0.6 & 6.5 & 3.8 & 2.4 & 3.6 & 1.9 & $<0.1$ & 14 & 40N/04E-22J01 \\
\hline 3.4 & 1.2 & 28 & 7.0 & 0.05 & 21 & 1.8 & $<0.1$ & 16 & 40N/04E-22R01 \\
\hline 5.4 & 0.6 & 9 & 3.6 & 0.05 & 7.8 & 7.9 & $<0.1$ & 28 & $40 \mathrm{~N} / 04 \mathrm{E}-29 \mathrm{H} 02$ \\
\hline 18 & 4.6 & 37 & 21 & 0.05 & 0.1 & 28 & 0.4 & 38 & 40N/04E-30G01 \\
\hline 8.4 & 2.6 & 26 & 29 & 0.1 & 14 & 19 & $<0.1$ & 46 & 40N/04E-31R02 \\
\hline 6.7 & 1.5 & 6.5 & 34 & 0.05 & 14 & 11 & 0.1 & 34 & 40N/05E-06K01 \\
\hline 110 & 2.9 & 2.6 & 1.5 & 0.05 & 8.1 & 39 & 0.5 & 16 & $41 \mathrm{~N} / 02 \mathrm{E}-33 \mathrm{~J} 01$ \\
\hline 11 & 3.4 & 66 & 11 & 43 & 26 & 15 & $<0.1$ & 10 & 41N/03E-32Q01 \\
\hline 6.5 & 9.6 & 39 & 12 & 20 & 66 & 9.5 & $<0.1$ & 15 & 41N/03E-34M01 \\
\hline 3.2 & 1.3 & 27 & 5.7 & 0.05 & 24 & 5.0 & $<0.1$ & 17 & 41N/03E-34Q01 \\
\hline 5.4 & 4.1 & 34 & 8.0 & 21 & 19 & 9.4 & $<0.1$ & 14 & 41N/03E-35L01 \\
\hline 4.2 & 1.7 & 12 & 2.6 & 7.3 & 5.2 & 4.0 & $<0.1$ & 9.3 & $41 \mathrm{~N} / 03 \mathrm{E}-36 \mathrm{~J} 01$ \\
\hline 3.9 & 0.6 & 15 & 3.8 & 0.05 & 5.8 & 4.9 & $<0.1$ & 25 & $41 \mathrm{~N} / 03 \mathrm{E}-36 \mathrm{~J} 02$ \\
\hline 5.2 & 1.1 & 28 & 6.0 & 13 & 12 & 6.5 & 0.2 & 24 & 41N/04E-31J02 \\
\hline 5.6 & 0.9 & 31 & 9.9 & 16 & 8.1 & 9.1 & 0.1 & 23 & 41N/04E-32Q01 \\
\hline 4.9 & 1.2 & 38 & 8.7 & 15 & 17 & 9.9 & $<0.1$ & 19 & 41N/04E-32R01 \\
\hline 4.9 & 1.4 & 35 & 7.4 & 5.8 & 21 & 7.8 & $<0.1$ & 16 & 41N/04E-33H01S \\
\hline 6.1 & 1.7 & 37 & 7.3 & 5.6 & 24 & 8.2 & $<0.1$ & 15 & $41 \mathrm{~N} / 04 \mathrm{E}-33 \mathrm{H} 04$ \\
\hline 5.3 & 1.3 & 42 & 8.9 & 15 & 15 & 10 & $<0.1$ & 19 & 41N/04E-33N04 \\
\hline
\end{tabular}


Appendix Table 5. Concentration of trace elements in well water samples from portions of the Lynden-EversonNooksack-Sumas study area, Whatcom County, Wash., and British Columbia, Canada

$[\mu \mathrm{g} / \mathrm{L}$, micrograms per liter; <, less than; --, not analyzed; SUMS, Sumas aquifer; EVRS, Everson-Vashon unit; VSHN, Vashon unit; Codes: BDRK, bedrock unit; USGS, U.S. Geological Survey; BCME, British Columbia Ministry of Environment]

\begin{tabular}{|c|c|c|c|c|c|c|c|c|c|}
\hline $\begin{array}{l}\text { Local } \\
\text { well number }\end{array}$ & Date & $\begin{array}{l}\text { Hydro- } \\
\text { geo- } \\
\text { logic } \\
\text { unit } \\
\text { code }\end{array}$ & $\begin{array}{l}\text { Agency } \\
\text { ana- } \\
\text { lyzing } \\
\text { sample } \\
\text { (code } \\
\text { number) }\end{array}$ & $\begin{array}{l}\text { Arsenic, } \\
\text { dis- } \\
\text { solved } \\
(\mu \mathrm{g} / \mathrm{L} \\
\text { as As) }\end{array}$ & $\begin{array}{l}\text { Barium, } \\
\text { dis- } \\
\text { solved } \\
(\mu \mathrm{g} / \mathrm{L} \\
\text { as } \mathrm{Ba})\end{array}$ & $\begin{array}{l}\text { Beryl- } \\
\text { lium, } \\
\text { dis- } \\
\text { solved } \\
(\mu \mathrm{g} / \mathrm{L} \\
\text { as Be })\end{array}$ & $\begin{array}{l}\text { Boron, } \\
\text { dis- } \\
\text { solved } \\
(\mu \mathrm{g} / \mathrm{L} \\
\text { as B) }\end{array}$ & $\begin{array}{l}\text { Cad- } \\
\text { mium, } \\
\text { dis- } \\
\text { solved } \\
(\mu \mathrm{g} / \mathrm{L} \\
\text { as Cd })\end{array}$ & $\begin{array}{l}\text { Chro- } \\
\text { mium, } \\
\text { dis- } \\
\text { solved } \\
(\mu \mathrm{g} / \mathrm{L} \\
\text { as } \mathrm{Cr})\end{array}$ \\
\hline $39 \mathrm{~N} / 02 \mathrm{E}-01 \mathrm{P} 02$ & $08-29-90$ & SUMS & USGS & $<1$ & 41 & - & - & $<1$ & $<1$ \\
\hline $39 \mathrm{~N} / 02 \mathrm{E}-10 \mathrm{~F} 01$ & $08-28-90$ & SUMS & USGS & $<1$ & 38 & - & - & $<1$ & $<1$ \\
\hline $39 \mathrm{~N} / 02 \mathrm{E}-12 \mathrm{~K} 03$ & $08-29-90$ & SUMS & USGS & $<1$ & 20 & - & - & $<1$ & $<1$ \\
\hline \multirow[t]{2}{*}{$39 \mathrm{~N} / 02 \mathrm{E}-14 \mathrm{M} 01$} & $08-28-90$ & SUMS & USGS & 1 & 54 & -. & -. & $<1$ & $<1$ \\
\hline & $08-28-90$ & -. & USGS & 1 & 54 & -. & -- & $<1$ & $<1$ \\
\hline $39 \mathrm{~N} / 02 \mathrm{E}-27 \mathrm{~F} 03$ & $08-28-90$ & SUMS & USGS & $<1$ & 10 & -- & - & $<1$ & $<1$ \\
\hline $39 \mathrm{~N} / 03 \mathrm{E}-02 \mathrm{~B} 02$ & $08-28-90$ & SUMS & USGS & 1 & 55 & -. & -- & $<1$ & $<1$ \\
\hline $39 \mathrm{~N} / 03 \mathrm{E}-08 \mathrm{C} 02$ & $08-30-90$ & SUMS & USGS & $<1$ & 10 & -- & -- & $<1$ & $<1$ \\
\hline $39 \mathrm{~N} / 03 \mathrm{E}-13 \mathrm{E} 01$ & $04-23-91$ & BDRK & USGS & -. & 93 & $<0.5$ & 310 & $<1$ & $<5$ \\
\hline $39 \mathrm{~N} / 03 \mathrm{E}-26 \mathrm{~J} 01$ & $04-25-91$ & BDRK & USGS & - & 1,100 & $<2$ & 60 & $<3$ & $<20$ \\
\hline $39 \mathrm{~N} / 04 \mathrm{E}-03 \mathrm{P} 01$ & $08-31-90$ & VSHN & USGS & 6 & 200 & -- & -- & $<1$ & $<1$ \\
\hline 39N/04E-19M01 & $04-25-91$ & BDRK & USGS &.- & 46 & $<0.5$ & -- & 1 & $<5$ \\
\hline 39N/04E-30D01 & $04-26-91$ & EVRS & USGS & -. & 44 & $<0.5$ & -. & $<1$ & $<5$ \\
\hline $40 \mathrm{~N} / 02 \mathrm{E}-27 \mathrm{~B} 01$ & $08-30-90$ & EVRS & USGS & $<1$ & 4 & - & -. & $<1$ & $<1$ \\
\hline 40N/03E-03B01 & $08-30-90$ & SUMS & USGS & $<1$ & 9 & -- & -- & $<1$ & $<1$ \\
\hline $40 \mathrm{~N} / 03 \mathrm{E}-05 \mathrm{~N} 02$ & $08-29-90$ & SUMS & USGS & $<1$ & 6 & -- & -. & $<1$ & $<1$ \\
\hline $40 \mathrm{~N} / 03 \mathrm{E}-16 \mathrm{~A} 02$ & $08-27-90$ & SUMS & USGS & $<1$ & 6 & -- & - & $<1$ & $<1$ \\
\hline 40N/03E-32M01 & $08-29-90$ & SUMS & USGS & $<1$ & 5 & -- & -- & $<1$ & $<1$ \\
\hline 40N/04E-05P02 & $08-29-90$ & SUMS & USGS & $<1$ & 13 & -- & -- & $<1$ & 2 \\
\hline 40N/04E-09N03 & $08-28-90$ & SUMS & USGS & $<1$ & 390 & -. & - & 3 & $<1$ \\
\hline $40 \mathrm{~N} / 04 \mathrm{E}-20 \mathrm{~F} 01$ & $08-30-90$ & SUMS & USGS & $<1$ & 76 & - & -- & $<1$ & $<1$ \\
\hline $41 \mathrm{~N} / 04 \mathrm{E}-31 \mathrm{~J} 02$ & $08-31-90$ & SUMS & USGS & $<1$ & 7 & - & - & $<1$ & $<1$ \\
\hline $41 \mathrm{~N} / 04 \mathrm{E}-32 \mathrm{Q} 01$ & $04-30-91$ & SUMS & USGS & -. & 8 & $<0.5$ & 9.9 & $<1$ & $<5$ \\
\hline 41N/04E-33H04 & $05-01-91$ & SUMS & USGS & - & 20 & $<0.5$ & 9.9 & $<1$ & $<5$ \\
\hline 092G.008.2.2.2-15 & $03-04-87$ & SUMS & BCME & $<1$ & 10 & -- & - & $<10$ & $<10$ \\
\hline $092 \mathrm{G} .008 .2 .4 .4-11$ & $03-04-87$ & SUMS & BCME & $<1$ & 60 & -- & -. & $<10$ & $<10$ \\
\hline $092 \mathrm{G} .009 \cdot 1 \cdot 1 \cdot 1-06-25$ & $01-30-92$ & SUMS & $\mathrm{BCME}$ & $<1$ & 50 & $<1$ & 28 & $<2$ & $<2$ \\
\hline 092G.009.1.1.1-06-35 & $01-30-92$ & SUMS & BCME & $<1$ & 10 & $<1$ & 19 & $<2$ & $<2$ \\
\hline 092G.009.1.1.1-07-55 & Q1-30-92 & SUMS & BCME & $<1$ & $10^{* *}$ & $<1$ & 8 & $<2$ & $<2$ \\
\hline 092G.009.1.1.1-07-75 & $01-30-92$ & SUMS & $\mathrm{BCME}$ & 3 & 13 & $<1$ & $<8$ & $<2$ & $<2$ \\
\hline 092G.009.1.1.2-11-25 & 01-29-92 & SUMS & BCME & $<1$ & 6 & $<1$ & 21 & $<2$ & $<2$ \\
\hline 092G.009.1.1.2-11-35 & 01-29-92 & SUMS & $\mathrm{BCME}$ & $<1$ & 6 & $<1$ & 28 & $<2$ & $<2$ \\
\hline 092G.009.1.1.2-12-55 & 01-29-92 & SUMS & BCME & $<1$ & 6 & $<1$ & 9 & $<2$ & $<2$ \\
\hline 092G.009.1.1.2-12-75 & $01-29-92$ & SUMS & $\mathrm{BCME}$ & 2 & 11 & $<1$ & 9 & $<2$ & $<2$ \\
\hline 092G.009.1.1.2-13 & 01-30-92 & SUMS & $\mathrm{BCME}$ & -. & $<10$ & -- & -- & $<10$ & $<10$ \\
\hline 092G.009.1.1.4-18-25 & 01-30-92 & SUMS & BCME & $<1$ & 5 & $<1$ & $<8$ & $<2$ & $<2$ \\
\hline 092G.009.1.1.4-18-35 & 01-30-92 & SUMS & BCME & $<1$ & 3 & $<1$ & $<8$ & $<2$ & $<2$ \\
\hline 092G.009.1.1.4-19-55 & $01-30-92$ & SUMS & BCME & $<1$ & 4 & $<1$ & $<8$ & $<2$ & $<2$ \\
\hline 092G.009.1.1.4-19-75 & 01-30-92 & SUMS & BCME & 1 & 15 & $<1$ & $<8$ & $<2$ & $<2$ \\
\hline 092G.009.1.2.3-10 & $10-27-88$ & SUMS & BCME & $<1$ & 10 & - & - & $<10$ & $<10$ \\
\hline 092G.009.1.3.3-08 & $09-28-88$ & SUMS & BCME & $<1$ & 40 & - & -- & $<10$ & $<10$ \\
\hline $092 \mathrm{G} .009 .2 .1 .1-37$ & $07-29-84$ & SUMS & BCME & $<250 *$ & -. & -- & - & $<10$ & $<10$ \\
\hline $092 \mathrm{G} .009 .2 .1 .2-24$ & $07-29-84$ & SUMS & BCME & $<250^{*}$ & -- & -- & -- & $<10$ & $<10$ \\
\hline 092G.009.2.1.3-47 & $10-20-88$ & SUMS & BCME & $<1$ & 80 & - & -- & $<10$ & $<10$ \\
\hline $092 \mathrm{G} .009 .2 \cdot 1.4-20$ & $10-20-88$ & SUMS & BCME & $<1$ & $<10$ & -. & - & $<10$ & $<10$ \\
\hline $092 \mathrm{G} .009 .2 \cdot 1.4-23$ & $10-20-88$ & SUMS & BCME & $<1$ & $<10$ & - & - & $<10$ & $<10$ \\
\hline
\end{tabular}


Appendix Table 5. Concentration of trace elements in well water samples from portions of the Lynden-EversonNooksack-Sumas study area, Whatcom County, Wash., and British Columbia, Canada--Continued

\begin{tabular}{|c|c|c|c|c|c|c|c|c|c|c|c|}
\hline $\begin{array}{l}\text { Cobalt, } \\
\text { dis- } \\
\text { solved } \\
(\mu \mathrm{g} / \mathrm{L} \\
\text { as Co })\end{array}$ & $\begin{array}{l}\text { Copper, } \\
\text { dis- } \\
\text { solved } \\
(\mu \mathrm{g} / \mathrm{L} \\
\text { as } \mathrm{Cu})\end{array}$ & $\begin{array}{l}\text { Lead, } \\
\text { dis- } \\
\text { solved } \\
(\mu \mathrm{g} / \mathrm{L} \\
\text { as } \mathrm{Pb})\end{array}$ & $\begin{array}{l}\text { Lithium, } \\
\text { dis- } \\
\text { solved } \\
(\mu \mathrm{g} / \mathrm{L} \\
\text { as } \mathrm{Li})\end{array}$ & $\begin{array}{l}\text { Mercury, } \\
\text { dis- } \\
\text { solved } \\
(\mu \mathrm{g} / \mathrm{L} \\
\text { as } \mathrm{Hg})\end{array}$ & $\begin{array}{l}\text { Molyb- } \\
\text { denum } \\
\text { dis- } \\
\text { solved } \\
(\mu \mathrm{g} / \mathrm{L} \\
\text { as Mo) }\end{array}$ & $\begin{array}{l}\text { Nickel, } \\
\text { dis- } \\
\text { solved } \\
(\mu \mathrm{g} / \mathrm{L} \\
\text { as } \mathrm{Ni})\end{array}$ & $\begin{array}{l}\text { Sele- } \\
\text { nium } \\
\text { dis- } \\
\text { solved } \\
(\mu \mathrm{g} / \mathrm{L} \\
\text { as } \mathrm{Se})\end{array}$ & $\begin{array}{l}\text { Silver, } \\
\text { dis- } \\
\text { solved } \\
(\mu \mathrm{g} / \mathrm{L} \\
\text { as } \mathrm{Ag})\end{array}$ & $\begin{array}{l}\text { Stron- } \\
\text { tium } \\
\text { dis- } \\
\text { solved } \\
(\mu \mathrm{g} / \mathrm{L} \\
\text { as } \mathrm{Sr})\end{array}$ & $\begin{array}{l}\text { Vana- } \\
\text { dium } \\
\text { dis- } \\
\text { solved } \\
(\mu \mathrm{g} / \mathrm{L} \\
\text { as V) }\end{array}$ & $\begin{array}{l}\text { Zinc, } \\
\text { dis- } \\
\text { solved } \\
(\mu \mathrm{g} / \mathrm{L} \\
\text { as } \mathrm{Zn})\end{array}$ \\
\hline -- & 40 & $<1$ & -- & $<0.1$ & -- & -- & $<1$ & $<1$ & -. & -. & 6 \\
\hline -- & 2 & $<1$ & -. & $<0.1$ & -. & -- & $<1$ & $<1$ & -. & -. & 43 \\
\hline .- & 4 & $<1$ & -- & $<0.1$ & -. & .. & $<1$ & $<1$ & -. & -- & 10 \\
\hline -- & 2 & $<1$ & -- & $<0.1$ & -. & -. & $<1$ & $<1$ & - & -. & 170 \\
\hline-- & 2 & $<1$ & -- & $<0.1$ & -. & -- & $<1$ & 1 & -. & -- & 160 \\
\hline -- & 11 & $<1$ & -- & $<0.1$ & -. & -. & $<1$ & 1 & -. & .- & 7 \\
\hline -- & 15 & $<1$ & -- & $<0.1$ & -. & -- & $<1$ & $<1$ & -- & -. & 46 \\
\hline -- & 10 & $<1$ & -- & $<0.1$ & .. & -. & $<1$ & $<1$ & .. & .- & 10 \\
\hline$<3$ & 190 & $<10$ & $<4$ & -- & $<10$ & $<10$ & -. & $<1$ & 270 & $<6$ & 130 \\
\hline$<9$ & $<30$ & $<30$ & 18 & - & $<30$ & $<30$ & -. & $<3$ & 1,700 & $<18$ & 150 \\
\hline -. & 1 & $<1$ & -- & $<0.1$ & -. & -. & $<1$ & $<1$ & -. & -- & 180 \\
\hline$<3$ & $<10$ & $<10$ & $<4$ & -- & 40 & $<10$ & -. & 2 & 240 & $<6$ & 85 \\
\hline$<3$ & $<10$ & $<10$ & $<4$ & -- & 20 & $<10$ & -. & $<1$ & 230 & $<6$ & 7 \\
\hline -. & 160 & $<1$ & -- & $<0.1$ & -. & -- & $<1$ & $<1$ & -- & -. & 11 \\
\hline -. & 13 & $<1$ & -- & $<0.1$ & -- & - & $<1$ & $<1$ & - & -- & 240 \\
\hline -- & 3 & $<1$ & -- & $<0.1$ & -- & -- & 1 & 1 & -- & -. & 26 \\
\hline -- & 34 & 1 & -- & $<0.1$ & .- & -- & $<1$ & 1 & -. & -- & 7 \\
\hline -. & 28 & $<1$ & -- & $<0.1$ & .- & -- & $<1$ & $<1$ & -. & -- & 36 \\
\hline -- & 6 & $<1$ & -- & $<0.1$ & -. & -- & $<1$ & 2 & -- & -- & 18 \\
\hline -- & 2 & 1 & -- & $<0.1$ & -. & -- & $<1$ & 1 & -- & -. & 48 \\
\hline -- & 1 & $<1$ & -. & $<0.1$ & -. & -- & $<1$ & 1 & -. & -. & 45 \\
\hline -- & 68 & $<1$ & -. & $<0.1$ & -- & - & $<1$ & 1 & -. & -. & 68 \\
\hline$<3$ & 20 & $<10$ & $<4$ & -. & $<10$ & $<10$ & -- & $<1$ & 120 & $<6$ & 14 \\
\hline$<3$ & $<10$ & $<10$ & 4 & -. & $<10$ & $<10$ & -. & $<1$ & 120 & $<6$ & $<3$ \\
\hline$<100$ & 50 & $<100$ & -. & -. & $<10$ & $<50$ & .. & -. & -. & $<10$ & 20 \\
\hline$<100$ & $<10$ & $<100$ & -. & .- & $<10$ & $<50$ & -. & -- & -- & $<10$ & 20 \\
\hline 3 & 4 & $<20$ & -. & -. & $<4$ & $<8$ & $<30$ & $<10$ & 120 & $<3$ & $20 * *$ \\
\hline$<3$ & $<2$ & $<20$ & -- & - & $<4$ & $<8$ & $<30$ & $<10$ & 150 & $<3$ & 25 \\
\hline$<3$ & 3 & $<20$ & -- & -. & $<4$ & $<8$ & $<30$ & $<10$ & 85 & $<3$ & 32 \\
\hline$<3$ & 2 & $<20$ & -. & - & $<4$ & $<8$ & $<30$ & $<10$ & 63 & 5 & 16 \\
\hline$<3$ & 2 & $<20$ & -- & -- & $<4$ & $<8$ & $<30$ & $<10$ & 79 & $<3$ & 14 \\
\hline$<3$ & 3 & $<20$ & -. & -- & $<4$ & $<8$ & $<30$ & $<10$ & 110 & $<3$ & 41 \\
\hline$<3$ & $6^{* *}$ & $<20$ & -. & -. & $<4$ & $<8$ & $<30$ & $<10$ & 76 & 3 & $19 * *$ \\
\hline$<3$ & $6^{* *}$ & $<20$ & -. & -. & $<4$ & $<8$ & $<30$ & $<10$ & 68 & 6 & 14 \\
\hline$<100$ & $<10$ & $<100$ & -. & -. & $<10$ & $<50$ & -- & -. & -. & $<10$ & 110 \\
\hline$<3$ & 4 & $<20$ & -. & -. & $<4$ & $<8$ & $<30$ & $<10$ & 50 & $<3$ & $12 * *$ \\
\hline$<3$ & 2 & $<20$ & .- & -. & $<4$ & $<8$ & $<30$ & $<10$ & 49 & $<3$ & 17 ** \\
\hline$<3$ & 1 & $<20$ & .- & -. & $<4$ & $<8$ & $<30$ & $<10$ & 50 & $<3$ & $24 * *$ \\
\hline$<3$ & 1 & $<20$ & .- & .- & $<4$ & $<8$ & $<30$ & $<10$ & 64 & $<3$ & 34 \\
\hline$<100$ & $<10$ & $<100$ & -. & .. & $<10$ & $<50$ & -- & -. & -- & $<10$ & 30 \\
\hline$<100$ & $<10$ & $<100$ & -. & .- & 10 & $<50$ & -. & -. & -- & $<10$ & 100 \\
\hline$<100$ & $<10$ & $<100$ & -- & .. & $<10$ & $<50$ & -. & -- & -. & $<10$ & $<10$ \\
\hline$<100$ & $<10$ & $<100$ & -. & -. & $<10$ & $<50$ & -. & -- & - & $<10$ & $<10$ \\
\hline$<100$ & 20 & $<100$ & .- & -. & $<10$ & $<50$ & -- & -. & -. & $<10$ & 130 \\
\hline$<100$ & 90 & $<100$ & -. & -. & $<10$ & $<50$ & -. & -. &.- & $<10$ & 140 \\
\hline$<100$ & 20 & $<100$ & -. & -. & $<10$ & $<50$ & -- & -- & -- & $<10$ & 90 \\
\hline
\end{tabular}

${ }^{*}$ Data not included in determining range of arsenic concentration.

** Analytical report indicates suspected contamination. 
Appendix Table 6. Total recoverable concentrations of pesticides in selected well water samples from portions of the Lynden-Everson-Nooksack-Sumas study area, Whatcom County, Wash., and British Columbia, Canada

$[\mu \mathrm{g} / \mathrm{L}$, micrograms per liter; $<$, less than; --, not analyzed $]$

Triazines and other nitrogen containing herbicides

Local

well

number

39N/02E-01P02

39N/02E-10F01

39N/02E-12K03

39N/02E-14M01

39N/02E-26H01

39N/02E-27F03

39N/03E-02B02

39N/03E-08C02

40N/02E-27B01

40N/03E-03B01

40N/03E-05N02

40N/03E-11E04

40N/03E-16A02

40N/03E-31P03

40N/03E-32M01

40N/04E-05P02

40N/04E-09N03

40N/04E-20F01

41N/03E-32Q01

41N/03E-35L01

41N/04E-31J02

0926.009.1.1.2-11-25

0926.009.1.1.4-18-20

0926.009.1.1.4-18-35
Date

08-29-90

08-28-90

08-29-90

08-28-90

08-28-90

04-23-91

08-28-90

08-28-90

08-30-90

08-30-90

08-30-90

08-30-90

08-30-90

08-29-90

05-02-91

08-27-90

04-26-91

08-29-90

08-29-90

08-28-90

08-30-90

05-01-91

05-01-91

08-31-90

04-17-91

04-17-91

04-17-91
Ala-

chlor

$(\mu \mathrm{g} / \mathrm{L})$

$<0.1$

$<0.1$

$<0.1$

$<0.1$

$<0.1$

$<0.2$

$<0.1$

$<0.1$

$<0.1$

$<0.1$

Ame-

tryn

$(\mu \mathrm{g} / \mathrm{L})$

Atra-

zine

$(\mu \mathrm{g} / \mathrm{L})$

Cyan-

Metolachlor $(\mu \mathrm{g} / \mathrm{L}) \quad(\mu \mathrm{g} / \mathrm{L}) \quad(\mu \mathrm{g} / \mathrm{L})$

Metribuzin

$<0.1$

$<0.1$

$<0.1$

$<0.1$

$<0.1$

$<0.1$

$<0.1$

$<0.1$

$<0.1$

$<0.1$

$<0.1$

$<0.1$

$<0.1$

$<0.1$

$<0.1$

$<0.1$

$<0.1$

$<0.1$

$<0.1$

$<0.1$

$<0.1$

$<0.1$

$<0.2$

$<0$.

$<0.1$

$<0.1$

$<0.1$

$<0.1$

$<0.1$

$<0.1$

$<0.1$

$<0.1$

$<0.1$

$<0.1$

$<0.1$

$<0.1$

$<0.1$

$<0.1$

$<0.1$

$<0.1$

$<0.1$

$<0.1<0.1$

$<0.1$

$<0.1$

$<0.1$

$<0.1$

$<0.1<0.1$

$<0.1$

$<0.1$

$<0.1$

$<0.1$

$<0.1<0.1$

$<0.1$

$<0.1$

$<0.1$

$<0.1$

$<0.1<0.1$

$<0.1$

$<0.1$

$<0.1$

$<0.1$

$<0.2<0.1$

$<0.1$

$<0.2$

$<0$.

$<0.1$

$<0.1<0.1$

$<0.1$

$<0.1$

$<0.1$

$<0.1$

$<0.2<0.1$

$<0.1$

$<0.2$

$<0.2$

$<0.1$

$<0.1<0.1$

$<0.1$

$<0.1$

$<0.1$

$<0.1$

$<0.1<0.1$

$<0.1$

$<0.1$

$<0.1$

$<0.1$

$<0.1<0.1$

$<0.1$

$<0.1$

$<0.1$

$<0.1$

$<0.1<0.1$

$<0.1$

$<0.1$

$<0.1$

$<0.1$

$<0.2<0.1$

0.1

$<0.2$

$<0.2$

$<0.1$

$<0.2<0.1$

$<0.1$

$<0.2$

$<0.2$

$<0.1$

$<0.1<0.1$

$<0.1$

$<0.1$

$<0.1$

$<0.1$

$<0.1<0.1$

$<0.1$

$<0.1$

$<0.1$

$<0.1$

$<0.1<0.1$

$<0.1$

$<0.1$

$<0.1$

$<0.1$

$<0.1<0.1$

$<0.1$

$<0.1$

$<0.1$

$<0.1$ 
Appendix Table 6. Total recoverable concentrations of pesticides in selected well water samples from portions of the Lynden-Everson-Nooksack-Sumas study area, Whatcom County, Wash., and British Columbia, Canada-Continued

\begin{tabular}{|c|c|c|c|c|c|c|c|}
\hline $\begin{array}{l}\text { Local } \\
\text { well } \\
\text { number }\end{array}$ & Date & $\begin{array}{l}\text { Prome- } \\
\text { tone } \\
(\mu \mathrm{g} / \mathrm{L})\end{array}$ & $\begin{array}{l}\text { Prome- } \\
\text { tryn } \\
(\mu \mathrm{g} / \mathrm{L})\end{array}$ & $\begin{array}{l}\text { Pro- } \\
\text { pazine } \\
(\mu \mathrm{g} / \mathrm{L})\end{array}$ & $\begin{array}{l}\text { Sima- } \\
\text { zine } \\
(\mu \mathrm{g} / \mathrm{L})\end{array}$ & $\begin{array}{l}\text { Sime- } \\
\text { tryn } \\
(\mu \mathrm{g} / \mathrm{L})\end{array}$ & $\begin{array}{l}\text { Tri- } \\
\text { flura- } \\
\text { lin } \\
(\mu \mathrm{g} / \mathrm{L})\end{array}$ \\
\hline $39 \mathrm{~N} / 02 \mathrm{E}-01 \mathrm{P} 02$ & $08-29-90$ & $<0.1$ & $<0.1$ & $<0.1$ & $<0.1$ & $<0.1$ & $<0.1$ \\
\hline $39 \mathrm{~N} / 02 \mathrm{E}-10 \mathrm{~F} 01$ & $08-28-90$ & $<0.1$ & $<0.1$ & $<0.1$ & $<0.1$ & $<0.1$ & $<0.1$ \\
\hline $39 \mathrm{~N} / 02 \mathrm{E}-12 \mathrm{~K} 03$ & $08-29-90$ & $<0.1$ & $<0.1$ & $<0.1$ & $<0.1$ & $<0.1$ & $<0.1$ \\
\hline \multirow{2}{*}{ 39N/02E-14M01 } & $08-28-90$ & $<0.1$ & $<0.1$ & $<0.1$ & $<0.1$ & $<0.1$ & $<0.1$ \\
\hline & $08-28-90$ & $<0.1$ & $<0.1$ & $<0.1$ & $<0.1$ & $<0.1$ & $<0.1$ \\
\hline $39 \mathrm{~N} / 02 \mathrm{E}-26 \mathrm{H} 01$ & 04-23-91 & $<0.2$ & $<0.1$ & $<0.1$ & $<0.1$ & $<0.1$ & $<0.1$ \\
\hline $39 \mathrm{~N} / 02 \mathrm{E}-27 \mathrm{~F} 03$ & $08-28-90$ & $<0.1$ & $<0.1$ & $<0.1$ & $<0.1$ & $<0.1$ & $<0.1$ \\
\hline 39N/03E-02B02 & $08-28-90$ & $<0.1$ & $<0.1$ & $<0.1$ & $<0.1$ & $<0.1$ & $<0.1$ \\
\hline \multirow[t]{2}{*}{$39 \mathrm{~N} / 03 \mathrm{E}-08 \mathrm{C} 02$} & $08-30-90$ & $<0.1$ & $<0.1$ & $<0.1$ & $<0.1$ & $<0.1$ & $<0.1$ \\
\hline & 08-30-90 & $<0.1$ & $<0.1$ & $<0.1$ & $<0.1$ & $<0.1$ & $<0.1$ \\
\hline \multirow[t]{2}{*}{$40 \mathrm{~N} / 02 \mathrm{E}-27 \mathrm{~B} 01$} & 08-30-90 & $<0.1$ & $<0.1$ & $<0.1$ & $<0.1$ & $<0.1$ & $<0.1$ \\
\hline & $08-30-90$ & $<0.1$ & $<0.1$ & $<0.1$ & $<0.1$ & $<0.1$ & $<0.1$ \\
\hline 40N/03E-03B01 & $08-30-90$ & $<0.1$ & $<0.1$ & $<0.1$ & $<0.1$ & $<0.1$ & $<0.1$ \\
\hline 40N/03E-05N02 & $08-29-90$ & $<0.1$ & $<0.1$ & $<0.1$ & $<0.1$ & $<0.1$ & $<0.1$ \\
\hline 40N/03E-11E04 & $05-02-91$ & $<0.2$ & $<0.1$ & $<0.1$ & $<0.1$ & $<0.1$ & $<0.1$ \\
\hline $40 \mathrm{~N} / 03 \mathrm{E}-16 \mathrm{~A} 02$ & $08-27-90$ & $<0.1$ & $<0.1$ & $<0.1$ & $<0.1$ & $<0.1$ & $<0.1$ \\
\hline 40N/03E-31P03 & $04-26-91$ & $<0.2$ & $<0.1$ & $<0.1$ & $<0.1$ & $<0.1$ & $<0.1$ \\
\hline 40N/03E-32M01 & $08-29-90$ & $<0.1$ & $<0.1$ & $<0.1$ & $<0.1$ & $<0.1$ & $<0.1$ \\
\hline 40N/04E-05P02 & $08-29-90$ & $<0.1$ & $<0.1$ & $<0.1$ & $<0.1$ & $<0.1$ & $<0.1$ \\
\hline 40N/04E-09N03 & $08-28-90$ & $<0.1$ & $<0.1$ & $<0.1$ & $<0.1$ & $<0.1$ & $<0.1$ \\
\hline 40N/04E-20F01 & $08-30-90$ & $<0.1$ & $<0.1$ & $<0.1$ & $<0.1$ & $<0.1$ & $<0.1$ \\
\hline $41 \mathrm{~N} / 03 \mathrm{E}-32 \mathrm{Q} 01$ & $05-01-91$ & $<0.2$ & $<0.1$ & $<0.1$ & $<0.1$ & $<0.1$ & $<0.1$ \\
\hline $41 \mathrm{~N} / 03 \mathrm{E}-35 \mathrm{~L} 01$ & 05-01-91 & $<0.2$ & $<0.1$ & $<0.1$ & $<0.1$ & $<0.1$ & $<0.1$ \\
\hline $41 \mathrm{~N} / 04 \mathrm{E}-31 \mathrm{~J} 02$ & $08-31-90$ & $<0.1$ & $<0.1$ & $<0.1$ & $<0.1$ & $<0.1$ & $<0.1$ \\
\hline $0926.009 \cdot 1 \cdot 1 \cdot 2-11-25$ & $04-17-91$ & $<0.1$ & $<0.1$ & $<0.1$ & $<0.1$ & $<0.1$ & $<0.1$ \\
\hline $0926.009 .1 .1 .4-18-20$ & $04-17-91$ & $<0.1$ & $<0.1$ & $<0.1$ & $<0.1$ & $<0.1$ & $<0.1$ \\
\hline $0926.009 .1 .1 .4-18-35$ & $04-17-91$ & $<0.1$ & $<0.1$ & $<0.1$ & $<0.1$ & $<0.1$ & $<0.1$ \\
\hline
\end{tabular}


Appendix Table 6. Total recoverable concentrations of pesticides in selected well water samples from portions of the Lynden-Everson-Nooksack-Sumas study area, Whatcom County, Wash., and British Columbia, Canada--

Continued

Carbamate insecticides and metablites

\begin{tabular}{|c|c|c|c|c|c|}
\hline $\begin{array}{l}\text { Local } \\
\text { well } \\
\text { number }\end{array}$ & Date & $\begin{array}{l}\text { Aldi- } \\
\text { carb } \\
(\mu \mathrm{g} / \mathrm{L})\end{array}$ & $\begin{array}{l}\text { Aldi- } \\
\text { carb } \\
\text { sulfone } \\
(\mu \mathrm{g} / \mathrm{L})\end{array}$ & $\begin{array}{l}\text { Aldi- } \\
\text { carb } \\
\text { sulf- } \\
\text { oxide } \\
(\mu \mathrm{g} / \mathrm{L})\end{array}$ & $\begin{array}{l}\text { Car- } \\
\text { baryl } \\
(\mu \mathrm{g} / \mathrm{L})\end{array}$ \\
\hline 39N/02E-01P02 & $08-29-90$ & $<0.5$ & $<0.5$ & $<0.5$ & $<0.5$ \\
\hline $39 \mathrm{~N} / 02 \mathrm{E}-10 \mathrm{~F} 01$ & $08-28-90$ & $<0.5$ & $<0.5$ & $<0.5$ & $<0.5$ \\
\hline $39 \mathrm{~N} / 02 \mathrm{E}-12 \mathrm{~K} 03$ & $08-29-90$ & $<0.5$ & $<0.5$ & $<0.5$ & $<0.5$ \\
\hline \multirow{2}{*}{ 39N/02E-14M01 } & $08-28-90$ & $<0.5$ & $<0.5$ & $<0.5$ & $<0.5$ \\
\hline & $08-28-90$ & $<0.5$ & $<0.5$ & $<0.5$ & -- \\
\hline $39 \mathrm{~N} / 02 \mathrm{E}-26 \mathrm{H} 01$ & $04-23-91$ & $<0.5$ & $<0.5$ & $<0.5$ & $<0.5$ \\
\hline $39 \mathrm{~N} / 02 \mathrm{E}-27 \mathrm{~F} 03$ & $08-28-90$ & $<0.5$ & $<0.5$ & $<0.5$ & $<0.5$ \\
\hline 39N/03E-02B02 & $08-28-90$ & $<0.5$ & $<0.5$ & $<0.5$ & $<0.5$ \\
\hline \multirow[t]{2}{*}{$39 \mathrm{~N} / 03 \mathrm{E}-08 \mathrm{C} 02$} & $08-30-90$ & $<0.5$ & $<0.5$ & $<0.5$ & $<0.5$ \\
\hline & $08-30-90$ & $<0.5$ & $<0.5$ & $<0.5$ & $<0.5$ \\
\hline \multirow[t]{2}{*}{ 40N/02E-27B01 } & $08-30-90$ & $<0.5$ & $<0.5$ & $<0.5$ & $<0.5$ \\
\hline & $08-30-90$ & $<0.5$ & $<0.5$ & $<0.5$ & $<0.5$ \\
\hline 40N/03E-03B01 & $08-30-90$ & $<0.5$ & $<0.5$ & $<0.5$ & $<0.5$ \\
\hline $40 \mathrm{~N} / 03 \mathrm{E}-05 \mathrm{~N} 02$ & $08-29-90$ & $<0.5$ & $<0.5$ & $<0.5$ & $<0.5$ \\
\hline 40N/03E-11E04 & $05-02-91$ & $<0.5$ & $<0.5$ & $<0.5$ & $<0.5$ \\
\hline $40 \mathrm{~N} / 03 \mathrm{E}-16 \mathrm{~A} 02$ & $08-27-90$ & $<0.5$ & $<0.5$ & $<0.5$ & $<0.5$ \\
\hline 40N/03E-31P03 & $04-26-91$ & $<0.5$ & $<0.5$ & $<0.5$ & $<0.5$ \\
\hline 40N/03E-32M01 & $08-29-90$ & $<0.5$ & $<0.5$ & $<0.5$ & $<0.5$ \\
\hline 40N/04E-05P02 & $08-29-90$ & $<0.5$ & $<0.5$ & $<0.5$ & $<0.5$ \\
\hline 40N/04E-09N03 & $08-28-90$ & $<0.5$ & $<0.5$ & $<0.5$ & $<0.5$ \\
\hline 40N/04E-20F01 & $08-30-90$ & $<0.5$ & $<0.5$ & $<0.5$ & $<0.5$ \\
\hline 41N/03E-32Q01 & $05-01-91$ & $<0.5$ & $<0.5$ & $<0.5$ & $<0.5$ \\
\hline 41N/03E-35L01 & $05-01-91$ & $<0.5$ & $<0.5$ & $<0.5$ & $<0.5$ \\
\hline 41N/04E-31J02 & $08-31-90$ & $<0.5$ & $<0.5$ & $<0.5$ & $<0.5$ \\
\hline $0926.009 .1 .1 .2-11-25$ & $04-17-91$ & $<0.5$ & $<0.5$ & $<0.5$ & $<0.5$ \\
\hline $0926.009 .1 .1 .4-18-20$ & $04-17-91$ & $<0.5$ & $<0.5$ & $<0.5$ & $<0.5$ \\
\hline $0926.009 .1 .1 .4-18-35$ & $04-17-91$ & $<0.5$ & $<0.5$ & $<0.5$ & $<0.5$ \\
\hline
\end{tabular}


Appendix Table 6. Total recoverable concentrations of pesticides in selected well water samples from portions of the Lynden-Everson-Nooksack-Sumas study area, Whatcom County, Wash., and British Columbia, Canada-Continued

\begin{tabular}{|c|c|c|c|c|c|c|c|}
\hline $\begin{array}{l}\text { Local } \\
\text { well } \\
\text { number }\end{array}$ & Date & $\begin{array}{l}\text { Carbo- } \\
\text { furan } \\
(\mu \mathrm{g} / \mathrm{L})\end{array}$ & $\begin{array}{l}\text { 3-Hydroxy } \\
\text { carbo- } \\
\text { furan } \\
(\mu \mathrm{g} / \mathrm{L})\end{array}$ & $\begin{array}{l}\text { Metho- } \\
\text { myl } \\
(\mu \mathrm{g} / \mathrm{L})\end{array}$ & $\begin{array}{l}\text { 1-Naph- } \\
\text { thol } \\
(\mu \mathrm{g} / \mathrm{L})\end{array}$ & $\begin{array}{l}\text { Oxamyl } \\
(\mu \mathrm{g} / \mathrm{L})\end{array}$ & $\begin{array}{l}\text { Propham } \\
(\mu \mathrm{g} / \mathrm{L})\end{array}$ \\
\hline 39N/02E-01P02 & $08-29-90$ & $<0.5$ & $<0.5$ & $<0.5$ & $<0.5$ & $<0.5$ & $<0.5$ \\
\hline $39 \mathrm{~N} / 02 \mathrm{E}-10 \mathrm{~F} 01$ & $08-28-90$ & $<0.5$ & $<0.5$ & $<0.5$ & $<0.5$ & $<0.5$ & $<0.5$ \\
\hline $39 \mathrm{~N} / 02 \mathrm{E}-12 \mathrm{~K} 03$ & $08-29-90$ & $<0.5$ & $<0.5$ & $<0.5$ & $<0.5$ & $<0.5$ & $<0.5$ \\
\hline \multirow[t]{2}{*}{ 39N/02E-14M01 } & $08-28-90$ & $<0.5$ & $<0.5$ & $<0.5$ & $<0.5$ & $<0.5$ & $<0.5$ \\
\hline & $08-28-90$ & $<0.5$ & $<0.5$ & - & $<0.5$ & $<0.5$ & -- \\
\hline $39 \mathrm{~N} / 02 \mathrm{E}-26 \mathrm{H} 01$ & $04-23-91$ & $<0.5$ & $<0.5$ & $<0.5$ & $<0.5$ & $<0.5$ & $<0.5$ \\
\hline $39 \mathrm{~N} / 02 \mathrm{E}-27 \mathrm{~F} 03$ & $08-28-90$ & $<0.5$ & $<0.5$ & $<0.5$ & $<0.5$ & $<0.5$ & $<0.5$ \\
\hline 39N/03E-02B02 & $08-28-90$ & $<0.5$ & $<0.5$ & $<0.5$ & $<0.5$ & $<0.5$ & $<0.5$ \\
\hline \multirow[t]{2}{*}{$39 \mathrm{~N} / 03 \mathrm{E}-08 \mathrm{C} 02$} & $08-30-90$ & $<0.5$ & $<0.5$ & $<0.5$ & $<0.5$ & $<0.5$ & $<0.5$ \\
\hline & 08-30-90 & $<0.5$ & $<0.5$ & $<0.5$ & $<0.5$ & $<0.5$ & $<0.5$ \\
\hline \multirow[t]{2}{*}{ 40N/02E-27B01 } & $08-30-90$ & $<0.5$ & $<0.5$ & $<0.5$ & $<0.5$ & $<0.5$ & $<0.5$ \\
\hline & $08-30-90$ & $<0.5$ & $<0.5$ & $<0.5$ & $<0.5$ & $<0.5$ & $<0.5$ \\
\hline 40N/03E-03B01 & 08-30-90 & $<0.5$ & $<0.5$ & $<0.5$ & $<0.5$ & $<0.5$ & $<0.5$ \\
\hline 40N/03E-05N02 & $08-29-90$ & $<0.5$ & $<0.5$ & $<0.5$ & $<0.5$ & $<0.5$ & $<0.5$ \\
\hline 40N/03E-11E04 & $05-02-91$ & $<0.5$ & $<0.5$ & $<0.5$ & $<0.5$ & $<0.5$ & $<0.5$ \\
\hline 40N/03E-16A02 & $08-27-90$ & $<0.5$ & $<0.5$ & $<0.5$ & $<0.5$ & $<0.5$ & $<0.5$ \\
\hline 40N/03E-31P03 & $04-26-91$ & $<0.5$ & $<0.5$ & $<0.5$ & $<0.5$ & $<0.5$ & $<0.5$ \\
\hline 40N/03E-32M01 & $08-29-90$ & $<0.5$ & $<0.5$ & $<0.5$ & $<0.5$ & $<0.5$ & $<0.5$ \\
\hline 40N/04E-05P02 & $08-29-90$ & $<0.5$ & $<0.5$ & $<0.5$ & $<0.5$ & $<0.5$ & $<0.5$ \\
\hline 40N/04E-09N03 & $08-28-90$ & $<0.5$ & $<0.5$ & $<0.5$ & $<0.5$ & $<0.5$ & $<0.5$ \\
\hline 40N/04E-20F01 & $08-30-90$ & $<0.5$ & $<0.5$ & $<0.5$ & $<0.5$ & $<0.5$ & $<0.5$ \\
\hline 41N/03E-32Q01 & $05-01-91$ & $<0.5$ & $<0.5$ & $<0.5$ & $<0.5$ & $<0.5$ & $<0.5$ \\
\hline 41N/03E-35L01 & $05-01-91$ & $<0.5$ & $<0.5$ & $<0.5$ & $<0.5$ & $<0.5$ & $<0.5$ \\
\hline 41N/04E-31J02 & $08-31-90$ & $<0.5$ & $<0.5$ & $<0.5$ & $<0.5$ & $<0.5$ & $<0.5$ \\
\hline $0926.009 .1 .1 .2-11-25$ & $04-17-91$ & $<0.5$ & $<0.5$ & $<0.5$ & $<0.5$ & $<0.5$ & $<0.5$ \\
\hline $0926.009 \cdot 1 \cdot 1.4-18-20$ & $04-17-91$ & $<0.5$ & $<0.5$ & $<0.5$ & $<0.5$ & 0.5 & $<0.5$ \\
\hline $0926.009 .1 .1 .4-18-35$ & $04-17-91$ & $<0.5$ & $<0.5$ & $<0.5$ & $<0.5$ & $<0.5$ & $<0.5$ \\
\hline
\end{tabular}


Appendix Table 7. Concentrations of volatile organic compounds in well water samples from portions of the Lynden-Everson-Nooksack-Sumas study area, Whatcom County, Wash., and British Columbia, Canada

$[\mu \mathrm{g} / \mathrm{L}$, micrograms per liter; $<$, less than]

\begin{tabular}{|c|c|c|c|c|c|c|c|c|c|}
\hline $\begin{array}{l}\text { Local } \\
\text { well } \\
\text { number }\end{array}$ & Date & $\begin{array}{l}\text { Chloro- } \\
\text { methane } \\
\text { total } \\
(\mu \mathrm{g} / \mathrm{L})\end{array}$ & $\begin{array}{l}\text { Di- } \\
\text { chloro- } \\
\text { methane } \\
\text { total } \\
(\mu \mathrm{g} / \mathrm{L})\end{array}$ & $\begin{array}{l}\text { Tri- } \\
\text { chloro- } \\
\text { methane } \\
\text { total } \\
(\mu \mathrm{g} / \mathrm{L})\end{array}$ & $\begin{array}{l}\text { Tetra- } \\
\text { chloro- } \\
\text { methane } \\
\text { total } \\
(\mu \mathrm{g} / \mathrm{L})\end{array}$ & $\begin{array}{l}\text { Bromo- } \\
\text { methane } \\
\text { total } \\
(\mu \mathrm{g} / \mathrm{L})\end{array}$ & $\begin{array}{l}\text { Di- } \\
\text { bromo- } \\
\text { methane } \\
\text { total } \\
(\mu \mathrm{g} / \mathrm{L})\end{array}$ & $\begin{array}{l}\text { Tri- } \\
\text { bromo- } \\
\text { methane } \\
\text { total } \\
(\mu \mathrm{g} / \mathrm{L})\end{array}$ & $\begin{array}{l}\text { Bromo- } \\
\text { di- } \\
\text { chloro- } \\
\text { methane } \\
\text { total } \\
(\mu \mathrm{g} / \mathrm{L})\end{array}$ \\
\hline \multirow[t]{2}{*}{$39 \mathrm{~N} / 02 \mathrm{E}-01 \mathrm{P} 02$} & $08-29-90$ & $<0.2$ & $<0.2$ & $<0.2$ & $<0.2$ & $<0.2$ & $<0.2$ & $<0.2$ & $<0.2$ \\
\hline & $04-25-91$ & $<0.2$ & $<0.2$ & $<0.2$ & $<0.2$ & $<0.2$ & $<0.2$ & $<0.2$ & $<0.2$ \\
\hline $39 \mathrm{~N} / 02 \mathrm{E}-10 \mathrm{~F} 01$ & $08-28-90$ & $<0.2$ & $<0.2$ & $<0.2$ & $<0.2$ & $<0.2$ & $<0.2$ & $<0.2$ & $<0.2$ \\
\hline $39 \mathrm{~N} / 02 \mathrm{E}-12 \mathrm{~K} 03$ & $08-29-90$ & $<0.2$ & $<0.2$ & $<0.2$ & $<0.2$ & $<0.2$ & $<0.2$ & $<0.2$ & $<0.2$ \\
\hline \multirow[t]{2}{*}{$39 \mathrm{~N} / 02 \mathrm{E}-14 \mathrm{M} 01$} & $08-28-90$ & $<0.2$ & $<0.2$ & $<0.2$ & $<0.2$ & $<0.2$ & $<0.2$ & $<0.2$ & $<0.2$ \\
\hline & $08-28-90$ & $<0.2$ & $<0.2$ & $<0.2$ & $<0.2$ & $<0.2$ & $<0.2$ & $<0.2$ & $<0.2$ \\
\hline $39 \mathrm{~N} / 02 \mathrm{E}-26 \mathrm{H} 01$ & $04-23-91$ & $<0.2$ & $<0.2$ & $<0.2$ & $<0.2$ & $<0.2$ & $<0.2$ & $<0.2$ & $<0.2$ \\
\hline $39 \mathrm{~N} / 02 \mathrm{E}-27 \mathrm{~F} 03$ & $08-28-90$ & $<0.2$ & $<0.2$ & $<0.2$ & $<0.2$ & $<0.2$ & $<0.2$ & $<0.2$ & $<0.2$ \\
\hline 39N/03E-02B02 & $08-28-90$ & $<0.2$ & $<0.2$ & $<0.2$ & $<0.2$ & $<0.2$ & $<0.2$ & $<0.2$ & $<0.2$ \\
\hline \multirow[t]{2}{*}{$39 \mathrm{~N} / 03 \mathrm{E}-08 \mathrm{C} 02$} & $08-30-90$ & $<0.2$ & $<0.2$ & $<0.2$ & $<0.2$ & $<0.2$ & $<0.2$ & $<0.2$ & $<0.2$ \\
\hline & $08-30-90$ & $<0.2$ & $<0.2$ & $<0.2$ & $<0.2$ & $<0.2$ & $<0.2$ & $<0.2$ & $<0.2$ \\
\hline \multirow[t]{2}{*}{$40 \mathrm{~N} / 02 \mathrm{E}-27 \mathrm{~B} 01$} & $08-30-90$ & $<0.2$ & $<0.2$ & $<0.2$ & $<0.2$ & $<0.2$ & $<0.2$ & $<0.2$ & $<0.2$ \\
\hline & $08-30-90$ & $<0.2$ & $<0.2$ & $<0.2$ & $<0.2$ & $<0.2$ & $<0.2$ & $<0.2$ & $<0.2$ \\
\hline 40N/03E-03B01 & $08-30-90$ & $<0.2$ & $<0.2$ & $<0.2$ & $<0.2$ & $<0.2$ & $<0.2$ & $<0.2$ & $<0.2$ \\
\hline $40 \mathrm{~N} / 03 \mathrm{E}-05 \mathrm{~N} 02$ & $08-29-90$ & $<0.2$ & $<0.2$ & $<0.2$ & $<0.2$ & $<0.2$ & $<0.2$ & $<0.2$ & $<0.2$ \\
\hline 40N/03E-11E04 & $05-02-91$ & $<0.2$ & $<0.2$ & $<0.2$ & $<0.2$ & $<0.2$ & $<0.2$ & $<0.2$ & $<0.2$ \\
\hline 40N/03E-16A02 & $08-27-90$ & $<0.2$ & $<0.2$ & $<0.2$ & $<0.2$ & $<0.2$ & $<0.2$ & $<0.2$ & $<0.2$ \\
\hline 40N/03E-31P03 & $04-26-91$ & $<0.2$ & $<0.2$ & $<0.2$ & $<0.2$ & $<0.2$ & $<0.2$ & $<0.2$ & $<0.2$ \\
\hline 40N/03E-32M01 & $08-29-90$ & $<0.2$ & $<0.2$ & $<0.2$ & $<0.2$ & $<0.2$ & $<0.2$ & $<0.2$ & $<0.2$ \\
\hline 40N/04E-05P02 & $08-29-90$ & $<0.2$ & $<0.2$ & $<0.2$ & $<0.2$ & $<0.2$ & $<0.2$ & $<0.2$ & $<0.2$ \\
\hline 40N/04E-09N03 & $08-28-90$ & $<0.2$ & $<0.2$ & $<0.2$ & $<0.2$ & $<0.2$ & $<0.2$ & $<0.2$ & $<0.2$ \\
\hline 40N/04E-20F01 & 08-30-90 & $<0.2$ & $<0.2$ & $<0.2$ & $<0.2$ & $<0.2$ & $<0.2$ & $<0.2$ & $<0.2$ \\
\hline 41N/03E-32Q01 & $05-01-91$ & $<0.2$ & $<0.2$ & $<0.2$ & $<0.2$ & $<0.2$ & $<0.2$ & $<0.2$ & $<0.2$ \\
\hline $41 \mathrm{~N} / 03 \mathrm{E}-35 \mathrm{~L} 01$ & $05-01-91$ & $<0.2$ & $<0.2$ & $<0.2$ & $<0.2$ & $<0.2$ & $<0.2$ & $<0.2$ & $<0.2$ \\
\hline $41 \mathrm{~N} / 04 \mathrm{E}-31 \mathrm{~J} 02$ & $08-31-90$ & $<0.2$ & $<0.2$ & $<0.2$ & $<0.2$ & $<0.2$ & $<0.2$ & $<0.2$ & $<0.2$ \\
\hline $0926.009 .1 .1 .2-11-25$ & $04-17-91$ & $<0.2$ & $<0.2$ & $<0.2$ & $<0.2$ & $<0.2$ & $<0.2$ & $<0.2$ & $<0.2$ \\
\hline $0926.009 .1 .1 .4-18-20$ & $04-17-91$ & $<0.2$ & $<0.2$ & $<0.2$ & $<0.2$ & $<0.2$ & $<0.2$ & $<0.2$ & $<0.2$ \\
\hline 0926.009.1.1.4-18-35 & $04-17-91$ & $<0.2$ & $<0.2$ & $<0.2$ & $<0.2$ & $<0.2$ & $<0.2$ & $<0.2$ & $<0.2$ \\
\hline
\end{tabular}


Appendix Table 7. Concentrations of volatile organic compounds in well water samples from portions of the Lynden-Everson-Nooksack-Sumas study area, Whatcom County, Wash., and British Columbia, Canada-Continued

\begin{tabular}{|c|c|c|c|c|c|c|c|c|c|}
\hline $\begin{array}{l}\text { Local } \\
\text { well } \\
\text { number }\end{array}$ & $\begin{array}{l}\text { Di- } \\
\text { bromo- } \\
\text { chloro- } \\
\text { methane } \\
\text { total } \\
(\mu \mathrm{g} / \mathrm{L})\end{array}$ & $\begin{array}{l}\text { Tri- } \\
\text { chloro- } \\
\text { fluoro- } \\
\text { methane } \\
\text { total } \\
(\mu \mathrm{g} / \mathrm{L})\end{array}$ & $\begin{array}{l}\text { Di- } \\
\text { chloro- } \\
\text { di- } \\
\text { fluoro- } \\
\text { methane } \\
\text { total } \\
(\mu \mathrm{g} / \mathrm{L})\end{array}$ & $\begin{array}{l}\text { Chloro- } \\
\text { ethane } \\
\text { total } \\
(\mu \mathrm{g} / \mathrm{L})\end{array}$ & $\begin{array}{l}1,1-\mathrm{Di}- \\
\text { chloro- } \\
\text { ethane } \\
\text { total } \\
(\mu \mathrm{g} / \mathrm{L})\end{array}$ & $\begin{array}{l}\text { 1,2-Di- } \\
\text { chloro- } \\
\text { ethane } \\
\text { total } \\
(\mu \mathrm{g} / \mathrm{L})\end{array}$ & $\begin{array}{l}1,1,1- \\
\text { Tri- } \\
\text { chloro- } \\
\text { ethane } \\
\text { total } \\
(\mu \mathrm{g} / \mathrm{L})\end{array}$ & $\begin{array}{l}1,1,2- \\
\text { Tri- } \\
\text { chloro- } \\
\text { ethane } \\
\text { total } \\
(\mu \mathrm{g} / \mathrm{L})\end{array}$ & $\begin{array}{l}1,1,1,2- \\
\text { Tetra- } \\
\text { chloro- } \\
\text { ethane } \\
\text { total } \\
(\mu \mathrm{g} / \mathrm{L})\end{array}$ \\
\hline \multirow[t]{2}{*}{$39 \mathrm{~N} / 02 \mathrm{E}-01 \mathrm{P} 02$} & $<0.2$ & $<0.2$ & $<0.2$ & $<0.2$ & $<0.2$ & $<0.2$ & $<0.2$ & $<0.2$ & $<0.2$ \\
\hline & $<0.2$ & $<0.2$ & $<0.2$ & $<0.2$ & $<0.2$ & $<0.2$ & $<0.2$ & $<0.2$ & $<0.2$ \\
\hline $39 \mathrm{~N} / 02 \mathrm{E}-10 \mathrm{~F} 01$ & $<0.2$ & $<0.2$ & $<0.2$ & $<0.2$ & $<0.2$ & $<0.2$ & $<0.2$ & $<0.2$ & $<0.2$ \\
\hline $39 \mathrm{~N} / 02 \mathrm{E}-12 \mathrm{~K} 03$ & $<0.2$ & $<0.2$ & $<0.2$ & $<0.2$ & $<0.2$ & $<0.2$ & $<0.2$ & $<0.2$ & $<0.2$ \\
\hline \multirow[t]{2}{*}{$39 \mathrm{~N} / 02 \mathrm{E}-14 \mathrm{M} 01$} & $<0.2$ & $<0.2$ & $<0.2$ & $<0.2$ & $<0.2$ & $<0.2$ & $<0.2$ & $<0.2$ & $<0.2$ \\
\hline & $<0.2$ & $<0.2$ & $<0.2$ & $<0.2$ & $<0.2$ & $<0.2$ & $<0.2$ & $<0.2$ & $<0.2$ \\
\hline $39 \mathrm{~N} / 02 \mathrm{E}-26 \mathrm{H} 01$ & $<0.2$ & $<0.2$ & $<0.2$ & $<0.2$ & $<0.2$ & $<0.2$ & $<0.2$ & $<0.2$ & $<0.2$ \\
\hline $39 \mathrm{~N} / 02 \mathrm{E}-27 \mathrm{~F} 03$ & $<0.2$ & $<0.2$ & $<0.2$ & $<0.2$ & $<0.2$ & $<0.2$ & $<0.2$ & $<0.2$ & $<0.2$ \\
\hline 39N/03E-02B02 & $<0.2$ & $<0.2$ & $<0.2$ & $<0.2$ & $<0.2$ & $<0.2$ & $<0.2$ & $<0.2$ & $<0.2$ \\
\hline \multirow[t]{2}{*}{$39 \mathrm{~N} / 03 \mathrm{E}-08 \mathrm{C} 02$} & $<0.2$ & $<0.2$ & $<0.2$ & $<0.2$ & $<0.2$ & $<0.2$ & $<0.2$ & $<0.2$ & $<0.2$ \\
\hline & $<0.2$ & $<0.2$ & $<0.2$ & $<0.2$ & $<0.2$ & $<0.2$ & $<0.2$ & $<0.2$ & $<0.2$ \\
\hline \multirow[t]{2}{*}{$40 \mathrm{~N} / 02 \mathrm{E}-27 \mathrm{~B} 01$} & $<0.2$ & $<0.2$ & $<0.2$ & $<0.2$ & $<0.2$ & $<0.2$ & $<0.2$ & $<0.2$ & $<0.2$ \\
\hline & $<0.2$ & $<0.2$ & $<0.2$ & $<0.2$ & $<0.2$ & $<0.2$ & $<0.2$ & $<0.2$ & $<0.2$ \\
\hline 40N/03E-03B01 & $<0.2$ & $<0.2$ & $<0.2$ & $<0.2$ & $<0.2$ & $<0.2$ & $<0.2$ & $<0.2$ & $<0.2$ \\
\hline $40 \mathrm{~N} / 03 \mathrm{E}-05 \mathrm{~N} 02$ & $<0.2$ & $<0.2$ & $<0.2$ & $<0.2$ & $<0.2$ & $<0.2$ & $<0.2$ & $<0.2$ & $<0.2$ \\
\hline $40 \mathrm{~N} / 03 \mathrm{E}-11 \mathrm{E} 04$ & $<0.2$ & $<0.2$ & $<0.2$ & $<0.2$ & $<0.2$ & $<0.2$ & $<0.2$ & $<0.2$ & $<0.2$ \\
\hline 40N/03E-16A02 & $<0.2$ & $<0.2$ & $<0.2$ & $<0.2$ & $<0.2$ & $<0.2$ & $<0.2$ & $<0.2$ & $<0.2$ \\
\hline $40 \mathrm{~N} / 03 \mathrm{E}-31 \mathrm{P} 03$ & $<0.2$ & $<0.2$ & $<0.2$ & $<0.2$ & $<0.2$ & $<0.2$ & $<0.2$ & $<0.2$ & $<0.2$ \\
\hline 40N/03E-32M01 & $<0.2$ & $<0.2$ & $<0.2$ & $<0.2$ & $<0.2$ & $<0.2$ & $<0.2$ & $<0.2$ & $<0.2$ \\
\hline 40N/04E-05P02 & $<0.2$ & $<0.2$ & $<0.2$ & $<0.2$ & $<0.2$ & $<0.2$ & $<0.2$ & $<0.2$ & $<0.2$ \\
\hline $40 \mathrm{~N} / 04 \mathrm{E}-09 \mathrm{~N} 03$ & $<0.2$ & $<0.2$ & $<0.2$ & $<0.2$ & $<0.2$ & $<0.2$ & $<0.2$ & $<0.2$ & $<0.2$ \\
\hline 40N/04E-20F01 & $<0.2$ & $<0.2$ & $<0.2$ & $<0.2$ & $<0.2$ & $<0.2$ & $<0.2$ & $<0.2$ & $<0.2$ \\
\hline $41 \mathrm{~N} / 03 \mathrm{E}-32 \mathrm{Q} 01$ & $<0.2$ & $<0.2$ & $<0.2$ & $<0.2$ & $<0.2$ & $<0.2$ & $<0.2$ & $<0.2$ & $<0.2$ \\
\hline $41 \mathrm{~N} / 03 \mathrm{E}-35 \mathrm{~L} 01$ & $<0.2$ & $<0.2$ & $<0.2$ & $<0.2$ & $<0.2$ & $<0.2$ & $<0.2$ & $<0.2$ & $<0.2$ \\
\hline $41 \mathrm{~N} / 04 \mathrm{E}-31 \mathrm{~J} 02$ & $<0.2$ & $<0.2$ & $<0.2$ & $<0.2$ & $<0.2$ & $<0.2$ & $<0.2$ & $<0.2$ & $<0.2$ \\
\hline $0926.009 .1 .1 .2-11-25$ & $<0.2$ & $<0.2$ & $<0.2$ & $<0.2$ & $<0.2$ & $<0.2$ & $<0.2$ & $<0.2$ & $<0.2$ \\
\hline $0926.009 .1 .1 .4-18-20$ & $<0.2$ & $<0.2$ & $<0.2$ & $<0.2$ & $<0.2$ & $<0.2$ & $<0.2$ & $<0.2$ & $<0.2$ \\
\hline $0926.009 .1 .1 .4-18-35$ & $<0.2$ & $<0.2$ & $<0.2$ & $<0.2$ & $<0.2$ & $<0.2$ & $<0.2$ & $<0.2$ & $<0.2$ \\
\hline
\end{tabular}


Appendix Table 7. Concentrations of volatile organic compounds in well water samples from portions of the Lynden-Everson-Nooksack-Sumas study area, Whatcom County, Wash., and British Columbia, Canada--

Continued

\begin{tabular}{|c|c|c|c|c|c|c|c|c|c|}
\hline $\begin{array}{l}\text { Local } \\
\text { well } \\
\text { number }\end{array}$ & $\begin{array}{l}1,1,2,2- \\
\text { Tetra- } \\
\text { chloro- } \\
\text { ethane } \\
\text { total } \\
(\mu \mathrm{g} / \mathrm{L})\end{array}$ & $\begin{array}{l}1,2- \\
\text { Dibromo } \\
\text { ethane } \\
\text { total } \\
(\mu \mathrm{g} / \mathrm{L})\end{array}$ & $\begin{array}{l}\text { Vinyl } \\
\text { chlo- } \\
\text { ride } \\
\text { total } \\
(\mu \mathrm{g} / \mathrm{L})\end{array}$ & $\begin{array}{l}\text { 1,1-Di- } \\
\text { chloro- } \\
\text { ethene } \\
\text { total } \\
(\mu \mathrm{g} / \mathrm{L})\end{array}$ & $\begin{array}{l}\text { cis } \\
1,2-\mathrm{Di}- \\
\text { chloro- } \\
\text { ethene } \\
\text { total } \\
(\mu \mathrm{g} / \mathrm{L})\end{array}$ & $\begin{array}{l}\text { Tri- } \\
\text { chloro- } \\
\text { ethene } \\
\text { total } \\
(\mu \mathrm{g} / \mathrm{L})\end{array}$ & $\begin{array}{l}\text { Tetra- } \\
\text { chloro- } \\
\text { ethene } \\
\text { total } \\
(\mu \mathrm{g} / \mathrm{L})\end{array}$ & $\begin{array}{l}\text { 1,2-Di- } \\
\text { chloro- } \\
\text { propane } \\
\text { total } \\
(\mu \mathrm{g} / \mathrm{L})\end{array}$ & $\begin{array}{l}\text { 1,3-Di- } \\
\text { chloro- } \\
\text { propane } \\
\text { total } \\
(\mu \mathrm{g} / \mathrm{L})\end{array}$ \\
\hline \multirow[t]{2}{*}{$39 \mathrm{~N} / 02 \mathrm{E}-01 \mathrm{P02}$} & $<0.2$ & $<0.2$ & $<0.2$ & $<0.2$ & $<0.2$ & $<0.2$ & $<0.2$ & 1.6 & $<0.2$ \\
\hline & $<0.2$ & $<0.2$ & $<0.2$ & $<0.2$ & $<0.2$ & $<0.2$ & $<0.2$ & 2.8 & $<0.2$ \\
\hline $39 \mathrm{~N} / 02 \mathrm{E}-10 \mathrm{~F} 01$ & $<0.2$ & $<0.2$ & $<0.2$ & $<0.2$ & $<0.2$ & $<0.2$ & $<0.2$ & $<0.2$ & $<0.2$ \\
\hline $39 \mathrm{~N} / 02 \mathrm{E}-12 \mathrm{~K} 03$ & $<0.2$ & $<0.2$ & $<0.2$ & $<0.2$ & $<0.2$ & $<0.2$ & $<0.2$ & $<0.2$ & $<0.2$ \\
\hline \multirow{2}{*}{$39 \mathrm{~N} / 02 \mathrm{E}-14 \mathrm{M} 01$} & $<0.2$ & $<0.2$ & $<0.2$ & $<0.2$ & $<0.2$ & $<0.2$ & $<0.2$ & $<0.2$ & $<0.2$ \\
\hline & $<0.2$ & $<0.2$ & $<0.2$ & $<0.2$ & $<0.2$ & $<0.2$ & $<0.2$ & $<0.2$ & $<0.2$ \\
\hline $39 \mathrm{~N} / 02 \mathrm{E}-26 \mathrm{H} 01$ & $<0.2$ & $<0.2$ & $<0.2$ & $<0.2$ & $<0.2$ & $<0.2$ & $<0.2$ & $<0.2$ & $<0.2$ \\
\hline $39 \mathrm{~N} / 02 \mathrm{E}-27 \mathrm{~F} 03$ & $<0.2$ & $<0.2$ & $<0.2$ & $<0.2$ & $<0.2$ & $<0.2$ & $<0.2$ & $<0.2$ & $<0.2$ \\
\hline $39 \mathrm{~N} / 03 \mathrm{E}-02 \mathrm{~B} 02$ & $<0.2$ & $<0.2$ & $<0.2$ & $<0.2$ & $<0.2$ & $<0.2$ & $<0.2$ & $<0.2$ & $<0.2$ \\
\hline \multirow{2}{*}{ 39N/03E-08C02 } & $<0.2$ & $<0.2$ & $<0.2$ & $<0.2$ & $<0.2$ & $<0.2$ & $<0.2$ & $<0.2$ & $<0.2$ \\
\hline & $<0.2$ & $<0.2$ & $<0.2$ & $<0.2$ & $<0.2$ & $<0.2$ & $<0.2$ & $<0.2$ & $<0.2$ \\
\hline \multirow[t]{2}{*}{$40 \mathrm{~N} / 02 \mathrm{E}-27 \mathrm{~B} 01$} & $<0.2$ & 0.3 & $<0.2$ & $<0.2$ & $<0.2$ & $<0.2$ & $<0.2$ & 5.6 & 0.2 \\
\hline & $<0.2$ & 0.3 & $<0.2$ & $<0.2$ & $<0.2$ & $<0.2$ & $<0.2$ & 5.6 & 0.2 \\
\hline 40N/03E-03B01 & $<0.2$ & $<0.2$ & $<0.2$ & $<0.2$ & $<0.2$ & $<0.2$ & $<0.2$ & $<0.2$ & $<0.2$ \\
\hline $40 \mathrm{~N} / 03 \mathrm{E}-05 \mathrm{~N} 02$ & $<0.2$ & $<0.2$ & $<0.2$ & $<0.2$ & $<0.2$ & $<0.2$ & $<0.2$ & $<0.2$ & $<0.2$ \\
\hline 40N/03E-11E04 & $<0.2$ & $<0.2$ & $<0.2$ & $<0.2$ & $<0.2$ & $<0.2$ & $<0.2$ & $<0.2$ & $<0.2$ \\
\hline 40N/03E-16A02 & $<0.2$ & $<0.2$ & $<0.2$ & $<0.2$ & $<0.2$ & $<0.2$ & $<0.2$ & $<0.2$ & $<0.2$ \\
\hline $40 \mathrm{~N} / 03 \mathrm{E}-31 \mathrm{P} 03$ & $<0.2$ & $<0.2$ & $<0.2$ & $<0.2$ & $<0.2$ & $<0.2$ & $<0.2$ & $<0.2$ & $<0.2$ \\
\hline 40N/03E-32M01 & $<0.2$ & $<0.2$ & $<0.2$ & $<0.2$ & $<0.2$ & $<0.2$ & $<0.2$ & $<0.2$ & $<0.2$ \\
\hline 40N/04E-05P02 & $<0.2$ & $<0.2$ & $<0.2$ & $<0.2$ & $<0.2$ & $<0.2$ & $<0.2$ & $<0.2$ & $<0.2$ \\
\hline 40N/04E-09N03 & $<0.2$ & $<0.2$ & $<0.2$ & $<0.2$ & $<0.2$ & $<0.2$ & $<0.2$ & $<0.2$ & $<0.2$ \\
\hline 40N/04E-20F01 & $<0.2$ & $<0.2$ & $<0.2$ & $<0.2$ & $<0.2$ & $<0.2$ & $<0.2$ & $<0.2$ & $<0.2$ \\
\hline 41N/03E-32Q01 & $<0.2$ & $<0.2$ & $<0.2$ & $<0.2$ & $<0.2$ & $<0.2$ & $<0.2$ & $<0.2$ & $<0.2$ \\
\hline 41N/03E-35L01 & $<0.2$ & $<0.2$ & $<0.2$ & $<0.2$ & $<0.2$ & $<0.2$ & $<0.2$ & $<0.2$ & $<0.2$ \\
\hline 41N/04E-31J02 & $<0.2$ & $<0.2$ & $<0.2$ & $<0.2$ & $<0.2$ & $<0.2$ & $<0.2$ & $<0.2$ & $<0.2$ \\
\hline $0926.009 .1 .1 .2-11-25$ & $<0.2$ & $<0.2$ & $<0.2$ & $<0.2$ & $<0.2$ & $<0.2$ & $<0.2$ & $<0.2$ & $<0.2$ \\
\hline $0926.009 .1 .1 .4-18-20$ & $<0.2$ & $<0.2$ & $<0.2$ & $<0.2$ & $<0.2$ & $<0.2$ & $<0.2$ & $<0.2$ & $<0.2$ \\
\hline $0926.009 .1 .1 .4-18-35$ & $<0.2$ & $<0.2$ & $<0.2$ & $<0.2$ & $<0.2$ & $<0.2$ & $<0.2$ & $<0.2$ & $<0.2$ \\
\hline
\end{tabular}


Appendix Table 7. Concentrations of volatile organic compounds in well water samples from portions of the Lynden-Everson-Nooksack-Sumas study area, Whatcom County, Wash., and British Columbia, Canada-Continued

\begin{tabular}{|c|c|c|c|c|c|c|c|c|c|c|}
\hline $\begin{array}{l}\text { Local } \\
\text { well } \\
\text { number }\end{array}$ & $\begin{array}{l}\text { 2,2-Di- } \\
\text { chloro- } \\
\text { propane } \\
\text { total } \\
(\mu \mathrm{g} / \mathrm{L})\end{array}$ & $\begin{array}{l}1,2-\mathrm{Di}- \\
\text { bromo-3- } \\
\text { chloro- } \\
\text { propane } \\
\text { total } \\
(\mu \mathrm{g} / \mathrm{L})\end{array}$ & $\begin{array}{l}1,2,3- \\
\text { Tri- } \\
\text { chloror- } \\
\text { propane } \\
\text { total } \\
(\mu \mathrm{g} / \mathrm{L})\end{array}$ & $\begin{array}{l}\text { 1,1-Di- } \\
\text { chloro- } \\
\text { propene } \\
\text { total } \\
(\mu \mathrm{g} / \mathrm{L})\end{array}$ & $\begin{array}{l}\text { cis } \\
1,3-\mathrm{Di}- \\
\text { chloro- } \\
\text { propene } \\
\text { total } \\
(\mu \mathrm{g} / \mathrm{L})\end{array}$ & $\begin{array}{l}\text { trans } \\
1,3-\mathrm{Di}- \\
\text { chloro- } \\
\text { propene } \\
\text { total } \\
(\mu \mathrm{g} / \mathrm{L})\end{array}$ & $\begin{array}{l}\text { Benzene } \\
\text { total } \\
(\mu \mathrm{g} / \mathrm{L})\end{array}$ & $\begin{array}{l}\text { Chloro- } \\
\text { benzene } \\
\text { total } \\
(\mu \mathrm{g} / \mathrm{L})\end{array}$ & $\begin{array}{l}\text { 1,2-Di- } \\
\text { Chloro- } \\
\text { benzene } \\
\text { total } \\
(\mu \mathrm{g} / \mathrm{L})\end{array}$ & $\begin{array}{l}1,3-\mathrm{Di}- \\
\text { chloro- } \\
\text { benzene } \\
\text { total } \\
(\mu \mathrm{g} / \mathrm{L})\end{array}$ \\
\hline \multirow[t]{2}{*}{$39 \mathrm{~N} / 02 \mathrm{E}-01 \mathrm{P} 02$} & $<0.2$ & $<0.2$ & $<0.2$ & $<0.2$ & $<0.2$ & $<0.2$ & $<0.2$ & $<0.2$ & $<0.2$ & $<0.2$ \\
\hline & $<0.2$ & $<0.2$ & $<0.2$ & $<0.2$ & $<0.2$ & $<0.2$ & $<0.2$ & $<0.2$ & $<0.2$ & $<0.2$ \\
\hline $39 \mathrm{~N} / 02 \mathrm{E}-10 \mathrm{~F} 01$ & $<0.2$ & $<0.2$ & $<0.2$ & $<0.2$ & $<0.2$ & $<0.2$ & $<0.2$ & $<0.2$ & $<0.2$ & $<0.2$ \\
\hline $39 \mathrm{~N} / 02 \mathrm{E}-12 \mathrm{~K} 03$ & $<0.2$ & $<0.2$ & $<0.2$ & $<0.2$ & $<0.2$ & $<0.2$ & $<0.2$ & $<0.2$ & $<0.2$ & $<0.2$ \\
\hline \multirow[t]{2}{*}{$39 \mathrm{~N} / 02 \mathrm{E}-14 \mathrm{M} 01$} & $<0.2$ & $<0.2$ & $<0.2$ & $<0.2$ & $<0.2$ & $<0.2$ & $<0.2$ & $<0.2$ & $<0.2$ & $<0.2$ \\
\hline & $<0.2$ & $<0.2$ & $<0.2$ & $<0.2$ & $<0.2$ & $<0.2$ & $<0.2$ & $<0.2$ & $<0.2$ & $<0.2$ \\
\hline $39 \mathrm{~N} / 02 \mathrm{E}-26 \mathrm{H} 01$ & $<0.2$ & $<0.2$ & $<0.2$ & $<0.2$ & $<0.2$ & $<0.2$ & $<0.2$ & $<0.2$ & $<0.2$ & $<0.2$ \\
\hline $39 \mathrm{~N} / 02 \mathrm{E}-27 \mathrm{~F} 03$ & $<0.2$ & $<0.2$ & $<0.2$ & $<0.2$ & $<0.2$ & $<0.2$ & $<0.2$ & $<0.2$ & $<0.2$ & $<0.2$ \\
\hline 39N/03E-02B02 & $<0.2$ & $<0.2$ & $<0.2$ & $<0.2$ & $<0.2$ & $<0.2$ & $<0.2$ & $<0.2$ & $<0.2$ & $<0.2$ \\
\hline \multirow[t]{2}{*}{$39 \mathrm{~N} / 03 \mathrm{E}-08 \mathrm{C} 02$} & $<0.2$ & $<0.2$ & $<0.2$ & $<0.2$ & $<0.2$ & $<0.2$ & $<0.2$ & $<0.2$ & $<0.2$ & $<0.2$ \\
\hline & $<0.2$ & $<0.2$ & $<0.2$ & $<0.2$ & $<0.2$ & $<0.2$ & $<0.2$ & $<0.2$ & $<0.2$ & $<0.2$ \\
\hline \multirow[t]{2}{*}{$40 \mathrm{~N} / 02 \mathrm{E}-27 \mathrm{~B} 01$} & $<0.2$ & $<0.2$ & 1.4 & $<0.2$ & $<0.2$ & $<0.2$ & $<0.2$ & $<0.2$ & $<0.2$ & $<0.2$ \\
\hline & $<0.2$ & $<0.2$ & 1.2 & $<0.2$ & $<0.2$ & $<0.2$ & $<0.2$ & $<0.2$ & $<0.2$ & $<0.2$ \\
\hline 40N/03E-03B01 & $<0.2$ & $<0.2$ & $<0.2$ & $<0.2$ & $<0.2$ & $<0.2$ & $<0.2$ & $<0.2$ & $<0.2$ & $<0.2$ \\
\hline $40 \mathrm{~N} / 03 \mathrm{E}-05 \mathrm{~N} 02$ & $<0.2$ & $<0.2$ & $<0.2$ & $<0.2$ & $<0.2$ & $<0.2$ & $<0.2$ & $<0.2$ & $<0.2$ & $<0.2$ \\
\hline $40 N / 03 E-11 E 04$ & $<0.2$ & $<0.2$ & $<0.2$ & $<0.2$ & $<0.2$ & $<0.2$ & $<0.2$ & $<0.2$ & $<0.2$ & $<0.2$ \\
\hline $40 \mathrm{~N} / 03 \mathrm{E}-16 \mathrm{~A} 02$ & $<0.2$ & $<0.2$ & $<0.2$ & $<0.2$ & $<0.2$ & $<0.2$ & $<0.2$ & $<0.2$ & $<0.2$ & $<0.2$ \\
\hline $40 \mathrm{~N} / 03 \mathrm{E}-31 \mathrm{P} 03$ & $<0.2$ & $<0.2$ & $<0.2$ & $<0.2$ & $<0.2$ & $<0.2$ & $<0.2$ & $<0.2$ & $<0.2$ & $<0.2$ \\
\hline 40N/03E-32M01 & $<0.2$ & $<0.2$ & $<0.2$ & $<0.2$ & $<0.2$ & $<0.2$ & $<0.2$ & $<0.2$ & $<0.2$ & $<0.2$ \\
\hline 40N/04E-05P02 & $<0.2$ & $<0.2$ & $<0.2$ & $<0.2$ & $<0.2$ & $<0.2$ & $<0.2$ & $<0.2$ & $<0.2$ & $<0.2$ \\
\hline 40N/04E-09N03 & $<0.2$ & $<0.2$ & $<0.2$ & $<0.2$ & $<0.2$ & $<0.2$ & $<0.2$ & $<0.2$ & $<0.2$ & $<0.2$ \\
\hline $40 \mathrm{~N} / 04 \mathrm{E}-20 \mathrm{~F} 01$ & $<0.2$ & $<0.2$ & $<0.2$ & $<0.2$ & $<0.2$ & $<0.2$ & $<0.2$ & $<0.2$ & $<0.2$ & $<0.2$ \\
\hline $41 \mathrm{~N} / 03 \mathrm{E}-32 \mathrm{Q} 01$ & $<0.2$ & $<0.2$ & $<0.2$ & $<0.2$ & $<0.2$ & $<0.2$ & $<0.2$ & $<0.2$ & $<0.2$ & $<0.2$ \\
\hline $41 \mathrm{~N} / 03 \mathrm{E}-35 \mathrm{~L} 01$ & $<0.2$ & $<0.2$ & $<0.2$ & $<0.2$ & $<0.2$ & $<0.2$ & $<0.2$ & $<0.2$ & $<0.2$ & $<0.2$ \\
\hline $41 \mathrm{~N} / 04 \mathrm{E}-31 \mathrm{~J} 02$ & $<0.2$ & $<0.2$ & $<0.2$ & $<0.2$ & $<0.2$ & $<0.2$ & $<0.2$ & $<0.2$ & $<0.2$ & $<0.2$ \\
\hline $0926.009 .1 .1 .2-11$ & $-25<0.2$ & $<0.2$ & $<0.2$ & $<0.2$ & $<0.2$ & $<0.2$ & $<0.2$ & $<0.2$ & $<0.2$ & $<0.2$ \\
\hline 0926.009.1.1.4-18 & $-20<0.2$ & $<0.2$ & $<0.2$ & $<0.2$ & $<0.2$ & $<0.2$ & $<0.2$ & $<0.2$ & $<0.2$ & $<0.2$ \\
\hline 0926.009.1.1.4-18 & $-35<0.2$ & $<0.2$ & $<0.2$ & $<0.2$ & $<0.2$ & $<0.2$ & $<0.2$ & $<0.2$ & $<0.2$ & $<0.2$ \\
\hline
\end{tabular}


Appendix Table 7. Concentrations of volatile organic compounds in well water samples from portions of the Lynden-Everson-Nooksack-Sumas study area, Whatcom County, Wash., and British Columbia, Canada-Continued

\begin{tabular}{|c|c|c|c|c|c|c|c|c|}
\hline $\begin{array}{l}\text { Local } \\
\text { well } \\
\text { number }\end{array}$ & $\begin{array}{l}\text { 1,4-Di- } \\
\text { chloro- } \\
\text { benzene } \\
\text { total } \\
(\mu \mathrm{g} / \mathrm{L})\end{array}$ & $\begin{array}{l}\text { Bromo- } \\
\text { benzene } \\
\text { total } \\
(\mu \mathrm{g} / \mathrm{L})\end{array}$ & $\begin{array}{l}\text { Toluene } \\
\text { total } \\
(\mu \mathrm{g} / \mathrm{L})\end{array}$ & $\begin{array}{l}2- \\
\text { Chloro- } \\
\text { toluene } \\
\text { total } \\
(\mu \mathrm{g} / \mathrm{L})\end{array}$ & $\begin{array}{l}4- \\
\text { Chloro- } \\
\text { toluene } \\
\text { total } \\
(\mu \mathrm{g} / \mathrm{L})\end{array}$ & $\begin{array}{l}\text { Di- } \\
\text { methyl- } \\
\text { benzene } \\
\text { total } \\
(\mu \mathrm{g} / \mathrm{L})\end{array}$ & $\begin{array}{l}\text { Ethyl- } \\
\text { benzene } \\
\text { total } \\
(\mu \mathrm{g} / \mathrm{L})\end{array}$ & $\begin{array}{l}\text { Ethenyl- } \\
\text { benzene } \\
\text { total } \\
(\mu \mathrm{g} / \mathrm{L})\end{array}$ \\
\hline \multirow[t]{2}{*}{$39 \mathrm{~N} / 02 \mathrm{E}-01 \mathrm{P} 02$} & $<0.2$ & $<0.2$ & $<0.2$ & $<0.2$ & $<0.2$ & $<0.2$ & $<0.2$ & $<0.2$ \\
\hline & $<0.2$ & $<0.2$ & $<0.2$ & $<0.2$ & $<0.2$ & $<0.2$ & $<0.2$ & $<0.2$ \\
\hline $39 \mathrm{~N} / 02 \mathrm{E}-10 \mathrm{~F} 01$ & $<0.2$ & $<0.2$ & $<0.2$ & $<0.2$ & $<0.2$ & $<0.2$ & $<0.2$ & $<0.2$ \\
\hline $39 \mathrm{~N} / 02 \mathrm{E}-12 \mathrm{~K} 03$ & $<0.2$ & $<0.2$ & $<0.2$ & $<0.2$ & $<0.2$ & $<0.2$ & $<0.2$ & $<0.2$ \\
\hline \multirow[t]{2}{*}{$39 \mathrm{~N} / 02 \mathrm{E}-14 \mathrm{M} 01$} & $<0.2$ & $<0.2$ & $<0.2$ & $<0.2$ & $<0.2$ & $<0.2$ & $<0.2$ & $<0.2$ \\
\hline & $<0.2$ & $<0.2$ & $<0.2$ & $<0.2$ & $<0.2$ & $<0.2$ & $<0.2$ & $<0.2$ \\
\hline $39 \mathrm{~N} / 02 \mathrm{E}-26 \mathrm{H} 01$ & $<0.2$ & $<0.2$ & $<0.2$ & $<0.2$ & $<0.2$ & $<0.2$ & $<0.2$ & $<0.2$ \\
\hline $39 \mathrm{~N} / 02 \mathrm{E}-27 \mathrm{~F} 03$ & $<0.2$ & $<0.2$ & $<0.2$ & $<0.2$ & $<0.2$ & $<0.2$ & $<0.2$ & $<0.2$ \\
\hline $39 \mathrm{~N} / 03 \mathrm{E}-02 \mathrm{~B} 02$ & $<0.2$ & $<0.2$ & $<0.2$ & $<0.2$ & $<0.2$ & $<0.2$ & $<0.2$ & $<0.2$ \\
\hline \multirow[t]{2}{*}{$39 \mathrm{~N} / 03 \mathrm{E}-08 \mathrm{C} 02$} & $<0.2$ & $<0.2$ & $<0.2$ & $<0.2$ & $<0.2$ & $<0.2$ & $<0.2$ & $<0.2$ \\
\hline & $<0.2$ & $<0.2$ & $<0.2$ & $<0.2$ & $<0.2$ & $<0.2$ & $<0.2$ & $<0.2$ \\
\hline \multirow[t]{2}{*}{ 40N/02E-27B01 } & $<0.2$ & $<0.2$ & $<0.2$ & $<0.2$ & $<0.2$ & $<0.2$ & $<0.2$ & $<0.2$ \\
\hline & $<0.2$ & $<0.2$ & $<0.2$ & $<0.2$ & $<0.2$ & $<0.2$ & $<0.2$ & $<0.2$ \\
\hline $40 \mathrm{~N} / 03 \mathrm{E}-03 \mathrm{~B} 01$ & $<0.2$ & $<0.2$ & $<0.2$ & $<0.2$ & $<0.2$ & $<0.2$ & $<0.2$ & $<0.2$ \\
\hline $40 \mathrm{~N} / 03 \mathrm{E}-05 \mathrm{~N} 02$ & $<0.2$ & $<0.2$ & $<0.2$ & $<0.2$ & $<0.2$ & $<0.2$ & $<0.2$ & $<0.2$ \\
\hline $40 \mathrm{~N} / 03 \mathrm{E}-11 \mathrm{E} 04$ & $<0.2$ & $<0.2$ & $<0.2$ & $<0.2$ & $<0.2$ & $<0.2$ & $<0.2$ & $<0.2$ \\
\hline 40N/03E-16A02 & $<0.2$ & $<0.2$ & $<0.2$ & $<0.2$ & $<0.2$ & $<0.2$ & $<0.2$ & $<0.2$ \\
\hline $40 \mathrm{~N} / 03 \mathrm{E}-31 \mathrm{P} 03$ & $<0.2$ & $<0.2$ & $<0.2$ & $<0.2$ & $<0.2$ & $<0.2$ & $<0.2$ & $<0.2$ \\
\hline 40N/03E-32M01 & $<0.2$ & $<0.2$ & $<0.2$ & $<0.2$ & $<0.2$ & $<0.2$ & $<0.2$ & $<0.2$ \\
\hline 40N/04E-05P02 & $<0.2$ & $<0.2$ & $<0.2$ & $<0.2$ & $<0.2$ & $<0.2$ & $<0.2$ & $<0.2$ \\
\hline 40N/04E-09N03 & $<0.2$ & $<0.2$ & $<0.2$ & $<0.2$ & $<0.2$ & $<0.2$ & $<0.2$ & $<0.2$ \\
\hline 40N/04E-20F01 & $<0.2$ & $<0.2$ & $<0.2$ & $<0.2$ & $<0.2$ & $<0.2$ & $<0.2$ & $<0.2$ \\
\hline $41 \mathrm{~N} / 03 \mathrm{E}-32 \mathrm{Q} 01$ & $<0.2$ & $<0.2$ & $<0.2$ & $<0.2$ & $<0.2$ & $<0.2$ & $<0.2$ & $<0.2$ \\
\hline $41 \mathrm{~N} / 03 \mathrm{E}-35 \mathrm{~L} 01$ & $<0.2$ & $<0.2$ & $<0.2$ & $<0.2$ & $<0.2$ & $<0.2$ & $<0.2$ & $<0.2$ \\
\hline 41N/04E-31J02 & $<0.2$ & $<0.2$ & $<0.2$ & $<0.2$ & $<0.2$ & $<0.2$ & $<0.2$ & $<0.2$ \\
\hline $0926.009 .1 .1 .2-11-25$ & $<0.2$ & $<0.2$ & $<0.2$ & $<0.2$ & $<0.2$ & $<0.2$ & $<0.2$ & $<0.2$ \\
\hline $0926.009 .1 .1 .4-18-20$ & $<0.2$ & $<0.2$ & $<0.2$ & $<0.2$ & $<0.2$ & $<0.2$ & $<0.2$ & $<0.2$ \\
\hline 0926.009.1.1.4-18-35 & $<0.2$ & $<0.2$ & $<0.2$ & $<0.2$ & $<0.2$ & $<0.2$ & $<0.2$ & $<0.2$ \\
\hline
\end{tabular}


Appendix Table 8. Concentrations of selected nitrogen species in ground water of the Lynden-Everson-NooksackSumas study area, Whatcom County, Wash., and British Columbia, Canada

[mg/L, milligrams per liter; --, no data; <, less than]

\begin{tabular}{|c|c|c|c|c|c|c|c|c|c|c|}
\hline $\begin{array}{l}\text { Local } \\
\text { well number }\end{array}$ & Date & $\begin{array}{l}\text { Nitro- } \\
\text { gen, } \\
\text { organic, } \\
\text { total } \\
(\mathrm{mg} / \mathrm{L} \\
\text { as } \mathrm{N})\end{array}$ & $\begin{array}{l}\text { Nitro- } \\
\text { gen, } \\
\text { ammonia, } \\
\text { dis- } \\
\text { solved } \\
(\mathrm{mg} / \mathrm{L} \\
\text { as } \mathrm{N})\end{array}$ & $\begin{array}{l}\text { Nitro- } \\
\text { gen, } \\
\text { ammonia, } \\
\text { total } \\
(\mathrm{mg} / \mathrm{L} \\
\text { as } \mathrm{N})\end{array}$ & $\begin{array}{l}\text { Nitro- } \\
\text { gen, } \\
\text { nitrite, } \\
\text { dis- } \\
\text { solved } \\
\text { (mg/L } \\
\text { as N) }\end{array}$ & $\begin{array}{l}\text { Nitro- } \\
\text { gen, } \\
\text { nitrite, } \\
\text { total } \\
\text { (mg/L } \\
\text { as N) }\end{array}$ & $\begin{array}{l}\text { Nitro- } \\
\text { gen, am- } \\
\text { monia + } \\
\text { organic, } \\
\text { dissolved } \\
(\mathrm{mg} / \mathrm{L} \\
\text { as } \mathrm{N})\end{array}$ & $\begin{array}{l}\text { Nitro- } \\
\text { gen, am- } \\
\text { monia + } \\
\text { organic, } \\
\text { total } \\
(\mathrm{mg} / \mathrm{L} \\
\text { as } \mathrm{N})\end{array}$ & $\begin{array}{l}\text { Nitro- } \\
\text { gen, } \\
\mathrm{NO}_{2}+ \\
\mathrm{NO}_{3} \text {, } \\
\text { total } \\
\text { (mg/L } \\
\text { as } \mathrm{N} \text { ) }\end{array}$ & $\begin{array}{l}\text { Nitro- } \\
\text { gen, } \\
\mathrm{NO}_{2}+ \\
\mathrm{NO}_{3} \text {, dis- } \\
\text { solved } \\
\text { (mg/L } \\
\text { as } \mathrm{N} \text { ) }\end{array}$ \\
\hline $092 \mathrm{G} .008 .1 .2 .2-01$ & $10-01-91$ & - & $<0.01$ & - & $<0.01$ & - & $<0.0$ & -- & 0.9 & 1.0 \\
\hline $092 \mathrm{G} .008 .1 .4 .2-15$ & $10-01-91$ & - & 0.56 & - & $<0.01$ & -- & 0.6 & - & - & $<0.05$ \\
\hline 092G.008.2.1.1-02 & $10-01-91$ & - & 0.55 & - & $<0.01$ & - & 0.6 & -- & - & $<0.05$ \\
\hline 092G.008.2.2.1-03 & $10-01-91$ & - & $<0.01$ & - & 0.37 & - & -. & - & 3.6 & 3.6 \\
\hline 092G.008.2.2.3-03 & $10-01-91$ & - & $<0.01$ & - & $<0.01$ & - & $<0.0$ & - & 4.2 & 4.2 \\
\hline 092G.008.2.3.3-14 & $10-01-91$ & -- & 0.07 & - & $<0.01$ & - & - & - & -- & $<0.05$ \\
\hline 092G.008.2.4.1-18 & $10-01-91$ & - & 0.01 & - & $<0.01$ & - & $<0.0$ & -- & 8.1 & 8.1 \\
\hline 092G.008.2.4.2-14 & $10-01-91$ & -- & $<0.01$ & -- & $<0.01$ & - & $<0.0$ & -- & 8.4 & 8.4 \\
\hline \multirow[t]{2}{*}{ 092G.009.1.1.1-06-20 } & $12-11-91$ & -- & -. & 0.01 & -- & 0.01 & -- & $<0.2$ & 20 & -- \\
\hline & $12-15-92$ & -- & - & $<0.01$ & -- & 0.01 & - & -- & 15 & - \\
\hline 092G.009.1.1.1-06-35 & $12-11-91$ & - & -. & $<0.01$ & - & $<0.01$ & - & $<0.2$ & 19 & - \\
\hline \multirow[t]{2}{*}{$092 \mathrm{G} .009 \cdot 1 \cdot 1.1-07-55$} & $12-11-91$ & - & -- & 0.02 & - & 0.01 & -- & $<0.2$ & 10 & - \\
\hline & $12-15-92$ & - & - & $<0.01$ & - & 0.01 & -- & -- & 11 & -- \\
\hline \multirow[t]{2}{*}{ 092G.009.1.1.1-07-75 } & $12-11-91$ & -- & -- & $<0.01$ & - & 0.24 & -- & $<0.2$ & 3.3 & -. \\
\hline & $12-15-92$ & - & - & $<0.01$ & - & 0.25 & -- & - & 3.9 & - \\
\hline \multirow[t]{2}{*}{$092 \mathrm{G} .009 .1 \cdot 1.2-11-25$} & $12-11-91$ & -- & - & 0.02 & - & $<0.01$ & -. & $<0.2$ & 6.9 & -- \\
\hline & $12-15-92$ & -- & -- & $<0.01$ & -- & 0.02 & -- & - & 9.6 & -- \\
\hline \multirow[t]{2}{*}{$092 \mathrm{G} .009 .1 \cdot 1.2-11-35$} & $12-11-91$ & -. & - & $<0.01$ & -- & $<0.01$ & -- & $<0.2$ & 13 & -- \\
\hline & $12-15-92$ & -- & - & $<0.01$ & -- & 0.02 & -. & - & 16 & - \\
\hline \multirow[t]{2}{*}{ 092G.009.1.1.2-12-55 } & $12-11-91$ & -- & - & $<0.01$ & -- & $<0.01$ & -. & $<0.2$ & 8.8 & - \\
\hline & $12-15-92$ & -- & - & $<0.01$ & -- & $<0.01$ & -. & -- & 7.2 & -- \\
\hline \multirow[t]{2}{*}{$092 \mathrm{G} .009 .1 .1 .2-12-75$} & $12-11-91$ & -- & -- & $<0.01$ & -- & 0.19 & -. & $<0.2$ & 3.8 & -- \\
\hline & $12-15-92$ & $-\cdot$ & $\cdots$ & $<0.01$ & -. & 0.26 & - & - & 3.5 & - \\
\hline 092G.009.1.1.4-17 & $09-30-91$ & - & $<0.01$ & -. & $<0.01$ & - & $<0.0$ & - & 16 & 16 \\
\hline 092G.009.1.1.4-18-25 & $12-10-91$ & -. & -. & $<0.01$ & - & $<0.01$ & - & $<0.2$ & 3.3 & -- \\
\hline 092G.009.1.1.4-18-35 & $12-10-91$ & -. & - & $<0.01$ & - & $<0.01$ & -. & $<0.2$ & 4.8 & - \\
\hline 092G.009.1.1.4-19-55 & $12-10-91$ & - & - & $<0.01$ & - & 0.66 & -. & $<0.2$ & 6.8 & -. \\
\hline 092G.009.1.1.4-19-75 & $12-10-91$ & -. & - & 0.01 & -- & 0.01 & - & $<0.2$ & 5.3 & - \\
\hline 092G.009.1.2.4-31 & $09-30-91$ & - & $<0.01$ & - & $<0.01$ & - & $<0.0$ & - & 9.9 & 9.9 \\
\hline 092G.009.1.3.4-26 & $09-30-91$ & - & $<0.01$ & - & $<0.01$ & - & $<0.0$ & - & 4.9 & 4.9 \\
\hline $092 \mathrm{G} \cdot 009 \cdot 2 \cdot 1 \cdot 2-19$ & $10-02-91$ & -- & $<0.01$ & -. & $<0.01$ & -. & $<0.0$ & -- & 9.1 & 9.1 \\
\hline $092 \mathrm{G} .009 .2 .1 .4-26$ & $10-02-91$ & -- & $<0.01$ & - & 0.09 & -- & $<0.0$ & - & 6.9 & 6.9 \\
\hline 092G.009.2.2.3-11 & $10-01-91$ & -- & 1.40 & - & $<0.01$ & - & 1.5 & - & 0.06 & 0.06 \\
\hline \multirow[t]{11}{*}{$39 \mathrm{~N} / 02 \mathrm{E}-01 \mathrm{P} 02$} & $08-29-90$ & -- & $<0.01$ & - & $<0.01$ & -- & 0.3 & - & 9.3 & 9.3 \\
\hline & $10-18-90$ & - & -. & 0.04 & -- & $<0.01$ & -- & -. & 14 & -. \\
\hline & $11-14-90$ & 0.56 & -. & 0.04 & - & $<0.01$ & - & 0.6 & 9.5 & -. \\
\hline & $12-18-90$ & -- & - & 0.02 & - & $<0.01$ & - & - & 6.1 & -- \\
\hline & 03-13-91 & 0.48 & - & 0.02 & - & $<0.01$ & - & 0.5 & 7.6 & - \\
\hline & $04-25-91$ & 0.30 & $\therefore$ & $<0.01$ & - & $<0.01$ & - & 0.3 & 6.5 & -- \\
\hline & $05-21-91$ & -- & -. & $<0.01$ & - & 0.01 & - & - & 5.4 & - \\
\hline & $06-26-91$ & 0.69 & -. & 0.01 & - & $<0.01$ & - & 0.7 & 9.9 & .. \\
\hline & $07-18-91$ & -- & -. & 0.03 & -. & 0.01 & - & - & 9.6 & $-\cdot$ \\
\hline & $08-23-91$ & 0.48 & - & 0.02 & - & $<0.01$ & - & 0.5 & 7.9 & -- \\
\hline & $09-25-91$ & -. & -. & 0.03 & -- & 0.01 & - & - & 7.9 & -- \\
\hline
\end{tabular}


Appendix Table 8. Concentrations of selected nitrogen species in ground water of the Lynden-Everson-NooksackSumas study area, Whatcom County, Wash., and British Columbia, Canada--Continued

\begin{tabular}{|c|c|c|c|c|c|c|c|c|c|c|}
\hline $\begin{array}{l}\text { Local } \\
\text { well number }\end{array}$ & Date & $\begin{array}{l}\text { Nitro- } \\
\text { gen, } \\
\text { organic, } \\
\text { total } \\
(\mathrm{mg} / \mathrm{L} \\
\text { as } \mathrm{N})\end{array}$ & $\begin{array}{l}\text { Nitro- } \\
\text { gen, } \\
\text { ammonia, } \\
\text { dis- } \\
\text { solved } \\
(\mathrm{mg} / \mathrm{L} \\
\text { as } \mathrm{N})\end{array}$ & $\begin{array}{l}\text { Nitro- } \\
\text { gen, } \\
\text { ammonia, } \\
\text { total } \\
(\mathrm{mg} / \mathrm{L} \\
\text { as } \mathrm{N})\end{array}$ & $\begin{array}{l}\text { Nitro- } \\
\text { gen, } \\
\text { nitrite, } \\
\text { dis- } \\
\text { solved } \\
(\mathrm{mg} / \mathrm{L} \\
\text { as } \mathrm{N})\end{array}$ & $\begin{array}{l}\text { Nitro- } \\
\text { gen, } \\
\text { nitrite, } \\
\text { total } \\
(\mathrm{mg} / \mathrm{L} \\
\text { as N) }\end{array}$ & $\begin{array}{l}\text { Nitro- } \\
\text { gen, am- } \\
\text { monia + } \\
\text { organic, } \\
\text { dissolved } \\
(\mathrm{mg} / \mathrm{L} \\
\text { as } \mathrm{N})\end{array}$ & $\begin{array}{l}\text { Nitro- } \\
\text { gen, am- } \\
\text { monia + } \\
\text { organic, } \\
\text { total } \\
\text { (mg/L } \\
\text { as } \mathrm{N} \text { ) }\end{array}$ & $\begin{array}{l}\text { Nitro- } \\
\text { gen, } \\
\mathrm{NO}_{2}+ \\
\mathrm{NO}_{3} \text {, } \\
\text { total } \\
(\mathrm{mg} / \mathrm{L} \\
\text { as } \mathrm{N})\end{array}$ & $\begin{array}{l}\text { Nitro- } \\
\text { gen, } \\
\mathrm{NO}_{2+}+ \\
\mathrm{NO}_{3} \text {, dis- } \\
\text { solved } \\
\text { (mg/L } \\
\text { as } \mathrm{N})\end{array}$ \\
\hline & $10-23-91$ & .. & -- & 0.03 &.- & 0.01 & -- & $<0.2$ & 8.4 & .. \\
\hline \multirow[t]{15}{*}{$39 \mathrm{~N} / 02 \mathrm{E}-10 \mathrm{~F} 01$} & $08-28-90$ & .. & 0.02 & -. & $<0.01$ & -- & 0.6 & -. & 4.9 & 4.9 \\
\hline & $10-16-90$ & .. & -- & 0.05 & -- & $<0.01$ & -- & -. & 3.7 & -. \\
\hline & $11-14-90$ & .. & .. & 0.04 & -- & $<0.01$ & -- & $<0.2$ & 1.6 & -. \\
\hline & $12-18-90$ & -. & .. & 0.02 & -. & $<0.01$ &.- & - & 8.6 & -. \\
\hline & $01-16-91$ & 0.80 & -- & $<0.01$ & - & $<0.01$ & -- & 0.8 & 15 & -- \\
\hline & $02-20-91$ & -- & -. & $<0.01$ & -. & $<0.01$ & -. & -. & 12 & -. \\
\hline & $03-13-91$ & 0.48 & -. & 0.02 & -- & $<0.01$ & -- & 0.5 & 9.8 & -- \\
\hline & $03-13-91$ & 0.38 & -. & 0.02 & -- & $<0.01$ & - & 0.4 & 9.9 & -. \\
\hline & $04-25-91$ & 0.59 & 0.02 & 0.01 & $<0.01$ & $<0.01$ & 0.5 & 0.6 & 8.2 & 8.2 \\
\hline & $05-21-91$ & -. & .. & $<0.01$ & -- & $<0.01$ & -- & - & 12 & -. \\
\hline & $06-26-91$ & 0.79 & -- & 0.01 & -. & $<0.01$ & -- & 0.8 & 11 & .- \\
\hline & $07-18-91$ & .. & .. & 0.04 & -- & $<0.01$ & -. & -- & 8.4 & -. \\
\hline & $08-23-91$ & 0.58 & -- & 0.02 & -- & $<0.01$ & -- & 0.6 & 6.3 & .. \\
\hline & $09-25-91$ & -. & -- & 0.03 & - & 0.01 & -. & - & 3.7 & -. \\
\hline & $10-23-91$ & -- & -- & 0.02 & - & $<0.01$ & - & $<0.2$ & 3.0 & -- \\
\hline $39 \mathrm{~N} / 02 \mathrm{E}-11 \mathrm{~B} 01$ & $04-23-91$ & -. & -- & 0.01 & -. & $<0.01$ & -. & $<0.2$ & 3.3 & -. \\
\hline $39 \mathrm{~N} / 02 \mathrm{E}-12 \mathrm{~K} 03$ & $08-29-90$ & -. & 0.07 & -- & $<0.01$ & -- & 0.6 & -- & 4.5 & 4.5 \\
\hline $39 \mathrm{~N} / 02 \mathrm{E}-13 \mathrm{~B} 01$ & $04-26-91$ & -. & 0.06 & -. & $<0.01$ & -. & 0.2 & -- & 0.13 & 0.13 \\
\hline $39 \mathrm{~N} / 02 \mathrm{E}-14 \mathrm{~L} 01$ & $04-25-91$ & -. & 0.04 & -- & 0.02 & -- & $<0.2$ & - & 0.63 & 0.63 \\
\hline \multirow[t]{2}{*}{$39 \mathrm{~N} / 02 \mathrm{E}-14 \mathrm{M} 01$} & $08-28-90$ & -. & $<0.01$ & -- & $<0.01$ & - & 0.5 & - & 3.7 & 3.7 \\
\hline & $08-28-90$ & -. & 0.01 & -. & $<0.01$ & -. & 0.2 & -- & 3.7 & 3.7 \\
\hline $39 \mathrm{~N} / 02 \mathrm{E}-16 \mathrm{H} 03$ & $04-25-91$ &.- & $<0.01$ & -- & $<0.01$ & -. & $<0.2$ & - & 0.83 & 0.83 \\
\hline $39 \mathrm{~N} / 02 \mathrm{E}-22 \mathrm{D} 02$ & $04-25-91$ & -. & 0.03 & -- & $<0.01$ & -. & $<0.2$ & -- & -. & $<0.05$ \\
\hline $39 \mathrm{~N} / 02 \mathrm{E}-24 \mathrm{C} 02$ & $04-26-91$ & -. & 0.02 & -. & $<0.01$ & -. & 0.3 & -. & 2.6 & 2.6 \\
\hline $39 \mathrm{~N} / 02 \mathrm{E}-24 \mathrm{R} 02$ & $04-24-91$ & -- & $<0.01$ & -. & $<0.01$ & -- & 0.6 & - & 5.2 & 5.2 \\
\hline $39 \mathrm{~N} / 02 \mathrm{E}-26 \mathrm{H} 01$ & $04-23-91$ & 0.59 & -. & 0.01 & -- & 0.01 & -. & 0.6 & 12 & -. \\
\hline \multirow[t]{15}{*}{$39 \mathrm{~N} / 02 \mathrm{E}-27 \mathrm{~F} 03$} & $08-28-90$ & -. & 0.03 & -. & $<0.01$ & -. & 0.4 & -- & 12 & 12 \\
\hline & $10-18-90$ & -. & -. & 0.04 & -. & $<0.01$ & -- & -- & 12 & -. \\
\hline & $11-14-90$ & 0.36 & -. & 0.04 & -. & $<0.01$ & -. & 0.4 & 12 & -. \\
\hline & $12-18-90$ & -- & -. & 0.02 & - & $<0.01$ & - & -- & 13 & -- \\
\hline & $01-16-91$ & 1.1 & -. & $<0.01$ & -. & $<0.01$ & -. & 1.1 & 13 & -. \\
\hline & $01-16-91$ & 1.0 & -- & $<0.01$ & -- & $<0.01$ & -- & 1.0 & 13 & -. \\
\hline & $02-20-91$ & -- & -. & $<0.01$ & -- & $<0.01$ & -. & -- & 13 & -- \\
\hline & $03-14-91$ & 0.47 & -. & 0.03 & -. & 0.03 & - & 0.5 & 14 & -. \\
\hline & $04-25-91$ & 0.68 & -. & 0.02 & -- & $<0.01$ & - & 0.7 & 14 & -. \\
\hline & $05-21-91$ & -- & -. & $<0.01$ & -- & $<0.01$ & .. & -. & 13 & -. \\
\hline & $06-26-91$ & 0.80 & -- & $<0.01$ & -. & $<0.01$ & - & 0.8 & 13 & -. \\
\hline & $07-17-91$ & -. & -. & 0.04 & -- & 0.01 & -- & -. & 12 & -. \\
\hline & $08-23-91$ & 0.89 & -- & 0.01 & -- & $<0.01$ & -. & 0.9 & 11 & -. \\
\hline & $09-25-91$ & -. & -. & 0.04 & -. & 0.02 & - & -. & 11 & -- \\
\hline & $10-23-91$ & -. & -. & 0.02 & -- & $<0.01$ & -- & $<0.2$ & 11 & -. \\
\hline $39 \mathrm{~N} / 02 \mathrm{E}-27 \mathrm{~F} 04$ & $04-24-91$ & -. & -- & 0.01 & -. & 0.01 & -. & $<0.2$ & 2.6 & -. \\
\hline 39 N/O2E-27J01 & $04-24-91$ & 0.39 & -. & 0.01 & -. & $<0.01$ & - & 0.4 & 14 & - \\
\hline 39N/02E-27Q04 & $07-10-91$ & - & $<0.01$ & -- & $<0.01$ & -. & 0.6 & - & 5.8 & 5.8 \\
\hline
\end{tabular}


Appendix Table 8. Concentrations of selected nitrogen species in ground water of the Lynden-Everson-NooksackSumas study area, Whatcom County, Wash., and British Columbia, Canada--Continued

\begin{tabular}{|c|c|c|c|c|c|c|c|c|c|c|}
\hline $\begin{array}{l}\text { Local } \\
\text { well number }\end{array}$ & Date & $\begin{array}{l}\text { Nitro- } \\
\text { gen, } \\
\text { organic, } \\
\text { total } \\
\text { (mg/L } \\
\text { as } \mathrm{N})\end{array}$ & $\begin{array}{l}\text { Nitro- } \\
\text { gen, } \\
\text { ammonia, } \\
\text { dis- } \\
\text { solved } \\
\text { (mg/L } \\
\text { as } \mathrm{N})\end{array}$ & $\begin{array}{l}\text { Nitro- } \\
\text { gen, } \\
\text { ammonia, } \\
\text { total } \\
(\mathrm{mg} / \mathrm{L} \\
\text { as } \mathrm{N})\end{array}$ & $\begin{array}{l}\text { Nitro- } \\
\text { gen, } \\
\text { nitrite, } \\
\text { dis- } \\
\text { solved } \\
\text { (mg/L } \\
\text { as } \mathrm{N})\end{array}$ & $\begin{array}{l}\text { Nitro- } \\
\text { gen, } \\
\text { nitrite, } \\
\text { total } \\
(\mathrm{mg} / \mathrm{L} \\
\text { as N) }\end{array}$ & $\begin{array}{l}\text { Nitro- } \\
\text { gen, am- } \\
\text { monia + } \\
\text { organic, } \\
\text { dissolved } \\
(\mathrm{mg} / \mathrm{L} \\
\text { as } \mathrm{N})\end{array}$ & $\begin{array}{l}\text { Nitro- } \\
\text { gen, am- } \\
\text { monia + } \\
\text { organic, } \\
\text { total } \\
(\mathrm{mg} / \mathrm{L} \\
\text { as } \mathrm{N})\end{array}$ & $\begin{array}{l}\text { Nitro- } \\
\text { gen, } \\
\mathrm{NO}_{2}+ \\
\mathrm{NO}_{3} \text {, } \\
\text { total } \\
\text { (mg/L } \\
\text { as } \mathrm{N} \text { ) }\end{array}$ & $\begin{array}{l}\text { Nitro- } \\
\text { gen, } \\
\mathrm{NO}_{2}+ \\
\mathrm{NO}_{3} \text {, dis- } \\
\text { solved } \\
(\mathrm{mg} / \mathrm{L} \\
\text { as } \mathrm{N})\end{array}$ \\
\hline $39 \mathrm{~N} / 02 \mathrm{E}-28 \mathrm{~J} 03$ & $04-25-91$ & -. & $<0.01$ & -- & $<0.01$ & -- & $<0.2$ & - & 1.4 & 1.4 \\
\hline \multirow[t]{13}{*}{$39 \mathrm{~N} / 03 \mathrm{E}-01 \mathrm{C} 01$} & $10-18-90$ & -- & -- & 0.05 & - & $<0.01$ & -- & -- & 0.40 & -- \\
\hline & $11-15-90$ & - & -- & 0.05 & -- & $<0.01$ & - & $<0.2$ & 0.30 & - \\
\hline & $12-17-90$ & - & -- & 0.04 & -. & $<0.01$ &.- & - & 0.30 & -- \\
\hline & $02-20-91$ & - & -. & 0.01 & -- & $<0.01$ & -- & - & 0.30 & -. \\
\hline & 03-13-91 & -. & - & 0.04 & - & $<0.01$ & - & $<0.2$ & 0.29 & - \\
\hline & $04-22-91$ & -. & -. & 0.01 & -- & $<0.01$ & - & $<0.2$ & 0.37 & -- \\
\hline & $05-22-91$ & -- & -- & 0.01 & -- & $<0.01$ & - & -- & 0.31 & -. \\
\hline & $06-25-91$ & - & -- & 0.02 & -- & $<0.01$ & - & $<0.2$ & 0.28 & -. \\
\hline & $07-17-91$ & -- & - & 0.05 & -- & $<0.01$ & -- & -- & 0.26 & -- \\
\hline & $08-22-91$ & 0.28 & -- & 0.02 & - & $<0.01$ & - & 0.3 & 0.28 & -- \\
\hline & $09-26-91$ & -- & - & 0.03 & -- & $<0.01$ & -- & -. & 0.27 & -. \\
\hline & $10-23-91$ & -- & -. & 0.04 & -. & 0.01 & -- & $<0.2$ & 0.33 & - \\
\hline & $12-12-91$ & -- & - & 0.02 & -. & $<0.01$ & - & $<0.2$ & 0.30 &.- \\
\hline $39 \mathrm{~N} / 03 \mathrm{E}-02 \mathrm{~B} 02$ & $08-28-90$ & -- & 0.05 & -. & $<0.01$ & -- & 0.3 & -- & 0.20 & 0.20 \\
\hline $39 \mathrm{~N} / 03 \mathrm{E}-05 \mathrm{~L} 02$ & $04-23-91$ & 0.20 & -- & $<0.01$ & -- & 0.01 & -- & 0.2 & 4.6 & -- \\
\hline $39 \mathrm{~N} / 03 \mathrm{E}-07 \mathrm{~K} 02$ & $04-26-91$ & -- & $<0.01$ & -. & $<0.01$ & -- & 0.9 & -- & 19 & 19 \\
\hline $39 \mathrm{~N} / 03 \mathrm{E}-08 \mathrm{CO} 2$ & $08-30-90$ & .. & $<0.01$ & -. & $<0.01$ & - & 1.6 & -- & -- & $<0.10$ \\
\hline \multirow[t]{12}{*}{$39 \mathrm{~N} / 03 \mathrm{E}-10 \mathrm{~L} 01$} & $10-16-90$ & -- & - & 0.35 & - & 0.01 & -- & - & 0.30 & - \\
\hline & $11-15-90$ & 0.32 & -- & 0.38 & -- & 0.02 & - & 0.7 & 0.70 & -- \\
\hline & $11-16-90$ & 0.34 & -- & 0.36 & - & 0.02 & - & 0.7 & 0.70 & - \\
\hline & $12-17-90$ & -. & -- & 0.16 & -. & $<0.01$ & - & - & 2.6 & - \\
\hline & $02-21-91$ & -. & -- & 0.15 & -- & $<0.01$ & -- & - & 2.8 & - \\
\hline & $04-29-91$ & 0.31 & - & 0.19 & - & $<0.01$ & -- & 0.5 & 2.5 & - \\
\hline & $05-22-91$ & -- & - & 0.22 & -- & 0.01 & -. & -. & 1.9 & -- \\
\hline & $06-25-91$ & 0.27 & - & 0.33 & - & $<0.01$ & - & 0.6 & 0.97 & - \\
\hline & $07-17-91$ & -- & -- & 0.32 & - & 0.02 & - & - & 1.4 & - \\
\hline & $08-23-91$ & 0.30 & - & 0.30 & -. & $<0.01$ & -. & 0.6 & 1.8 & - \\
\hline & $09-26-91$ & -- & -- & 0.35 & -- & 0.01 & -. & - & 0.34 & -- \\
\hline & $10-23-91$ & 0.13 & - & 0.37 & - & 0.02 & -- & 0.5 & 0.14 & - \\
\hline 39N/03E-11M01 & $08-21-91$ & - & 0.02 & - & $<0.01$ & -- & 0.7 & - & - & $<0.05$ \\
\hline $39 \mathrm{~N} / 03 \mathrm{E}-13 \mathrm{E} 01$ & $04-23-91$ & 0.37 & - & 0.13 & -- & 0.01 & - & 0.5 & $<0.05$ & -. \\
\hline $39 \mathrm{~N} / 03 \mathrm{E}-15 \mathrm{C} 02$ & $08-20-91$ & -- & $<0.01$ & - & $<0.01$ & -- & $<0.2$ & -- & - & $<0.05$ \\
\hline $39 \mathrm{~N} / 03 \mathrm{E}-16 \mathrm{~F} 02$ & $04-30-91$ & -- & 0.01 & - & 0.01 & -. & $<0.2$ & -- & 1.2 & 1.2 \\
\hline $39 \mathrm{~N} / 03 \mathrm{E}-17 \mathrm{R} 03$ & $04-23-91$ & -- & - & $<0.01$ & - & $<0.01$ & -- & $<0.2$ & 1.4 & - \\
\hline \multirow[t]{10}{*}{$39 \mathrm{~N} / 03 \mathrm{E}-19 \mathrm{~N} 01$} & $10-16-90$ & - & - & 0.04 & -. & $<0.01$ & - & - & 1.4 & - \\
\hline & $11-16-90$ & -. & - & 0.04 & -. & $<0.01$ & - & $<0.2$ & 1.4 & -. \\
\hline & 01-19-91 & -. & - & $<0.01$ & -- & $<0.01$ & - & $<0.2$ & 1.3 & - \\
\hline & $02-20-91$ & - & -. & $<0.01$ & -. & $<0.01$ & - & - & 1.3 & -- \\
\hline & $03-13-91$ & -- & -. & 0.02 & -. & 0.01 & -. & $<0.2$ & 1.3 & -- \\
\hline & $04-23-91$ & -. & -- & 0.01 & - & $<0.01$ & -- & $<0.2$ & $<0.05$ & - \\
\hline & $05-21-91$ & -. & -. & $<0.01$ & -. & $<0.01$ & -. & -- & 1.1 & -- \\
\hline & $08-23-91$ & -. & - & 0.01 & - & $<0.01$ & -. & $<0.2$ & 1.1 & - \\
\hline & $09-26-91$ & - & -. & 0.01 & -- & $<0.01$ & - & - & 1.1 & - \\
\hline & $10-23-91$ & -. & - & 0.03 & -- & 0.01 & - & $<0.2$ & 1.3 & - \\
\hline
\end{tabular}


Appendix Table 8. Concentrations of selected nitrogen species in ground water of the Lynden-Everson-NooksackSumas study area, Whatcom County, Wash., and British Columbia, Canada--Continued

\begin{tabular}{|c|c|c|c|c|c|c|c|c|c|c|}
\hline $\begin{array}{l}\text { Local } \\
\text { well number }\end{array}$ & Date & $\begin{array}{l}\text { Nitro- } \\
\text { gen, } \\
\text { organic, } \\
\text { total } \\
(\mathrm{mg} / \mathrm{L} \\
\text { as } \mathrm{N})\end{array}$ & $\begin{array}{l}\text { Nitro- } \\
\text { gen, } \\
\text { ammonia, } \\
\text { dis- } \\
\text { solved } \\
\text { (mg/L } \\
\text { as } \mathrm{N})\end{array}$ & $\begin{array}{l}\text { Nitro- } \\
\text { gen, } \\
\text { ammonia, } \\
\text { total } \\
\text { (mg/L } \\
\text { as } \mathrm{N} \text { ) }\end{array}$ & $\begin{array}{l}\text { Nitro- } \\
\text { gen, } \\
\text { nitrite, } \\
\text { dis- } \\
\text { solved } \\
(\mathrm{mg} / \mathrm{L} \\
\text { as } \mathrm{N})\end{array}$ & $\begin{array}{l}\text { Nitro- } \\
\text { gen, } \\
\text { nitrite, } \\
\text { total } \\
(\mathrm{mg} / \mathrm{L} \\
\text { as N) }\end{array}$ & $\begin{array}{l}\text { Nitro- } \\
\text { gen, am- } \\
\text { monia + } \\
\text { organic, } \\
\text { dissolved } \\
(\mathrm{mg} / \mathrm{L} \\
\text { as } \mathrm{N})\end{array}$ & $\begin{array}{l}\text { Nitro- } \\
\text { gen, am- } \\
\text { monia + } \\
\text { organic, } \\
\text { total } \\
(\mathrm{mg} / \mathrm{L} \\
\text { as } \mathrm{N})\end{array}$ & $\begin{array}{l}\text { Nitro- } \\
\text { gen, } \\
\mathrm{NO}_{2+}+ \\
\mathrm{NO}_{3} \text {, } \\
\text { total } \\
\text { (mg/L } \\
\text { as } \mathrm{N} \text { ) }\end{array}$ & $\begin{array}{l}\text { Nitro- } \\
\text { gen, } \\
\mathrm{NO}_{2+} \\
\mathrm{NO}_{3} \text {, dis- } \\
\text { solved } \\
\text { (mg/L } \\
\text { as } \mathrm{N} \text { ) }\end{array}$ \\
\hline & $12-12-91$ & -. & - & $<0.01$ & - & 0.01 & -- & $<0.2$ & 1.4 & - \\
\hline $39 \mathrm{~N} / 03 \mathrm{E}-20 \mathrm{~F} 02$ & $08-20-91$ & .. & $<0.01$ & - & $<0.01$ & -- & $<0.2$ & -- & 2.7 & 2.7 \\
\hline $39 \mathrm{~N} / 03 \mathrm{E}-21 \mathrm{~K} 01$ & $04-24-91$ & -- & 0.02 & - & $<0.01$ & -- & $<0.2$ & -- & -- & $<0.05$ \\
\hline $39 \mathrm{~N} / 03 \mathrm{E}-23 \mathrm{~J} 01$ & $04-26-91$ & -. & 0.80 & - & $<0.01$ & -- & 1.0 & -- & 0.16 & 0.16 \\
\hline $39 \mathrm{~N} / 03 \mathrm{E}-24 \mathrm{~B} 01$ & $04-26-91$ & - & $<0.01$ & -- & $<0.01$ & -- & $<0.2$ & -- & 0.38 & 0.38 \\
\hline $39 \mathrm{~N} / 03 \mathrm{E}-26 \mathrm{D} 01$ & $04-23-91$ & - & - & 0.28 & - & 0.01 & - & $<0.2$ & $<0.05$ & -- \\
\hline 39N/03E-26J01 & $04-25-91$ & -- & 2.0 & -. & $<0.01$ & -- & 2.4 & - & -. & $<0.05$ \\
\hline \multirow[t]{11}{*}{$39 \mathrm{~N} / 03 \mathrm{E}-26 \mathrm{P} 02$} & $10-18-90$ & -. & - & 0.81 & - & $<0.01$ & -- & -. & $<0.10$ & -- \\
\hline & $11-16-90$ & 0.30 & -. & 0.80 & -- & $<0.01$ & -- & 1.1 & $<0.10$ & -. \\
\hline & $12-18-90$ & - &.- & 0.79 & - & $<0.01$ & -. & -- & $<0.10$ & - \\
\hline & $03-13-91$ & 0.17 & -- & 0.73 & -- & 0.02 & -- & 0.9 & $<0.05$ & - \\
\hline & $04-22-91$ & 0.03 & -- & 0.77 & -. & 0.02 & -. & 0.8 & $<0.05$ & -. \\
\hline & $05-22-91$ & -. &.- & 0.73 & -- & $<0.01$ & -- & - & $<0.05$ & -. \\
\hline & $06-26-91$ & 0.29 & -. & 0.71 & -. & $<0.01$ & - & 1.0 & $<0.05$ & -. \\
\hline & $07-17-91$ & - & -- & 0.74 & -- & $<0.01$ & -- &.- & $<0.05$ & - \\
\hline & $08-23-91$ & 0.19 & -- & 0.71 & -- & $<0.01$ & - & 0.9 & $<0.05$ & -- \\
\hline & $09-26-91$ & -. & -- & 0.75 & -- & $<0.01$ & -- & -. & $<0.05$ & -. \\
\hline & $10-23-91$ & 0.11 & -- & 0.79 & -- & 0.01 & -- & 0.9 & $<0.05$ & - \\
\hline 39N/03E-28R01 & $08-20-91$ & -- & 0.96 & -- & $<0.01$ & -- & 1.3 & -. & -. & $<0.05$ \\
\hline $39 \mathrm{~N} / 03 \mathrm{E}-29 \mathrm{C} 01$ & $04-25-91$ & - & $<0.01$ & - & 0.01 & -- & $<0.2$ & - & -. & $<0.05$ \\
\hline 39N/03E-31R02 & $04-26-91$ & -- & 0.62 & - & $<0.01$ & - & 0.8 & -. & 0.17 & 0.17 \\
\hline $39 \mathrm{~N} / 03 \mathrm{E}-32 \mathrm{~J} 01$ & $04-25-91$ & - & 0.23 & -- & $<0.01$ & -- & 0.4 & -. & -. & $<0.05$ \\
\hline 39N/03E-33R01 & $04-24-91$ & 0.70 & -- & 0.20 & -- & $<0.01$ & -- & 0.9 & $<0.05$ & -- \\
\hline $39 \mathrm{~N} / 03 \mathrm{E}-34 \mathrm{~N} 01$ & $04-25-91$ & - & 0.02 & - & $<0.01$ & -- & 0.2 & - & -. & $<0.05$ \\
\hline $39 \mathrm{~N} / 03 \mathrm{E}-35 \mathrm{~L} 01$ & $04-24-91$ & 0.09 &.- & 0.41 & -- & 0.01 & $-\cdot$ & 0.5 & $<0.05$ & -- \\
\hline $39 \mathrm{~N} / 03 \mathrm{E}-36 \mathrm{P} 01$ & $04-24-91$ & 0.11 & - & 0.29 & -- & 0.01 & -- & 0.4 & $<0.05$ & -- \\
\hline \multirow[t]{12}{*}{ 39N/04E-03P01 } & $10-16-90$ & -. & -. & 0.23 & -- & $<0.01$ & -. & -. & $<0.10$ & -. \\
\hline & $01-17-91$ & -- & -- & 0.19 & -- & $<0.01$ & -. & $<0.2$ & $<0.10$ & -- \\
\hline & $02-19-91$ & -- & -- & 0.20 & -- & $<0.01$ & -. & -- & $<0.10$ & - \\
\hline & $02-19-91$ & -- & -. & 0.20 & -. & 0.01 & -- & -. & $<0.10$ & -- \\
\hline & $04-24-91$ & 0.99 & -- & 0.21 & - & 0.01 & -- & 1.2 & $<0.05$ & -- \\
\hline & $05-22-91$ & -. & -. & 0.19 & -. & $<0.01$ & -. & -- & $<0.05$ & -. \\
\hline & $06-25-91$ & 0.10 & -. & 0.20 & - & $<0.01$ & -. & 0.3 & $<0.05$ & - \\
\hline & $07-17-91$ & - & -- & 0.23 & -- & 0.01 & -- & - & $<0.05$ & - \\
\hline & $08-22-91$ & -- & -. & 0.02 & -- & $<0.01$ & -. & $<0.2$ & $<0.05$ & - \\
\hline & $09-25-91$ & -- & -. & 0.21 & -- & $<0.01$ & -- & - & $<0.05$ & - \\
\hline & $10-23-91$ & - & -. & 0.03 & - & $<0.01$ & -- & $<0.2$ & 0.15 & -- \\
\hline & $12-13-91$ & - & - & 0.02 & -- & $<0.01$ & -- & - & $<0.05$ & -- \\
\hline 39N/04E-10M01 & $04-27-91$ & - & 0.25 & -- & $<0.01$ & -. & 0.4 & -- & -. & $<0.05$ \\
\hline $39 \mathrm{~N} / 04 \mathrm{E}-16 \mathrm{~F} 01$ & $04-25-91$ & $-\cdot$ & $<0.01$ & -- & $<0.01$ & -- & $<0.2$ & - & 1.5 & 1.5 \\
\hline $39 \mathrm{~N} / 04 \mathrm{E}-16 \mathrm{H} 01$ & $04-25-91$ & - & $<0.01$ & -. & $<0.01$ & - & 0.4 & - & 5.0 & 5.0 \\
\hline 39N/04E-16Q02 & $04-24-91$ & -. & $<0.01$ & -. & $<0.01$ & -- & 0.3 & -. & 3.6 & 3.6 \\
\hline $39 \mathrm{~N} / 04 \mathrm{E}-18 \mathrm{M} 01$ & $04-23-91$ & -- & -- & 0.14 & -- & $<0.01$ & - & $<0.2$ & $<0.05$ & -- \\
\hline 39N/04E-19M01 & $04-25-91$ & -- & 0.33 & -- & $<0.01$ & -- & 0.4 & - & -- & $<0.05$ \\
\hline $39 \mathrm{~N} / 04 \mathrm{E}-20 \mathrm{H} 01$ & $04-24-91$ & -- & - & $<0.01$ & -- & $<0.01$ & -- & $<0.2$ & 0.70 & -- \\
\hline
\end{tabular}


Appendix Table 8. Concentrations of selected nitrogen species in ground water of the Lynden-Everson-NooksackSumas study area, Whatcom County, Wash., and British Columbia, Canada--Continued

\begin{tabular}{|c|c|c|c|c|c|c|c|c|c|c|}
\hline $\begin{array}{l}\text { Local } \\
\text { well number }\end{array}$ & Date & $\begin{array}{l}\text { Nitro- } \\
\text { gen, } \\
\text { organic, } \\
\text { total } \\
(\mathrm{mg} / \mathrm{L} \\
\text { as } \mathrm{N})\end{array}$ & $\begin{array}{l}\text { Nitro- } \\
\text { gen, } \\
\text { ammonia, } \\
\text { dis- } \\
\text { solved } \\
(\mathrm{mg} / \mathrm{L} \\
\text { as } \mathrm{N})\end{array}$ & $\begin{array}{l}\text { Nitro- } \\
\text { gen, } \\
\text { ammonia, } \\
\text { total } \\
(\mathrm{mg} / \mathrm{L} \\
\text { as } \mathrm{N})\end{array}$ & $\begin{array}{l}\text { Nitro- } \\
\text { gen, } \\
\text { nitrite, } \\
\text { dis- } \\
\text { solved } \\
\text { (mg/L } \\
\text { as N) }\end{array}$ & $\begin{array}{l}\text { Nitro- } \\
\text { gen, } \\
\text { nitrite, } \\
\text { total } \\
(\mathrm{mg} / \mathrm{L} \\
\text { as } \mathrm{N})\end{array}$ & $\begin{array}{l}\text { Nitro- } \\
\text { gen, am- } \\
\text { monia + } \\
\text { organic, } \\
\text { dissolved } \\
(\mathrm{mg} / \mathrm{L} \\
\text { as } \mathrm{N})\end{array}$ & $\begin{array}{l}\text { Nitro- } \\
\text { gen, am- } \\
\text { monia + } \\
\text { organic, } \\
\text { total } \\
(\mathrm{mg} / \mathrm{L} \\
\text { as } \mathrm{N})\end{array}$ & $\begin{array}{l}\text { Nitro- } \\
\text { gen, } \\
\mathrm{NO}_{2}+ \\
\mathrm{NO}_{3} \text {, } \\
\text { total } \\
\text { (mg/L } \\
\text { as } \mathrm{N})\end{array}$ & $\begin{array}{l}\text { Nitro- } \\
\text { gen, } \\
\mathrm{NO}_{2+} \\
\mathrm{NO}_{3} \text {, dis- } \\
\text { solved } \\
\text { (mg/L } \\
\text { as } \mathrm{N} \text { ) }\end{array}$ \\
\hline $39 \mathrm{~N} / 04 \mathrm{E}-22 \mathrm{~L} 01$ & $04-23-91$ & 0.50 & -- & $<0.01$ & -- & 0.03 & -- & 0.5 & 15 & - \\
\hline $39 \mathrm{~N} / 04 \mathrm{E}-28 \mathrm{~F} 01$ & $04-26-91$ & -- & $<0.01$ & -- & $<0.01$ & - & 0.2 & - & 1.2 & 1.2 \\
\hline $39 \mathrm{~N} / 04 \mathrm{E}-30 \mathrm{D} 01$ & $04-26-91$ & -- & 0.45 & -- & $<0.01$ & - & 0.9 & - & -- & - \\
\hline $39 \mathrm{~N} / 04 \mathrm{E}-32 \mathrm{~A} 01$ & $04-26-91$ & -- & 0.40 & -- & $<0.01$ & -- & 0.6 & -- & -- & $<0.05$ \\
\hline $39 \mathrm{~N} / 04 \mathrm{E}-32 \mathrm{~N} 01$ & $04-24-91$ & 0.15 & -- & 0.35 & -- & 0.01 & -- & 0.5 & $<0.05$ & -- \\
\hline $39 \mathrm{~N} / 04 \mathrm{E}-33 \mathrm{E} 01$ & $04-26-91$ & -- & 0.28 & -- & $<0.01$ & - & 0.5 & -- & - & $<0.05$ \\
\hline $40 \mathrm{~N} / 02 \mathrm{E}-02 \mathrm{D} 01$ & $08-21-91$ & - & 0.05 & -- & $<0.01$ & -- & 0.4 & -. & - & $<0.05$ \\
\hline \multirow[t]{12}{*}{$40 \mathrm{~N} / 02 \mathrm{E}-03 \mathrm{C} 01$} & $11-16-90$ & 0.08 & -- & 0.32 & -- & $<0.01$ & - & 0.4 & $<0.10$ & - \\
\hline & $02-21-91$ & -- & -- & 0.30 & - & $<0.01$ & -- & -- & $<0.10$ & -- \\
\hline & $03-14-91$ & 0.08 & - & 0.32 & -- & $<0.01$ & -- & 0.4 & 0.05 & -- \\
\hline & $03-14-91$ & 0.08 & - & 0.32 & - & $<0.01$ & - & 0.4 & $<0.05$ & - \\
\hline & $04-30-91$ & -- & 0.30 & - & $<0.01$ & -- & 0.3 & - & -- & $<0.05$ \\
\hline & $05-21-91$ & -- & -. & 0.31 & -- & 0.01 & -- & - & $<0.05$ & -- \\
\hline & $06-25-91$ & 0.15 & -- & 0.25 & - & $<0.01$ & -- & 0.4 & $<0.05$ & -- \\
\hline & $07-17-91$ & -- & -- & 0.32 & -- & 0.01 & -- & - & $<0.05$ & -- \\
\hline & $08-22-91$ & 0.14 & - & 0.26 & -. & $<0.01$ & - & 0.4 & $<0.05$ & -- \\
\hline & $09-25-91$ & -. & -- & 0.31 & -- & $<0.01$ & - & - & $<0.05$ & -- \\
\hline & $10-24-91$ & 0.05 & -- & 0.35 & -- & $<0.01$ & - & 0.4 & 0.14 & - \\
\hline & $12-12-91$ & 0.0 & -- & 0.30 & -- & 0.01 & -- & 0.3 & $<0.05$ & -- \\
\hline $40 \mathrm{~N} / 02 \mathrm{E}-04 \mathrm{~A} 02$ & $04-26-91$ & -- & 0.14 & -- & $<0.01$ & -- & 0.4 & -- & -- & $<0.05$ \\
\hline $40 \mathrm{~N} / 02 \mathrm{E}-10 \mathrm{~N} 02$ & $08-21-91$ & 0.30 & 2.2 & 2.1 & 0.01 & $<0.01$ & 2.7 & 2.4 & 1.4 & 1.4 \\
\hline $40 \mathrm{~N} / 02 \mathrm{E}-12 \mathrm{C} 01$ & $08-22-91$ & - & 0.24 & -- & $<0.01$ & -- & 0.5 & - & -- & $<0.05$ \\
\hline $40 \mathrm{~N} / 02 \mathrm{E}-13 \mathrm{~J} 04$ & $07-19-91$ & -- & 0.22 & -- & $<0.01$ & - & 0.3 & -- & - & $<0.05$ \\
\hline $40 \mathrm{~N} / 02 \mathrm{E}-13 \mathrm{~J} 05$ & $08-13-91$ & 4.0 & -- & 46 & -- & $<0.01$ & -- & 50 & $<0.05$ & -- \\
\hline $40 \mathrm{~N} / 02 \mathrm{E}-13 \mathrm{~J} 07$ & $07-19-91$ & -- & 63 & - & 0.02 & -- & 63 & -- & -- & $<0.05$ \\
\hline \multirow[t]{2}{*}{$40 \mathrm{~N} / 02 \mathrm{E}-14 \mathrm{P} 02$} & $04-30-91$ & - & $<0.01$ & - & $<0.01$ & - & 1.4 & - & 16 & 16 \\
\hline & $08-20-91$ & -- & - & $<0.01$ & - & $<0.01$ & - & -- & 13 & -- \\
\hline $40 \mathrm{~N} / 02 \mathrm{E}-15 \mathrm{~A} 02$ & $08-21-91$ & -- & -- & 0.03 & - & 0.02 & - & - & 3.2 & - \\
\hline $40 \mathrm{~N} / 02 \mathrm{E}-15 \mathrm{C} 01$ & $09-05-91$ & -- & - & 0.04 & - & $<0.01$ & - & -- & 0.12 & - \\
\hline $40 \mathrm{~N} / 02 \mathrm{E}-15 \mathrm{H} 02$ & $08-21-91$ & - & - & $<0.01$ & - & $<0.01$ & - & -- & 3.2 & - \\
\hline $40 \mathrm{~N} / 02 \mathrm{E}-15 \mathrm{H} 03$ & $09-05-91$ & - & - & 0.12 & - & $<0.01$ & - & - & 0.07 & - \\
\hline $40 \mathrm{~N} / 02 \mathrm{E}-15 \mathrm{~J} 01$ & $04-29-91$ & - & 0.28 & - & $<0.01$ & -- & 0.5 & -- & 0.21 & 0.21 \\
\hline $40 \mathrm{~N} / 02 \mathrm{E}-15 \mathrm{P} 01$ & $08-21-91$ & -- & 0.02 & - & $<0.01$ & -- & 0.2 & - & 1.4 & 1.4 \\
\hline $40 \mathrm{~N} / 02 \mathrm{E}-15 \mathrm{R} 03$ & $08-21-91$ & - & -- & $<0.01$ & -- & $<0.01$ & -- & -- & 8.2 & - \\
\hline $40 \mathrm{~N} / 02 \mathrm{E}-16 \mathrm{~B} 02$ & $04-27-91$ & - & $<0.01$ & - & $<0.01$ & -- & 0.6 & -- & 6.4 & 6.4 \\
\hline $40 \mathrm{~N} / 02 \mathrm{E}-21 \mathrm{D} 01$ & $08-20-91$ & - & -- & 0.04 & -. & $<0.01$ & -- & - & 0.59 & - \\
\hline $40 \mathrm{~N} / 02 \mathrm{E}-21 \mathrm{~J} 05$ & $08-21-91$ & -. & -- & $<0.01$ & - & $<0.01$ & - & -. & 4.8 & - \\
\hline $40 \mathrm{~N} / 02 \mathrm{E}-21 \mathrm{~N} 02$ & $08-22-91$ & - & -- & 0.04 & -- & 0.02 & - & -- & 8.2 & - \\
\hline 40N/02E-21R01 & $04-30-91$ & -- & $<0.01$ & -- & $<0.01$ & - & 0.8 & - & 20 & 20 \\
\hline $40 \mathrm{~N} / 02 \mathrm{E}-21 \mathrm{R} 03$ & $08-23-91$ & - & - & $<0.01$ & -- & $<0.01$ & - & - & 22 & -- \\
\hline $40 \mathrm{~N} / 02 \mathrm{E}-22 \mathrm{E} 02$ & $08-21-91$ & -- & -. & $<0.01$ & -- & $<0.01$ & - & - & 4.8 & - \\
\hline $40 \mathrm{~N} / 02 \mathrm{E}-22 \mathrm{~N} 02$ & $08-22-91$ & -. & - & $<0.01$ & -- & $<0.01$ & - & - & 13 & - \\
\hline $40 \mathrm{~N} / 02 \mathrm{E}-22 \mathrm{~N} 07$ & $08-22-91$ & -. & -. & $<0.01$ & -- & $<0.01$ & - & -- & 5.0 & - \\
\hline $40 \mathrm{~N} / 02 \mathrm{E}-22 \mathrm{R} 02$ & $04-29-91$ & - & $<0.01$ & -- & $<0.01$ & -- & $<0.2$ & - & 2.8 & 2.8 \\
\hline $40 \mathrm{~N} / 02 \mathrm{E}-23 \mathrm{~A} 03$ & $08-20-91$ & -- & - & $<0.01$ & -- & $<0.01$ & - & - & 6.7 & -- \\
\hline
\end{tabular}


Appendix Table 8. Concentrations of selected nitrogen species in ground water of the Lynden-Everson-NooksackSumas study area, Whatcom County, Wash., and British Columbia, Canada--Continued

\begin{tabular}{|c|c|c|c|c|c|c|c|c|c|c|}
\hline $\begin{array}{l}\text { Local } \\
\text { well number }\end{array}$ & Date & $\begin{array}{l}\text { Nitro- } \\
\text { gen, } \\
\text { organic, } \\
\text { total } \\
(\mathrm{mg} / \mathrm{L} \\
\text { as } \mathrm{N})\end{array}$ & $\begin{array}{l}\text { Nitro- } \\
\text { gen, } \\
\text { ammonia, } \\
\text { dis- } \\
\text { solved } \\
\text { (mg/L } \\
\text { as } \mathrm{N})\end{array}$ & $\begin{array}{l}\text { Nitro- } \\
\text { gen, } \\
\text { ammonia, } \\
\text { total } \\
(\mathrm{mg} / \mathrm{L} \\
\text { as } \mathrm{N})\end{array}$ & $\begin{array}{l}\text { Nitro- } \\
\text { gen, } \\
\text { nitrite, } \\
\text { dis- } \\
\text { solved } \\
(\mathrm{mg} / \mathrm{L} \\
\text { as N) }\end{array}$ & $\begin{array}{l}\text { Nitro- } \\
\text { gen, } \\
\text { nitrite, } \\
\text { total } \\
\text { (mg/L } \\
\text { as N) }\end{array}$ & $\begin{array}{l}\text { Nitro- } \\
\text { gen, am- } \\
\text { monia + } \\
\text { organic, } \\
\text { dissolved } \\
(\mathrm{mg} / \mathrm{L} \\
\text { as } \mathrm{N})\end{array}$ & $\begin{array}{l}\text { Nitro- } \\
\text { gen, am- } \\
\text { monia + } \\
\text { organic, } \\
\text { total } \\
(\mathrm{mg} / \mathrm{L} \\
\text { as } \mathrm{N})\end{array}$ & $\begin{array}{l}\text { Nitro- } \\
\text { gen, } \\
\mathrm{NO}_{2}+ \\
\mathrm{NO}_{3} \text {, } \\
\text { total } \\
(\mathrm{mg} / \mathrm{L} \\
\text { as } \mathrm{N})\end{array}$ & $\begin{array}{l}\text { Nitro- } \\
\text { gen, } \\
\mathrm{NO}_{2+}+ \\
\mathrm{NO}_{3} \text {, dis- } \\
\text { solved } \\
\text { (mg/L } \\
\text { as } \mathrm{N} \text { ) }\end{array}$ \\
\hline $40 \mathrm{~N} / 02 \mathrm{E}-23 \mathrm{~B} 02$ & $08-21-91$ & -. & -- & $<0.01$ & -. & $<0.01$ &.- & - & 11 & -. \\
\hline 40N/02E-23D01 & $04-30-91$ & -. & $<0.01$ & -- & 0.05 & -- & 0.4 & -- & 4.0 & 4.0 \\
\hline 40N/02E-23D04 & $08-22-91$ & -. & -- & 0.03 & - & $<0.01$ & - & - & 13 & -. \\
\hline $40 \mathrm{~N} / 02 \mathrm{E}-23 \mathrm{~N} 01$ & $04-27-91$ & -. & 0.13 &.- & $<0.01$ & - & 0.4 & -- & 1.5 & 1.5 \\
\hline $40 \mathrm{~N} / 02 \mathrm{E}-23 \mathrm{P} 01$ & $08-22-91$ & -. & - & $<0.01$ & - & $<0.01$ & -- & -. & 20 & - \\
\hline $40 \mathrm{~N} / 02 \mathrm{E}-26 \mathrm{~A} 03$ & $10-04-91$ & - & $<0.01$ & -. & $<0.01$ & - & $<0.0$ & -. & 13 & 13 \\
\hline $40 \mathrm{~N} / 02 \mathrm{E}-26 \mathrm{~B} 02$ & $08-22-91$ & -. & -- & $<0.01$ & -. & $<0.01$ & -- & - & 7.6 & -. \\
\hline $40 \mathrm{~N} / 02 \mathrm{E}-26 \mathrm{C} 03$ & $09-05-91$ & -. &.- & 0.02 & -. & 0.02 & -- & -- & 2.2 & -. \\
\hline $40 \mathrm{~N} / 02 \mathrm{E}-26 \mathrm{C} 04$ & $08-22-91$ & -- & -. & $<0.01$ & -. & $<0.01$ & -. & -- & 4.0 & -. \\
\hline $40 \mathrm{~N} / 02 \mathrm{E}-26 \mathrm{D} 02$ & $09-05-91$ & -- & -- & 0.03 & -- & 0.02 &.- & - & 5.6 & -- \\
\hline \multirow[t]{13}{*}{$40 \mathrm{~N} / 02 \mathrm{E}-27 \mathrm{~B} 01$} & $08-30-90$ & - & $<0.01$ & -- & $<0.01$ & -- & 0.3 & - & 11 & 11 \\
\hline & $10-17-90$ & - & -- & 0.04 & -- & $<0.01$ & -- & -- & 12 & -- \\
\hline & $11-14-90$ & 0.67 & -. & 0.03 & -. & $<0.01$ & -- & 0.7 & 11 &.- \\
\hline & $12-18-90$ & .- & - & 0.02 & -- & $<0.01$ & - & - & 10 & -- \\
\hline & $02-20-91$ & - & -- & $<0.01$ & -- & $<0.01$ & -- & -- & 7.4 & - \\
\hline & $02-20-91$ & -- & -- & $<0.01$ & -. & $<0.01$ & - & -- & 7.5 & -- \\
\hline & $03-14-91$ & 0.28 & -- & 0.02 & -. & $<0.01$ & -- & 0.3 & 6.3 & - \\
\hline & $04-24-91$ & 0.19 & -. & 0.01 & -. & $<0.01$ & -. & 0.2 & 6.6 & -. \\
\hline & $05-21-91$ & -. & -- & 0.01 &.- & $<0.01$ & -- & - & 7.9 & - \\
\hline & $06-26-91$ & 0.70 & -- & $<0.01$ & -. & $<0.01$ & -- & 0.7 & 8.1 & -- \\
\hline & $07-18-91$ & -- & - & 0.03 & -- & $<0.01$ & -- & - & 9.2 & - \\
\hline & $08-14-91$ & -. & -- & 0.09 & -. & $<0.01$ & -- & -- & 9.2 & -- \\
\hline & $09-25-91$ & -. & -. & 0.02 & -- & 0.01 & - & -- & 9.2 & -. \\
\hline $40 \mathrm{~N} / 02 \mathrm{E}-27 \mathrm{C} 01$ & $08-22-91$ & -. & -. & $<0.01$ & -. & $<0.01$ & -. & -- & 7.8 & -. \\
\hline 40N/02E-27D02 & $08-22-91$ &.- & -. & $<0.01$ & -- & $<0.01$ & -- & -- & 7.2 & .- \\
\hline \multirow[t]{2}{*}{$40 \mathrm{~N} / 02 \mathrm{E}-27 \mathrm{~N} 02$} & $04-30-91$ & $-\cdot$ & $<0.01$ & $-\cdot$ & $<0.01$ & -- & 0.8 & - & 14 & 14 \\
\hline & $08-21-91$ & -. & $<0.01$ & -. & $<0.01$ & -- & 0.6 & -- & 9.0 & 9.0 \\
\hline $40 \mathrm{~N} / 02 \mathrm{E}-28 \mathrm{G} 01$ & $08-23-91$ & -. & -. & $<0.01$ & -. & $<0.01$ & -. & -- & 7.4 & -. \\
\hline $40 \mathrm{~N} / 02 \mathrm{E}-33 \mathrm{~B} 02$ & $10-02-91$ & -- & $<0.01$ & -. & $<0.01$ & -- & $<0.0$ & - & 1.8 & 1.8 \\
\hline 40N/03E-02B01 & $05-02-91$ & -- & 0.02 & -. & $<0.01$ & -. & 0.4 & -- & 9.0 & 9.0 \\
\hline 40N/03E-03A02 & $05-01-91$ & -. & 0.01 &.- & $<0.01$ & -- & 0.7 & -- & 9.9 & 9.9 \\
\hline \multirow[t]{14}{*}{ 40N/03E-03B01 } & $08-30-90$ & -. & 0.01 & -. & $<0.01$ & -. & 0.5 & -- & 7.8 & 7.8 \\
\hline & $10-18-90$ & -. & -- & 0.04 & -- & $<0.01$ & -- & -- & 6.3 & -. \\
\hline & $11-14-90$ & 0.46 & -- & 0.04 & - & $<0.01$ & -- & 0.5 & 7.0 & -. \\
\hline & $12-18-90$ & -. & -- & 0.02 & -- & $<0.01$ & -- & -- & 6.7 & -- \\
\hline & $02-20-91$ & - & -- & 0.03 & $*$ & $<0.01$ & -. & - & 7.4 & - \\
\hline & $03-14-91$ & 0.50 & -. & $<0.01$ & - & $<0.01$ & -. & 0.5 & 8.2 & -. \\
\hline & $04-23-91$ & 0.38 & -- & 0.02 & -- & $<0.01$ & - & 0.4 & 10 & -. \\
\hline & $05-21-91$ & -- & -. & 0.04 & - & 0.01 & -. & - & 11 & - \\
\hline & $06-25-91$ & 0.60 & -. & $<0.01$ & -- & $<0.01$ & -. & 0.6 & 10 & -. \\
\hline & $07-17-91$ & -- & -. & 0.04 & -. & 0.01 & -- & - & 10 & -- \\
\hline & $08-21-91$ & 0.56 & -. & 0.04 & -- & $<0.01$ & -. & 0.6 & 9.3 & -. \\
\hline & $09-25-91$ & -. & -. & 0.03 & -. & $<0.01$ & -- & -- & 6.2 & -. \\
\hline & $10-24-91$ & -. & -. & 0.02 & -- & $<0.01$ & - & $<0.2$ & 5.8 & -. \\
\hline & $12-13-91$ & -. & -. & 0.01 & -- & $<0.01$ & - & -- & 6.1 & - \\
\hline
\end{tabular}


Appendix Table 8. Concentrations of selected nitrogen species in ground water of the Lynden-Everson-NooksackSumas study area, Whatcom County, Wash., and British Columbia, Canada--Continued

\begin{tabular}{|c|c|c|c|c|c|c|c|c|c|c|}
\hline $\begin{array}{l}\text { Local } \\
\text { well number }\end{array}$ & Date & $\begin{array}{l}\text { Nitro- } \\
\text { gen, } \\
\text { organic, } \\
\text { total } \\
(\mathrm{mg} / \mathrm{L} \\
\text { as } \mathrm{N})\end{array}$ & $\begin{array}{l}\text { Nitro- } \\
\text { gen, } \\
\text { ammonia, } \\
\text { dis- } \\
\text { solved } \\
(\mathrm{mg} / \mathrm{L} \\
\text { as } \mathrm{N})\end{array}$ & $\begin{array}{l}\text { Nitro- } \\
\text { gen, } \\
\text { ammonia, } \\
\text { total } \\
(\mathrm{mg} / \mathrm{L} \\
\text { as } \mathrm{N})\end{array}$ & $\begin{array}{l}\text { Nitro- } \\
\text { gen, } \\
\text { nitrite, } \\
\text { dis- } \\
\text { solved } \\
\text { (mg/L } \\
\text { as N) }\end{array}$ & $\begin{array}{l}\text { Nitro- } \\
\text { gen, } \\
\text { nitrite, } \\
\text { total } \\
(\mathrm{mg} / \mathrm{L} \\
\text { as N) }\end{array}$ & $\begin{array}{l}\text { Nitro- } \\
\text { gen, am- } \\
\text { monia + } \\
\text { organic, } \\
\text { dissolved } \\
(\mathrm{mg} / \mathrm{L} \\
\text { as } \mathrm{N})\end{array}$ & $\begin{array}{l}\text { Nitro- } \\
\text { gen, am- } \\
\text { monia + } \\
\text { organic, } \\
\text { total } \\
(\mathrm{mg} / \mathrm{L} \\
\text { as } \mathrm{N})\end{array}$ & $\begin{array}{l}\text { Nitro- } \\
\text { gen, } \\
\mathrm{NO}_{2}+ \\
\mathrm{NO}_{3} \text {, } \\
\text { total } \\
\text { (mg/L } \\
\text { as } \mathrm{N} \text { ) }\end{array}$ & $\begin{array}{l}\text { Nitro- } \\
\text { gen, } \\
\mathrm{NO}_{2}+ \\
\mathrm{NO}_{3} \text {, dis- } \\
\text { solved } \\
(\mathrm{mg} / \mathrm{L} \\
\text { as } \mathrm{N})\end{array}$ \\
\hline $40 \mathrm{~N} / 03 \mathrm{E}-03 \mathrm{R} 02$ & $05-02-91$ & -- & 0.02 & -- & 0.05 & - & 0.7 & -- & 12 & 12 \\
\hline 40N/03E-05L01 & $08-14-91$ & 3.0 & 34 & 34 & $<0.01$ & $<0.01$ & 35 & 37 & 0.05 & $<0.05$ \\
\hline 40N/03E-05M05 & 08-14-91 & 0.52 & - & 0.08 & -- & $<0.01$ & -- & 0.6 & 18 & - \\
\hline $40 \mathrm{~N} / 03 \mathrm{E}-05 \mathrm{~N} 02$ & $08-29-90$ & -- & 0.03 & -- & $<0.01$ & - & 0.3 & - & 1.3 & 1.3 \\
\hline 40N/03E-07A02 & $05-01-91$ & - & $<0.01$ & -- & $<0.01$ & - & 1.2 & - & 11 & 11 \\
\hline \multirow[t]{2}{*}{$40 \mathrm{~N} / 03 \mathrm{E}-09 \mathrm{G} 01$} & $05-02-91$ & -- & 0.07 & -- & $<0.01$ & - & $<0.2$ & - & - & $<0.05$ \\
\hline & $08-21-91$ & -- & 0.03 & -- & $<0.01$ & - & $<0.2$ & -- & - & $<0.05$ \\
\hline $40 \mathrm{~N} / 03 \mathrm{E}-10 \mathrm{C} 02$ & 05-03-91 & 0.48 & -- & 0.02 & - & 0.01 & - & 0.5 & 6.2 & -- \\
\hline $40 \mathrm{~N} / 03 \mathrm{E}-10 \mathrm{~K} 01$ & $05-02-91$ & -- & 0.02 & -- & $<0.01$ & -- & 0.4 & -- & 7.6 & 7.6 \\
\hline 40N/03E-10R02 & $05-01-91$ & -. & 0.02 & -- & $<0.01$ & -. & $<0.2$ & - & 1.4 & 1.4 \\
\hline $40 \mathrm{~N} / 03 \mathrm{E}-11 \mathrm{E} 04$ & $05-02-91$ & - & 0.01 & - & $<0.01$ & - & $<0.2$ & - & 1.5 & 1.5 \\
\hline \multirow[t]{12}{*}{$40 \mathrm{~N} / 03 \mathrm{E}-16 \mathrm{~A} 02$} & $08-27-90$ & -- & 0.03 & - & $<0.01$ & -- & 0.4 & - & 7.4 & 7.4 \\
\hline & $10-17-90$ & - & -- & 0.04 & -- & $<0.01$ & - & - & 8.3 & -- \\
\hline & $11-14-90$ & 0.46 & -- & 0.04 & - & $<0.01$ & - & 0.5 & 8.3 & - \\
\hline & $12-17-90$ & -- & - & 0.02 & - & $<0.01$ & - & - & 8.2 & -- \\
\hline & $02-21-91$ & - & - & $<0.01$ & - & $<0.01$ & - & - & 6.5 & - \\
\hline & $03-14-91$ & 0.20 & - & $<0.01$ & -. & $<0.01$ & -- & 0.2 & 6.4 & -. \\
\hline & $04-23-91$ & 0.40 & -- & $<0.01$ & -- & $<0.01$ & - & 0.4 & 12 & - \\
\hline & $05-21-91$ & -- & - & $<0.01$ & -- & $<0.01$ & - & - & 14 & -- \\
\hline & $06-25-91$ & 0.70 & - & $<0.01$ & -- & $<0.01$ & - & 0.7 & 15 & -- \\
\hline & $07-17-91$ & - & -- & 0.03 & - & 0.01 & - & - & 13 & - \\
\hline & $08-22-91$ & 0.59 & -. & 0.01 & -- & $<0.01$ & -- & 0.6 & 14 & -. \\
\hline & $09-26-91$ & -. & -- & 0.01 & -- & $<0.01$ & - & - & 16 & -- \\
\hline 40N/03E-16F01 & $05-01-91$ & -. & 0.07 & - & 0.01 & -. & $<0.2$ & - & 0.35 & 0.35 \\
\hline 40N/03E-16K01 & $05-01-91$ & - & $<0.01$ & -- & $<0.01$ & -- & 0.5 & - & 3.7 & 3.7 \\
\hline 40N/03E-19A01 & $10-04-91$ & -- & 0.10 & - & $<0.01$ & - & $<0.0$ & - & - & $<0.05$ \\
\hline 40N/03E-24E01 & $10-02-91$ & -- & 1.2 & - & $<0.01$ & -. & 1.3 & -. & 0.06 & 0.06 \\
\hline $40 \mathrm{~N} / 03 \mathrm{E}-25 \mathrm{~F} 01$ & $08-21-91$ & -- & 0.41 & - & 0.01 & -. & 1.0 & -- & 1.2 & 1.2 \\
\hline $40 \mathrm{~N} / 03 \mathrm{E}-31 \mathrm{~L} 01$ & $05-01-91$ & -- & $<0.01$ & -- & $<0.01$ & -- & 0.5 & - & 7.2 & 7.2 \\
\hline \multirow[t]{2}{*}{ 40N/03E-31P03 } & $04-26-91$ & -- & $<0.01$ & - & $<0.01$ & - & 0.8 & -- & 19 & 19 \\
\hline & $12-13-91$ & - & -- & $<0.01$ & -- & $<0.01$ & - & $<0.2$ & 14 & -- \\
\hline $40 \mathrm{~N} / 03 \mathrm{E}-32 \mathrm{~L} 01$ & $04-25-91$ & -- & $<0.01$ & -- & $<0.01$ & - & 0.6 & -- & 12 & 12 \\
\hline \multirow[t]{13}{*}{ 40N/03E-32M01 } & $08-29-90$ & -- & 0.02 & - & $<0.01$ & - & 0.4 & - & 11 & 11 \\
\hline & $10-17-90$ & -. & -- & 0.04 & -- & $<0.01$ & - & -- & 11 & -- \\
\hline & $11-16-90$ & 0.67 & -. & 0.03 & -. & $<0.01$ & -. & 0.7 & 11 & -- \\
\hline & $12-17-90$ & -- & -. & 0.02 & -. & $<0.01$ & -. & - & 8.9 & - \\
\hline & 01-19-91 & 0.60 & - & $<0.01$ & -- & 0.01 & - & 0.6 & 11 & -- \\
\hline & $02-21-91$ & -. & -. & $<0.01$ & -- & 0.02 & - & - & 11 & - \\
\hline & $03-13-91$ & 0.78 & -. & 0.02 & -. & $<0.01$ & - & 0.8 & 12 & -- \\
\hline & $04-24-91$ & 0.59 & -. & 0.01 & - & 0.01 & -. & 0.6 & 13 & -. \\
\hline & $05-21-91$ & - & -. & $<0.01$ & -. & 0.02 & - & - & 11 & -- \\
\hline & $06-25-91$ & 0.70 & -- & $<0.01$ & -. & $<0.01$ & -- & 0.7 & 10 & - \\
\hline & $07-18-91$ & -. & -. & 0.03 & -. & 0.01 & -- & -. & 12 & -- \\
\hline & $08-23-91$ & 0.49 & - & 0.01 & - & $<0.01$ & - & 0.5 & 12 & - \\
\hline & $09-26-91$ & -. & -. & $<0.01$ & -. & $<0.01$ & - & -- & 12 & -- \\
\hline
\end{tabular}


Appendix Table 8. Concentrations of selected nitrogen species in ground water of the Lynden-Everson-NooksackSumas study area, Whatcom County, Wash., and British Columbia, Canada--Continued

\begin{tabular}{|c|c|c|c|c|c|c|c|c|c|c|}
\hline $\begin{array}{l}\text { Local } \\
\text { well number }\end{array}$ & Date & $\begin{array}{l}\text { Nitro- } \\
\text { gen, } \\
\text { organic, } \\
\text { total } \\
(\mathrm{mg} / \mathrm{L} \\
\text { as } \mathrm{N})\end{array}$ & $\begin{array}{l}\text { Nitro- } \\
\text { gen, } \\
\text { ammonia, } \\
\text { dis- } \\
\text { solved } \\
\text { (mg/L } \\
\text { as } \mathrm{N} \text { ) }\end{array}$ & $\begin{array}{l}\text { Nitro- } \\
\text { gen, } \\
\text { ammonia, } \\
\text { total } \\
(\mathrm{mg} / \mathrm{L} \\
\text { as } \mathrm{N})\end{array}$ & $\begin{array}{l}\text { Nitro- } \\
\text { gen, } \\
\text { nitrite, } \\
\text { dis- } \\
\text { solved } \\
(\mathrm{mg} / \mathrm{L} \\
\text { as N) }\end{array}$ & $\begin{array}{l}\text { Nitro- } \\
\text { gen, } \\
\text { nitrite, } \\
\text { total } \\
(\mathrm{mg} / \mathrm{L} \\
\text { as N) }\end{array}$ & $\begin{array}{l}\text { Nitro- } \\
\text { gen, am- } \\
\text { monia + } \\
\text { organic, } \\
\text { dissolved } \\
(\mathrm{mg} / \mathrm{L} \\
\text { as } \mathrm{N})\end{array}$ & $\begin{array}{l}\text { Nitro- } \\
\text { gen, am- } \\
\text { monia + } \\
\text { organic, } \\
\text { total } \\
(\mathrm{mg} / \mathrm{L} \\
\text { as } \mathrm{N})\end{array}$ & $\begin{array}{l}\text { Nitro- } \\
\text { gen, } \\
\mathrm{NO}_{2}+ \\
\mathrm{NO}_{3} \text {, } \\
\text { total } \\
\text { (mg/L } \\
\text { as } \mathrm{N} \text { ) }\end{array}$ & $\begin{array}{l}\text { Nitro- } \\
\text { gen, } \\
\mathrm{NO}_{2+} \\
\mathrm{NO}_{3} \text {, dis- } \\
\text { solved } \\
\text { (mg/L } \\
\text { as } \mathrm{N} \text { ) }\end{array}$ \\
\hline & $12-13-91$ & -- & -- & $<0.01$ & $-\cdot$ & 0.01 & -- & -. & 10 & .. \\
\hline $40 \mathrm{~N} / 03 \mathrm{E}-32 \mathrm{Q} 01$ & $04-25-91$ & - & 0.01 & -- & $<0.01$ &.- & $<0.2$ & -- & 2.8 & 2.8 \\
\hline $40 \mathrm{~N} / 03 \mathrm{E}-33 \mathrm{~J} 02$ & $04-26-91$ & - & 0.25 & -- & $<0.01$ & -- & 0.3 & - & -. & $<0.05$ \\
\hline 40N/03E-36Q01 & $04-30-91$ & -- & $<0.01$ & -- & $<0.01$ & -. & $<0.2$ & - & 2.3 & 2.3 \\
\hline 40N/04E-01K02 & $10-04-91$ & - & 0.55 & - & $<0.01$ & -- & 0.8 & -- & -. & $<0.05$ \\
\hline 40N/04E-05N02 & $05-02-91$ & - & 0.01 & -- & $<0.01$ & -. & $<0.2$ & - & 2.3 & 2.3 \\
\hline 40N/04E-05P01 & $05-02-91$ & - & 0.02 & -- & 0.01 & -- & 0.7 & - & 11 & 11 \\
\hline 40N/04E-05P02 & $08-29-90$ & - & $<0.01$ & - & $<0.01$ & -- & 0.5 & -. & 12 & 12 \\
\hline \multirow[t]{3}{*}{ 40N/04E-09B01 } & $02-21-91$ & - & - & $<0.01$ & - & $<0.01$ & - & - & $<0.05$ & -- \\
\hline & $05-03-91$ & - & 0.26 & -- & 0.02 & -. & 0.5 & -- & -. & $<0.05$ \\
\hline & $01-15-92$ & 0.0 & -- & 0.20 & -- & $<0.01$ & -- & 0.2 & $<0.05$ & - \\
\hline 40N/04E-09N03 & $08-28-90$ & -. & 0.25 & -- & $<0.01$ & -. & 0.3 & -- & -- & $<0.10$ \\
\hline 40N/04E-17G01 & $10-03-91$ & - & 0.14 & -. & $<0.01$ & - & 0.3 & -- & 0.06 & 0.06 \\
\hline \multirow[t]{11}{*}{ 40N/04E-20F01 } & $08-30-90$ & - & 0.05 & - & $<0.01$ & -- & 0.3 & - &.- & $<0.10$ \\
\hline & $11-15-90$ & - & -. & 0.06 & -- & $<0.01$ & - & $<0.2$ & 0.70 & -. \\
\hline & $12-17-90$ & -- & -- & 0.03 & - & $<0.01$ & -. & -- & 1.5 & -- \\
\hline & $02-19-91$ & - & -- & 0.02 & -- & 0.01 & -- & -- & 1.5 & -. \\
\hline & $03-14-91$ & - & -- & 0.03 & -- & $<0.01$ & - & $<0.2$ & 0.80 & -. \\
\hline & $04-23-91$ & 0.37 & -. & 0.03 & -- & 0.01 & -. & 0.4 & 0.62 & -. \\
\hline & $05-22-91$ & - & -- & 0.04 & -- & 0.01 & -- & - & 0.36 & -- \\
\hline & $08-22-91$ & 0.15 & -- & 0.05 & -- & $<0.01$ & -. & 0.2 & 0.14 & - \\
\hline & $09-25-91$ & -- & -- & 0.06 & $-\cdot$ & 0.01 & - & -- & 0.13 & - \\
\hline & $10-23-91$ & -- & -- & 0.06 & -- & 0.01 & - & $<0.2$ & 0.22 & -- \\
\hline & $12-13-91$ & -. & -. & 0.03 & -- & 0.01 & -- & -- & 0.45 & -. \\
\hline 40N/04E-22G01 & $05-02-91$ & -- & 0.02 & - & $<0.01$ & $-\cdot$ & 0.3 & -- & 3.7 & 3.7 \\
\hline 40N/04E-22J01 & $05-02-91$ & - & 0.19 & - & $<0.01$ & -- & $<0.2$ & - & 2.4 & 2.4 \\
\hline 40N/04E-22R01 & $05-03-91$ & -. & 0.03 & -- & 0.01 & -.. & $<0.2$ & -. & ... & $<0.05$ \\
\hline 40N/04E-29H02 & $05-03-91$ & -- & 0.22 & -- & 0.02 &.- & 0.3 & -. & -- & $<0.05$ \\
\hline \multirow[t]{2}{*}{ 40N/04E-30G01 } & 09-05-91 & $-\cdot$ & -- & 0.70 & -- & 0.03 & - & -- & $<0.05$ & -- \\
\hline & $10-03-91$ & -- & 0.59 & -- & $<0.01$ & - & 0.7 & -. & -- & $<0.05$ \\
\hline \multirow[t]{2}{*}{ 40N/04E-31R02 } & $09-05-91$ & -- & -- & 0.20 & -- & $<0.01$ & - & - & $<0.05$ & - \\
\hline & $10-04-91$ & -- & 0.19 & -- & $<0.01$ & -- & 0.3 & - & 0.14 & 0.14 \\
\hline 40N/04E-34P01 & $08-21-91$ & - & $<0.01$ & - & $<0.01$ & - & $<0.2$ & - & 1.0 & 1.0 \\
\hline 40N/05E-06K01 & 07-03-91 & -- & 0.04 & -- & $<0.01$ & -- & 0.2 & - & -- & $<0.05$ \\
\hline 41N/02E-33J01 & $04-29-91$ & -. & 0.16 & -- & $<0.01$ & -. & 0.3 & -. & -- & $<0.05$ \\
\hline $41 \mathrm{~N} / 02 \mathrm{E}-35 \mathrm{P} 01$ & 04-30-91 & -. & 0.09 & -- & $<0.01$ & -. & $<0.2$ & - & -. & $<0.05$ \\
\hline 41N/03E-32Q01 & $05-01-91$ & -. & 0.05 & -- & 0.01 & -. & 0.7 & -. & 43 & 43 \\
\hline 41N/03E-34M01 & $05-01-91$ & -- & $<0.01$ & -- & $<0.01$ & -- & 1.1 & -- & 20 & 20 \\
\hline 41N/03E-34Q01 & $05-02-91$ & -- & 0.02 & -- & 0.01 & -- & $<0.2$ & -- & -. & $<0.05$ \\
\hline 41N/03E-35L01 & $05-01-91$ & - & 0.18 & -- & $<0.01$ &.- & 0.7 & - & 21 & 21 \\
\hline $41 \mathrm{~N} / 03 \mathrm{E}-36 \mathrm{~J} 01$ & $05-02-91$ & - & 0.01 & -. & $<0.01$ & - & 0.4 & - & 7.3 & 7.3 \\
\hline $41 \mathrm{~N} / 03 \mathrm{E}-36 \mathrm{~J} 02$ & $05-02-91$ & -- & 0.08 & -. & $<0.01$ & -. & $<0.2$ & -. & -.. & $<0.05$ \\
\hline \multirow[t]{3}{*}{$41 \mathrm{~N} / 04 \mathrm{E}-31 \mathrm{~J} 02$} & $08-31-90$ & - & $<0.01$ & -. & $<0.01$ & -- & 0.5 & -. & 13 & 13 \\
\hline & $10-18-90$ & -- & -- & 0.04 & $-\cdot$ & $<0.01$ & -- & - & 14 & - \\
\hline & $11-14-90$ & 0.45 & -- & 0.05 & -. & $<0.01$ & - & 0.5 & 2.9 & - \\
\hline
\end{tabular}


Appendix Table 8. Concentrations of selected nitrogen species in ground water of the Lynden-Everson-NooksackSumas study area, Whatcom County, Wash., and British Columbia, Canada--Continued

\begin{tabular}{|c|c|c|c|c|c|c|c|c|c|c|}
\hline $\begin{array}{l}\text { Local } \\
\text { well number }\end{array}$ & Date & $\begin{array}{l}\text { Nitro- } \\
\text { gen, } \\
\text { organic, } \\
\text { total } \\
(\mathrm{mg} / \mathrm{L} \\
\text { as } \mathrm{N})\end{array}$ & $\begin{array}{l}\text { Nitro- } \\
\text { gen, } \\
\text { ammonia, } \\
\text { dis- } \\
\text { solved } \\
\text { (mg/L } \\
\text { as N) }\end{array}$ & $\begin{array}{l}\text { Nitro- } \\
\text { gen, } \\
\text { ammonia, } \\
\text { total } \\
(\mathrm{mg} / \mathrm{L} \\
\text { as } \mathrm{N})\end{array}$ & $\begin{array}{l}\text { Nitro- } \\
\text { gen, } \\
\text { nitrite, } \\
\text { dis- } \\
\text { solved } \\
\text { (mg/L } \\
\text { as } \mathrm{N} \text { ) }\end{array}$ & $\begin{array}{l}\text { Nitro- } \\
\text { gen, } \\
\text { nitrite, } \\
\text { total } \\
\text { (mg/L } \\
\text { as N) }\end{array}$ & $\begin{array}{l}\text { Nitro- } \\
\text { gen, am- } \\
\text { monia + } \\
\text { organic, } \\
\text { dissolved } \\
(\mathrm{mg} / \mathrm{L} \\
\text { as } \mathrm{N})\end{array}$ & $\begin{array}{l}\text { Nitro- } \\
\text { gen, am- } \\
\text { monia + } \\
\text { organic, } \\
\text { total } \\
(\mathrm{mg} / \mathrm{L} \\
\text { as } \mathrm{N})\end{array}$ & $\begin{array}{l}\text { Nitro- } \\
\text { gen, } \\
\mathrm{NO}_{2}+ \\
\mathrm{NO}_{3} \text {, } \\
\text { total } \\
(\mathrm{mg} / \mathrm{L} \\
\text { as } \mathrm{N} \text { ) }\end{array}$ & $\begin{array}{l}\text { Nitro- } \\
\text { gen, } \\
\mathrm{NO}_{2+} \\
\mathrm{NO}_{3} \text {, dis- } \\
\text { solved } \\
\text { (mg/L } \\
\text { as } \mathrm{N} \text { ) }\end{array}$ \\
\hline & $12-18-90$ & .. & -. & 0.03 & .. & $<0.01$ &.- & -. & 13 & - \\
\hline \multirow[t]{9}{*}{$41 \mathrm{~N} / 04 \mathrm{E}-31 \mathrm{~J} 02$} & $01-17-91$ & 0.60 & -- & $<0.01$ & -- & $<0.01$ & - & 0.6 & 13 & -- \\
\hline & $02-19-91$ & -. & -. & 0.01 & -. & $<0.01$ & -. & - & 11 & - \\
\hline & $03-14-91$ & 0.50 & -. & $<0.01$ & - & 0.01 & -. & 0.5 & 10 & - \\
\hline & $04-23-91$ & -. & -- & 0.02 & - & $<0.01$ & -- & $<0.2$ & 8.1 & -- \\
\hline & $05-21-91$ & -- & -- & $<0.01$ & -- & $<0.01$ & - & -- & 8.6 & - \\
\hline & $06-25-91$ & 0.80 & -. & $<0.01$ & -- & $<0.01$ & -. & 0.8 & 10 & -- \\
\hline & $07-17-91$ & -. & -- & 0.04 & - & 0.01 & -. & - & 11 & -- \\
\hline & $08-22-91$ & 0.58 & -. & 0.02 & -- & $<0.01$ & - & 0.6 & 13 & -- \\
\hline & $09-25-91$ & -. & -- & $<0.01$ & -- & $<0.01$ & -- & - & 13 & .. \\
\hline 41N/04E-31R02 & $05-02-91$ & -. & 0.02 & -- & $<0.01$ & -- & 0.3 & - & 8.6 & 8.6 \\
\hline $41 \mathrm{~N} / 04 \mathrm{E}-32 \mathrm{Q} 01$ & $04-30-91$ & -. & $<0.01$ & -. & $<0.01$ & -- & 1.1 & -- & 16 & 16 \\
\hline $41 \mathrm{~N} / 04 \mathrm{E}-32 \mathrm{R} 01$ & $05-01-91$ & -. & 0.03 & -. & 0.01 & -- & 0.8 & -- & 15 & 15 \\
\hline \multirow[t]{2}{*}{$41 \mathrm{~N} / 04 \mathrm{E}-33 \mathrm{H} 01 \mathrm{~S}$} & $05-01-91$ & -- & 0.02 & -- & $<0.01$ &.- & 0.4 & -. & 5.8 & 5.8 \\
\hline & $01-14-92$ & -. & -. & $<0.01$ & -. & $<0.01$ & - & $<0.2$ & 6.3 & - \\
\hline \multirow[t]{2}{*}{$41 \mathrm{~N} / 04 \mathrm{E}-33 \mathrm{H} 04$} & $05-01-91$ & - & 0.02 & -- & 0.01 & - & 0.4 & - & 5.6 & 5.6 \\
\hline & $01-14-92$ & -- & - & $<0.01$ & -. & $<0.01$ & -. & $<0.2$ & 5.4 & -. \\
\hline $41 \mathrm{~N} / 04 \mathrm{E}-33 \mathrm{~N} 04$ & $07-20-91$ & -. & 0.03 & -. & 0.02 & .. & 0.7 & -- & 15 & 15 \\
\hline
\end{tabular}

